ANIMALS IN ANCIENT GREEK WARFARE:

A STUDY OF THE ELEPHANT, CAMEL, AND DOG

A Dissertation
presented to
the Faculty of the Graduate School
at the University of Missouri-Columbia
In Partial Fulfillment
of the Requirements for the Degree
Doctor of Philosophy
by
JENNA RAE RICE
Dr. Ian Worthington, dissertation supervisor
MAY 2020


CC Copyright by Jenna Rice 2020

All Rights Reserved 
The undersigned, appointed by the dean of the Graduate School, have examined the [thesis or dissertation] entitled:

\section{ANIMALS IN ANCIENT GREEK WARFARE: \\ A STUDY OF THE ELEPHANT, CAMEL, AND DOG}

Presented by Jenna Rae Rice,

a candidate for the degree of doctorate of philosophy, and hereby certify that, in their opinion, it is worthy of acceptance.

Professor Ian Worthington

Professor Theodore Tarkow

Professor Susan Langdon

Professor Dennis Trout

Professor Lois Huneycutt

Professor John Frymire 
To Mom and Dad, who supported me and cheered me on, who made this possible. Thank you. 


\section{ACKNOWLEDGEMENTS}

I would like to thank Ian Worthington, for guiding and supporting my research, encouraging my zoological curiosity, and reading and commenting on drafts of dissertation chapters as well as related conference papers and articles.

Thank you to my dissertation committee members, Professors Ian Worthington, John Frymire, Lois Huneycutt, Susan Langdon, Theodore Tarkow, and Dennis Trout, for their willingness to serve on the committee and consider my dissertation for acceptance. My thanks especially to Professor Langdon for teaching me how to navigate CARC's Beazley Archive and "read" the scenes of Attic pottery, and to Professor Tarkow for our helpful discussions of the Hippaemon epigram.

I was fortunate enough to have several chapters evaluated by historians of animal culture, and I am grateful to Professor Emeritus Ken Kitchell for reading and commenting on Part III of the dissertation as well as for sharing his Arts article with me before publication. Thank you to Professor Linda Evans for reading and providing many helpful notes on the camels of Part II and for pointing me in the direction of further human-animal studies.

I am greatly appreciative of the many conversations which impacted, stimulated, and helped organize my dissertation research. Thank you to Professor Emerita Barbara Wallach for her patience and advice, and to Profs. Larry Tritle and Tom Palaima, whose conference talks on the ancient combat experience informed my methodology below. Thank you also to Dr. Katia Margariti for our chats on Molossian hounds and for sharing her specialized knowledge. 
Finally, thank you to the University of Missouri's Department of History, which provided me with the Dissertation Fellowship that enabled me to complete my research in the spring of 2020 . 


\section{Table of Contents}

ACKNOWLEDGEMENTS ....

Abbreviations of Ancient Authors ..................................................................................................

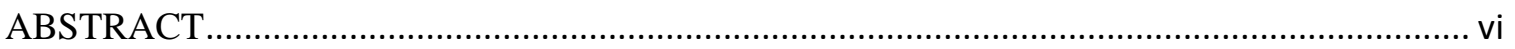

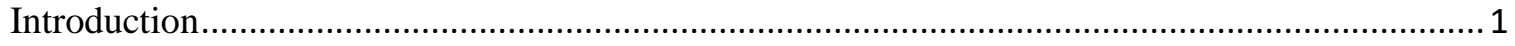

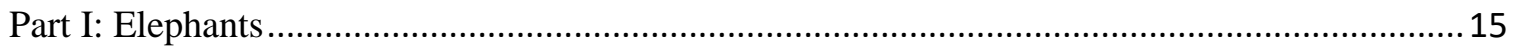

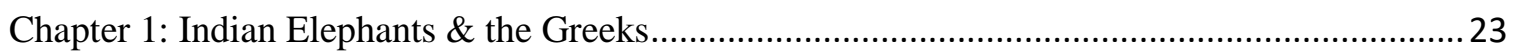

Chapter 2: “A Friendly Wall:”The Limitations of War Elephants .............................................51

Chapter 3: Alexander's Elephants \& the Diadochs ................................................................ 91

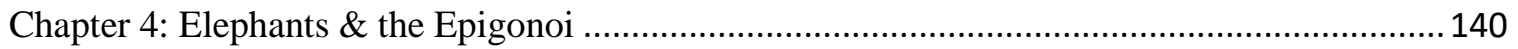

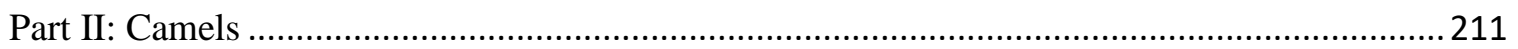

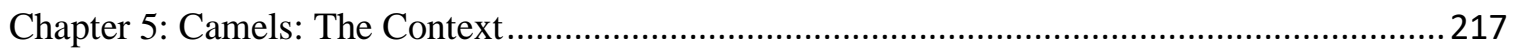

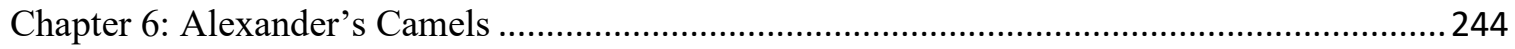

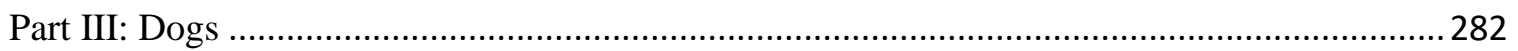

Chapter 7: Domestication \& Perception of the Dog in Ancient Greece ......................................290

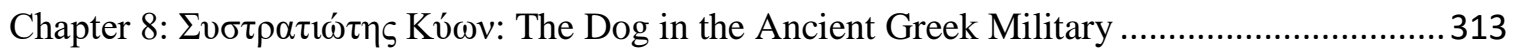

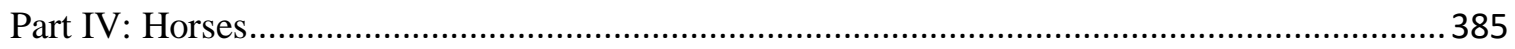

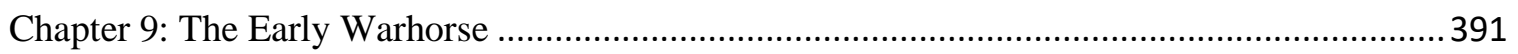

Chapter 10: Evolved Cavalry in The Classical \& Hellenistic Ages........................................... 412

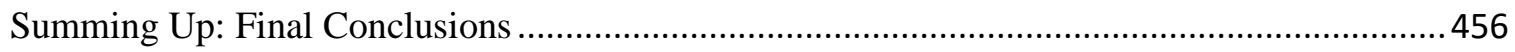

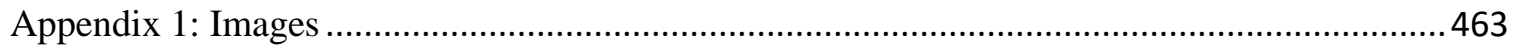

Appendix 2: A Note on the Camel Use of the Diadochs ....................................................... 470

Appendix 3: Summary of Beazley Archive Dog and Warrior Scenes ......................................472

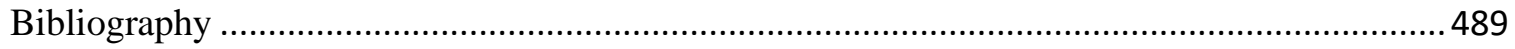

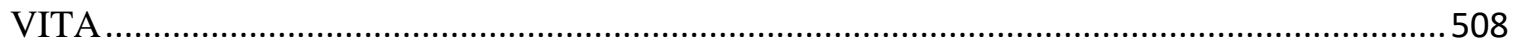




\section{Abbreviations of Ancient Authors}

\begin{tabular}{|c|c|}
\hline Ael. & Aelian \\
\hline Aen.Tact. & Aeneas Tacticus \\
\hline Aes. & Aeschylus \\
\hline App. & Appian \\
\hline Ar. & Aristophanes \\
\hline Arist. & Aristotle \\
\hline Arr. & Arrian \\
\hline Curt. & Curtius \\
\hline $\mathrm{DH}$ & Dionysius of Halicarnassus \\
\hline Diod. & Diodorus Siculus \\
\hline Eur. & Euripides \\
\hline Hdt. & Herodotus \\
\hline Jos. & Josephus \\
\hline Just. & Justin \\
\hline Lib. & Libanius \\
\hline Nep. & Cornelius Nepos \\
\hline Paus. & Pausanias \\
\hline Plut. & Plutarch \\
\hline Poll. & Julius Pollux \\
\hline Polyaen. & Polyaenus \\
\hline Polyb. & Polybius \\
\hline Thuc. & Thucydides \\
\hline Xen. & Xenophon \\
\hline
\end{tabular}




\title{
ANIMALS IN ANCIENT GREEK WARFARE: A STUDY OF THE ELEPHANT, CAMEL, AND DOG
}

\author{
Jenna Rae Rice \\ Professor Ian Worthington, Dissertation Supervisor
}

\begin{abstract}
My dissertation asserts that the study of animals is integral to the thorough understanding of the ancient military landscape, and three animals in particular warrant particular attention: the elephant, camel, and dog. I place these animals into the broader context of ancient warfare through the use of human-animal studies, zoological research, archaeological studies, and careful historical analysis, proving their impact in the GrecoMacedonian military. I contend that the war elephant's tactical significance is overstated by modern scholarship and requires a re-evaluation, concluding that due to a combination of physiological and behavioral reasons, elephants were not compatible with Greek military practices. They were, however, compatible with Diadoch politics, and were used by generations of Seleucids and Ptolemies as an emblem of legitimacy, martial strength, and royalty.
\end{abstract}

I consider the military value of the camel within the Greek realm, arguing that it has been largely ignored and requires analysis from a fresh perspective. I use recent zoological studies to argue against scholarship that dismisses the camel's abilities to tolerate extreme environments, and I assess the its value within the army of Alexander the Great through a series of specific case studies. Subsequently, I investigate the use of dogs in the ancient military sphere through a study of literary and archaeological sources. I show how dogs participated both directly in battle (Ionia) and in a more auxiliary fashion as guards, hunters, and companions. Finally, I present a survey of scientific 
archaeological, and historical studies of the ancient warhorse, considering its status within the scholarly community as a goal and model for future studies of other animals that functioned in the ancient military sphere. 


\section{Introduction}

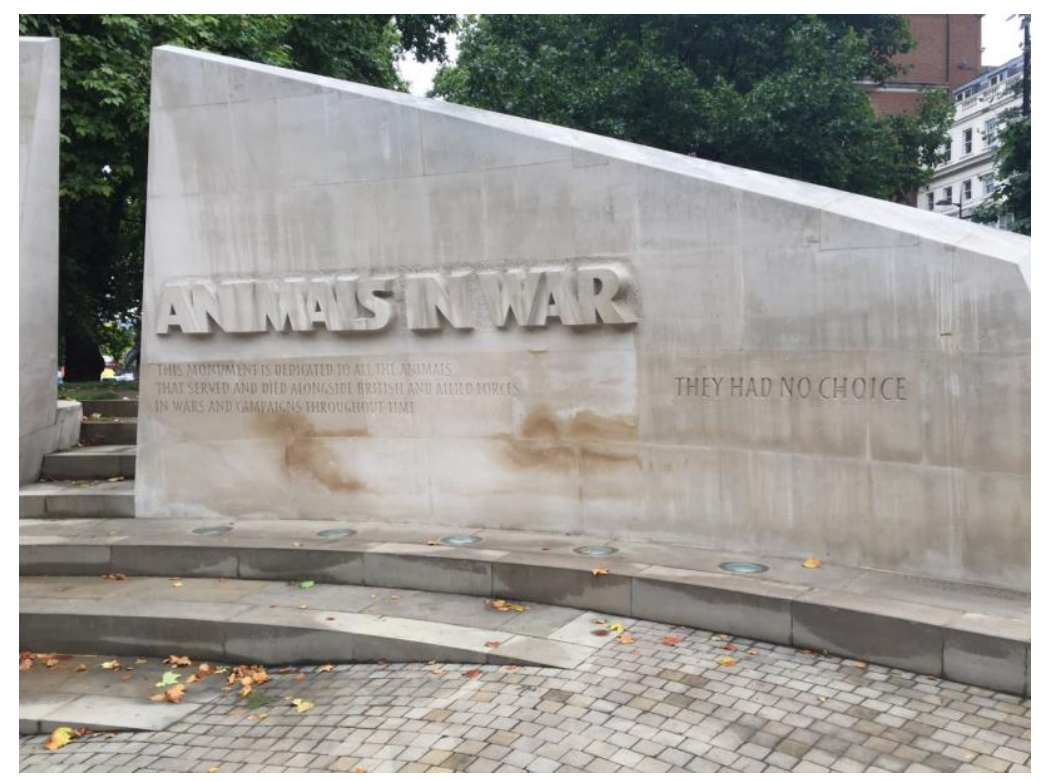

Photo 1 Right Wall of Memorial; Photo: Jeanne R. Rice, used with permission.

In 2004, London's Hyde Park unveiled the Animals in War Memorial, the first British war memorial dedicated not to a specific military animal, but to all animals incorporated into human conflict throughout time. Designed by David Backhouse, the memorial is comprised of two curving walls of Portland stone with bas-relief carvings of participating animals and a series of bronze sculptures, including two pack mules, a horse, and a dog. The wall depicts a menagerie, including elephants, dromedaries, Bactrian camels, cows, bison, horses in gas masks, a mule, dog, ram, cat, and three carrier pigeons. The monument reads:

"This monument is dedicated to all the animals that served and died alongside British and Allied forces in wars and campaigns throughout time."

Below this, in smaller, starker font: "They had no choice." 
The memorial was neither managed nor funded by the Royal Parks, but rather by citizens, who collectively raised the $£ 2$ million necessary to erect the wall and statue series. A committee to construct and maintain the monument was formed and headed by Major General Peter Davies CB, who has a commendable history of involvement in societies dedicated to better understanding and protecting animals, especially in the military arena. ${ }^{1}$ Joining Major General Davies on the board of trustees are Brigadier Andrew Parker Bowles OBE, Colonel Ronnie McCrum MVO, Petplan founder David Simpson, Blu Cross executive Alan Kennard MBE FCA, the scholar and veterinarian Andrew Higginsm BVetMed MSc PhD FRSB MRCVS, as well as the journalist and

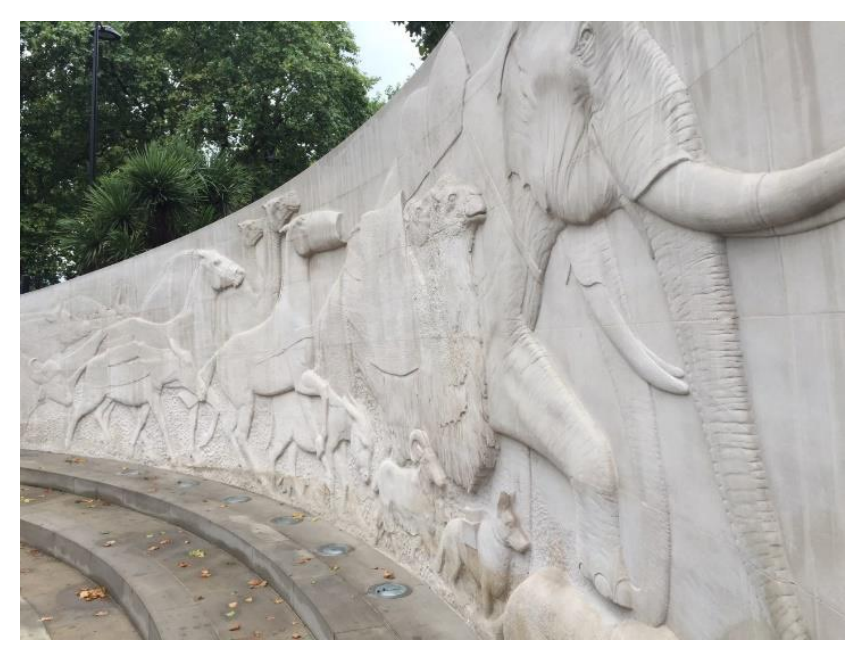

Photo 3 Left wall of memorial; Photo: Jeanne R. Rice. Used with permission.

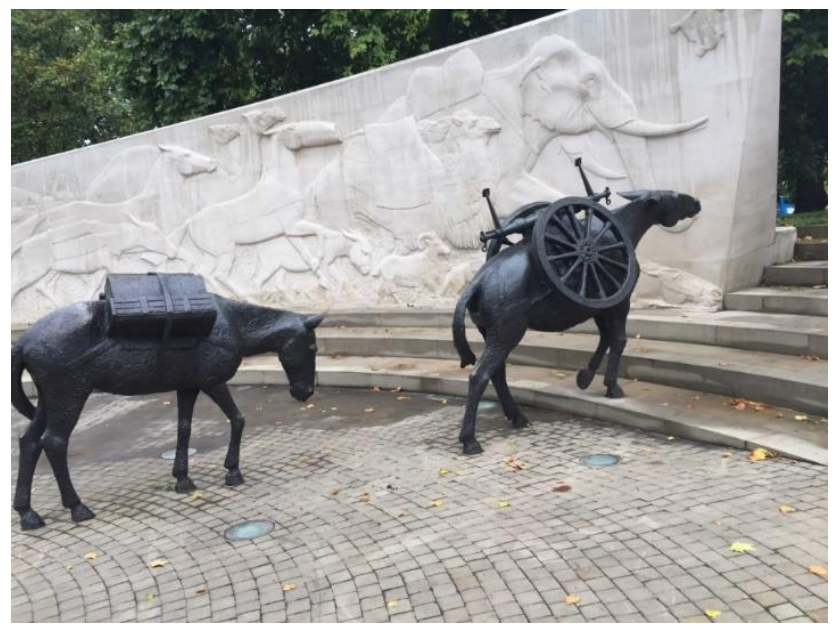

Photo 2 Bronze statue set in center of memorial; Photo: Jeanne R. Rice. Used with permission.

popular author Jilly Cooper, whose book Animals in War ignited the memorial project.

This combination of military and medical professionals, entrepreneurs, scientists, and

\footnotetext{
${ }^{1}$ Major General Davies was the chair of the Royal Society for the Prevention of Cruelty to Animals for over a decade (1991-2002), the Director General for the World Society of Protection of Animals (20022009), and remains chairman of the King's College Marjan Center for the Study of Conflict and Conservation. Cf. the Animals in War Memorial Fund website, which publicizes the history and funding of the monument: http://www.animalsinwar.org.uk/index.cfm?asset_id=1373
} 
journalists indicates the considerable intersectionality of concern and the study of military animals. The Animals in War Memorial is not solely a product of rising public concern and respect for service animals, nor is it unique to the $21^{\text {st }}$ century. However, it does represent a much broader understanding of the degree to which humans have depended, and continue to depend, on animals in the military sphere. Up

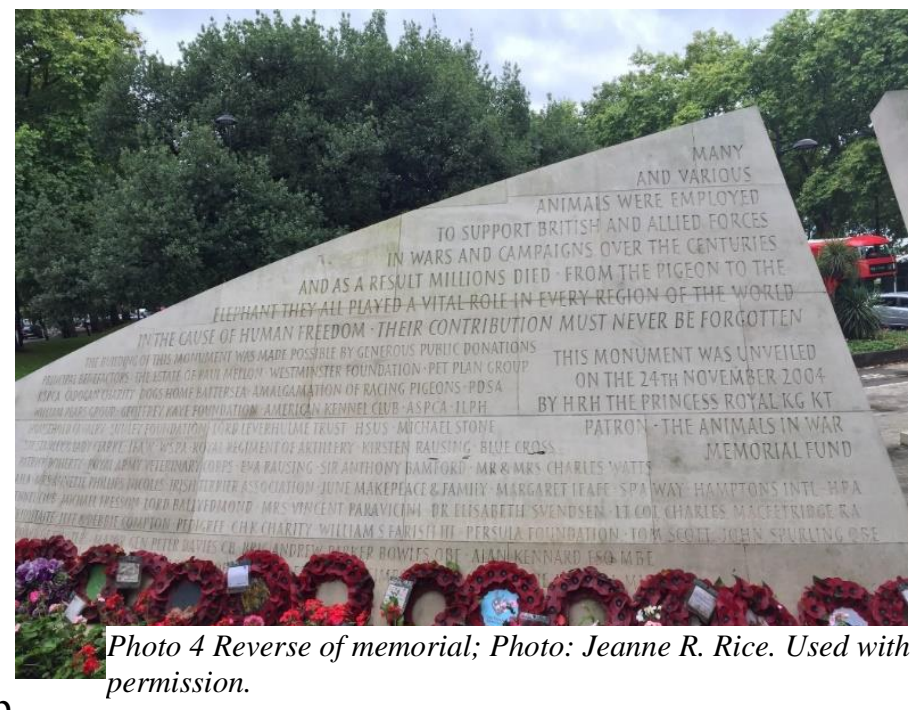
until very recently, waging war would have been unthinkable without the contributions of animals, and even today, in the age of nuclear weaponry and machine warfare, animals continue to be used to perform functions that neither humans, nor their machinery can. In light of this, human conflict of the past certainly cannot be studied or fully understood without due consideration being given to the non-human participants. However, because of the persistence of human exceptionalism, ${ }^{2}$ the extent to which animals impacted human experiences and events of the past has long been studied at a distance, if at all. The presence and roles of animals were often taken for granted and excluded from consideration. To a degree, this began to change with the emergence of ecological and environmental history in the mid twentieth century, and by the 1980s, animal-centered histories intruded on the more established field of social history. ${ }^{3}$ More

\footnotetext{
${ }^{2}$ See Walker (2013) for an excellent discussion of the problem of human exceptionalism within the field of history. Cf. Derr (2011), 82-83.

${ }^{3}$ See Shaw (2013a), 3-5. for a brief survey of the emergence of histories that considered the roles of nonhuman animals.
} 
recently, history has merged with an entirely new field, that of Human-Animal Studies (HAS), which makes the investigation of human-animal interactions its primary purpose and may be applied to myriad fields of study. HAS often investigates the social relationships between humans and other animals, implicitly recognizing the ability of non-human animals to act rationally and make decisions, even if these are not on par with the human intellect. Podberscek, Paul, and Serpell have noted the importance of this field when studying societies which, much like our own, have been "dependent on animals as sources of food, raw materials, companionship, and religious and artistic expression since the Paleolithic Period."

In the past several decades, HAS has overlapped with ancient history and classical studies, creating interest in the ways in which humans understood, shared space with, and interacted with animals in the ancient past. ${ }^{5}$ Such interest has encompassed the fields of ancient social, intellectual, and environmental history, but ancient military history has been largely left out. This seems a shocking omission in light of a long tradition of scholarly interest in both the strategic and social aspects of ancient military history.

However, a few notable works stand out as pioneers in HAS-ancient studies. While they will be discussed in greater detail throughout the dissertation, they merit mention here first. H.H. Scullard's 1974 study of elephants in the ancient world focuses on the use of these animals in combat by Macedonians, Carthaginians, and Romans, and relies on a combination of historical and scientific data to press home the argument that

\footnotetext{
${ }^{4}$ Anthony Podberscek, Elizabeth Paul, James Serpell (eds) (2000), Companion Animals \& Us: Exploring the Relationships Between People \& Pets, CUP, 2.

5 The examples are numerous, one may consider: Lewis and Llewellyn-Jones (2018); Fogen and Thomas (2017); Campbell (2014); Calder (2011); Osborne (2007), Snyder and Moore (eds) (2002); Brewer et al. (2001); Bodson, (2000); Podberscek et al. (2000); Mullin (1999).
} 
elephants revolutionized western combat. Although in Part I below I will argue that his conclusions are flawed, Scullard's study is an exceptional example of a scholarly foray into HAS before the terminology itself even emerged.

Donald Engels' 1978 study of Macedonian military logistics may focus on the expert planning of Alexander the Great during his Asian Campaign (334-323), but it is essentially a study of beasts of burden, especially the donkey, mule, and ox. Engels calculates weight-bearing capacity, endurance, and basic food requirements for the majority of species that Alexander utilized in his campaigns; the author contends that much of Alexander's route and timing hinged on his ability to re-supply his army at critical junctures of the campaign, a consideration which often came down to a study of burden-bearing animals.

More recently, Adrienne Mayor's 2003 study of bio-chemical warfare focused heavily on the role of animals in ancient armies, offering assessments of how animals were weaponized in antiquity. Although the study slides at times into sensationalism and perhaps overinterprets the role of war elephants as biological weapons, ${ }^{6}$ the essence of her argument is well-received. Animals played an integral role in ancient combat, and that role may be extended to animal parts (e.g. viper venom) and the objectification of living creatures (e.g. Hannibal's snake bombs; Nep. 23.10).

As HAS continues to expand within the broader fields of ancient history and classical studies, it is imperative to reflect upon animals' roles in combat and the military sphere in general. Ancient Greek poleis were martial cultures, and many of their social

\footnotetext{
${ }^{6}$ I agree with Van Wees (2004b), 280 that her assessment of elephants as biological weapons but exclusion of cavalry horses is curious. Perhaps the exotic nature of war elephants to westerners influenced her conclusions, but certainly the use of war horses constitutes as much a manipulation of natural forces as the use of war elephants.
} 
values (e.g. andreia, arete) were closely linked to the world of combat. Their literature and art were dominated by considerations of war, and the institution and practice of warfare was inextricably linked to Greek religion. The conscientious scholarly community should mine every facet of the ancient combat experience for details, and this extends to the non-human participants in battle, who played key roles in forming the landscape of the ancient Greek military sphere. It is this concern which catalyzed my dissertation research.

Following an examination of scholarly literature concerning military animals in the ancient Greek world, I determined that three animals in particular were either misunderstood in their function as war animals or simply ignored. Below I will argue that the elephant, camel, and dog merit re-evaluation in their roles as war animals, and each of the three is the subject of a separate case study with distinct conclusions. The fourth study is of the warhorse, which essentially acts as a control and standard for comparison, as it is the most often studied military animal of the ancient world.

My methodology varies by case study, shifting in response to the questions each study poses and the availability and quality of available evidence. However, the dissertation as a whole has been shaped in part by the work of Thorsten Fogen and Edmund Thomas (2017). In their edited volume, Interactions between Animals and Humans in Graeco-Roman Antiquity, they assert that their goal is to show:

\footnotetext{
"that animals and humans are interconnected on a variety of different levels and that their encounters and interactions often result from their belonging to the same structures, "networks" and communities or at least from finding themselves together in a certain setting, context, or environment-wittingly or unwittingly."7
}

\footnotetext{
${ }^{7}$ Fogen and Thomas (2017), 7.
} 
The authors view the past through the analytical lens of HAS by seeking to identify (1) the categories of interactions between humans and animals, (2) the contexts in which those interactions occur, and (3) the nature and quality of the evidence that can illuminate those interactions for us. ${ }^{8}$ In the case of my dissertation, categories (1) and (2) remain largely the same in each case study. The primary category of interaction between humans and the animal in question is martial, with additional categories including functional/utilitarian and emotional, where the categories of companion animal and war animal overlap. The context of the interactions studied is almost exclusively the military sphere, which may include battle, sieges, military marches, or military transport. In the case of elephants, as will be discussed in chapters 3-4, the military context merges with the political as the animals develop symbolic significance that extends beyond their tactical function on the battlefield. Of both of these categories, I ask the overarching question: how did these animals function in a military capacity? Have their roles been properly and fully represented in modern scholarship?

Category (3) is where the studies differ the most significantly, as the quantity and quality of the evidence limits the types of questions that can be asked. Limitations of evidence are the bane of all ancient historians, and in response to this I have found it most effective to cast a wide net, but to sift carefully through the contents. I have summarized this approach by category.

\section{Chronology}

This "wide net" approach includes a broad chronological spectrum, which ranges

${ }^{8}$ Ibid., 5. 
from the Archaic through Hellenistic Periods (c. 800-31 bce), inasmuch as is applicable. I consider evidence from such a broad timeline in order to amass as much as possible and evaluate the emergence of any general pattern of use, such as becomes apparent in the case of the dog in chapters 7-8. In the case of elephants and camels, however, we shall see that the Greeks and Macedonians had little to no contact with them until the late Classical Period, which naturally limits the study. However, context is key to piecing together a general picture of any military animal's function, and where appropriate I rely on archaeozoological evidence that predates the general chronological restriction above. Region

Due to considerations of time and space that accompany dissertation writing, I have restricted my study to the Greek and Macedonian world. This is not to say that nonGreek regions are ignored, but rather that my conclusions regarding the military roles of the animals under consideration are largely restricted to the Greek world. Indeed, the original cultural contexts of domestication of the elephant (Mesopotamia, India) and camel (Arabia, Bactria and Persia) are assessed carefully before a discussion of the Greek use of these animals begins, in order to understand which, if any, practices are borrowed. Types of Evidence

The subsequent case studies make use of a wide variety of evidence that extends beyond literary sources. Epigraphic, archaeological, archaeozoological, ecological, biological, and behavioral studies are all incorporated as needed in order to flesh out the often limited details of the historical narrative. Where possible, statements made by ancient sources or recent scholarship about the behavior or abilities of particular animals 
are checked against reliable scientific studies. ${ }^{9}$

\section{Format}

While the introduction of each case study will outline the goals and general questions asked, all studies will contain three sections intended to provide additional context for the animal in question. The issue of domestication of the elephant, camel, dog, and horse will be discussed first, along with a survey of the ancient Greek knowledge and understanding of said animal. The ancient Greeks lived much more closely with animals that humans do today, and their perceptions and knowledge of that animal's behavior and capabilities are key to understanding how those animals were employed in a military context. Similarly, the background to the domestication of the elephant, camel, dog, and horse informs our understanding of how the animals were initially expected to fit into human networks.

As a point of comparison, the non-Greek use of each animal in a military context will also be considered. This permits assessment of broader Mediterranean practices and is especially significant in cases where a non-indigenous animal is incorporated into a Greek army. Consideration of Egyptian, Assyrian, Persian, Arabian, Scythian, and Indian use of some of the above animals, as each case permits, will enhance our understanding of the context in which Greeks may have observed these animals functioning while also giving consistent structure to the dissertation. Ultimately, while the case studies are similarly structured, the nature of the evidence and the degree to which these animals have been evaluated thus far will impact the contours of the corresponding chapters. A

\footnotetext{
${ }^{9}$ Shaw (2013a), 9-11 considers some of the benefits and problems associated with the use of scientific studies within the field of history, noting that they can never be taken at "face value." For this reason, I attempt to present something of the nature of the studies I use (especially behavioral studies) alongside the results, in order to offer context to the reader.
} 
brief summary is warranted.

Part I of the dissertation contains chapters 1-4 and will re-assess the tactical value of elephants while providing new explanations for their use in Greco-Macedonian combat. Chapter 1 will introduce the reader to the role and significance of elephants in ancient Indian combat, as this is the context in which the Macedonians first encountered and learned how to use war elephants. Additionally, chapter 1 will provide a brief assessment of the types of elephants used in ancient Greek war and a review of ancient Greek knowledge of elephants before and after they were mainstays of warfare. Finally, the chapter will discuss the first Macedonian encounters with elephants during the eastern campaigns of Alexander while noting the tactical shortcomings of the animals.

Subsequently, Chapter 2 will investigate subsequent Hellenistic battles in which shortcomings evident at Hydaspes reappear time and again. The risks and deficiencies of elephant use in battle will be divided and analyzed by category, with the conclusion that elephants served most effectively against troops that were unfamiliar with them, when they were used as psychological weapons.

Next, Chapter 3 will consider why elephants continued to be employed in the context of war despite their shortcomings in battle. This chapter will show that the elephant's symbolic link to Alexander was used by many of his Diadochs throughout the Diadoch Wars to advertise their relationship with the late king and thus their legitimacy as successors to his empire. Further, chapter 3 will evaluate the methods and means by which some of the most prominent Successors used elephants to enhance their image as true heirs to the Macedonian conqueror. Chapter 4 will continue this evaluation down through subsequent generations of established Successor dynasties with a primary focus 
on the Seleucid and Ptolemaic ones. Here I will argue that as Alexander fell out of the equation, elephants became symbols of martial might, wealth, and royal power in their own right, spurring the Seleucids and Ptolemies to amass large elephant corps and deploy them in their numerous wars.

Part II will consider the military use of camels in response to Engels' (1978) study, which I will argue offered an incomplete and rather dismissive assessment of their unique capabilities. Chapter 5 will open with a discussion of the domestication of the camel in the non-Greek world while also surveying the relatively few extant sources on them. Subsequently the military and non-military functions of the camel in the Middle East and Persia will be considered in order to offer context for the adoption of these animals by the Macedonian army, which will be the subject of Chapter 6 . The chapter will conclude with a discussion of Greek knowledge of the camel, considering the difference before, and after, Alexander the Great's campaigns. Chapter 6 considers the Macedonian use of the camels from an historical and biological perspective in order to prove that their value, under certain environmental conditions, was greater than that of traditional Greek pack animals, contrary to Engels' conclusions. By fleshing out references in the Alexander historians (Diodorus, Plutarch, Curtius, and Arrian, here) with detailed considerations of physiological capabilities, chapter 6 will highlight the contributions of both the dromedary and Bactrian camel to Alexander's army. This chapter approaches the evidence chronologically and uses an extended biological case study to examine the historicity of the reports of Alexander's march to Siwah. It concludes that both species of Old World camel should be considered a form of environmental specialist forces within the already highly diverse and highly specialized 
Macedonian army of Alexander.

Part III contains chapters 7 and 8 and investigates the military dog. Because much has been written about the dog in antiquity, but very little about its military involvement, I contend that the ancient dog was just as likely to have served in a martial capacity as its modern equivalent and thus merits further study. Chapter 7 opens with a discussion of the domestication of the canine, a critical facet of the overarching argument that dogs are especially fit for military service because of their uniquely flexible cognition, which evolved alongside man's. Because the dog, unlike the elephant or camel, was not foreign to the Greek world, the social perception of the dog as a pet, companion, and pest, is briefly surveyed in order to understand the complex ancient view of "man's best friend."

Chapter 8 begins by illustrating the long history of the use of military dogs in the armies of Greece's neighbors. It proposes that the inflexible term "military dog" be expanded to connote any canine which participates in the military sphere, rather than simply signifying the equivalent of an attack dog. This chapter will explore recent research in the social cognition of dogs to explain how they were capable of performing complex functions with human guidance, and both modern military manuals as well as ancient Cynegetici will be used as points of reference. In chapter 8, I will assert that while the literary evidence of the dog's military function is more abundant from the middle Classical Period forward, depictions of dogs in the military sphere date back to the early Archaic Period. A survey and analysis of such Greek pottery will follow, supporting the conclusions that canines did participate in the military sphere, and their functions included tracking, guarding, and in a few rare cases, participating in battle.

Part IV contains chapters 9 and 10 and offers a survey of the ancient warhorse. 
The purpose of Part IV is both to illustrate the use of a familiar animal in the context of ancient combat as well as to highlight the degree of research that has already been done on Greek cavalry. Because the dissertation contends that more military animals merit deeper study, an explanation of what has already been completed is warranted, and the warhorse is the perfect example. Studies of ancient cavalry are numerous, and while the focus of study tends to be the behavior of humans (tactical, strategic, and social functions of cavalry and hippeus), everything from the domestication of the horse to the degree of force it projects in a cavalry charge has been the subject of historical inquiry. Chapter 9 offers a brief sketch of an abundance of scholarly literature detailing the domestication of the horse in Europe and the early Greek use of it as a chariot-puller and mount. This chapter will also illustrate the complex and numerous academic arguments regarding the stages of evolution of cavalry. Chapter 10 will discuss the better documented use of cavalry in the Classical through Hellenistic Periods, surveying the function and effectiveness of this branch of the ancient army. By drawing together numerous threads of historical research, chapter 10 allows us to deduce a general scholarly consensus that cavalry was never more effective in the Greek world than under Philip and Alexander. More importantly, I would contend, it reveals the degree of research and consideration given to the ancient horse's participation in the military sphere, something which is noticeably lacking in the field of HAS for many other military animals. By concluding the dissertation with this chapter, I hope to encourage further studies of non-human participants in war. While the abundance of evidence regarding the use of warhorses certainly surpasses that of any other animal, that should not impede study entirely. Rather, the extent to which these animals have been studied in a martial capacity should 
serve as a goal for additional research. In what follows, I will present my contribution to this goal, a careful study of three mis- or underrepresented animals that played a significant role in the practice of warfare in the ancient Greek world.

Notes

All dates in the following chapters are b.c.e. unless otherwise noted.

I have attempted to follow general patterns of Anglicization in my presentation of Greek words and names, except where specific terminology is needed, in which case the word is italicized. Certain exceptions were inevitable, e.g. the Stoa Poikile rather than Poicile. All English translations of ancient Greek and Latin sources are from the Loeb Classical Library, unless otherwise noted.

My use of the adjective and noun "Greek" is meant to encompass Greek, Macedonian, and Epirote. ${ }^{10}$

The images in Appendix 1 are under copyright by numerous museums, and therefore only the captions will appear in the published form of the dissertation. The print copies, intended only for the use of the Dissertation Committee, will contain all photos as well as captions.

\footnotetext{
${ }^{10}$ Regarding the debate over whether ancient Macedonians were truly "Greeks" and the modern political
} implications of Macedonian identity, see Errington (1990). 
Part I: Elephants 


\section{Introduction}

In 326, the army of Alexander the Great met and defeated the Indian king Porus on the plains of the Hydaspes River. This was the first time the Macedonians had faced a significantly large elephant corps, ${ }^{11}$ and the grisly and horrifying means by which these animals destroyed their enemies are preserved in great detail by some of the ancient authors.

\footnotetext{
"Some of the Macedonians were trodden under foot, armour and all, by the beasts and died, their bones crushed. Others were caught up by the elephants' trunks and, lifted on high, were dashed back down to the ground again, dying a fearful death. Many soldiers were pierced through by the tusks and died instantly, run through the whole body" (Diod.17.88.1).

"The brutes caused great terror, and their trumpeting not only threw into confusion the horses...but also the men and the ranks" (Curt.8.14.23).

"But some, who pursued the elephants too eagerly, so irritated them by wounds that they turned upon them. Hence, being trampled under foot, they served to the rest as a lesson to attack with greater caution. It was a particularly awful spectacle when with their trunks they seized men and their weapons and passed them over their heads to the drivers" (Curt.8.14.26-27).

"Driven senseless by their misery, [the elephants] attack friends and foes alike, and thrust themselves in all directions, trampling and killing" (Arr.Anab. 5.17.6).
}

These were fearsome animals and portrayed, at least initially, as an asset to Porus' men, who, when hard-pressed by the Macedonian cavalry, fell back to their mighty elephants, "as if to some friendly wall” (Arr. Anab.5.17.2). But appearances are deceiving.

The gruesome depictions of a large elephant corps in action have impacted the way modern scholars reconstruct battles during the Diadoch Wars. Because more detail exists for the battle of Hydaspes than any of the battles fought by the Successors, one is obliged to fill in the gaps with details from Hydaspes, but one must do so cautiously. The vivid and terrifying detail with which Porus' elephants are described implies that elephant

\footnotetext{
${ }^{11}$ The plausible presence of 15 elephants at Gaugamela in 331 (Arr.Anab. 3.8.6) cannot be compared to the considerable forces under Porus' command at Hydaspes ( Diod. 17.87.1-17.89.3; Curt. 8.13.5-8.14.46; Arr.Anab.5.9.1-5.19.3).
} 
strength, if properly harnessed, would play a significant or even decisive role in battle. This is not consistent with the extant descriptions of elephant maneuvers during the Diadoch Wars. Although they are iconic aspects of Hellenistic battle and figure prominently in the scanty narrative history of the wars between Alexander the Great's Successors, it is their perceived and psychological effects that often overshadow the comparatively limited tactical benefit these animals brought to the battlefield. Grouped by Sabin into the "exotic" weapons category of the Hellenistic age, they are most often described by sources with the stress laid on "the terrifying sights, sounds and smells which they created." 12 Perhaps as a result of such accounts, they have been long associated with a revolution in Greek warfare, significant enough to turn the tide of battle when two armies are otherwise evenly matched. ${ }^{13}$ H.H. Scullard's 1974 The Elephant in the Greek and Roman World set the stage for viewing elephants in Hellenistic war as the equivalent of the early tank during the Great War. Scullard argues that they were powerful, intimidating, and with a bit of fine-tuning they could make a massive difference in the outcome of a battle. For years, his was the only complete scholarly study of elephants' involvement in Diadoch War battles. Subsequently, Kistler's 2006 study of war elephants revived Scullard's perspective and re-emphasized the tactical utility of the war elephant, claiming that even Alexander "had big plans" 14 for them, had he only lived long enough to realize them (cf. p.47).

In the 1940s, and again more recently, elephants' effectiveness in battle has been questioned or dealt with ambiguously, but not thoroughly studied with a view to tactical

\footnotetext{
12 Sabin (2007) 421.

${ }^{13}$ E.g. Fuller (1945), 32; Scullard (1974) in general privileges the role of elephants, esp. pp. 64-147 in his coverage of Alexander's Successors.

${ }^{14}$ Kistler (2006), 39.
} 
efficiency. ${ }^{15}$ Initially, Glover (1944) made the argument that elephants were not especially useful in the field because of the way that Macedonian armies used them, although he gives a nod to the successful employment of their psychological shock value. ${ }^{16}$ By failing to mass elephants together on the wings, ${ }^{17}$ generals lost the effectiveness of elephants. While Glover marvels at this military tendency "to have a little of something everywhere," ${ }^{18}$ he condemns it as relatively useless for defensive and offensive purposes, championing the value of massed elephant attacks on the wings. However, as we shall see, this was not especially effective either. Ultimately, Glover concludes that cost had nothing to do with the elimination of the elephant corps from ancient battlefields, as the Romans could have managed this, had they wanted. Rather, he credits the Romans with recognizing the inutility of the elephants on the fields while the Diadochs took longer to reach this decision. Thus Glover concludes that "for the more serious purposes of war, the elephant was not worth the trouble. He was troublesome to feed, troublesome to move... he became quite unmanageable; and this is the reason for his disappearance from the battlefield." ${ }^{19}$ This comment is incorrect on two levels, which we shall discuss in the subsequent few chapters.

First, the elephant did not become unmanageable; from the first moment the Macedonians encountered this animal in battle, its tendency to stampede through the lines of men deploying it was noted and used to Alexander's advantage. The risks of deploying

\footnotetext{
${ }^{15}$ Glover (1944), 261-263, 265-266, (1948), esp. pp.10-11 ; Epplett (2007), 221 distinguishes between tactical and "perceived" value of war elephants . Other scholars have at least mentioned the detrimental effects of elephant use in battle, including (but not limited to) e.g. Fischer-Bovet (2014), 153; Waterfield (2011) 24-5; Sabin (2007) 420-1; Bar-Kochva (1976); 75-83; Adcock (1957) 55-6.

${ }^{16}$ Glover (1944), 159-160.

${ }^{17}$ Ibid., 162-163.

${ }^{18}$ Ibid.

${ }^{19}$ Glover (1948), 11.
} 
the elephant were quite well known. Second, Glover's acknowledgement that elephants ceased to be used in war "at the decline of the Hellenistic kingdoms" 20 indicates the animal's relative inutility was not simply "realized." The war elephant was deployed down through the middle of the second century; it would not have taken nearly 200 years for generals to realize that elephants were not "worth the trouble." Something else was at work.

Since Glover, other scholars have hinted at problematic aspects of elephant warfare, but no thorough study pursuing his suspicion of their utility has been done. Some scholars have noted the risk of using elephants in battle and the frequency with which they do damage to their own side. ${ }^{21}$ Epplett distinguishes between tactical and "perceived" value of war elephants, a nod to the psychological power of an elephant corps and their limited tactical impact. ${ }^{22}$ Fischer-Bovet notes more specifically that elephants "never played a significant role in achieving a victory when both armies used them" 23 in a land battle, as they would only butt heads with one another, useless against the opposing phalanx and less than frightening to the opposing cavalry, which had been trained to work with elephants. I argue that we must take Fischer-Bovet's assessment one step further. In Hellenistic battles elephants were in fact not effective, but at best provided a friendly bulwark that allowed the key units of an army to make a decisive blow, and at worst, posed a serious threat to the good order and physical safety of their own side, as I will prove in chapters one and two.

This conclusion begs the question why. Why would the Successors have gone to

\footnotetext{
${ }^{20}$ Ibid., 10.

${ }^{21}$ Waterfield (2014) 24-5; Sabin (2007) 420-1; Bar-Kochva (1976); 75-83; Adcock (1957) 55-6.

${ }^{22}$ Epplett (2007), 221.

${ }^{23}$ Fischer-Bovet (2014) 153.
} 
such efforts to maintain and even enhance their elephant corps? Further, why did the Seleucids and Ptolemies maintain elephant corps as late as the 140s? These are two distinct questions about two very different eras. Accordingly, I propose two answers which take into consideration the political climate in the age of the first generation of Diadochs (322-281), during which time the generals-turned-kings' legitimacy was constantly in question, as well as the subsequent generations, who were born kings. ${ }^{24}$ Alexander's Successors, all experienced military men, would never have run the substantial risk of employing elephants without the expectation of reward. While this came occasionally in the psychological impact the animals made on the enemy, the primary value of elephants was symbolic and propagandistic. Elephants became inextricably linked with Alexander and his far-reaching campaigns. Possession of these animals was a powerful political tool used to advertise the legitimacy of any generalturned-satrap who owned them. And almost every vying Successor did. The Diadochs' manipulation of the animal in battle, public displays, and especially on state-controlled images like coins, highlighted their close affiliation with Alexander, who had bested the animals in battle in India. As I shall show, there is a direct correlation between the military aggression of certain Diadochs and the circulation of images that emphasize their closeness to Alexander and are suggestive, through the presentation of the elephant, of a shared royal status. Eventually, the elephant became a symbolic both of Alexander and also of victory.

It is in this respect that the use of the elephant was passed on to later generations, who no longer needed Alexander as a touchstone for legitimacy. Born kings, the

\footnotetext{
${ }^{24}$ Fleischer (1996), 31 notes this distinction in e.g. numismatics especially, pointing out a clear shift in
} royal portraiture by the second generation of Successors. 
Epigonoi maintained elephant corps in order to advertise the breadth of their power and depth of their pockets. The animal had become an emblem of royalty and a source of significant competition between the Seleucids and Ptolemies, both of which went to great lengths to augment their pachyderm forces. The competition between them to amass elephant armies was dubbed an "arms race," 25 but it had value in the political and economic world as well. Maintaining an elephant corps cost money, and augmenting it either through trade or conquest, required extensive financial and military resources. The animals' value was so great that both dynasties went to extreme lengths to acquire them. The Seleucids campaigned as far East as India, receiving elephants as tribute or, by the time of Antiochus III, by right of conquest, and they maintained a heavily populated breeding center in Apameia to augment their elephant corps. The Ptolemies created extensive trade networks along the Erythraean coast and developed transportation and training infrastructure to acquire, move, and tame wild African forest elephants. Additionally, a combination of coinage and statuary combined with literary accounts of elephants on parade prove that the animals were symbolically significant well after the immediate need to tie a Hellenistic dynasty to Alexander had faded.

Ultimately, the Successors' reasons for maintaining elephants were not purely tactical, but also linked to legitimacy, psychological weapons, and military competition, but as the animals came to be associated with kingship beyond Alexander, they were maintained by later generations for the status they conferred. As we shall see, in Hellenistic warfare, a battle between kings was not only a military conflict, but a

${ }^{25}$ Spinage (1994), 265. 
presentation of a nation's strength, and elephants came to embody the East, the martial success, power, wealth, and extensive resources of emerging Hellenistic dynasts. ${ }^{26}$

${ }^{26}$ Cf. Kosmin (2013), 104-109. 


\section{Chapter 1: Indian Elephants \& the Greeks}

Because we will soon consider the devastating shortcomings of the elephant in Greco-Macedonian warfare, it is pertinent to examine first why and how the animals were used in Indian warfare, and how much the Classical Greeks knew about elephants before Alexander's campaigns.

\section{Part A: Elephants in Indian Warfare}

Details of elephant deployment in Indian pitched battle may be found in religious Vedic literature, Buddhist literature like the Nikayas and Vinaya, and Indian epics like the Mahabharata and Ramayana. Although many of these works speak of the mythical past, the point at which they were written down helps scholars to understand what pitched battle looked like in India. ${ }^{27}$

The four Vedas (the Rig Veda, Sama Veda, Yajur Veda, and Atharva Veda), were composed over time between the $16^{\text {th }}$ and $11^{\text {th }}$ centuries in northwestern India and modern-day Pakistan. They survived by being passed down orally, much like the works of Homer, which would naturally allow for some innovation in transmission. Of the four, the Rig Veda is the most significant and the longest, divided into ten mandalas, or volumes, which record a number of mythical and foundation stories. In the Rig Veda, elephants appear as objects of wealth and admiration, and it was during the Vedic Period (roughly 1500-1000) that Indians first began capturing, training, and domesticating

${ }^{27}$ Singh (1965), 2. 
elephants. ${ }^{28}$ Although no explicit description of the deployment of elephants in pitched battles exists in the Vedas, numerous allusions to the capture, taming, and training of elephants, as well as reference to an hastipa, or "elephant-keeper" in the Yajur Veda are suggestive. ${ }^{29}$ Singh theorizes that an obscure passage in the Rig Veda that mentions an elephant smiting its foe might be the earliest Indian reference to elephants in war, although he concedes that the Vedic Aryans were best known for their chariotry, an element of war that predated elephant use, even though it was retained as elephants were adopted into the armies of kings. ${ }^{30}$ Singh notes in particular that the elephant serves as the fire-god Agni's mount as he marches to war, and thus the elephant "makes its debut as a royal mount in the Vedic literature; and if the context proves anything, the venue is the field of battle." ${ }^{31}$ This is of course not reference to the deployment of an elephant corps or the use of elephants by mortals, although the association is significant.

However, the early presence of trained Indian elephants ridden by man is attested by the archaeological and epigraphic record not only in India, but in Mesopotamia, Egypt, and Syria. A plaque of an Indian elephant being ridden by a human figure was found in southern Mesopotamia and dates to the late $3^{\text {rd }}$ millennium, indicating domestication and training, if not military use, of elephants. The Pharaoh Thutmose II received elephants as tribute from the Syrians, and Thutmose III was known to hunt elephants. This indicates the presence of elephants in western Asia (it is well known that they lived in NE Africa) at an early date, and Singh theorizes they were transported from

\footnotetext{
${ }^{28}$ Singh (1965), 73ff. Gethin (1998), 12 puts the date of composition at the earliest extreme of Singh's range, the fifteenth century.

${ }^{29}$ VS 30.2, Singh (1965), 77.

${ }^{30}$ Rig Veda 9.57.3, Sing (1965), 76; on chariots see Singh (1965), 23-52 and Pant (1997), 89.

${ }^{31}$ Singh (1965), 76.
} 
India. The $12^{\text {th }}$ century Assyrian king Tiglath Pileser I was also known to hunt elephants and capture them near the Euphrates. These were undoubtedly Indian elephants as well, and the archaeozoological record shows that wild Indian elephants abounded in Asia before being overhunted. ${ }^{32}$ In light of such a long pedigree of domestication, it is highly likely that Vedic Period Aryans might have employed the animals in the military sphere.

Ancient Aryan battle tactics often focused on their most powerful branch of the army, the chariotry, but it is far from impossible that elephants played an early role as well. What is known is that by the $6^{\text {th }}$ century elephants had been fully incorporated into the ranks of Indian armies. The Sama Vidhana Brahmana, one of the works attached to the Vedas much later in the $6^{\text {th }}$ century, does reference elephants as part of the quintessential "four-fold army." "33 In later periods, the evidence is clearer yet. Buddhist religious texts, such as the Nikayas and Vinaya, place elephants explicitly within the context of battle, often mounted by kings. Standardized upon the Buddha Gautama's death c. $400,{ }^{34}$ these Buddhist texts reveal significant details about the esteem in which elephants were held as well as the rigorous training process a military elephant had to undergo. For example, a passage in in the Majjhima Nikaya illustrates the great skill an elephant rider was expected to have when the Buddha asks Prince Bodhi whether he is skilled at using a goad and riding on an elephant. The Buddha anticipates an answer in

\footnotetext{
${ }^{32}$ Ibid., 72-74; on early elephant population distribution see Sukumar (1992), 2-3; on elephant population shifts see Spinage (1994), 24-40.

${ }^{33}$ Sama Vidhana Brahmana 3.6.11; Pant (1997), 89; Sing (1965), 35.

${ }^{34}$ The exact date of the Nikayas and Vinaya is much debated, although it is generally agreed that a standardized format emerged upon the Buddha Gautama's (i.e. the Buddha) death at the end of the fifth century, during the First Buddhist Council, or samgiti. The Nikayas and Vinaya are considered "the authoritative word of the Buddha" (Gethin [1998], 44) and were passed down orally from teacher to student for generations. The mass production of texts (many of which can be found digitized) is a product of the twentieth and twenty-first century and augmented western interest in traditional Buddhist teachings. Cf. Gethin (1998), 39ff. on the textual tradition and translation of Buddhist texts.
} 
the affirmative in order to parallel the difficult learned skill set of elephant riding with a lifetime of self-denial. ${ }^{35}$

In addition to the training a human must undergo to learn how to command an elephant in battle, the Majjhima Nikaya also details the hardships the elephant had to endure to become fit for a king's army. An elephant in training had to "practice" for battle by being surrounded and mounted by men with lances, the noisy clashing of drums, the blare of the conch shell, and constant abuse by bladed and blunt weapons like axes and arrows. ${ }^{36}$ This form of training sounds more like torture, and it emphasizes how deeply concerned Indian elephant trainers were with preparing the animal for any eventuality. The tests war elephants underwent included both the physical element of being harassed and potentially lacerated by weapons, and also the psychological, by being surrounded by soldiers and having their senses assaulted by chaotic noise. A detailed description of the cacophony of battle appears in the late fifth century epic poem

\section{Mahabharata:}

"Sanjaya said, "On the forenoon of that awful day, O king, the terrible battle that mangled the bodies of (so many) kings commenced. And the loud shouts, resembling leonine roars of the Kurus and the Srinjayas, both desirous of victory in battle... a tumultuous uproar was heard mingled with the flaps of leathern fences and the blare of conches. And many were the leonine roars that rose there of men shouting against one another. And, $\mathrm{O}$ bull of Bharata's race, the sound of bowstrings stretched by (hands cased in) fences, the heavy tread of infantry, the furious neigh of chargers, the falling of sticks and iron hooks (on the beads of elephants), the clash of weapons, the jingle of bells of elephants rushing against one another, and the clatter of cars resembling the roar of clouds, mingled together, produced a loud uproar making one's hair stand on end." ${ }^{37}$

Because of the sensorial chaos that accompanied battle, Singh notes that a king's elephant was expected to "endure frightening sights, sounds, smells, tastes, and touches"

\footnotetext{
${ }^{35}$ Majjhima Nikaya 2.94-95.

${ }^{36}$ Ibid., 1.175-178; this appears in Curtius' account of Hydaspes as well, when he notes that Porus' elephants were untroubled by the blasting of horns because they had been trained to endure it $(8.14 .10-11)$.

${ }^{37}$ Mhb. 6.45, trans. Kisari Mohan Ganguli $(1883,1896)$.
} 
in battle, and "like burnished gold purged of all its dross" the elephant thus became "a kingly attribute." 38 Pant, too, praises the versatility of the elephant: "as a royal insignia, as a loyal friend, as an intelligent animal and as a trampling force an elephant was par excellence," 39 and yet, he recognizes their shortcomings even in the context of Indian warfare. If wounded, elephants tended to retreat, performing their trampling act on the wrong forces at great cost. The brutal gauntlet referenced in the Majjhima Nikaya indicates that Indians were well aware of the potential havoc an injured elephant could wreak on an army, and the king's mount, above all, needed to be stalwart enough to face down enemy infantry, cavalry, and chariots.

The Indian epics Mahabharata and Ramayana, which were brought into their final form in the late fifth or early fourth century, provide more chronologically relevant details about elephant battle participation, however they should be approached with caution. Singh notes that while elephants were certainly useful for armies in fording rivers, clearing a marching path, and battering down walls, their astounding deeds in Hindu epic are much exaggerated. Singh believes that the Indians were "cognizant of the use of the elephant in war though skeptical of its value."40 The animal's nonetheless significant role in battle, for which it was often heavily armed, armored, and decorated, indicates its symbolic power even if the elephant "frequently became ungovernable when wounded, and caused more damage than good." ${ }^{41}$ Indeed, the players of the epic Mahabharata generally seem to recognize this, and when their supporting force is destroyed, many kings flee their elephants in order to escape, permitting Arjuna to kill

\footnotetext{
${ }^{38}$ Majjima Nikaya 3.132-133; Singh (1965), 79

${ }^{39}$ Pant (1997), 87.

${ }^{40}$ Singh (1965), 84.

${ }^{41}$ Ibid.
} 
one with a single iron bolt from his arrow. ${ }^{42}$ While a single arrow could not kill an elephant (except, perhaps if fired by a son of Indra), their potential vulnerability is an historical reality. The epic highlights some of the precautions historical actors may have taken to protect their elephants. For example, elephants do appear to have been at least in part shielded from attack by supporting forces. In the Mahabharata, Prince Vikarna charges Arjuna on an elephant supported by four chariots. When Abhimanyu slaughters enemy elephants, he does not spare the foot-soldiers set to protect the elephants' rear. ${ }^{43}$ Similarly, the battle between Arjuna and Bhishma, who leads the enemy army of Duryodhana, is depicted in the second and third portion of the sixth book of the Mahabharata, and there references men assigned to protect elephants:

\footnotetext{
"The foot-soldiers that protected the elephants, endowed with broad chests, and capable of smiting effectually, with wrath excited, and armed with pikes and bows, and bright battle-axes, and with maces and clubs, and short arrows, and lances, and with shafts, and stout bludgeons mounted with iron spikes and swords, well-grasped of the brightest polish, ran hither and thither, $\mathrm{O}$ king, and seemed resolved to take one another's life." 44
}

Pant points to the Vinaya Pitaka, an earlier Buddhist treatise which claims that 12 men accompany an elephant in war: four on its back, two watching each foot. ${ }^{45}$ The third century Arthashastra of Kautilya mentions a recommended minimum of 15 attendants per elephant and chariot (10.5). Pant rightly notes that Porus' elephant army was defeated by Alexander's men when they quickly realized the Indian soldiers guarding the elephants were better targets than the elephants themselves; after slaughtering the human guards, the elephants were easy to set running back through the Indian lines. ${ }^{46}$ This was due in some part to the fact that elephants were unable to advance very far against the

\footnotetext{
${ }^{42}$ Mhb. 4.60.8; Singh (1965), 83.

${ }^{43}$ Singh (1965), 81-84.

${ }^{44}$ Mhb. 6.46.

${ }^{45}$ Cf. Ael.HA 13.10 who notes that three rode an elephant and does not mention attendants.

${ }^{46}$ Pant (1997), 91-93.
} 
Macedonian phalanx, whose front ranks bristled with sarissae that jutted out a great distance from the soldiers themselves (Arr.5.17.3-6). Macedonian weaponry differed considerably from the type of fluid, close-contact fighting described in the Indian epics and so made defeat of the animals much easier. Porus' elephant riders were unable to control the animals once they were injured. The special Indian infantry meant to protect the elephants could be armed with a vast array of implements, including spears and swords, bows, and heavier items like clubs, axes, and maces. ${ }^{47}$ Once that supported vanished, elephants were at the mercy of the mounted warriors who can outpace them and harass them from all sides.

In light of this, it is unsurprising that the epic's description of elephant deployment suggests that they were sent out in a line, but never strung thinly out or in total isolation. They were intended to "give stability to the army, to support and cover its flanks, and to maintain links between the centre and the wings." 48 Indeed, this is how Porus used his elephants at Hydaspes in 326, who were posted not more than 100 feet apart from one another, but also not closely packed (Arr.5.15.5). While Porus does not appear to have used chariots to support his elephants, he does clearly use infantry, filling the gaps between the elephants with heavily armed foot soldiers (Arr.5.15.6, 5.16.2) the same way in which Glover claims the Macedonians did in error. ${ }^{49}$ Arrian emphasizes that Porus never expected Alexander's infantry would dare thrust itself within the narrow spaces between the advancing elephants (Arr.5.15.6), and indeed they would not have been able to without the sarissa, which put a healthy distance between the bristling

\footnotetext{
${ }^{47}$ Singh (1965), 83, citing Mhb.6.44.13-15, see also Pant (1997), 90-91.

${ }^{48}$ Singh (1965), 82.

${ }^{49}$ Glover (1948), 6.
} 
Macedonian phalanx and the elephants.

Pant outlines the three services of an Indian war elephant as follows: "a moving wall in attack at the outset of the battle, as a standing wall in defense and thirdly, as individual foragers through the confused crowd of blood-seeking desperadoes." $" 50$ The Mahabharata suggests a certain code of conduct when bringing elephants into the fray,

"Then the Kurus, the Pandavas, and the Somakas made certain covenants, and settled the rules, O bull of Bharata's race, regarding the different kinds of combat. Persons equally circumstanced must encounter each other, fighting fairly. And if having fought fairly the combatants withdraw (without fear of molestation), even that would be gratifying to us. Those who engaged in contests of words should be fought against with words. Those that left the ranks should never be slain. A car-warrior should have a car-warrior for his antagonist; he on the neck of an elephant should have a similar combatant for his foe; a horse should be met by a horse, and a foot-soldier, O Bharata; should be met by a foot-soldier." ${ }^{51}$

Singh rightly dismisses such a covenant as "noble but impracticable,"52 noting that the epic itself frequently cites clashes between elephants and charioteers, knights, and infantry.

The Ramayana, whose earliest known written text dates to the $5^{\text {th }}$ century, provides additional details of elephant armor, decoration, and display the animals' psychological and symbolic significance. Written in Sanskrit verse, the epic details the travels of the prince Rama as he is exiled and then returns to his homeland, Ayodhya. The text presents idealized versions of kingship and occasionally offers philosophical and ethical tangents. Elephants feature largely in this work, as Ayodhya, of which Rama is rightful ruler, is filled with elephants, but so is Lanka, the enemy territory of the prince Ravana, whose elephants were superior and well capable of killing their enemies in

\footnotetext{
${ }^{50}$ Pant (1997), 90.

${ }^{51}$ Mhb.6.1, translated by Ganguli (1883-1896).

${ }^{52}$ Singh (1965), 83.
} 
battle. ${ }^{53}$ In the Ramayana, elephants are a key part of the "four-fold army" $" 54$ and are heavily adorned. Pant points to some of the most notable passages containing descriptions of elephants' war gear, much of which appears to have been ceremonial in order to intimidate the enemy. And indeed, Rama was disturbed by Ravana's display of force, his elephants decorated in pennants, standards, and canopies, mountain-sized and armed with everything from clubs, which they wielded in their trunks, to darts, swords, and missiles ${ }^{55}$ Clearly the visual of elephants decked out in battle glory was at least as intimidating as looking at the glistening armor of an army.

Perhaps the most iconic item of elephant decoration was the howdah, the tented seat where the elephant driver, and perhaps an archer or two, would sit. Howdahs are reported in use at least as early as the $5^{\text {th }}$ century, as the Ramayana mentions a type of howdah called a vimana. The Mahabharata records a different type of howdah, the padma, which Pant translates to an 'eight-cornered saddle,' or type of howdah. ${ }^{56}$ Along with their tusks, elephants were given iron harnesses and spikes, and metal armor is described as well. The famous trunk armor of the Mughal Period is likely not ancient due to the degree of specialized metallurgy needed to produce it. Additionally, a standardized name for such armor, the pakhar, does not appear until that period. ${ }^{57}$ Wool or goat-hair blankets were also used - these must have been a secondary form of armor or to prevent the howdah from digging into the elephant, as Indian climate would make any covering for the sake of warmth unnecessary. It is worth noting that the appearance of the elephant

\footnotetext{
${ }^{53}$ Ram. Book V [Sundar-Kanda], Canto 6, Line 31-33.

${ }^{54}$ Pant (1997) 89-91, see for e.g. Ramayana Book I, Canto XXII; Book II Canto LI, Canto LXXXVI.

55 Pant (1997), 89, see Ram. Kalyana-Kalpataru Canto 53, Line 10-11, ibid., Canto 59, line 12

56 See Pant (1997), 107. Depictions of howdahs from the 5th century BCE onward on pp. 107-111; the imari, or canopied turret, is described on p.111-12

${ }^{57}$ Pant (1997), 113 see also pl. LIX figs 82-85.
} 
played a significant role in the battle - a tactic that the Macedonians readily adopted. This was psychological to be sure, but likely also tied to status. Elephants were decked out in gold with gilded tusks, gold netting, and elaborate bell harnesses that could include one, three, or multiple bells. Indeed, charging into battle with "bells ringing" seems to be a key facet of the elephant's ability to produce terror in their opponents. ${ }^{58}$ The sum total of practical and decorative additions to the four-fold army is described in the Mahabarata:

"With sixty thousand cars and ten thousand elephants, the ruler of the Kalingas, accompanied by Ketumat, went out. His huge elephants, looking like hills, and adorned with yantras ${ }^{59}$ lances, quivers and standards, looked exceedingly beautiful." 60

Putting aside the clearly mythical number of elephants depicted in the epic, this intimidating description of a well-adorned elephant corps perhaps has echoes in some of the Greek accounts of Hydaspes: "[Porus'] whole array looked very much like a city, for the elephants resembled towers, and the soldiers between them curtain walls.",61

As we shall see, the Macedonians adopted the custom of using elephants in war from the Indians with few if any modifications to suit their own unique style of combat. The fact that Indians did not fight in phalanx formation or use sarissae would prove problematic, as would the lack of highly mobile elephant support, like the charioteers of the four-fold army. Unfortunately for the Macedonians, borrowing a mode of warfare that developed organically in response to Indian culture, terrain, and environment would prove especially challenging.

\footnotetext{
${ }^{58}$ See Mhb. 6.17, 6.43.5; Singh (1965), 83; Pant (1997), 107-117.

${ }^{59}$ Yantras refer to a sort of machinery, potentially a catapult. See Singh (1965), 112-113.

${ }^{60}$ Mhb. 6.17 trans. Ganguli.

${ }^{61}$ Diod.17.87.2; the same comparison is made by Curt.8.14.13.
} 


\section{Part B - Elephants and the Ancient Greeks}

Now that we have context for elephants in Indian culture, where the Greeks and Macedonians first encountered them, it is necessary to consider what knowledge the Greek-speaking world possessed of elephants before, and after, Alexander's campaigns. We should begin with the basics. In antiquity and the present day, only two genera of elephants are known: the African elephant (Loxodonta Africana) and the Indian elephant (Elephas maximus) [Image 1.1]. Of the former genus, there are two species: the Loxodonta Africana Africana [Image 1.2] and Loxodonta Africana cyclotis [Image 1.3], commonly referred to as the African bush elephant and the African forest elephant, respectively. Because ancient writers consistently refer to the Indian elephant as larger than its African counterpart, Scullard has convincingly shown that the Loxodonta Africana cyclotis, the forest elephant, was the only African elephant that the ancients knew of and utilized, as the bush elephant is indisputably larger than the Indian. ${ }^{62}$

Beyond size, the two genera of elephants are readily distinguishable by other characteristics. The Indian elephant has shorter, smaller ears and a convex back, and the smaller forest elephant has long ears and a concave back. ${ }^{63}$ These physiological distinctions did not escape ancient artists, whose portrayals of elephants are detailed enough that the genus can be distinguished. Scullard's investigation of elephants illustrates this well with a collection of photos. The elephant medallions minted by

\footnotetext{
${ }^{62}$ Scullard (1974) 24, 60ff. On the change in this elephant's habitat and distribution in Africa since antiquity, see pp. 24-31. Charles (2008), $338 \mathrm{n} .2$ accepts Scullard's theory and applies it to Hannibal's African elephants as well.

${ }^{63}$ In general on African elephants see Spinage (1994), 24-32; on the Asian (Indian) elephant see 33-40; Sukumar, an expert zoologist of the Asian elephant, has published a treatise on ecological management of elephants (1992) and a more general study of the species (1994), both of which are excellent sources for introductory biological information as well as some of the outstanding questions in the field, including the on-going epidemic of ivory poaching.
} 
Alexander reveal on the obverse what are clearly Indian elephants, recognizable not simply by context, but by their short ears and convex backs [Images 1.4-1.5]. The same physiological features appear accurately on the coinage of Seleucus, Ptolemy, and Antiochus III [Images 1.6-1.8]. Conversely, the concave back and long, wide ears of the African (forest) elephant are accurately depicted in a third century b.c.e. tomb at Marissa in Judea and on an abundance of Roman mosaics. ${ }^{64}$ Additionally, the Indian was considered more ferocious in battle, and Polybius' account of Raphia strongly indicates that the majority of third century Ptolemaic elephants were African forest elephants. As Charles' careful evaluation of Polybius' description has revealed, Ptolemy's forest elephants were both too small to carry turrets and frightened by the larger Indian elephants in battle to the point that they ran away. ${ }^{65}$ Turret-bearing elephants were certainly not used earlier than Pyrrhus' invasion of Italy, and they will be discussed below. ${ }^{66}$

Indian elephants were the first with which the Greeks came into contact, and they were the core of the Diadochs' elephant corps until the reign of Ptolemy II, who began the practice of elephant wrangling in the Sudan, bringing African elephants into his army. ${ }^{67}$ Between the reign of Alexander the Great and the end of his Successors' wars, Indian elephants had been incorporated into the armies of several Hellenic kings and were deployed regularly in pitched battle. They were kept, if not deployed, by numerous

\footnotetext{
${ }^{64}$ Scullard (1974) has conveniently collected these images in his work and explained the genus identity of the elephants depicted. See especially Plate VIII fig. b; Plate XIII figs. a, b, g, h; Plate XV figs. c, d. On Alexander's elephant medallions, see chapter 2 and relevant notes.

${ }^{65}$ Charles (2007); Fischer-Bovet (2014) 154.

${ }^{66}$ Scullard (1974) 240-5. Scullard (p.104-5) suggests that the first Greek use of turrets may have been by Pyrrhus at the Battle of Heraclea, but expresses some reservation about Zonaras' anachronism (8.3) and reliance on Roman sources.

${ }^{67}$ Fischer-Bovet (2014) 153-5; Casson (1993).
} 
key players in the conflict: Perdiccas, Antigonus Monopthalmus, Demetrius, Antipater and Polyperchon, Eumenes, Seleucus and Ptolemy. It was the latter two whose dynasties developed significant elephant corps, drawing on a steady supply of elephants from India and northeast Africa, respectively.

Before the wild trumpeting of injured elephants and the thunder of their charging feet became expected cacophonies in battle, the Greco-Macedonian world had an extremely limited understanding of the animal. For a long time, knowledge the very knowledge of elephants was limited to elephas, or ivory, the only tangible evidence of the beasts that traveled so far west. It is unsurprising that the Greek word for the animal is the same as the word for the product gleaned from it. As Scullard points out, for Homer, elephas meant only ivory; it was not until Herodotus that elephants themselves were discussed, and even then only briefly. ${ }^{68}$

Indeed Herodotus makes no attempt to describe elephants, and it is unlikely that he had any knowledge of their form. His brief references couch elephants within the context of tribute and expensive, exotic materials, rather than describing them as potential weapons. He refers to elephants only three times in his Histories. He notes that among the many tribute-paying peoples of the Persian Empire are the Callantian Indians and Ethiopians near Egypt who every year give the same set of gifts as tribute: two choinexes of raw gold, 200 blocks of ebony, five Ethiopian boys, and 20 massive elephants' teeth (3.97.3). Elephants crop up again in his description of Ethiopia, located "at the southwest

\footnotetext{
${ }^{68}$ Scullard (1974) 32. Homer (Il. 4.141) describes the color of Menelaus' wound "as when a woman stains

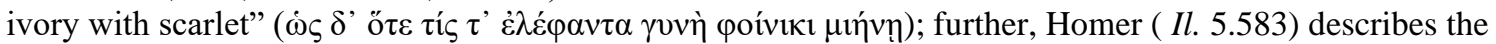

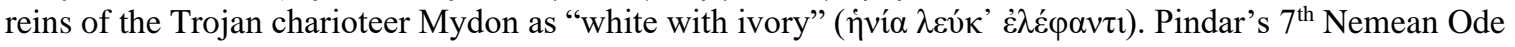

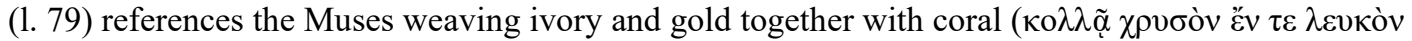
$\left.\dot{\varepsilon} \lambda \dot{\varepsilon}_{\varphi} \alpha \nu \theta^{\prime} \alpha \mu \alpha \tilde{\alpha}\right)$, and uses the same word to describe the gleaming shoulder furnished with ivory ( $\dot{\varepsilon} \lambda \dot{\varepsilon} \varphi \alpha \nu \tau \imath$

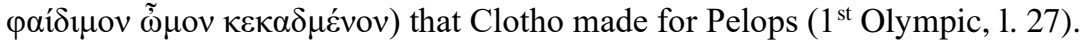


edge of the inhabited world" (3.114) and known for producing gold, ebony, and large elephants. The fact that elephantas is couched within a list of precious resources suggests that Herodotus, like his Greek audience, would be considering the elephants' value in terms of its ivory, perhaps even interpreting the word as the substance ivory, rather than the animal from which the ivory comes. ${ }^{69}$ Most Greeks could not have known what an elephant looked like at all. Neither statement reveals anything particular about the nature of elephants other than accurately pointing out that they can be found in North Africa and India. Finally, Herodotus references elephants in a list of frightening and somewhat obscure creatures native to western Libya, such as giant serpents and lions, horned donkeys, dog-headed creatures, and headless animals with eyes inset on their chests. He insists that his list is only a sampling of "many other creatures which are not just fabulous inventions" (4.191.4). His avowal suggests an expectation of disbelief, and he is unable to offer further evidence.

The greatest source of information on elephants before Alexander's campaign was Ctesias of Cnidus' Persica and Indica, both of which survive only in fragments. Since Ctesias served in the court of Artaxerxes II, it is likely that he had the opportunity to view elephants in person. Aelian (HA 17.29) preserves Ctesias' claim that he saw them in person at Babylon, where they were being used to uproot date palms with their trunks. ${ }^{70}$ Ctesias notes that elephants were used in India for tiger-hunting as well as sieges ${ }^{71}$ and that the Scythian king Derbikes received a gift of elephants from Indians and used them

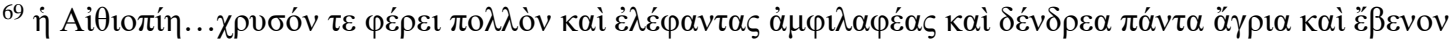

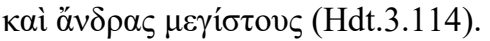

${ }^{70}$ Bigwood (2003), 542-543 sees no reason to doubt Ctesias' claim.

${ }^{71}$ Ind. 7, Jacoby 491; Ind.3, Jacoby 487; Scullard (1974) 34.
} 
to ambush the cavalry of Cyrus the Great. ${ }^{72}$ Whether or not this would have been feasible depends on the Persian cavalry's familiarity with elephants; as we will see, horses trained and raised around elephants are not afraid to ride near them in battle. Nonetheless, Scullard characterizes this account as the more reliable of two. ${ }^{73}$ Ctesias also recorded Semiramis' alleged use of dummy elephants (a story with which Alexander was likely familiar), which she constructed to frighten her Indian enemies; the account is drawn out at length by Diodorus. ${ }^{74}$ When the Indian king Strabrobates brought his beasts forward against Semiramis' fake ones, they smashed through the wooden creations and sent Semiramis withdrawing to Bactria. As Scullard notes, thereafter the only extant Greek writer to mention the animal is Plato, who claims Atlantis abounded with elephants. ${ }^{75} \mathrm{~A}$ detailed analysis would not come until Aristotle, who gained much of his insight from Alexander's campaign. Not long after his death many Greeks and Macedonians would have become quite familiar with elephants, as these animals marched throughout Asia, sailed to Piraeus, and disembarked on the Peloponnese during the Diadoch Wars following Alexander's death.

Following Alexander's Asian campaign, Greek scientific knowledge of the elephant must have expanded considerably. ${ }^{76}$ Aristotle's Historia Animalium and De Partibus Animum offers extensive accounts of the physiology, behavior, and mating habits of the animal, but whether it was written in response to information brought from Alexander's campaign or scientific patronage is doubtful. ${ }^{77}$ There is considerable

\footnotetext{
${ }^{72}$ Persica 6, Jacoby 457.

${ }^{73}$ Scullard (1974) 34-5.

${ }^{74}$ Diod.2.16ff.

75 Plato Critias 114e; Scullard (1974) 36.

76 Stoneman (2008) 69-72; Scullard (1974) 52-60.

${ }^{77}$ Scullard (1974) 37-52 provides a good summary and translation.
} 
scholarly debate regarding the origins and quality of Aristotle's information. ${ }^{78}$ Most recently tackled by Bigwood, the issues of Aristotle's immense knowledge of the elephant and "obviously slender"79 knowledge of India are difficult to reconcile. What Aristotle says about India is limited and clearly belongs to the period before Alexander's invasion (327-325), and the animals he references there "belong to the world of fable." 80 Bigwood suspects that much of Aristotle's knowledge came not from personal observation but from reading, among other things, the works of Ctesias. But he cautions against assuming Aristotle is more accurate because of his jibes at writers like Ctesias. In one case, Aristotle mocks Ctesias for his claim that pigs are native to India, arguing instead that neither wild nor tame pigs can be found there (HA 8.28.606a8), which is, and was, blatantly false. Aristotle makes similar claims regarding elephants, discarding out of hand Ctesias' statement about the viscosity of elephant semen (HA 3.22.523a26, GA 2.2.736a2) and leading Bigwood to conclude that "Aristotle's criticisms do not necessarily imply exhaustive research or firsthand investigation." ${ }^{81}$ Other valid candidates as sources of information about elephants include Eudoxus of Cnidus, a fourth century mathematician who spent at least some time in Egypt, where he might have observed Ptolemaic elephants, and Alexander's historian Callisthenes. Bigwood suggests that Callisthenes' family relation to Aristotle would have made him a viable correspondent. $^{82}$

Ancient records of elephants are included in the accounts of Alexander's admiral

\footnotetext{
${ }^{78}$ Following Bigwood (2003), 537 n. 1, I refer the reader to Scullard (1974) 37-52 for an assessment of what Aristotle has to say about the elephant. It is not necessary to repeat his account here.

${ }^{79}$ Bigwood (2003), 538.

${ }^{80}$ Ibid., 539.

${ }^{81}$ Bigwood (2003), 540.

82 Bigwood (2003), 546-548 on Euxodus and Callisthenes, see also bibliography.
} 
Nearchus and navigator Onesicritus, whose works survive only in fragments through Pliny, Strabo, and Arrian. Nearchus' account details, among other things, how wild elephants are caught by Indians with foot-traps and tame elephants (Strabo 15.1.43), and Onesicritus records the wild inaccuracy that elephants live between 300-500 years (ibid) and rates those of Taprobane (Ceylon) as superior in warfare, especially siegecraft (Pliny NH 6.81). The later writers Megasthenes and Agatharcides contributed further through direct observation. Megasthenes, a Seleucid ambassador to the court of Chandragupta Maurya, had the opportunity to observe elephants up close in the royal court at Pataliputra, and it is from him that we learn that Indian elephants are significantly larger than their African (forest elephant) counterparts. He adds to the information provided by Nearchus with a detailed account of herding and capturing wild elephants, which is preserved in Arrian's Indica (13ff). Agatharcides of Cnidus, an Alexandrian writer, produced among other works On the Erythrean Sea, written at some point in the second century and preserved in fragments through Diodorus, Strabo, and Photius. In this he mentions African elephants as part of his larger discussion of the people, flora and fauna along the coast of the Red Sea. ${ }^{83}$ Although the use of elephants in war was "as old as civilization" $" 84$ in India, for the Greeks and Macedonians it was a relatively novel venture, and the animals did not mesh well with the Hellenic form of war.

\section{Part C- Greeks, Macedonians, and Elephants: The First Meeting}

In order to show that the elephant was a greater potential hindrance in battle than an asset and to suggest that Alexander's men would have known this, a close

\footnotetext{
${ }^{83}$ Burstein (1996) 4-6.

${ }^{84}$ Ibid., 4.
} 
investigation of the first Greco-Macedonian encounter with elephants on the battlefield is necessary. Somehow between the reign of Alexander and the Wars of the Successors, the elephant shifted from a semi-mythic and certainly foreign beast to the ancient equivalent of a tank, an apparent necessity for Hellenistic pitched battle, however destructive and difficult to maneuver. This transition did not occur through Alexander, as the following narrative summary will demonstrate. Although he accumulated an elephant corps of significant size, Alexander's elephants were rarely on display, occasionally given away as gifts, and never deployed in battle. ${ }^{85}$ Their presence in the Alexander histories is elusive, which makes their conspicuousness in the Wars of the Successors all the more fascinating.

Alexander and his soldiers met with elephants in battle for the first time at Gaugamela in $331 .{ }^{86}$ Although they would have known that the Great King could call upon troops from all of his satrapies, whether or not they expected to see elephants in battle at Gaugamela is unclear. Indeed, Darius III's hold on the Indian satrapy appears to have been tenuous, as only the Indi living west of the Indus sent assistance, which consisted of only 15 elephants. ${ }^{87}$ These elephants were used not as chargers, but as a living wall to guard the Great King in battle; they were posted directly in front of the king's Royal Squadron, interspersed with chariots, both of which were more useful as psychological than tactical weapons (Arr.3.11.3-7). Indeed, the elephants' participation in the battle seems to have been insignificant; the Companion Cavalry broke through the

\footnotetext{
${ }^{85}$ Alexander gives 30 to Taxiles as a gift (Arr.5.3.5), uses their trumpeting at Calanus' funeral (Arr.7.3.6), and puts them on display at the Susa weddings (Phylarchus apud Athenaeus XII, 539ff.).

${ }^{86}$ For the Battle of Gaugamela, see: Diod.17.56-17.61, Plut.Alex.31-33, Curt.4.15.1-22, Arr.3.13-3.15.7, Justin 11.14.1-3; Worthington (2014) 187-93; Bosworth (1988) 74-85.

${ }^{87}$ Arr.Anab. 3.8.3, 3.8.6.
} 
Persian line to the left of the elephant and chariot guard, forcing Darius to flee (Arr.3.13.3). Any direct encounter with elephants is lost, if indeed it occurred at all. ${ }^{88}$ After the battle, Parmenion was able to capture elephants and camels from the Persian baggage train ${ }^{89}$ although what the elephants were doing here, rather in the front lines as Arrian specifies at 3.11.6, is unclear. This inconsistency does not prove that elephants were a later addition to the battle narrative, but suggests that they did not play an especially prominent or effective role. Further, their placement on the front lines interspersed with chariots begs the question how Persian cavalry managed their mounts so close to elephants. Given that these 15 elephants were brought in from the Indian satrapies, they were not animals that the Persians themselves had trained or kept in camp long, making the change that horses could cope with them rather low.

Additionally unknown is what Alexander did with the elephants after the battle. Did they accompany him to Babylon? Were some of them sent back to Europe with Aristotle in mind? Despite the uncertainty, Scullard chastises historians' dismissal of the elephants who participated at Gaugamela, suggesting that their role in the battle might have put the idea of India, the "land of elephants" into Alexander's head in the first place.$^{90}$ While that is impossible to prove or disprove, there is no evidence that Alexander made any military use of his acquisitions at this time. He clearly did not train or experiment much with the elephants taken after Gaugamela or those acquired on his march to Susa (Curt.5.2.10), as by the Battle of Hydaspes he has acquired over 100 and did not deploy any of them. To the contrary, he was wary that his cavalry would refuse to

\footnotetext{
${ }^{88}$ Curt.4.12.6-13 details the Persian deployment at Gaugamela and makes no mention of elephants.

${ }^{89}$ Arr.Anab.3.15.4, 3.15.6.

${ }^{90}$ Scullard (1974) 65.
} 
fight out of fear of the elephants (Arr.5.10.2) and explicitly instructed Craterus to lead the cavalry across the river only if Porus took his elephants away from the crossing (Arr.5.11.4)..$^{91}$

However, just because Alexander did not train his men and horses to fight with elephants did not mean they were not informed about how to fight against them. It is important to note that by the famous Battle of Hydaspes in 326, the sight of elephants themselves was likely no longer foreign to the Macedonian army. Alexander had acquired a substantial number of the animals between Gaugamela and the Hydaspes. ${ }^{92} \mathrm{He}$ captured several elephants after the siege of Ora (Arr.4.27.9) and even went elephant wrangling himself. After seizing a herd of elephants that belonged to the Assaceni's ally Abisares, he thereafter kept Indians in his army who specialized in the hunting of elephants (Arr.4.30-7.-8).

The Indian raja Taxiles made Alexander a gift of 30 elephants and then an additional 56, ${ }^{93}$ and the Arachosian resistance movement was brought to a close with 30 more elephants, which Alexander handed off to Taxiles as a gift. Scullard surmises that Alexander simply had no need for more elephants at this point, ${ }^{94}$ and so gave them to an ally to cement a friendship, but it seems more likely that his intention to move quickly precluded the accompaniment of even more elephants. It was in Taxila that Alexander received word that Porus would not surrender to him (Arr. 5.8.4), and he would have known that the crossing of the Hydaspes would not be easy for elephants. Earlier in the

\footnotetext{
${ }^{91}$ Kistler (2006), 39 suggests this is untrue and that Alexander really did want to use his elephants but had no way of getting them across the Hydaspes in silence.

${ }^{92}$ A detailed analysis and narrative of Alexander's acquisition of elephants is provided by Scullard, pp. 6476. I provide here only the highlights.

${ }^{93}$ Arr.Anab.5.3.5; Curt.8.12.11. These two accounts may be variations on the same gift and cannot necessarily be taken as separate incidents.

${ }^{94}$ Scullard (1974) 66.
} 
season he had had ships constructed to sail his men down the Indus River (Arr.4.30.9), and one wonders how the elephants made the journey, as it is doubtful the elephantagoi of the early $3^{\text {rd }}$ century had been created yet. ${ }^{95}$ Similarly troubling is the crossing of the Indus River, which Arrian supposes must have been effected by a pontoon bridge (Arr.5.7.1-5). Could this possibly have supported the elephants Alexander acquired at Ora and among the Assaceni, or had they been left behind on permanent garrison duty somewhere in the north?

Exactly where the elephants Alexander acquired ended up cannot be answered with the extant sources, but what is clear is that Alexander had no intention of using them to combat Porus. It is significant that had he wanted to, he could have done so. As Scullard notes, Alexander could have fielded around 150 of them to Porus' $200,{ }^{96} \mathrm{a}$ worthwhile ratio that might have had some shock value in a culture that valued the military capacity of the elephant. ${ }^{97}$ Additionally, Alexander could have taken the time to train and prepare his men and horses to fight alongside them, as he had all the necessary resources in Taxila, where he spent much of the spring of 326. As noted above, Taxiles gave Alexander a large number of elephants, suggesting that trained mahouts could have been made available to him as well. Alexander did not need to set out when he did either, as the monsoon rains had swollen the Hydaspes and forced him to wait at its banks longer than he might have liked, and he might have used the time to prepare an offensive that

\footnotetext{
95 Casson (1993) 253-4.

${ }^{96}$ Regarding the number of elephants Porus fielded, I use Scullard's number, which comes from Arrian. Curtius and Diodorus provide varying numbers of 85 and 130. For a discussion and reference, see Scullard pp.67-72 and esp. n.36.

${ }^{97}$ Polyaenus 4.3.22 claims that Alexander did in fact deploy elephants, but this is rightly rejected by scholars because it is absent from the Alexander historians and proves problematic in that the elephants would have had difficulty crossing the Hydaspes amid a storm and would have brought Alexander's strategy to a halt. See further Scullard, n.34. Cf. Kistler (2006), 39.
} 
included elephants. Instead, he made a clear decision not to employ them, a rule of battle which he maintained throughout the rest of his Indian campaign.

Kistler's insistence that Alexander "had big plans" for his elephants but simply died before he could use his own elephants is not supported by clear evidence. ${ }^{98}$ It is almost impossible to prove what Alexander "would have" done, but it is possible to prove what he could have done. In fact, Alexander had numerous opportunities to use his elephants in the westward march back through India in 326-325, but he never did. Alexander preferred to wage his campaign among the Malli with the aid of stealth and speed, ${ }^{99}$ a de facto rejection of his potential elephant corps. It is specifically known that elephants could be deployed in Sambus' territory because Sambus himself owned 30 (Arr.Anab.17.102.7), but Alexander did not put them to use. It must be remembered that amassing an elephant corps does not necessitate that it must be deployed in battle; ${ }^{100}$ the symbolic clout of such animals in India was worth the expense of traveling with them, and Alexander would have been well aware of that. ${ }^{101}$ Tactically, however, Alexander must have recognized that the use of elephants was not necessary to defeat other elephants; once disabled, the animals could prove as deadly to their own side as to their enemy.

This is exactly what happened. ${ }^{102}$ Porus' stationed his elephants perhaps 100 feet

\footnotetext{
${ }^{98}$ Kistler (2006), 39, cf. 42.

${ }^{99}$ E.g. Arr. 6.6.1-3 records Alexander's use of highly mobile light and mounted troops during his invasion of Malli territory. His subsequent siege of an unnamed Malli city (6.6.4-5) made no use of elephants, and Arrian emphasizes the difficulty of light-armed infantry in keeping up with Perdiccas' detachment in the Malli territory (6.6.6). His subsequent attack of the "city of Brahmans," and numerous other towns also involve no use of elephants (Arr. 6.7.4-9.6).

${ }^{100}$ Contra Kistler (2006), 41.

${ }^{101}$ Cf. Singh (1965), 78; Epplett (2007), 116.

${ }^{102}$ For a full account of the Battle of the Hydaspes River, see: Diod.17.87.1-17.89.3; Plut.Alex.60; Curt. 8.13.5-8.14.46; Arr. 5.9.1-5.19.3; Justin 12.8.1-7. See further: Worthington (2014) 243-50; Bosworth (1988) 126-30.
} 
apart, with room for the Indian light infantry to move forward between them and trap any advancing Macedonian infantry between their weapons and the elephants' feet. ${ }^{103}$ Already Alexander observed that the true threat was not the elephants, but the infantrymen using them as a bulwark. ${ }^{104}$ Hence Alexander planned to use his cavalry to throw the Indian infantry and cavalry into confusion; the Macedonian infantry was ordered not to advance on the elephants until the Indian infantry backing up the elephant corps had been thrown out of order (Arr.5.16.2-3). Although the Indians retreated to the wall of their elephants more quickly than was expected, launching the animals at the static Macedonian phalanx, the infantry held its own. Arrian stresses that "the action was like none of their previous battles" (Arr. 5.17.3) and so temporarily Porus' men got the better of Alexander's, using the elephants to approach the phalanxes and create gaps. The psychological impact of the animals would have been significant.

Accounts of the battle at Hydaspes offer the earliest detailed historical record of how elephants behave in battle, and Diodorus provides an especially gruesome depiction. Elephants stepped on their enemies, "armor and all” (17.88.1) and crushed even their bones under the weight of their bodies. ${ }^{105}$ Some used their tusks like spears, piercing the Macedonians' armor and running entirely through their bodies. Interestingly Diodorus also notes that the elephants were trained to deliver a "fearful death" (17.88.1) by using their trunks to lift soldiers up over their heads before slamming them back into the ground until they died. The psychological impact of vying with up to $20012,000 \mathrm{lbs}$.

\footnotetext{
103 This is Arrian's account at 5.15.5-7. However, Diod.17.87.5 and Curt.8.14.13 claim that infantry was stationed in line with and between the elephants.

${ }^{104}$ Diodorus (17.87.5) and Curtius (8.14.13) both specifically compare elephants to towers, and the men between them to curtain walls.

${ }^{105}$ Diod.17.88.1; Curt.8.14.26
} 
beasts is difficult to overstate, and Diodorus is right to label the soldiers' deaths $\delta \varepsilon v o i ́$ (ibid). However, this was not the first time Alexander's men had been faced with novelty in battle, ${ }^{106}$ and their ability to turn the tide in their favor speaks to their impeccable response time and thorough preparedness for battle with elephants. They would have known upon departure from Taxila what animals they would be facing in Porus' realm (Arr.5.8.4).

Some of that preparedness is revealed in the way the Macedonian light infantry knew exactly how and where to target elephants' vulnerabilities before going into battle, and Curtius suggests that they had had help, likely from Taxiles, in preparing special weapons to do this (Curt. 8.14.28). Rather than trying to kill the elephants by piercing their undercarriage, the army focused only on disabling them. Curtius refers to the use of axes (secures) to cut off the elephants' feet (Curt. 8.14.28). Curtius also notes the use of copides, defined as sharp sickles, which were used to slice off the trunks, measures which not only disabled but likely killed the elephants in the long run and sent many rushing against their own side. ${ }^{107}$ The exceptionally gruesome manner in which the army hacked at their enemy produces sympathy even from Curtius, who rightly remarks that "[The Macedonians'] fear left nothing untried, not only in dealing death, but also in new ways of making death itself painful" (Curt.8.14.29). The Macedonian phalanxes, brought into battle before they had desired, were equally well prepared. They knew to target the elephants' mahouts and isolate the beasts in the field, and their sarissae allowed soldiers

\footnotetext{
${ }^{106}$ E.g. consider Darius' scythed chariots, a potent psychological weapon to which the Macedonians responded cleverly and efficiently. See Worthington (2014) 191, Bosworth (1988) 78-9. Consider further the Scythian circling tactic, which initially gave Alexander difficulty along the Jaxartes before he adapted, using artillery fire to cover his advance. See: Arr. 4.4.1-7, Fuller (1958) 238-41.

107 Curt.8.14.29; Scullard (1974) 75. Although Curtius makes it seem as though the copides are unusual,

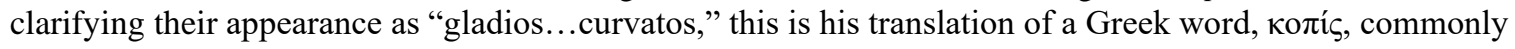
used to refer to a cavalryman's sword. Cf. Gaebel (2002), 161-164.
} 
to kill or at least unseat the mahouts without getting too close to the elephants. ${ }^{108}$ Once the mahouts were unseated, the elephants "some of them wounded, others overcome by their toils and bereft of their masters... driven senseless by their misery, they attacked friends and foes alike, and thrust themselves in all directions, trampling and killing” (Arr.5.17.5-6).

The destruction wrought by elephants to their own side should not be underestimated; Alexander's troops certainly recognized and took advantage of it. Arrian emphasizes that because the Macedonians were attacking in open fields, they were able to give ground whenever an elephant approached and then turn to attack its rear when it passed. The result was that "it was the Indians, who were at close quarters with the elephants, who incurred the most harm from them" (Arr. 5.17.6). In cases where elephants were badly wounded, even having a rider made no difference; often the animals were out of control with pain and turned back, stampeding their own allies (Diod.17.88.3) or picking up their own men in confusion and slamming them into the ground with their trunks (Curt.8.14.31). Generations later, the Carthaginians would implement safety procedures to prevent this problem, which indicates that it was pervasive both in Indian and African forest elephants. Hasdrubal is credited with the creation of a chisel blade wristband and mallet, which a mahout was to drive into the elephant's neck if it could no longer be controlled. ${ }^{109}$ Evidently at Hydaspes this happened rather quickly. When Porus attempted to rally his men, he gathered about him forty elephants or an original 130 (as stated by Diodorus) "which were not yet out of hand" (Diod.17.88.4), indicating that the rest or at least the majority were either dead, injured, or in a retreat of their own.

\footnotetext{
${ }^{108}$ Diod.17.88.3, Curt.8.14.16.

${ }^{109}$ Mayor, Greek Fire, Poison Arrows, 197.
} 
Once worn out, elephants become entirely useless for tactical retreat, unable to keep up with cavalry or infantry and dangerous if injured (Curt.8.14.19). The general ineffectiveness of riderless elephants is alluded to again after the battle, when Porus views some of his elephants fallen "while others, bereft of their masters, were wandering about pitiably" (Arr. 5.18.4). Because the elephants were prone to falling out of formation, Alexander was able to capture the remaining Indians taking refuge around the elephants by surrounding them in a ring with his cavalry and bringing infantry forward in a tight formation to slaughter the remaining Indian soldiers (Arr. 5.17.7).

After seeing that an army with virtually no past experience of combating a large number of elephants on the field defeated its opponents, it is unsurprising that Alexander chose not to gamble by including elephants in his own deployment and risking the injury of his men. Indeed, Alexander explains the danger of using elephants in battle to his men when they refuse to cross the Hyphasis River. Although fear of potentially bigger and more elephants (Curt.9.2.16) probably did not play a significant role in the mutiny, Curtius has Alexander address the issue through an analysis of elephant battlefield behavior based on recent experience. It is worth quoting this portion of the speech Curtius gives Alexander in its entirety.

\footnotetext{
"But let us imagine that all those things are true; does the great size of the beasts or the multitude of the enemy terrify us? So far as the elephants are concerned, we have a recent experience before our eyes; they rushed with greater fury against their own men than against us; their bodies, great as they are, were mutilated by axes and sickles. But what difference does it make whether they are as many as Porus had, or that there are 3000, when you have seen that after one or two are wounded the rest are turned to flight? Furthermore, they manage even a few elephants with difficulty and inconvenience; but, when so many thousands are gathered together, they trample one another-where such huge and unwieldy masses of bodies have been able neither to stand nor to flee. For my part, I so despised those animals that after I had them, I did not make use of them against the enemy, knowing well enough that they inflicted more damage on their own side than on the enemy." 110
}

${ }^{110}$ Curt.9.2.19-21. 
Curtius has Alexander raise well-founded concerns, and the overall sense of Curtius' account above goes a long way toward explaining why Alexander never deployed elephants himself. ${ }^{111}$ Interestingly, Scullard deems this portion of Curtius' speech "nonsense" and asserts that "the men who had fought against Porus knew better. ${ }^{" 12}$ More recently, Kistler has argued for tossing the entire passage out because Alexander's evaluation of elephants occurred within the context of a persuasive speech meant to belittle them and reduce his men's fear of the Gangetic plain. ${ }^{113}$ While I have no wish to detract from the horror that the participants of Hydaspes must have experienced, many of them were veterans and would have recognized that their victory could be repeated against elephants in the future now that they knew the effect that disabling the animals would have on the opposing army. Curtius' account of Alexander's explanation is a logical one, and there is no reason to assume that Alexander would have presented a blatantly facetious argument to weathered troops, who had already fought against elephants in battle. Alexander's claim that elephants could be turned against the men deploying them was demonstrably true, and his veterans would have known it (Curt.9.2.19). While the stress of taking on enormous animals in war might not diminish much over time, I do not think that fear of larger elephants in the Ganges Valley played the critical role in the mutiny at the Hyphasis River. ${ }^{114}$ Whether he truly said it or not, Alexander's argument is a reasonable one in light of Macedonian experience, and later examples of elephant use in battle prove the hypothesis true, as we shall see.

\footnotetext{
${ }^{111}$ Although he acquired elephants after Hydaspes (Arr. 5.21.2) and they traveled with him on his westward march back through India in 325, there is no record of them being used. Scullard (1974) supposes they assisted in the transport of siege equipment, which is plausible but nowhere specified (75).

${ }^{112}$ Scullard (1974) 72.

${ }^{113}$ Kistler (2006), 38-41.

${ }^{114}$ Cf. Scullard (1974) 76.
} 


\section{Chapter 2: "A Friendly Wall:" 115The Limitations of War Elephants}

The Successors' use of elephants in light of the outcome of the battle at Hydaspes might not initially raise questions. The Macedonians had only faced elephants closely on one occasion, and the army had been infused with new blood between the time of the Indian Campaign and 321, including men who had no experience with the animals. Perhaps Perdiccas, the first Successor to use elephants in an attack in 321 , believed that he could make better strategic use of them against Ptolemy, who had few if any elephants at the time of the siege of the Fort of Camels. However, the practice of maintaining and even expanding elephant corps over time seems to defy logic in light of the ambiguous success of the animals.

Below I argue that elephants rarely, if ever, played a key role in a Diadoch military victory and that the first generation Diadochs must have witnessed and recognized this, making their deployment of elephants appear on the surface futile or wantonly reckless. However, a deeper symbolism undergirds the use of elephants in battle; the animals were not merely tanks, but emblems of a general's power, wealth, and legitimacy. In his study of Greek and Macedonian warfare, Adcock rightly remarks that Seleucus made the elephant the "badge of his dynasty"116 — and he was not the only one. Elephant corps were incorporated into the armies of Perdiccas, Antigonus Monopthalmus, Demetrius Poliorcetes, Lysimachus, and Ptolemy. Adcock notes that the "generals were slow to despair of elephants" even though they "are not a talisman of

\footnotetext{
115 Arr.5.17.2.

116 Adcock (1957) 54.
} 
victory" but in fact appear more frequently on the defeated side of a battle. ${ }^{117}$ Before considering the symbolic power of these animals, which shall be the subject of chapters 3 and 4 , it is necessary to provide a thorough investigation to expand and support the opinion expressed in brief by Adcock.

By looking closely at the battles that occurred during the Wars of the Successors following Alexander's death and pinpointing specific deficiencies and dangers involved in the use of elephants in war, it will be possible to rule out the argument that elephants were employed by the generals solely for efficiency's sake. In what follows I outline some of those deficiencies while providing evidence from major pitched battles and sieges of the early Hellenistic period which involved elephants. I limit this study to the lifespan of the first generation of Successors (323-281), as they established the tradition of deploying elephants in battle that set the pattern for their descendants.

Of the many problems involved in the deployment of elephants in Hellenistic pitched battle or sieges, three broad categories stand out, and this part of the chapter will be divided to consider these factors accordingly: (A) elephants do not directly turn the tide of battle or deal the decisive blow; (B) elephants have virtually no success in siege warfare and in pitched battle can be disarmed easily by technological innovation and without the use of an opposing elephant corps in battle; (C) elephants' intuitive intelligence, complex social relationships, and herding tendencies made them a hazard to their own side in battle. Finally, I conclude that while elephants served as an effective screen if and when they could be massed in large enough numbers, (D) most elephant

${ }^{117}$ Ibid., 55-56. 
success in battle was due to psychological, not practical, factors and circumstances that could not be replicated by even the most skilled tactician.

\section{Factor A: The Decisive Blow}

In the Greco-Macedonian military tradition established by Philip II and Alexander the Great, cavalry played a prominent and often decisive role in pitched battle. ${ }^{118}$ At the battle of Chaeronea, Philip's feigned retreat on the right wing allowed Alexander to launch the cavalry into a gap between the Athenian contingent and the Sacred Band, encircling the Thebans in a total rout and reversing to face the remaining Boeotians. ${ }^{119}$ At the battles of Issus and Gaugamela, it was once again Alexander's cavalry that broke the enemy line. ${ }^{120}$ The Successors continued to rely heavily on the speed and agility of horses to launch lightning attacks against their opponents, and the cavalry continued to have success in dealing the decisive blow in pitched battle. ${ }^{121}$ The introduction of elephants threatened the efficiency of the cavalry, as horses are instinctively afraid of elephants and required special training in order to run alongside them or attack their flanks. However, once a general's cavalry is well trained, horses can harass and outdistance elephants easily. In this light, the creation of elephant corps as a strategic necessity or even boon is questionable. However, at times the sources' overestimation of the tactical significance of elephants is problematic - in places Diodorus appears to put more stock in the lore surrounding the war elephant than the actual behavior of the elephant in battle. In the

\footnotetext{
118 See Wheeler (2007) and associated bibliography; Hunt (2007) 145-6; Wheeler (2007) 221; Sekunda (2007) 330-3333, Sekunda (1984) 14-23.

119 Worthington (2014) 85-90; Gaebel (2002), 154-156.

${ }^{120}$ Worthington (2014) 165-70, 188-93; Gaebel: 185-188; Bosworth (1988) 55-64, 74-85.

121 Sabin (2007) 422-5; Sekunda (2007) 344-7; Gaebel (2002), 199-229 discusses how cavalry peaked under Philip and Alexander but was still used effectively by the Diadochs.
} 
following examples, we will consider the reality behind the effectiveness of elephants on the battlefield, especially in comparison with cavalry, the punching arm of the Macedonian military machine (see further chapter 10).

\section{Orcynia (320/19)}

Consider for example the Battle of Orcynia in the winter of 320/19. ${ }^{122}$ Following on the heels of the Triparadeisus Settlement, Antigonus was sent after Eumenes in Cappadocia and approached his camp in Orcynia. Antigonus was outnumbered 2:1 by Eumenes with regard to the infantry he could field, and more than that with respect to cavalry. ${ }^{123}$ Although Antigonus brought 30 elephants with him, he must have been aware well before the battle that they could not make up such a significant difference, which explains his bribe to Eumenes' cavalry captain Apollonides. ${ }^{124}$ Arranging that Apollonides would take the bulk of Eumenes' cavalry and flee after the battle had begun, Antigonus secured his victory and slew 8,000 of the enemy, sending Eumenes fleeing to Nora, where he stationed himself for the winter. ${ }^{125}$ If indeed the elephants participated in combat, it is surprising that Diodorus makes no mention of their role, especially in light of the differences between Antigonus' and Eumenes' forces. The terrain would not have proven a hindrance, as Diodorus specifies that it was "well suited for cavalry fighting" and thus, flat (Diod.18.40.6), ideal for the deployment of elephants as well. Diodorus' focus is on the desertion of Eumenes' cavalry, which ultimately won the day. The

\footnotetext{
122 On the Battle of Orcynia, see Diod.18.40-42; Anson (2015) 142-5. Following Anson (144 n.21), I reject Polyaenus' account that the battle never occurred because of a trick by Antigonus (4.6.19).

${ }^{123}$ Eumenes possessed 20,000 infantry and 5,000 cavalry, while Antigonus fielded only 10,000 infantry and 2,000 cavalry with 30 elephants. Anson (2015) suggests that Antigonus' infantry numbers are erroneous on Diodorus' part; see p.144 n.20.

${ }^{124}$ Diod.18.40.5; Anson (2015) 142-3.

${ }^{125}$ On Nora, see Diod.18.41.1-2; Plut.Eum.9-11; Strabo 12.2.6; Nepos.Eum.5.3-7; Justin 14.2.2-3; Anson (2015) 145-7.
} 
disparity in elephant forces between the two generals does not appear to have played a role in Antigonus' tactical calculations.

One wonders if the elephants were present merely to provide visual reminder of Antigonus' status as a legitimate power and strategos autokrator of Asia, the title awarded him at Triparadeisus in the name of Philip III. ${ }^{126}$ It is probable that those elephants came directly or through descent from Alexander's own elephant corps and served as a reminder to Eumenes of his limited power and "outsider" status as a Greek among Macedonians. At Orcynia, Antigonus fielded Macedonian troops and "Alexander's" elephants, and Eumenes relied heavily (and mistakenly) on a mercenary cavalry, which cost him the battle. It was not long after his stay in Nora that Eumenes sent an embassy to ask Antipater for terms of surrender (Diod.18.42.1). The symbolic potential of the war elephant likely held its own unique value, as we shall see in chapters 3 and 4.

\section{Cretopolis (319)}

In a similar vein as the Battle of Orcynia, Antigonus' battle against Eumenes' ally Alcetas was also decided by cavalry desertion, rather than the might of the elephant, although the latter played an interesting role in the final stages of the engagement. ${ }^{127}$ In the winter of 319, Antigonus went after Eumenes' ally in Pisidia, occupying the steep ridges of Cretopolis with a force of 40,000 infantry, 7,000 cavalry, and likely the same 30 elephants that followed him to Orcynia. Considerably outnumbered, Alcetas used a force of 16,000 infantry and a mere 900 cavalry to scale the ridges, attempting to fight uphill

\footnotetext{
${ }^{126}$ Diod.18.39.7, 18.40.1; Anson(2015) 142.

${ }^{127}$ For the battle on the ridge in Pisidia, see Diod.18.44-45.3; Champion 31-2; Anson (2015) 147-9.
} 
and force Antigonus from his perch. After an infantry engagement in which Diodorus reports both sides saw losses (18.44.4), Antigonus broke the stalemate by sending his far superior cavalry about Alcetas' phalanx, cutting off its line of retreat and effectively pinning his phalanx. It was at this point that Alcetas was routed and faced "imminent destruction" (Diod.18.44.5), and only then did Antigonus employ his elephants in a downhill charge, more or less guaranteed of their safety because of his entrapment of Alcetas' men, and secure in knowing they would not wheel around and stampede his troops, as they were charging downhill. The last stage incorporation of elephants was far from necessary to win the battle; rather, it was a power play on Antigonus' part meant to intimidate Alcetas and any other allies of Eumenes and so prevent them from assisting him further. The role of the elephants was tactically superfluous, but psychologically very effective.

\section{Paraetacene (317)}

The final clashes between Antigonus Monopthalmus and Eumenes began in late 317, and Eumenes' eventual defeat was decided through two set piece pitched battles interrupted by a brief Antigonid ambush. The first of those battles was that of Paraetacene ${ }^{128}$ in the winter of 317 , recorded primarily by Diodorus, who in turn drew on the eye-witness account of Hieronymus. Because of elephants' size and ferocious fighting style, one is often tempted to credit them with not only psychological, but tactical victory, and Diodorus was no exception. At the opening of the battle, Antigonus' elephant corps of 65 was heavily outnumbered by Eumenes' 125, and the lopsided casualty ratio

\footnotetext{
${ }^{128}$ For the Battle of Paraetacene see: Diod.19.26-32; Plut. Eum.14; Anson (2015)190-5; Champion (2014) 52-9; Waterfield (2011) 98-9; Scullard (1974) 85-90.
} 
between Antigonus' and Eumenes' infantry is reported at 3,700:540, which suggests that Eumenes' elephants did exactly what they were supposed to do. ${ }^{129}$ However, a closer investigation of the elephant corps' performance reveals that this is not the case.

The generals deployed their armies as follows. ${ }^{130}$ Both generals placed their infantry in the center with cavalry on the wings and a line of elephants in front of the fighters. Antigonus placed the largest portion of his elephant corps on the right wing, put 24 in front of his infantry, and a mere 10 on the left wing, which was made up primarily of light cavalry (4,900 men). Eumenes in turn bolstered his left wing with 45 elephants, stretching 40 across the infantry lines and the lesser quantity $(2,900)$ of cavalry on his right, likely relying on his 4:1 elephant ratio to protect him against Antigonus' cavalry assault.

However, by 317 Antigonus' cavalry was well trained to work with elephants and had no difficulty launching a flank assault on Eumenes' elephant corps; this is how the battle opened. Antigonus' left wing light cavalry took off under Pithon's command, wheeling out and charging the right flank of Eumenes' cavalry and elephants. Pithon's cavalry were Median and Parthian mounted bowmen and "well trained in the execution of the wheeling movement" (Diod. 19.29.2). In keeping with Macedonian tradition, the cavalry thrust Eumenes' right line back successfully, using projectile weapons against the elephants. The mounted archers were able to fire from a distance and outpace the

\footnotetext{
${ }^{129}$ According to Diod.19.31.4-5 the lost infantrymen were 3,700:540, and the injured 4,000:900. This seems lopsided and is questioned by Devine (1985), 86 but supported by Anson (2015), $194 \mathrm{n} .80$ because Antigonus' casualties are in accord with the remaining troops reported at Gabiene. Champion (2014) 58-9 does not question the uneven casualty ratio, pointing to the fact that Antigonus went to extremes to conceal his losses from Eumenes' herald while holding the field (cf. Polyaenus 4.6.10).

${ }^{130}$ Like Scullard (1974) 86, I rely on the reconstruction by Kromayer and Kahnes (1929). Diodorus' account of each general's troop strength varies slightly between chapters 26 and 32. Roisman (2012), 217 provides a clean map and excellent numerical breakdown of deployment on either side of the field. Cf. Anson (2015) 191-2 for details.
} 
elephants easily, avoiding any counter initiative by the animals, who were in turn unable to retreat or regroup. Diodorus describes the scene:

\begin{abstract}
“They [Antigonus' mounted archers on his left wing] did not consider it safe to make a frontal attack against elephants, yet by riding out around the wing and making an attack on the flanks, they kept inflicting wounds with repeated flights of arrows, suffering no harm themselves because of their mobility but causing great damage to the beasts, which because of their weight could neither pursue nor retire when the occasion demanded."131
\end{abstract}

Eumenes used a similar tactic on his left, sending out an advance guard of 50

lancemen on horseback, presumably to dissuade the assault of Antigonus' 30 elephants.

This might have helped had his right wing not collapsed so quickly under the assault of

Pithon's mounted archers. Pithon's bowmen had so successfully harassed the elephants

on Eumenes' right that Eumenes had to take cavalry from his left wing to support his

right. His right wing was then able to repel and pursue Antigonus' mounted bowmen and

cavalry to the foothills.

It is at this point that Diodorus notes: "since the elephants also followed,

[Eumenes' cavalry] easily routed the forces of Pithon" (19.30.4). This claim is suspicious

on two counts. First, Diodorus already claimed that at least some of the elephants were

severely injured (19.30.2), and their inability to counter the onslaught of mounted archers

would not have changed. Secondly and more importantly, Eumenes' cavalry is explicitly

stated to have damaged Pithon's cavalry so much that they began a long-range pursuit all

the way to the foothills (19.30.4). Indian elephants can run up to 15 miles per hour, which

is easily outstripped by a horse, and they cannot maintain even that speed for very

long. ${ }^{132}$ Hence, the elephants cannot be responsible for the rout. ${ }^{133}$

\footnotetext{
${ }^{131}$ Diod.19.30.2.

${ }^{132}$ For a discussion of elephant speeds and whether their rapid movement constitutes running in biomechanical terms, see Ren et al. (2010), 7078.

${ }^{133}$ Anson (2015), 193 rightly credits Eumenes' light cavalry with this victory and does not mention the elephant pursuit.
} 
Thus, Eumenes' cavalry had Pithon's men on the run, and his Silver Shields got the better of Antigonus' center (Diod.19.30.5-6). ${ }^{134}$ And yet, it was Eumenes who retreated at the end of the day. Antigonus' only success was against Eumenes' left wing, where the heaviest complement of 45 elephants was stationed. Antigonus charged the gap created by the forward march of the Silver Shields, buzzing past the slow-moving elephant wall and cutting into the flank, winning the day (Diod. 19.30.8-10). Like so many of Alexander's battles, this was a battle largely decided by speed and agility, qualities elephants are not known for. ${ }^{135}$ It is important to note that while killing an elephant would have been extremely difficult, all that was needed was to injure or discombobulate them and steer clear of their reach. With horses trained to tolerate elephants and light-armed cavalry capable of harassing the animals from afar, the elephants did little more on a tactical level than provide an additional stumbling block for advancing cavalry.

Scullard ends his discussion of Paraetacene thus: “[Eumenes'] 125 elephants, which had faced only 64 [sic] enemy beasts, had helped his right and center to success but had failed to win him an overall victory." 136 This positive view of the elephants' contribution fits nicely with Scullard's opinion that elephants improved Hellenistic warfare, but I would rephrase his summary. Rather, Eumenes' overconfidence in his

\footnotetext{
${ }^{134}$ Diod. 19.30.5-6; on the Silver Shields under Eumenes see especially Roisman (2012), 177-236.

Roisman asserts that at Paraetacene Eumenes' hypaspists are under-credited for their role in pushing back Antigonus' infantry, and perhaps too much credit is readily assigned to the Silver Shields. See esp. p. 219220.

${ }^{135}$ It should be noted that the role of the infantry is unclear, but conflict would have been brutal and handto-hand. Diodorus does not say how the elephants in the center fought one another, although head-butting and tusk-gouging was likely. Champion argues that the elephants did not even participate in the center of the battle; there is no clear record of their behavior and "the most likely conclusion is that neither side was prepared to risk the dangers involved and withdrew their elephants prior to the start of the fighting" (Champion 57).

${ }^{136}$ Scullard (1974) 90.
} 
significantly larger elephant corps led him to lose the battle. Eumenes had thinned out his left wing and relied too heavily on his elephants to guard the phalanx's flank. Antigonus' cavalry outmaneuvered the slow elephant corps. Antigonus' infantry losses were certainly heavy, but it was his cavalry that came into direct contact with the elephants, of whom he lost only 54 (Diod.19.31.5). So we see from Paraetacene that having a larger elephant corps played no clear role in securing a decisive victory, and the animals were of no greater aid in the subsequent battle of Gabiene. ${ }^{137}$

Interim (317/6)

Between Paraetacene and Gabene, Antigonus followed Eumenes' retreat and, finding his winter camps stationed several miles apart from one another, he marched through the desert in darkness to surprise them (Diod.19.37). Although Eumenes caught on when he spotted enemy campfires and began gathering his six camps into one for protection, his elephants were slow moving and could not unite quickly enough.

Antigonus pursued the elephants on his way to Eumenes' camps, once again sending light cavalry and archers against them. The elephants were trained to form a hollow square around the baggage train, but because they were supported only by 400 horsemen in the rear, there was no possible retaliation to Antigonus' onslaught. He sent the cavalry against them, 2,000 Median lancers and 200 Tarentines (Diod.19.39.2-3). The mahouts were either killed or disabled, and they could not counter-attack efficiently against rapid and highly mobile antagonists.

Diodorus' stated reason for this raid does not sync well with his description of the ${ }^{137}$ For the Battle of Gabiene, see Diod.19.40-44; Plut.Eum.15-17; Polyaenus 4.6.12-15; Anson (2015)198-
202; Champion (2014) 60-68; Waterfield (2011) 99-100; Scullard (1974) 91-94. 
circumstances, much like his attribution of victory to Eumenes' elephants instead of his commander Eudamus. Diodorus states that Antigonus did this because he "hoped that, by attacking the elephants when they were isolated, he could easily gain control of them and deprive the enemy of the strongest element in his army" (Diod. 19.39.3). However, this sounds more like the opinion of Diodorus than of a seasoned general who had just seized the field from an elephant army. Indeed, after his desert crossing it seems more likely Antigonus was looking for a quick way to do harm to his enemy and obtain necessary supplies. Immediately prior to his discussion of the skirmish, Diodorus in fact claims that Antigonus was wary of launching the attack at all because "it was dangerous to lead an army that had been undergoing hardship and was in need of everything against hostile forces that were already assembled and were well provided with everything." ${ }^{.138}$ If elephants truly constituted the "strongest element" (19.39.3) of Eumenes' army, they were the last unit Antigonus would want to attack. In fact, Diodorus' description seems more accurate than his assessment. Seeking out supplies against the slow-moving baggage train, Antigonus' men used the tried and true method of mounted missile launchers to harass Eumenes' men. Ultimately it was Eumenes' cavalry and light infantry that interceded and saved the day, blocking Antigonus' access to the baggage train within the hollow square of elephants. From there, both sides began to form up for the final pitched battle of the winter season (Diod.19.39).

Gabiene (317/6)

The Battle of Gabiene ${ }^{139}$ involved the survivors of the elephants that fought at

\footnotetext{
${ }^{138}$ Diod.19.38.5. See also Champion (2014) 61-62.

${ }^{139}$ For the Battle of Gabene, see Diod.19.40-44; Plut.Eum.15-17; Polyaenus 4.6.12-15; Anson (2015)198202; Champion (2014) 60-68; Waterfield (2011) 99-100; Scullard (1974) 91-94.
} 
Paraetacene, totaling about 179, of which Eumenes possessed the majority with a force of 114. Once again, having a superior number of elephants would not assist lead him to victory, and the role of cavalry, not elephants, would prove crucial. Antigonus' infantry and cavalry forces still outnumbered Eumenes', but he had suffered significant losses from the harsh desert crossing and fielded fewer than at Paraetacene: he deployed 22,000 infantry, placed in the center of his line, with right and left wings composed of 4,000 and 5,000 cavalrymen and commanded by Demetrius and Pithon, respectively. Eumenes countered with a center of 17,000 infantry and a left and right wing of 3,500 and 2,500 cavalry, respectively. The left cavalry would be led by Eumenes himself and Peucestas, and the right by Philip. ${ }^{140}$ To counter Antigonus' higher numbers, he must have relied on his superior elephant corps, which he stationed across his entire battle line with the heaviest concentration (60) curving around his left wing to oppose Antigonus' right. This is similar to his arrangement of elephants at Paraetacene, which proved ineffective in the face of Antigonus' light cavalry and Parthian archers. ${ }^{141}$

The battle opened with the elephant charge followed by the cavalry, which engaged primarily in combat among one another. The massed cavalry on Eumenes' left wing was thinned out quickly by Peucestes' desertion (Diod.19.42.4), and Philip's cavalry on Eumenes' right was ordered not to engage immediately. Antigonus' left wing charge against Eumenes' cavalry got the better of them, eventually forcing them to retreat. Of the elephant combat on Antigonus' right and center, we know little. Diodorus' account, although the most complete, does not provide any detail on what the elephants

\footnotetext{
${ }^{140}$ For a detailed discussion of deployment and the distance covered by the line of infantry and cavalry, see Scullard (1974) 91-93, who relies on the study of Kromayer and Kahnes. See also: Champion (2014) 62-64. ${ }^{141}$ Scullard (1974) 91 rightly puzzles over this decision, as Eumenes had adopted the same formation at Paraetacene to no effect.
} 
did. One must wonder why_certainly not all of Diodorus' readers could have been expected to be familiar with elephant charges in battle; this would have been a spectacle worth recording. It is possible that the first engagement was not seen at all by most due to the dry salt and sand of the terrain, which Diodorus and Polyaenus both report kicked up a dust storm that provided a screen for Antigonus' foray behind enemy lines. ${ }^{142}$ However, battles between elephants are not specifically detailed anywhere during the Successor wars of the first generation, and one is compelled to look as far forward in time as Raphia for a full description of elephants fighting one another:

"The way in which these animals fight is as follows. With their tusks firmly interlocked they shove with all their might, each trying to force the other to give ground, until the one who proves strongest pushes aside the other's trunk, and then, when he has once made him turn and has him in the flank, he gores him with his tusks as a bull does with his horns." ${ }^{143}$

Evidently the elephant charge against Antigonus' right and center was not decisive. If Eumenes had intended his superior number of elephants to counterbalance Antigonus' greater force, it failed. ${ }^{144}$

$\operatorname{Ipsus}(301)$

Eumenes' attempt at using elephants as a deterrent against cavalry was not in theory a bad one — with a large enough number, it could work, as indeed it did years later at Ipsus. ${ }^{145}$ Nonetheless, even there, the elephants' role was secondary and relied heavily

\footnotetext{
${ }^{142}$ Diod. 19.42.1; Polyaenus 6.4.13.

${ }^{143}$ Polybius 5.84.

${ }^{144}$ Champion (2014) 65.

${ }^{145}$ For the Battle of Ipsus, see Plut.Demetr.28-30; App. Syr. 55. While the end of Diodorus' $20^{\text {th }}$ book sets up the battle, the actual engagement, described in the opening of the $21^{\text {st }}$ book, survives only in fragments. See the reconstruction of Bar-Kochva (1976), 75-77, 105-110 and the analysis by Wrightson (2015), 62-67 which emphasizes the role of combined forces. Additional descriptions may be found in e.g. Champion (2014), 152-62; Waterfield (2011), 151-154; Scullard (1974), 97-98.
} 
on the sheer size of the elephant corps, which the sources place between $400-480 .{ }^{146}$

Ipsus, the largest battle of the first generation Successors, came to pass after over

20 years of combat among Alexander's generals. Antigonus' final attempt to reunify

Alexander's empire collapsed with his defeat by the allied forces there in $301 .{ }^{147}$ Because

Seleucus had acquired 500 elephants on the eve of the battle from Chandragupta, ${ }^{148}$ the

conflict at Ipsus involved the largest elephant corps ever fielded by a Greek general. ${ }^{149}$ It

is difficult to overestimate the visual impact of such a large elephant corps on a

battlefield; between 400-480 were stationed on the allied side with Antigonus fielding

only 75. In terms of infantry and cavalry, the sides were closely matched.

While one would expect that the elephant corps broke the tie, they did so only

indirectly, playing auxiliary roles and acting primarily as a screening device,

impenetrable and effective primarily because of their large numbers. As Wrightson has

shown, Seleucus' use of elephants as a screen against enemy cavalry "demonstrates the

\footnotetext{
${ }^{146}$ The number of elephants Seleucus acquired and brought to Ipsus has often been scrutinized by modern historians, but the ancient sources are in general agreement of a range of 400-500. Strabo at 15.2.9 and 16.2.10 specifies that 500 were given by Chandragupta and kept in the stables at Apameia. Diod. 20.113.5 describes 480 elephants deployed by Seleucus at Ipsus, suggesting that perhaps 20 were deemed unfit for battle or died on the return march from India. Plut.Demetr.28.6 specifies 400. Grainger (1990), 109-111 supports the number, unimpressed by attempts to explain it away as a stock number used by Indians to mean 'a lot.' Contra Tarn (1940), 84, who suggests that the number 500 is merely a "stereotyped expression" of Indian literature and points to variations in numbers expressed by the sources. As Grainger notes, this does not explain why Greek writers would use Indian expressions of size in their own records, and zoological estimates of elephant populations in India support the number as realistic. Cf. Bar-Kochva (1976), 76-77.

${ }^{147}$ For the Battle of Ipsus, see Plut.Demetr.28-30; App. Syr. 55. While the end of Diodorus' $20^{\text {th }}$ book sets up the battle, the actual engagement, described in the opening of the $21^{\text {st }}$ book, survives only in fragments. See the reconstruction of Bar-Kochva (1976), 75-77, 105-110 and the analysis by Wrightson (2015), 62-67 which emphasizes the role of combined forces. Additional descriptions may be found in e.g. Champion (2014), 152-62; Waterfield (2011), 151-154; Scullard (1974), 97-98.

${ }^{148}$ Strabo 15.2.9, 16.2.10; Plut.Alex.52

${ }^{149}$ How many of Seleucus' elephants were actually deployed is debated. Diodorus claims 480 of them were brought into battle (20.113.4), suggesting that Seleucus transported them all with a travel loss of 20.

Plutarch claims Seleucus fielded 400 (Demetrius 28.3). See Bar-Kochva's (1976) defense of these high numbers against Tarn's earlier rejection pp.76-7.
} 
most effective tactic of elephants in battle, $" 150$ but this was only possible because of the enormous number of war elephants he possessed. Although there is some debate as to whether all elephants were stationed at the flanks and on the front lines or whether certain elephants were held by Seleucus in reserve, they were clearly put into motion at the crucial juncture of the battle, indicative of pre-determined strategy. ${ }^{151}$

In the center, the elephants butted heads, engaging in battle with one another directly, ${ }^{152}$ their mahouts presumably shooting arrows or throwing javelins. Diodorus specifies that some of the allied elephants came from Lysimachus, and that they clashed on one wing with Antigonus' elephants (21.1-2). On the other wing (presumably the Antigonid right), Demetrius' rapid pursuit of Antiochus' retreating cavalry caused the Antigonid cavalry to venture too far from the main line. The Seleucid elephant corps advanced crossways and, because of their large numbers, were able to act as a sort of living barrier against which Demetrius' cavalry was powerless. Because Demetrius could not return his cavalry to support Antigonus' infantry, the Seleucid light cavalry stationed alongside the elephants cut across the field and harassed Antigonus' exposed flank, destroying its formation and forcing a messy retreat that ultimately led to Antigonus'

\footnotetext{
${ }^{150}$ Wrightson (2015), 66.

${ }^{151}$ Wrightson (2015), 65 believes that elephants were held in reserve contra Bar-Kochva (1976), 108. The idea that Seleucus and Antiochus had planned the latter's withdrawal to lure Demetrius away from the Antigonid flank was originally Tarn's, and Wrightson has made a new case for it. Because of the amount of time it would take to station so many elephants in an oblique screen, Seleucus had to have been prepared to move them immediately once Demetrius had pursued Antiochus well behind the Seleucid line. The timing and effectiveness of the strategy is suggestive of premeditation, and as Wrightson rightly notes, all of the Diadochs would have had Philip's feigned retreat at Chaeronea for point of reference. Cf. 61-62. On Chaeonea: Polyaen. Strat. 4.2.2 claims Phlip engaged in a false retreat ( $\varepsilon \ddot{\xi} \xi \alpha \varsigma \dot{\varepsilon} v \varepsilon \dot{\varepsilon} \kappa \lambda \imath v \varepsilon v$ ), and Frontinus Strat. 2.1.9 implies it by claiming Philip's goal in retreating was to tire out the overeager and out of practice Athenians. Neither Diodorus (16.85.6) nor Justin (9.3.9) says anything of this plot.

${ }^{152}$ Wrightson (2015), 66 questions the deployment of elephants in front of infantry at Ipsus, which he calls "the most confusing aspect of the use of elephants by fourth century generals." Champion (2014), 57 finds the deployment of elephants in front of the infantry at Paraetacene so improbable that he doubts they were present there at all. Contra Glover (1944), 260 who claims that clustering elephants on the wings should only be done when one lacks a sufficient number to stretch across the front lines "like a screen of tanks."
} 
death.

Although a more detailed account of the battle is desirable, Bar-Kochva's reconstruction provides sufficient information to show that if indeed Seleucus did use most or all of his elephants, their role was ancillary to that of Antiochus' cavalry. ${ }^{153}$ The private war of elephants and mahouts that occurred on the allied right at Ipsus does not appear to have involved elephants facing cavalry or infantry. The barrier of elephants launched against Demetrius' strung out cavalry line likely incurred some damage, but their primary objective was only to bar Demetrius' return to the Antigonid line. As in all the above examples, elephants played an auxiliary role in battle that is perhaps not equivalent to the risk and cost of deploying them at all. Indeed, elephants were not a necessity for a general to defeat enemy elephants in the field, as the experience of the Megalopolitans of the Peloponnese and Ptolemy in Egypt will show, and it is to them that we turn now.

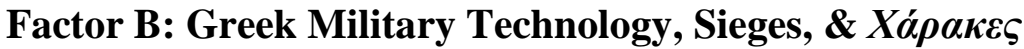

While elephants often play auxiliary roles in pitched battle, serving as a screen against cavalry and a psychological weapon, they were far less effective in the context of a siege and could be easily undermined by Greek military technology. This occurs in large part because the animals are slow-moving and, in the context of a siege, forced to remain still until the walls fall, making them vulnerable to projectiles and less tactically effective than the siege towers used by Alexander. Upon first glance, the ancient sources would seem to suggest the exact opposite, lauding elephants' destructive strength, but appearances are

\footnotetext{
${ }^{153}$ I relied largely on Bar-Kochva (1976), 75-77, 105-110 and the analysis by Wrightson (2015), 62-67, despite their differing opinions regarding the reserve of elephants behind the lines.
} 
deceiving.

Ctesias' fourth century account of India suggests that elephants were regularly used in sieges there; he calls elephants "demolishers of walls" 154 and claims to have witnessed elephants uprooting date palms in Babylon, suggestive of their destructive power. ${ }^{155}$ Aelian specifies that the Persian kings used them to overturn walls as well (NA 17.29). A contemporary of the Successors, Aristotle, specifies that elephants were capable of battering down some walls with their broad foreheads and tusks (HA 9.1). Onesicritus' account, in comparing Indian and African elephants, emphasizes the Indian elephants' superior strength through their ability to stand on their hind legs and tear down trees or battlements (apud Strabo 15.43).

Although elephants were used in sieges by Indians and Persians, Alexander never deployed them in this context, and his Successors only attempted it on a rare few occasions. The first Successor to put the animals to use in siege warfare was Perdiccas. In 321, he invaded Egypt with some of Alexander's elephants in order to oust Ptolemy from power and retrieve Alexander's body. His southward march involved a brief siege at the Fort of Camels, ${ }^{156}$ where he utilized elephants to no effect. Perdiccas sent the elephants against the fortress along with the infantry and their scaling ladders. The elephants were trained to tear down the palisades (Diod.18.34.2) but were easily disabled when Ptolemy and his soldiers stood on top of the battlements and used their long-reaching sarissae to

\footnotetext{
${ }^{154}$ Ctesias Ind. 7, Jacoby 487.

${ }^{155}$ Ctesias' claim is preserved in Ael.HA 17.29, and it is factually plausible, as elephants can and do uproot trees with their trunks or push them over with their body weight. While this is done in the wild for nutrition, some extreme views hold that elephants are uniquely responsible for changes in vegetation patterns and deforestation in parts of Africa, which Sukumar disproves (1994), 57f. This natural tendency has been put to industrial in Asia. Up until the 1980s if not more recently, elephants were used in the logging industries of Burma and Thailand, cf. Sukumar (1992), 35; Singh (1965), 84.

${ }^{156}$ For the siege of the Fort of Camels, see Diod.18.33-36; Waterfield (2011) 64-5. See also p.63, 73-4, 108-109.
} 
poke out the eyes of the attacking elephants and kill their mahouts, rendering them useless (Diod.18.34.2-3). Although Diodorus reports that both sides lost many men, it was Perdiccas who retreated, unable to take the fort, and famously lost 2,000 men to crocodiles in the Nile, resulting in his assassination. ${ }^{157}$ Thus neither Perdiccas nor Polyperchon three years later, had success using elephants to break through enemy walls or tear down fortifications. The siege of Megalopolis was the last elephant-led siege by Successors until Pyrrhus' invasion of Italy, undoubtedly because the defense against elephants was relatively manageable, and the cost for the invading army was exceptionally high, as a general risked the death or capture of his elephants.

The only other recorded attempt of using elephants in sieges during the Diadoch Wars was Polyperchon's siege of Megalopolis in 317. Early in the years of the Wars of the Successors, Antipater, regent of Macedonia for Alexander IV, named Polyperchon his successor-regent and the inheritor of his elephant corps. Antipater's son Cassander immediately mobilized against Polyperchon, forcing the latter to respond to the cities of Greece that went over to his competitor. Sailing down from Macedonia with his army and elephants in tow, Polyperchon found Piraeus occupied and unassailable and turned instead against the city of Megalopolis when it declared for Cassander (Diod.18.68). Although Polyperchon arrived with 65 Indian elephants, the Megalopolitans resisted his men and beasts and severely damaged his forces in the ensuing conflict, ${ }^{158}$ proving that however beneficial elephants might be to a siege, they can ultimately be defeated with proper preparation. Indeed, the elephants themselves likely caused Polyperchon to lose the siege.

${ }^{157}$ Diod.18.35-36.5; Arrian, FGrH, 156. 9. 28-29; Justin, 13. 8. 10; Pausanias, 1. 6. 3; Strabo, 17. 1. 8.
${ }^{158}$ For the Siege of Megalopolis, see Diod. 18.70-71; Scullard (1974) 82-4. 
Upon receiving word of Polyperchon's approach, the Megalopolitans began preparation by erecting palisades, constructing bolt-throwing machinery, and digging out a moat around the city. Weak places in the walls were patched up and refortified from within (Diod.18.70.1-3). Indeed "word had spread abroad concerning the magnitude of the royal army and the multitude of the accompanying elephants, which were reputed to possess a fighting spirit and a momentum of body that were irresistible" (Diod.18.70.3). In spite of the city's preparations, Polyperchon's army made considerable headway through sapping, mining, and the use of missiles and siege towers. After tearing down three of Megalopolis' towers, Macedonian soldiers poured in through the gaps in the wall and engaged in bitter hand to hand fighting with the defenders, who ultimately forced the invaders out and hastily built up another wall and palisade overnight (Diod.18.70.4-7). The elephants were clearly the back-up troops, as they were not used in the first attempt, but only brought in after the traditional siege techniques failed. That day Polyperchon ordered a path cleared to bring in his living siege equipment, but within the city a veteran of Alexander's wars named Damis was assisting the Megalopolitans.

As in pitched battle, elephants are only useful against those with no experience of them; Damis' participation in Alexander's campaigns allowed him to advise the Megalopolitans on how to create traps that would disable the elephants. Studding wooden frames with long protruding nails, he had them buried under the sand and dirt within shallow trenches in the city to pierce the elephants' feet and disable them (Diod.18.71.24). Additionally, Damis instructed the city not to place troops directly in front of the invading forces, but to arrange light-armed infantry along the sides of the path armed with javelins, bows, and catapults to assail the flanks of the elephants. As a result, when 
the mahouts rode their elephants into Megalopolis at full charge through an unguarded gate, the elephants were immediately impaled on the spikes by the force of their own weight and unable to advance or retreat. Diodorus illustrates the disturbingly inhumane scene that ensued and the disastrous results for Polyperchon's men:

\footnotetext{
"suffering great pain because of the cloud of missiles and the nature of the wounds caused by the spikes, [the elephants] wheeled about through their friends and trod down many of them." 159
}

The Megalopolitan missile launchers attacked their flanks and slaughtered their mahouts so that either the elephants were killed or severely disabled; those that could move in any way caused more trouble for Polyperchon's men than the Megalopolitans. Additionally, Diodorus reports that the collapse of the leading elephant ended the charge entirely: "Finally the elephant that was the most valiant and formidable collapsed; of the rest, some became completely useless, and others brought death to many of their own side" (Diod. 18.71.6). After this debacle, Polyperchon withdrew his troops and left only a small force to guard Megalopolis, but he was unable to prevent it from declaring support for Cassander.

Thus we have seen that both Perdiccas' and Polyperchon's attempts to use elephants in sieges ultimately caused the army deploying the animals more problems than the besieged. Had Polyperchon not relied so heavily on the elephants, he might have managed a swifter seizure of the Messenian capital. Such an effort would have taken time, as Hellenistic sieges were typically managed with traditional late Classical siege equipment: battering rams, siege towers, torsion catapults, but Polyperchon's haste

${ }^{159}$ Diod. 18.71.6. 
precluded the long wait that sometimes accompanied such endeavors. ${ }^{160}$ Ultimately it seems to have been the dread of prolonged sapping and rebuilding of interior walls that led Polyperchon to bring in his elephants in the hopes of hastening the affair and returning to confront Cassander directly. ${ }^{161}$ In the long run, this likely killed some of his elephants and permanently disabled others; Diodorus gives no account of how the injured members of the elephant corps were transported out, if indeed they were at all (18.71.5).

The effective use of technology against elephants was not restricted to sieges, and the caltrops of Megalopolis were used again in 312 by Ptolemy at the Battle of Gaza. ${ }^{162}$ In 314, Antigonus posted his son Demetrius in Coele-Syria with a massive military detachment including 43 elephants, and Demetrius spent two years accumulating support and waiting on an expected attack from Ptolemy. ${ }^{163}$ In 312, that attack came from the combined forces of Ptolemy and Seleucus. Both of these generals would later found dynasties famous for their elephant corps, but at Gaza neither fielded any. It is important to recognize that although Ptolemy did not deploy any elephants, he did possess at least some. In 312, he would have had at least some of the surviving elephants he had captured from Perdiccas after his death and his troops' surrender to Ptolemy. ${ }^{164}$ It is and extremely unlikely that every single one of Perdiccas' (and hence, Alexander's) elephants had died. Elephants have lifespans comparable to a human's and, like the Diadochs, were known to

\footnotetext{
${ }^{160}$ Sekunda (2007) 450-7.

${ }^{161}$ Diod.18.70.6-7-18.71.1, 18.72.1.

${ }^{162}$ For the Battle of Gaza see Diod.19.80-84; Polyb.15.12; Champion 91-97; Waterfield 120-122; cf. p.117-

120 on Ptolemy's use of the battle as propaganda.

${ }^{163}$ Diod.19.69.1, 19.80.1.

${ }^{164}$ It is known that at least some, if not all, of Perdiccas' elephants survived because they were used to assist Perdiccas' army in fording the Nile in retreat (Diod. 18.35). Ptolemy would have come into possession of these animals along with the rest of Perdiccas' land forces, who surrendered to him after assassinating Perdiccas See Diod. 18.36f; Worthington (2016), 97-99.
} 
fight well into their 60s. ${ }^{165}$ Not a full decade had passed since Perdiccas' invasion, and many must have still been alive, although certainly some of them had been badly wounded in the siege. While the animals are admittedly slow to reproduce, ${ }^{166}$ there is no reason to believe that one or two elephants were not born in the nine-year interim. In order to defeat Demetrius' elephants, Ptolemy prepared spiked devices that Diodorus calls $\chi \alpha ́ \rho \alpha \kappa \varepsilon \varsigma$, a term which usually refers to palisade stakes but here means a device consisting of metal devices covered in upward-pointing spikes or nails and connected to one another by chain. Concealing these beneath the sand and dirt, the Ptolemaic army planned to pin enemy elephants in place, preventing a successful charge and making their elimination by mobile troops easy (Diod.19.84.1-4). They were light enough that men could rush forward and put them into place just before the charge, hindering the elephants' approach. Along the right wing, Ptolemy planned to station light-armed missile launchers: archers and javelin men. They were to attack the elephants and their mahouts from the side to disable the former and kill the latter. The nature of this plan reveals knowledge of elephant biology, as this particular ruse was not employed on the Indian campaign (only by Damis at Megalopolis, as above). Diodorus explains the success of such a device with a general statement on elephant behavior: "on smooth and yielding ground these beasts display in direct onset a might that is irresistible, but on terrain that is rough and difficult their strength is completely useless because of the tenderness of their feet" (19.84.4).

\footnotetext{
${ }^{165}$ In fact, the ancient Indians claimed that an elephant was at the peak of its martial prowess at age 60, see Singh (1965), 81 and n.9; Singh compares ancient wisdom to modern, which claims elephants between 25 40 are at their peak strength. However, he acknowledges that even octogenarian elephants may be used in tiger hunts due to their experience and discipline.

${ }^{166}$ Cf. Sukumar (1992), 178-191.
} 
However, the truth is somewhat more complex. Although covered in thick skin, toenails, and a massive layer of fat, elephant feet are incredibly sensitive. The method of weight dispersion that prevents elephants' feet from becoming stuck in the mud also makes them exceptionally susceptible to the use of the $\chi \alpha \dot{\rho} \alpha \xi$. Because of the animal's considerable body mass, the elephant's foot actually expands and almost doubles in diameter when the animal puts weight on it. This is facilitated by a vast network of fatty tissues in the foot which allow the rounded sole to splay out, offering a broader surface to absorb the weight and impact of a step. When this occurs, the thick tissue stretches out, ${ }^{167}$ making the elephant's foot more vulnerable.

However, this injury alone would not kill the animal, only render it immobile. It is plausible that Ptolemy's plan all along was the capture of Demetrius' elephants, not their decisive defeat. Indeed, he and Seleucus would have been familiar with the specialized weaponry that the Indians used against elephants; Alexander had had certain blades constructed before Hydaspes to prepare his men, ${ }^{168}$ but such implements permanently mutilated and often killed elephants, whereas Ptolemy's were designed to pin them in place and allow javelin throwers and archers to pick off the mahouts with ease.

Ptolemy and Seleucus' plans fell into place. Just as Demetrius' elephants "advanced for a certain distance in a way to inspire terror" (19.84.1), they were stopped short by the spiked devices, impaled and made vulnerable to the quick-moving javelin throwers and archers, who killed or wounded both animals and mahouts. Diodorus emphasizes that all went according to plan:

\footnotetext{
167 Spinage (1994), 53; Wiedner (2015), 518.

${ }^{168}$ Curt.8.14.29 refers to axes and copides, see above p.49.
} 
"Thus, too, on this occasion, since Ptolemy shrewdly foresaw what would result from the setting up of the spikes, he rendered the power of the elephant unavailing. The final outcome was that, after most of the mahouts had been shot down, all the elephants were captured." 169

The absolute brutality and chaos of Gaza was astounding: as mahouts ruthlessly stabbed at their mounts with goads while being picked off from below by Ptolemy's men, the elephants panicked Demetrius' nearby cavalry, and many of them deserted despite his pleas (Diod. 19.84.5). This resulted in a collapse of Demetrius' forces by nightfall. The outcome of the battle is noteworthy, especially because Diodorus claims that the two sides were well matched in infantry and cavalry and both suffered significant losses.

There was severe fighting because of the zeal of both sides. In the first charge, indeed, the fighting was with spears, most of which were shattered, and many of the antagonists were wounded; then, rallying again, the men rushed into battle at sword's point, and, as they were locked in close combat, many were slain on each side." ${ }^{170}$ (Diod. 19.83.4-5).

The difference appears to lie with the perceived tactical significance of the elephants.

When Demetrius' men saw that their elephants being injured and captured by Ptolemy and Seleucus' men, they began to lose heart.

\footnotetext{
"The final outcome was that, after most of the mahouts had been shot down, all the elephants were captured. When this happened, most of Demetrius' horsemen were panic-stricken and rushed into flight; and he himself was left with a few and then, since no one heeded him when he begged them each to stand and not desert him, was forced to leave the field with the rest.... There followed also those of the infantry who preferred to leave their lines and, abandoning their heavy arms, save themselves by travelling light." 171
}

The psychological bolster that the wall of elephants had initially provided proved ultimately detrimental to the campaign, forcing Demetrius to retreat while sustaining severe losses (Diod. 19.84.5f.).

\section{Factor C - The Nature of Elephants}

\footnotetext{
${ }^{169}$ Diod. 19.84.4-5.

${ }^{170}$ Ibid. 19.83.4-5.

${ }^{171}$ Ibid. 19.84.5-7.
} 
Next the third, and perhaps the most illustrative example of the risks of deploying elephants in battle, stems from the animal's own nature. Elephants are not made for battle or massed fighting; slow-moving and unable to leap or to walk backwards, they have difficulty charging and no real ability to retreat. Because of their sheer size, they cannot be controlled if they become frightened or badly injured, often leading to more injuries on their own side than the enemy. Most importantly, elephant family groups are fiercely protective of their relatives because they spend at least part of their lives in close-knit family groups. Male elephants live with their mothers, grandmothers, and siblings until they reach sexual maturity at between 10-15 years of age, at which time they leave the herd. Female elephants remain in family herds for their entire lives. Elephant "families," which refers to a group of elephants that live and travel together but may include multiple generations, are led by the oldest female, the matriarch. She may be accompanied by her offspring and "grandchildren," including immature tuskers. During the dry season however, entire clans may be seen in familial clusters relatively close to one another in numbers ranging from 50 to 200 elephants, likely to assist in the search for water. Family bonds remain strong not just between mother and offspring, but sisters, aunts, and nieces as well. ${ }^{172}$ As a result, there exists a complex social hierarchy that often centers on the protection of the immature members of the herd. Indeed, Sukumar notes that "the elephant family group is superbly geared to confront any predator other than man"173 due to the size of the adult elephants. While tigers are about the only non-human predator Indian elephants face in the wild, the massive cats are rarely successful in capturing even

\footnotetext{
172 On family organization among Indian elephants, see Sukumar (1994), 86-94.
}

${ }^{173}$ Sukumar (1994), 96. 
elephant calves and do not stand a chance against the adults.

Despite this certainty, elephants are known to be extremely reactive to even nonthreatening animals. Sukumar records his observation of an elephant family gathered at a watering hole during a drought. ${ }^{174} \mathrm{He}$ observed that the matriarch of the herd began scraping her feed on the ground and tasting the air with her trunk, giving signs of distress. Shortly, a pack of five dholes appeared from the thicket, and immediately the elephants formed a defensive wall around their young, lunging forward against the dholes, who quickly fled. Sukumar expresses his surprise at their behavior, remarking that "they were certainly not after the elephants!"175 but probably only wanted access to the water. In a similar case, when an elephant matriarch detected human observation, she brought the entire nine-member herd charging toward her with a single call where they stood until Sukumar and his assistants carefully retreated (Sukumar 106-7). Thus, the protection of family members was paramount, and in some cases this duty extends to standing vigil over the dead and repeatedly visiting or picking up the remains of dead family members. ${ }^{176}$

This "complex and sensitive system of social interaction" 177 speaks to elephant intelligence, and there is evidence that the ancients understood and respected the intelligence of the elephant, recognizing its capacity for emotion in an almost human way. Arrian claims "if there is an intelligent animal, it is the elephant" (Ind.14.4), explaining that in battle elephants have been known to protect their riders, either lifting them back up with their trunks or standing over them if they are wounded on the field. He

\footnotetext{
174 Ibid., 96-97.

175 Sukumar (1994), 96.

176 Ibid., 101-102.

177 Ibid., 93.
} 
remarks that an elephant that killed its rider displayed guilt, suggesting that the bond that could form between horse and rider also emerged between elephant and mahout. A similar account of a grief-stricken elephant also occurs in Strabo, who says that the elephant is in nature "close to a rational animal $\left[\lambda o \gamma ı \kappa \tilde{\varphi} \zeta \omega \omega_{\varphi}\right]$ " (15.42). He references the elephants again as a standard of rational animals when he illustrates that apes are intelligent animals and "no less so than the elephant" (5.29). Aristotle's careful assessment, which may have come from the observations of those traveling with Alexander, is highly laudatory: the elephant is one of the tamest and gentlest animals

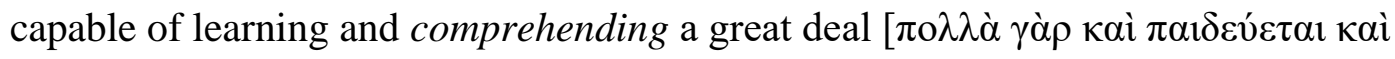

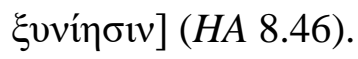

The intellectual merits of the elephant coupled with its size make it a hazard in battle, where it can neither be goaded forward against a clear threat nor be controlled when panicked by pain or made to engage in orderly retreat. On a number of occasions during the Diadoch Wars, we find examples of elephants using their logos to address a crisis within the herd in a way that preserved their lives and endangered the soldiers deploying them. One of the most notable such examples is the injury or death of a

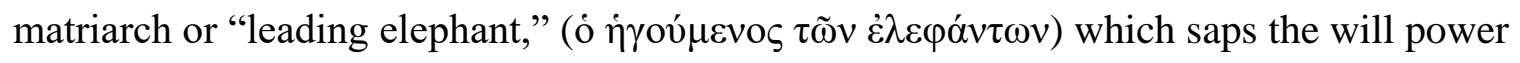
of the entire herd. ${ }^{178}$ The high-risk circumstances of a battlefield heighten the importance of the matriarch's decision-making. If she falls, elephants will often retreat, turning around and running through the lines of the very soldiers that deployed them.

As early as Hydaspes, we see elephants making a chaotic and destructive retreat. As the Macedonian pikemen harassed them, Arrian writes that "driven senseless by their

\footnotetext{
178 This tendency has been noted by scholars before, e.g. Scullard (1974) and Wrightson (2015).
} 
misery, [the elephants] attack friends and foes alike, and thrust themselves in all directions, trampling and killing" (Arr. Anab. 5.17.6). The Macedonian light infantry fighting in the more open part of the field flung javelins at the elephants as they turned around to flee and were able to keep out of their way. It was the Indians at close quarters with the elephants who were badly injured (ibid). A similar phenomenon occurred at the Siege of Megalopolis when Polyperchon's elephants were pinned in close or injured from the caltrops. Diodorus explains that total chaos broke out when "Finally the elephant that was the most valiant and formidable collapsed; of the rest, some became completely useless, and others brought death to many of their own side" (Diod. 18.71.6).

At the decisive Battle of Gabiene, Eumenes' elephant-heavy defense fell apart when his leading elephant collapsed: "It was at this time, while the elephants also were struggling against each other, that Eumenes' leading elephant [ó $\pi \rho \circ \gamma \gamma o v ́ \mu \varepsilon v o \varsigma]$ fell after having been engaged with the strongest of those arrayed against it." ${ }^{179}$ Similarly, the Romans finally gained the upper hand against Pyrrhus' elephants at the Battle of Maleventum because of the elephant tendency to follow their leader:

"[The Romans,] hurling their javelins at the elephants compelled them to wheel about and run back through the ranks of their own men, thus causing disorder and confusion there. This gave the victory to the Romans..." (Plut. Pyrrh. 25.5).

At least some of the Diadochs were aware of this tendency, as they prepared or responded to it accordingly. At the Siege of the Fort of Camels (321), Ptolemy deliberately went after Perdiccas' leading elephant in order to disengage the unit.

"Ptolemy, however, who had the best soldiers near himself and wished to encourage the other commanders and friends to face the dangers, taking his long spear and posting himself on the top

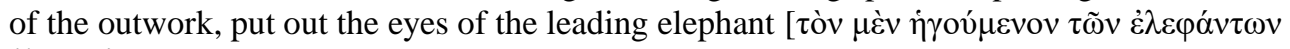
$\grave{\varepsilon} \xi \varepsilon \tau u ́ \varphi \lambda \omega \sigma \varepsilon v]$, since he [Ptolemy] occupied a higher position, and wounded its Indian

${ }^{179}$ DIod. 19.42.6. 
mahout...his friends fought boldly and made the beast next in line entirely useless by shooting down the Indian who was directing it." 180

Even though Diodorus' intent is to showcase Ptolemy's Homeric fighting style and bravery by going after the dominant elephant, the future pharaoh undoubtedly knew that Perdiccas' elephants would be disheartened by the injury of the leader. Eumenes seemed aware of this pattern as well, as he determined when to withdraw from Gabiene based on the loss of his leading elephant: "Thereupon [seeing the leading elephant fall] Eumenes, seeing that his forces were everywhere having the worst of it, led what remained of the cavalry out of the battle. "181 While one may be tempted to once again suspect Diodorus of crediting too much power to the elephants, in this case his statement follows a broader pattern and is credible. The collapse of o $\pi \rho{ }$ Eumenes needed to accept his losses and organize a retreat.

Such a behavioral pattern sheds light on a puzzling aspect of elephant deployment that Wrightson has noted: the Macedonians repeatedly stationed many of their elephants in front of the infantry, like towers along a wall, even though generals knew that elephants could not effectively penetrate the phalanx. ${ }^{182}$ This formation was clearly borrowed from the Indians, as we see at Hydaspes and in some of the mythical battles of the Mahabharata. ${ }^{183}$ While larger numbers of elephants could be gathered together on the

\footnotetext{
180 Diod. 18.34.2-3.

${ }^{181}$ Diod. 19.42.6.

${ }^{182}$ Wrightson (2015), 66 questions the deployment of elephants in front of infantry at Ipsus, which he calls "the most confusing aspect of the use of elephants by fourth century generals." Champion (2014), 57 finds the deployment of elephants in front of the infantry at Paraetacene so improbable that he doubts they were present there at all. Contra Glover (1944), 260 who claims that clustering elephants on the wings should only be done when one lacks a sufficient number to stretch across the front lines "like a screen of tanks." 183 The elephants at Hydaspes are likened to towers along walls by Diod.17.87.2 and Curt.8.14.13. The Mahabharata describes elephants stretched across the center of a line when King Yudhishthira "took up his position in the centre of his army, surrounded by huge and furious elephants resembling moving hills" (Mhb. 6.19.24). Singh (1965), 82 notes that among the ancient Indians, elephants were generally stationed to "maintain links between the center and the wings," which would require their presence amid or in front of the infantry.
} 
wings of a line where a stampede would do less damage, those stationed in front of and between phalanxes must have served to challenge the enemy's advance and prevent exposure of the flank. I would suggest that in addition to these reasons, elephants were placed far enough apart to allow for a light infantry guard and prevent elephants from herding and retreating back through the lines of their own men. ${ }^{184}$

This attempt failed in so many cases because even the distance and chaos of battle would not have stopped a herd from communicating, even though the soldiers around them would not have been aware of it. Since 1976, zoologists have suspected that elephants can communicate in vocal ranges beyond human hearing, and the studies of Katharine Payne in the 1980s used Asian elephants to prove it. ${ }^{185}$ Payne discovered that elephants are able to use infrasonic calls to communicate with one another at a frequency of 14 to 24 hertz-well below the range of human hearing, which at its best ranges from 20-20,000 hertz. Sukumar calculates that a human living in a modern urbanized setting can only hear sounds above 30-40 hertz, and amid the cacophony of battle, this would reasonably be higher. It is possible that elephants used this ability to send distress signals to one another amid battle, possibly determining as a group when it was time to retreat. While this vocal range would serve numerous evolutionary purposes, including

\footnotetext{
${ }^{184} \mathrm{An}$ armed guard for each elephant was a typical part of battlefield formation for both the Indians and the Macedonians. In the Mahabharata, elephants are depicted accompanied and protected by light-armed infantry (Mhb.6.46); Kautilya's Arthashastra recommends at least 15 men per elephant (10.5); see esp. Singh (1965), 81-84. For a summary of auxiliary troops assigned to elephants by Macedonian generals, see Epplett (2007), 227-230. It is also possible that the mahout's bird's eye view provided a useful perspective in battles on the plains, where elephants were most often used. E.g. Gabiene was especially chaotic because of the dust rising from the fields (Diod.19.42.1). Cf. Kistler (2006), 22-23, although he does not provide evidence.

${ }^{185}$ Payne et al. (1986), esp. p.300. While Payne et al.'s research shows that these infrasonic calls can come from any elephants and be in response to a variety of events and external stimuli, the frequency with which elephants communicate at this level is important here. It further explicates elephants' herding behavior on battlefields, especially in cases where they were stationed apart from one another and might have had trouble communicating. Cf. Sukumar (1994), 94-96.
} 
communication among family members over great distances and even an elephant cow's advertisement of estrus, it could also be used to send distress signals. ${ }^{186}$ This ability would have enabled elephants to protect one another more efficiently and determine, as a group when it was necessary to retreat, foiling the human attempt to use them as bulldozers and barricades.

\section{Factor D: Psychological Weapons}

Where elephants did play a decisive role, it was psychological, not practical. As some scholars have noted, ${ }^{187}$ elephants function best as psychological weapons against troops that are hemmed in close, as at the Battle of Cyrrhestica, or against those who are entirely unfamiliar with an elephant, as in the case of Antiochus I's so-called "Elephant Victory" (see p.132f.) and of Pyrrhus' initial battles with Rome, including Heraclea (280) and Ausculum (279). It is worth considering these examples of successful deployments of elephants for psychological purposes in order to understand part of their military value.

Cyrrhestica (285)

Near the end of the Diadoch Wars, Seleucus' star was rising and Demetrius, having been ousted from Macedonia, was in dire straits. In Phrygia his men were struck by famine and illness due to lack of supplies, and many were swept away in an ill-fated crossing of the Lycus River (Plut.Demetr. 46.5-47.1). When he reached Cilicia and pled with Seleucus to afford his men food and supplies, Seleucus held him in suspicion and offered two months of winter quarters, hemming him in. Demetrius' retaliation and

\footnotetext{
186 Sukumar (1994), 94-96.

${ }^{187}$ E.g. Wrightson (2015); Glover (1948), 4.
} 
subsequent attacks led to his being pinned in the straits of Cyrrhestica by Seleucus' men and, according to Polyaenus (4.9.3), a bevy of eight elephants blocking the opening to the pass. Both Plutarch and Polyaenus agree that Seleucus persuaded Demetrius' troops to defect with a speech, and both include the details of Seleucus' bravado in leaping down from his horse and throwing off his helmet to address the men (Plut. Demetr. 49.2; Polyaen. 4.9.3). While persuasion had become a valid means of winning over the enemy's troops during the Diadoch Wars, Polyaenus' account suggests that the trapped state of Demetrius' men and Seleucus' conveniently placed elephant corps probably proved more persuasive than his speech. Plutarch's account does not, however, preclude the presence of elephants, as the biographer very clearly states implies the presence of a large army (Demetr. 49.1).

Pyrrhus in Italy (280-275)

While Alexander's army may have fought off an elephant corps successfully the first time, it must be remembered that it was not the first time the Macedonians ever saw an elephant (see pp.43-46 above). The psychological shock of facing a wall of elephants in battle was somewhat defrayed by knowledge of the animal's form. While certainly every pitched battle against an elephant would be terrifying for even the most stalwart soldier, the first few would be especially impacted by the element of surprise and potentially paralyzed, not knowing how to ward off or defeat the animals. Although Pyrrhus' invasion of Italy does not usually constitute a part of the Successor Wars, an investigation of the military potential of elephants would be incomplete without a discussion of Pyrrhus' western forays. While Pyrrhus' victories were 'pyrrhic,' they were still victories; however, they reveal that elephants were useful only inasmuch as they 
were psychological weapons whose shock value was high. ${ }^{188}$

In 280, Pyrrhus possessed at least 20 elephants, and possibly as many as $50 .{ }^{189}$ Called into Italy on behalf of Tarentum, Pyrrhus stayed with the goal of conquering the peninsula for himself after defeating Rome. Word of his elephants arrived before the Epirote king himself, and the Tarentines honored and advertised their new ally with coinage featuring a physiologically accurate Indian elephant beneath their standard leaping dolphin. ${ }^{190}$ The awe in which these massive animals were held was a prelude to the horror they could evoke in enemies on the battlefield.

Because Rome's attention was split between Etruria and Tarentum, the Senate sent Valerius Laevinus and an army in an attempt to prevent local enemies of Rome from joining up with the Epirote army outside of the city of Heraclea. ${ }^{191}$ After Rome rejected Pyrrhus' offer of arbitration between Tarentum and Rome, the army of Valerius Laevinus faced off against Pyrrhus for what would prove to be a spectacularly bloody battle. Plutarch claims that there were seven shifts in fortune for either side, pulsing back and forth (Pyrrh.17.1), but Roman fortune shifted once Pyrrhus released his elephants, which were reinforced by cavalry. While naturally Pyrrhus' cavalry had been trained to move with elephants, the Roman cavalry panicked, "and their horses, before they got near the animals, were terrified and ran away with their riders" (Plut. Pyrrh. 17.3). While the elephants were able to crowd the Roman troops back and denude their flanks of cavalry, Pyrrhus sent his Thessalian horsemen in to drive home the victory.

\footnotetext{
${ }^{188}$ Pyrrhus' campaigns and the role of elephants are nicely summarized by Scullard (1974), 100-119; cf. Green (1990) 228-232 and in general Champion (2009), chapters V-VIII.

${ }^{189}$ Paus. 1.12.3 notes 20, Just.17.2.14 notes 50 on loan from Ptolemy Ceraunus.

190 Scullard (1974), 103, PL. XIVa

${ }^{191}$ Narratives of the battle of Heraclea may be found in Plut. Pyrrh. 16-17; DH 19.8-12; Orosius 4.1.10

references the location, and the Epitome of Zonaras 8; cf. Scullard 101-104
} 
The massive size and strength of the Indian elephants Pyrrhus brought to Italy would have been terrifying to an army unfamiliar with them. That horror may have been increased by the presence of turrets. The twelfth century Byzantine theologian Zonaras (8.3) suggests Pyrrhus' elephants were outfitted with turrets at Heraclea, which would have increased their size and firing power. The second century CE poet Florus (1.13.10) claims that Pyrrhus' elephants wore turrets at Ausculum, and generally scholars have attributed the invention of the elephant turret to Pyrrhus' campaigns. ${ }^{192}$ Especially compelling, despite the physiological inaccuracy, ${ }^{193}$ is the third century Campanian painted plate that depicts a mother and calf elephant, tail and trunk intertwined in realistic fashion. The mother bears a turret with clearly defined edges and nooks. The image is one Scullard declares to be "almost certainly" (Plate VIIIa) a depiction of Pyrrhus" famous elephants, indicative of the impression they made on the Roman people.

Pyrrhus stretched the psychological impact of his elephants to their limit, on the battlefield and in negotiations as well. Following Heraclea, Pyrrhus was joined by Rome's other enemies, the Samnites, Lucanians, and a handful of Greek poleis from Southern Italy. The peace negotiations that ensued that winter with Rome reveal a novel use of the animals. When Gaius Fabricius was sent to negotiate in person with Pyrrhus, the Epirote allegedly concealed an elephant behind draperies, dropping the fabric at the last moment to allow the elephant to extend its trunk over Fabricius' head and trumpet loudly. Even if this pageantry did occur, it is doubtful that Fabricius never flinched, as

\footnotetext{
192 Scullard (1974), 104-105; Charles (2008), 338.

193 The plate depicts an elephant cow with tusks, which would suggest an African, not Asian, species, as only Asian elephant bulls can grow tusks. However, the presence of a turret is suggestive of an Indian elephant like Pyrrhus', as Charles (2008) has shown that African forest elephants like those used by the Carthaginians and Ptolemies rarely, if ever, donned turrets.
} 
Plutarch claims (Plut.Pyrrh. 20.1-3). Nonetheless, the Romans did not agree to peace terms, and Pyrrhus marched against Ausculum in 279, ${ }^{194}$ where he engaged the Roman army for a second time. Plutarch records that on the first day of battle, the terrain was so rough that Pyrrhus could use neither his horses nor elephant corps, limiting his tactical advantages and the psychological weapon he had brandished against Fabricius earlier. Plutarch specifically notes that Pyrrhus sought out a flat plain in order to use his elephants (21.6), and once again the animals were effective. Plutarch tells us that:

"The greatest havoc was wrought by the furious strength of the elephants, since the valour of the Romans was of no avail in fighting them, but they felt that they must yield before them as before an onrushing billow or a crashing earthquake, and not stand their ground only to die in vain, or suffer all that is most grievous without doing any good at all." 195

Although Pyrrhus lost a considerable number of men, ${ }^{196}$ he was recognized the victor of the battle. However, two of our sources indicate that already the Romans had begun to devise machinery to repel the elephants. Dionysius of Halicarnassus records that the Romans had constructed wagons with extended, rotating arms covered in spikes; these could be whipped about against the elephants; similarly, cranes had been attached to hurl iron and pitch-soaked debris at the animals. The wagons were occupied by archers and slingers to agitate the elephants further (DH 20.1.6-7). While the descriptive accounts given by Dionysius and Zonaras (7.5.1-7) differ, both conclude that the machines were not especially useful. Dionysius notes that Pyrrhus' light infantry was able to kill the wagon operators before they could do significant damage, and Zonaras claims the elephants on either wing of Pyrrhus' army sent the Roman cavalry to flight so quickly that the wagons were useless. Scullard suggests that the authors' reports reflect a genuine

\footnotetext{
${ }^{194}$ For Ausculum see Plut. Pyrrh.21.5-10; DH 20.1-3; Zonaras 7.5.1-7; Scullard 105f.

195 Plut. Pyrrh. 21.7.

${ }^{196}$ Plut. Pyrrh. 21.8 notes 6,000 casualties among the Romans and 3,500 among Pyrrhus' men.
} 
innovation, reasoning that neither author would make up a Roman tactic that ultimately reflected poorly on the army. ${ }^{197}$ This seems most logical, as the Romans (and Fabricius especially) would have been well aware that Pyrrhus would use his elephants again and must have come up with some sort of plan to thwart them. Thus already the psychological shock value of the elephants was on the decline; like Ptolemy at the Siege of the Fort of Camels, the Romans were devising methods of protecting themselves against the elephants. Pyrrhus' losses were more significant following Ausculum, after which he purportedly said "if we are victorious in one more battle with the Romans, we shall be utterly ruined" (Plut.Pyrr.21.9).

Next, Pyrrhus moved on Sicily; we know that he brought his elephants along with him thanks to Diodorus' account of his campaign against the Carthaginians on behalf of the Greek cities of Sicily (Diod.22.8.2). While Scullard notes that "no doubt they were useful in attacks upon strongpoints," their exact role in the sieges is not recorded. Presumably the Carthaginian-manned cities did not yet have the technology to undermine elephants in sieges as Ptolemy and the Megalopolitans did (see p.69f.), as it is not until Pyrrhus' return to Italy that a loss of two elephants is mentioned, the result of a brieflydescribed battle with a force of 10,000 Mamertines upon landing (Plut.Pyrrh. 24).

By fall of 276, Pyrrhus arrived at Tarentum, where he recruited men and marched on Samnite territory where the Roman army had encamped. Pyrrhus found the consul Manius Curius Dentatus near Maleventum ${ }^{198}$ and sought to defeat him decisively before his fellow consul could arrive with aid, forcing a night march with "the most warlike of his elephants" (Plut.Pyrrh. 25.2) that led to his troops becoming lost in the forest and

\footnotetext{
197 Cf. Scullard (1974), 106-110.

${ }^{198}$ For the Battle of Maleventum/Beneventum, see: Plut.Pyrrh. 25; Dionysius 20.11-12; Zonaras 8.6.6.
} 
arriving late, in full view of the consul's army as they emerged from the forest. Plutarch's narrative of the battle is compact. ${ }^{199}$ Despite exhaustion, Pyrrhus' men and elephants were able to bear down upon the parapets the Romans had established. Ultimately, the Romans, "full of fresh vigour" ${ }^{200}$ had success in driving the elephants away from the parapets with javelins, an event with predictable results:

"hurling their javelins at the elephants compelled them to wheel about and run back through the ranks of their own men, thus causing disorder and confusion there. This gave the victory to the Romans"201

Dionysius of Halicarnassus' additional account of the Romans gaining momentum after wounding an elephant cub at Maleventum (DH 22.12.3) should be discarded; it is unlikely any elephant small enough to be recognized as a "cub" would have been deployed. ${ }^{202}$ However, his general account of elephant deaths at the hands of the Romans is not problematic; Dionysius specifies that the Romans killed two (presumably adultsized), and trapped eight more, at which point the Indian mahouts surrendered (22.12.3). Pyrrhus' elephants presented the Romans with their first glimpse of the animal, (Pliny NH 8.16), and Eutropius (2.14.3) claims that four of the beasts were paraded through the city during Curius Dentatus' triumph, an assertion that Scullard finds credible despite later claims that Metellus ( $N H$ 7.139) was the first to lead elephants in a triumph (Scullard 111).

\footnotetext{
199 Plut. Pyrrh.25; see also DH 20.11-12, Zonaras 8.6.6, Scullard 111-113

200 Plut. Pyrrh. 25.4; cf. DH 20.11.

201 Plut. Pyrrh. 25.5.

202 This anecdote does appear in later sources in modified form, including Florus 1.13.12 and Zonaras 8.6; both claim the elephant calf was injured and, crying for its mother, caused chaos among the elephants. Scullard (1974), 112 notes that the behavior of the calf is reasonable, which is so, but the behavior of the mahouts in deploying a baby elephant is absolutely not. Anyone familiar with elephant behavior, in which an entire female herd will violently protect calves, would know better than to risk deploying an immature elephant in battle. The elephant zoologist Raman Sukumar relates a similar, but thankfully less dangerous, experience of observation near Karapallam, India. Cf. Sukumar (1992), 87-88.
} 
In addition to the use of well-defended parapets, the Romans supposedly capitalized on the elephant's natural fear of squealing pigs, a point which Aelian makes (HA 1.38) without tying the event to any one particular battle. However, given that he concludes with the statement that the Romans used this tactic to bring about "glorious victory" (1.38), the only battle can be that of Beneventum/Maleventum. Scullard (11415) sees it as a genuine possibility, linking it to the now well-known piece of Aes Signatum stamped with a clearly Indian elephant (wearing a bell) on one side and a pig on the other.

Pyrrhus left Italy with only a skeletal framework of garrisons in place, trying his hand instead at Gonatas' unoccupied throne in Macedonia while the Antigonid king was campaigning in Megara. Here too, Pyrrhus' aims were thwarted. Thus, we have seen that even the psychological impact of a charging elephant corps can be blunted enough to enable troops which have only been recently acquainted with the animals to defeat them, just as Alexander's Macedonians did at Hydaspes. The Romans learned quickly how to undermine the elephants (with or without squealing pigs) and reduced their utility to risk value in battle.

While the sight of an elephant marching toward a man on the battlefield is arguably always daunting, the professional armies of the Hellenistic Age found ways to counteract the fearsome impression of the elephant and thus counterbalance the fear factor. For the Ptolemies and Seleucids, the potentially deadly elephant corps was maintained at least as late as the Seventh Syrian War, ${ }^{203}$ and in the majority of battles in

\footnotetext{
${ }^{203}$ Seleucid elephant forces are referenced by Josephus (AJ 13.5.3) at Antioch during the Seventh Syrian War (147-145), when the supporters of Antiochus VI Dionysus, the son of Alexander Balas, seized the animals from Demetrius II. Cf. Grainger (2010), $337 \mathrm{ff}$.
} 
which they were used, war elephants exhibited the very same problems that we have discussed here. The costly maintenance and high risk of using these animals in war indicates that elephants' tactical utility was not the only reason for which an elephant corps might be maintained, as we shall see in subsequent chapters. ${ }^{204}$

\section{Conclusions to Chapters 1 \& 2}

At this point our investigation of the major battles between the first generation of Successors has revealed that there is no significant correlation between the strength of a general's elephant corps and his success in battle. A close examination of the victories of elephant-heavy armies reveals that the cavalry, not the elephant corps, dealt the decisive blow and routed the enemy. Although the Macedonians adopted the Indian custom of deploying war elephants and even mimicked Indian deployment patterns, the differences in combat style precluded significant success for the animals. In many cases, a superior number of elephants has no impact at all, and the fighting comes down to the traditional modes of combat: cavalry and infantry. Elephants have been shown to be no more useful in sieges than in pitched battle. Despite their size and strength, they can be immobilized and incapacitated with relatively cheap and easily constructed traps, at which point their strength becomes a greater hazard for their mahouts and the soldiers advancing alongside them.

The very nature of the animals, both physiological and intellectual, made them hazards in battle rather than assets. When injured or upset, they could do serious harm to

\footnotetext{
${ }^{204}$ Contra Glover (1948), who argues that cost did not prohibit the Romans from adopting an elephant corps, but rather the "administrative headache" (10) that the animal entailed. The implication that the Seleucids and Ptolemies failed to learn these lessons is not convincing.
} 
their own side, and their inability to retreat quickly or in good order could easily lead to a panicked dash through their own side's lines. As intuitive herd animals, elephants that see their leader injured or killed in war understand what that means for their own chances of success or survival, and they become despondent and useless against the enemy. Thus, their primary strength in war was the horror they evoked in their opponents. No matter how many times soldiers faced elephants on the field, it is hard to believe that they ever would have come to see them as non-threatening. Even veterans of Alexander's Indian campaigns must have shuddered at the sight of a massed elephant charge. However, as we have seen, both the Macedonians and the Romans developed tactics to counter that psychological impact.

If a close investigation of the relatively scanty narrative histories of the Successor Wars reveals, at best, the ambiguity of elephant success in ancient combat, it must have been obvious to the generals who deployed them. This begs the question, why did the Successors use elephants at all? The cost of acquiring, training, maintaining, and transporting large elephant corps must have been astronomical; why would anyone invest in these animals if similar or better results could be achieved simply through superior cavalry and infantry? In the following chapters, I will address this question in greater detail. As we shall see, elephants evolved from serving as battlefield screens and psychological weapons to becoming symbols of a Successor dynasty's wealth and military potency. Regardless of their effectiveness in battle, elephants became the animals of kings. 


\section{Chapter 3: Alexander's Elephants \& the Diadochs}

In chapters one and two, we reviewed how the ancient sources' emphasis on the exotic and psychological horror of the charging elephants has misled some interpreters to believe that this indicates the success of the elephants in battle. Through a close blow-byblow analysis of the major battles of the Diadoch Wars that involved elephants, we have seen how that is not the case. The skilled and largely successful generals of the Diadoch Wars must have recognized this all along. After all, Alexander himself remarked on the potential of elephants to do more harm than good to their own side; accordingly, he never deployed them, despite multiple opportunities (Curt.9.2.19-21; see p.47). The conclusion of chapter two demands further explanation: why, if not purely for tactical purposes, did the Successors maintain elephant corps and even seek to expand their stock throughout the Diadoch Wars?

One possible explanation comes from Glover, who claims that "men have always been slow, or reluctant, to read aright the lessons of facts [regarding an elephant's inutility.] ${ }^{\prime 205}$ One of the first scholars to provide a detailed examination of war elephants, Glover's two-part study ${ }^{206}$ concludes that (1) elephants were never brought together to charge en masse by the Macedonians, even though this was the most effective means of deploying them.Glover also adds (2) that generally elephants were an "administrative headache"207 that were difficult to feed, transport, and wield, and far too risky a gambit to deploy in battle, despite their psychological value against untried troops. Finally, (3)

\footnotetext{
205 Glover (1948), 11.

${ }^{206}$ Glover (1944) and Glover (1948) are distinct and separate articles, but both address the same topic and follow the same thread of argument.

${ }^{207}$ Glover (1948), 10.
} 
Glover concludes that the Roman experience with Carthaginian elephants ended the trend of western use of the animals in battle, as the Romans readily recognized the drawbacks of using elephants in battle and declined to keep them for anything other than entertainment purposes. $^{208}$

The implication that Romans recognized the inherent problems with elephant use in battle but generations of Hellenistic kings and generals failed to is unlikely. None of the Diadochs or their heirs would have run such a substantial risk in war without good reason, and those reasons are the focus of this chapter. The tactical significance, as we have seen, has been overestimated by ancient writers. Indeed, the two dynasties which maintained elephant corps the longest, the Ptolemies and Seleucids, were founded by generals who made a name for themselves in India and would have been quite familiar with the tactical difficulties the elephant presented. ${ }^{209}$ And yet, the possession of elephants by one general spurred competition and an ancient "arms race"210 that demanded every competitor in the Diadoch Wars meet the ante of an elephant corps. In addition to this "stockpiling" of sorts, the elephant's potent symbolism was also exploited by most of Alexander's generals, and it is the propagandistic value of the animal that concerns us here. ${ }^{211}$

\footnotetext{
${ }^{208}$ Ibid., esp. pp. 10-11.

${ }^{209}$ Seleucus and Ptolemy I traveled with Alexander throughout India and participated in the Battle of Hydaspes against Porus' elephant corps. Indeed, most of the details for the Indian campaign in Arrian's Anabasis come from Ptolemy's own history of Alexander. For the Battle of Hydaspes, see: Diod. 17.87.117.89.3; Curt. 8.13.5-8.14.46, cf. 18.13.17-20 on Ptolemy's involvement; Arr. 5.9.1-5.19.3. Discussion: Worthington (2016) 53-67 on Ptolemy, and for Ptolemy's history see Worthington (2016) Appendix 1. On Seleucus, Bevan (1985), 292-294; Grainger (1990), 9-11.

${ }^{210}$ Spinage (1994), 265.

${ }^{211}$ Cf. Troncoso (2013), Epplett (2007), 216.
} 
The Diadochs sought legitimacy above all else, and the many media through which they established and propagated their right to rule have long been studied by scholars. ${ }^{212}$ One of their most dynamic symbols was the elephant, an exotic emblem of power tied directly to Alexander himself. Whether Alexander ever intended to adopt the elephant as a symbol of his reign cannot be known, but his Successors certainly associated him with the kingly beast of the East. This association is so long lived that it even served as a medium for symbolic moralizing in Jean Mercier's $16^{\text {th }}$ century Emblemata, in which ancient war elephants are referenced and, inevitably, Alexander is as well. ${ }^{213}$ Such a pervasive association is the product of diligent Diadoch campaigns for legitimacy. Indeed, the elephant played a key role in the images many of the Diadochs fashioned for themselves, serving as one more means of linking themselves to Alexander and advertising legitimacy and continuity with the Argead Dynasty. Through battlefield display and widely circulated coinage, the Successors fought to tie themselves to Alexander's world-conquering success through the image of the elephant.

The purpose of this chapter is not to suggest that the Successors accumulated and fought with elephants solely for their symbolic purpose, but rather to emphasize that the symbolic clout these animals carried has been overlooked by modern scholarship because of their devastating potential on the battlefield. ${ }^{214}$ The significance of elephants in the

\footnotetext{
212 The bibliography for such a topic is immense. Consider for example: Kosmin (2014, 2013), Bosworth (2002), Stewart (1993), and a number of essays in Troncoso and Anson (2013), Erskine (2003), Ogden (2002), and Bilde et al. (1996).

${ }^{213}$ Bright and Bowen (1983) link this tradition to Alexander's well-known conquest of India as recorded in the Alexander Romances.

${ }^{214}$ Notable exceptions would be Troncoso (2013), whose essay asserts the symbolic potency of elephants, and Kosmin (2013), who links the Indian elephant to Seleucid victory propaganda. Epplett (2007), 221 mentions the symbolic potential of the animals, but the nature of his essay does not permit extensive discussion. My chapter expands on such ideas in conjunction with chapter one and considers the changing function of elephant symbolism from the era of the Diadoch Wars to the reigns of the Epigonoi and beyond.
} 
armies and menageries of the Successors changed over time, as we shall discuss in chapter four, but their initial importance was to help to confer legitimacy. Alexander's elephants served as a significant link between the Macedonian king and the generals vying for parts, or all, of his kingdom. ${ }^{215}$ This chapter argues that in addition to being a truly terrifying addition to the battlefield lineup (arguably for both sides), the elephant was one among many means of representing continuity with Argead rule for competing generals during the Diadoch Wars.

\section{Part A The importance of propaganda}

It must be remembered that by 322 , there were three potential contenders for the throne of the Macedonian Empire, and none of them were Alexander's generals. Alexander's potential heirs included Alexander IV, his legitimate son, Philip III Arrhidaeus, his half-brother and the son of Philip, and Heracles, his illegitimate son by the Persian princess Barsine. Any claims to territory that Alexander's generals made were just that-hollow assertions without any validity. In order to combat the legitimate claims of royal blood, the Successors utilized a combination of fictive loyalty, appointing "epistateis" of the royal brood and dating official documentation by the years of their reign, ${ }^{216}$ and imitation of Alexander himself. Because regional control and secret

\footnotetext{
${ }^{215}$ Gruen (1985/2018) advances the argument that all of the Successors were similarly set on expansion and does not view Antigonus as the only general covetous of Alexander's entire empire. See his bibliography for the history of this argument.

${ }^{216}$ Gruen (1985/2018 reprinted in Karanos), 110 n.6 argues that up until Antigonus Monophthalmus took the title basileus, all Successors had professed loyalty to the Argead throne, with Babylonian and Egyptian records counting the regnal years of Alexander IV even after his death in 310. See further: Diod. 20.20.1-4, 20.28.1-4; Justin, 15.2.3. On the strength of support for this effort, see, especially, Diod. 20.20.3-4, 20.28.1. Gruen argues that this loyalty, at least as a façade, remains in place until the Battle of Salamis between Demetrius and Ptolemy, which Demetrius wins. After this, Antigonus claims the crown, and sends a diadem to Demetrius as well, after which he asserted his own dynasty in a distinct break from the past and the Argeads (112).
} 
alliances shifted dynamically throughout the Diadoch Wars (due in no small part to the steady decline in the number of competing generals), territorial claims were managed largely through pretensions to legitimacy and tight control over one's own army. Indeed, much of Successor propaganda was intended to convince the Macedonian soldiers themselves. Several battles of the Diadoch Wars were won not through direct fighting, but through the desertion or defection of key military units to the opposing general's side. ${ }^{217}$ When legitimacy stemmed not from birth, but from persuasion and demonstrations of power, soldiers altered their loyalties as necessity and logic demanded, and every display of power counted.

Bilde et al. are right to point out that each Successor dynasty "had to legitimate their claim to monarchy according to the specific local needs and traditions," 218 and the first generation had more in common than any other- they all used their ties to Alexander and the Argead line to legitimize their power. One of the many ways in which Successors managed this was through the adoption and deployment of the elephant, both in the flesh and as a symbol. ${ }^{219}$ The animal was not only a sigil of kings in Indian epic (Mhb. 6.17); the Ptolemies and Seleucids both adopted it for their dynasties, and most of the less successful Diadochs employed them as well, including Antigonus Monophthalmus, Demetrius, Eumenes, Perdiccas, Cassander, Polyperchon, and

\footnotetext{
${ }^{217}$ To offer a few examples, consider the desertion of Perdiccas' men to Ptolemy during the Egyptian campaign, primarily because they found him a better leader (Diod. 18.33.2-3); the desertion of Eumenes' general Perdiccas (not to be confused with the late regent) before the Battle of Gabiene (Diod. 18.40.1-4), and the desertion of Eumenes' hipparch Apollonides who was persuaded by Antigonus to desert Eumenes mid-battle (Diod.18.40.5-8); the desertion of Demetrius' men to Ptolemy after Gaza (Diod. 18.84.5); Polyperchon's general Alexander 's desertion to Cassander (Diod.19.64.3); Antigonus had to torture would-be deserters in large numbers (both generals and mercenaries alike) to prevent defection of his men to Ptolemy (Diod. 20.75).

${ }^{218}$ Bilde et al. (1996), 11.

${ }^{219}$ Alan Lloyd (1982), pp.33-35 provides a good overview of how to define slippery terminology like 'propaganda' and 'symbol' within the context of ancient history.
} 
Lysimachus. Although Troncoso argues that only Seleucus and Ptolemy ever employed elephant symbolism successfully, while the other successors looked upon the animals only in practical terms, this may not be the case. ${ }^{220}$ The persistent and risky deployment of elephants in battle was a show of force and legitimacy which most of the Successors vied for. Before examining Diadoch use of elephants, we must first establish the link between elephants and Alexander that made the exploitation of this symbol worthwhile to the Diadochs. While Troncoso rightly notes that no one ever saw the Macedonian king riding one of his elephants into battle, ${ }^{221}$ Alexander did make conspicuous display of his elephants on at least two occasions. His Successors cinched the connection after his death by capitalizing on Alexander's own association with Dionysus and the legends of Dionysus in India, enmeshing Alexander, the elephant, Dionysus, and India in a tangled web of imagery.

\section{Part B Alexander's Elephants}

Although more closely linked to elephants posthumously and by his Successors, Alexander did make efforts to acquire and keep an elephant corps of his own, although as we have seen (p.47), he never deployed them. Scullard offers a detailed account of Alexander's encounters with and acquisition of elephants and keeps a running tally, which we can condense here. ${ }^{222}$ Following Gaugamela (331), Alexander acquired Darius' 15 elephants from the Indian contingent of his army; Arrian reports that Parmenion

\footnotetext{
220 Troncoso (2013), 264-265.

${ }^{221}$ Troncoso (2013), 270.

${ }^{222}$ Scullard (1974), 64-76.
} 
rounded them up when he seized the Persian baggage train (Arr.3.15.4). Exactly what he did with them is unknown. As Alexander marched to Susa, the satrap pre-empted his arrival by sending out gifts, among which were dromedaries and a dozen elephants sent to Darius III from India (Curt.5.2.10). Potentially these were intended to serve at Gaugamela and did not arrive in time, and it is not known what became of them. Scullard, perhaps due to Pliny's influence (NH 8.17.44), speculates that some might have been sent back to Aristotle in Greece at this time, but Romm and Bigwood provide good reason to doubt this. ${ }^{223}$

Alexander did not acquire more elephants again until crossing the Hindu Kush into India, where he was promised 25 elephants from Taxiles, the raj of Taxila (Arr. 4.22.6). He campaigned against the Assaceni, who had 30 elephants in their force (Arr. 4.25.5), and seized Ora and its elephants (4.27.9). He pursued another Assacenian leader into the mountains, and Arrian notes that Alexander was then especially eager to learn more of the elephants (4.30.6). He at some point brought Indian specialists into his army to help him seize the elephants of a certain Abisares, whose elephants he captured while they were being watered along the Indus. ${ }^{224}$ At this point Scullard notes that Alexander integrated the elephants into the army "perhaps rather for purposes of transport or to impress the tribes through whose territory he advanced than for actual fighting," ${ }^{225}$ which rightly acknowledges the animals' symbolic clout in India and Alexander's reluctance to

\footnotetext{
${ }^{223}$ Scullard (1974), 65; cf. Romm (1989), who notes, among other things, the lateness of the source (p. 569) and the absence of reference to scientific patronage amid Plutarch's effusive praise of Alexander's devotion to his instructor (De Alexandri, 327f-328b). Romm concludes that Roman-era pseudo-scientists used such a story in an attempt to lean on Aristotle's scientific credentials while presenting their own accounts of natural marvels. Bigwood (1993) acknowledges Aristotle's debt to Ctesias' account of elephants, suggesting a less intimate and first-hand knowledge of the animals.

${ }^{224}$ Arr.4.30.7-8; Diod.17.86.2-3 says "Aphrices" for Abisares.

225 Scullard (1974), 66.
} 
employ them in battle. ${ }^{226}$

In Taxila, Alexander was given the initially promised 25 elephants (Arr.5.3.5) and then gifted an additional 56 more (Curt.8.12.2), unless Arrian's and Curtius' accounts both present different quantities of elephants from a single, initial gift. There is no evidence that he wanted or attempted to deploy these animals against Porus, ${ }^{227}$ who had 200 of his own stationed in front of the infantry. ${ }^{228}$ After the battle, Alexander took a contingent of Indian warriors from Porus, along with elephants (Arr.5.21.2), and received 40 from Abisares, Porus' ally. Despite numerous sieges as he marched east, there is no record of his deploying any of them. After Hyphasis, Alexander and the Macedonians marched west again, and Alexander acquired elephants from Oxycanus (Arr.6.16.2) and another 30 elephants from the Indian king Sambus. ${ }^{229}$ By his death in 323, Scullard estimates that Alexander must have had close to 200 elephants, many of whom would go on to fight in the wars among his Successors. ${ }^{230}$ Certainly Alexander's capture of elephants and demand of elephant 'troops' from Porus and Abisares indicate an interest, but Kistler's insistence that Alexander had great plans for them is not supportable. ${ }^{231}$

Before the Diadoch Wars broke out, there are four clearly documented uses of elephant imagery either by Alexander or in close association with him. The two documented uses of elephants and elephant imagery in Alexander's reign are (1) the

\footnotetext{
${ }^{226}$ Cf. Kistler (2006) above p.47.

${ }^{227}$ Kistler (2005), 39 and Scullard (1974), 67-72 give possible reasons, including the difficulty of crossing the river, lack of experience fielding elephants, and the risk of undermining the Macedonian cavalry advance.

${ }^{228}$ Arr.5.15.4 gives the number 200, which may be an exaggeration drawn from Ptolemy's account, although it is far from implausible. Diod. 17.87.6 writes 130 elephants, and Curt.8.13.6 writes only 85.

${ }^{229}$ Arr.6.16.4 notes that Sambus gave Alexander all of his elephants once he was captured, and Diod. 17.102.7 notes that Sambus had initially fled his kingdom with 30 .

${ }^{230}$ Scullard (1974), 74.

${ }^{231}$ E.g. Kistler (2006), 38-41.
} 
elephant medallions he minted following the battle at the Hydaspes, and (2) the elephant agema that allegedly surrounded his formal court. Immediately after his death, (3) elephants appear on his funeral carriage, perhaps Perdiccas' idea, as he later (4) used the elephants as state executioners in a grisly display. Let us begin with Alexander's own elephant coinage.

The well-known elephant medallions depicting the Battle of the Hydaspes (326) were produced in commemoration of Alexander's most famous military undertaking. His victory over the Indian raj Porus and his four-fold army was a considerable feat, to which Arrian devotes more detail than any other single event, including the siege among the Malli (Multan) where Alexander was almost fatally injured. ${ }^{232}$ Alexander celebrated the victory through a festival that included athletic and equine competitions along the Hydaspes River (Arr. 5.20.1). The king also founded two cities to immortalize the Macedonian victory: Nicaea ("Victory City") and Bucephala, honoring Bucephalas who allegedly died of battle injuries. ${ }^{233}$ In addition to the celebrations, Alexander minted this series of silver coins of different weights that feature three interrelated sets of designs all inspired by the victory at Hydaspes. ${ }^{234}$ These coins have two slightly different types and are much debated, although it is agreed that they represent Macedonian victory over Porus' army. ${ }^{235}$ Both types feature an obverse with two riders on an elephant and a

\footnotetext{
${ }^{232}$ The account of the Hydaspes and its aftermath lasts in Arrian from 5.8.4-5.20.4. Even the account of the siege of Multan, where Alexander was badly injured, endures only from 6.8.1-6.12.3. Perhaps greater detail of the land battle was available in Arrian's sources, Ptolemy and Aristoboulus, especially given Ptolemy's extensive use of the Indian campaign for propagandistic purposes. Diodorus too gives it a comparatively extensive description, from 17.87-17.89.4, larger than the siege of Aornus and its accompanying legends (17.85-17.86.3).

${ }^{233}$ Plut. Alex. 61. Hamilton (1969) contends that Bucephalas may well have died of old age, supporting the tradition that he was 30 years old (169).

${ }^{234}$ Stewart (1993) figs. 68-69 provide excellent close-up photographs. See especially Holt (2003).

235 See Bosworth (1988), 130; Heckel (2012), 124-5; Lane Fox (1996), Price (1982), Stewart (1993), 201f, Worthington (2014), 249. For competing theories and thorough analysis see Holt (2003) and bibliography.
} 
warrior on a rearing horse facing the elephant, the warrior heaving a spear forward. Both reverse sides feature a keraunophoros figure that holds the thunderbolt in his right hand and a spear in his left. This has been understood to represent a Zeus-Alexander fusion reminiscent of the well-known painting of Alexander Keraunophoros at Ephesus. ${ }^{236}$ One coin type features a clearly helmeted keraunophoros with plumes coming out of the top, and the other features what appears to be a long-haired soldier without a helmet, but with clearly defined thighs, reminiscent of black figure Atticware. Stewart notes that the first of these coin types to emerge was found in Bokhara, Afghanistan (ancient Sogdiana), and subsequent finds came from Babylonia. However, the 1973 recovery of a coin horde in Iraq revealed many more of these so-called Porus decadrachms, and additional coin types with interrelated imagery.

The additional coin types included a silver tetradrachm with an obverse of an (Indian) archer with a long bow and a reverse of an Indian elephant, easily identified by its small ears and rounded back. Also found in that horde was a coin type that sheds light on Indian warfare in the fourth century. The silver coin features on the obverse an elephant carrying a warrior standard bearer on its back, and on the reverse a chariot manned by a charioteer and archer. ${ }^{237}$ One finds echoes in this of the chariot-jumping style of fighting at Sangala (Arr.5.23.1-3) and the chariot support given war elephants in Indian armies (see above p.31). This indicates that the descriptions provided by the Mahabharata of the chariots and elephants of India's fourfold army were still in play in

\footnotetext{
Holt accepts the scholarly consensus that the figure with a thunderbolt on the reverse represents Alexander, but he discards the notion, and rightly I think, that the medallions might represent Alexander's other battle against elephants at Gaugamela (68-92).

${ }^{236}$ See Stewart (1993), 191-200. Stewart dates the commission of the painting to 324 after Alexander's return from India.

237 This coin is depicted in Morkholm (1991), 53, pl. 3 45-6.
} 
the late fourth century. ${ }^{238}$

Because the coins were unmarked other than minting officials' initials, ${ }^{239}$ viewers had to rely on context clues to decipher them, a sure indication that the images represented recognizable modes of Indian warfare. The conspicuous absence of a clear legend contributes to Holt's conclusion that the coins were not intended as standard currency, but as commemorative medallions of some value, a creative way of distributing loot to the Macedonians while celebrating an iconic victory. ${ }^{240}$ Stewart draws different conclusions, supposing that they were struck by Alexander's subordinates, a "quasiautonomous coinage" 241 because the majority of coins unearthed come from the Mesopotamian region. He does not link them directly to Alexander at all due to lowquality die impressions and a total lack of even so much as an A $\Lambda$ E $\Xi A N \Delta P O Y$ on the coin. Were they commemorative medallions, this would not necessarily be requiredindeed, the images speak for themselves so well that despite differing interpretations, scholars have easily recognized exactly what the images depict over two millennia later. Whether these coins were intended as commemorative gifts or meant for circulation in the East, their use of imagery closely linked Macedonian victory in India to their victory over elephants, and it is unsurprising that some of Alexander's Successors would

\footnotetext{
${ }^{238}$ Frequent references to a "fourfold army" appear in the epics, especially the Ramayana. The army's major wings include: infantry, cavalry, charioteers, and elephant-riders . See Pant (1997), 89-91, see for e.g. Ramayana Book I, Canto XXII; Book II Canto LI, Canto LXXXVI)

${ }^{239}$ Stewart (1993), 202.

${ }^{240}$ Holt (2003), 146-150. See chapter 7 especially. Regarding the reverse of the medallion, which shows [likely] Alexander in battle gear and chlamys being crowned by Nike and wielding a thunderbolt, Holt asserts that Alexander takes credit through the coins for the lightning storm that covered the Macedonians' crossing and helped to win the battle (153). He argues that the king is "highlight[ing] his supernatural leadership" by "remind[ing] men that have grown wearied and worried that he has special powers to exercise on their behalf" (155). While I find his argument regarding the purpose of the medallions particularly compelling, his assertion that divine attributes in art are meant to indicate divine powers in life seems far-fetched.

${ }^{241}$ Stewart (1993), 202.
} 
manipulate similar imagery. Alexander and the elephant would reappear on Successor coinage for generations as the king's generals attempted to remind their followers of their military success at the legendary battle of Hydaspes.

Alexander's elephants appear next not on coinage but in the flesh at his formal, and somewhat "medized" court. To our sources, all writing in the Common Era (Polyaenus, Athenaeus, and Aelian), the entire display serves as an example of Alexander's expenditures and the increasing opulence of his court, a court which the sources describe as reveling in the luxury of the East. The earliest and best-known record comes from the third century Phylarchus' Histories apud Athenaeus, whose Deipnosophistae of the third century CE records details provided by the Histories of Phylarchus. It is worth considering the relevant part of the passage in full:

The expense of all this [i.e. the luxe lifestyle of the Persian kings], says Phylarchos, was far less than the daily sums squandered by Alexander; for he had a tent capable of containing a hundred couches, and fifty golden pillars supported it. And over it were spread golden canopies wrought with the most superb and costly embroidery, to shade all the upper part of it. And first of all, five hundred Persian Melophoroi (King's body-guards) stood all round the inside of it, clad in robes of purple and apple-green; and besides them there were bowmen numbering one thousand, some clad in garments of a fiery red and others in purple, and many of them had blue cloaks. And in front of them stood five hundred Makedonian Argyraspides; and in the middle of the tent was placed a golden chair, on which Alexander used to sit and transact business, his body-guards standing all around. And on the outside, all round the tent, was a troop of elephants regularly equipped, and a thousand Makedonians, having Makedonian dresses, and then ten thousand Persians: and the number of those who wore purple amounted to five hundred, to whom Alexander gave this dress for them to wear. And though he had such a numerous retinue of friends and servants, still no one dared to approach Alexander of his own accord, so great was his dignity and the veneration with which they regarded him. ${ }^{242}$

In Athenaeus' account, the grand display appears to be for holding court and transacting business, and Aelian (VH 9.3) repeats Athenaeus' account almost verbatim, but leaves out reference to the elephants. A slightly different description occurs in

Polyaenus (4.3.24), who specifies that this display describes Alexander's court of justice

${ }^{242}$ Athenaeus 12.539D = BNJ 81 F 41, edited and translated by Franca Landucci (2017). I have retained Landucci's transliterations and helpful parenthetical notes. 
among the barbarians, specifically in Hyrcania, Bactria, and India, where the exhibition was meant to impress the barbarians. Contrarily, his court of justice for the Macedonians and Greeks was quite plain. While it is perfectly plausible such a display occurred in India, it is far less likely that Alexander set elephants up around his court in Hyrcania or Bactria, where he was constantly on the move combating the forces of Bessus and then Spitamenes. The only elephants he possessed at the time were those from Gaugamela, and whether he brought them further east is unknown; they are certainly never mentioned.

All three sources agree that the formal display was part of doing business, but how often it was used, beyond the references Polyaenus provides, is unknown. The historian Ephippus of Olynthus makes a note of the golden throne as well, linking it specifically to business transactions. ${ }^{243}$ Bosworth, however, refers to the spectacle as a description of the mass marriage ceremony at Susa, noting the significance of Alexander's "unforgettable display of regal glory in his last years" 244 even though Polyaenus specifically places the description earlier in Alexander's life, and neither Athenaeus nor Aelian suggest a date. Although not citing Chares of Mytilene, ${ }^{245}$ likely Bosworth had this account in mind when he placed the elaborate court described by our sources above within the historical context of the Susa wedding. Indeed, similarities between the wedding tent and the audience tent have provoked debate over whether they were one and the same. ${ }^{246}$ While the description provided by Chares smacks of luxe living, it is far from identical to the descriptions in Phylarchus apud Athenaeus,

\footnotetext{
${ }^{243}$ BNJ 126 F 4 and commentary by Luisa Prandi 2016.

${ }^{244}$ Bosworth (2002), 255.

${ }^{245}$ Bosworth (2002), 255 n.36.

246 Charles BNJ 125 F 4 and commentary by Sabine Muller (2017).
} 
Polyaenus, and Aelian - there is no reference to rings of Melophoroi, bowmen,

Argyraspides, bodyguards, or elephants, suggesting an entirely different scenario is being described in either case. ${ }^{247}$ Furthermore, Spawforth notes that Chares would have no reason to describe the Susa tent twice within his book 10 of his Histories if it were one and the same. ${ }^{248}$

Arrian's description of the wedding only further compounds the problem, as he specifies that chairs, not couches, were set up at the wedding for the groomsmen and their brides, as the ceremony was conducted in Persian fashion. ${ }^{249}$ Indeed, Phylarchus' apud Athenaeus reference to the tent's capacity to contain one hundred couches is not indicative of festivity. As Landucci points out in her commentary, this is a commonly used unit to measure interior space. ${ }^{250}$ Landucci also concludes that Athenaeus' description uses the Apadana of Persepolis as a model, a means of emphasizing Alexander's adoption of Persian court ceremony and thus his corruption by luxury. The similarities between Alexander's tent (as described in our sources) and the Apadana, combined with the stark absence of concentric rings of military men in Chares' description of the wedding tent, tilt the scales heavily in favor of viewing the two as distinct. The elephants appear only in the context of the royal audience tent, which is the more logical place for them. It would be difficult to enjoy wedding festivities while surrounded by a ring of elephants, who, even staked down, could easily get into trouble

\footnotetext{
${ }^{247}$ Indeed, Chares notes that far from standing in rings about the central tent, "the rest of the army, infanterists and < cavallerists and > members of the fleet, embassies and other visitors to the court were hosted in the courtyard" (BNJ 125 F 4, translated by Muller 2017).

${ }^{248}$ See Muller (2017) commentary and Spawforth, A (2007), 118-20.

${ }^{249}$ Arr. 7.4.6-7; cf. Plut.Alex. 70.2 refers to couches, but conflates the Opis reconciliation feast with the Susa weddings.

${ }^{250}$ See Landucci (2017) and E.S. McCartney (1934), 'The Couch as a Unit of Measurement', CPh 29, pp. 30-5.
} 
and at the very least cause a severely unappetizing mess. Furthermore, the fact that the

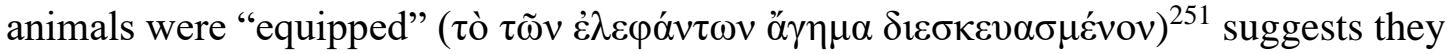
were meant to be especially intimidating, more appropriate for an audience hall than a wedding. Alexander certainly went to a great deal of trouble to put these animals on display in his great tent, a visual representation of the extent of his conquests and the forces under his command, radiating outward from the central golden throne. Such a display, whether utilized only once or, as Polyaenus would have it, multiple times (4.3.24), clearly made a deep impression on Alexander's generals. They would subsequently compete to acquire elements of this display, including both the loyalty of the Argyraspides and possession of elephants, during the Diadoch Wars following Alexander's death. More immediately, however, elephants appear once again in close connection to Alexander on his funeral carriage, as a new but integral part of the Macedonian army.

Diodorus gives the best literary depiction of Alexander's funeral carriage, describing four painted tablets hung on the tomb-shaped hearse that featured:

(1) "On the first of these tablets was a chariot ornamented with work in relief, and sitting in it was Alexander holding a very splendid sceptre in his hands. About the king were groups of armed attendants, one of Macedonians, a second of Persians of the bodyguard, and armed soldiers in front of them.

(2) "The second tablet showed the elephants arrayed for war who followed the bodyguard. They carried Indian mahouts in front with Macedonians fully armed in their regular equipment behind them.

(3) "The third tablet showed troops of cavalry as if in formation for battle;

(4) "and the fourth, ships made ready for naval combat." ${ }^{252}$

${ }^{251}$ BNJ $81 \mathrm{~F} 41$.

${ }^{252}$ Diod. 18.27.1; see also Stewart (1993), 216-220. 
Thus the fourfold army of the Macedonians: infantry, elephant corps, cavalry, and navy.

The carriage took nearly two years to complete (Diod. 18.28.2), and its final form was a spectacle worthy of the empire its occupant had ruled (Diod. 18.26-28). Stewart assesses the elephant corps painting, whose "mixed crews bore further witness not only to the awesome strength of the Macedonian military, but also the importance of the Indian contingent in the imperial army." ${ }^{, 253}$ Certainly these were the thoughts of at least one of Alexander's Successors, Perdiccas, who likely played a key role in the design of the funeral carriage. Although Alexander's half-brother Arrhidaeus was assigned the task, it is unlikely that Alexander's chiliarch (Curt.10.6.4) left Arrhidaeus with total control over the costly design of this mobile monument, as he is reported to have suffered from some sort of mental disability. ${ }^{254}$ While Alexander's scepter, armor, and elephants were on pictorial display on the funeral carriage, Perdiccas kept the real articles in Babylon. ${ }^{255}$ The elephants, importantly, had been employed in the meantime to end intra-army quarrel over Alexander's heir; their participation added an authoritative, if grisly, dimension to the act. The course of events leading up to the execution is worth considering in detail, as it illuminates the first symbolic use of live elephants by one of the Diadochs.

The chaos surrounding Alexander's death is well known, and during the two years

\footnotetext{
253 Stewart (1993), 220.

${ }^{254}$ Arrhidaeus is described by the sources as handicapped in some way, either mentally, physically, or both, but there is too much variation in the reports to conclude anything specific. Dexhippus BNJ 100 F 31 notes

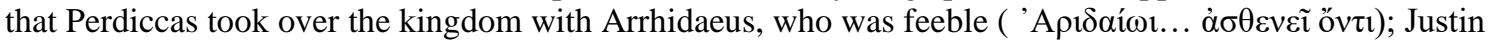
13.2.11 specifies that Ptolemy objected to Arrhidaeus' kingship because of a weakness that Arrhidaeus suffered (propter valetudinem maiorem quam patiebatur); Diod 18.2.2 notes that the infantry supported him

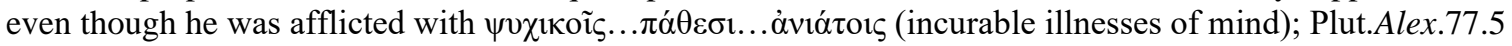
less convincingly claims Arrhidaeus was rendered mentally unfit because he was drugged by Olympias. See further Sharples (1994).

${ }^{255}$ Stewart points out that Perdiccas must have kept Alexander's diadem, scepter, and armor in Babylon, as Eumenes was later able to use them in 318 to establish his cult of Alexander (1993, p. 216). Diod.18.60.461.3, 19.15.3-4; Plut. Eum. 13.3-4; Nep. Eum.7.2-3; Polyaenus 4.8.2.
} 
in which Alexander's body was mummified, his funeral carriage built, the king's generals and high-ranking officials bickered over his heirs. ${ }^{256}$ Perdiccas used ceremony and symbolic display to his advantage from the outset, and the context in which elephants were eventually used as executioners is worth investigating in its entirety. Leaving the king's throne empty, Perdiccas draped his robe across it, setting up on the seat his diadem, armor, and signet ring (Curt. 10.6.4), which Alexander had passed to Perdiccas before his death to signify his regency (Curt. 10.6.18). Evidently Perdiccas' initial hesitation, whether feigned or not (Curt.10.6.18) prompted the protest of Meleager, an infantry general. Meleager's protest was a vicious one that questioned not only Perdiccas' ability to fill the king's shoes, which was likely a fair question of any of his generals, but his willingness to protect the lives of Alexander's descendants. Meleager and his followers among the infantry were staunch supporters of Arrhidaeus, soon to be Philip III Arrhidaeus, Philip II's son and Alexander's half-brother. Meleager claimed that whether the army determined Perdiccas as regent or Roxane's child should rule did not matter, as ultimately Perdiccas would usurp power for himself. He goes on at length. Even if Curtius has artificially expanded what might have been a laconic retort, the gist of it is significant:

"That is why no king pleases him except one who is not yet born, and amid the great haste of
all, which is not only reasonable but even necessary, he [Perdiccas] alone waits for the completion
of months, and already divines that a male child has been conceived. And could you doubt that he
is even ready to suborn one? If, by the God of Faith! Alexander had left this man to be king in his
place, that would be the only one of his commands that I should think ought not to be obeyed."257

${ }^{256}$ E.g. Errington (1990), 114-119; in general on the funeral carriage and transportation of Alexander's body, see Erskine (2002).

${ }^{257}$ Curt.10.6.21-23. 
Thereafter, Meleager declared the royal treasuries the right of the people and lead a small troop to plunder them, but they are stopped by the suggestion of an unknown man that Arrhidaeus be made king with Alexander's legitimate child yet unborn. While Meleager's dissent might be taken simply as a means of rousing men to loot the treasury, he very publicly called Perdiccas' loyalty to the regime into question, neutralizing the effect of Alexander's gift of his signet ring to the chiliarch. This was an insult Perdiccas would not forget.

After Meleager, Pithon, and their crew had clamored in favor of Arrhidaeus, the high-ranking generals decided to wait on Roxane's birth, naming Perdiccas and Leonnatus regents and extracting from them an oath to submit to any progeny of Alexander. At this time, Meleager burst in again, demanding Arrhidaeus be made king, partially only out of fear of what might become of him under Perdiccas' rule. (Curt. 10.7.10-11). This led quickly to a standoff between the generals and infantry, with Meleager taking up arms to guard the new king, true Argead stock, and Perdiccas, outnumbered, bolted himself and the generals in Alexander's chambers to protect the body. Soon the entire meeting devolved into brawling, with spears flying against Perdiccas and his sect, who were unable to persuade the infantry over to their side (Curt. 10.7.17ff). Shortly after, Meleager tried to have Perdiccas assassinated via the authority of the infantry-supported king Philip III Arrhidaeus (Curt. 10.8.3-4). Perdiccas used the cavalry to encircle the city and prevent the importation of grain, starving them out, at which point Arrhidaeus willingly and publicly renounced the crown, removing his own diadem and offering it to anyone worthier (Curt.10.8.11ff).

Such a challenge to Perdiccas' authority would not go unpunished, and Meleager 
remained Perdiccas' primary target. Alexander had not been dead a year, and Perdiccas' power was already crumbling, pitting various units of the army against one another. A strong assertion of authority was necessary to counterbalance the accusations of disloyalty voiced by Meleager and his band, especially considering such strong support among the infantry for Arrhidaeus and the lack of a formal will on Alexander's part. Had his authority been unanimously recognized thereafter, Perdiccas might have held a trial for Meleager and the ringleaders of the failed revolt in the Macedonian fashion. Instead, he arranged a duplicitous reconciliation between Meleager's men and his own, having suborned Arrhidaeus for his own purposes beforehand. The two feuding units of the army met and were purified according to Macedonian ritual, by marching through the separated entrails of a dog and standing together in arms on a wide field (Curt.10.8.12). While the army stood in formation, Arrhidaeus rode before the infantry, demanding that the persons guilty of discord be brought forth. At this moment, Perdiccas' men began hauling the ringleaders out of the crowd, and at Perdiccas' orders, they were flung before the elephant corps and violently trampled to death under the animals' massive feet (Curt. 10.9.18). Meleager himself managed to escape, fleeing to a nearby temple for refuge; ignoring its sacrosanctity, Perdiccas had him hauled out and slain anyways. ${ }^{258}$

Perdiccas' underhanded method of executing his enemies is not especially noteworthy in an era of such political chaos, but his use of the elephant corps to effect their impromptu execution is. The plot was unquestionably his, but so too was the order to crush the infantrymen to death. Curtius explicitly notes that Arrhidaeus said nothing,

\footnotetext{
${ }^{258}$ Curt. 10.9.21; Arr. (156) Events After the Death of Alexander 1.4; see also Worthington (2016), 74-78; Roisman (2012), 79-81; Waterfield (2012), 24-25; Green (1990), 7-8, who makes no comment on the use of elephants in the execution.
} 
neither preventing nor encouraging the act (10.9.19): the entire army was meant to understand that Perdiccas held power as regent, and Meleager and his compatriots had far overstepped. The choice of an elephant executioner was deliberate and calculated, and one cannot help but think of Hamilcar's similar use of elephants. Polybius tells us that "like any good draught player," Hamilcar was good at taking his enemy by surprise, and one of his most morale obliterating techniques was throwing his enemies to his elephants (Polyb. 1.84.8). Just as one day Seleucid elephants would trample rebels, embodying in their massive forms the overwhelming power of the state, ${ }^{259}$ Alexander's elephants had done the same to dissenters who challenged the king's appointed regent.

The elephants were not simply psychological weapons. They were Alexander's elephants, symbols of his far- reaching empire and unique kingship. Perdiccas' use of them to execute Meleager branded the latter as an enemy of the state and showed Perdiccas himself to be a (theoretically temporary) heir to Alexander's power. Indeed, he kept the elephant corps under his direction up until his death in Egypt. The combination of the psychological impact of an elephant corps and their symbolic potency as emblems now linked to Alexander made the elephants an important part of the Diadoch Wars despite their tactical ineffectiveness.

\section{Part C: Elephant Symbolism \& Propaganda Among the Diadochs}

While elephants' behavior on the battlefield commands the most attention from our Greek sources, these animals appeared on parade and on state coinage in a variety of

\footnotetext{
${ }^{259}$ Kosmin (2014), 2-3.
} 
ways meant to advertise the legitimacy, battlefield prowess, martial strength, and wealth of the Successors as they vied for partial or total control of Alexander's empire. Because of the well-known source issues that accompany the study of the Diadoch Wars, ${ }^{260}$ any and all relevant references to elephants, as symbols or live animals, have been collected here in order that we may next examine how and why elephants were such an effective and flexible symbol of power. Part $\mathrm{C}$ will examine the evidence chronologically rather than by theme for two reasons: because (1) the significance of elephant displays was generally nuanced and is not always conducive to simple categorization, and because (2) the political and chronological context in which elephants appear is key to understanding their connotation as propaganda. Because the Diadochs, not the Epigonoi, set the standard for elephant significance, their use of the animals should be traced closely and in chronological order. In chapter four, where we shall investigate the use of elephants by the Epigonoi, evidence will be classified thematically in order to understand the specific ways in which the Diadochs' descendants capitalized and expanded on the patterns set by their dynastic founders.

As Gruen has noted, in the Hellenistic Age kings were made through selfrepresentation, and "the symbols of power take a central place."261 The busts and coin portraits proliferated throughout the era are only one aspect of symbolic selfrepresentation; another of equal importance is the army so intimately linked to the strength and perceived legitimacy of the Diadochs. While many elements were drawn

\footnotetext{
${ }^{260}$ Some of the major source problems of the era of the Diadochs are outlined in Meeus (2013) and Wheatley (2009), although Meeus' hesitation about using limited source material to "connect the dots" (pp. 92-93) should not be applied too strictly, or few if any conclusions about the era could be drawn.

${ }^{261}$ Gruen (1996), 116.
} 
from regionally ingrained traditions, ${ }^{262}$ the use of entirely novel emblems of power also occurred. One of the most persuasive was the elephant, whose strength and early association with Alexander conferred a perception of legitimacy upon the general deploying them.

\section{Ptolemy \& Perdiccas}

After the preparation of Alexander's funeral carriage, Perdiccas sent it on its way back to Aegae, the old capital of Macedonia and traditional burial place of Macedonian kings. This move was not only a nod to tradition, but a power play; it was the civic and religious duty of the inheriting Macedonian king to bury his predecessor, ${ }^{263}$ and as regent of the two kings, Perdiccas took on this highly symbolic duty. For the same reasons, ${ }^{264}$ Ptolemy interceded, halting the funeral carriage's passage through Damascus and taking Alexander's body with him back to Egypt. Ptolemy interred Alexander in the ancient Egyptian capital at Memphis and later placed it in a shrine to Alexander ktistes in Alexandria, which would also serve to house generations of Ptolemaic mummies. ${ }^{265}$

As Worthington has pointed out, this ambitious move was a political statement:

\footnotetext{
262 E.g. Ptolemy's adoption of pharaonic regalia and (some) ruling customs see Worthington (2016), 186187; Thompson (2018), 18-19.

263 Worthington (2016), 94.

${ }^{264}$ On Ptolemy's motivations see Worthington (2016), 93-95, 129-133. There is a literary tradition that Alexander wanted to be buried at the shrine of Ammon in Siwah: Diod. 18.3.5, 18.28.3; Curt. 10.5.4; Just. 12.15.7, 13.4.6, Erskine (2002), 171; Meeus (2008), 66-68, Worthington (2016), 94. However, Ptolemy’s control of the Libyan shrine and the sole passageway through the Desert of Siwah leading to it offers no compelling reason why he would not have entombed Alexander there, if adhering to the king's last wishes is what he had in mind. On Ptolemy's control of Cyrenaica, the primary access route to Siwah, see Worthington (2016), 92-93 and Arr. FgrH 156 F 9, 19; Diod. 18.21.9, Just. 13.6.20.

265 On the theft of Alexander's body: Diod. 18.28.2-3; Arr. FGrH 156 F 9, 25; Pausanias 1.6.3; Erskine (2002), 167-171. On burial in Memphis and alternate narratives regarding the reinterring of Alexander under Ptolemy II, see Worthington (2016), 131-132; Erskine (2002).
} 
Ptolemy "was no longer a bodyguard, but an equal."266 Perdiccas' response needed to be quick and decisive if he was to maintain the precarious balance of power struck at Babylon not twelve months prior. ${ }^{267}$ As regent for Arrhidaeus and Alexander IV, the authority of his command could not be so casually flouted. While Perdiccas had Alexander's signet ring and the brittle Babylon Settlement to grant him authority, it did not hurt to have additional persuasive ammunition. He brought with him Arrhidaeus as well as the queen Roxanne and Alexander IV, who could not have been more than one year old at the time. Pausanias notes that Perdiccas brought the heirs along to lend an air

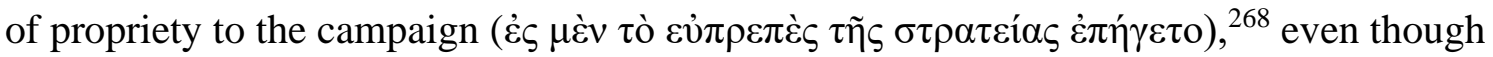
in reality he was intent on bringing Egypt back into the imperial fold in addition to the recovery of the late king's body. In many ways, this was simply a more involved variation on his earlier response to Meleager. Like Meleager, Ptolemy refuted Perdiccas' legitimacy as regent and guardian of the kings by seizing Alexander's body and arraying his own forces in defense of Egypt as though it were his own territory.

Perdiccas marched not only to retrieve Alexander's funeral carriage and body, but to reassert his legitimate claims to authority. The regent arrived at the head of the very fourfold army that was depicted on Alexander's now displaced funeral carriage (minus the navy) (Diod.18.33.6), and his approach to the Fort of Camels would have been a spectacular display; it is difficult to suppose he was not conscious of this. ${ }^{269}$ We know that Ptolemy's men had plenty of time to absorb the sight of Alexander's army marching

\footnotetext{
266 Worthington (2016), 94-95.

${ }^{267}$ Babylon settlement: Arr. FgrH 156 F 1, 5-8; Diod. 18.3.1-4; Curt. 10.10.1-4; Just. 13.4.5, 13.9-25; Deuxippus BNJ 100 F 8 and commentary of Jeremy McInerney (2007). Discussion: Worthington (2016), 79-83, Green (1990), 8-9.

${ }^{268}$ Paus.1.6.3.

${ }^{269}$ For the Siege of the Fort of Camels, see: Diod. 18.33-37; Arr. FGrH 156 F 26-27; Paus. 1.6.3; Strabo

17.1.8; Just. 13.8.1-2, 10; Roisman (2012), 93-107; Worthington (2016), 95-99.
} 
on them because they espied Perdiccas' men well before their arrival and even had time to ambush them, using noise-makers in an attempt to throw them into disorder (Diod. 18.34.1). Unfortunately for Perdiccas, it was Ptolemy who reaped the benefit of the elephant battle. The satrap of Egypt made such a conspicuous display of his struggle against the animals that they became a talisman of his dynasty.

Perdiccas assailed Ptolemy's men on the walls, using his elephants to tear down the palisades with their trunks (Diod. 18.34.2). Ptolemy, leaning over the parapets, led his men to victory by a direct assault on the elephants; the satrap himself put out the eye of the leading elephant, disabling it, and helped to kill the mahouts of the subsequent attacking elephants (Diod.18.34.3); presumably the elephant-involved portion of the siege ended rather quickly, with the rest of the day's efforts involving fights between men. (Diod. 18.34.4-5). While Ptolemy undoubtedly played up his encounter with Perdiccas' leading elephant, his battlefield prowess and unaffected manner were not lost on Perdiccas' men. Ptolemy must have appeared especially appealing after the Nile, by current and by crocodile, killed nearly 2,000 of Perdiccas' men in retreat the next night. $^{270}$ Diodorus' less than subtle comparison of Ptolemy's and Perdiccas' martial prowess reminds us that the ability to lead and skill on the field both played an enormously important role throughout the Diadoch Wars. ${ }^{271}$ Diodorus references Ptolemy's excellent generalship (18.34.4) and indirectly juxtaposes it to the blatant

\footnotetext{
${ }^{270}$ Diod. 18.35.5-6. Other sources attribute the loss of these troops to Ptolemy himself, e.g. Polyaenus 4.19, Strabo 17.1.8, Ael. VH 4.19, Frontinus Strat. 4.7.20, but I agree with Roisman (2012, p. 101 n.43) that Diodorus' account is perfectly credible. A combination of drowning and animal attacks suffices as an explanation and certainly gives Perdiccas' generals better reason to assassinate him, as the losses were selfinduced.

${ }^{271}$ Bilde et al. (1996), 11.
} 
disgust both commanders and rank and file alike felt toward Perdiccas, ${ }^{272}$ whose retreat across the river within a day's time must have been less than inspiring to the veterans after the many and victorious sieges under Alexander. Far less decorously, Pausanias simply states that Perdiccas had lost his reputation as a soldier (Paus. 1.6.3), which seems excessively harsh for one failed siege. ${ }^{273}$

The details of the siege that survived portray Ptolemy's fighting style as "Homeric" 274 and strongly suggest that the future pharaoh made much of his brutal day of battling. Roisman notes that the longest extant account of the siege is Diodorus' (18.3337), which has "almost shameless bias in favor of Ptolemy" 275 and an undoubtedly proPtolemaic source that is now lost to us. Certainly, Ptolemy did well to capitalize on his success in this siege, and he could hardly have done better than to emphasize his one-onone struggle with an elephant, a story that brings to mind his struggles alongside Alexander in India, the Macedonian victory at Hydaspes, and perhaps the well-known elephant medallions or Porus coins. Having thrown his hat into the ring, Ptolemy did not stop with a heroizing literary tradition, but offered a visual as well.

Ptolemy was the first of the Successors to mint coinage featuring the face of Alexander, which he issued out of Alexandria in 320. Alexander's profile had been more or less reproduced from the late king's own Heracles tetradrachm. ${ }^{276}$ However, Heracles' Nemean lion headdress had been replaced by that of an elephant, an image evocative of the Indian campaign and, in light of when it was minted, Ptolemy's most recent victory

\footnotetext{
${ }^{272}$ Diod. 18.36.2-5; note that Just. 13.8.2 corroborates this, suggesting Perdiccas' arrogance and general demeanor played a role in the eventual mutiny.

${ }^{273}$ Roisman (2012) rightly points out that Perdiccas' hasty retreat is what doomed his men in trying to cross the river, and in this sense poor generalship is accurate (pp. 98-102).

274 Worthington (2016), 96.

${ }^{275}$ Roisman (2012), 97 and n. 30 for the lost source.

${ }^{276}$ Stewart (2003) fig. 30 offers a detailed plate.
} 
over the animals at the Fort of Camels [Image 3.1, right]. ${ }^{277}$ This coin type was minted in response to Perdiccas' failed invasion ${ }^{278}$ and advertised Ptolemy's legitimacy as satrap and loyalty to Alexander's heirs.

The coin design is a brilliantly layered mélange of compelling symbolism, all of which any reasonably informed Greek or Macedonian would have understood at a glance. ${ }^{279}$ The stark similarities to Alexander's own coinage keep this innovative departure well within the bounds of propriety, as does the legend $\mathrm{BA} \Sigma \mathrm{I} \Lambda \mathrm{E} \Omega \Sigma$ A $\Lambda E \Xi A N \triangle P O Y$. The obverse is in clear imitation of Alexander's Heracles-Zeus tetradrachm [cf. Image 3.1, left], and the reverse is unremarkable, a duplication of dies used by Alexander. Two reverse designs exist: either a seated Zeus and eagle or Athena Promachos, armed with shield and spear beside an eagle. Troncoso refers to the obverse image of the as exuviae elephantis and links the image to a message of Macedonian ethnic superiority linked to the conquest of India. He views the elephant scalp as "a trophy, an icon of a formidable beast that was nevertheless defeated by the Macedonian phalanx." ${ }^{280}$ By contrast to Alexander's own Porus coinage, which exhibited "zoological parity," 281 or relative equality between the status of the rearing horse and elephant, and by extension, their riders, Ptolemy's coinage portrays the exuviae elephantis and emphasizes Macedonian superiority.

While Ptolemaic Egypt's bureaucracy was unquestionably anchored in the

\footnotetext{
${ }^{277}$ Image of the coin found in Zervos (1967) series B-v, Stewart (1993) fig. 76-77, see also: Appendix 4. The coin is dated to 320 by Lorber (2005), and confirmed by Arnold-Biucchi (2006), 60 and Troncoso (2013), 256, contra Stewart (1993), 232f.

${ }^{278}$ Cf. Troncoso (2013), 256-257.

${ }^{279}$ I offer below my own interpretation, which overlaps with and departs from other interpretations in various ways. Cf. See Stewart (1993), 233-43; Lorber (2005), 62; Troncoso (2013), 256-7.

280 Troncoso (2013), 256.

${ }^{281}$ Ibid., 257.
} 
religion, culture, and language of the Greeks and Macedonians, it is not clear that Ptolemy's primary concern in 320 was one of ethnic hegemony. The emphasis Troncoso rightly places on the timing of the coin's debut in fact suggests that the link to Alexander and to Ptolemy's victories in India were the primary themes of the coin. ${ }^{282}$ The image of the elephant was one emblem through which Ptolemy effected this synthesis-his emphasis of his own distant relation to the Argead line, his seizure of Alexander's body and establishment of the Soma in Alexandria as well as the ktistes cult of the conqueror, are all forms by which Ptolemy enhanced his own legitimacy as a contender for a fragment of Alexander's empire.

In this particular issue, the innovation lies in the replacement of Heracles, Alexander's divine ancestor, with the now-deified conqueror himself, and the addition of the horns of Ammon and the iconic elephant scalp. Lorber has theorized that the elephant scalp is not a reference to India, but Ptolemaic appropriation of Egyptian culture. The Pharaoh Tuthmose III was known to hunt elephants in Syria, and as Lorber points out, Alexander was affiliated with Tuthmose, another conqueror of Asia, in the Temple of Ammon-Ra at Karnak. ${ }^{283}$ Nonetheless, it cannot be denied that among Macedonian viewers of this coin, the elephant symbolized India.

The addition of Ammon's horns indicates Alexander's now divine status and tie him conveniently to the Libyan shrine now under Ptolemy's hegemony. The much more noticeable elephant scalp suggests that Alexander's exploits have surpassed those of Heracles, whose defeat of the Nemean lion is less impressive than Alexander's conquest of India and its elephants, an expedition in which Ptolemy (allegedly) played a starring

\footnotetext{
${ }^{282}$ Ibid., 258.

${ }^{283}$ In general Lorber (2012).
} 
role. The Indian campaign appears to be where the Egyptian satrap earned his stripes. Although he had been a Somatophylax since $330,{ }^{284}$ the details of Ptolemy's undertakings shine through Arrian's account (which relied heavily on Ptolemy's lost history). In India, Ptolemy is said to have engaged the Aspasian king in combat and slew him, stripping his armor in Homeric fashion, ${ }^{285}$ and performed equally well near Arigaeum, against "the most warlike" (Arr.4.25.3) of Indian tribes in the region, where Ptolemy claims he and Leonnatus captured over 40,000 men and over 230,000 oxen, a gross exaggeration reflective of Ptolemy's pride in his success in India. ${ }^{286}$

Additionally, Ptolemy's assistance in the siege of Aornus Rock was critical, a reference point once again linked to the coin-Heracles had allegedly failed to take it, but Ptolemy and Alexander had not. Even if Arrian's account, which relies so heavily on the now lost account penned by Ptolemy, is heavily exaggerated, it is fair to assume that Ptolemy was playing up these victories by word of mouth prior to recording his deeds on papyrus. Thus, Arrian's account reflects a version of the Indian campaign which Ptolemy wished to propagate, and his chosen numismatic imagery fits the same mold.

Ptolemy's defeat of Perdiccas' elephants (and subsequent acquisition of them) that occasioned this coin was reminiscent of this faraway victory, a potent reminder of Ptolemy's skills as a general and, perhaps, suggestive of special divine patronage by Alexander. This would not be the only time that Ptolemy used zoological symbolism to imply divine patronage - his cult of Agathos Daimon, which centered on a serpent, was

\footnotetext{
${ }^{284}$ Just. 13.4.10; Worthington (2016), 39, 43 f.

${ }^{285}$ Arr. 4.24.4-5; Worthington (2016), 54-55.

${ }^{286}$ Arr. 4.25.3; Worthington (2016), 55-56.
} 
linked to a story in which Alexander saved Ptolemy from poisoning in India. ${ }^{287}$ Indeed, Ptolemy's link to deified Alexander through the possession of his body and construction of a shrine may be foreshadowed in the coinage as well; it certainly gave Ptolemy the opportunity to found and preside over a state cult to the conqueror. ${ }^{288}$

It has been suggested that one of the cult statues of Alexander set up in his shrine was the model for the face on the tetradrachm, which may be so. However, no extant statue type is directly linked with the coin, and its stunning similarity to Alexander's Heracles makes the coin, not the statue, the more likely and practical model for Ptolemy's tetradrachm. ${ }^{289}$ In either case, this compacted image drew together several disparate themes in the person of Alexander, linking Ptolemy to him in a way that highlighted the satrap's greatest victories. The more general interpretation of the coin's obverse as an emblem of victory appears in Troncoso: he reasons that the adoption of this coin type within a few years by the Syracusan tyrant Agathocles, who never fought elephants, indicates a broader appeal for the image. ${ }^{290}$ Evidently the symbolic potency of the coin type was impressive enough that Seleucus copied it in later years, as we shall see.

\section{Antigonus \& Eumenes}

Thus we have seen that Ptolemy adeptly turned Perdiccas' display of power and legitimacy to his own favor, and the elephant played a significant role in symbolism

\footnotetext{
${ }^{287}$ The story appears in Diod.17.103.4-8; Curt. 9.8.22-28; Strabo 15.2.7; Just.12.10.2-3; Oros.Hist.3.19.11. For a complete discussion of the cult of the Agathos Daimon see Ogden (2013), pp. 241-253.

${ }^{288}$ Morkholm (1991), 63.

289 Troncoso (2013), 257 neither accepts nor rejects the theory of a shrine statue model, but remains open to it; Morkholm (1991), 63-4 is similarly inclined. For further bibliography see Troncoso (2013), 269 n.10.

290 Troncoso (2013), 259.
} 
through which Ptolemy communicated his suitability as the satrap of Egypt. While Troncoso is right to note that Ptolemy and Seleucus made the most use of the elephant on their coinage, the sources afford us a brief glimpse into the display of the animals by Eumenes of Cardia and Antigonus Monophthlamus, whose enmity largely defined fighting in the eastern satrapies until Eumenes death in $316 .{ }^{291}$ Neither Eumenes nor Antigonus minted coins of their own design, so the wealth of numismatic evidence available for Ptolemy and Seleucus is lacking in their cases. Eumenes did not control any mints, ${ }^{292}$ and Antigonus appears to have minted coins only near the end of his life, with the earliest emissions coming from the Abydus mint. He reproduced Alexander's Heracles-Zeus coin type in drachms and tetradrachms, but unlike Demetrius, incorporated nothing more of his own design than the addition of an anchor to the reverse. ${ }^{293}$ However, both generals engaged one another in two major battles and one skirmish in between, in which elephants played a prominent (if not terribly effective) role. The battles of Paraetacene (317/6) and Gabiene (316) would have the highest number of pachyderm participants until Ipsus in 301, and they merit a brief interlude here. ${ }^{294}$ In the winter of 317, Antigonus' and Eumenes' men, the latter's bolstered by Peucestas' assistance, met in two final clashes that resulted in Eumenes' capture and execution. Marching through Persia, either general sought to outmaneuver the other and take him unawares. En route to Gabiene, which possessed a flat and dusty plain ideal for cavalry and elephant deployment, Eumenes took up a position on a ridge against

\footnotetext{
${ }^{291}$ A detailed account of the campaigning by Antigonus and Eumenes can be found in Anson (2015), 163212.

${ }^{292}$ Diod. 18.41.4 tells us that he lost these as well as control of most of his satrapy after the Battle of Orcynia in 320.

${ }^{293}$ Morkholm (1991), pl. 5 nos. 80-86; see also p. 61.

${ }^{294}$ Diodorus gives us 65 for Antigonus (Diod.19.27.1) and 114 for Eumenes (19.28.4).
} 
Antigonus, halting their progress abruptly in the land of the Paraeceni, as both generals arranged their battle lines. ${ }^{295}$ Both Diodorus and Plutarch give us a brief glimpse of the field as the rank and file might have seen it, and their emphasis on the imposing image of Antigonus' men is worthy of consideration here:

\begin{abstract}
"When the army [of Antigonus] arrived, he drew it all up for battle and marched down in aweinspiring array against the enemy. Including reinforcements brought by Pithon and Seleucus, Antigonus had in all more than twenty-eight thousand foot soldiers, eight thousand five hundred horsemen, and sixty-five elephants. ${ }^{296}$
\end{abstract}

Plutarch, whose biographical focus rests on Eumenes and his men, rather than a blow-byblow account of the engagement, emphasizes the visual impact that Antigonus' display made on Eumenes' soldiers:

\begin{abstract}
"The gleams of their golden armour in the sun flashed down from the heights as they marched along in close formation, and on the backs of the elephants the towers and purple trappings were seen, which was their array when going into battle. Accordingly, the foremost Macedonians halted in their march and called with loud cries for Eumenes, declaring that they would not go forward unless he was in command of them; and grounding their arms they passed word to one another to wait, and to their leaders to keep still, and without Eumenes not to give battle or run any hazard even with the enemy." 297
\end{abstract}

This is the only mention of the type of raiment with which elephants were adorned in battle, and it is an important one. While the meaning of the "towers" ( $\pi$ v́pyol) on Antigonus' elephants is somewhat debated given the limited evidence for their appearance in battle, at the very least they are meant to indicate imposing howdahs. ${ }^{298}$

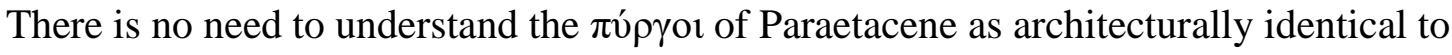
those mentioned at the Battle of Raphia a century later (Polyb.5.84.2), and the howdahs of Alexander's elephants would have been stock piled with weapons, much like a small

\footnotetext{
${ }^{295}$ For the battle of Paraetacene (317) see: Diod.19.26-34; Plut.Eum.14-15, after which it melts into a description of Gabiene. Discussion: Scullard (1974), Champion (2014), 52-59; Anson (2015) 190-195. 


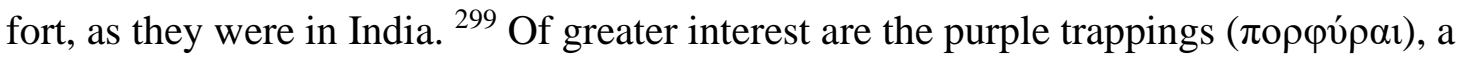
stock symbol of royalty appropriate for Alexander's elephants and Antigonus' new position as general of Asia following the Triparadeisus Settlement. ${ }^{300}$ The appearance of the $\pi о \rho \varphi v ́ \rho \alpha$ is not a fanciful detail, but a serious expense incurred by Antigonus with the knowledge that at least some of the fabric would be ruined in battle. It is highly unlikely that the elephants traveled in extra cloth, and Antigonus' army was forced to array itself quickly when Eumenes' outpaced it. Nonetheless, care was taken to adorn the elephants properly, a sure indication that the power of their appearance was recognized and valued. Antigonus, as general of Asia, was an extension of royal Argead power. It would not be surprising to learn that Eumenes' elephants were similarly arrayed, given his own careful self-identification as an Alexander loyalist throughout the tumultuous wars. ${ }^{301}$

Perhaps this display of elephants and magnificent show of force led to the perception of the elephants' tactical utility as described by the sources. Diodorus' actual description of the battle indicates that cavalry and the Argyraspides (19.30.5) played the major parts, but his emphasis on the appearance of the elephants, which his source Hieronymous would certainly have witnessed as well, indicates the powerful hold their strength had on the army. Even though both Eumenes (Diod. 19.28.2) and Antigonus (Diod. 19.29.6) filled in the spaces between the elephants with light armed infantry, presumably to guard them in such a way as a densely packed phalanx could not, the battle

\footnotetext{
299 Singh (1965), 82.

${ }^{300}$ On the Triparadeisus Settlement, see e.g. Worthington (2016), 100-103; Green (1990), 14-15; a good introduction to the significance of purple dye may be found in Jensen (1963).

${ }^{301}$ No account exists of how Eumenes' elephants were adorned, but given that they had arrived fresh from India under the leadership of the elephantarches Eudamus, who murdered Porus and made off with his elephants (Diod.19.14.8), it is probable that they were richly decorated. For Eumenes' loyalty to the royal family and his creation of a military cult of Alexander, see Anson (2015), 165-168.
} 
proved that the Macedonians had developed more skill in antagonizing the enemy's elephants than in safeguarding their own (Diod. 19.29.1-2). And yet, Diodorus attributes Eumenes' cavalry squadron's victory in part to the elephants without ever specifying in what way they contributed. When Eumenes found that Antigonus' flank as held by Pithon was hard pressed, he sent light-armed cavalry and mounted archers to outflank it, causing the line to collapse. Diodorus notes that "since the elephants also followed, he easily routed the forces of Pithon, and pursued them to the foothills" (19.30.4).

However, the elephants cannot be credited with this victory. They were injured in part and would never have been able to keep up with Pithon's retreating light-armed cavalry. Indeed, Diodorus criticizes elephants' plodding pace only a few lines above his assured conclusion that they played a key role in pursuing and routing Pithon's cavalry (Diod.19.30.2). It appears that the awe-inspiring might of the elephants led Diodorus to overstate their tactical significance to the battle. This is just the sort of psychological impact that Eumenes and Antigonus both expected their elephant corps would have, and Eumenes simply made the mistake of relying too heavily on his elephants.

The symbolic importance of elephants appears twice more in the brief accounts of the campaigns between Antigonus and Eumenes. Once, during the skirmish between the battles of Paraetacene and Gabiene, and again during the parade of captives and booty following Antigonus' victory at Gabiene. As discussed above (pp.63-64), Antigonus took great pains to capture Eumenes' elephants after the march away from Paraetacene. While his declaration that they were the strongest element of Eumenes' army illustrates the persistence of the misconception of elephants' tactical utility, as discussed in chapter 2, the capture of an enemy's elephants would have dealt a powerful psychological blow and 
been as worth advertising for Antigonus as it was for Ptolemy (see p.117f.). Indeed,

Antigonus did receive a grand display of his conquest when the battle drew to a close.

Justin understandably characterizes the procession following Eumenes' speech as a

triumphum, with Eumenes, the most valuable captive, at the helm:

The army followed, surrendering their general, and being themselves made prisoners; and, leading up a triumph over themselves to the camp of their conqueror, resigned to him, together with their own persons, all their honour gained under king Alexander, and the palms and laurels of so long a warfare; and, that nothing might be wanting to the procession, the elephants and auxiliaries of the east, brought up the rear. ${ }^{302}$

The royal context of elephants appears again in Plutarch's version of Eumenes' speech after the Battle of Gabiene, when his own men turned him over to Antigonus following the latter's decisive victory and capture of Eumenes' baggage train (Diod. 19.43.7-9). We are told that Antigonus was reluctant to execute Eumenes and considered his skill valuable. Ultimately, Antigonus was persuaded by his Macedonians, who wanted Eumenes killed, and gave him a merciful death while paying due respect to his remains. ${ }^{303}$ Plutarch creates a speech for Eumenes, presumably based on the gist of the Cardian's final words, in which he condemns the Macedonians who bound his hands and delivered him to his enemy. ${ }^{304}$ Recognizing that Antigonus "wants a dead and not a living Eumenes," he offers with dark irony to spare his own men's hands in the deed:

\footnotetext{
"And if ye would spare your own hands, one of mine, if released, will suffice to do the business. And if ye cannot trust me with a sword, cast me under the feet of your elephants, all bound as I am. If ye do this, I will absolve you from your guilt towards me, holding that ye have shown yourselves most just and righteous in your dealings with your own general." 305
}

\footnotetext{
302 Just.14.4.15-21, trans. Rev. John Selby Watson, 1853, London.

${ }^{303}$ So says Diod.19.44.1-2. Plutarch Eum. 19.1 states that while Antigonus did return Eumenes' body to his relatives, he executed him by starvation. Nep.Eum. 12.4 claims his jailors strangled him without Antigonus' knowledge, but agrees with Diodorus and Plutarch that his remains were brought to his family (13).

${ }^{304}$ Plut.Eum. 17.3-5; Justin 14.4 records a speech with the same general tone, condemning the Macedonians who betrayed him and offering to kill himself instead.

305 Plut.Eum. 17.4.
} 
The reference to execution by elephant is interesting and immediately evocative of Perdiccas' method of executing Meleager's cohorts for challenging his authority. Once again, elephants appear as an emblem of royal authority; if legitimacy is suggested by Eumenes, it is with as much irony as the rest of his speech. And in fact, Antigonus did mobilize ten of his elephants, using them to hold off the crowd, which became both saddened and violent following Eumenes' speech (Plut. Eum. 18.1-2). However, Plutarch suggests that Antigonus saw in him some bearing of nobility yet; when asked how Eumenes should be guarded, he allegedly replied "Just as ye would guard an elephant or lion." $" 306$

\section{Ptolemy at Gaza}

Just as he capitalized on his victory at the Fort of Camels, Ptolemy would once again spread word of his elephant victory following the Battle of Gaza in 312 through coinage, using similar imagery to communicate his military abilities. A brief survey of the role and fate of elephants in the battle may help illuminate Ptolemy's choices in coin design. Antigonus, who had stationed his son Demetrius in Syria in 314 (Diod.19.69.1), ordered him to invade and make war on Ptolemy in 312, while Antigonus himself remained preoccupied with Tyre, which was held fast by Ptolemaic allies. ${ }^{307}$ Demetrius' infantry was far outnumbered by Ptolemy's, and his cavalry forces barely exceeded those of Egypt. ${ }^{308}$ Ptolemy also had the aid of his fellow Hydaspes veteran, the displaced

\footnotetext{
${ }^{306}$ Plut.Eum.18.2; also reported in Nep. Eum. 11.1.

${ }^{307}$ On the battle see Diod.19.80-84; Plut. Demetr.5; App.Syr. 54; Paus. 1.6.5; Polyb.15.12; Just. 15.1.5-9; Worthington (2016), 120-122; Champion (2014) 91-97; Grainger (1990), 70-75.

${ }^{308}$ Diod. 19.80.4 claims that Demetrius had 12,500 infantry to Ptolemy's 18,000, and 4,500 cavalry to Ptolemy's 4,000.
} 
Seleucus, who had taken refuge in Alexandria when asked for an "accounting" of his affairs as satrap of Babylon and forced out by Antigonus. ${ }^{309}$ But Demetrius had a trump card-43 of his father's elephants (Diod. 19.80.4).

After the Siege of the Fort of Camels (320), Ptolemy did possess some elephants as of 312, but at Gaza he did not deploy any. This was deliberate. Just like Alexander at Hydaspes, ${ }^{310}$ Ptolemy and Seleucus would prove that one did not require elephants to defeat an elephant corps in pitched battle, even when the climactic and topographical conditions were ideal for elephant charges. Although there was the typical last-minute jostling of troops and re-arrangement of line formation in response to the reports of scouts, Ptolemy's plan to undermine the utility of Demetrius' elephants originated well

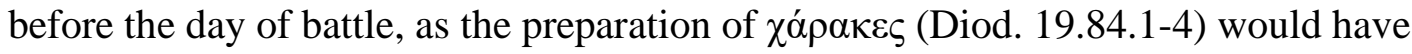
required time and planning.

The battle has been described above (pp.74-77), but the motivation and significance of Ptolemy's capture of Demetrius' elephants must be discussed here. Along with his report of Ptolemy's clever plot, Diodorus concludes the narrative with a coda meant to emphasize Ptolemy's magnanimity but in so doing reveals his real motives for fighting. After the battle, Ptolemy and Seleucus turned over the royal baggage carts, which they had seized, without ransom to Demetrius, as well as several of his philoi. Notably, Ptolemy did not return his elephants. Diodorus writes that they did the generous return of the baggage and hostages was meant to emphasize that Ptolemy's and Seleucus' true concern was not with prizes of war, but territory that Antigonus had refused to yield

\footnotetext{
${ }^{309}$ Diod. 19.55.2; Grainger (1990), 48-51.

${ }^{310}$ Worthington (2016), 120-121.
} 
as agreed upon, a point of input that was surely Seleucus'. ${ }^{311}$ Although Diodorus wishes to emphasize Ptolemy's benevolence, the satrap's real motivations are clear. Whatever booty he could have taken from Demetrius mattered little in the face of the real prize: he had captured 43 of Antigonus' elephants, some 8,000 of his men (Diod. 19.84.4, 19.85.34), and opened a path to campaigning further north, where he quickly captured Sidon (Diod. 19.86.1). Moreover, Ptolemy had waged his first major pitched battle and "had proven he was a fierce adversary in the field and more than a competent general of an army:" 312 Ptolemy was en route to becoming a Hellenistic king, and the Gaza victory offered a compelling and persuasive visual. Just like Alexander, Ptolemy had defeated the enemy's elephants on the field.

Following his victory and the seizure of Sidon, Ptolemy immediately began minting revised emission of his Alexander coins. As in the case of the 320 types, Alexander's profile appeared on the obverse, crowned with the horns of Ammon and the iconic elephant scalp headdress. Two different types have been identified and convincingly dated to this period, both with the same obverse and reverse images of either Athena Promachos, in the Argead tradition, or the Ptolemaic eagle carrying a thunderbolt. ${ }^{313}$ Just like the first emission of such a coin type, the second elephant-capped Alexander follows another elephant victory, and thus Ptolemy's role in India and connection to Alexander is highlighted again through the medium of the elephant. ${ }^{314}$

The coin was minted in both Alexandria and Sidon, where Ptolemy wanted to

\footnotetext{
${ }^{311}$ Diod. 19.85.3; Just. 15.1.8-9; Worthington (2016), 121.

312 Worthington (2016), 122.

${ }^{313}$ On the date, see Lorber (2005), 63-64; Troncoso (2013), 256; Images found in Zervos (1967) series Cxii, D-xiii, Stewart (1993) figs 78-79. Evidently the coin retained popularity or utility, as Ptolemy II reissued the same design, using only the Ptolemaic eagle and thunderbolt for the reverse. See Stewart (1993), Appendix 4, p.435.

${ }^{314}$ Worthington (2016), 107-108.
} 
maintain influence. Troncoso points to the role of elephants in Ptolemaic coinage as war prizes, an especially relevant note to the 312 emission. However, Alexander, divinity, and elephants were tangled together in a net of numismatic symbolism here in order to cast as wide and compelling a net as possible. Stewart has pointed out that Ptolemy may have created this multifaceted coinage based on a longstanding Egyptian "practice of combining royal insignia to create a complex symbolic code." 315 For this reason, the variety of denominations in which the type was coined is unsurprising. ${ }^{316}$ Small additions to the coin's obverse include the presence of Dionysus' mitra on Alexander's forehead as well as a detailed scaly aegis around his shoulders, emphasizing both association with divinity and god-like conquests. If the stories of Alexander's triumphant march from Carmania are true, the conqueror may have set the precedent for such images himself. ${ }^{317}$

The different legends appearing on these coin types emphasize Ptolemy's ties to

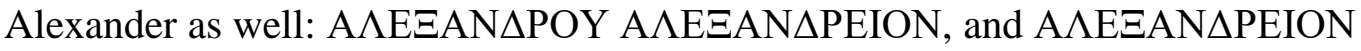
ПTO $\Lambda$ EMAIOY both highlight Ptolemy's possession of Alexander's body and close association with, even active imitation of, the deified king. ${ }^{318}$ This must have been an especially sore point for Demetrius, whose self-styling in the guise of Alexander is well known, ${ }^{319}$ and Ptolemy did hesitate to capitalize on his victory and advertise that he, after

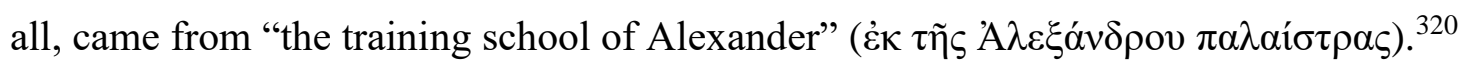

\footnotetext{
315 Stewart (1993), 233.

316 Troncoso (2013), 256 notes that denominations for this coin type included: gold staters, silver tetradrachms, drachms, hemidrachms, hemiobols, and bronze units.

317 The vulgate tradition supports the account of Alexander's Bacchic revel, and Arrian denies it, claiming neither of his sources includes it. See: Diod. 17.106; Curt. 9.10.22-28; Plut.Alex.67; Arr. 6.28.1-2; cf. Bosworth (1988b), 67-72.

318 See Stewart (1993), 229-243.

${ }^{319}$ Bosworth (2002), 254-255 has shown that many of the Successors strove to liken themselves to Alexander through conspicuous acts of bravery in the front lines. Demetrius effected this at the Battle of Salamis (Plut. Dem. 20.52.1-2), Gaza (Diod. 19.84.5-6, also see 19.83.5), and Ipsus (Plut. Dem. 29.4-5). ${ }^{320}$ Plut.Demetr.5.2.
} 


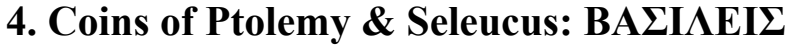

Between 305-303, both Ptolemy and Seleucus began minting coins in their own name, rather than Alexander's, and along with the surviving Diadochs, they adopted the title basileus; Ptolemy was the first to do so. ${ }^{321}$ In addition to attaching their own name to the coin legends, some of the Diadochs also began placing their own faces on the obverse of state coinage, another trend which Ptolemy initiated. By all counts he chose a realistic, not idealized, likeness, although similarities to Alexander's profile are noticeable. ${ }^{322}$ Although relegated to the reverse side, Alexander still appeared on Ptolemaic coinage, and he was still in close association with the elephant, which had become an emblem of victory and legitimacy intimately tied to Ptolemy's record-breaking feats in the conquest of India and defense of his new kingdom, Egypt. ${ }^{323}$

\section{a. Coins of Ptolemy: Alexander's Elephants and Succession}

Minted in the high denominations of gold staters and half-staters, Ptolemy's basileus coin type was produced at Alexandria and Cyrene, inscribed with the legend: ПTO $\mathrm{E}$ MAIOY $\mathrm{BA} \Sigma \mathrm{I} \Lambda \mathrm{E} \Omega \Sigma$. The obverse featured a slightly "Alexander-ized" Ptolemy, whose hooked nose and jutting chin appear in the coinage of his son and grandson as well, ${ }^{324}$ but whose

\footnotetext{
${ }^{321}$ The date at which Ptolemy assumed the diadem and proclaimed himself basileus is much debated, and literary and epigraphic sources are contradictory. Diod.20.53.2; Plut.Dem.18.1; Just.15.2.10; App. Syr. 54 support a date of 306, while Porphyry BNJ 260 F 2, Parian Marble BNJ 239 B 23, and Egyptian documents suggest 305/4. For modern bibliography and discussion see: Worthington (2016) 160-163 and Sickinger's (2016) commentary on Parian Marble BNJ 239 B 23.

322 Images of the coin found in Stewart (1993), fig 76,;Morkholm (1991) Pl. VII no. 96,;see also Bosworth (2007).

${ }^{323}$ For elephants as emblems of victory, see also: Troncoso (2013); Bosworth (2007), 18, who notes that the beasts were "material proof of his conquests." For Ptolemy's bravery and military feats at Aornus, the stronghold Heracles allegedly failed to take, see Arr. 4.29.1-6; Worthington (2016), 56-57.

${ }^{324}$ E.g. Morkholm (1991), pl. 18 no. 297-298, pl. 20 no. 312 and catalogue.
} 
curling hair and analstole (cowlick) combined with disproportionately wide, upward gazing eyes are strongly reminiscent of his Alexander coinage. ${ }^{325}$ Ptolemy wears the aegis and diadem on the obverse, and on the reverse, Alexander appears in the aegis as well, holding the thunderbolt in his right hand as he rides an elephant-drawn quadriga. ${ }^{326}$ The specific date of the coin is debated, and the nuances of that debate are not directly relevant here. The general contention is that the coin can be dated either to (1) the year of, (or one of the years immediately following) Ptolemy's adoption of the title basileus, in $306 / 5$ or $305 / 4$, or (2) that it should be dated considerably later to c.298-297, when the Ptolemaic gold standard was reintroduced. ${ }^{327}$ In terms of the historical narrative, there is no difficulty in dating the coin to the year of or directly following Ptolemy's adoption of the diadem, whether one finds $306 / 5$ or 305/4 more appealing. Ptolemy and his competitors had already hesitated several years after the murders of Alexander IV (310) and Heracles (309) to begin calling themselves king, and it was Ptolemy that took the first step. ${ }^{328} \mathrm{He}$ would have no need to wait longer for the emission of coinage with corresponding legends. However, Lorber has presented the argument that the Ptolemaic helmet series, also minted in denominations of gold staters and contemporaneous with the elephant quadriga staters, can be dated only as early as 298 , a

\footnotetext{
${ }^{325}$ See above p.202 with Image 3.1; Arnold-Biucchi (2006), 36-37.

${ }^{326}$ There is some uncertainty regarding Alexander's dress. Although he is generally understood to be portrayed in heroic nudity, Bosworth's close examination of the Westmoreland quadriga coin led him to believe Alexander was depicted in military dress with cuirass and epaulettes that are partially eroded. See Bosworth (2007), 17. Clothed or not, the image is a deified Alexander because of the presence of the thunderbolt.

${ }^{327}$ The coin is dated to 305 or later by Stewart (1993), Appendix 4; to 304 by Troncoso (2013), 262; and to the early third century by Lorber (2005), 45-47, whose work provides an excellent summary of the chronology debate.

${ }^{328}$ Worthington (2016), 128, 160-162; also see on the death of the Argeads: pp.125-128; Cassander's murder of Alexander IV: Diod. 19.105.2; Polyperchon's murder of Heracles and Barsine: Diod.20.28.1-2; Just.15.2.3; Paus.9.7.2.
} 
fact which "undercuts the longstanding assumption that Ptolemy introduced his elephant quadriga gold staters shortly after assuming the diadem, and it would seem to deny a specific celebratory significance to the coinage itself or to its evocative type." 329 Bosworth does not address this argument but places the coin firmly in 306/5, noting that the stater "seems a perfect echo of the political situation in 306/5 BC,"330 but some of his observations could be applied just as well to 298-297, fitting Lorber's date too. Bosworth reads in this coin a re-legitimization of Ptolemy's hold on Egypt and an "encoded message of warning to Seleucus, his rival and reluctant ally." 331 Ptolemy, just like Alexander, had won Egypt by the spear, through his defensive victories against Perdiccas (320) and Demetrius (312), and he now portrayed himself as Alexander's direct and legitimate heir. The coin type nicely complements the legends cultivated by Ptolemy about his close relationship with Alexander, including the rumor that the two were halfbrothers by Philip II, ${ }^{332}$ and that Alexander personally sought out the herbs that saved Ptolemy from a snakebite in India. ${ }^{333}$

However, Ptolemy did not need to include elephants in a picture of Alexander to portray himself as legitimate successor. While certainly they harken back to India, the elephant-scalp coins did the same, and a new design was unnecessary. What is its significance? Bieber and Morkholm have noted that the Alexander statue in the chariot appears similar to the Alexander Aigiochos statue at the Soma where the king's cult was

\footnotetext{
${ }^{329}$ Lorber (2005), 60.

${ }^{330}$ Bosworth (2007), 21.

331 Ibid.

${ }^{332}$ Satyros, BNJ 631 F 1; Curt. 9.8.22; Paus. 1.6.2; Worthington (2016), PAGE; cf. Collins (1997), who argues that Ptolemy I did not start the rumor, but that it emerged from two independent sources, the Macedonian court at Pella and possibly Ptolemy Ceraunus, in his brief attempt to seize control of Macedonia.

333 The story appears in Diod.17.103.4-8; Curt. 9.8.22-28; Strabo 15.2.7; Just.12.10.2-3; Oros.Hist.3.19.11.

For a complete discussion of the cult of the Agathos Daimon see Ogden (2013), pp. 241-253
} 
centered in Alexandria, suggesting a theme of divine patronage for Ptolemy. ${ }^{334}$ Troncoso has no problem with this interpretation but emphasizes the significance of the elephants (which are not part of the Aigiochos statue); he sees in them a victory emblem, reflective of spear-won territory, an argument which complements Bosworth's reading of the coin as a reflection of elephant imagery in earlier Ptolemaic coins in conjunction with defensive military victories of Egypt. ${ }^{335}$

Because of the highly interpretive nature of coin analysis, there is no reason why these explanations cannot overlap and the coin cannot carry both religious and military significance. Indeed, I propose an additional explanation. The goal of producing a coin type is to make it easily recognizable to whoever is holding it, and the limited technologies of the fourth and third centuries meant that heavily detailed images were likely to fade over time or be lost on those who failed to examine them closely. This is especially so for a coin's smaller reverse type image, which often had to share space with the legend, monogram, or subsidiary symbols. ${ }^{336}$ For example, there is still uncertainty about whether the Alexander of the elephant quadriga type is clothed in armor or heroically nude, ${ }^{337}$ and different viewers have different interpretations, but they all center on the assumption that the figure is Alexander. It is worth asking how one draws this conclusion.

Bosworth notes the obvious parallels between the coin's reverse type and a description of Ptolemy II's celebratory parade in Alexandria, during which a statue of

\footnotetext{
334 Bieber (1964), 53; Morkholm (1991), 63.

335 Troncoso (2013), 259; Bosworth (2007), 20-21; on Ptolemy's possession of Egypt as “spear-won territory" see Worthington (2016), 100-101 with Diod. 18.39.50

${ }^{336}$ Arnold Biucchi (2006), 22-25.

${ }^{337}$ Bosworth (2007), 17.
} 
Alexander was drawn by elephants in a chariot. ${ }^{338}$ However, this clue postdates the coin considerably, and we must ask again, how could the tiny figure of Alexander in the quadriga be identified as Alexander upon first glance? There are two possible clues, and neither pertains to any particular depiction of the figure itself, but to its attributes. The lightning bolts that the figure carries and the elephants drawing his chariot indicate that this is Alexander. The lightning bolts are reminiscent of the Alexander keraunophoros painting at Ephesus ${ }^{339}$ as well as the Porus coins minted by the king himself after Hydaspes, where a figure which is likely Alexander is shown clasping Zeus' token attribute (see above). However, this token alone would not have been a clear enough point of reference, as the majority of hands through which these coins passed would not have had access to the Porus coinage. It is the presence of elephants that make an identification of Alexander definite. The deified Alexander had become closely associated not only with the horns of Ammon, but with the elephants of India, reminiscent of his competition with Heracles and Dionysus in what he considered his "prime achievement." 340

For modern readers, Alexander's Indian campaign is perhaps less compelling a narrative than his activities in Persia, perhaps because the campaign was so gruesome and its long-term gains so limited. ${ }^{341}$ During the wars of the Diadochs, however, Alexander's conquest of a quasi-mythical land represented the farthest any western military power had ever come. Naturally the token emblem of India, the elephant, would become one of

\footnotetext{
${ }^{338}$ Bosworth (2007), 17; see Athenaeus 197d-203b with Rice (1983) and Stewart (1993), 252-259. See also below pp.194-196.

${ }^{339}$ Stewart (1993), 36-37; Plut. Mor. 335A, Alex. 4.1.

${ }^{340}$ Bosworth (2007), 19.

${ }^{341}$ Around the time of Alexander's death, the Mauryan dynasty supplanted the Nanda dynasty in India, and within a generation had expanded into Macedonian-won territory. See Habib and Jha (2004), 12-20.
} 
Alexander's attributes, making his image easily recognizable. This rule applies to Ptolemy's earlier Alexander coinage as well: the Heracles-Zeus tetradrachm on which the elephant-scalp Alexander coin was based was debated contentiously by numismatists - is it Heracles, or a cryptogram for Alexander? ${ }^{342}$ There is, however, no such question about the coin type depicting Alexander in an elephant scalp—who else would wear it?

It is not until the last years of Seleucus' life that we see the elephant becoming somewhat normalized within the Greek menagerie, familiar enough to enter the religious realm. Although it never became a standard emblem of any traditional deities, Seleucus did produce coin reverse types featuring elephant-drawn chariots bearing the goddesses Athena and Artemis. According to Troncoso, Seleucus "aimed at exploiting the power of images to carve a new space for the exotic creatures on a celestial level." ${ }^{\text {343 }}$ This falls more in line with the "battle of images" that Troncoso and Bosworth see between Ptolemy and Seleucus than it represents any attempt to link Athena or Artemis permanently with an Indian animal. ${ }^{344}$ While Ptolemy capitalized on the cult of Alexander on his coinage, Seleucus challenged this with the portrayal of traditional and established deities on his own, letting his elephant scalp Alexanders be replaced by obverse types featuring bearded Zeus. His international reputation as elephantarches ${ }^{345}$ helped link his dynasty to the goddesses driving the chariots, implying that his elephant victory at Ipsus was won "with the support of the gods, but they were Olympians, not newly created deities like Ptolemy's Sarapis and Alexander himself." ${ }^{346}$

\footnotetext{
${ }^{342}$ See Brown (1995), 25 who articulates the debate.

${ }^{343}$ Troncoso (2013), 263.

${ }^{344}$ Troncoso (2013), 262; Bosworth (2007) 21-22.

${ }^{345}$ Plut.Demetr.25.4.

${ }^{346}$ Bosworth (2007), 22.
} 
The possibly deified or at least sacrosanct elephants with bull horns that appear on late Seleucid coinage indicate association with another Olympian, Dionysus, appropriate for an Indian animal; however, the coins carefully avoid any depiction of anthropomorphic deities. ${ }^{347}$ This would have been necessary because of the wellestablished pictorial trope of Alexander and his elephants. It is worth noting that Seleucus only ever portrayed female deities in the elephant chariots, figures which would be readily recognizable as non-Alexanders. The patron god of the Seleucid house, Apollo, does not appear in elephant context; his beardlessness might risk the confusion of his image with Alexander's.

\section{b. Coins of Seleucus: From Alexander's Elephants to Seleucus'}

Seleucus used Ptolemy’s elephant-scalp Alexander image for himself, minting gold darics, double darics, as well as bronze issues out of Babylon, Susa, and Ecbatana. ${ }^{348}$ The obverse of the coin imitated Ptolemy's with the exception of the horns of Ammon, which Seleucus removed, and the reverse drew on traditional Macedonian imagery, depicting Nike holding a stylis and wreath over a horse's head, with some variations. The inscription $\mathrm{A} \Lambda \mathrm{E} \Xi \mathrm{AN} \triangle \mathrm{POY}$ over some coins of this indicates Seleucus had not yet begun minting coins in his own name. However, other examples of this coin feature $\Sigma \mathrm{E} \Lambda \mathrm{EYKOY}$ instead. The date, as with most coins, is somewhat contentious, but

\footnotetext{
${ }^{347}$ Images found in Newell (1938) no. 325 pl. 24 no. 21; see Troncoso (2013), 261 and Kritt (1997) for the date.

${ }^{348}$ An image of this coin may be found in Houghton and Lorber (2002), 101, 183, 219; Stewart (1993), fig. 115 and Appendix 4; Morkholm (1991), pl. 8 no. 137. For a discussion see Troncoso (2013), 259-60; Stewart (1993), 314-315.
} 
is generally placed after Seleucus' Indian campaign in 305/4. ${ }^{349}$ Troncoso reads the coins as a celebration of Seleucus' imitatio Alexandri, even though Seleucus' gains were quite limited; he rightly notes that "Seleucid propaganda had no need to speak the language of the historical truth." ${ }^{350}$ Bringing back 500 Indian elephants was a triumph in and of itself (see p.67), and the coinage may be seen as celebratory, just as when Ptolemy used the same image after Gaza (312).

Seleucus did not lean for too long on Ptolemy's image before creating several of his own, departing from designs that incorporated Alexander at all after his successes at Ipsus (301). His elephants, however, remained an important totem of his reign. Because of the animals' highly visible role at Ipsus (see pp. 66-69), Seleucus became the first of a dynasty of "elephant kings" 351 by wielding the symbolic elephant far more adroitly than he ever managed to wield the flesh and blood equivalent. The famous stables of Apameia where the Seleucid elephants were kept and bred, was built on the Orontes River. This was one of many Seleucid foundations meant to advertise the wealth and breadth of the king's power. ${ }^{352}$ Bilde et al. note that a key part of Hellenistic kingship was the introduction of legitimizing institutions, which included building programs and the creation of conspicuous palaces and monuments. ${ }^{353}$ Nothing could be more monumental than a stable complex capable of housing Seleucus' 500 elephants and over 30,000 mares. Even if these numbers constitute an exaggeration of two or threefold, they are still

\footnotetext{
${ }^{349}$ See relevant bibliography of Troncoso (2013), 269 n. 11, in which the coin is placed in the context of Seleucus' Indian campaign. Cf. Kritt (1997), 108-18, who argues for a later date of 300-298, in the wake of Ipsus, which Troncoso (2013) accepts with caveats: see pp. 259, n.11-12.

350 Troncoso (2013), 260.

351 As per Kosmin (2014).

352 On Seleucid settlements see e.g. Cohen (2019); Engels (2017), 157-210; Kosmin (2014), 183-251.

${ }^{353}$ Bilde et al. (1996), 11.
} 
impressive. ${ }^{354}$ It is therefore unsurprising that the mint of Apameia-on-Orontes churned out elephant coinage like the standalone elephant bronze types that bear some resemblance to Alexander's Porus coins. ${ }^{355}$

The standalone elephant type features a simplistic design of an Indian elephant on the obverse and on the reverse a horse head with horns beneath an anchor, another wellknown Seleucid emblem. The legend reads BA $\Sigma \mathrm{I} \Lambda \mathrm{E} \Omega \Sigma \Sigma \mathrm{E} \Lambda \mathrm{EYKOY} .{ }^{356}$ The coin design is clearly reflective of Strabo's report, and both sides of the coin make clear reference to India, through elephants and the Bacchic horns on the horse. The coin is dated post-Ipsus, usually to c.300, although Newell suggests a range as broad as $300-280 .{ }^{357}$ The standard interpretation of the coin as advertisement of the Seleucid arsenal does not require reevaluation. The Seleucid elephant corps at this time until Seleucus' battle with Ptolemy Keraunos was the largest any one Seleucid king would ever command; this decline might explain the shift in Apameian coin design under Antiochus I, who issued coins featuring Heracles, Zeus, tripods, and arrows. ${ }^{358}$ This Apameian coin design was also used by the neighboring kingdom of Pergamum, which produced a similar type in silver denominations. Newell suggests a date of 281/80, viewing the coins as Pergamene recognition of Seleucid suzerainty and celebration of Seleucus' victory over

\footnotetext{
${ }^{354}$ Strabo 16.2.10; see also Diod. 20.113.4, who puts the number of elephants at Ipsus, and thus at Apameia, at 480.

${ }^{355}$ Cf. Troncoso (2013), 260; Holt (2003), pls. 6-10.

${ }^{356}$ Images found in Newell (1941), no. 1128 (see pp.156-157 as well); Lorber (2002), no. 35. See also the standalone elephant from the Susa mint, Newell (1944), no. 334-335, pl. 25 nos. 11-12, in which the elephant wears a bell.

357 Newell (1941), 156; Hadley (1974), 62; Troncoso (2013), 261.

${ }^{358}$ See Newell (1941) pp. 155-158, nos 1128-1134. Even at the battle of Raphia, Antiochus III was only able to field 102 elephants, a much smaller fraction of his ancestor's corps (Polyb. 5.79.13).
} 
Lysimachus. ${ }^{359}$ Now we see that Seleucus' elephants had become synonymous with his dynasty, and Alexander was no longer needed as a conduit for legitimacy. Seleucus had successfully co-opted the elephant for himself.

In subsequent years, elephants appeared on Seleucid coinage in the company of traditional Macedonian gods like Zeus and Athena. Although the dates are somewhat debated, there is general agreement that they post-date Ipsus. ${ }^{360}$ A series of silver staters from the Susa mints feature an obverse with Zeus' head in laurel and a reverse image of a standalone elephant with noticeably long tusks. ${ }^{361}$ These mints also produced silver drachms with Athena's helmeted head on the obverse and a reverse featuring an elephant head and trunk, a spearhead hovering in the exergue overhead. ${ }^{362}$ A lone elephant head appeared on the reverse of silver obols out of the Susa mint as well, with helmeted Athena on the obverse. ${ }^{363}$ An abundance of coin types featuring Athena driving elephant bigas and quadrigas, ${ }^{364}$ and two featuring Artemis driving an elephant biga, ${ }^{365}$ were also minted out of Susa and feature a distinct departure from the Ptolemaic image of Alexander in the elephant quadriga, as discussed above (p.137-138).

It is perhaps in such coins that we find the origin point of the foundation myth of Antioch-by-Daphne, which features the often propagated Seleucid images of Zeus,

\footnotetext{
${ }^{359}$ Newell (1941), 157, 316-317. The type produced under Philataerus of Pergamum reversed Seleucus' order, placing the horned horse's head on the obverse and the elephant on the reverse, beneath a legend reading: BA $\Sigma \mathrm{I} \Lambda \mathrm{E} \Omega \Sigma \Sigma \mathrm{E} \Lambda \mathrm{EYKOY}$. See Newell (1941) nos. 1528, 1529.

${ }^{360}$ E.g. Newell (1944) calls them the "victory issues" (121, pp. 115 f.); Morkholm (1991), Troncoso (2013), 258-264

${ }^{361}$ Images in Newell (1944), pl. 24 no 18, pl. 2525 no. 1, and pl. pl. 25 no. 6; see further p. 118 nos. 323, 326, 330; Morkholm (1991), pl. viii no. 138.

362 Images in Newell (1944), no. 317, pl. 24 no. 12

${ }^{363}$ Newell (1944), pl. 24 no. 21.

${ }^{364}$ Images in Newell (1944), pp. 116-120, nos. 314-316, 324, 326-328, 333, 338-340. See Pl. 24 nos. 6-7, 20; pl. 25 nos. 1, 3-4, 10, 16-18.

${ }^{365}$ Images in Newell (1944), p. 119, nos. 329, 331, pl. 25 nos. 5, 8. NB: Artemis' image appears only on staters.
} 
eagles, and elephants. Recorded in the Orationes of Libanius, a fourth century citizen of Antioch-by-Daphne, the foundation legend appears in the context of an encomium for the city. Unsurprisingly, elephants play a key role. While Alexander allegedly used grain to trace out the plans of Alexandria, which was later consumed by birds in an omen of future prosperity and fortune, Seleucus made his own luck when he laid out the plans for Antioch with a wall of elephants. Libanius provides all the necessary elements of a foundation legend, noting that Seleucus was led to the site of Antioch-by-Daphne by an eagle sent from Zeus, and that he marked out the city grid with grain, a clear parallel with the Alexander story. But the exterior defensive walls were demarcated by elephants.

"Outlining the city, he stationed the elephants at intervals, at the places where the towers were to be, and to mark out the length and breadth of colonnades and side streets he used, for the dividing lines, wheat which had been brought by ships which stood in the river."366

Thus, elephants both figuratively and literally helped to build Seleucus' kingdom, appearing in battle, on celebratory coinage, and forming the sturdy defensive walls of one of Seleucus' key foundations. ${ }^{367}$ Whether or not the story Libanius relates is accurate or not is unimportant and unknowable. The significance of the legend lies in the long-lived association of the Seleucids and their elephants, testimony to the impactful usage of the animals in royal insignia. As we shall see, the Diadochs' heirs in Syria and Egypt would continue to keep, acquire, and deploy elephants in similar ways, taking cues from their founders and intensifying inter-dynastic competition over this kingly beast.

\footnotetext{
${ }^{366}$ Lib.Or. 11.90, trans. Downey.

${ }^{367}$ In general on the geographic significance of this city and Seleucus' plans in founding it, see Kosmin (2014), 188-189 and Engels (2017), 409 ff, who provides a lengthy overview of the Syrian tetrapolis.
} 


\section{Chapter 4: Elephants \& the Epigonoi}

Above we discussed the impact of the display of elephants and the use of elephant symbolism on coins by the founders of the two longest-lived dynasties of Alexander's Successors. However, elephants did not vanish either Successor army upon the death of the founder. Although Glover claims that the animals' evidence ineffectiveness ultimately led to their disappearance within the military realm, ${ }^{368}$ a careful examination of the sources will prove that this is far from true. Elephants' ties to Alexander may not have been as relevant as in the days of the Diadoch Wars, but the animals were important in other ways. Like their fathers, Antiochus I Soter and Ptolemy II Philadelphus would continue the elephant "arms race" in an attempt to keep one another on their toes. They and their progeny would go to great lengths to maintain an elephant corps and continue deploying the elephants in war, regardless of their immediate tactical success.

It is important to remember that elephants were used by generations of Seleucids and Ptolemies in displays, both domestic and military. In addition to elephants being housed in royal stables, zoos, and transported on parade, the animals were showcased in the context of war, at which point the battlefield became a venue of presentation. What appears counterintuitive at first glance is in fact psychologically effective-elephants may be easily undermined, as we have seen in chapter one, but their presence on the field reflects the strength of the king deploying them. As such, the animals appear in ancient descriptions and depictions of martial parades and also became a target of Rome in its

\footnotetext{
${ }^{368}$ E.g. Glover (1948), 10-11.
} 
attempts to curtail the power of the Seleucid dynasty under Antiochus III and IV.

The elephant had become an emblem of Hellenistic eastern kingship as well as of victory and of the particular dynasties of the Seleucids and Ptolemies. True kings could field elephants in war, and conversely the inability to deploy an elephant corps signaled a loss of strength, with the result that both the Seleucids and Ptolemies went to great lengths to keep up their elephant numbers. As we shall see, simply maintaining an elephant corps was a powerful sign of wealth and resources, and conspicuously advertised by both dynasties in the forms of new settlements dedicated to elephant hunts, the creation of a military compound famous for its elephant corps, civic parades, portraiture, and state coinage. This section will begin with an assessment of the continued use of the elephant corps in battle and then continue on to discuss the use of elephant symbolism to denote wealth, power, and vast economic resources.

\section{Part A: Elephant Corps \& Later Wars}

Because the use of elephant corps persisted past the Diadochs, it is worthwhile to consider the contexts in which these animals were deployed against the enemy. In almost every case, elephant use falls into one of two categories: (1) use against troops that are unfamiliar with the animals, or (2) use of elephants in the wars of the Seleucids and Ptolemies, in which matching the enemy on the battlefield by producing elephants was part of inter-dynastic competition.

\section{The "Elephant Victory" Of Antiochus I}

As we saw with Pyrrhus' Italian campaign in chapter one (pp.85-92), elephants do have the potential to turn the tide of battle when deployed against an army unfamiliar with 
them. Amidst the events of the First Syrian War (274-271/0), Antiochus I Soter, the son and heir of Seleucus I, found himself in one of the rare circumstances in which elephants could be deployed militarily with success. Although there is some doubt as to the historicity of the event, ${ }^{369}$ most authors generally accept as true some form of the socalled "Elephant victory" against a tribe of Celts whom the Greeks called Galatians. Hordes of Galatians, invited by the Bithynian dynast Nicomedes, an enemy of Antiochus I, poured into Anatolia from the north. Antiochus I's alliance with Antigonas II Gonatas of Macedonia, fellow enemy of the Galatians, resulted in a united effort to repulse the roving bands. The sequence of events of the battle are not known, and indeed the year it occurred is disputed, with a general agreement on sometime between $275-269 .{ }^{370}$ What is generally maintained is that Antiochus I's use of elephants against Galatians, who were wholly unfamiliar with the animal, proved a resounding success, allowing the Seleucid king to settle the Galatians in central Anatolia and prevent raids on his territory (see Coskun 58-60 especially for the bibliography). Coskun rightly points out that ancient sources are largely silent on the issue, with Appian, Lucian, and much later, the Suda, referencing the victory clearly, while a host of other inscriptional and literary sources have been mistakenly (in Coskun's view) associated with the "Elephant Victory."371 Appian claims the victory earned Antiochus the epithet "Soter," but says little else (Syr. 65). Only Lucian specifies that 16 elephants were used (Zeux 11), but he greatly exaggerates the numbers in the Galatian army. ${ }^{372}$ Further, Lucian writes within the

\footnotetext{
${ }^{369}$ Coskun (2012) provides the most updated bibliography on the debate while simultaneously arguing against the battle's historicity.

${ }^{370}$ Grainger (2010), 80 supports Bar Kochva's (1973) argument for 272, but he rightly emphasizes the difficulty of dating this particular battle due to recurrent skirmishes between marauding Galatian tribes and Antiochus I.

${ }^{371}$ Coskun (2012), see e.g. nn.14-20.

372 Ibid., 63.
} 
context of a satire, emphasizing through Antiochus' character that it was shameful for one of the finest Greco-Macedonian armies to have been saved from defeat only by cunning stratagem.

Lucian's story, whether historical or not, would never have functioned even for rhetorical purposes if a strong association between the Seleucids and elephants was not already established. Even by the second century CE when Lucian wrote, Seleucus' then extinct dynasty was still closely associated with the elephant, a fact which prompts Coskun to conclude that "the elephant trophy [in Lucian's story] is the least fictional element of the whole account." ${ }^{, 373}$ Indeed, Seleucid coinage and other iconography may have helped color this account for Lucian, if such a story did not already exist. Other evidence suggestive of the propagandistic value of an elephant victory emerges in the Suda's reference to a Magnesian poet named Simonides, whose epic poem in honor of Antiochus III, the "Great" references an elephant victory against Galatian cavalry. ${ }^{374}$ Putting aside attempts to explain the record as an error for Antiochus I or to conclude that ancestral victories were re-attributed to Antiochus III, the poem links an Antiochus and elephants, leading Coskun to conclude eloquently: "It appears that, around 275 b.c., two key motifs - the defeat of Galatians and the deployment of war elephants - were combined and employed by the court of Antiochus in its public self-representation." 375 The twofold significance of this propaganda is given as an advertisement of Antiochus' vast empire and access to the resources of the East, and his ability to defend what was his, especially in a period of intense competition against Philadelphus.

\footnotetext{
${ }^{373}$ Coskun (2012), 65.

${ }^{374}$ As per Coskun (2012), 67-68; cf. Suda s.v. Simonides of Magnesia.

375 Ibid., 68.
} 
In practice, there is no reason why such a battle could not have taken place, and this would hardly be the only event of the Hellenistic era that remains poorly documented. As we have seen, the only occasion in which elephants play a decisive offensive role in battle is when they are pitted against an enemy that has never seen them before. Just as Pyrrhus initially did during his Italian campaigns (p9.77-83), Antiochus I may well have deployed elephants successfully against the Galatians. The number of 16 seems staggeringly small considering Seleucus I's possession of 500 not so long ago, but the loss of elephants in his ill-fated Macedonian campaign may have been great. If the "Elephant Victory" did occur, it would have fed nicely into the growing association between Seleucids and elephants, a fitting victory for the son of an "elephantarches" (Plut.Demetr. 25.4).

\section{Plausible Elephant Use in the First Syrian War}

By the opening of the First Syrian War (274-271/0), we know that both dynasties had elephants, but the total number is unclear. Based on the description of the Alexandrian procession of Philadelphus, which predated the elephant hunting grounds on the Erythraean coast (and thus the presence of any African elephants), Ptolemy may have had as many as 96 Indian elephants, survivors of those captured by his father (e.g. 43 at Gaza), although many of these must have been very old, and the number is suspiciously high. ${ }^{376}$ If we are to believe Lucian (Zeux.11), Antiochus I had at least 16 that had not been seized by Ptolemy Ceraunus in Macedonia. Very little exists regarding the actual conflicts of this war, but the movement of troops, such as may be reconstructed, makes the use of elephants in pitched battle perfectly plausible.

${ }^{376}$ Scullard (1974), 124-125. 
The basic structure of the First Syrian War has been treated most recently by Grainger, whose combination of literary and epigraphic sources provides a thorough investigation which I follow here. ${ }^{377}$ After Antiochus I provoked the governor of Cyrene and brother of the pharaoh, Magas, to revolt from Egypt, Philadelphus marched against Antiochus. ${ }^{378}$ His invasion of Syria forced Antiochus to leave Sardis, as the Babylonian Chronicles indicate. ${ }^{379}$ He marched inland by foot while his navy of some 330 warships sailed the Phoenician coast. Many men were left to guard Egypt, Cyrenaica, and garrison posts en route. ${ }^{380}$ Exactly what occurred in Syria is not clear, although it is known that Antiochus successfully repulsed the army of Philadelphus, but all of the former's gains were temporary and quickly eliminated by the end of the war. Grainger credits Antiochus' successful defense of his territory to his veteran forces, who had been fighting in the north parts of Anatolia, the well-built defensive positions of northern Syria that Seleucus I established, and Antiochus' own experience as a general, which Philadelphus lacked. ${ }^{381}$ One must wonder whether elephants had been involved; the likelihood seems good, especially on the part of Antiochus. The royal stables at Apameia would have been easily accessible to the Seleucid army and were located in the valley of Coele-Syria so that they might have been transported to meet invading forces as needed. Further, the Babylonian Chronicles report that Antiochus sent for elephants in 274 from his Bactrian satrap, ${ }^{382}$ which makes sense if he had been anticipating an attack from Philadelphus after his role in inciting the rebellion of Magas.

\footnotetext{
377 Grainger (2010), 73-87.

${ }^{378}$ For the revolt, Magas' failed march on Egypt, and Philadelphus' invasion of Cyrenaica, see Paus. 1.7.1 2; Grainger (2010), 80f. 
Scullard theorizes that it was the First Syrian War which convinced Philadelphus of his need to acquire a greater elephant corps in order to match the forces of Antiochus. Indeed, the elephant hunting project did begin shortly after this war, and it is likely that the promise of future clashes between the two dynasties played a role in prompting Philadelphus' project. ${ }^{383}$ However, to suggest that he initiated such a costly and complex undertaking simply to prevent a loss on the battlefield would be oversimplifying Philadelphus' decision. Whether or how many elephants were used in the first of the Syrian Wars is unknown, but if this conflict represented the first of much head-butting between the two kings, ${ }^{384}$ it makes sense that following a stalemate, either side would devote greater resources to enhancing its military forces. Not only that, but both kings needed to be seen to be confident and wealthy masters of a stable regime. Elephants were not merely the newest military technology_indeed, Philadelphus would have known well from his father that deploying an elephant corps was not necessary to defeat an elephant corps - they were powerful symbols of wealth, resources, and Hellenistic kingship. As we shall see below, Philadelphus and Antiochus both emphasized this connection.

\section{Elephants as War Prizes in the Third Syrian (Laodicean) War}

\section{Named for the Seleucid queen Laodice, the Laodicean or Third Syrian} War (c.246-241) was instigated by Ptolemy III Euergetes, Philadelphus' heir. Euergetes'

\footnotetext{
383 Scullard (1974), 124.

384 The First Syrian War was ended with a reaffirmation of the antebellum status quo and the Peace of 271/0, which was short-lived. Although the treacherous Magas had been neutralized by the persistent threat of a revolt from Libya, the conflict between dynasties had set a dangerous precedent for fighting over the fertile plains of Coele-Syria. The relatively unremarkable results of the war should not suggest a lack of danger. Indeed, Grainger (2010), 89f. has shown that the post war peace agreements were meant to last only until one, if not both, of the signatories had been replaced by his heir.
} 
sister Berenice had been married off to the Seleucid king Antiochus II in the peace that ended the Second Syrian War, binding the dynasties in friendship. However, Antiochus II abandoned Berenice and returned to living with his former wife Laodice in Ephesus, whose children were his presumptive heirs. When he died in 246 at Ephesus, ${ }^{385}$ civil war broke out between Seleucus II (borne by Laodice) and Antiochus Hierax (borne by Berenice) and their regent mothers. Even though Berenice was murdered before Euergetes could reach her, Euergetes continued his invasion of Seleucid territory. It is known that he marched as far as the Euphrates River, and the highly laudatory inscription from Adulis adds detail. Lost now, the inscription (OGIS 54) was recorded by a sixth century traveler named Cosmas Indicopleustes. It records that Euergetes marched into Seleucid territory with a force of infantry, cavalry, navy, and elephants, the fourfold army once depicted on Alexander's funeral carriage.

The importance of the elephants in his army is made clear in the inscription by a clear classification of breed. Specifically, the king came $\mu \varepsilon \tau \grave{\alpha} . . . \dot{\varepsilon} \lambda \varepsilon \varphi \alpha ́ v \tau \omega v$

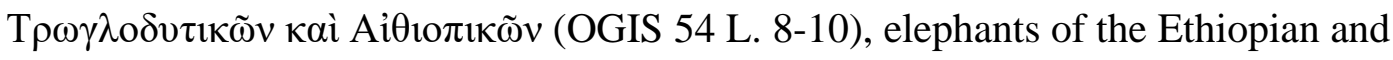
Troglodytic breed, both of which were Loxodonta cyclotis, or African forest elephants. The inscription goes on to note that both Euergetes and his father (Philadelphus) were the first to hunt these sorts of elephants, and the first to bring them back to Egypt and prepare them for war (OGIS 54 L. 10-13). The inscription specifies that Euergetes came into

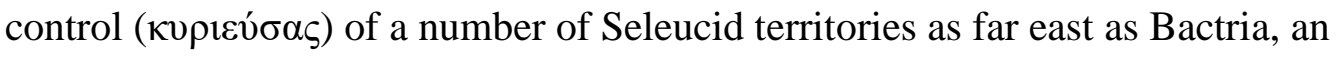
exaggeration which Grainger rightly corrects. ${ }^{386}$ The inscription also notes that Euergetes

\footnotetext{
385 On the date, see Grainger (2010) 135 and Sachs and Hunger (1988-2002), -246, -245.

${ }^{386}$ Grainger (2010), 161-162 views the inscription as exaggerated, as reaching Bactria at this point would have required Euergetes to campaign through the autonomous Parthian state. Further, Appian (Syr.65)
} 


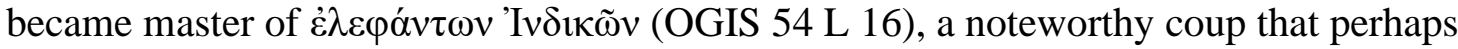
brings to mind the devastating effects of Ptolemy I's capture of Demetrius' elephants at Gaza in 312, a symbolic victory which so demoralized the Antigonid army that many began to desert. ${ }^{387}$ Without a description of a battle between Seleucus II and Euergetes, any comparison is highly conjectural, but it does illuminate the psychological blow the seizure of the enemy's elephant corps could deal, a factor which might explain Euergetes' detailed boasts in the inscription. Grainger suggests that Euergetes' capture of Indian elephants implies not a battle, but the capture of Apameia itself, the crown jewel of western Seleucid cities. ${ }^{388}$ If indeed Euergetes had come into complete control of this massive military complex with its easily defensible citadel, it seems unlikely that the Seleucids could have wrested it from him with ease. And yet, Euergetes chose not to hold it or any other north Syrian territory, withdrawing his forces when he returned to Egypt to quell local revolts.

Grainger offers extensive analysis of this decision, concluding that the risks of provoking Seleucus II to outright war outweighed the potential benefits, and Euergetes took prizes from the land as loot. ${ }^{389}$ This appears, in conjunction with the Adulis inscription, to serve as compensation for the abandonment of hard-won land. Grainger claims that "by annexing the cities of North Syria, [Euergetes] would be challenging Seleukos II to take them back. Many of them were named for Seleukos' family; they

\footnotetext{
gives Babylon as the farthest eastern point reached by Euergetes, and even there the king did not appoint a governor of his own choosing, as he did in Mesopotamia.

${ }^{387}$ See chapter 2. Even though Diodorus emphasizes how the two sides were well matched in infantry and cavalry (Diod. 19.83.4-5, 84.1), the injury and capture of the elephants caused Demetrius' men to begin to desert (Diod. 19.84.5-7). The psychological bolster that the wall of elephants had initially provided proved ultimately detrimental to the campaign, forcing Demetrius to retreat while sustaining severe losses (Diod. 19.84.5f.).

${ }^{388}$ Ibid., 161.

${ }^{389}$ Ibid., 164-165.
} 
were a large part of his inheritance; he would necessarily fight to recover them." ${ }^{390}$ This and the dynastic loyalty of the north Syrians cannot have been the sole reasons for Euergetes' decision to retreat. After all, the Coele-Syria had been fought over fiercely by Euergetes' father and the father and grandfather of Seleucus II; the two dynasties had a repetitive feud over the land that stretched back generations. Naturally, annexing muchsought territory would have been a prestigious coup for the third Ptolemaic king, and he needed to explain why he so quickly ceded the land his army had successfully seized. The recovery of sacred objects of Egyptian worship, ${ }^{391}$ among other unspecified sources of wealth, ${ }^{392}$ would have won Euergetes favor among his people at a time of revolt, but the capture of elephants, ${ }^{393}$ the sigil of the Seleucid house, would have gone a long way to compensate for Euergetes' eventual cession of won territory. ${ }^{394}$ Because the elephant had evolved over generations to become a symbol of eastern kingship, Euergetes' successful capture of them would have been a devastating blow to the young Seleucus II. Indeed, the Seleucid elephant corps would not be restored to a satisfactory number until the reign of Antiochus III.

\section{The Many Elephants of Antiochus III "The Great"}

The Laodicean War was ended with a treaty (Just.27.2.9), and the Seleucid dynasty suffered internal chaos and the loss of territory. Seleucus II was succeeded by his

\footnotetext{
${ }^{390}$ Ibid., 164.

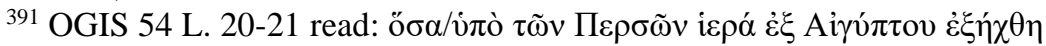

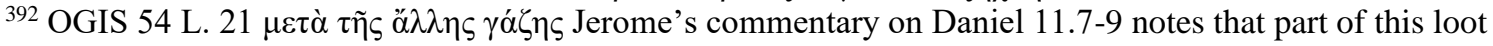
included 40,000 talents of silver, and that the value of the sacred objects amounted to 2,500 talents. Jerome makes no mention of the elephants, which is unsurprising, as their symbolic significance was limited to the era of warring Hellenistic kings.

${ }^{393}$ OGIS 54 L. 16

394 Jerome's commentary on the Book of Daniel 11.7-9 notes that Euergetes kept hold of certain Seleucid territories for a time, but without the full support of the army, any Ptolemaic garrisons would have fallen to Seleucus II's reconquest. It should be noted that Euergetes did keep control of Seleucia-in-Pieria. Cf. Grainger (2010), 164-166, 169.
} 
son Seleucus III Ceraunus (r.226-223), upon whose death the young Antiochus III (r.223187), to become "the Great" succeeded him. ${ }^{395}$ Antiochus III used elephants on at least five occasions, inasmuch as is known. First, he arrayed a small elephant corps of 10 against Molon, the usurping satrap of Media, and then he deployed 102 at the Battle of Raphia (217); he deployed elephants at Panium against Ptolemaic forces (c. 200), and later he brought elephants into Greece as an invading force at Thermopylae (191) and used them against Rome at Magnesia (190/89). Let us begin with the campaign against the rebel Molon.

When the Median satrap Molon revolted from Seleucid control and declared himself king, the Seleucid state had to respond (Polyb. 5.43ff). Hermeias, who had served as advisor to the late Seleucus III, urged Antiochus III to focus on the war for Syria with Ptolemy IV Philopator, and not to involve his own person in the fight with Molon. Polybius reports that Hermeias' reasoning was that "to fight against rebels was the business of generals but that against kings the king himself should plan the operations and command in the decisive battles" (Polyb.5.45.6). Accordingly, Antiochus III sent his general Xenoetas east instead. However, Xenoetas failed to overthrow Molon, forcing Antiochus III to put his war in Syria on hold to reclaim Media. Polybius records that Antiochus III marshalled his men at Apameia (5.50.1), where the elephant stables were still operational, and marched east. He must have had at least ten elephants with him, as he posted as many in front of his infantry (Polyb. 5.53.4).

No details of the elephants' participation are recoverable, and a unit of ten pales in comparison to the grand battles of Antiochus III's forefathers, but it is worth noting

\footnotetext{
${ }^{395}$ For the problems of the Seleucid state after the Third Syrian War, see Grainger (2010), 171-194;
} 
that no elephants had been sent forth at all with Xenoetas (Polyb.5.46.6-5.48.16). One wonders - could anyone other than the king deploy elephants in battle, and would they have been symbolically impactful without the presence of the king? In response to Molon's treachery, Antiochus III with his elephants certainly served as a reminder of royal authority, an occasion which bears some resemblance to the almost contemporary use of royal elephants by Philopator. When Philopator had discovered that a certain Scopas had been plotting to overthrow him, he waited until Scopas and his fellow conspirators met in Scopas' home, their usual place. Once they were inside, Philopator had the building surrounded not only with soldiers, but with elephants. ${ }^{396}$ The conspiracy could easily have been dealt with by Philopator's generals, and the ringleaders might have been dragged before his court, should he wish to become personally involved; there was no pressing need for the king's presence or his elephants at the arrest site. However, Philopator himself entered the building with his guards and seized the would-be assassin by his cloak, making the arrest in person (Polyb.18.53). While it was Perdiccas, over a century earlier, who first concocted the idea of using Alexander's elephants as a reminder of the origin of his power, the mighty animals had become simply a symbol of royal authority for the Ptolemies and Seleucids.

Elephants appear in significant numbers at Raphia in 217, a key battle of the Fourth Syrian War. ${ }^{397}$ Although this section of the chapter offers primarily brief surveys of instances in which Seleucids and Ptolemies brought elephants on campaign, a brief

\footnotetext{
${ }^{396}$ Polyb. 18.53 notes that one of Scopas' co-conspirators was a certain Charimortos, a figure that scholars have connected to the elephant hunt strategos commemorated in an inscription OGIS 86. See e.g. Casson (1993), 252. However, the inscription is dedicated during the reign of Euergetes and honors a certain Alexander, who is replacing a presumably retired Charimortos. By the time of Philopator, it is unclear whether Charimortos would even have been alive. If Polybius' account refers to the same man mentioned in the OGIS 86 inscription, Philopator certainly had a well developed sense of irony.

${ }^{397}$ Grainger (2010), 195-218 provides a detailed discussion of this war.
} 
digression on the tactical use of elephants at Raphia is warranted given the unusually detailed nature of the sources. Much as we found in chapter one, elephants at Raphia do not prove the deciding factor of the battle, and despite Antiochus III's superior elephant corps' strength and his success at driving Philopator's own elephants against his men, the Seleucid king lost the battle.

Polybius tells us that Philopator brought 73 elephants to the battle, and Antiochus brought $102 .{ }^{398}$ Philopator placed 40 elephants on the left wing where he himself was stationed, and the remaining 33 were stationed on his right wing, in front of the cavalry (Polyb.5.82.7), a location which seems counter-intuitive unless one imagines that the cavalry had been specially trained to weave between the elephants in a charge. Clearly the horses, at the very least, had been trained to tolerate the smell and noise of the elephants. Antiochus stationed 60 elephants on his right wing (also in front of his cavalry) opposite Philopator, where Antiochus himself planned to fight. ${ }^{399}$ On his left, he placed the remaining elephants. Polybius notes that the elephants entered battle first:

\begin{abstract}
"The elephants themselves fought still better, putting forth their whole strength and meeting forehead to forehead. The way in which these animals fight is as follows. With their tusks firmly interlocked they shove with all their might, each trying to force the other to give ground, until the one who proves strongest pushes aside the other's trunk, and then, when he has once made him turn and has him in the flank, he gores him with his tusks as a bull does with his horns." 400
\end{abstract}

The description is problematic in that it presupposes all of Antiochus' elephants were male. While both male and female African forest elephants are tuskers, only male Indian

\footnotetext{
${ }^{398}$ Polyb. 5.79.13; the species of elephant involved is somewhat debated. While Scullard has set the standard for understanding Ptolemaic elephants to be entirely African forest elephants, Charles (2007) has recently challenged that view by arguing Philopator used a combination of African and Indian elephants at Raphia, as only Indian elephants would be large enough to bear the turrets described by Polybius. It seems likely that this is true, as Euergetes captured at least some of the Seleucid stock at Apameia during the Third Syrian War (cf. pp.150-152).

${ }^{399}$ Polyb. 5.82.8-9; Scullard (1974), 141 provides a good map of the battle plan, see also 137-145; cf. BarKochva (1976), chapter 9; Charles (2007); Grainger (2010), 213-217.

400 Polyb. 5.84.2-5.
} 
elephants can grow more than short nubs. It seems unlikely that the stables of Apameia would house only male elephants, as an abundance of female elephants would be necessary to increase the royal stock and maintain good order, given the female tendency to herd. While male African elephants have occasionally been reported to travel in small groups for short durations, male Indian elephants do not do this, but live solitary lives and become absolutely volatile in musth. ${ }^{401}$ While it is probable that tuskers that met in battle did behave this way, as they have been filmed doing so in the wild, this cannot have been the sole means by which elephants fought in pitched battle. Head butting and the use of their trunks and feet as weapons, as the sources describe at Hydaspes, are equally likely to have occurred.

At Raphia, Polybius tells us that Philopator's elephants, being smaller than those of Antiochus, fled on the Ptolemaic left, tearing through men and horses and throwing the wing into confusion, which permitted Antiochus to advance (5.84.10). On the Ptolemaic right, events progressed differently. Philopator's generals Echecrates and Phoxidas, seeing the chaos on the left wing and noticing that the elephants on their (the right) wing refused even to advance against the enemy, essentially maneuvered around the animals. Phoxidas led his mercenary unit forward against the Seleucid infantry, and Echecrates took his cavalry back and around the flanks of his own elephants to outflank the enemy's cavalry, avoiding their corresponding elephant charge altogether (Polyb. 5.85.1-5). The elephants served at best as bulwarks in this battle, but really they seem only to present generals with unusual obstacles which, in this case, could not be led forward against the enemy nor permitted to charge through the ranks of cavalry aligned behind them.

\footnotetext{
${ }^{401}$ E.g. Sukumar (1992), 140, fig. on p. 139.
} 
While this formation was effective in Indian combat, where elephants could successfully attack infantry, elephants were not compatible with Macedonian military tactics. Antiochus' right wing had success primarily because Philopator's left wing elephants had thrown his men into chaos, and Antiochus' left wing began to collapse because Echecrates and Phoxidas had figured out a way to maneuver around their own elephants. Even though 16 of Philopator's elephants had been killed and almost all the rest captured, he was still the clear victor of the field because of his success against Antiochus' infantry and left-wing cavalry, which allowed for a bloody rout. Polybius claims Antiochus lost 10,000 in infantry, 300 in cavalry, and 4,000 in cavalry had been taken prisoner. Comparatively, only two of Antiochus' elephants were killed outright in battle, and three more died of wounds (Polyb. 5.86.1-6). Philopator's victory was unquestionable. Antiochus yielded the field, marching north and suing for peace as soon as he reached Antioch (Polyb.5.87.1).

A single account of elephant use appears in the context of the Fifth Syrian War at the Battle of Panium (c.200), although even basic details of the battle are lost. When Antiochus took the initiative after his anabasis to India and invaded Ptolemaic Syria, he did so with recently-tested and highly experienced forces. The recent death of Philopator had left his child heir, Ptolemy V Philometor, on the throne, rendering the central government weak enough to encourage rebellion in southern Egypt. At the same time, the Antigonid king Philip V of Macedonia is alleged to have formed a secret pact with Antiochus III in which they would seize key territories from the weak Ptolemaic state, and Antiochus III had his eye on Syria. ${ }^{402}$ Grainger surmises reasonably that Antiochus

${ }^{402}$ Polyb.15.20.1-2; Livy 31.14.5; App.Mac.4.1; Just.30.2.6. 
III marched into Syria during the Fifth Syrian War with elephants, although they surely were not involved in the siege of Damascus (202), ${ }^{403}$ and are not mentioned anywhere by Polybius at the siege of Gaza (201). ${ }^{404}$ They are known, however, to have participated at the Battle of Panium (200).

Antiochus III's encounter at Panium with Ptolemy V Philometor is poorly documented, and only fragments of conversation about it survive through Polybius. Polybius asserts that elephants were deployed by Antiochus, but the number and even location of the animals in the line is unclear. ${ }^{405}$ The entire record of the battle must be filtered through Polybius' harangue of the history of Zeno of Rhodes, and it cannot be reconstructed. Although Scullard asserts that "clearly elephants played an important part, ${ }^{406}$ there is insufficient evidence to support this. Their specific tactical role is unclear, a problem illustrated well by Polybius' criticism of Zeno:

"Next he [i.e. Zeno of Rhodes] states that the [Seleucid] phalanx, proving inferior in fighting power and pressed hard by the Aetolians, retreated slowly, but that the elephants were of great service in receiving them in their retreat and engaging the enemy. It is not easy to see how this could happen in the rear of the phalanx, or how if it did happen great service was rendered." ${ }^{407}$

Here Polybius points to one of many alleged flaws in Zeno's account, who does not explain how the elephants, posted in front of the phalanx, wound up behind it. However, Polybius also seems flummoxed by the reference to phalanxes clashing on the field even though elephants had been posted in front of them, a problem which Wrightson

\footnotetext{
${ }^{403}$ Polyaenus 4.15 records this and emphasizes the speed and stealth which made the siege successful. Cf. Grainger (2010), 248-249.

${ }^{404}$ Polyb. 16.22a; Grainger (2010), 250.

405 Polyb.16.18-19; cf. Grainger 256-7 and description at 258f.; Bar-Kochva Seleucid Army chapter 12.

406 Scullard (1974), 145.

${ }^{407}$ Polyb. 16.19.1-2.
} 
noted about elephant deployment as early as Ipsus. ${ }^{408}$ Polybius says that "[Zeno claims that] two phalanxes met and fought stubbornly, forgetting that it was impossible for them to meet as the elephants, cavalry, and light-armed troops were stationed in front of them." ${ }^{409}$ However, in this Zeno may have been correct, as stationing elephants in front of phalanxes was customary deployment, so long as the gaps between the animals were filled with light-armed skirmishers, as they were at Panium. ${ }^{410}$ Indeed, Polybius himself seems to imply that this is acceptable when he notes that "once the two phalanxes had met it was not possible for the elephants to distinguish friend from foe among those they encountered" (16.19.3), indicating that they were part of the melee, whether closer to the front or the rear.

Bar-Kochva's reconstruction of the battle, accepted and used by Grainger in his study of the Syrian Wars, ${ }^{411}$ credits the elephants with tactical success, noting that they formed an impenetrable wall which the Aetolian cavalry (fighting for Philometor) was unable to penetrate. Despite the Aetolians' success on one wing, they were prevented from advancing against the other Seleucid forces by a wall of Indian elephants. This inevitably brings Ipsus to mind, fought 101 years prior; the only useful deployment of elephants on the field was in large numbers as a barricade and against men (or horses) that were unfamiliar with them, as the Aetolians were. ${ }^{412}$ In this case, elephants did play a supporting role, preventing the Aetolian advance much as Seleucus I's elephants had prevented the advance of Demetrius Poliorcetes' cavalry (cf. pp.66-69). However, the

\footnotetext{
408 Wrightson (2015), 66.

${ }^{409}$ Polyb. 16.18.9.

${ }^{410}$ Polyb.16.18.7; cf. Epplett (2007), 227-230, who notes that most Macedonian battles with elephants involved an elephant guard of some sort.

${ }^{411}$ Bar-Kochva (1976), chapter 12; Grainger (2010), 257-260.

412 Polyb.16.19.4; cf. Grainger 260.
} 
Aetolian cavalry was also the most successful unit of the Ptolemaic forces, and Antiochus III was obliged to let them go in order to conserve and redirect his forces against the Ptolemaic phalanx. While the elephants prevented the Aetolians from assisting the rest of the army, their use in this capacity was contingent upon their numbers (Antiochus III had at least 150 available to him after his anabasis to India) and the Aetolian horses' unfamiliarity with and fear of the massive animals. Philometor possessed primarily much smaller forest elephants, so any encounters the Aetolian cavalry may have had before the battle were not only limited, but with a much smaller, different-looking elephant. ${ }^{413}$ Panium ended the Fifth Syrian War, and Philopator claimed much of Coele-Syria; his son Ptolemy V Epiphanes was given Cleopatra, daughter of Antiochus III, as his wife, a truce which ended the conflict between this generation of Ptolemies and Seleucids. ${ }^{414}$

Antiochus turned westward for a time, invading Greece with the assistance of the Aetolians and meeting Roman resistance at Thermopylae (191), where he used an unspecified number of elephants (Livy 36.15-19; App.Syr.18-20). The brief and disastrous battle here begs the question why Antiochus would bring such massive animals into battle in narrow passes. While the Macedonians were hard-pressed, their Aetolian allies were completely overtaken on Callidromus Hill, allowing the Roman forces to unite in their assault on the main body of the army. This prompted the veteran forces of Antiochus to flee, and here the presence of the elephants does prove decisive, but for the Romans. Livy notes that the Macedonian retreat was:

"impeded by the entrenchments of the camp and the confined space through which the pursuers had to pass, but the elephants were the greatest hindrance, for it was difficult for the infantry to get

413 There is some suspicion that Philometor possessed a combination of Indian and African forest elephants, but Charles (2007) had shown that Ptolemaic possession of Indian elephants at Raphia (even the descendants of those captured by Euergetes) is unsupported.

${ }^{414}$ Grainger (2010), 269-270. 
past them, and impossible for the cavalry; the frightened horses created more confusion than in the actual battle. The plunder of the camp still further delayed the pursuit." ${ }^{415}$

Once again, elephants proved more harmful in battle than useful, and in the end the animals were killed, trapped in the narrows (Livy 36.19.6), along with many thousands of Macedonian and Aetolian casualties. ${ }^{416}$

Antiochus may have made more use of his elephant corps than any other Seleucid king; unfortunately he also had the worse track record. Elephants appeared in battle again when Antiochus squared off with Rome at Magnesia (190/89), ${ }^{417}$ in which the elephants formed one of many specialized units of "exotic" (to the Romans) weapons. Here once again, the elephants had little success. The battle formation described by Appian and Livy sounds almost like a military parade, with specialist forces from all corners of the Seleucid Empire answering the call to muster. ${ }^{418}$ We hear of slingers, archers, javelinthrowers, and a host of peltasts from Phrygia, Lycia, Pamphylia, Pisidia, Crete, Tralles, and Cilicia; these were joined by Dahae horsemen and mounted archers from Mysia and Elymais. Appian also mentions Arabian knights riding on dromedaries and scythed chariots, the antiquated machine that the Persians had once adopted from the Assyrians. ${ }^{419}$ These devices, like the elephants, were true representations of eastern kingship, and like the elephants, they appeared to inspire terror in the enemy. Livy describes them in great detail, noting that the wheels had turning scythed attached to the

\footnotetext{
${ }^{415}$ Livy 36.19.4; App.Syr.19 only mentions a disorderly retreat and does not specify the role elephants played, although he acknowledges their presence at Thermopylae at 18.

416 The numbers are inconsistent. Livy repeats the estimates of Valerius Antias with a great deal of skepticism: 40,000 of 60,000 Seleucid dead and another 5,000 taken prisoner. Appian reports Seleucid casualties of 10,000, including prisoners (Syr.20).

${ }^{417}$ Accounts of the battle appear in Livy 37.35-44; App.Syr. 30-36.

${ }^{418}$ Livy uses this variety to emphasize the uniformity of the Roman forces 37.39 vs. 37.40 .

${ }^{419}$ Ropp (2013), 174-180; cf. Glover (1950), 5-8 who places both chariots and elephants in the category of "curiosities" of ancient warfare. Both were used, without great success, by Antiochus III at Magnesia.
} 
hub and, external to that, projecting spikes in order to cut the enemy forces apart in all directions (37.41).

And of course, Antiochus III had his elephants, acquired from Euthydemus of Bactria and Sophagasenus (Subhagasena) of India. ${ }^{420}$ While Appian does not specify how many were deployed, Livy gives 54 in total (37.39). The king placed two elephants between each of ten phalanx units, which he had arranged into sections 50 ranks wide and 32 deep (App Syr. 32; Livy 37.39-40). Depending on whether the elephants were placed only between two phalanx units or also on the exterior of the outermost units, between 18-22 elephants were deployed in this way. It seems likely that the remaining elephants would have been deployed across the front of the line, as in most previous battles.

While the Romans were no longer unfamiliar with the elephant, Livy's account indicates that the psychological force of using the animals was still very much in effect. The Romans withdrew their own elephant corps of 16, fearing that their smaller numbers, stature (being forest elephants) and inadequacy in robore would make them useless against Antiochus' larger animals (Livy 37.40.4). Appian claims that the Seleucid infantry was like a wall, of which the elephants were the towers, and Livy adds that each mahout was assisted by four armed men (App.Syr.32; and Livy 37.40). It is likely that assisting forces of light-armed infantry were also included as part of each elephant's guard, as this had been Seleucid and Ptolemaic practice since the days of the Diadoch Wars. ${ }^{421}$

Livy emphasizes the size and height of the Seleucid elephant corps and notes that Antiochus deliberately enhanced the animals' height with decorative head pieces and

\footnotetext{
${ }^{420}$ Kosmin (2014), 35f.

${ }^{421}$ For a general summary, see Epplett (2007), 227-230.
} 
crests (frontalia et cristae), ${ }^{422}$ which were probably brought back from India where such adornment was common. ${ }^{423}$ Livy notes that the height especially made them terrifying to the Romans, despite their own familiarity with the elephant genus (Livy 37.40.4). The Romans drew up against Antiochus with 10,000 legionaries, 10,000 allied forces, and 3,000 of Eumenes' Pergamene troops on the left, while a combination of Roman, Italian, and ally cavalry formed up the left under the command of Domitius. The Pergamene king managed the infantry on the left (App.Syr.31; Livy 37.39). ${ }^{424}$

Although elephants were used, their role in the battle is almost insignificant, as the early fumble of the Seleucid forces sealed Antiochus' fate. The behavior of the special units involved in the first wave assault indicates that such disparate units were not often, if ever, brought together on the field of battle. The Pergamene king Eumenes sought to agitate the horses drawing the chariots in order to send them careening together or back through their own lines. Livy claims that he sent his light-armed Cretans against them and terrified both the horses and the camels, making chaos of Antiochus' charge, and in this he was successful (37.41). However, Antiochus would naturally have anticipated archers and slingers being used against his initial assault, as this is a standard use of combined forces in the Hellenistic Period.

The effectiveness of the projectile assault was certainly enhanced by the low visibility of the plain because of a heavy fog (Livy 37.38; App.Syr.33), and, I contend, by the mingling of camel and equine cavalry. Both Livy's and Appain's accounts show that

\footnotetext{
${ }^{422}$ Livy 37.40.4.

${ }^{423}$ E.g. Singh (1965), 82-83 points to descriptions of Yudhisthira's white-tusked elephant clad in gold and garlands in battle.

${ }^{424}$ The exact total of either force's troops is difficult to attain as the sources are in some disagreement. Appian claims Antiochus had a total of 70,000 men with him, but does not differentiate between cavalry and infantry, only specifying that the central phalanx amounted to 16,000 Macedonian troops. Livy attributes to Antiochus 60,000 infantry and 12,000 cavalry, or more (App.Syr.32; Livy 37.37).
} 
not only cavalry, but the Arabian knights on dromedaries were part of the initial charge, a danger which Antiochus had clearly not accounted for. As we shall see in Part II, unless otherwise trained, horses are instinctively afraid of camels and can be thrown into confusion or urged to flee by their presence. Sending Macedonian and Arabian cavalry forward together likely contributed to the chaos caused by the Roman projectile assault (Livy 37.41.1; App.Syr.34).

After the chaotic and failed initial charge (which Livy contemptuously dubs an inane ludibrium), many of the Seleucid reserve forces fled in fear, exposing much of the right wing of Antiochus' formation to the Roman sword. Livy notes that the cataphracti, or mail-clad horses, were unable to escape the swifter enemy mounts and put to the sword while the phalanx was successfully attacked. Livy notes that many fleeing Seleucid soldiers were killed inadvertently in the panic by horses, camels, and stampeding elephants retreating toward the camp (37.43.9). Even the elephants stationed with the phalanx, Livy notes, did not ultimately prove a hinderance to the Romans due to their experience with the animals in the Punic Wars (37.41.5). The Roman cavalry wounded the Seleucid elephants with darts and used swords to cut through the sinews of their legs, immobilizing them in gruesome foreshadowing of the follow up to the Treaty of Apameia (Livy 37.42).

After Antiochus III himself advanced successfully against the Roman left, demolishing it and pursuing those who fled in a long-distance rout, the Roman right advanced against the Macedonian phalanx, hampering it on all sides. Appian notes that the Roman cavalry was unable to pierce the line of sarissae, and despite its loss of support (App.Syr.35), the Seleucid infantry managed a slow retreat while maintaining 
perfect order, although constantly assaulted with projectiles. It was not until the elephants, stationed between either phalanx in twos, became fearful or unmanageable due to injury, that the phalanx formation finally collapsed and broke into flight (App. Syr. 35). Livy and Appian record a total casualty of 50,000 infantry and 3,000 horse for the Seleucid forces and notes that 15 Seleucid elephants had been captured. While these numbers, especially set against the staggeringly low Roman casualties of 300 infantry and 2400 horse, may be exaggerated (Livy 37.44), Antiochus' forces were clearly badly damaged. The 15 elephants captured are a curious addition — where were the other 39 ? They could not have followed Antiochus' cavalry in its pursuit of the Roman right, and any that fled successfully back to the Seleucid camp would have been captured, as Eumenes' horsemen overtook the camp before the end of the battle (Livy 37.43.10-11). The answer may be found in Appian's account, who notes Antiochus' shock when he returned from his long-distance pursuit of the Roman right wing and "saw the field of battle strewn with the bodies of his own men, horses, and elephants, and his camp already captured" (App.Syr.36). Exactly how many were killed is unclear, and Appian specifically notes that only some were slaughtered (Syr.36), but certainly Rome considered Antiochus' remaining elephant corps a substantial enough threat to warrant demanding the extermination of the entire corps.

The treaty of Apameia and demands of the Romans provide further evidence of the symbolic significance of the Seleucid elephant. The Romans had had little trouble with the elephants tactically, and the Seleucid infantry and navy certainly warranted greater concern than its elephant corps. And yet it was both the navy (less 12, 
App.Syr.39) and elephant corps that Rome demanded be surrendered. ${ }^{425}$ Although Livy's account only preserves the territorial cessions expected of Antiochus, and the surrender of several Greek agitators, the speech he attributes to Publius Scipio indicates that Roman interest was in curbing the power and status of Antiochus. He ends his list of demands with the dire warning: "If he [i.e. Antiochus] now causes any delay, let him consider, that it is more difficult to pull down the majesty [maiestatem] of kings from the highest to the middle stage, than it is to precipitate it from the middle to the lowest. ${ }^{\text {"26 }}$ Scipio's warning is made in keeping with the maiestas of the king, which is sharply curtailed by the proposed loss of territory West of the Taurus mountains, the royal navy, and especially the royal elephant corps, the sigil of the Seleucid house. Neither source indicates what measures were taken to ensure that Antiochus followed through with his original agreement to the treaty, and indeed elephants appear in the army of his son Antiochus IV.

\section{Elephants in the Sixth Syrian War and the Judean "Revolts"}

Antiochus IV Epiphanes deployed elephants twice in battle and once in parade, acts which ultimately caught the eye of Rome and led to the brutal enforcement of the Apameia Treaty that the Senate had made with the king's father. The elephants very clearly served as an emblem of royal authority, accompanying the king in his invasion of Egypt and assisting in the suppression of revolts within Seleucid borders. Following political instability in Ptolemaic Egypt, Antiochus IV launched the Sixth Syrian War

\footnotetext{
${ }^{425}$ App. Syr. 38; cf. Livy 37.46 who makes no mention of elephants or ships.

${ }^{426}$ Livy 37.45.18.
} 
(170-168) by invading Egypt by way of the Sinai Desert in November of $170 .{ }^{427}$ The account of this battle is lost entirely, and even the number of men and precise location is unknown. ${ }^{428}$ However, the elephant's exceptional ability to store water (a product of evolving in an ecosystem defined by wet and dry seasons) makes it quite plausible that these animals participated in the initial march. ${ }^{429}$ The First Book of Maccabees includes the detail that Antiochus invaded Egypt with chariots, elephants, cavalry, and a large fleet (1.Macc.1.17), a war party reminiscent of the fourfold army depicted on Alexander's funeral carriage over a century prior. In Egypt, Antiochus IV was victorious and proceeded with success past even Pelusium, besieging Alexandria itself and living off the chora until the intervention of Popillius Laenas and Rome forced him back into Syria (Polyb.9.27.5).

Elephants participated again in the military intervention in Judea during the era of the Maccabean Revolt, which was preceded by smaller-scale unrest. In 170/69, what amounted to a civil war in Judea fought between two local factions was perceived by the Seleucid government to be an uprising against its own suzerainty. Antiochus' response was to attack and sack the city, carting off golden temple treasure, including the golden altar. ${ }^{430}$ Because the animals symbolized Seleucid royalty and the legitimate ruling government, it is likely that they were present to respond to unrest that was perceived as

\footnotetext{
${ }^{427}$ For the Sixth Syrian War, see Grainger (2010), $291 \mathrm{ff}$.

${ }^{428}$ Cf. Porphyry 260 F 49a; Grainger (2010), 296.

${ }^{429} \mathrm{Cf}$. Sukumar (1992), 79-80 who notes that while there is no comparable data for Indian elephants, it is worth considering that African elephants have been observed living without free drinking water for 14 days when they wandered into an enclosure in Kenya by accident. While two immature elephants died on the $15^{\text {th }}$ and $17^{\text {th }}$ day, the adults survived. Ideally, where free standing water is available, elephants can drink up to 225 liters a day, but they are capable of extracting a good deal of moisture from their food or digging for it by creating small wells in the ground with their trunks.

430 1. Macc. 1.16-24; Grainger (2010), 312-313 cites a value of 1800 talents' worth of gold seized from the temple but does not provide a reference.
} 
threatening to the kingdom's stability. They were unquestionably present in the quelling of subsequent revolts.

Antiochus IV's violent attack on the temple naturally provoked distinctly antiSeleucid sentiment, which flared as Antiochus marched to the eastern half of his empire in imitation of his father, grandfather, and the dynasty's founder. But the king left instructions with his son and Lysias to bring his forces against Judea to snuff out the revolt, which Lysias did. As we have established, elephants are especially effective against troops which are unaccustomed to fighting them, as would have been the case in Judea. Attended by infantry, cavalry, scythed chariots, and 22 or 32 elephants, Lysias and Antiochus V invaded Judea and fought a battle near Beth-Zachariah. ${ }^{431}$ Although the Second Book of Maccabees claims Judean success against overwhelming forces (2.Macc 13.16), the First Book's account is the more likely which specifies that Judas' men fled in terror. ${ }^{432}$ Indeed, the role of elephants as a psychological weapon is well illustrated by the battle: each elephant carried a tower, three men, and its mahout, and the animals were stationed on the flanks of the phalanxes. General fear of the army (1.Macc.6.41, 47) and specifically fear of the elephants appears in the account of Eleazar, who rushed the lead elephant. Assuming that Antiochus V must have been riding the largest elephant because of its royal armor, Eleazar broke through the line to approach it, slid beneath the animal, and stabbed it in the belly with his spear, at which point the elephant collapsed and

\footnotetext{
4312 Macc.13.2 reports an obviously exaggerated force of 110,000 infantry and 5,300 cavalry, and 2. Macc.6.30 suggests even higher numbers of 100,000 infantry and 20,000 cavalry with 32 elephants. Comparison with Magnesia, the most recent battle about which details have survived, indicates that these numbers are implausible. Antiochus III fielded 70,000 men in total at Magnesia (App.Syr.32), and Antiochus IV would have brought at least half of his forces east with him (e.g. 1 Macc.3.34). However, the number of 22 or 32 elephants is not at all implausible, as we have seen; 1 Macc.3.34 claims that Antiochus IV left his elephants with his son and Lysias, a number which he may have acquired after his father's eastern campaigns and his own success against Ptolemy VI.

4321 Macc.6.47; cf. Grainger (2010), 316.
} 
crushed him. ${ }^{433}$

A curious nuance appears in the record of this battle, that the elephants had been given grape and mulberry juice to prepare them to fight (1 Macc.6.34). How this might have been known is unclear, but there are two possible explanations. Either the mahouts were giving elephants alcoholic beverages to set them in a rage, which would have made controlling them impossible, ${ }^{434}$ or the Judean soldiers mistook temporal gland residue for dark berry juice. Male elephants in musth excrete a dark liquid from glands along the sides of their foreheads, and it often stains the skin dark for several days. Some sexually mature females excrete small quantities as well, and animals producing this hormone often exhibit more violent behavior than normal. ${ }^{435}$ While taking an elephant into battle in such a state would be a risk, it might also explain how Eleazar was able to cut past the phalanx (1 Macc. 6.45-46) to reach the elephant in the first place. In either case, the loss of the leading elephant (2 Macc.13.15) did not result in a general retreat of the other elephants, and shortly after the retreat of the Judean army, both sides entered into negotiations.

The terms established by Judas Maccabeus and Lysias, on behalf of Antiochus V, endured until the overthrow of Antiochus by his cousin, Demetrius I Soter (r. 162-150), the son of Seleucus IV. The treaty collapsed and Judea revolted, and here we have some evidence that at least some elephants had survived. When Nicanor, the former elephantarches was sent as strategos to invade Jerusalem (2.Macc. 14.12), he brought

\footnotetext{
433 1Macc.6.43-46; cf. 2 Macc.13.15; Kosmin (2014), 2-3.

${ }^{434}$ Cf. Sukumar (1992), 79-80.

435 On musth and elephant aggression, see Sukumar (1992), 139-140; Spinage (1994), 143-145 also discusses temporal gland secretion.
} 
with him an unspecified number of elephants. ${ }^{436}$ Despite (or possibly because of) the presence of elephants, Nicanor loses the battle and perishes amid the fighting. No detailed description is given, and the animals do not appear again under Seleucid command until they are seized from Ptolemy VI in later years.

\section{Ptolemaic Elephants in Seventh Syrian War}

The Seventh Syrian War (147-145) has its roots in a Seleucid civil war between Demetrius II Nicator, son of Demetrius I, and his alleged uncle, the illegitimate son of Antiochus IV named Alexander Balas. The details of this war are not relevant here except inasmuch as Demetrius II overthrew Balas with the aid of Ptolemy VI (who had initially

allied himself to Balas by marriage) ${ }^{437}$ In turn, Ptolemy VI was able to acquire most of Coele-Syria for his assistance. Upon his death, Demetrius II quickly retook his garrisons, mistreating his soldiers, according to Josephus (AJ 13.4.9) and keeping his elephants. No record of Ptolemaic use of elephants in the Seventh Syrian War exists, but if they had marched into Coele Syria with him, he must have maintained at least some vestige of the elephant corps marshalled by his ancestors. Demetrius II's elephants were seized by supporters of Antiochus VI Dionysus, the son of Alexander Balas, where the animals had been kept at Antioch (AJ 13.5.3).

\section{Part B: Elephants as Indicators of Wealth: The Cost of an Elephant Corps}

\footnotetext{
4362 Macc.15.20; cf. Sekunda (1994), 27.

${ }^{437}$ Grainger (2010), $337 \mathrm{f}$. provides a detailed discussion of the war.
} 
Thus we have seen that the Ptolemaic and Seleucid dynasties maintained elephant corps at least as late as the 140s, but exactly when the Ptolemies stopped funding elephant hunts along the Red Sea is unknown. While a balance sheet of maintenance costs would be ideal, no such financial records exist for either dynasty, and we must restrict our questions to what the very limited sources can tell us. Fortunately, we can still reconstruct some features of ancient elephant-keeping that shed light on the financial and labor resources that were set aside for this purpose.

In light of the animals' performance throughout the first generation of Diadochs, scholars have wondered at the cost effectiveness of the animals. Glover considers their transport, training, and maintenance problematic, ${ }^{438}$ and Green expresses reasonable doubt about whether elephants "were in fact worth the time, money, and trouble expended on them" as an "increasingly highly valued arm in ancient warfare." ${ }^{439}$ This value, however, does not need to stem entirely from military performance. For example, Waterfield rightly stresses their symbolic value throughout the Diadoch Wars, because they "[served] as a potent symbol of a war leader's might" and may have "rais[ed] the morale of the men who felt secure that they had these awesome beasts on their side."440 The cost of maintaining elephants, too, had positive repercussions. While no Seleucid or Ptolemy would amass a corps equal to the size of Seleucus I's, the upkeep of any sizeable elephant stable was an impressive display of wealth, extensive resources, and power. We have already seen that the inhabitant of Apameia's stables became an

\footnotetext{
${ }^{438}$ Glover (1948), 10-11.

${ }^{439}$ Green (1990), 329.

${ }^{440}$ Waterfield (2011), 63.
} 
iconic image immortalized on Seleucid coinage, and the biodiversity of the Ptolemies' kingdom was often advertised in public parades and the pharaoh's menagerie. ${ }^{441}$ Hubbard rightly emphasized Philadelphus' and Euergetes' "zoos," pointing out that both pharaohs were eager to display the products of their extensive realm. One supposes that the elephant appeared rather commonplace next to the "imposing list of specimens" 442 found in the procession of Philadelphus and the 14 cubit pythons he kept on display in the capital. ${ }^{443}$ By the end of the Diadoch Wars, elephants were no longer entirely foreign, but had become associated with Hellenistic kingship, and in particular with these two dynasties. Maintaining what might have been the ancient world's most costly weapon was not merely insurance against the enemy, but a statement of success.

\section{The Ptolemaic Elephant Hunting Program}

Philadelphus began an extensive elephant hunting and training program early in his reign and immediately following the end of the First Syrian War. ${ }^{444}$ This was likely done to expand on his father's elephant corps and likely to correct the effects of natural wastage, given elephants' limited interest in reproducing in captivity. ${ }^{445}$ However, it is useful to understand Ptolemy's elephant hunting program not only in the context of practical acquisition, but of competitive development, a key characteristic of the inter-

\footnotetext{
441 The long list of exotic animals on parade in Alexandria under Philadelphus has been preserved by Athenaeus. See Athen.200c-201b; Rice (1983).

442 Hubbell (1935), 74.

${ }^{443}$ Ael.HA 16.39 .

${ }^{444}$ For the hunting program in general see Casson (1993) and his bibliography for the historiography of the hunting program, esp. n.1.

445 The elephant does not reproduce quickly even in ideal settings in the wild due to long gestation and nursing periods and a comparatively late onset of sexual maturity, meaning elephant cows will reproduce at most once every 3-5 years. As Spinage has noted, elephants in captivity have less success reproducing, often due to the stressful environment and overwork by mahouts. Cf. Spinage (1994), 79-92.
} 
war period between the First and Second Syrian Wars. ${ }^{446}$ Both kings were invested in expansion, and it is well known that the Ptolemaic fleet was especially active in the Black Sea region, Greece during the Chremonidean War (267-261), Palestine, ${ }^{447}$ and, importantly for us, the Red Sea region.

While Antiochus I and II maintained inroads into India, Philadelphus had to locate a new source of elephants, which he eventually found along the Erythraean coast in modern day Eritrea and Somalia. Here Philadelphus also found a new elephant. The loxodonta Africana cyclotis, or the African forest elephant, is the smallest elephant species and has physiological differences from its Indian counterpart. Shorter in height and width, the forest elephant a concave, not convex, back, and has larger ears which facilitate cooling in hot, arid environments, where it was likely to be captured. The loxodonta Africana Africana, or the African bush elephant, is the largest land mammal on the planet and lived too deep in Africa's interior for the Ptolemies to make steady prey out of it. Indeed whether the Greek-speaking world was aware of its existence is unclear, but this elephant was not hunted by the Ptolemies. ${ }^{448}$ Shorter stature aside, the African forest elephant had an asset that Antiochus' Indian elephants lacked—-both sexes of the forest elephant grow tusks, whereas the female Indian elephant cannot. Given the implausibility that Seleucus only acquired and fought with male (i.e. tusked) elephants in battle, roughly half of his corps would be untusked, fighting primarily with trunk, skull, and feet. Philadelphus' advantage could be considerable.

By the time of Ptolemy I, Egyptian hegemony did not extend further up the Nile

\footnotetext{
446 Grainger (2010), 89-115.

${ }^{447}$ For the interwar period see Grainger (2010), 89-100.

${ }^{448}$ Cf. Scullard (1974), 60-63; Casson (1993), 248.
} 
than Meroe, a kingdom that lies north of Khartoum. The significance of the forest elephant to the culture of Meroe and to kingship status is archaeologically well documented, ${ }^{449}$ and it is unsurprising that the Ptolemies turned to this elephant-revering culture as a potential source of elephants. Very little is known of Ptolemy I's forays along the Erythraean coastline, although Pliny mentions that the Isle of Topaz was at least on Ptolemy's radar, as his wife Berenice was the first queen to import topaz gems. ${ }^{450}$ It was Philadelphus who used military force, garrisons, hunting lodges, dikes, and laborious canal building to occupy and hold this territory. ${ }^{451}$ The details of his Ethiopian campaign are lost, but fragments of Aghatharcides' On the Erythraean Sea are preserved in Strabo and Diodorus and offer glimpses into Ptolemaic activity. ${ }^{452}$

The exact dates at which various dikes and garrisons were constructed are not known (with a few exceptions), but the Ptolemies did not venture into Somalia until the elephant population of Eritrea's and Ethiopia's coastlines began to decline. Philadelphus' first foundation, Philotera, rests on the north-west shore of the Erythraean Sea and was named for his sister, according to Strabo (16.4.5). Strabo also notes that a certain Satyros founded Philotera after he "had been sent for the purpose of investigating the Troglodytic country and the hunting of elephants." ${ }^{\prime 43}$ What the exact perimeters of "Troglodytic country" constituted are unclear, as Strabo also tells us that the Troglodytes were nomadic (16.4.17). However, Troglodytic country implied further into the African interior than the settlements of the Red Sea Coast, which Casson estimates included

\footnotetext{
${ }^{449}$ Cf. Ibid., 126-127, pl. 8a.

${ }^{450}$ Pliny NH 37.108; Mueller (2006), 151.

${ }^{451}$ For Philadelphus' settlements on the Erythraean coast, see Preaux (YEAR), 360f.

452 See Scullard (1974), 126-127.

${ }^{453}$ Strabo 16.4.5; as Casson (1993), 249 points out, both Philadelphus and Euergetes are said to have captured "Troglodytic" elephants for military purposes. Cf. OGIS 54.
} 
Meroe or territories within Ethiopia that fell under Meroetic control. ${ }^{454}$ In their territory, the city Berenice "Trogolodytica" was founded around the same time, its harbor being the primary Ptolemaic harbor on the Erythraean Sea. South of that, a certain Eumedes founded Ptolemais Theron under the orders of Philadelphus, a risky task. Strabo emphasizes the military nature of these expeditions when he notes that Eumedes began his construction work in secret, enclosing a peninsula and fortifying it against attacks from the locals, whom he won over quickly through keen diplomacy (Strabo 16.4.7).

Elephant hunting grounds must have been established with the aid (willing or otherwise) of locals who had perfected the science of the hunt. Therefore, it is unsurprising that elephant hunting grounds, even if they hold native names, appear close to Greco-Macedonian stopping points. For example, near the Isle of Straton (off the coast of Eritrea), Strabo reports a hunting ground called Saba whose exact location is unknown, ${ }^{455}$ and a series of hunting grounds can be found south of the Harbor of Eumenes (Strabo 16.4.13) on the Ethiopian shore. These were managed by the Ichthyophagi and the Creophagi and the Colobi, about whom Strabo goes on at length, suggesting Ptolemaic exploration ultimately led to cooperation in the elephant hunt. Further south, later Ptolemaic settlements dating to the reign of Ptolemy IV Philopator can be found. These include the hunting grounds of Pythangelus and those of Lichas as well as the city Arsinoe, which was not a hunting ground but a major settlement, which Strabo emphasizes has a harbor. ${ }^{456}$ Additional settlements down through the reign of

\footnotetext{
${ }^{454}$ Casson (1993), 249 n. 6 provides a good bibliography of Meroetic elephant art and discussion.

${ }^{455}$ Strabo 16.4.8; Scullard (1974) makes no reference to it on his map, fig. 13 p. 129.

456 Strabo 16.4.14; Lichas may be dated by the inscription OGIS 82.
} 
Ptolemy IV Philometor indicate continued elephant hunting. ${ }^{457}$ Mueller's survey of these locations leads her to conclude, in agreement with Casson and Burstein, that locations increasingly further south indicate steady erosion of elephant populations due to Ptolemaic overhunting. ${ }^{458}$

Although Strabo specifically explains the foundation of Philotera in terms of elephant hunting, modern historians have extrapolated other explanations. For example, Preaux's exhaustive study of the Ptolemaic economy characterizes the hunt for elephants as "un simple caprice d'amateur d'animaux," ${ }^{459}$ but the level of planning and investment that this study reveals suggests more thoughtful intentions on the Ptolemies' part. Mueller doubts that the many foundations along the Eritrean and Ethiopian coasts were merely byproducts of an elephant hunting program and argues for the reverse. She proposes that the primary objective of Ptolemaic expansion was exploratory, with elephant acquisition as a fortuitous byproduct. Mueller argues that Philadelphus sought the expansion of geographic knowledge that would allow him to follow in the adventurous footsteps of Alexander, finding, learning about, and conquering unknown lands. Exploration initiatives, Mueller explains, "provided the ground for new settlement and for the permanent presence of Ptolemaic rule." ${ }^{460}$ There is no reason why this explanation must conflict with Strabo's - exploration could easily have prompted a more intensive, costly settlement program geared toward providing Ptolemaic Egypt with elephants.

Mueller's answer seems compatible with Grainger's explanation, which takes

\footnotetext{
${ }^{457}$ Mueller (2006), 154-155 and table 4.1 for a list of all geographic locations where elephant hunters are reported.

${ }^{458}$ Casson (1993), 256-271; Burstein (1996). 806.

${ }^{459}$ Préaux (1935), 35.

${ }^{460}$ Mueller (2006), 156; cf. 155-157.
} 
account of the broader historical context of Philadelphus' initiative. Grainger notes that perhaps due to Philadelphus' experiences in the First Syrian War, "he undertook three complementary tasks: the expansion of his navy...the foundation of new cities and the fortification of old cities... a series of elephant hunt expeditions and the transportation of the captured animals...to Egypt," ${ }^{461}$ which required massive construction efforts, as we shall see. It is the expense which Philadelphus and his successors were willing to take on that is of interest here, and there is abundant evidence that the elephants were of singular importance given the investment in their capture, transport, and training. That utility, in a period of cold war and competitive development, need not be primarily tactical. From the 270s forward, we know that Philadelphus invested considerable labor and wealth in the creation of a canal linking the Nile and the Red Sea, and a major road that cut across the Eastern Desert and linked the harbor of Berenice Troglodytica to Coptus. Later Ptolemies continued to found garrisoned settlements in elephant-rich territories that were increasingly interlinked to facilitate the capture and transport of the animals by sea and by land.

Philadelphus was especially active along the Erythraean coast. ${ }^{462} \mathrm{He}$ was the first to complete a canal linking the Red Sea and the Nile, complete with a lock to prevent the latter from flooding. At the mouth of the river flowing through the lock he founded the city of Arsinoe. ${ }^{463}$ Herodotus and Diodorus both reference earlier attempts at linking the two bodies of water by Egyptian Pharaohs and Darius I of Persia, and Diodorus notes that

\footnotetext{
461 Grainger (2010), 101.

462 See Mueller (2006), 151-157.

463 Strabo 16.4.7; Mueller (2006), 152. A translation of the Pithom Stele, which records Philadelphus' activity from c. 270-264, is reproduced in Mueller (2006), appendix II. 192-199.
} 
Philadelphus was the first to do it. ${ }^{464}$ While the canal had myriad uses and undoubtedly helped stimulate trade with Arabia, it could also have facilitated the transport of elephants by sea. The predominantly coastal locations of the hunting sites referenced above indicate that all elephants made at least part of their journey to Lower Egypt by water.

We know, for example, that the port of Berenice Troglodytica accepted many elephant-laden ships into its port, an arduous journey for the animals. ${ }^{465}$ A reference to elephantegoi (elephant transport ships) at Berenice Troglodytica appears in a letter from the reign of Ptolemy III Euergetes and can be dated specifically to $224 .{ }^{466}$ In the letter a certain Manres son of Nectanebo, stationed at Berenice Troglodytica, addresses elephant hunters at a garrison post further south in order to reassure them that grain provisions were still coming, but a new ship had had to be built following the wreck of the previous one. ${ }^{467}$ As Scullard and Preaux note, ${ }^{468}$ this tells us that ships traveling between Berenice Troglodytica - the primary Ptolemaic port of the Red Sea-and other garrison points carried elephants to Berenice Troglodytica and brought back grain to supply the soldiers and elephant hunters in other locations. ${ }^{469}$ Because Manres' letter also specifies that new ships had been constructed at Berenice Troglodytica, we know that the settlement also

\footnotetext{
${ }^{464}$ Hdt. 2.158 says Nechos (II) of Egypt attempted it but stopped because of an oracle, and he notes that Darius I completed excavation but for whatever reason did not progress further. See also Hdt. 4.39.1. Diod. 1.33.9-12 calls Nechos II "Necho" but otherwise agrees, adding that Philadelphus completed the work. The Pithom Stele honors the completion of the canal. For discussion see Préaux (1935), 56-57.

${ }^{465}$ Casson (1993), 257-259.

${ }^{466}$ Papyri Petrie II 40(a), in Wilcken Chrestomathie no. 452. See Scullard (1974), 131-133 ; Preaux (1939), 35; Mueller (2006), 152-153.

${ }^{467}$ Cf. Mueller (2006), 152-153.

${ }^{468}$ Scullard (1974), 132 ;Préaux (1935), 35.

${ }^{469}$ Casson (1993), 254 has since noted that this does not appear to have been the case in every elephant hunting port. His work emphasizes how the Pithom stele presents evidence of farming by soldiers, perhaps Greek emigrants and cleruchs, in the elephant hunt locations. For these garrison and hunting posts to have been self-sustaining would have alleviated a great deal of pressure from the elephantagoi ships.
} 
possessed a ship yard. ${ }^{470}$ Scullard suggests further that elephant transport ships were of a unique design, distinct from vessels meant to transport goods or troops. ${ }^{471}$ He points to Diodorus (3.40.3), who notes that shipwrecks along the Ethiopian coast were common for elephant transports because of how low they ride in the shallow, seaweed-clogged seas of the coast and because of their reliance on the wind, rather than rowing power, which made them difficult to maneuver in poor weather. Casson concurs and notes that while the lack of galleys would provide additional space, the hulls would need to be reinforced in order to support considerably greater weight. ${ }^{472}$ Specialized vessels would indicate Ptolemaic investment in product development and testing and perhaps the presence of specially trained ship builders at Berenice Troglodytica. This is consistent with Ptolemaic patronage of architects, physicists, and inventors at Alexandria, ${ }^{473}$ and it is once again indicative of the crown's interest in acquiring elephants at any cost.

After reaching land at Berenice Troglodytica, however, elephants made a presumably safer journey by land to Coptus in the Nile Valley along a major roadway constructed by Philadelphus. There is some confusion about the length of the road and varying routes, but both Strabo and Pliny mention a path connecting Berenice Troglodytica to Coptus which contained watering holes along the way that, according to Pliny, could provide water for around 2,000 people. ${ }^{474}$ This would have facilitated the travel of larger groups, whereas in the past only camel trains had been able to pass

\footnotetext{
${ }^{470}$ However, Strabo 17.1.45 specifically notes that Berenice Troglodytica has no harbor, but many convenient landing places. One wonders where the shipyard was located.

${ }^{471}$ Scullard (1974), 131.

${ }^{472}$ Casson (1993), 253-254.

${ }^{473}$ Préaux (1935), 56-57; Worthington (2016), 139-144.

${ }^{474}$ Strabo 17.1.45; Pliny NH 6.26. Strabo gives a travel time of six to seven days, while Pliny says twelve. Both reference watering holes, and Pliny elaborates that a path between Myus Hormus, which lies north of Berenice Troglodytica, and the Nile Valley also existed. As the Loeb commentator notes, Strabo inexplicably describes Myus Hormus and Berenice as though they are close together.
} 
through (Pliny NH 6.26). Indeed by Strabo's day, he reports that all merchandise coming into Egypt from India, Arabia, and Ethiopia travels along this path to Coptus, indicating that perhaps some of the watering holes had been expanded for heavy traffic since. The initial construction, effected by Ptolemaic soldiers (Strabo 17.1.45), must have served as a pathway for elephants for at least a generation, as it is clear they were being imported to Berenice Troglodytica in the late third century.

Thus, although we lack the detailed budgets of these projects, Preaux urges her readers to wonder at what these projects must have cost (56). Indeed the canal would have presented Philadelphus' men with a harrowing task; Herodotus reports that 120,000 of Pharaoh Nechos II's men died in its construction (Hdt. 2.158.5), and even the improved technology of the third century would not have eliminated risk or cost. If facilitation of trade with the East had been the primary motivation, Philadelphus must have been disappointed. Preaux notes that "l'effort n'est, du reste, pas récompensé d'un succès inmédiate, ${ }^{475}$ even though ultimately the Ptolemies gained the upper hand in the aromatics market. While such successes would have helped mediate the extreme costs of canals, roadways, and specialized transport vessels, ultimately funding had to come from taxes. Philadelphus would have been at pains to increase taxes and increase GrecoMacedonian immigration to Egypt as cleruchs in order to install them in newly founded cities and use their labor (military and domestic) in exchange for land, the one thing Philadelphus had in abundance. ${ }^{476}$ Naturally, these Greeks and Macedonians also paid taxes. ${ }^{477}$ Philadelphus pushed the expansion of Egypt's already well-developed economic

\footnotetext{
475 Préaux (1935), 361; Grainger (2010), 102.

476 Grainger (2010), 102-103.

${ }^{477}$ For the collection of taxes in general in Ptolemaic Egypt, Grainger (2010), 102-104 provides a brief synopsis and lengthy bibliography after the reforms of Philadelphus. See especially Préaux (1935);
} 
bureaucracy in order to make tax collection more efficient and monopolize the region's wealthiest resources in the name of the pharaoh. This "wealth collection program" 478 must nonetheless have pushed the Egyptian budget given the cost of increasing a navy and developing an elephant hunting, training, and transport system.

It should be remembered that elephant hunting settlements required not only the transport of hunters, but also of builders. Training and holding facilities for elephants and dwellings for trainers, soldiers, hunters, ship builders, and of course the craftsmen themselves, would have to be constructed quickly. Graffiti in Apollonopolis (Edfu) in the Nile Valley, which Bernand dates to the reign of Philadelphus, testifies to the presence of carpenters. ${ }^{479}$ One inscription preserves the words of a $\tau \dot{\varepsilon} \kappa \tau \omega \nu$ named Dorion, who writes that he survived the elephant hunt, which must have been a harrowing journey. Dorion employs the passive of soteo as a verb of motion, claiming that he was "saved back to

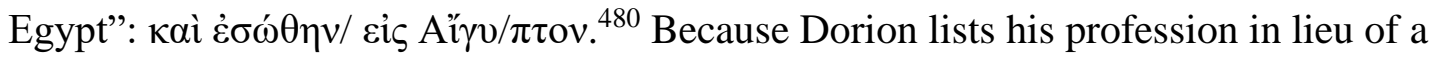
patronymic, this appears to have been his primary role in the hunt. Likely he helped to build the settlement housing at the location of the hunting grounds. ${ }^{481}$

Further evidence of the significance of the elephant hunt comes from the hunters themselves, most if not all of whom were soldiers. Elephant-hunting settlements like Philotera, Berenice Troglodytica, and Ptolemais Theron required military expertise to maintain a garrison and hunting grounds against local resistance as well as to capture elephants. This was a novel and risky process in which neither Macedonians nor

Worthington (2016) notes that almost everything known of the Ptolemaic economy comes from the reign of Philadelphus, see pp. 192-197, esp. n. 38 and bibliography.

${ }^{478}$ Grainger (2010), 104

${ }^{479}$ Casson (1993), 254.

${ }^{480}$ Ibid.

${ }^{481}$ Bernand (1972), 9 b. 
indigenous peoples were skilled. Macedonians had previously purchased their elephants, and native peoples hunted the animals to eat, not to capture, train, and ride. ${ }^{482}$ A clear indicator of the expense of the elephant acquisition initiative is the rate of pay provided for a large number of soldiers and elephant hunters. Although only a few examples remain, they provide sufficient context for extrapolation.

Preaux's study reveals the high cost of elephant-hunting soldiers and the status of their strategoi. A papyrus records the payment of a troupe of elephant hunters, dispensed in silver from Apollonopolis nome in Upper Egypt in a quantity of two talents for 231 soldiers under the command of a certain Peitholaus. ${ }^{483}$ Préaux breaks down their three month pay of two talents to show that each man earned a balance of 1,860 drachmae, or 4 obols a day, which she equates to "le traitement d'un scribe de rang élevé ou celui d'un officier qui sert en Egypte;" 484 Casson calls the sum "princely." ${ }^{485}$ And even so, payment to soldiers was only a small part of the overall costs, which included transportation, food for the elephants and soldiers, arms, and then months of Indian trainers' time. ${ }^{486}$ Préaux uses the extant balance sheet of the nome Arsinoe to illustrate how tight the Ptolemaic budget was in some places, especially when juxtaposed to the cost of manning a single elephant expedition. The papyrus preserving the balance sheet of that nome shows an income of 11 talents and 1102 drachmae and expenses that total 9 talents and 5990 drachmae (much of which went to canal maintenance), leaving less than the required two talents to pay the soldiers of an elephant expedition. ${ }^{487}$ While Arsinoe does not

\footnotetext{
${ }^{482}$ Casson (1993), 249-250; cf. Scullard (1974), 126-133, whose discussion of Meroe indicates that Meroeans may have learned the technique and eventually replaced Indian mahouts.

${ }^{483}$ P.Eleph. 28 = Chrest. Wilck. (1912), no. 451.

${ }^{484}$ Préaux (1935), 36.

485 Casson (1993), 253.

486 Préaux (1935), 36; Casson (1993), 253-254.

${ }^{487}$ Préaux (1935), 36-37 citing the Tebtynis Papyrus 701.
} 
necessarily represent the wealthiest or largest Egyptian nome, it serves nonetheless as a good example of limited Ptolemaic resources and the significance of such a high rate of pay for elephant hunting soldiers.

Indeed, the strategoi in charge of the expeditions appear to have commanded a great deal of respect, and some of them are recorded in dedicatory inscriptions from the reign of Ptolemy IV Philopator. This has led Casson to argue that it was elephants' military function that made them desirable, as they were being acquired and managed by the army. ${ }^{488}$ While the title strategos is only explicitly given to men under Philopator, Casson supposes the list of elephant wranglers under Philadelphus (Strabo 16.769) also included strategoi. This seems likely, but the stress on elephants' links to combat because of the profession of the elephant hunters is not as clear-cut. Among the Greeks and Macedonians, soldiers would have been the only individuals with any experience with elephants - there would be no alternative professionals to send out. Furthermore, these soldiers were hunters and transporters - trainers and elephant riders would have been Indian, not Macedonian, and their particular skill-set would not have been put at risk in the dangers of a hunt. Furthermore, soldiers would have been necessary for the protection of the new settlement. As mentioned above, local resistance to colonization required a defense plan.

The prestige of the elephant as an emblem does appear to have transferred to the strategoi involved in their capture. The status of elephant hunters is reflected in the inscriptions they established in their own (and the Ptolemies') honor at the location of the elephant hunt. ${ }^{489}$ Unfortunately most extant inscriptions date to the late third century and

488 Casson (1993), 252.

${ }^{489}$ Scullard (1974), 136. 
the reign of Philopator (excepting the graffiti of Dorion, above), but they are significant in that they reveal that the elephant hunt was continued through at least four generations of Ptolemies and that those involved gained status by association. A certain Lichas of Acarnania not only erected a commemorative stele for himself, but had an Ethiopian elephant hunting ground named for him. ${ }^{490}$ The stele comes from Apollonopolis (Edfu) in the Nile Valley, and dates to c. 217-208 (OGIS 82). It reads:

$1 \quad \beta \alpha \sigma \imath \lambda \varepsilon \tilde{\imath} \Pi \tau \sigma \lambda \varepsilon \mu \alpha i ́ \omega \imath$

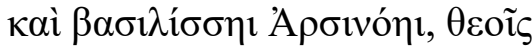

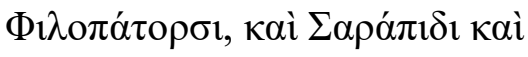

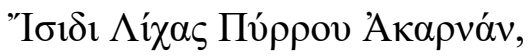

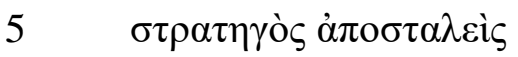

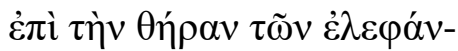

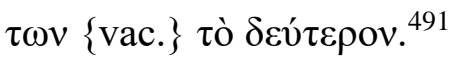

To King Ptolemy

And Queen Arsinoe, the

Father-loving gods, and to Sarapis and To Isis, [by] Lichas, son of Pyrrhus the Acharnanian

Who was sent as strategos

To the elephant hunt

For the second time.

The text suggests that Lichas' veteran status as a commander of the elephant hunt was noteworthy, and the location is unsurprising. A variety of graffiti has been preserved from Apollonopolis, a popular location to pass through for those en route to Egypt from the south, as noted in the case of Dorion the carpenter above (p.181). ${ }^{492}$

An inscription somewhat similar to that of Lichas is $O G I S$ 86, a dedication by an Alexander of Oroanda, son of Syndaios. The provenance of the inscription is now unknown, but its contents are preserved. Bernand dates the inscription to c.210-204,

\footnotetext{
${ }^{490}$ Strabo 16.773; Scullard (1974), fig. 13 p. 129.

491 The text is reproduced from Dittenberger (1903-1005) OGIS 82. The translation to the right is my own.

492 Further information regarding the inscriptions and graffiti may be found in Bernand (1972) and Mairs (2010).
} 
under the reign of Philopator because of the dedicatory opening, which honors a Ptolemy

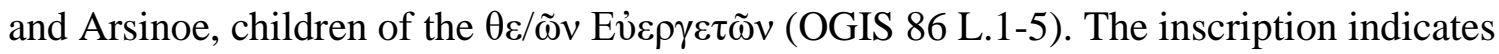

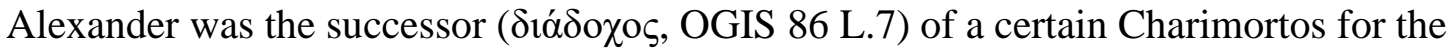
position of strategos of the elephant hunt. ${ }^{493}$ Strabo mentions a Charimortus in the context of geographical markers on the Erythraean coast above Somalia in a land which

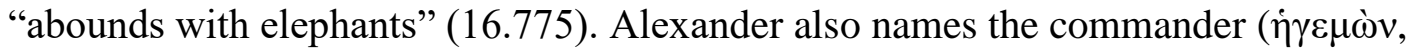
OGIS 86 L.11) of his men, Apoasis of Etenna, the son of Miorbollos. The inscription is

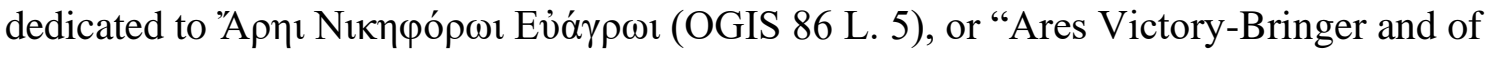
the good hunt," a title which draws a god from the traditional pantheon into the realm of elephants, not unlike the coins of Seleucus I, who portrayed Athena and Artemis both on elephant-drawn chariots (see above pp. 137-138).

How successful these elephant hunts were remains an open question, as the ancient sources report a number anywhere from 300-500 elephants in the corps of Philadelphus. ${ }^{494}$ These numbers seem impossibly large for a system of elephant acquisition and training that was not even a generation old. Seleucus had acquired as many as a gift from the Mauryan dynasty in India, where the skill set and system of elephant hunting and training had existed for centuries. ${ }^{495}$

The limited number of elephants that could be collected, trained, and harnessed for war by the state has prompted some scholars to see the hunting grounds as a location for collecting not only war elephants, but ivory. This would have significantly offset the

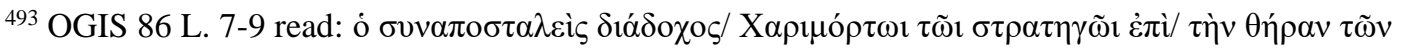
غ̇ं $\varepsilon \varphi \alpha ́ v \tau \omega \nu$

${ }^{494}$ Appian (Praef.10) claims PtoII had 300 elephants, Jerome's commentary on the Book of Daniel (11.6) and Porphyrius (FGrH 260 F 42) claim he had 400, and 3 Maccabees (5.2) says he had 500.

${ }^{495}$ E.g. Fischer-Bovet (2014), 154 finds the number an exaggeration, as does Burstein (1996), 802; Scullard (1974), 133 thinks it unlikely based on the number of elephants described in the Grand Procession.
} 
extreme costs of the expeditions.

Burstein, for example, sees Ptolemaic expansion further south along the Erythraean coast as an example of a search for more ivory, not simply more war elephants. He does not believe that the majority of herds along the latitudes of the northern Red Sea could have been captured at a faster rate than elephant reproduction all within the confines of a century. ${ }^{496}$ Further, Burstein points to the Battle of Raphia (see pp.154-157), at which Philopator could only field 73 elephants to Antiochus III's 102, an indication of the scale and success of the elephant hunt and training program at the end of the third century. Burstein reasons that only a relatively small number of elephants must have been captured each year if 73 was the most that Philopator could field in a moment of crisis that was the Fourth Syrian War. And yet Ptolemaic hunting grounds pushed increasingly farther south and into Somalia, indicative of a rapid decline in the elephant population. The few war elephants acquired by the Ptolemies are not sufficient explanation for this expansion, and Burstein argues that "another factor must have been involved, and there is one obvious candidate: ivory." ${ }^{297}$ Pointing to the 600 ivory tusks on display at the Grand Procession the papyrological evidence of an ivory tax in Elephantine, and fragments of a payment letter to soldiers who participated in the elephant hunt that makes reference specifically to tusks, Burstein recognizes that the tusks on display at Alexandria may be the product of many years of gift exchange, and from Ethiopian gift-bearers, not directly acquired by Greek elephant hunters. Nevertheless, he rightly highlights the clear evidence of an ancient ivory trade. ${ }^{498}$

\footnotetext{
${ }^{496}$ Burstein (1996), 802.

${ }^{497}$ Ibid.

${ }^{498}$ Ibid., 804-806; cf. Athen. 201A; P. Petrie III 114.
} 
However, the level of decimation to the elephant population of North-Eastern Africa is nowhere attested and cannot easily be guessed at. Further, the southward movement of Ptolemaic settlements attests more to the Greek preference to settle and travel on the coastlines than any indication that the dense African interior had been penetrated and stripped of elephants. Nonetheless, Burstein's argument shows the possibility of dual motivation of Ptolemaic elephant acquisition and offers an appealing theory as to how several generations of kings funded the costly hunts.

\section{Seleucid Elephant Trade}

There is less evidence for the Seleucid supply and maintenance costs of elephants, but because the Seleucids purchased rather than hunted their elephants, the costs must have been lower than the Ptolemies'. However, Seleucid access to elephants depended on solid diplomatic relations with the Mauryan dynasty of India. An examination of Seleucid elephant corps numbers, inasmuch as the sources permit, will offer a sense of the relative ease or difficulty with which elephants were obtained. Even though obtaining Indian elephants may have been easier for the Seleucids than the Ptolemies, maintaining them, as we shall see, was still a powerful advertisement of wealth.

The initial Seleucid elephant corps was obtained directly from India, with the first installment in the number of $500,{ }^{499}$ the product of an exchange with Chandragupta

\footnotetext{
499 The number of elephants Seleucus acquired and brought to Ipsus has often been scrutinized by modern historians, but the ancient sources are in general agreement of a range of 400-500. Strabo 15.2.9 and 16.2.10 specify that 500 were given by Chandragupta and kept in the stables at Apameia; 480: Diod. 20.113.5 describes 480 elephants deployed by Seleucus at Ipsus, suggestive that perhaps 20 were deemed unfit for battle or died on the return march from India; Plut.Demetr.28.6 specifies 400. Grainger (1990) supports the number, unimpressed by attempts to explain it away as a stock number used by Indians to mean 'a lot' (Cf. Tarn [1940], 84.) as this would not explain why Greek writers would use it. Instead,
} 
Maurya (Sandrocottus) (r.322-298), in return for Seleucus' cession of tenuously held Macedonian territory in the Punjab. ${ }^{500}$ Kosmin has drawn together the basic tenets of the peace terms between Chandragupta and Seleucus to emphasize that it was meant to be a lasting peace that firmly demarcated the boundaries of the Seleucid state. He also argues convincingly that the treaty ensured friendly relations with the Mauryan dynasty in the future and suggests "the land-for-elephants agreement was reperformed as regular, ceremonial gift-giving, exchanges that generated solidarity and renewed equality of rank...rather than functioning as unidirectional signs of subservience, as in Persepolitan imperialism." ${ }^{501}$ Kosmin gives some examples of the sort of gifts that were exchanged between the Seleucids and Maruyans, but figs and sweet wines could not possibly have compensated for gifts of elephants; ${ }^{502}$ it seems reasonable that good diplomacy kept trade routes between the dynasties open in addition to an exchange of gifts, and later Seleucids were thus able to purchase their elephants.

Whatever the elephants' cost, their maintenance would have cost more. Seleucus wisely turned this expense into an advantage by advertising the number of his elephants and the abundant and fertile land used to maintain them. Unfortunately, only one site of Seleucid elephant stables is known, in Apameia. ${ }^{503}$ Seleucus built up from the small settlement of Pella, Syria a grand military complex of which the elephant corps must

Grainger convincingly defends the number (1990 pp. 109-111). Because elephants once roamed much of the Asian continent, the meagre remaining population of a severely endangered animal need not reflect similarly small populations in antiquity, when elephant hunting was less efficient and widespread. On the population of the Asian elephant see Spinage (1994), 33-38; Sukumar (1992), 10-31.

500 Just.15.4; App.Syr.55; Strabo 15.2.9; discussion: Kosmin (2014), 31-37; Grainger (1990), 108-111.

${ }^{501}$ Kosmin (2014), 35; see in general 32-37.

502 Ibid., 35.

${ }^{503}$ Cf. Epplett (2007), 225-226 for conjecture regarding later elephant stables at Bactra. In general on Apameia-on-Axios and in the Valley of Orontes see Grainger (1990), 126-127, Kosmin (2014), 108-109, and a general history of the Tetrapolis, of which Apameia was a part, see Engels (2017), 409ff.; on Ptolemy’s elephant hunting settlements see Scullard (1974), 126-133 and Mueller (2006), 151-157. 
have been the crown jewel. Named for his wife, this was the city of Apameia, which bordered the Orontes River and contained an abundant sprawl of rich pasture land, a lake, and marshy wetlands. Atop a naturally formed hill, Seleucus established the acropolis, which Strabo specifies was partially hidden within a hollow plain (16.2.10). Coele-Syria is contained by a series of parallel mountain ranges which run north and south interrupted by breaks and river valleys but generally prohibiting easy movement between east and west. Movement from the north to the south between the mountains is, however, relatively easy, making the territory a clear bone of contention between the Ptolemies and Seleucids. ${ }^{504}$ The elephant city of Apameia faced south, "the main base of the dynasty in the region, a standing defense against Ptolemaic attack, and a standing menace of a Seleukid invasion." ${ }^{" 505}$

Because Apameia rested in the northern half of Coele-Syria, the rich territory disputed by generations of Seleucids and Ptolemies, it was less economically and bureaucratically developed, but had better access to rich arable land. Grainger notes that northern Coele-Syria had been deurbanized since the campaigns of the Assyrians. ${ }^{506}$ The pastureland is of the utmost importance in the maintenance of elephants, who could easily subsist on a diet made primarily of grass and supplemented in small part by other forage, whether grains, leaves, or fruits. Aristotle provides an estimate of elephant intake requirements, noting that the elephant can eat no more than nine Macedonian medimni (360 kg) of fodder in one setting, but this is unhealthy for the animal. Generally he claims that it takes six to seven medimni of fodder (240-280kg), five of wheat (200kg), fourteen

\footnotetext{
${ }^{504}$ Grainger (2010), 5-7.

505 Ibid., 57.

${ }^{506}$ Ibid., 41-51; Strabo 16.2.10 does note that there are several dependent towns in the area.
} 
metretae of water at one time, and five mareis of wine! ${ }^{507}$ While elephants can and do become intoxicated in the wild by consuming fermented organic material or getting into alcoholic vats in cultivated regions, why Aristotle would consider this advisable is never made clear. ${ }^{508}$

Aristotle's estimation of elephant consumption is a good one, although it remains a generalization. Sukumar's detailed studies of the Indian elephant show that in general an elephant can consume between $1.5 \%$ and $1.9 \%$ of its body weight in a 12 hour period of feeding. The only exception to this is in the case where elephants consume food from cultivated fields, where ripe forage is available in a condensed space and requires little effort to acquire. In this case, an elephant may consume between $1.5 \%$ of its body weight in only six to seven hours. ${ }^{509}$ The quantity of food which an individual elephant requires is impossible to measure specifically in the cases of Seleucid elephants, as too many variables remain unclear. The weight of an elephant, the type and quality of the forage, and the season would all impact the day to day intake of the animal. For example, a nursing elephant cow would require more than her non-nursing counterpart, and the weight of the foliage consumed would depend on whether it was eaten in wet or dry season.

However, Sukumar's study of elephant consumption of grass in both seasons

\footnotetext{
507 Arist. HA 8.9. Estimates of medimni weight are drawn from the Athenian medimnos, which is equated to $40 \mathrm{~kg}$ in weight See Oliver (2007), $124 \mathrm{n}$. 70. Smith (1875), 762 notes that the Attic metretes is equivalent to a bit less than 9 liters. While some have doubted an equivalent Macedonian measure because of this very passage of Aristotle, which would imply elephants can consume over 120 liters of water at once, Smith does not see a problem with this. Indeed, it may be possible, as Sukumar reports Asian elephants consuming more than 100 liters in one watering and over 225 liters in a single day (1992), 79.

${ }^{508}$ Sukumar (1992), 79-80 provides the amusing anecdote of elephants getting into illegal breweries and downing gallons of palm toddies before going on drunken rampages through the forests. Certainly elephant trainers would not have provided elephants with such a drink at a military base.

${ }^{509}$ Ibid., 78-79.
} 
provides a rough estimate that can be applied to Seleucus' elephants. In the dry season, elephants consumed $33.6 \mathrm{~kg}$ in 12 hours, and in the wet season, $44.4 \mathrm{~kg}$. This is a great deal less than the staggering total of $740 \mathrm{~kg}$ of total food suggested by Aristotle. Even higher daily consumption estimates only range from 150-300 $\mathrm{kg}$ of fresh weight. While Sukumar does acknowledge that "it is also possible that estimates of feeding on grass alone cannot be extrapolated to the entire diet, ${ }^{, 510}$ such observation is sufficient to cast Aristotle's assumptions into question. The quantity Aristotle estimates elephants require per day is a staggering 16 times what Sukumar has observed Indian elephants consuming in the wild during the peak of the rainy season. ${ }^{511}$

As Sukumar's study has shown, Indian elephants are both grazers and browsers and can adjust their diet depending on available plant life, a shift which naturally occurs with the change between wet and dry seasons in India. ${ }^{512}$ Indeed, a sub-species of the Indian elephant, the Sri Lankan elephant, relies almost exclusively on grass for food. ${ }^{513}$ Although the image of elephant trunks being used to browse lofty branches is a common one, they very often rely on the sensitive and highly dexterous tips of their trunks to pluck up young shoots of grass after a first rain or tear them out roots and all later in the season. ${ }^{514}$ Grass is low in protein in the dry season but extremely resilient and easy to amass in large numbers. It would not be surprising if Seleucus relied heavily on the pastureland to feed not only his horses, but his elephants, with sufficient forage being brought in during winter. While it is unlikely the animals would be allowed to graze side

\footnotetext{
${ }^{510}$ Ibid., 79.

${ }^{511}$ Ibid., 78 and table 5.4 .

${ }^{512}$ Sukumar (1992), 69-85.

513 Ibid., 74.

${ }^{514}$ Ibid., 71-85.
} 
by side, the unavoidable proximity because of the location and size of the stables would have afforded the Seleucids the opportunity to inure their cavalry to elephants. Within a generation or two of horses, there would not have been many, if any mounts, that had not grown up in the presence of elephants, which would make them a tolerable sight in battle.

Strabo describes how Seleucus made Apameia the base of his operations, installing there the majority of his military forces, both human and animal, as well as special trainers including horse-breakers and teachers of the art of war (16.2.10). Here too Seleucus kept his cavalry stud stables, which consisted of 300 stallions and 30,000 mares, a sure indication of the fertility of the pastureland. ${ }^{515}$ One must assume that elephant trainers were brought here as well, and the presence of the royal equine stud suggests any elephant breeding programs the Seleucids undertook would have occurred at Apameia as well. However, elephant reproduction are low even in the wild. Sukumar notes that elephant reproduction rates are cyclical because of long gestation and nursing periods for females as well as late sexual maturity in both male and female elephants (see III.B.i). The earliest recorded example of calving was a 13-year old elephant cow, although mid to late teens is more common. As a result, if many elephants calve in one year, several years will pass before so many are capable of reproducing again. Sukumar's study averaged a fertility rate of under $23 \%$ in the wild ${ }^{516}$ but in captivity, this is markedly lower. ${ }^{517}$ Thus, it is unsurprising that later Seleucids would need to restock Apameia's elephant stables with importations rather than relying on natural increase.

\footnotetext{
515 Strabo 16.2.10; the bulk of Seleucid herds under the reign of Antiochus III is said to be in Media, not Coele-Syria (Polyb. 5.44.1-2), and it is likely that royal herds were kept in both places at both times, as an ample supply of cavalry in various pasturelands across the empire would be necessary to maintain its borders.

516 Sukumar (1992), 181.

${ }^{517}$ Sukumar (1992), 178-191.
} 
Over time, the Seleucid elephant corps did decrease significantly, demonstrating the difficulty of acquiring elephants by purchase. Either the Seleucids did not have sufficient land to trade in exchange for 500 elephants again, or, more likely, local rajas after the collapse of the Mauryan dynasty did not have so many to give. The limited nature of the ancient sources makes estimating the strength of the Seleucid elephant corps at any given time difficult. It is known that Antiochus I Soter (r.281-261) had (allegedly) 16 elephants, as these are referenced in the "elephant victory" against a Gallic tribe (Luc. Zeux 11). However, the number possessed by his heir Antiochus II Theos (r.261-246) is unclear. Because the Mauryan dynasty dissolved after the death of Asoka in 232, any beneficial diplomatic supply lines from India would have faltered during the reign of Seleucus II Callinicus (r.246-226), who suffered an already serious loss of elephants to Euergetes (see above p.150f.). ${ }^{518}$ Seleucus II's losses are unclear, but he must have passed on some elephants to Seleucus III Ceraunus and then to Antiochus III "the Great," who fielded 102 at the Battle of Raphia in 217. ${ }^{519}$ Thereafter, Antiochus undertook his anabasis to India, where he re-asserted the friendship of his dynasty's founder with a local raj named Sophagasenus (Polyb.11.34-11-12) and received elephants from him which Polybius tells us brought his elephant corps to 150 in number, a fraction of its size a century prior. ${ }^{520}$ However, this was celebrated in a fashion reminiscent of the dynasty's

\footnotetext{
${ }^{518}$ Scullard (1974), 138 notes that Seleucus II "had lost most of his elephants to Ptolemy III in 246," but his reference to the Adulis inscription (OGIS 54) does not support that claim. We do not know how many elephants Ptolemy III captured, nor what fraction of Seleucus II's total forces the captured elephants amounted to.

${ }^{519}$ Polyb. 5.65, 5.79-86; Scullard (1974), 137-145.

${ }^{520}$ Kosmin (2014), 35-37 argues that the "friendship" that Antiochus III established with Sophagasenus was meant as an "act of renewal" of the peace made between Seleucus I and Chandragupta, but the perceived equality between the kings was a fiction. Although Antiochus III did not attempt to conquer Indian territory or integrate it into the Seleucid state, Kosmin rightly notes that the gift-giving went only one way, making Antiochus III's relationship with India one of king to tribute state, not king to king.
} 
founder; as Scullard points out, Antiochus III advertised his anabasis with elephant coinage. ${ }^{521}$ Following the Battle of Magnesia (190/89) after which Antiochus III was ordered by Rome to dismantle his elephant corps, at least some of the animals appear to have been kept fighting fit, as they are used by Antiochus Epiphanes in his attacks on Judea (2 Macc.13.2).

\section{Part C: Elephants on Parade}

Both dynasties made an effort to display their elephants off the battlefield as well, an advertisement of the wealth of the kingdom and the far reach of royal territory. Even though the animals were becoming increasingly familiar sights in battle, most denizens of Ptolemaic Egypt and Seleucid Syria would not have seen elephants before. Further, unlike the other rarities of the animal kingdom displayed in royal processions (e.g. ostriches, antelopes, cf. Athen.5.200F), elephants straddled the line between the military and menagerie; they were participants in war like the soldiers and cavalry horses on parade, but they were evidence of the far reach of the king's empire as well. It is also fair to place great weight on the domestic display of elephants, above other animals, because of the considerable risk involved in the process. War elephants were neither fully domesticated nor containable. Proceeding amid crowds of a major city with dozens of elephants in tow was a gamble regardless of the skill of mahouts; these were military animals and potentially deadly. Two parades involving elephants are known to us: the Great Procession of Philadelphus, the Daphne Procession of Antiochus IV. They both

${ }^{521}$ Scullard (1974), 144 and fig. 16e. 
qualify as military processions and included multiple elephants and so merit a brief investigation here.

In 275, Philadelphus organized a massive celebratory parade for the Ptolemaia, a festival in honor of his dynasty and father. It was the year before the outbreak of the First Syrian War, but directly amid pressures from Antiochus I and Magas of Cyrenaica, which may have prompted the heavy martial element of the parade. ${ }^{522}$ A detailed description of the parade appears in Athenaeus (5.196aff.), who draws on the now lost history of Callixenus of Rhodes. Interestingly, the elephants appear in two separate parade displays, neither of which are military. Elephants appear first following a display of costumed Sileni and Satyrs in crowns riding on asses (5.200E), and they and their chariots are followed by: male goats, saiga antelopes, beisa antelopes, leucoryse, ostriches, deer, wild asses, and the train is ended with horse-drawn quadrigae. Elephants appear very clearly in the contest of an imperial menagerie, separate from the 57,600 infantry and 23,200 cavalry who march later (5.203A), but tied to Dionysus and his Sileni and Satyrs, evocative of the legendary revel the god held on his march back from India.

Elephants appear again in the parade drawing a chariot which holds a massive statue of Alexander, a float that directly proceeds a display designed for Zeus (5.202a-b). However, the military retinue at the end of the parade, decorated head to foot in panoplies, bring the ceremony to a close and are distinctly separate from the elephants. Hence here, elephants appear tied iconographically to Philadelphus and especially to Alexander, the conqueror of India, but they are not part of the military display. Rather, they serve as representatives of Ptolemaic conquests beyond Egypt, not unlike the

${ }^{522}$ Grainger (2010), 81-84 provides context. 
leopards, giraffe, rhino, and 24 massive lions (5.201c-f), proof of the breadth of Philadelphus' domain. Additionally, elephants served as a link between the Ptolemaic dynasty and Alexander himself; Philadelphus' elephants draw Alexander's cult statue through the stadium of Alexandria, linking the progenitor of Macedonian Egypt to the legendary conqueror. Elephants' continued participation in Ptolemaic processions is suggested by a tomb painting from the necropolis of Marissa, the capital of Ptolemaiccontrolled Idumaea. Beneath a painted epitaph for a certain Sabo, daughter of Kosnatanos, is a portrait of exotic animals on parade. Dated to the second century, when Marissa belonged to the Ptolemies, the tomb painting features an elephant, among other animals and people, being led in a parade, indicative that this was not an uncommon sight even a century later. ${ }^{523}$

The Seleucids, too, engaged in great displays of wealth. One of the best-known examples is the Daphne Procession of Antiochus IV in $166,{ }^{524}$ which was a victory parade in honor of Antiochus' campaign in Egypt. Polybius explicitly notes that it was intended to outdo the triumph of Aemilius Paullus after his conquest of Macedonia as well (30.25.1). Grainger reasons that it may also have been meant to imitate and surpass the famous Ptolemaic procession of the past century. ${ }^{525}$ The celebration's first half was entirely martial, while the second displayed the wealth of the Seleucid empire in gold and silver, a civilian parade. It is in the first procession that elephants appear; Polybius lists out the many units that comprised the army, all of which correspond to different

\footnotetext{
${ }^{523}$ Sekunda (1994), figs 58-59; Peters and Thiersch (1905), 54, on date see p. 77.

${ }^{524}$ For the date of the procession vis-à-vis the Babylonian Chronicles see Gera and Horowitz (1997), 240241. Gera and Horowitz show that the procession recorded in the Chronicles of 169/8 indicates a local one, not the grand procession at Daphne near Antioch.

${ }^{525}$ Grainger (2010), 315.
} 
territories under Seleucid Control. ${ }^{526}$ From Mysians and Cilicians to Nisaean knights, the armed forces of Antiochus state were on parade in celebration of victory in the Sixth Syrian War against Egypt. Elephants brought up the rear of the procession, four of them leading one chariot, two drawing another, and 36 more riding with howdahs.

Although what role, if any, elephants specifically played in the campaign, they are referred to among Antiochus' invading forces, and it is plausible that they were deployed in the battle in the Sinai Desert and thus served as emblems of victory once again for the parade in Daphne. ${ }^{527}$ Whether the animals actually played a significant tactical role is, as we have seen, irrelevant. By celebrating his victory with elephants and flaunting that internationally, ${ }^{528}$ Antiochus IV was able to recoup his loss of face following the ultimatum of Popillius Laenas during the Seleucid siege of Alexandria in 168, an embarrassment that Antiochus was unlikely to have forgotten. ${ }^{529}$

The elephants' very presence flew in the face of the Treaty of Apameia that followed the Seleucid loss at Magnesia (189) and required the destruction of the elephant corps. According to the description provided by Polybius (30.25.11), at least 46 elephants were still alive by 166 . Sherman-White and Kuhrt have theorized that the Romans never carried out the terms of the treaty by force until the Seleucid state was considerably weaker in $162,{ }^{530}$ but Sekunda proposes another theory. He suggests that the treaty had

\footnotetext{
${ }^{526}$ See Polyb. 30.25-26; Diod. 21.16.

527 Macc. 1.17 notes that Antiochus IV invaded Egypt with elephants, and there may have been a battle in the Sinae Desert between him and the regents of Ptolemy V Epiphanes. See Grainger (2010), 295-297 and Porphyry $260 \mathrm{~F} 49 \mathrm{a}$.

${ }^{528}$ Polybius (30.25.1) does specify that Antiochus IV wanted notoriety for the celebration and went to the effort of sending out embassies to announce the games throughout Greece, encouraging people to visit Antioch and Daphne.

${ }^{529}$ contra Grainger (2010), 307 who argues that Antiochus IV wanted Rome to intervene to give him an easy out without appearing to be withdrawing from a failed siege.

${ }^{530}$ Sherman-White and Kuhrt (1993), 215.
} 
been carried out after Magnesia, but either Seleucus IV or Antiochus IV later acquired more elephants from Demetrius of Bactria, and the Romans were only re-implementing the treaty's regulations in $162 .{ }^{531}$ Given the extreme reaction of the people to the slaughter of the Seleucid elephants in 162 and the fact that Antiochus had elephants to leave with his son, Antiochus V, before his anabasis ${ }^{532}$ it seems more likely that the Romans never implemented the treaty's conditions, but became insistent upon it after the military successes of Antiochus IV in Egypt and the East. Indeed, Grainger has noted that the Senate feared Antiochus IV's power after his gains in the Sixth Syrian War, and it is reasonable then that the Romans waited for a moment of Seleucid weakness to demand the destruction of the navy and elephant corps. ${ }^{533}$

By 164, they had it. Antiochus IV died campaigning in the East, leaving the young heir, Antiochus V Eupator, in a vulnerable position. It was only then that the Senate sent an embassy to enforce the terms of the treaty, burning Seleucid ships and violently slaughtering the elephant corps by hand. Grainger notes that neither Antiochus IV nor V was bound by the treaty agreed to by Antiochus III, but in fact "the Senate was actually responding to the fight administered to Rome by Antiochus' great display in 166." 534 It is plausible that the Romans believed the Seleucid dynasty to be bound to its treaty, which justified (in the Senate's eyes) the invasive enforcement of the treaty's terms by a foreign power. Certainly the ostentation of Antiochus IV in flaunting his elephants and the strength of his dynasty despite his father's losses, contributed.

\footnotetext{
${ }^{531}$ Sekunda (1994), 27.

5321 Macc.3.34 specifies that Antiochus IV left his son and regent in the western half of the empire with his elephants when he left to campaign after the parade at Daphne.

533 Grainger (2010), 316.

534 Grainger (2010), 317.
} 
Previously such policing had been impossible due to the strength of Antiochus IV's regime, but the shaky legs of Antiochus V's administration offered an excellent opportunity to cripple the regime permanently.

Rome sent an embassy of three senators, Gnaeus Octavius, Lucius Aurelius, and Spurius Lucretius "with orders in the first place to burn the decked warships, next to hamstring the elephants, and by every means to cripple the royal power" (Polyb. 31.2.11). The slaughter of these animals is bemoaned by Appian, who relates that it was such a pitiful sight that the instigator, Gnaeus Octavius, was murdered publicly in the gymnasium of Laodicea by a certain Leptines, who had become enraged over the slaughter of the elephants. ${ }^{535}$ Leptines' response indicates two things: that the elephants were well recognized as an emblem of Seleucid power and autonomy and that their slaughter had been public. It is not known how many elephants were killed. Antiochus IV left his son with his elephant corps (1 Macc.3.34) when he marched off from Daphne to the eastern empire, but at the Battle of Beth-Zachariah (162), the Seleucids deployed either 22 or 32 (see above p.168f.), and it is doubtful that they brought their entire force to bear against a localized rebellion.

Even if the Senators had spared some of the Seleucid stock, the act of hamstringing several dozen Indian elephants cannot have been anything other than public, and indeed for the Senate to impress their message with force, it would have to have been. By having the tendons on the backs of their legs cut, the elephants would have been immediately immobilized, but death from exsanguination would have been slow in coming. The highly vocal nature of elephant communication means that their deaths

\footnotetext{
${ }^{535}$ App. Syr. 46; cf. Grainger (2010), 317-318.
} 
would have been loud and painful, especially among elephant cows, who live in complex social groups. While Appian (Syr. 46) emphasizes the grisly and sorrowful sight, Sekunda points to Pliny's description of the Roman circus as the best approximation from antiquity, whose account emphasizes both the pathos-filled tenacity of wounded elephants and the cruel indifference of the Roman audience. ${ }^{536}$

"In the second consulship of Pompeius, at the dedication of the temple of Venus Victrix, twenty elephants, or, as some say, seventeen, fought in the Circus against a number of Gætulians, who attacked them with javelins. One of these animals fought in a most astonishing manner; being pierced through the feet, it dragged itself on its knees towards the troop, and seizing their bucklers, tossed them aloft into the air: and as they came to the ground they greatly amused the spectators, for they whirled round and round in the air, just as if they had been thrown up with a certain degree of skill, and not by the frantic fury of a wild beast. ${ }^{, 537}$

This event occurred a century later, so the callous indifference of the Roman audience is not relevant. The imagery, however, affords us a fair approximation of the horror in the Apameian stables that prompted Leptines of Laodicea to slaughter a Roman senator. The Romans could not have found a more brutal or visceral metaphor had they tried; by slaying the sigil of the Seleucid dynasty in an act that could not have been anything but public, they issued a dire warning not to defy Roman injunction again. ${ }^{538}$

\section{Part D: Elephants in Royal Portraiture: Statues and Coinage}

Given the importance of elephants to both the Seleucid and Ptolemaic regime, their incorporation into royal portraiture, such as remains today, is unsurprising. The personal monarchies of the Hellenistic Age resulted in a proliferation of royal sculpture, a trend

\footnotetext{
${ }^{536}$ Sekunda (1994), 27.

${ }^{537}$ Pliny $\mathrm{NH} 8.7$.

${ }^{538}$ Cf. Kosmin (2013), 107-108.
} 
arguably started by Alexander, whose posthumous portraiture took on a life of its own. ${ }^{539}$ Through sculpture and coinage, both dynasties found ways to incorporate the elephant into official imagery. Among the post-Diadoch generations, elephants appear more frequently in Ptolemaic sculpture and in Seleucid coinage, but it is not possible to draw specific conclusions about the way either dynasty utilized elephant imagery on the basis of the various media through which those images survive today. For both dynasties, the elephant proved a very flexible image that could transmit messages of military strength, royal authority, and wealth, depending upon how it was used.

A brief investigation of the evidence will show that the Diadoch-era mythology of Alexander and the elephant was transferred to at least one Ptolemaic king, Ptolemy II Philadelphus. Further, we shall see that Seleucid elephants, as they appeared on coins, were associated with both the ritual of the eastern anabasis and, more generally, with the Seleucid state. It is quite possible that Seleucid statuary and Ptolemaic coinage featuring elephants were both produced and simply remain lost to time, and I will refrain from drawing conclusions about elephant imagery based solely on the medium of depiction.

\section{Ptolemaic Statues and Statuettes}

It is telling that we have at least fragmentary portraiture of most of the Ptolemies, indicative of a new scale of production of royal images. ${ }^{540}$ While the Theo Adelphoi pharaohs are best known from their twin images on coins, ${ }^{541}$ a pair of bronze statuettes

\footnotetext{
${ }^{539}$ Stewart (1993) and Sheedy's edited work (2007) provide thorough studies of Alexander imagery in use by the Diadochs.

${ }^{540}$ Stanwick's (2002) work offers a detailed survey of Ptolemaic statuary with a focus on the ways in which the Macedonian pharaohs blended Egyptian and Greek artistic elements.

${ }^{541}$ E.g. Morkholm (1991), pl. 18 nos. 297, 298.
} 
from Egypt offer three-dimensional portraits [Image 4.1]. The two statuettes stand at $1 \mathrm{ft}$. 3.5 in. (male) and 1 ft. 2 in. (female) and are bronze hollow cast statues. Edgar has identified them as Ptolemy II Philadelphus and Arsinoe II, and Kyrieleis concurs, although he notes that identification of statues as Philadelphus are notoriously difficult. ${ }^{542}$ The statuettes are known to have come from Egypt, but exactly where they were unearthed is not documented. Philadelphus' statue is of special interest because of its assimilation to Alexander and Argead ancestry. The statue is of the doryphoros type, a lax pose in the nude in which one hand grips a spear. ${ }^{543}$ In one arm he holds a club, evocative of Heracles, Alexander's Argead ancestor. The statuette's hair comes to a small tuft, Alexander's anastole, and most importantly, atop the head is an elephant skin cap, the very same that Alexander wore in the coinage of Ptolemy I.

If investigated in isolation, the male figure might have been mistaken for Alexander (Edgar claims that the Philadelphus' coin portrait resembles the statuette's features, but coin portraits are generally less than lifelike, small, and badly worn), but if the statuettes were found (and presumably displayed or even produced) as a pair, ${ }^{544}$ then the presence of a female carrying a scepter and double cornucopiae identifies her securely as Arsinoe II, and her mate as Philadelphus. Edgar points out that Arsinoe II's coinage employed the same emblem, and Athenaeus refers to it specifically (11.497), claiming it evoked the queen's generosity. ${ }^{545}$ If indeed this pair of statuettes portrays the Theoi

\footnotetext{
${ }^{542}$ Edgar (1906); Kyrieleis (1975), 20-21, see plates 8-9, figs. 5-6 B1, 1-2 J2 and B1.

${ }^{543}$ See Stewart (1993), 161-171 on doryphoros type. This is not the only Ptolemaic statue portrayed thus; Edgar published on a $2.5 \mathrm{~m}$. limestone statue of a Ptolemy, who he also identifies as Philadelphus, from the ancient city of Aphroditopolis, Egypt. This Ptolemy wears the aegis and carries a spear, and his hair features Alexander's anastole.

${ }^{544}$ Dyads and Triads were common in Ptolemaic statues; see Stanwick (2002), 36.

${ }^{545}$ Edgar (1906), 282; Athen.11.497; on the coin see Morkholm (1991), pl. 18 nos 294, 295, 299, and pl. 19 nos. 307-308.
} 
Adelphoi , Philadelphus' choice to portray himself in Alexander's elephant skin cap and bearing Heracles' club, ${ }^{546}$ is a bold one but aligns well with his public display of elephants on parade in Alexander's city. Although a legitimate king by birth, Philadelphus still uses totems of Alexander's reign and cult to enhance his own prestige, and indeed in the context of his achievements, the elephant scalp takes on new meaning. Philadelphus did not conquer India, but rather the Erythraean coast; his exploratory endeavors and the completion of the canal linking the Nile and Red Sea facilitated the importation of African elephants, linking the animals to his reign in a new way.

Alexander was no longer the only figure to don the elephant scalp headdress.

The image of the lion-skin cap appears again in three-dimensional art in a small bronze knight from Athribis, Egypt, of an uncertain date [Image 4.2].${ }^{547}$ The bronze knight is missing his horse, but clearly sits astride one. He wears open-toed sandals which Sekunda identifies as a cavalry boot and aside from those and a chiton, he is heroically nude. ${ }^{548}$ His identifying feature is the elephant skin cap he wears over his head, its trunk raised like the uraeus. Identification of the figure is difficult; the angle of the trunk is suggestive of a Ptolemaic king, but the heroic nudity and idealized face is especially reminiscent of Alexander. ${ }^{549}$ However, if we are to accept Edgar's identification of the

\footnotetext{
${ }^{546}$ Edgar (1906), 281 also views the buskins that the figure wears as equivalent with the footwear of Athenian tragic actors and thus an emblem of Dionysus, further linking Alexander-, Heracles-, and Indiaimagery. The need for this under Philadelphus' reign is unclear, but Edgar does note Theocritus' encomium (17.13-33) for Philadelphus, which mentions the pharaoh's links to Heracles and Alexander both through his deified father.

${ }^{547}$ Excellent photos may be found in Sekunda (1994), figs. 49-51 and Kyrieleis (1975), pl. 10 figs. 1-3, B2. Kyrieleis also provides a catalogue entry on p. 166.

${ }^{548}$ Sekunda (1994), 77.

${ }^{549}$ Kyrieleis (1975), 22. Sekunda emphasizes that "it is certainly not" Alexander $(1994,77)$, but does not explain why, suggesting either a Ptolemy or Demetrius I of Bactria. Kyrieleis $(1975,22)$ rightly dismissed earlier theories that the statuette could be identified as Demetrius, noting that finding an image of a Bactrian king in Egypt would require substantial explanation. There is no good reason to dismiss Alexander entirely as a possible subject, although similarities with the Philadelphus dyad statuette make it more likely that the image is an idealized Philadelphus.
} 
male half of the statuette pair from Egypt as Philadelphus, already in the heroic nude doryphoros pose, it is plausible that the bronze statuette is a reproduction of the same image. Indeed, Kyrieleis cautiously groups the statuette with other images of Philadelphus, noting that "obwohl sich bei ihr die Benennung als Philadelphus vielleicht nicht mit der gleichen Sicherheit begrunden last."550

Another portrait in an elephant-skin cap from Egypt may be dated to the late Ptolemaic or early Roman Period and is strongly suggestive of the longevity of the association of elephants and the Ptolemies. ${ }^{551}$ The small bronze head likely decorated the end of an oil lamp, and it depicts a beardless young man wearing an elephant scalp over his head, the tusks jutting out like horns, trunk trumpeting overhead in blatant imitation of the Egyptian uraeus, while beneath the curve of a scroll, once attached to the lamp, seems to resemble the traditional false beard attached to pharaonic imagery. ${ }^{552}$ Pryce identifies the elephant as African and the face as Alexander's. While there are far too few details to identify the species of elephant represented, identifying the face as Alexander's because of the Ptolemaic tradition of portraying him in an elephant skin cap is possible. However, it is equally plausible that the image was intended to represent a contemporary pharaoh given the positioning of the elephant's trunk, and certainly there is a dearth of Ptolemaic imagery linking Alexander to traditional emblems of pharaonic rule.

Contrarily, there is abundant evidence of Ptolemaic portraiture created with Egyptian elements, and Stanwick has noted that the majority of Ptolemaic royal statues features an uraeus, an emblem which "evokes the essential meaning of kingship in

\footnotetext{
${ }^{550}$ Kyrieleis (1975), 22.

${ }^{551}$ Pryce (1935), pl. XLI a, b.

${ }^{552}$ Ibid., 135.
} 
Egypt — the pharaoh as rightful ruler and protector against chaos. ${ }^{553}$ If Edgar's assessment of the Theoi Adelphoi statuettes is correct, Philadelphus may have set the precedent for the portrayal of living Ptolemaic pharaohs in Alexander's elephant skin cap, making such a portrait, generations later, rather unspectacular. What is noteworthy is the long-lived association of the Egyptian kings and elephants, especially considering that there is no evidence that elephant hunting persisted after Ptolemy VI. Indeed, several late, but unclearly identified Ptolemaic kings appear in the elephant scalp headdress both in statuettes and royal seals, suggesting the appeal of the image post-dated the actual use and presence of elephants in war and in the capital. ${ }^{554}$

We must also consider the frustratingly enigmatic bust of a Hellenistic king. ${ }^{555}$ Of undocumented provenance but ostensibly from Asia Minor, the bust is usually dated to the Hellenistic age, between the third and first centuries. It measures $1 \mathrm{ft} .3 .75 \mathrm{in}$. tall and is made of a white marble streaked with purple. Based on the slanted neck and crack running up the side to the ear, Smith concludes that it was removed from a larger than life-size statue. Most of the facial features are badly eroded and the nose is missing. However, Smith notes that "the vigorous upward turn of the head, the parted lips, the ideal agelessness, and the smooth, flat sculptural style are all typical of Hellenistic ruler portraits. ${ }^{, 556}$ Evidence of attributes made of other materials that were added onto the statue later indicate a Hellenistic royal portrait. In the temples of the bust are two "excavated" cuttings in the temples that are rectangular in shape, quite distinct from the dowel holes elsewhere. In addition to the rectangular holes, part of the originally sculpted

\footnotetext{
${ }^{553}$ Stanwick (2002), 34.

${ }^{554}$ See Smith (1986), p. 63 n. 12 for a list of additional images.

555 Image published in Smith (1986), figs. 1a-d.

556 Smith (1986), 59.
} 
hair was cut out as if to place something directly over the head, which rules out the possibility of simply attaching bull horns to the forehead, unless a helmet were added in addition. Smith finds plausible Frel's assessment that the bust was elaborated on after construction, perhaps upon the death and divinization of the king whom it represented. He proposes that the massive rectangular excavation spots at the temple were used to support an elephant-skin helmet, and indeed the wide ears and upraised trunk would have required additional frontal support. ${ }^{557}$

Although we have only a few extant examples, that the elephant skin cap appeared in any royal portraiture of the Hellenistic age is indicative of its significance as a recognizable royal attribute. Among the many Egyptian emblems the Ptolemies incorporated into royal iconography, ${ }^{558}$ the elephant stands alone, neither Egyptian nor, initially, Macedonian. With respect to elephant imagery, the Ptolemies did not have any pre-existing legends to draw on, so they created their own.

\section{Elephant Coinage of the Epigonoi and Forward}

Although the elephant coinage of the Diadochs is more prolific than that of the Epigonoi and subsequent generations, the reproduction of Diadoch coin types and the incorporation of new, celebratory coin types reveals that the elephant was still an important icon, especially for the Seleucid state. Under Philadelphus, the elephant coin types of Ptolemy I were reproduced, likely both a testament to the dynasty's now-deified founder as well as one of the city's patron gods, Alexander, who wears the emblem of his

\footnotetext{
${ }^{557}$ Ibid., 63; Frel (1981), 78.

${ }^{558}$ Stanwick (2002), 33-40 gives a cumulative list of common Egyptian attributes found on Ptolemaic statues, including the uraeus, nemes, and the double crown.
} 
most difficult conquest. ${ }^{559}$ By contrast, the Seleucids moved away from using Alexander as an explanatory link between the elephant and the concept of kingship; most often, the Seleucid elephant stands alone.

Kosmin has pointed out that Seleucid elephants appear on coinage in conjunction with the eastward expeditions of kings, with those who campaign (successfully or unsuccessfully) minting emblems of their victory there. ${ }^{560}$ Kosmin sees this coin type as a product or even advertisement of a ritualized gift-exchange that symbolized royal parity between the Mauryan and Seleucid empires, and subsequently subjugation, after the dynasty's collapse and the campaign of Antiochus III. ${ }^{561} \mathrm{He}$ has convincingly shown that the Seleucid policy of advertising this campaign success put special emphasis on eastern satrapies, and they 'represent a deliberate choice to privilege Seleucus' military activities in India over those, in, say, Babylonia, Iran, Bactria, or the West." ${ }^{562}$ In support of this thesis, he notes a comparative dearth of elephant types on precious metal coinage produced under Seleucid kings who did not campaign in India, including Antiochus I, II, Seleucus II, Antiochus Hierax, Seleucus III, and Achaeus. But the significance of the elephant was not simply abandoned-Antiochus III, following his victorious campaign into the realm of Sophagasenus, revived it. ${ }^{563}$ Antiochus III's coins, like the type issued at Antioch after his campaign, featured his profile on the obverse and an Indian elephant with a mahout on the reverse, a clear advertisement of his campaigning. ${ }^{564}$

However, as Kosmin admitted, ${ }^{565}$ elephants do appear between the reigns of

\footnotetext{
${ }^{559}$ Morkholm (1991), 101; in general for third century Ptolemaic coinage see pp. 101-111.

${ }^{560}$ Kosmin (2013), 106.

${ }^{561}$ Kosmin (2014) in general; cf. Morkholm (1991), pp. 113 ff. on Seleucid coinage.

562 Kosmin (2013), 106.

${ }^{563}$ See Polyb. 11.34.11-12; Kosmin (2014), 106.

${ }^{564}$ Morkholm (1991), pl. 23 no. 353, cf. p. 115.

565 Kosmin (2013), n. 59.
} 
Seleucus I and Antiochus III, even if it is only on bronze units. Both Antiochus II and Seleucus II minted bronze units that depicted elephants on the reverse side of a Dioscuri coin, where one might expect to find a horse. ${ }^{566}$ A bronze unit of Seleucus III's features Apollo on the reverse, resting on the omphale stone with his bow, and beneath his feet stands an Indian elephant. ${ }^{567}$ Another design, featuring the portrait of Seleucus III on the obverse and an elephant on the reverse was minted down through the reign of Antiochus III, ${ }^{568}$ who used the same imagery again in coins of his own, replacing his father's portrait with his. ${ }^{569}$ While certainly Kosmin's linking the Indian campaigns to elephant coin types in higher-value metals is accurate, the continual presence of elephants on Seleucid bronze units over three generations suggests that the animals were as much of a standardized element as they were celebratory. A victory in India was not a prerequisite for placing elephants on Seleucid coinage, as the animal had been successfully incorporated into the many stock emblems of the Seleucid house, along with the deities Apollo, Zeus, as well as the famed Seleucid anchor.

\section{Conclusions to Chapters 3 \& 4}

Strabo tells us that in India, no private citizen was permitted to keep a horse or elephant, and "the possession of either is a royal privilege" so that even elephant hunters and trainers could do so only through subsidies in kind provided from the royal coffers (Strabo 15.1.41). By the time of Asoka, the Pillar Edict V (244) prohibited any tampering

\footnotetext{
566 Morkholm (1991), pl. 23 no 335 and p. 116.

${ }^{567}$ Ibid., pl. 22 no. 337, also p.114.

${ }^{568}$ Ibid., pl. 24 nos 357-359.

${ }^{569}$ Ibidl, pl. 24 no. 369.
} 
with the ecosystem of the elephant forests, protecting the breeding and birthing grounds of wild elephants in the name of the king. The animal itself was seen as an "item of "national wealth"” and its capture constituted a "royal monopoly." 570 For the Macedonians, the elephant's value as a royal attribute was not so different.

Initially co-opted as an arm of the military, the elephant quickly took on a new role in the early Hellenistic Period. Acquired in India, the elephants came to represent Alexander's farthest conquest, that which rivaled the legendary travel of deities like Heracles and Dionysus. Although Alexander never explicitly adopted the elephant as a personal or regnal emblem, his Successors did so for him. Possession of Alexander's elephants, a forceful visual reminder of the historic eastern campaigning of the Macedonian army, lent credibility to the claims of Alexander's regent and many warring generals. Hence, images of Alexander and his elephants appear on the funeral carriage of Perdiccas' design and on the coins of Ptolemy and Seleucus throughout the Diadoch Wars. Every contending general of any significance possessed elephants at some point in the war and endeavored to acquire more; even Ptolemy, who never deployed them, took pains to capture without killing his enemy's elephant corps at Gaza. Elephants became symbols of victory and of royalty, playing an important role in crafting the image of what a legitimate Successor and Hellenistic king ought to look like, especially if his basis of power was in the East. While Lysimachus lost his elephants and his life at Corupedium and Pyrrhus' elephant campaign flared and burned out quickly in Italy, the Ptolemaic and Seleucid dynasties made efforts to maintain their elephant corps and expand them throughout the following 150 years. Indeed, the significance of the elephant endured

${ }^{570}$ Habib and Jha (2004), 111, cf. 80, Arthashastra 2.32. 
beyond the wars of Alexander's generals and into the reigns of their descendants, legitimate Hellenistic kings.

When the association of the elephant with Alexander became unnecessary, the animal's power as an emblem of royal authority and totem of military victory persisted. Elephants were brought on campaign by Ptolemies and Seleucids through several of the Syrian Wars and as late as the Seventh (147-154). However, investigation of elephants' success in well-documented Diadoch War battles (chapter two) and sparsely documented battles of the third and second centuries (chapter four) have shown that it is unlikely that the animals were fielded solely for their tactical potential. Rather, elephants were now a prerequisite for Hellenistic kings of the East, and the long-lived animosity between the Ptolemies and Seleucids demanded that they compete actively in this elephant arms race. Both kingdoms underwent tremendous effort and expense in order to acquire more of the animals, by capture or by trade. The Ptolemies cultivated elephant hunting settlements along the African coast of the Red Sea, and the Seleucids built up a military complex at Apameia that was replenished by royal marches to the Indian periphery of the kingdom and good diplomatic relations therein. The considerable resources that the maintenance of an elephant corps required were in turn an advertisement of a kingdom's economic health, a point on which both states capitalized. Elephants appeared in domestic and military parades both as military animals and as tribute from the farthest reaches of the Ptolemaic and Seleucid kingdoms. The animals appear in royal portraiture and state coinage as easily recognizable emblems of conquest and martial victory. None of these factors should be ignored when evaluating the significance and impact of the war elephant on the Hellenistic states of the East. 
In this way, we have solved the problem presented by Glover in the introduction. Rather than credit the Romans with some sort of special prescience regarding the viability of war elephants, it is more logical to recognize that elephants were symbolically useful for Hellenistic kings, but markedly less so for the Romans. By the era of Roman military involvement in the Greek and Macedonian world, elephants had become iconic symbols of royalty, possessed and utilized by mighty kingdoms like those of the Seleucids, Ptolemies, and eventually the Carthaginians. Rome would have had no interest in advertising the wealth of its state with the same symbols used by the decadent East, nor would Rome have any use for emblems of royalty. As we have seen, at the Battle of Magnesia, the Roman army's mere 16 elephants were judged too few to be useful against the larger corps of Antiochus III, and the Roman general Domitius did not hesitate to exclude them from the battle lines altogether (App. Syr. 31; Livy 37.39.12). Their value was limited to what they could do tactically.

The elephant emblem smacked of royalty, both Carthaginian and GrecoMacedonian; the animal was suitable entertainment in the circuses (e.g. Pliny $N H$ 8.7) and occasionally useful in battle, but unlike for the Ptolemies and Seleucids, an elephant corps was not an ante the Romans felt the need to meet. Recently Nousek has produced an argument along these lines with respect to the elephant denarius of Julius Caesar. Caesar minted denarii featuring elephants on the reverse in order to mock his political enemies like Pompey, whose use of the animals while self-styling as Alexander, caused much ridicule. ${ }^{571}$ Even by the time of Augustus' paper thin veneer of republicanism,

${ }^{571}$ On the argument explaining the significance of Caesar's elephant denarius, see Nousek (2008) p.301f. Pompey's use of elephants in his triumph as a privatus borrowed heavily from eastern iconography and resulted in failure and ridicule. See Plut.Pomp.14, Gran.Licin. 36.1-4. 
elephants would have still been too closely linked to the Greek East and the ancestral enemy, Carthage, to be worth using symbolically the way the Hellenistic monarchies did. Among the Macedonians in the East, elephants were held in high esteem, and the subsequent generations of Ptolemies and Seleucids not because of their tactical utility, but in spite of it. A large elephant corps could prove a useful psychological deterrent or at the very least a barricade against cavalry, under the right circumstances. But, as we have seen, battlefield conditions rarely resembled those of Ipsus, and a powerful elephant corps rarely played a vital role in bringing about a victory. What it did do, domestically and on the field of battle, was communicate the strength, wealth, and resources of a ruler and the expanse of his domain in a way that helped shape the complex image of Hellenistic kingship. A king was defined by his military power, victories, his financial ability to maintain power, and the expanse of territory under his spear-won control. While the Ptolemies and Seleucids spent generations at war over the fertile territory of CoeleSyria, elephants were procured from India, Bactria, Eretria, and Somalia, marched back and forth on campaign, paraded through the streets of Alexandria and Antioch, and stamped onto state approved denominations of precious metal as a visual reminder of the royal issuer.

The ties between the ruling house and its elephants may be glimpsed through the sources in powerful scenes through which royal power is (re-)asserted with the presence of elephants: Antiochus I defending the Seleucid borders against foreign invaders with his elephant corps, his descendent Antiochus III marching his elephants against the rebel army of Molon; Philadelphus' elephants drawing Alexandria's eponymous patron in a chariot through the city, or Ptolemy Epiphanes arresting treacherous Scopas in person 
with his royal retinue of pachyderms. It is hardly surprising that the ancient sources recognize the incredible strength, ${ }^{572}$ depth of feeling, ${ }^{573}$ and keen intellect ${ }^{574}$ of these animals - one could hardly find a more suitable animal to serve as the guard and emblem of kings.

${ }^{572}$ E.g. Strabo 15.43; Plut. Pyrrh 21.7

${ }^{573}$ E.g. Strabo 15.42; Pliny $N H$ 8.1-3

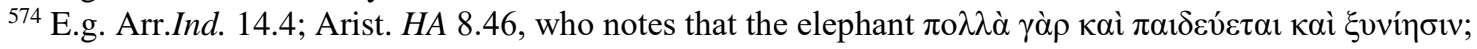

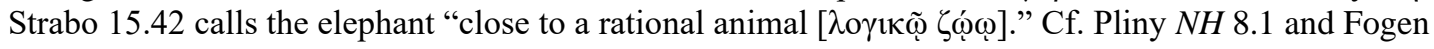
(2007), 185-188. 
Part II: Camels 


\section{Introduction}

Perhaps it appears an odd feature of a dissertation on ancient military animals, but the camel in fact played a crucial role in a number of ancient campaigns. However, its role as a messenger, pack-animal, desert guide, and even battle mount has been easily overshadowed by the more glorious and certainly more numerous accounts of ancient cavalry. Native to Asia and imported into North Africa in antiquity, camels did not play much of a role in Greek warfare before Alexander the Great's campaigns in Asia (334323). However, they had been a common sight in eastern baggage trains and battlefields for centuries predating the Macedonian invasion. Effectively utilized by the Arabs, Assyrians, and Persians, camels were adopted also by the Macedonians and Greeks for military use in the second half of the fourth century.

There has been little scholarly acknowledgement of the camel's role in ancient warfare on the whole, but especially in the Hellenic world. In part this is due to the fact that the Greeks had few encounters with camels before Alexander, but perhaps also to the fact that the presence of camels in the Alexander narratives are few and far between, lost amid a deluge of other logistical detail. However, infrequent references should not deter our investigation; Part II of the dissertation will fill an important gap in the continuum of knowledge of the ancient military.

Glover's 1950 article lists camels among elephants and Persian war chariots under the title of "curiosities" of ancient warfare, but exactly what distinguishes these apparati as "curious" is unclear. ${ }^{575}$ Are these things curious because they were not widely used in Europe, or because we have fewer references to them in ancient sources than we have of

\footnotetext{
${ }^{575}$ Glover (1950), 1.
} 
traditional weaponry? Glover unites all three curiosities in a reference to the military display of Antiochus III preceding the second century Battle of Magnesia (191). Among his troops, as we have seen, are war elephants, chariots, and dromedaries, ridden by Arab contingents. Glover's assessment of camels applies exclusively to the dromedary and is none too flattering. While he credits them with mental equilibrium in battle and the ability to terrify horses, he notes that the camel's "more natural place" is in the baggage train. ${ }^{576}$ Glover defends this factually correct statement in terms that imply baggage duty is somehow an animal demotion, undercutting the importance of food and supply transport: "if we are tempted to ask why [camels belong here], the reason may be that with all his [the camel's] advantages he really is not suited for prolonged and arduous campaigning. His main weakness is that he particularly susceptible to changes of climate, and perhaps this is why we hear little of Xerxes' camels." ${ }^{, 577}$

Glover is right to point to the environmental factor when it comes to choosing pack animals, but he does not differentiate between dromedaries, suited for arid and hot regions, and Bactrian camels, which can survive snowy steppes and high altitudes. In planning one's campaign, the type and quantity of supplies brought along depends largely on the environment, and so, naturally, would the type of pack animal and mount that carries those supplies. The camel's natural habitat is not so exclusive as to make it inefficax; far from having difficulty with long journeys and heavy burdens, camels are in fact superior to other pack animals in many ways. ${ }^{578}$ As we shall see, in environments

\footnotetext{
${ }^{576}$ Glover (1950), 4.

${ }^{577}$ Ibid., 4-5. We hear little of Xerxes' camels because the majority of them were mauled to death en route to Greece, (Hdt 7.125; Ael.NA.17.36) but enough of them survived the lion attacks that Pausanias divided them up after the Greek victory at Plataea (Hdt.9.81).

${ }^{578}$ Cf. Glover (1950), 5.
} 
that constitute camels' natural habitat, they can transport heavier burdens than horses or mules, draw nutrients from desiccated fodder, and endure drought better than other draught animals.

The most extensive research into the logistics of Alexander the Great's army comes from Engels, who convincingly argues that the nature and timing of the Macedonian king's progress through Asia was motivated in large part by his need to supply a vast and growing army. Engels uses calculations of human and animal consumption rates, burden bearing capacity, and Alexander's rate of travel to determine the most efficient animals in the baggage train and shed light on Alexander's logistical organization. ${ }^{579}$ While much of this will be discussed in detail below, it will suffice here to note that Engels' assessment of camels requires further evaluation. Engels fails to distinguish between the two types of camel used by Alexander (the dromedary and Bactrian), and relies heavily on anecdotal evidence from the British Army based on its experience with dromedaries. More recent biological studies as well as advanced DNA sequencing of the camelidae family have revealed that camels' powers of endurance are greater than Engels gives them credit for, and thus a re-evaluation is needed. ${ }^{580}$

As we shall see, recognition of the camel's environmentally-specific capabilities was not unique to Alexander's army. Indeed, the adoption of the camel from Arab tradition by other peoples has occurred often enough between the ninth and fourth centuries to constitute a pattern. Assyrian, Persian, and Macedonian kings recognized the

\footnotetext{
${ }^{579}$ Engels (1978), 123-30.

${ }^{580}$ In this chapter, I rely upon a 2014 publication of the whole genome sequencing of the Bactrian, dromedary, and alpaca camelids that resulted as a collaborative effort of many institutions and was supported by the King Abdulaziz City for Science and Technology, the Saudi Arabian Center for Science and Technology in Riyadh, Saudi Arabia. Wu et al. (2014).
} 
value placed on camel travel and transport by Arabs. The fourth century is often marked as a period during which foreign and non-traditional weapons were integrated into Greek armies after experiences with them on the field revealed their effectiveness. Peltas and long Egyptian light infantry spears became commoner sights alongside Greek phalanxes, and technological improvements under the patronage of Philip II further galvanized military change in the Greco-Macedonian World. ${ }^{581}$ It is not surprising then that the Greeks were willing to adopt foreign animals just as they had incorporated foreign technology; Alexander, as his father had, was constantly altering and improving his army. With campaigns of longer duration, greater complexity, and generals favoring "indirect approach" to battle, long-term planning for any eventuality was ideal. ${ }^{582}$ Larger armies endure greater logistical strain, and using environment-specific animals could alleviate that, a point which Roth illustrates with the account of Antigonus' foray into the Sinai Desert. It was neither the climate nor the death of men and animals that halted Antigonus' progress, but Ptolemaic resistance ${ }^{583}$ the journey itself was completed through the integration of camels into the supply line.

In order to understand the Macedonian adoption of the camel, chapter five will serve to outline the use of the camel by non-Greeks in the Middle East and North Africa, dividing camel function into military and non-military categories, with a greater emphasis on the former. This will aid us in contextualizing the origin of ancient military camel use and illustrate, as the sources permit, the traditions associated with their use which the Greeks and Macedonians adopt on an ad hoc basis while campaigning in the East.

\footnotetext{
${ }^{581}$ Worthington (2014), 32-38; Roth (2007), 368-9.

582 Roth (2007), 370-9; Sekunda (2007), Van Wees (2004a), 131-52; 326-30, 339-43; Hanson (1994), 2224; Adcock (1957), 71

${ }^{583}$ Diod.20.73-20.74.5; Roth (2007), 380-2.
} 
Additionally, chapter five will briefly examine Greek knowledge of the camel before and especially after Alexander's campaign. We will see that knowledge of the camel and its relatives expands, but the topic does not appear to constitute a point of interest for ancient writers, perhaps explaining the scarcity of reference to the animal in the otherwise detailed Alexander narratives.

Chapter six will examine the use of camels by the Macedonian army during Alexander's campaign in Asia (334-323). Here, the ancient narrative will be tempered by zoological studies of the camel, and reports of the animals' activities and endurance will be evaluated based on biological possibility and probability. In particular, I will use the Macedonian expedition to Siwah as a case study to evaluate the true advantages of cameltravel in a desert environment and challenge Engels' assessment of the dromedary's function in Alexander's army. Ultimately, Part II will come to the conclusion that played a demonstrably significant role in Alexander's campaigns and merit a place in the annals of ancient military history. 


\section{Chapter 5: Camels: The Context}

\section{PART A: Ancient Camel Use by Non-Greeks}

It is unsurprising that camels have long been used by ancient peoples for travel and subsistence, but their gangly, awkward appearance makes it difficult to conceive of effective use of camels in the military. However, evidence of "camel cavalry," or camels ridden by armed soldiers into pitched battle, can be found as early as the mid ninth century in the Battle of QarQar in the Levant; in this case, dromedaries made up the cavalry of the Arabian King Gindibu. ${ }^{584}$ The domestication of the camel, however, occurred long before this.

\section{Camel Biology \& Domestication}

Both types of camels, the dromedary and Bactrian, are members of the camelidae family along with "New World" camelids, the llama, alpaca, guanaco, and vicuna. The former camels are more familiar to us, colloquially distinguished as the "one-humped" and "twohumped" varieties [Images 5.1-5.6]. They are properly called the dromedary (Camelus dromedarius) and the Bactrian camel (Camelus Bactrianus), respectively, and despite similar evolutionary adaptations, they inhabit distinct ecological zones. The Bactrian camel today inhabits the dry steppe and semi-desert area from Kazakhstan to Mongolia, although they have been exported by humans as far west as Turkey, and as far south as India. The Bactrian prefers the Gobi steppe along the rivers, but when the snow melts, it may move into the desert. More versatile than its dromedary counterpart, the Bactrian

\footnotetext{
${ }^{584}$ Monolith Inscription of Shalmaneser III, Year 6, Col. II, lines 78-102, translated in Luckenbill (1926),
} 222-3. 
camel can withstand extreme cold and heat. The dromedary is often called the Arabian camel because of its origins on the Arabian Peninsula. While dromedaries are still raised there as herd animals, they no longer exist in the wild except for where they were imported to the Australian Outback, and the domesticated dromedary has spread to much of North Africa. ${ }^{585}$

Although the Old World camelids are more familiar to us, it was the "New World" camelids that evolved first, emerging as far back as the Tertiary Period; animals more clearly recognizable as camels, those that constitute the "main evolutionary line" 586 emerged in the Miocene and Pliocene periods and began migrating to the "Old World" throughout the Pliocene. ${ }^{587}$ Within Asia, the ancestors of the Bactrian and dromedaries separated, inhabiting different regions and slowly developing the means to cope with their habitats. Early camelids dwelled in dry open plains, with the ancestors of Bactrians living in the far East, western Asia, and as far north as the southern borders of Russia, in the case of the now extinct Camelus knoblochi. ${ }^{588}$ The ancestors of the dromedary moved into the Middle East, the Arabian Peninsula, and parts of North Africa as far west as Morocco. The earliest domestication of camelids occurred only by about 5500 in South America, and even later in the "Old World," although specific timelines are debated. ${ }^{589}$

The domestication of dromedaries first occurred either in in North Africa, around modern Somalia and Eritrea, or on the Arabian Peninsula around the turn of the third millennium. ${ }^{590}$ It is possible that the dromedary was first domesticated here for its milk

\footnotetext{
${ }^{585}$ Cf. Nowak (1999), 1078-1081; Fowler (1994), 526-7.

586 Gauthier-Pilters and Dagg (1981), 4.

${ }^{587} \mathrm{Wu}$ et al. (2014), 10 fig. 3; Gauthier-Pilters and Dagg (1981), 4-5.

588 Gauthier-Pilters and Dagg (1981), 4-6.

${ }^{589}$ Ibid., 117ff; Fowler (1993), 526-7.

${ }^{590}$ Ibid.; Kohler-Rollefson (2000), 3.
} 
and meat, but off the coast of Abu Dhabi on the island of Umm an-Nar the dromedary appears in what Kohler-Rollefson suggests is a trade context with the Asian mainland. ${ }^{591}$ A fourth millennium camel figurine has been unearthed in modern Oman, but archaeologists can only speculate on its significance, as it is not clear indication of domestication. Bactrian camels were domesticated at least as early as 2500 and brought as far west as Anatolia by humans; they appear to have been used primarily as beasts of burden, and clay figurines of this time period have been uncovered in the Kopet Dagh foothills of Turkmenistan, indicating camels were used to pull carts. Archaeological evidence of Bactrian camels as caravan animals appears in Pirak, Pakistan, and evidence of domestication for wool products appears in Shahr-i- Sokhta, Iran. ${ }^{592}$

It would make sense that the Arabian Peninsula was the origin of dromedary domestication, as it was certainly the origin point of camel cavalry. By the first millennium references to camel cavalry are often linked to the Aribi, or Arab tribes that used them. ${ }^{593}$ Pictographic depictions of camel cavalry from the seventh century reveal a technique of dual mounting that appears to have remained unchanged up through Diodorus' time, as he describes the same method among the Arabs, as we shall see. ${ }^{594}$ Longstanding traditions of camel use are important aspects of a complete study of the camel's role in ancient Greek warfare, as the animal was entirely foreign to the Greeks, who came to adopt it for the services in which it had been trained.

\footnotetext{
591 Ibid.

592 Trinks, Burger, Benecke, and Burger (2012) 79-86; Nowak (1999), 1078; Kohler-Rollefson (2000), 4.

${ }^{593}$ Kohler-Rollefson (2000), 4.

${ }^{594}$ Rabb (2011); Diod. 2.54.
} 


\section{Camel Use: The Sources}

Investigating the early eastern military use of the camel before the Persian adoption of it (and hence the emergence of Greek records) requires a close reliance on inscriptional cuneiform references to camels under Assyrian reign as well as archaeological evidence. Before Alexander's invasion of Asia, there was limited Greek knowledge of camels and their use in other parts of the world, so the Greek accounts began late. Herodotus' work provides us with the earliest Greek accounts of camel use, and he primarily focuses on the animals' military capacity in early eastern wars. Xenophon's Cyropaedeia augments this in its reconstruction the emergence and effectiveness of the Persian camel corps of Cyrus the Great. Post-Alexander authors like Diodorus and Strabo provide details on lesser-known camel-herding tribes and the varying cultural and functional uses of the animal. The majority of these accounts discuss primarily the dromedary, although in some accounts the camel type cannot be identified due to overlapping zones of habitation. What follows is a survey of non-Greek camel use divided by function, and subsequently by chronology, with particular focus on the military role of the animal. From this survey, some general conclusions can be drawn, namely that (1) The use of camel cavalry originated with Arabian tribes, (2) non-Arabian Eastern states occasionally adopted camel cavalry with success, (3) camels played a significant role in military transport (rather than as chargers) in Asia; and (4) Greek contact with camels was extremely limited before Alexander's invasion of Asia.

\section{Camel Military Function: Cavalry}

The earliest reference to eastern camel-mounted soldiers is the Biblical 
description of the Midianites and Ishmaelites, peoples of the Arabian Peninsula, who regularly raided the farms and fields of the Israelites, riding in atop myriad camels. Kohler-Rollefson dates this series of events to the late twelfth or early eleventh century and notes that the archaeological record of the Levant supports it, yielding dromedary bones within the same time period. ${ }^{595}$ Epigraphic evidence of this Arabian technique reveals that it was not used only for raiding villages, but also for pitched battle. The earliest pitched battle involving a camel corps can be dated to 853 at the Battle of QarQar, which pitted the Assyrian king Shalmanaser III against a coalition of twelve kings. The coalition is enumerated in Shalmanaser III's victory monument, the Kurkh Stele or Monolith Inscription, which reveals that one of his opponents, the Arabian king Gindibu contributed a camel corps force of 1,000 to the battle, along with other kings' infantry, cavalry, and chariot forces. ${ }^{596}$

Even though the Assyrians generally defeated dromedary warriors in battle, Kohler-Rollefson notes that they were "sufficiently impressed to integrate them into their national security system. $" 597$ The seventh century Assyrian king Esarhaddon used a camel corps to invade the Egyptian city of Thebes, and it is conceivable that camel training began before preparations for this expedition, as camels were taken in large number as war prizes as early as the seventh century. The Assyrian king Tiglath-Pileser III reportedly seized all of the Bactrian camels of the peoples of Bit-Kapsi, Bit-Sangi, and Bit-Tazzakki, and 30,000 dromedaries from the Arabian Queen Samsi following her

\footnotetext{
595 Judges 6:5; Kohler-Rollefson (1993), 182-3.

${ }^{596}$ Monolith Inscription of Shalmaneser III, Year 6, Col. II, lines 78-102, translated in Luckenbill (1926), 222-3.

${ }^{597}$ Kohler-Rollefson (1993), 184. In addition to the dromedaries Shalmaneser III captured or killed in Gindibu's army, the Assyrian king received Bactrian ("two-humped") camels as tribute from Asu the Guzanite, which he transported to Assur, the Assyrian capital. See Luckenbill (1926), 213-214 for the Monolith Inscription, Year of accession, Col. I lines 12-29).
} 
defeat in battle. ${ }^{598}$ References to both types of camel and careful, repeated emphasis of the seizure of "camels, female camels, together with their young," $" 599$ in Tiglath-Pileser III's inscriptions, supports Potts' theory that the Assyrians (at least by the $8^{\text {th }}$ century) might have been cross-breeding camels to produce a strong hybrid. ${ }^{600}$

A seventh century orthostat from Carchemish, a Syrian city along the Euphrates, reveals the way in which camels were mounted and evidences the Assyrian adoption of this Arabian style of riding. The orthostat depicts a dromedary ridden by an archer amid a lion hunt and constitutes the "earliest North Syrian depiction of this animal (and transportation on it)." ${ }^{901}$ A relief at Nineveh provides further detail; it depicting an Assyrian battle with Arabs, who ride double on a dromedary. The first Arab warrior wields a short spear, and on the back, his companion turns around to aim a bow. This Nineveh relief was commissioned during the time of Assurbanipal, the son of Esarhaddon whose invasion of Thebes involved the Assyrian use of a camel corps. ${ }^{602}$ Likely the style of fighting with projectile weapons and riding double depicted on Assurbanipal's relief was utilized in Esarhaddon's campaign as well. As Assyrian access to dromedaries came from Arabia, it is unsurprising that the same methods of riding and fighting (or hunting) from camelback were also imported. The Arabian technique of riding double on camelback and firing arrows mid-canter is also described much later Greek writers, revealing little change (Diod.2.54).

We may turn now to a less-certain account, that of the Assyrian queen Semiramis,

\footnotetext{
598 Tadmor (1994); Luckenbill (1926), 223, 271-2.

${ }^{599}$ Luckenbill (1926), 276 and 287

${ }^{600}$ Potts (2004), 158-61.

${ }^{601}$ Gilibert (2011), 118.

${ }^{602}$ Rabb (2011), 7-8.
} 
wife of Shamshi-Adad and queen regent for her son, involves an outlandish account of elephant mannequins and a thwarted invasion of India, but it does reveal an historical pattern: the adoption of camel cavalry by the Assyrians. ${ }^{603}$ This legendary account comes from Ctesias and has been transmitted through Diodorus, and it must be examined with a critical eye. Diodorus writes that Semiramis had planned the invasion of India for years and mustered her forces in Bactria, which amounted to an improbable: three million infantry, two hundred thousand cavalry, and one hundred thousand chariots. Among the cavalry were one hundred thousand camel riders who carried swords like cavalrymen, but the weapons were an astounding four cubits in length (Diod.2.17.1-2).

The improbable size of the sword fits well with the absurdly high number of troops at Semiramis' disposal. Although a four cubit sword is almost certainly impossible to wield effectively, Diodorus' exaggeration does address the real functional problem of using bladed weapons from camelback. Due to a camel's height and the difficulty of remaining seated atop one, projectile weapons like the bows and spears depicted in the Nineveh relief are the only feasible option. While it is certainly possible that Diodorus or Ctesias meant to describe a four cubit spear, rather than a sword, that would still have to function as a thrusting spear, rather than a javelin that can easily be aimed and launched by hand, and the length is too great. The account is cast further into doubt by Semiramis' alleged construction of an army of fake elephants, which were propelled underneath by camels and meant to frighten her enemies' war elephants (Diod.2.16.9-10).

While the fake elephant corps is probably fictitious, there is a kernel of truth built

\footnotetext{
603 The legendary tales associated with Semiramis (Sammuramat) are difficult to reconcile with her nebulous historical presence. Inscriptions uncovered from Assur include one that contains the name of Sammuramat, naming her only in relation to other kings, her husband (Shamshi-Adad), her son (AdadNirari), and her father-in-law, Shalmaneser. See Luckenbill (1929), 260.
} 
into the account. Diodorus notes that Semiramis was careful to bring her cavalry around the fake elephants to accustom the horses to the sight before battle, and so presumably also the smell of camels (Diod.2.17.3). This reflects a realistic precaution that would have had to precede battle for generals using both camels and horses, unless the animals were deployed at separate intervals as Cyrus did. Similarly, the account of camels' presence in Semiramis' army during her invasion of India should not be discounted entirely, even if the weapons of the camel corps and the dummy elephants appear unrealistic. Because Semiramis mustered her army in Bactria, it is possible that the Assyrians were using Bactrian camels as pack animals by this time. Diodorus does add that Semiramis used her camels to transport boats overland between rivers (Diod.2.17.1-2). Archaeological evidence would support this, as Bactrian camels were domesticated even before their dromedary relatives, roughly $2,700 .^{604}$

The Persians too adopted the camel into their military, although the animal served primarily for the transport of supplies and were often procured by or with the assistance of Arabs. There is however one important exception, Cyrus the Great's clash with Croesus. The account is preserved by Herodotus and Xenophon in his Cyropaedeia. Herodotus was the first of many western authors to note that horses are naturally frightened of camels, ${ }^{605}$ and his account of the use of camel cavalry involved the exploitation of this natural adversity. The use and, according to Xenophon, the "invention" (Xen.Cyro.6.1.30) of the camel corps occurred on the Persian side of the war between Croesus and Cyrus the Great. The camels ultimately played a pivotal role.

Anxious that Croesus' superior Lydian cavalry would get the better of him, Cyrus

${ }^{604}$ Kohler-Rollefson (1993), 182.
${ }^{605}$ Hdt.1.80,7.87; Xen.Cyro.6.2.18, 7.1.27,7.1.48; Diod.2.17.3; Polyaenus7.6.6; PlinyNH8.26. 
mustered his forces and ordered his pack camels to be unburdened and mounted like horses, allegedly at the last minute. At least some of the camel riders were bowmen; Xenophon specifies that two archers were mounted on each camel (Cyro.6.2.8), a tactic also used by the inhabitants of Arabia Eudaemon (Diod.2.54). Knowing that horses "could endure neither the sight nor smell of them," ${ }^{606}$ Cyrus put his own horses and infantry behind the camel corps, indicating that the camels would have followed the scythed chariots that opened the charge (Xen.Cyro.6.3.32-34).

That this was a last-minute change of plans, as Herodotus and Xenophon suggest, seems unlikely for several reasons. The mounted bowmen would have to have practiced riding and shooting from camelback, which is quite different from riding on a horse. Additionally, one wonders if camels trained as pack animals could have been made to charge against enemy cavalry (Xen.Cyro.7.1.27). The Border Security Force of present day India utilizes military dromedaries that are trained to execute a number of movements; they can be urged to charge much as horses can, with heels digging into their sides and jerking the reins attached to their nose. However, the camel must undergo a period of basic training to respond effectively, and this could take several weeks. ${ }^{607}$ Herodotus and Xenophon both indicate that this hasty change in deployment was effected because of Croesus' reliance on his cavalry and Cyrus' on-site recognition that horses fear camels. Since Cyrus clearly had at least pack camels in his retinue, he would already have been aware of the natural antipathy between the two animals. Whether or not he was aware of the degree on which Croesus would rely on his cavalry is unclear, but it seems doubtful that his camel corps was invented spur of the moment. The tradition of riding

${ }^{606}$ Hdt.1.80; cf. Xen.Cyro.6.2.18.

${ }^{607}$ Gahlot and Chadha (2000), 582-3. 
camels into battle, as we have seen, is not new, and certainly not Cyrus' invention.

Cyrus' use of camels against the Lydian cavalry however, should not be in doubt. Although camels cannot outpace horses, they would not have needed to if Cyrus held his cavalry and chariots back until the retreat of the enemy cavalry. He must have been entirely certain of horses' disdain for camels to risk opening a charge with these animals, as their riders would not have been heavily armed or able to keep up with the speed and agility of enemy horsemen should the Lydian cavalry have attempted to engage them in battle. However, Cyrus' suspicion proved true; Croesus' Lydian cavalry fell into disorder as the horses reared and retreated, frightened by the camels. The Lydian cavalrymen dismounted and fought by hand, costing Croesus the battle. ${ }^{608}$

Cyrus' victory against Croesus was a psychological one. The Lydian soldiers lost their horses due to fear, and the men would have been cut down by Cyrus' cavalry (presumably launched after the camel attack) and scythed chariots (Xen.Cyro.6.1.27-30), but probably not by the soldiers on camelback. Had the Lydian cavalry not fled, the camel corps would have been in dire straits indeed. Xenophon suggests that after Cyrus, camels were retired to permanent duty in the baggage train, as they were not effective mounts for soldiers in close-quarters fighting. Archers could fire from their backs, but because horses would not bear being near them and camels cannot catch up to a speeding horse, it would be difficult for a camel-rider to inflict damage on a horseman. ${ }^{609}$ Furthermore, even modern saddles for camels do not make riding easy, and brandishing a heavy blade on camelback with the camel charging at fifteen or twenty miles per hour

\footnotetext{
${ }^{608}$ Hdt.1.80; Xen.Cyro.7.1.27-28; Polyaenus 7.6.6.

${ }^{609}$ Xen.Cyro.7.1.48; see Gauthier-Pilters and Dagg (1981), 109-11, 125.
} 
would not be the most efficient means of fighting. ${ }^{610}$

Interestingly, despite the fact that the camels were the first animals on the field during this battle, Xenophon gives the victory to the Persian horses (Cyro.7.1.46), deriding the camel riders: "All they did was to scare the horses; their riders could take no part in the slaughter, and were never touched themselves by the enemy's cavalry" (7.1.48). This seems to discount his earlier reference to archers on camelback (6.2.8) and ignores the psychological impact of the animals and its direct tie to the Persian victory, which relied largely on the collapse of the Lydian cavalry. Xenophon's judgment is not analytical, but personal; he claims that "it was a useful arm, certainly, but no gallant gentleman would dream of breeding camels for his own use or learning to fight on camelback" (7.1.49). It was for this reason, he claims, that camels were put on permanent baggage duty thereafter.

With the exception of the incorporation of Arabian units into the Persian army, Xenophon's assessment appears to be true. During the reign of Cambyses II, the son of Cyrus the Great, camels only appear in the role of transport animals. Cambyses' invasion of Egypt, camels were used to transport water through the desert. Cambyses with the Arabs to fill camel skins with water, which would then be loaded on the backs of camels and transported to the desert to wait for the arrival of Cambyses' army (Hdt.3.7-3.9). Herodotus' self-described "less likely" account of Cambyses' preparation is not entirely unlikely. Although the aqueducts that he reports were made of ox hide and led from the

\footnotetext{
${ }^{610}$ Ancient depictions of camels are suggestive of, but do not allow total reconstruction of, saddle type, but modern varieties may lend some insight. The position of the saddle is limited, and third millennium evidence indicated that the first camel riders preferred to ride the crupper, or the forepart of the camel. The saddle cannot be placed directly atop the hump, which consists largely of fat and has the tendency to deform based on diet and pressure, but it may be placed in front of, against, or behind. By the sixth century, the North Arabian saddle's invention made riding into battle on camel back easier. See Tabbaa (2012) 164; Dostal (2012), 123-5.
} 
Red Sea to the desert are clearly mythical (Hdt.3.9.3), the account of underground water cisterns stationed throughout the desert is not. In fact, this reflects a later practice of camel drivers in the Sahara, which includes the Libyan Desert of Egypt. Underground cisterns placed several days' travel apart could water camels and people sufficiently to permit continued travel even in extreme climates. The exact origin point of desert pit stops like this is unknown, but they are referenced by the late fourth century (Diod.19.94.7-9) and have been used throughout history. Herodotus, perhaps unwittingly, records a factual solution to the problems of desert travel and camel herding in arid climates.

After Cyrus, the use of dromedary chargers was limited to their origin point, Arabia, although Bactrian camels appear to have been used for the same purpose by other peoples. Herodotus records that the Arabian, Caspian, and Parikanian contingents of Xerxes' invading army in 480 all rode on camels that were "no less swift than horses." 611 These regiments were marched behind the Persian horses to avoid scaring them (Hdt.7.87). These particular camels did not participate in any pitched battles, but in fact many were eaten by lions in Crestonia before they reached Greece (7.125). A number of the camels must have survived, as those that had been present behind the Persian lines at Plataea were distributed as prizes among the Greeks (9.81.2). The camel corps of Xerxes' army likely contained a combination of Bactrian and dromedary camels, given the regions from which his camel-riders came. The Arabian Peninsula is home to dromedaries, but a late fifth century painting of a camel on a Greek vase, ridden by a Persian, portrays a rather accurate image of the Bactrian type. Romm suggests that the

${ }^{611}$ Hdt.7.86.2; he refers again to Arabs riding camels through Thermopylae at 7.184.4. 
camel may have been depicted so faithfully because it was a descendent of one of the animals captured after Plataea and painted from life. ${ }^{612}$ If painted from an eastern image instead, its depiction of a Persian rider nonetheless illustrates the Greeks' failure to distinguish among the many and varied forms of military combat in the East.

The Arabian tribe of the Debae also made use of camel chargers. Diodorus discusses the tribe and emphasizes that the Debae relied on camels for "the most important needs of their life," namely: milk, meat, hair, and as military chargers (3.45.45). Strabo notes the same reliance upon camels existed among the Nabateans, another Arabian people who also used camels as battle chargers $(16.18,16.26)$. Neither author notes the type of weapon used, but presumably it was the age-old combination of bows and short throwing spears. A much later account of a Parthian camel corps in the third century CE indicates that this continued to be the tradition. Artabanus IV's Parthian camel brigade that temporarily fended off the army of Caracalla in 217 was armed with short throwing spears (Herodian Hist.4.15.1). Ultimately their dromedaries were defeated by caltrops which the Romans dropped from their horses after feigning a retreat, destroying the camels' feet. ${ }^{613}$

Diodorus provides a detailed account of the effectiveness of the Nabatean camel cavalry both in speedy desert travel and disorganized fighting through ambush. After having conquered Syria and Phoenicia in the late fourth century, one of Alexander's "successors," Antigonus Monopthalmus, made an attempt on the Arabian land of the Nabateans, which had long been unconquered by Mede and Persian kings of the past. ${ }^{614}$

\footnotetext{
612 Romm (2005), Fig.9.81b.

${ }^{613}$ Herodian, Hist.4.15.3. These caltrops are likely the same sort of device utilized by Ptolemy against Perdiccas' elephant corps (see pp.74-77).

${ }^{614}$ Hdt.3.4-9; see Champion (2014), 98-99.
} 
Diodorus credits the Nabateans' long-lived independence to their ability to make the desert their fortress, able to flee to it and outlast their enemies, who invaded on horseback (19.94.6). By secretly digging out underground reservoirs, a technique still used in modern camel herding societies, the Nabateans could occasionally water their animals and avoid encamping in one place for very long. They trained their herds to go without water for a time in order to facilitate steady movement through the desert (19.94.7-9).

Indeed, it was this ability that prevented the Nabateans from losing their freedom to Antigonus' general Athenaeus, who seized the high rock citadel where the Nabatean women, children, and goods were kept during the trading season. Athenaeus took his men and prisoners on a forced march from the captured rock and made camp by night, expecting that the Nabateans could not muster a force and catch up with him for two or three days. However, camels manage the desert terrain and climate more easily, especially by night, and a horde of 8,000 Nabateans caught up with Athenaeus before sunrise, sacking the camp and reclaiming their prisoners and goods. Most of Athenaeus' men were killed, dispatched by javelin from camelback; Diodorus specifies that fifty horsemen survived, but many of them were also wounded (19.95.1-6).

Antigonus' retaliation to this loss of over 4,500 men ${ }^{615}$ once again showcases the dominance of the camel brigade in Nabatean territory. Although Antigonus initially claimed that Athenaeus' actions were not due to any orders he himself gave, he quickly sent his son Demetrius to avenge his soldiers. Diodorus notes Demetrius' careful preparations: packing three days' worth of food that did not require cooking (and presumably water too) and taking along 4,000 light-armed infantry and the same number

615 This number was derived from the men listed at 19.94.1 and the number of dead listed at 19.95.6. 
of cavalry. The Nabatean response was simple and practical: they divvied up their flocks (of sheep and of camels), sent them into the desert, leaving nothing for Demetrius' army to seize or eat. As a result, Demetrius withdrew his men from the fortress after only two days of besieging it.

Although Diodorus claims Demetrius was swayed by the speech of the Arabs, which reminded him that they had nothing for him to seize more precious than water, ${ }^{616}$ it is more likely that Demetrius' men lacked sufficient supplies to continue the siege, a fact which the Nabateans also, supposedly, noted: "For neither can you, if you wish, remain here many days since you lack water and all the other necessary supplies" (Diod.19.97.5). The army's three days' of rations would have been consumed on the road (19.97.1), and because the Nabateans had evacuated their herds to the desert, Demetrius' army could not live off the land either. Waiting longer would make his men and horses too vulnerable to a Nabatean onslaught like that which decimated Athenaeus' regiments. For treating with the Nabateans instead of punishing them, Demetrius was rebuked by his father (19.100.1), and the Antigonids never successfully subdued Arabia.

Thus we have seen that while a camel corps was successfully employed by Cyrus on one occasion, they were not ideal for the Greek or Persian means of close-quarters combat. They are neither as quick nor as agile as horses, and a cavalry accustomed to camels would not have difficulty defeating their light-armed riders. However, in their arid and sandy domain, camels reign supreme. The guerrilla-like combat of the tribes of the Arabian Peninsula and Jordan as well as the terrain and climate made the use of a dromedary camel corps practical, but it was not easy to export this practice throughout all

${ }^{616}$ Diod.19.97.3-6; Cf. Plut. Demetrius 7.7 says Demetrius captured 700 camels successfully. 
of Asia. Up until this point, we have discussed only the dromedary in battle.

Unfortunately little is known of the use of the Bactrian camel mount, although Aelian does specifically mention, contrary to modern assumption, that the animals were used in battle. ${ }^{617}$ Because they are shorter, and have a more even gait than the dromedary, Bactrian camels would have made steady mounts, and their ability to withstand both drought and snowfall make the use of them as far west as Anatolia conceivable. ${ }^{618}$ However they, like their dromedary relatives outside of Arabia, appear to have functioned primarily as pack animals.

\section{Camel Military and Trade Function: Transportation}

The use of camels to transport military supplies in antiquity is well-attested and unsurprising in the East. Employed by Indians, Persians, Arabs, and probably Bactrians, both the Bactrian and dromedary camels facilitated long-distance trade and marched with ancient armies (presumably behind the horses) carrying necessary supplies. Because of their ability to bear a greater burden than horses and their high tolerance for inclement weather and food and water shortages, they were ideal baggage animals.

Herodotus mentions the Indians' use of riding camels when they hunt and steal from the famous gold-digging ants. He appears to be describing a dromedary, although both types of camel are known to India. While the ants are an obvious fiction, the details Herodotus provides about camels are logical and accurate and reveal knowledge of the animals' physiological virtues: heat tolerance, relative speed, and strength. While Indians

\footnotetext{
${ }^{617}$ Ael.NA. 55; cf. Potts (2004), 153 who asserts that the Bactrian camels were not ridden until the rise of the Mongol empire.

${ }^{618}$ Potts (2004), 147-150; Nowak (1999) 1078-81; Gauthier-Pilters and Dagg (1981), 3, 120-121.
} 
did not use camels to chase down dog-sized ants, they certainly could have used them to transport precious metals, among other goods.

Herodotus claims that Indians stole their gold from the ants in the morning, at which time in India the sun is so hot that locals sprinkle themselves with water and the ants retreat belowground (3.104). Indeed, dromedary camels, such as may be found in India, can regulate their body temperature up to 104 degrees Fahrenheit as needed to match the environment and prevent water loss through perspiration. ${ }^{619} \mathrm{Next}$, the Indians would load up their camels quickly before mounting them and fleeing. Herodotus notes that "their camels are as swift as horses, and much better able to bear burdens besides" (3.102.3). While a camel cannot run as quickly as a horse in an absolute sense, it could very likely outpace an equally burdened horse on sandy terrain. The wide diameter of a camel's foot enables it to walk on the sand without sinking deeply, and long legs provide a long stride even at a reasonable trot. Because of the arch principle, the camel is also able to carry a heavier burden than a horse. Its convex back evenly distributes weight across its body, allowing for up to about $150 \mathrm{~kg}$., which is about the maximum weight with which the camel can rise from kneeling. If loaded while standing, the camel can conceivably bear up to $300--400 \mathrm{~kg}$. Because a camel's hindquarters are slightly weaker due to a smaller foot diameter, the weight a camel can raise itself with is generally its limit. $^{620}$

The Persians also used camels extensively for transport and trade. Both Bactrian and dromedary camels would have been accessible within the expanse of the empire, and it is likely that both were used depending upon the location. Both types of camel appear

\footnotetext{
619 Gauthier-Pilters and Dagg (1981), 59-77.

${ }^{620}$ Gauthier-Pilters and Dagg (1981), 109-110. On 400kg, see Kohler-Rollefson (2000), 8.
} 
in Achaemenid iconography ${ }^{621}$ and occasionally in Greek art within a Persian context. ${ }^{62}$ Xerxes took camels across the Hellespont and into Europe in 480. While his Arabian allies rode them, the Persians employed them as pack animals as well. Possibly these were Bactrian camels, who can bear about 270 kilograms of weight, ${ }^{623}$ while the Arabian mounts would have been dromedaries. Herodotus and Aelian both reference Xerxes' use of baggage camels ${ }^{624}$ especially because many of them were eaten by lions. Pack camels were also present at some of the major conflicts of the Persian Wars, including Thermopylae and Plataea (Hdt.7.184.4, 9.81), after which they were seized by the victors as booty. It is unfortunate that we do not know the fate of Pausanias' camels or to what use, if any, the Greeks put them (Hdt. 9.81).

As we have seen above, many nomadic Arab tribes "get their livelihood from camels," which includes their use for transport and trade as well as military mounts. ${ }^{625}$ Trace references to other nomadic peoples' use of camels for trade appear throughout Strabo's Geography, and he describes what are certainly Bactrian camels. For example, Strabo mentions that it was because of the camel that the Aorsi tribe on the shores of the Caspian Sea dominated trade, as they could import Indian and Babylonian goods on camelback from among the Armenians and Medes, who served as middlemen, an indication of how widespread the use of the Bactrian camel had become for trade. According to Strabo, the measure of their success was their heavy use of gold ornaments in adornment (11.5.8). The "camel-breeders," who presumably made a living from their

\footnotetext{
${ }^{621}$ Potts (2004) 151-2; Curtis and Searight (2003), 229 fig.6 image 50; Boardman and Vollenweider (1978) items 104, 117, 121.

${ }^{622}$ Romm (2005), Fig. 9.81b.

${ }^{623}$ Potts (2004), 147.

${ }^{624}$ Hdt.7.83, 7.125; Ael.NA.17.36.

${ }^{625}$ Strabo 16.18, 16.26; Diod.4.35.4-5.
} 
stock, lived also in northern Persis where it is "wintry and mountainous" and farther north than where cattle breeders dwelled (Strabo 15.3.1). The heavy winter coat that Bactrian camels grow make them the only candidate for this description.

However, the Bactrian camel also has an excellent toleration of heat and can shed their winter fur in the warm months, and it might be this type of camel that was used in Mesopotamia, where camel drivers traveling from the Euphrates to Scenae had set up a sort of pony express for camels, with pit stops and underground cisterns filled with water between long stretches of desert (Strabo 16.27). The location of Alexander's most famous battle, Gaugamela, in fact translates to "Camel's House" and was so named by Darius I for the camel "which helped most on the toilsome journey through the deserts of Scythia [the Gobi Desert] with the burdens containing sustenance and support for the king" (Strabo 16.1.3). It is likely that some Scythian tribes kept camels as well, as Bactrian camels are native to the region and would prove especially useful for a nomadic society. Unfortunately there is no record of the Scythian use of camels other than Aelian's reference to the Massagetae tribe, whose camels, he claims, have greater sexual propriety than the Massagetae themselves (NA 6.60).

Because this chapter focuses on the Greek military use of the camel, discussion of non-military use of the camel by non-Greeks is limited. The above demonstrates that camel use was both widespread and multifaceted in the ancient East, and that both dromedaries and Bactrian camels were used in trade and military transport. Despite Xenophon's balking that a kalos k'agathos (Cyr.7.1.49) would never deign to train or mount a camel, Alexander's army adopted the camel into its military menagerie rather readily. 


\section{PART B: Greek Knowledge of the Camel: Aristotle, Diodorus, and Strabo}

Greek knowledge of the camel expanded considerably following Alexander's invasion of Asia, but the animal is discussed only in a limited fashion. The fourth century philosopher Aristotle, unsurprisingly, provides the most detail, and the majority of his accounts are accurate. Possibly through Alexander's patronage, ${ }^{626}$ the philosopher gathered enough information about camels to include references to them in his Historia Animalium, De Partibus Animalium, and De Generatione Animalium. Perhaps because camels were neither as foreign or as exotic as elephants, they receive far less attention in the philosopher's analysis. ${ }^{627}$

Generally, Aristotle references camels as illustrative examples of broader trends, including factual information in a list of examples rather than providing a discourse dedicated to camels specifically. This is part and parcel of his analytical approach of distinguishing differences between animals and then seeking the cause (HA 1.6). As we shall see, Aristotle's detailed knowledge of a camel's organs strongly suggests that he dissected them, although it seems unlikely that he studied any living camels in person. The not quite accurate generalizations about camel locomotion, reproduction, and behavior is suggestive of reliance on reports rather than direct observation. On the whole, Aristotle's assessments are generally correct, but there are a few significant exceptions. Briefly, we will consider the sort of information Aristotle provides, organized by topic rather than by work, and we will discuss any inaccurate information.

\footnotetext{
${ }^{626}$ As discussed in Part I (cf. pp. 40-41) there is limited evidence for Alexander's scientific patronage of Aristotle, and the philosopher may well have gathered this information from the reports of others, including his students.

${ }^{627}$ Cf. Scullard (1978) 37-52.
} 
In his longest discourse devoted to camels (HA 499a14-31), Aristotle differentiates the Bactrian from the Arabian (dromedary) camel based on the number of humps, and generalizes about both sub-groups of the animal thereafter, drawing comparisons with more familiar animals for his readers. He notes that camels have four teats as a cow does, a tail resembling a donkey, a knucklebone like an ox, and like many ruminants, camels are not ambidentate. Additionally, Aristotle adds that camels are cloven-hoofed. This appears to be a mere taxonomic detail, and indeed Aristotle grouped animals this way. He writes that camels have many traits similar to cloven-hoofed animals such as multiple stomachs, the tendency to ruminate, and a lack of a complete set of teeth, even though camels, unlike their fellow cloven-hoof animals, lack horns (PA.674a-b). However, the status of camels as cloven-hoofed animals reappears throughout his works in several places. ${ }^{628}$ In his Historia Animalium, Aristotle even defends his categorization with a specific illustration:

\footnotetext{
"It [the camel] is cloven-footed, and not ambidentate. It is cloven-footed in the following way: at the rear there is a small cleft reaching as far as the second joint of the toes; in front there is a cleft for a long distance, right along as far as the first joint of the toes; and there is something stretched across the clefts, like the webbing on a goose's foot." ${ }^{629}$
}

Because Aristotle was a prolific writer, it is not unusual that he would repeat facts, especially across the span of multiple works. However, the reference to camels as clovenhooved occurs at least five times and includes a justification for such a statement, which suggests that the fact was somewhat debated. Indeed, an Eastern categorization enshrined in the Old Testament groups camels among non-cloven-hoofed ruminants, making them ritually unclean animals because they chew the cud but do not have a split hoof. ${ }^{630}$ If this

${ }^{628}$ PA688b24-25, 689b1; GA771b10-11.

${ }^{629}$ Arist. HA 49a24-28.

${ }^{630}$ Leviticus 11.3-4; Deuteronomy 14.6-7. 
was a generally accepted fact among those who worked with camels in the Levant and considered the status of its hooves significant, Aristotle would have needed a defense for his reinterpretation.

Although his explanation is accurate in terms of description, Aristotle's categorization is incorrect. Camels are not cloven-hoofed; the split in the center of the foot is actually a split between two toes, not a cleft in a hoof. Camels still belong to the order Artiodactyla with other cloven hoofed animals, but this only indicates that they bear the brunt of their body weight on their third and fourth toes, the most developed of the two. A camel's hoof is not cloven but flat, measuring about 18-19 centimeters wide. The sole of a camel's foot, quite unlike a hoof, is very tender and easily bruised by walking over rough or rocky terrain, a fact which Aristotle himself notes, adding that in wartime camels sometimes had leather shoes applied to the base of their feet to prevent injury; this cushioning technique is still used today. ${ }^{631}$

The other details that Aristotle provides suggest that he received comprehensive reports on camels and may also have dissected them. For example, he notes that camels move laterally rather than diagonally, unusual for quadrupeds, ${ }^{632}$ and he is able to provide accurate information about camel genitalia and mating habits. ${ }^{633}$ However, in this case his numbers vary just enough to indicate that he might have relied on vague reports and generalizations. For example, Aristotle suggests that female camels generally mature by age three and maintain a year between a birth and new pregnancy. However, zoologists have shown that camels are much slower reproducers. The animals do not become

${ }^{631}$ Aristotle $H A$ 499a28-31; Gauthier Pilters and Dagg (1981), 102.

${ }^{632}$ Aristotle HA 498b8; Saber (2000) 104-109; Gauthier-Pilters and Dagg (1981), 101.

${ }^{633}$ Aristotle HA 500b, 540a13, 546b1, 571b20-25. 
capable of reproducing until age four or five, and female camels wait at least two years between birth and pregnancy because of the amount of time a calf remains with its mother. ${ }^{634}$ The gestation period of a camel is twelve to thirteen and a half months, which Aristotle estimates at ten or twelve (HA 578a and 546b), not far off, but also not the result of prolonged observation. In a similar vein, the philosopher's guess at camels' lifespan is a bit high at 50 years (HA.578a), but not impossible. Nowak notes that camels have been known to live up to fifty years, but even in the optimal conditions of modern captivity, their lifespan is generally thirty. ${ }^{635}$

Aristotle's close knowledge of the camel's innards also suggests dissection or detailed records from a witness of dissection. He records accurately that the camel lacks a gallbladder (PA.676b), a full set of teeth (HA501a13-16; PA674a), and that like horned ruminants, it has four stomachs (PA.674b) which aid in digestion. Indeed, depending on food and water availability, camels and their cloven hoof relatives are able to keep food content in their forestomach for maximum absorption for up to 74 hours. However, camels stand out in their unusual ability to breakdown and re-use protein through the recycling of urea in the kidney, making them more efficient nutrient recyclers. ${ }^{636}$ Interestingly, Aristotle does not make much of the camel's unusual ability to retain water and endure drought and dehydration, nor does he distinguish between the abilities of Bactrian and dromedary camels. Following the incorrect assertion that camels have to stir and muddy water before drinking it, ${ }^{637}$ Aristotle says without much marveling that camels can last four days without water, after which they will have to replenish lost

\footnotetext{
${ }^{634}$ Aristotle $H A$ 540a13 and 546b1; Chaudhary (2000), 466-7; Schwartz (1992) 49-64.

${ }^{635}$ Chaudhary (2000) 466, 476-7; Zhou (2000) 499, 503-4; Nowak (1999) 1078-81;Schwartz (1992), 49-64.

${ }^{636}$ Yagil (2000) 54-5; Schwartz (1992), 27-8.

${ }^{637}$ HA596a; cf. Gauthier-Pilters and Dagg (1981), 56.
} 
fluids. Perhaps this passage was the basis for Engels' model of camel water

requirements. ${ }^{638}$ However, it is not representative of both types of camels, nor does it take into account conditions of labor, heat, wind, and food availability, all of which impact a camel's water retention and energy levels. We will turn to those details in chapter six.

The first century historian Diodorus Siculus and the first century BCE-CE geographer Strabo both provide biological data on camels amid the ethnographical portions of their work, although this information is mostly limited to how camels are used by other peoples and, specifically, to dromedaries. The already incredible abilities of the dromedary are exaggerated in some of Diodorus' reports, which require reevaluation. For example, Diodorus asserts (2.54.5-7) that the camels raised in Arabia Eudaemon can carry the weight of five men atop a couch or the equivalent of 10 medimni (900 pounds) of grain, a gross exaggeration. ${ }^{639}$ The camels he describes must be dromedaries, based on their location. While dromedaries can bear greater weight than a horse because of the "arch principal," 640 they can only rise from a kneeling position with about $150 \mathrm{~kg}$. of weight on their backs. Although they can bear about double that if loaded while standing, they can only carry it for a limited duration; ${ }^{641} 10$ medimni of grain would not be feasible. The standard weight for a pack camel is $150-200 \mathrm{~kg} .{ }^{642}$

However, Potts has posed a reasonable explanation for this in her suggestion that the ancients were cross-breeding camels in order to produce the much stronger F1 generation, which would have been capable of carrying up to 1,000 lbs. Unfortunately

\footnotetext{
${ }^{638}$ Engels (1978), 129-130.

${ }^{639}$ If one midimnos equates to roughly 52.18 liters, and one liter of wheat grain weighs $1.74 \mathrm{lbs}$., that totals about 908 pounds.

${ }^{640}$ Saber (2000), 90-93; Gauthier-Pilters and Dagg (1981), 109.

${ }^{641}$ Gauthier-Pilters and Dagg (1981), 109-111.

${ }^{642}$ Kohler-Rollefson (2000), 8; Gauthier-Pilters and Dagg (1981), 109-110.
} 
archaeological evidence to support crossbreeding does not emerge until the Parthian Period, far too late for this study, but circumstantial evidence such as the Persian receipt of tribute in camels indicates at least a possibility of early camel hybridization. ${ }^{643}$

Diodorus' other assessments of camels are more accurate. He notes that dromedaries can travel a very great distance in a day even through waterless regions, their claim to fame. While camels are not the speediest of animals, they can make good time and maintain a decent pace over long distances, especially in hot, arid temperatures. Gauthier-Pilters and Dagg record the astounding feats of camels in the Sinai region and the Sahara: camels have crossed between Cairo and Gaza in two days' time and traveled over 90 miles in 20 hours or less in arid conditions while bearing riders. ${ }^{644}$

Both authors' use of the camel as a comparative standard in the description of other, more exotic eastern animals, suggests some degree of familiarity with the camel. Diodorus describes the "camelopards," or giraffes, primarily in terms of camel appearance, noting that they have a hump on their back as well and, incorrectly, that their necks are shorter than those of camels. ${ }^{645}$ Strabo repeats much of this information and correctly notes that the camelopards' necks are longer, but their forelegs are of similar length (Strabo 16.16). The association of camels and giraffes is quite apt, as the giraffe is the closest living relative of the camelid. ${ }^{646}$ Diodorus also discusses a less readily identifiable animal, the struthocamelus, which might be the ostrich. He compares the struthocamelus to a newly born camel, head bristling with fine hairs and wide eyes “indistinguishable in general appearance and color" from the camel (Diod.2.50.3-4). Such

\footnotetext{
${ }^{643}$ For the full argument, see Potts (2004), $157 \mathrm{ff}$.

${ }^{644}$ Gauthier-Pilters and Dagg (1981), 101-2.

${ }^{645}$ Diod.2.51.1; "longer" has been suggested, see n.2 in Oldfather (1939) Loeb.

${ }^{646}$ Gauthier-Pilters and Dagg (1981), 103.
} 
a comparison suggests Diodorus might have been misled by his sources.

Diodorus and Strabo report on many of the places where dromedary camels were raised, but do not discuss the Bactrian camels of Turkmenistan. In Arabia Eudaemon, dromedaries were the primary means of sustenance and travel for Arabs, providing milk, meat, and battle mounts (Diod.2.54). The Nabateans, along the Gulf of Akaba, and the Debae of Arabia also made use of camels in similar fashion. ${ }^{647}$ Beyond Arabia, camels were used primarily for trade. The Syria-Seleucia-Babylon route of traders ran through arid land and was regularly traversed by camel; along the route waystations with underground cisterns supplied water and a resting point for caravans (Strabo 16.27), similar to those later constructed near the Red Sea by Ptolemy II Philadelphus (Strabo 17.45) and perhaps the route established between the Nabatean city of Leuce Kome and Petra (Strabo 16.23-4). The more fertile territory of the Maranitae allegedly allowed herdsmen to raise large enough flocks that hecatombs sacrificed to local gods were of camels rather than cattle (Diod.2.43.1), a strong testimonial to regional reliance on the camel for food. While there is no absolute way to investigate the accuracy of such reports, it is useful to note that many of the practices he describes are still used today on the Arabian Peninsula. The maintenance of camel herds for milk, meat, and hair is necessary for the survival of groups like the Al Murrah Bedouins of Saudi Arabia, the Reguibat of the western Sahara, the Somali, and many Syrian pastoralists, and throughout history Arabs have relied heavily on the animals not only for sustenance, but for medicinal remedies. ${ }^{648}$

\footnotetext{
${ }^{647}$ Diod.19.94.4, 3.45.4-5; Strabo 16.18, 16.26.

${ }^{648}$ Kohler-Rollefson (2000), 8-10; Tabbaa (2012), 165-7; Bakhsh, El-Deeb, and Al-Judaibi (2000), 187191; Younan and Mwangi (2000), 207-210.
} 
Certainly, by the Hellenistic and Roman periods, the Greeks were aware of the camel's use for long-distance desert travel in the Middle East and Egypt, even if zoological specifics were limited to the investigations of Aristotle. Camels' role was understood as a specialized one, dependent on climate and terrain more than a particular task, and there is no evidence that they were imported to Europe for practical use. Among the Hellenistic dynasts in the East, however, occasional and casual references to the use of camels in the baggage train of an army suggest that their use in this capacity had become somewhat normalized (see Appendix 2). The continued use of at least the dromedary camel is testament to the impression they must have made on the Diadochs while serving under Alexander. It is to this period that we turn now. 


\section{Chapter 6: Alexander's Camels}

Before Alexander the Great's invasion of Asia, the Greeks and Macedonians might have been familiar with the camel from the rare but notable examples in Athenian $\operatorname{art}^{649}$ [Image 5.7-5.8] or the famous accounts of Cyrus' upbringing, as recorded by Xenophon. However, the camel remained an exoticism, something with which Greeks would have been personally unacquainted. The camel's first foray into Greece came with Xerxes' invasions in 480 , but there is no evidence that the camels were bred by the Greeks that captured them after Plataea, or even that the animals survived at all. Camels were brought over from the East again in 395 by Agesilaus, following his campaigning in Lydia (Xen.Hell.3.4.24). The account makes clear that these were pack animals from Tissaphernes' army, but what Agesilaus did with them is never stated. Thereafter, camels do not make another appearance in Greek history until Alexander's march through the Libyan Desert to Siwah, after which they crop up in accounts of military transport several more times. In this chapter, we will explore the ways in which camels were used by the Macedonian army, their limits, and the until now unrecognized value they contributed to both to the army and to Alexander's personal survival.

In his 1978 work Alexander the Great and the Logistics of the Macedonian Army, Engels presents a most excellent and thorough discussion of the Macedonian use of pack animals such as mules, oxen, and horses. Engels' work reevaluates Alexander's campaign strategies and movements based on logistical motives, revealing how and why Alexander

${ }^{649}$ Cf. Shauenburger (1955-56) and (1962) for the most recent catalogue of camel-themed Greek vases. 
demanded surrender of local rulers in advance of his approach. The capacity of different pack and yoke animals is the focus of Engels' text, but he has underestimated the capabilities, adaptability, and thus the contribution, of the camels in Alexander's army. In addition to highlighting the asset camels proved to be to the Macedonians, this part of the chapter will re-evaluate some of Engels' conclusions in light of newer scientific data and a careful focus on the contribution of each species of camel rather than generalizing based on the strength of the dromedary.

To do this, I rely on several scientific studies of camels. The studies of the dromedary by Schwartz and Dioli, and by Gauthier-Pilters and Dagg, were made of dromedaries in North Africa, and the latter's study focused largely on the dromedary's adaptations to the Sahara, a particularly relevant point for the study of Alexander's dromedaries in the Libyan Desert. Gahlot's Selected Topics on Camelids provides a wide range of detailed studies on camel domestication, reproduction, renal function, and role in modern societies. Potts' investigation of camel hybrids necessarily includes a discussion of Bactrian camels, as only these camels can be used for a backcross with an F1 hybrid, and Wu et al.'s publication of the results of DNA sequencing of the camelid family provides the most up to date data on camel evolutionary adaptations. ${ }^{650}$

While we will consider the ancient references to camel use by the Macedonian army in chronological order, the first and perhaps most famous use of the camel, Alexander's expedition to Siwah through the Libyan Desert, will serve as a case study

\footnotetext{
${ }^{650}$ It should be noted that the differences between the camels available to e.g. Gindibu in the $9^{\text {th }}$ century, Alexander in the $4^{\text {th }}$ century, and the modern camels, is primarily one of specialized breeds. Although Wu et al.'s research reveals that accelerated evolution to adapt to arid environments occurred in camel genetics, the divergence between the dromedary and Bactrian still occurred about 4.4 million years ago (Wu et al. 7; Supplementary Fig 11, Table 32). For our purposes, it is safe to assume that minimal, if any, change in fat storage, kidney function, the capacity for hyperhydration, \&c.
} 
and thus will be lengthier than subsequent accounts of camel use. By exploring the textual evidence of the march and combining it with biological data on dromedaries and ecological studies of the Libyan Desert, I will show that Engels' assumptions actually undercut dromedaries' abilities. Thereafter, I will draw similar conclusions, with corresponding evidence, from accounts of camel use elsewhere in Alexander's Asian campaigns.

\section{A. The Siwah Expedition: The Account}

The Macedonians' first recorded encounter with camels was in Egypt, indicating that the dromedary type was in use. ${ }^{651}$ After entering Egypt in 331 and being hailed a liberator, Alexander made plans to visit the famous oracle of Zeus-Ammon, located at Siwah, an oasis in the Libyan Desert (in modern Egypt, part of the Sahara Desert) [Image 6.1]. From Aristoboulus' account, Arrian tells us that Alexander took the coastal route as far as Paraetonium, situated on the north shore of Egypt against the Mediterranean, and then moved southward into the continent's interior ${ }^{652}$ in a march that took between seven and eight days and constituted "the most arduous march undertaken by the Macedonian army until the Gedrosian Desert." 653 This was a region "for the most part sandy and waterless" (Arr.3.3.3), a "flat waste of barren sands" that was "hardly endurable even for those who were lightly equipped and few in number" (Curt.4.7.6). Alexander must have

\footnotetext{
${ }^{651}$ Diod.17.49.3-6; Curt.4.7.6-17; Arr.3.3.3-6; Only Curtius specifies that camels were used, but horses would not have survived the journey. Worthington (2014), 180-182; Bosworth (1988), 71-74; Wilcken (1967) 121-124. Generally the concern of historians has been why Alexander traveled to Siwah rather than how.

${ }^{652}$ Arr.3.3.3; Engels (1978), 61.

${ }^{653}$ Engels (1978), 59.
} 
been advised by the Egyptians to travel by camel, rather than by horse (Curt.4.7.12), animals which would have been well equipped to deal with the deep sands, scalding winds, and arid heat of the Sahara.

After four days of travel through the desert, their water supply gave out (Diod.17.49.3; Curt.4.7.15), and to complicate matters a desert storm, likely a khamsin, obscured the route to the point that even local guides were confounded (Arr.3.3.4). All three sources mention that after a period of drought, unexpectedly early rains relieved the travelers' thirst, and either ravens or snakes led them through the desert to the oasis. ${ }^{654}$ Although this would certainly have been an untimely rainfall, it is not impossible. Ptolemy's and Aristoboulus' differing accounts of animals leading the party to the oasis are both plausible (Curt.4.7.15; Arr.3.3.5-6). Snakes and birds would be familiar with the location of an oasis in an otherwise waterless territory. It is to these god-sent animals that the sources give credit, rather than the camels who bore the Macedonians through the desert storm. This may not be reflective of Alexander's own opinion of the camel. As we shall see, he thereafter maintained camels in his army and even continued to add them upon capture from the enemy; undoubtedly their endurance in the Libyan Desert cemented their value in his mind.

Since our sources report that supplies gave out within four days, both men and camels would have gone waterless for three to three and one half days, relying on miraculous rain and, possibly underground cisterns across a well-traveled route. However, even these points of relief would have been limited, as the march occurred just before winter, a dry time to travel in the Sinai Peninsula because these months directly

${ }^{654}$ Diod.17.49.3; Curt.4.7.14; Arr.3.3.4. 
precede the rainy season. This means that any water remaining in wells or cisterns would have been brackish, if it were present at all. ${ }^{655}$ Additionally, the khamsin that the travelers faced must have taken them away from their route, as it clearly obscured the guides' signposts (Arr. 3.3.4).

For those three days, the Macedonians must have suffered severely, but their camels would have held up. Their intrepid efforts and natural ability to withstand the dehydrating heat and winds of a waterless desert surely recommended them to Alexander, who thereafter appears to have kept camels in his retinue. The degree to which the camels endured and their utility on long treks should be examined further. In his investigation of pack and yoked animals, Engels does this to a certain extent, and he sets a four-day maximum on working camels' travel between water breaks, making the sudden and unseasonal rainfall that Alexander's party experienced appear truly the miracle Arrian makes it out to be (3.3.4). Engels claims that "this expedition also shows that a baggage train consisting entirely of camels is in no better logistic condition than one of horses and mules for a journey of four days or longer; for while camels can carry more, in four days they will also need to consume more food and water to stay alive." ${ }^{956}$ This assertion requires reevaluation and a closer investigation of the dromedary's unique evolutionary adaptations, which Engels underestimates.

For a camel to require water for survival after four days, the climactic and labor conditions would have to be extreme, and food would have to be scarce or entirely unavailable. Even so, it seems unlikely that this would be too much for a dromedary to bear, considering modern zoological and anecdotal evidence. The dromedary's ability to

${ }^{655}$ Walter and Stadelmann (1974), 224; Engels (1978), 60.
${ }^{656}$ Ibid., 63. 
conserve water derive from its abilities to withstand the dehydrating khamsins of the desert, regulate its body temperature, and bear considerable burdens all contributed to the Macedonian party's survival in the Libyan Desert. Had horses or mules been taken on the journey, survival would have been unlikely.

\section{Water Retention \& Camels: The Facts}

A study of the dromedary camel in the Sahara Desert, of which the Libyan Desert is an extension, was performed by Gauthier-Pilters and Dagg and recorded in their work The Camel: Its Evolution, Ecology, Behavior, and Relationship to Man. Their study concludes that how often a camel needs to drink depends on a variety of variables, so that "generalizations about water requirements...have little value." ${ }^{\prime 657}$ Among those variables are: age, work, humidity, environmental temperature (including night and day fluctuations), and the type and quantity of food available to the camel. If a generalization must be made, Engels' assertion that camels require water at least every four days applies only to the most grueling environmental conditions. More specifically, the need to drink at "short, regular intervals" would be true in cases where the daily temperature met or exceeded 111 degrees Fahrenheit with a humidity of $14 \%$ or below, which is not generally the case in Egypt in the months of September and October. ${ }^{658}$

Further, Engels' model of the quantity of water camels must have to function also seems high. From their direct observations of dromedaries in the Sahara, Gauthier-Pilters and Dagg conclude that camels traveling with a heavy burden in high, arid heat may

${ }^{657}$ Gauthier-Pilters and Dagg (1981), 50.

${ }^{658}$ Gauthier-Pilters and Dagg (1981), 50-8; Zahran and Willis (1992), 18-20. 
require 20 to 30 liters of water a day, the equivalent of 5.3 to 8 gallons, whereas Engels asserts that the minimum for daily watering is 10 gallons, a model which provides no variation based on aridity or temperature. ${ }^{659}$ Rather than comparing varying models for camel trains, let us consider the variables mentioned above that impact a camel's need for water, applying them to the specific case of Alexander's journey to Siwah. ${ }^{660}$

It seems likely that Alexander took a camel train without any horses, whose requirement for water, limited load bearing capacity, and hooves would have made trekking the desert sands with a rider extremely difficult. The camel's wide feet and long legs enable it to move much more easily across the sand. ${ }^{661}$ Likely the camels Alexander took were of an appropriate age, neither elderly nor immature, and not pregnant or lactating factors which would reduce the animals' resistance to dehydration. ${ }^{662}$ Alexander would have been properly advised by the Egyptians and his guides about what camels would hold up best. We cannot know how many participated in the journey, but due to issues of supply, it cannot have been many. Engels' repetition of Curtius' statement that Alexander took few (pauces) men with him on this journey is reasonable, as water supply for a large number would not have been feasible. ${ }^{663}$ The water supply would have made up the majority of the dromedaries' burden, although the Macedonians must have ridden on camelback in addition to the weight of their packs, as arid desert sands can reach surface temperatures of over 150 degrees Fahrenheit in high heat, and humans are not especially adept at climbing dunes. ${ }^{664}$ A dromedary camel cannot regularly bear as much

\footnotetext{
${ }^{659}$ Gauthier-Pilters and Dagg (1981), 50-8; Engels (1978), 129.

${ }^{660}$ Here I lay out some of the basic biological advantages of the use of riding and pack camels, information which will be taken for granted in later assessments within the chapter.

${ }^{661}$ Gauthier-Pilters and Dagg (1981), 102.

662 Dahlborn (2000), 26.

${ }^{663}$ Curt.4.7.6; Engels (1978), 61 n.43.

${ }^{664}$ Grenot (1974), 114-20.
} 
as its Bactrian cousin, but it can still carry a significant amount, which usually averages c. $150 \mathrm{~kg}$, but can amount to as much as 300-400kg. ${ }^{665}$ Nomadic herdsmen who use camels frequently and for all things usually limit their loads to $150 \mathrm{~kg}$, although whether a camel is loaded kneeling or standing up impacts the weight it can carry. ${ }^{666}$

\section{Temperature on Alexander's March}

The factor of temperature is not as easy to analyze. Estimations of temperatures over two millennia in the past are difficult to make due to changing environmental conditions over time. For the significant factors of high and low temperatures as well as humidity, we must rely on more recent estimations as a point of reference. Alexander's journey took place during the winter months, as Arrian notes that he left Siwah for Memphis after consulting the oracle and then departed from Memphis at the beginning of Spring (3.6.1). Engels puts it Alexander's travel in October specifically, reasoning that the siege of Gaza ended in that month, and the Macedonians would not have lingered, but marched directly from Gaza to Pelusium. ${ }^{667}$ In October, the climactic extremes that would require 10 gallons of water a day per camel are not likely to be reached. We may consider two sources of data for the climate of Alexander's route through the Western Desert: records of the Mediterranean coastal belt of Egypt and those of the Siwah Oasis itself. Zahran and Willis show the climate trends from 1960 in five meteorological stations along the western Mediterranean coast of Egypt: Sallum, Sidi Barrani, Mersa Matruh, El-Dabaa, and Alexandria. Temperatures regularly peak in June, hitting a highest

\footnotetext{
665 Kohler-Rollefson (2000), 8.

666 Gauthier-Pilters and Dagg (1981), 109-10. Cf. Kohler-Rollefson (2000), 8.

${ }^{667}$ Engels (1978), 60.
} 
absolute maximum of over 111 degrees Fahrenheit, the cut-off for daily water requirements for dromedaries. However, this heat tapers off throughout the year, reaching lows of 32 in January and February. Relative humidity for these regions is of course higher than the inner desert, where it would drop due to distance from the sea or abrupt desert storms. ${ }^{668}$

\section{Foraging in the Libyan Desert}

Because carrying sufficient forage (in addition to the grain that was carried) for a camel would have added numbers to Alexander's retinue, Engels asserts that the camels were allowed to forage on their own in the small oases en route ${ }^{669}$ This is in keeping with modern camel travel as well. What Engels does not note is that the act of foraging allows camels to conserve and increase necessary body water content, making the journey less deadly than he imagines. The often salty plants of the desert actually help camels conserve body water, as salt is used to facilitate the transportation of water through the kidneys and the recycling of urea. Indeed, camels can make use of even desiccated fodder and will consume just about anything. They regularly feed on shrubs, trees, herbs, and vines, but even dried reeds, seed husks, and thorny plants that other animals avoid can be ingested by camels. ${ }^{670}$

Camels' ability to gain much-needed moisture from plants is well accounted for in relatively modern travel observations as well as zoological studies. Traveling the Sinai Peninsula in 1872, Paul Lenoir marveled that the camels traveling in his caravan "having

${ }^{668}$ Zahran and Willis (1992), 18-19.

${ }^{669}$ Engels (1978), 62.

${ }^{670}$ Valisco (2012), 154-6; see also Wu et al. (2014), 15. 
laid in a store of water can go for a week without drinking" so long as it has something to eat daily. ${ }^{671}$ Gauthier-Pilters' and Dagg's study of dromedaries was done in the Sahara as well, and they noted that camels there do not even drink during the cool months of the year, as they can obtain sufficient moisture from their food. ${ }^{672}$ The Al Murrah Bedouin of Saudi Arabia, camel pastoralists by profession, report that they do not take their camels to wells if the winter foliage is lush enough, and the Rwala Bedouins see their camels go 30 days without water if they are feeding on fresh green foliage. ${ }^{673}$ Obviously camels in hotter climates that are working, rather than simply roaming, will require more. However, the testimony above indicates the animals' ability to utilize moisture from plants. Additionally, Valisco notes that depending on the studies consulted, the presence of water, and the work load of the camel, camels might need as little as $5 \mathrm{~kg}$ of food matter a day or as many as $35 \mathrm{~kg}$, but traveling camels generally feed by foraging. ${ }^{674}$

Where would camels have encountered such foliage for grazing? It is likely that the riders might have slowed their pace in dune valleys, whose formation allows water to concentrate in sufficient quantities for plant life to emerge in concentrated vegetative growth. ${ }^{675}$ In the relatively barren regions of the Libyan Desert, Aristida pungens (drinn) and Cornulaca monacantha can still be found, and the hottest period of the summer, June through August, was already past by the time Alexander marched. Gauthier-Pilters and Dagg note that during the cool season, camels can travel as far as $1,000 \mathrm{~km}$. without water, so traveling less than a fourth of that (about 160 miles, see above) in a period of

\footnotetext{
${ }^{671}$ Manley and Abdel-Hakim (2006), 70.

${ }^{672}$ Gauthier-Pilters and Dagg (1981), 50; Nowak (1999), 1078-1081, Schwartz (1992), 111-12.

673 Valisco (2012), 159-60.

674 Ibid., 154-5.

${ }^{675}$ Gauthier-Pilters and Dagg (1981), 31-2; Walter and Stadelmann (1974), 218-19.
} 
middling heat should not have overburdened them. Historically, camels have survived much more strenuous tasks. For example, accounts exist of camels traveling over $600 \mathrm{~km}$. in the hot months of summer bearing $350 \mathrm{~kg}$ packs without water. In 1875 camels were used to cross the Victoria Desert in a 17 day march in summer, the first 13 days of which the camels received no water. ${ }^{676}$ While this would have placed a significant burden on the animal and by modern standards would certainly constitute animal cruelty, the example is meant to show that dromedaries have evolved in order to endure severe conditions as necessary.

\section{The Extremes of Dromedary Physiology}

Although it is always best to supply a camel with as much water as possible, they can endure a greater degree of dehydration than humans or any other pack animal. Camels can survive a loss of up to $40 \%$ of their body weight in water, while by comparison, humans can withstand a loss of only $12 \% .{ }^{677}$ In light of this, Engels' reassertion of Leonard's statement unfairly downgrades the results of millions of years of evolution: "the camel's powers or capabilities have been grossly exaggerated and the most culpable ignorance and negligence have been displayed." 678

Perhaps camels' ability to withstand drought appear exaggerated because these animals stand out among mammals as the most tolerant of hot, arid, and waterless climates. In order to emphasize the abilities of camels in juxtaposition to Engels' assertion that they add no more value as pack animals than any other, it is necessary to

\footnotetext{
${ }^{676}$ Gauthier-Pilters and Dagg (1981), 50.

${ }^{677}$ Ibid., 74-5.

${ }^{678}$ Engels (1978), 129.
} 
discuss exactly how camels differ in terms of evolutionary adaptation to drought. We can summarize the dromedary's ability to conserve water in four key points: (a) efficient thermoregulation, (b) preservation of body weight through slowing of the metabolism, (c) enhanced protein synthesis and urea recycling, and, as a preventative measure, (d) hyperhydration.

\section{a. Thermoregulation \& The Libyan Khamsin}

Because body water weight is lost most rapidly through perspiration, camels have evolved a number of mechanisms to reduce their need to sweat. A dehydrated camel will not sweat at all. The most obvious means of reducing the need to sweat in a healthy camel is a low pore density on the surface of their skin and the presence of thin, fine hairs across their body which permit short wave heat reflection and insulate the body against heat. Additionally, camels instinctively group together in the heat, reducing the surface area of their bodies that is exposed directly to higher temperatures. Lower nighttime desert temperatures permit camels to cool off efficiently through conduction and convection, either losing heat through contact with a cooler body (such as sand) or through the movement of cooler air across their skin. ${ }^{679}$

Unlike most mammals, the camel is not strictly homeothermic. It can alter its body temperature as needed, within a certain range. Dehydrated camels may experience variations in body temperature from 105 to 96 degrees Fahrenheit between day and night, reducing heat gain by matching the temperature of the environment during the hottest parts of the day and losing much of that heat during the night. ${ }^{680}$ This means that in

\footnotetext{
${ }^{679}$ Dahlborn (2000), 21-23; Schwartz (1992), 22-23; Gauthier-Pilters and Dagg (1981), 71-74.
}

${ }^{680}$ Dahlborn (2000), 21-22. 
regions where temperatures drop at night, a camel can go longer without water. Their body temperature change does not apply only to the surface of the skin, but to core temperature, including major organs. Camels usually reach their peak core temperature at midday, reducing the temperature gradient between their bodies and the environment, and thus making sweating unnecessary. This wide range of temperature fluctuation is a water saving device, making sweating unnecessary. Soaring temperatures and resulting heat stroke, which could easily kill cattle and horses, are not as problematic for the dromedary. ${ }^{681}$

The dromedary's ability to withstand high temperatures and dehydrating, arid siroccos might well have saved the lives of Alexander and his men. Arrian notes that the Macedonians were waylaid by a severe sandstorm on their way to Siwah, which disoriented even their guides. Arrian notes that "whenever the south wind blows in that country, it buries the route in sand... and it is impossible to find one's way, just as in an ocean of sand" (3.3.4). Strabo describes something similar, a cloud of thick dust (17.1.43). I agree with Engels that this must have been a khamsin, a sandstorm common to the Libyan Desert and so called because of its duration. Khamsin means "fifty," and the storms can last up to 50 days, although shorter ones are more common. Such storms buffet sand about and alter the dunes, and it is likely the result of a khamsin that Diodorus alludes to at 17.49.5.

Because of the heat of the surface sand and the aridity of the Sahara, these storms are devastating without proper shelter. Temperatures under khamsin wind conditions may rise anywhere from 77-115 degrees Fahrenheit, sapping moisture from the body very

\footnotetext{
681 Yagil (2000), 52; Schwartz (1992), 21-23.
} 
quickly. ${ }^{622}$ Even in locations where crops can normally be grown, the emergence of a khamsin could easily "blast" an ear of wheat, preventing it even from producing seeds or cause existing seeds to shrivel on contact. ${ }^{683}$ The experience of a more modern army under siege of a khamsin must to some degree represent the experience of Alexander's, as the climactic occurrence of the khamsin is not different from antiquity. Reports of temperatures as high as 117 degrees Fahrenheit, septic sores produced by constant abrasion from the sand, and even being buried alive illustrate the khamsins on the Palestinian Front during WWI. The Scots of the fifty-second division lost 82 men from marching during a khamsin; they became so dehydrated from the high temperature and low humidity that they simply fell from the column. ${ }^{684}$ It is not probable that a horse or mule would have survived such a storm amid the Libyan Desert without adequate water, or that Alexander and his men would have survived without their camels.

A camel's ability to alter its body temperature temporarily and cool down efficiently has helped it adapt to an environment in which khamsins are inevitable. Additionally, camels are well-adapted to travel in a windy desert. Thick eyelashes guard and shade their pupils, and unlike humans, camels can see their way through a sandstorm. Their eyelids are semi-translucent, enough that a camel can close its eyes against highvelocity sand and continue moving. ${ }^{685}$ This capability is well illustrated by the account of Arthur P. Stanley, who marched through Sinai with a Bedouin tribe in 1862: "Sheets of sand fleeting along the surface of the desert like streams of water...the Bedouins, each with his shawl thrown completely over his head, half of the riders sitting backwards, the

\footnotetext{
${ }^{682}$ Gauthier-Pilters and Dagg (1981), 21; Engels (1978), 62.

683 Arnon (1992), 73.

${ }^{684}$ Woodfin (2012), 32-33, 100.

${ }^{685} \mathrm{Wu}$ et al. (2014), 14; Gauthier-Pilters and Dagg, 68.
} 
camels meantime thus virtually left without guidance...yet moving straight onward with

a painful sense of duty." ${ }^{686}$ Such a description closely matches the khamsin reported in Curtius and alluded to in Arr. 3.3.4.

\section{b. Metabolic Control}

Death by dehydration ultimately comes from extreme loss of body weight, so the maintenance of body weight in drought is extremely important. More efficiently than humans or other pack animals, camels are also able to slow their metabolic rate to conserve energy and water. ${ }^{687}$ In a 1983 experiment, Schwartz and King discovered that camels kept in a state of heat stress without access to water lose on average 1-2\% of their body weight in a day, compared to goats, sheep, and cattle, which lose between 5-8\% each day. Their conclusion included the observation that camels in drought and high temperatures can survive 15-20 days without water. ${ }^{688}$ More recently, DNA sequencing has shown that this ability stems from a variety of complex upticks in the presence of aquaporin genes (genes that allow reabsorption of water for the functioning of the metabolism) in camels suffering water or heat stress. ${ }^{689}$ While working camels' survival might be shortened due to work stress, Schwartz's observations are nevertheless a testament to the camel's unique ability to maintain body weight during drought.

Such metabolic manipulation is managed through the assistance of fat reserves and high glucose plasma levels. Although the camel's humps are not, contrary to popular myth, where water is stored, they do contain fat reserves which help the camel withstand

\footnotetext{
${ }^{686}$ Manley and Abdel-Hakim (2006), 98.

${ }^{687}$ Gauthier-Pilters and Dagg (1981), 76.

688 Schwartz (1992), 21-23.

${ }^{689} \mathrm{Wu}$ et al. (2014), 16-19 for a detailed discussion on water reservation in the camel in renal medullary osmosis.
} 
starvation and weight loss. The difference between types of camel (and thus, number of humps) has been conclusively linked to the nature of the animal's metabolism by a 2014 DNA sequencing of camelids. Among camelids, metabolic functions evolved more rapidly, including: cellular responses to insulin and the insulin receptor signaling pathway, as well as glucose and fat metabolism. Compared to their relative the alpaca, "functional categories associated with ATP, mitochondria, liquid transport, and response to insulin stimulus evolved rapidly in both camel species" $" 690$ which improved energy storage. While many details of a camel's ability to conserve energy are not well understood, their maintenance of high blood glucose levels for a prolonged period (in what would be considered diabetes in other animals) without food has been noted. However, this is a delicate balance. This ability decreases when the camel enters starvation mode and blood glucose levels drop after about 96 hours. ${ }^{691}$

\section{c. Protein Synthesis \& Urea Recycling}

While Alexander's camels might not have been able to eat their fill en route to Siwah, they would have had access to some forage. Fortunately, camels are able both to eat and digest low-quality forage and to extract maximum benefit from the protein available therein. Gauthier-Pilters and Dagg note that "despite their low food intake compared with body weight (300-500kgs), desert camels are better able to tolerate hard work coupled with food and water shortages than are camels that graze on richer pastures in less arid regions." ${ }^{\circ 92}$ In the modern day Western Sahara, for example, camels have endured severe food and water shortages while remaining on the move at a rather quick

\footnotetext{
${ }^{690}$ Ibid., (2014), 12.

${ }^{691}$ Dahlborn (2000), 27-30.

${ }^{692}$ Gauthier-Pilters and Dagg (1981), 38. See also Wu et al. (2014), 12-13.
} 
pace. Gauther-Pilters and Dagg report that the Reguibat people use camels on long distance camel raids in which the camels traveled up to 100 kilometers between fertile grazing fields. Camels can subsist on thorny and dry plant materials like those which must have been found in the dune valleys of the Libyan Desert. ${ }^{693}$

In addition to slowing their metabolic rate, camels can recycle protein and keep in in their bodies for a longer period of time than other animals, which allows them to survive and function when food and water are scarce. Not only can camels consume the dry or thorny vegetation typical of arid regions, they regularly select forage with the highest greatest crude fiber and crude protein content of any grazing animal. ${ }^{694}$ In cases where camels cannot get high quality food or enough food, they increase the digestion of fiber by keeping the food in their stomach for a longer amount of time. They can keep low quality material in their forestomach for up to 74 hours to extract the maximum amount of energy from them. While this is a characteristic of ruminants and cattle can do this well, camels are able to retain protein more efficiently than other ruminants. For example, if camels are restricted to low-protein food, they can "recycle and utilize body urea for microbial protein synthesis" ${ }^{695}$ more efficiently than cattle. Schwartz references a 1988 study by Engelhardt which discovered that when dietary protein was reduced from $13 \%$ to $6 \%$ for dromedaries, it was made up in a rise in the urea recycling rate from $47 \%$ to $86 \%{ }^{696}$

Because the metabolic process itself requires water, water reaches the kidneys along with salt and urea, post-metabolic products. However, the camel's renal function

\footnotetext{
${ }^{693}$ Ibid., 38-39.

694 Schwartz (1992), 24-28.

695 Ibid., 27.

${ }^{696}$ Ibid., Yagil (2000), 54-55. See also Wu et al. (2014), 12-13.
} 
allows both salt and water to be reabsorbed into the blood, reused in a "continuous recycling of water and protein [which explains] the low demand of protein in the camel diet. ${ }^{1697}$ As a result, during periods of heat stress and water scarcity, camels produce concentrated urine with minimal water content and have low fecal water content as well. ${ }^{698}$ Gene sequencing has revealed that camels are better adapted to metabolizing salt than cattle or even their distant relative, the alpaca. In response to harsh environmental conditions, the camel can break down salts and reabsorb water. ${ }^{699}$ Additionally, camels' bodies respond to water restriction and metabolic stress through the production of glucose transporters, which facilitate glycolysis and are present in the renal medulla in these circumstances in order to regulate the level of sodium and K-ATPase (which pumps sodium out of sells) in order to prevent too much water from leaving the kidney through osmotic regulation. The gene sequencing also revealed that camels in heat stress facing dehydration experience and increased expression of genes that protect cells from heat shock and renal osmosis, which would hasten dehydration. Wu et al. conclude that "overall, the upregulation of osmoprotective genes indicates that camels have a sophisticated osmoprotective capability under WR [water restricted] conditions."

\section{d. Hyperhydration}

Finally, camels are able to take preventative measures against drought that other animals (including humans) cannot. Living in an environment where water scarcity is common for much of the year, camels know to take advantage of water when it is

\footnotetext{
697 Yagil (2000), 55.

${ }^{698}$ Gauthier-Pilters and Dagg (1981), 60-67.

${ }^{699}$ Gauthier-Pilters and Dagg (1981), 60-67; Wu et al. (2014), 14-18.

${ }^{700} \mathrm{Wu}$ et al. (2014), 18-19.
} 
available. Often they overhydrate, consuming more water than they need. Usually they do this after a period of dehydration, anticipating another long duration without water. In most animals, this would result in diuresis and further water loss, but the camels' ability to maintain water and control renal fluid excretion, as discussed above, means that they remain more hydrated. Studies have shown that camels "can retain a water load and tolerate hypoosmolality of the blood for very long periods" due to the special nature of red blood cells that permit retention of water without bursting. ${ }^{701}$ Certainly the Macedonians would have watered their camels at Paraetonium, where they could have been supplied by ship, before trekking inland from the shore (Arr.3.3.3).

In addition to preventative overhydration, camels which have suffered severe dehydration can rehydrate within a span of a few hours, something which would be impossible for other pack animals or humans. Contrary to Engels' statement that “unlike men, the physical condition of cavalry and transport animals cannot be restored by rest and proper diet after they have been worn out by several days of excessive work and inadequate rations, such treatment renders them unfit for further use,",702 camels rebound rather quickly. Schwartz notes that "the appearance of the animals can be quite deceptive. Hollow flanks, a retracted abdomen and a shrunken hump might be indicative of a severe systematic illness, but might also be the result of a week's dehydration, which is quickly

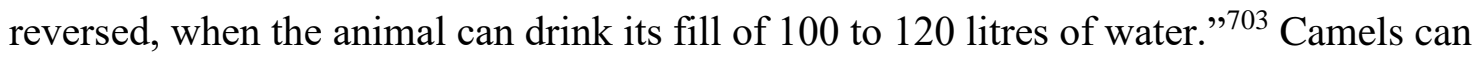
regain their lost body weight and healthy appearance just a few hours after watering. While they will need time to rest and graze, that is a far cry from being "unfit for further

\footnotetext{
${ }^{701}$ Dahlborn (2000), 25.

702 Engels (1978), 129.

${ }^{703}$ Scwartz (1992), 143.
} 
use." The dromedaries' hardy natures made them ideal pack animals for the Macedonians, especially in arid sandy regions. Thus, even though the camels traveling to Siwah ran out of water on the fourth day, death within another four days was not imminent ${ }^{704}$ a camel's evolutionary adaptations would have made it able to continue through the desert, hold up under the circumstances of a khamsin, and rely on forage and non-evaporative cooling measures to conserve body weight and liquid, as we have seen.

Camels brought Alexander to the Oasis of Siwah, and they would have brought him back as well. While the miraculous rain ${ }^{705}$ reported by ancient sources covers Engels' argument concerning the need for water every four days and the inability of camels to bear more than four days' water on a journey, ${ }^{706}$ there is nothing to explain how the camels traveled the eight days back from Siwah if they were unable to bear more than four days' of water rations. Surely there was not a second unseasonal torrent. Instead, since Alexander did return from Siwah, we can safely assume that his camel retinue made the journey not through the intervention of the gods but through the advantages of millions of years of evolutionary adaptation.

\section{B. Burden Bearing \& Racing Camels: Persepolis and Phrada}

Camels make their second appearance in the Alexander narrative at Gaugamela, where they were seized along with the rest of the Persian baggage train by Parmenion (Arr.3.15.4). Curtius suggests that the camels seized were about 300 in number, and they

\footnotetext{
${ }^{704}$ Cf. Engels (1978), 62-63.

705 Ibid., 62; Diod.17.49.3; Curt.4.7.14;Arr.3.3.4.

${ }^{706}$ Engels (1978), 63 n.52.
} 
were pack animals rather than mounts, used to carry the king's money along with about 600 mules (3.3.25). Transport, rather than desert travel, was the primary function of camels in Alexander's army, and so now our focus must shift to the way in which camels were adopted by the Macedonians for the purpose of heavy lifting and long-distance transport. Consideration should also be made of the camel's use as a long-distance messenger.

It is worth nothing that the sources for Alexander's campaign are generally careful in specifying the function of the camel rather than its type (dromedary or Bactrian). Distinct functions for camels indicate that the Macedonians used them often enough to recognize beneficial attributes of each and adopted them as working animals into the army. This is quite a shift from the general references and descriptions in Herodotus, who believed Cyrus' baggage camels were converted abruptly into chargers fit for battle. Additionally, the Macedonian use of the camel can be distinguished from Alexander's collection of other exotic animals, like elephants, of which he never made extensive (or perhaps any) use. Specific functions might also indicate specialized and selective breeding, and there is the possibility that a camel hybrid functioned as a pack animal in the army of Alexander as well. ${ }^{707}$

The baggage-carrying potential of Darius' (and then Alexander's) camels is considerable. While the type of camel captured at Gaugamela is unclear, it seems more likely that they were Bactrian than dromedary, as the former has a greater ability to bear weight over long distances, and both Arrian and Curtius specify that their purpose was the transportation of money and that they stood beside the mules. Bactrian camels weigh

\footnotetext{
${ }^{707}$ Potts (2004), 156-161.
} 
on average $460 \mathrm{kgs}$ and can carry loads of over half their body weight, $220-270 \mathrm{kgs} .^{708}$

There is some evidence of camel hybridization in antiquity between a male Bactrian and female dromedary, which would produce an F1 generation camel of superior strength, capable of bearing more than either parent at up to $500 \mathrm{~kg} \cdot{ }^{709}$ Hybrid camels have a single hump with a divet, greater strength than either parent, and toleration of aridity and temperature extremes on both ends of the spectrum, however, as mentioned above, there is still debate over the pre-Parthian evidence of their existence. ${ }^{710}$

It is likely that many of the camels captured at Gaugamela traveled back east again for the same load-bearing purpose when Alexander and his men looted Persepolis. Diodorus, Plutarch, and Curtius all mention the use of camels to transport the wealth of Persepolis back to Susa for safekeeping. Furthermore, Diodorus and Curtius distinguish the type of camel by function and separate them from other animals with similar function, a special mention which is suggestive of the perception of camels as a specialized unit. It is possible that the camel's superior weight-bearing ability also plays a role. Let us consider the three accounts of camels at Persepolis individually first.

(1) Diodorus:

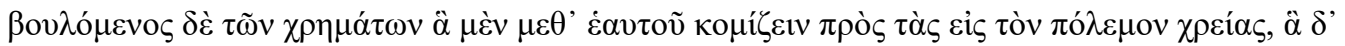

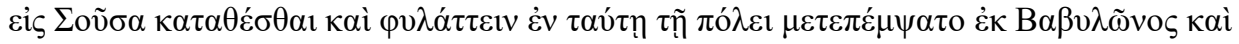

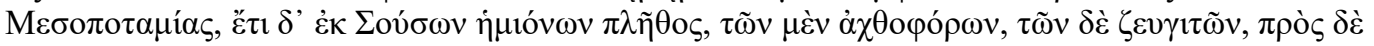

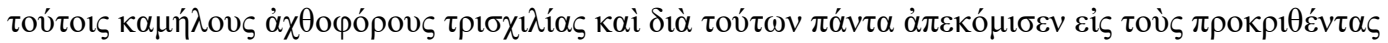

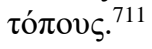

Diodorus presents an interesting description of the animals Alexander summoned to Persepolis to carry off the wealth there. He sent for animals from Babylon,

\footnotetext{
${ }^{708}$ Ibid., 147.

${ }^{709}$ Ibid., 156-157.

${ }^{710}$ Ibid., 158-161.

${ }^{711}$ Diod. 17.71.2
} 
Mesopotamia, and Susa. Among these, he sent for mules that were $\alpha \chi \theta$ opópor and

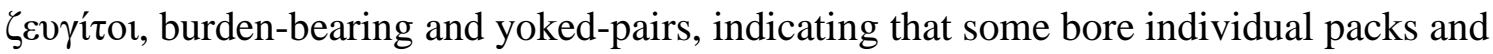

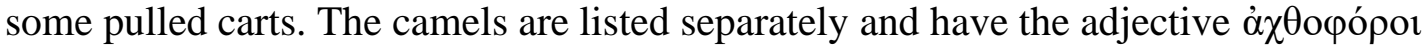
applied to them to indicate that they, like some of the mules, are pack animals, not yoked animals. Once again, this strongly indicates that either Bactrian or hybrid camels are in use, as dromedaries might bear riders and their kits well, but are not ideal for heavy furniture and gold, such as was removed from the city of Persepolis.

Animals put to different uses are often recognizable as such, and the practice of specialized camel use persists into modernity. Glover references the Great Britain War Office's Animal Management citing its statement that "the riding camel is as distinct from the baggage animal as a thoroughbred from a cart-horse." ${ }^{712}$ As we shall see, Diodorus recognizes this and uses the adjective $\dot{\alpha} \chi \theta$ oøópos to identify pack camels. He uses the adjective $\delta \rho \mu_{\alpha} \alpha \varsigma$ to specify racing or messenger camels, which could not be other than dromedaries, whose long legs and leaner form enable it to maintain good pacing over long distances. Diodorus' labels do not appear to be retroactively applied in light of new knowledge of the camel, but accurately reflect Alexander's use of them. (2) Plutarch:

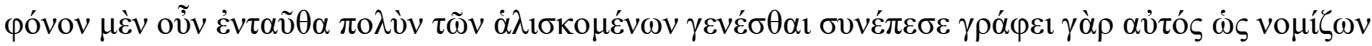

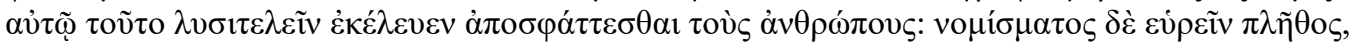

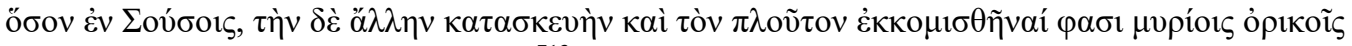

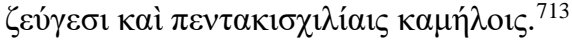

Plutarch makes no specific reference to the type of camel used; however, by juxtaposing the camels with the ỏ

\footnotetext{
${ }^{712}$ Glover (1950), 4.
}

${ }^{713}$ Plut.Alex.37.2. 
pack bearing animals. In fact, the sheer number of camels and mules involved in the looting is used as a term of measurement to describe the extent of the wealth Persepolis held. ${ }^{714}$ Even if reference to 5,000 camels is an exaggeration on Plutarch's part, it speaks to the accumulation of camel herds by the Persian empire, much of which were likely Bactrian camels. In fact these animals appear in the Apadana reliefs at Persepolis in the context of tribute from the eastern provinces, indicating that Persians much later than Cyrus continued to foster camel herds. ${ }^{715}$

(3) Curtius:

Ceterum aut de aliis quoquo dubitabimus aut credemus in huius urbis gaza fuisse $\mathrm{C}$ et $\mathrm{XX}$ milia talentum. Ad quae vehenda — namque ad usus belli secum portare decreverat — iumenta et camelos et a Susis et a Babylone contrahi iussit. ${ }^{716}$

Curtius' account echoes aspects of both Diodorus' and Plutarch's. He agrees with Plutarch that animals were sent for from Susa and Babylon, and he too carefully separates iumenta, or general "beasts of burden" from cameli, although they are serving the same purpose. Further, Curtius expresses similar awe to Plutarch's concerning the sheer quantity of wealth taken from Persepolis and, presumably, the number of animals needed to convey it, which Plutarch puts at 15,000. The camels alone would have had a carrying capacity of three million pounds, and if hybrids, over five million.

The adoption of camels as pack animals by the Macedonian army is not in itself a surprising occurrence. However, these accounts suggest a degree of specialization among camels that contributes to the ongoing discussion of Macedonian logistics. Engels’

\footnotetext{
${ }^{714}$ Similar uses of camels' carrying power to emphasize large quantities of wealth appear in Plut. Moralia, on the Fortune of Alexander 342 A and Plut.Alex.40.1.

${ }^{715}$ Lewis and Llewellyn-Jones (2017), East Staircase of the Apadana at Persepolis, section 3.a.

${ }^{716}$ Curt.5.6.9.
} 
account neither differentiates between camel by type nor considers the way in which the sources associate type and function, which once again undercuts their importance in the campaign. Alexander's collection and use of different types of camels for distinct purposes reveals a solid understanding of a foreign animal and judicious employment of it. The ancient sources clearly delineate the manner in which different animals transported goods or people, even if the translation of specific terminology remains a bone of contention among military historians concerned with logistics. The juxtaposition of iumenta and cameli by Latin authors and of $\zeta \varepsilon \tilde{v} \gamma \circ \varsigma$ and $\alpha \chi \theta 0 \varphi$ ópo $\varsigma$ by Greek authors impacts the way in which we understand the roles transport animals played. If we add to our consideration here Curtius' account that Sisimithres “multa iumenta et camelorum II milia adduxit pecoraque et armenta" (8.4.19) to replenish Alexander's supplies outside of Nautaca, we see the beginning of a pattern in terminology.

The distinction between iumenta and cameli was first noted by Rolfe in a 1936 article referencing a similar pattern in the works of Ammianus Marcellinus, who also separates camels from other burden bearing animals (e.g. 15.8.6). Rolfe suggests that Marcellinus adopted this tendency from Livy, of whom he was a "diligent follower,"717 but the pattern appears to be more widespread than Livy's work, as it precedes him in the accounts of Herodotus ${ }^{718}$ and Diodorus, as we have seen above. In fact the translation of iumenta and similar terminology has become a bone of contention among scholars of ancient military logistics, and its juxtaposition with cameli enables us to shed new light on the significance and uniqueness of camels.

\footnotetext{
${ }^{717}$ Rolfe (1936), 138.

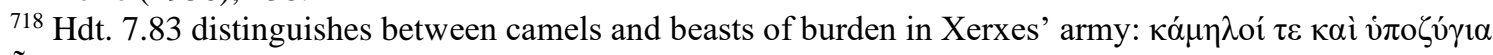
ทे $\gamma \circ$
} 


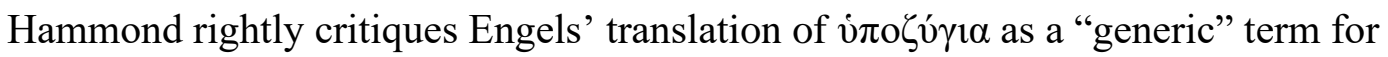
pack animals, as it strictly means "draught-animals under a yoke" and may be distinguished from $\alpha \chi \chi \theta$ oøópos, or a burden-bearing animal. ${ }^{719}$ The sources utilize different terminology on purpose, in order to indicate the means of transport used in

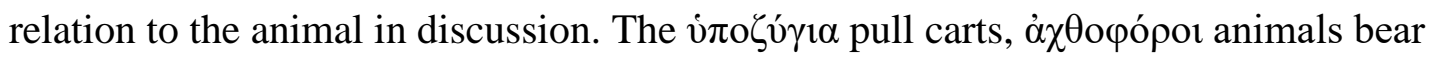
burdens free standing. Hammond shows that Alexander certainly used carts in transportation, but "the advantage of porters is that they can traverse very difficult ground or deep snow, and that they are not dependent on trails or roads. ${ }^{, 720}$ Camels are especially adept at this, and although Hammond errs in asserting that camels require "dry going and desert conditions," he is correct in noting their efficiency at transport when terrain does not permit the use of carts, as would have been the case for Alexander's men in the wintry territory of Nautaca. ${ }^{721}$

From Hammond's assessment, we see that the yoked and burden-bearing animals are listed distinctly for good reason, but still the camel stands out, mentioned separately and by name in the above examples of listed transport animals. Aside from an appearance that might have been somewhat exotic to the Greeks, camels are distinguished in the sources because they constitute something of a "specialized unit." Their ability to bear a much greater percentage of their body weight than other pack mammals for a longer distance makes them exceptional additions to a baggage train. A study by Youself, Webster, and Yousef shows that unlike other mammals, the rate of energy expenditure in camels is not proportionate to the burden that they bear. While many mammals "increase

\footnotetext{
${ }^{719}$ Hammond (1983), 27 n.2.

${ }^{720}$ Ibid., 28.

${ }^{721}$ Ibid.
} 
their rate of energy expenditure in direct proportion to the mass supported by the muscles when they walk at a given speed," camels do not. ${ }^{722}$ Because of the arched construction of the torso and myofibers within their muscular structure, camels do not experience a rise in energy requirement proportional to weight burden while bearing packs that amount to as much as $21-34 \%$ of their body weight. ${ }^{723}$ This is quite different from other load bearing animals, including horses. Rose illustrates this point with a comparison of the horse and racing camel; if both walk at a pace of $8 \mathrm{~m} / \mathrm{sec}$ and possess similar body weight, the camel has only half of the horse's oxygen requirement, meaning it uses less energy to move. ${ }^{724}$ While there was no means of calculating energy expenditure and $\mathrm{O} 2$ output in antiquity, those who worked with and relied on camels would have noticed camels' impressive economy of locomotion through the observation that the animals can travel greater distances with greater loads than other mammals, traits that later contribute to the epithet "ships of the desert."

If the $\dot{\alpha} \chi \emptyset$ oó́po $\varsigma$ camel can travel great distances with heavy burdens, unburdened it should be able to maintain a speedier pace. There are some accounts of ancient messenger camels bred for their speed. Before the sack of Persepolis, Alexander received many gifts from Abulites, the satrap of Susa. Among these were Indian elephants and "dromades cameli...velocitatis eximiae" (Curt.5.2.10). It is safe to assume that these camels are dromedaries not only because of the etymological distinction, but because they were renowned for their swiftness. While dromedaries cannot compete with horses over short distances, they can be bred and trained to run quickly. Today in the

\footnotetext{
722 Youself, Webster, and Youself (1989), 1087.

723 Ibid., 1083-1084.

${ }^{724}$ Ibid., 1085-1087; Rose (2000), 44-47.
} 
United Arab Emirates, dromedary racing is a popular sport, and maximum speeds over short distances have been recorded at just under 28 miles per hour. ${ }^{725}$ However, for long treks dromedaries are well known (and aptly named) for making good time, able to manage a faster pace for a longer duration carrying rider and kit. Gauthier-Pilters and Dagg record dromedary camels with riders traveling the 186 miles between Gaza and Cairo in two days; in Australia, it is common for transport camels to travel 50-55 miles in a day, and dromedaries have been recorded traveling 90 miles in a ten hour period, maintaining an average of 9 miles per hour without stopping. ${ }^{726}$

Alexander used dromedaries on several occasions, perhaps the best-known is also one of the most important and highly contested legal decisions of his reign. Camels ran from Phrada to Ecbatana bearing the message of Philotas' execution and Parmenion's own impending death, which was quickly delivered to the Macedonian general

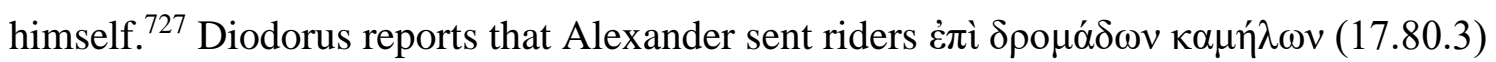
in order that they arrive at Ecbatana before word of Philotas' death could reach Parmenion. This is corroborated by Strabo, who adds that the riders covered a journey that normally takes $30-40$ days in only $11(15.2 .10)$. Curtius, who also gives an 11-day travel time, adds that the camels were specifically selected so that the riders could travel to "places which were even made desert by dryness" (7.2.18).

The 11-day travel time is astounding. If the ancient city of Ecbatana corresponds roughly to the modern city of Hamadan, Iran and Phrada corresponds to Farah, Afghanistan, this is distance of about 1,286 miles, meaning the camels would need to

\footnotetext{
${ }^{725}$ Gahlot and Chada (2000), 588-90.

${ }^{726}$ Gauthier-Pilters and Dagg (1981), 101-102.

${ }^{727}$ Worthington (2014), 216-220; Bosworth (1988), 101-104.
} 
travel about 116 miles per day and maintain a jogging pace for 11-12 hours of each day.

For a week and a half period, this is highly unlikely. Gauthier-Pilters and Dagg find credible but astounding the 1913 account of Captain Chalet, who traveled with a company of camels for only half that distance in as many days. ${ }^{728}$ Thus, it is not likely that Alexander's messengers covered so much territory so quickly, as camels would require rest and recuperation in between long journeys. It is possible that the riders switched their mounts out for fresh ones at various stopping points like those Strabo describes in Mesopotamia (16.27), but unfortunately no knowledge of where those stopping points might be has come down to us. If fresh camels were made available, plausible What seems more likely is that this episode of camel travel is an exaggeration of the camel's already impressive speed and endurance.

\section{Winter Camels: Bactrian Aid in Nautaca}

Although references to camels in the ancient sources are few, they do represent the wide variety of uses to which camels were put and the extreme conditions which the animals can endure. In the winter of 328/7, camels were deployed as pack animals amid the low temperatures of a hailstorm. After the Macedonians departed from their winter quarters in Nautaca at the first signs of spring, they were met on the third day of the march with the abrupt drop in temperature that precedes a hailstorm. The higher temperatures had been a "false spring," and as the air cooled abruptly, rainfall turned into hail and the moisture on the ground froze over. ${ }^{729}$ After taking cover in the forest,

\footnotetext{
${ }^{728}$ Gauthier-Pilters and Dagg (1981), 101.

${ }^{729}$ Curt.8.3.7; alluded to in Arr. 4.21.10.
} 
overnight 2,000 soldiers froze to death, and Curtius reports in grisly detail that many more faced starvation (8.4.19).

Presumably the pack animals bearing winter rations (Curt. 8.2.13) and those brought along as food had died or disappeared in significant numbers as well, for Alexander promised his men that he would "make good all that had been lost" (Curt.8.4.18) and relied on his alliance with the Sogdian satrap Sisimithres to do so. Sisimithres sent him 2,000 camels in addition to iumenta and cattle (Curt.8.4.19) which saved the Macedonians from hunger as well as from the loss of pack animals. The sheer number Curtius reports, even if somewhat exaggerated, reveals the degree to which Sogdians must have relied on camels. As we have seen, camels reproduce rather slowly compared to other domesticated mammals; healthy females calve six or seven times during their lives. This is a substantial herd that Sisimithres was able to spare, and it indicates a strong degree of camel breeding in the Sogdian region, where we have already seen the domesticated Bactrian has prehistoric roots.

Remarkably, Engels makes no mention of the Macedonian use of camels despite his insistence that the region around Nautaca endured severe winters and late harvests, making foraging for grain en route impossible. ${ }^{730}$ We can deduce that the cameli Curtius mentions are Bactrian, based not only on function, but also on their ability to weather the cold season. Bactrian camels can still be found in North-East Afghanistan, and their thicker winter coats and darker tinted hair enables them to absorb and retain heat from the sun. Shorter legs than a dromedary and a stout body make them ideal pack animals, ${ }^{731}$ especially in comparison to Alexander's horses, whose hooves were worn down in the

\footnotetext{
${ }^{730}$ Engels (1978), 106-107.

${ }^{731}$ Gauthier-Pilters and Dagg (1978), 3; Nowak (1999), 1078.
} 
Sogdian region, prompting him to change mounts throughout his travel (Curt. 8.2.34-36). Although Bactrian camels had been used to pull carts in the prehistoric Turkmenistan region, ${ }^{732}$ there is no evidence that the Greeks ever used them in this way, nor would it have been efficient to find suitable roads for wagon wheels when Bactrian camels are already adept at crossing the snowy steppes and hills. In this light it is not surprising that when Alexander repaid Sisimithres, he sent him "xxx milia pecorum" from booty seized later from among the Sacae, but appears to have kept all the camels (Curt. 8.4.20).

\section{The Missing Camels: Gedrosia to Carmania}

Alexander does not appear to have taken his camels into India, an unsurprising decision. While the dromedary can and does function well in the arid parts of India, ${ }^{733}$ it would not do well marching through sub-tropical forests. The humid environment and monsoon flooding of the Punjab region where the Macedonians were marching would have made navigation problematic for any camel, as they have difficulty maneuvering across muddy terrain. While it is reported that camels know how to swim, ${ }^{734}$ they are easily bogged down in muddy riverbeds and would not be able to keep up with Alexander's customary swift pace. While removing camels from the march through India was prudent, the Macedonians certainly could have used them in their march through the Gedrosian Desert to Carmania, the most climactically strenuous and devastating leg of the Macedonian campaign. ${ }^{735}$

\footnotetext{
${ }^{732}$ Kohler-Rollefson (2000), 3.

733 Arr.Ind. 17; Gahlot and Chada (2000), 582-589.

734 Nowak (1999), 1078.

${ }^{735}$ For accounts of the Gedrosian march, see Worthington (2014), 262-263; Bosworth (1988) 139-146, Wilcken (1967), 199-201.
} 
It is necessary to address first the question of whether camels can survive in the desert that consumed the armies of Semiramis and Cyrus (Arr.6.24.2-3). Descriptive evidence of the region and anecdotal accounts indicate that camels could and did inhabit Gedrosia. Most importantly, Arrian notes that when Nearchus' fleet sailed along the Makran coast, they weighed anchor at a small collection of villages called Taa, which were quickly abandoned by the natives upon arrival of the fleet. Finding some grain, the Macedonians' real prize was the capture of seven camels, who were slaughtered and eaten (Arr.Ind.29.5). Further, Aristoboulus' detailed discussion of the flora of Gedrosia (Arr.Anab.6.22.4-8) indicates that there would have been occasional fodder for camels. Spikenard, a grassy herb, evidently grew in abundance; laurel-like trees and unspecified blooming trees grew nearer to shore, ${ }^{736}$ and Acacia catechu, a thistle stalk, could be cut up for the juice its thick branches store. ${ }^{737}$ Although much of it was desert, there were agricultural settlements in eastern Gedrosia, and it was heavily-dependent on monsoon rains. Strabo explains that Alexander's departure was planned in congruence with the summer rains (monsoons) (16.4.3), which matches with the disaster the army met when the post-monsoon mountain runoff flooded its camp.

So too, Bosworth notes that Alexander was marching in the opportune season, just in time to live off the harvest. ${ }^{738}$ Along certain pit stops in the desert, access to grain and dates is reported (Arr.6.23.6), and water was available through coastal wells (Arr.6.23.1, Strabo 16.4.2). Many of the difficulties belabored by Arrian would have presented less of

\footnotetext{
${ }^{736}$ Strabo 15.2.5 notes that these produce epilepsy in animals, but it is indicative of the potential for plant growth.

${ }^{737}$ Strabo 15.2 .5 oddly suggests that the juice had a blinding effect, when in fact it has medicinal properties that alleviate sore throats and diarrhea.

${ }^{738}$ Bosworth (1988), 143.
} 
a problem for camels than for the Macedonian pack animals and are reminiscent of the conditions of the Libyan Desert: lack of water, scorching sand, and loose dunes that made walking on hooves difficult (Arr.6.24.4). Lack of water can only be tolerated for so long, even by camels, but if access to wells and monsoon-fed mountain runoff sustained some of Alexander's men, it could have sustained camels as well. Further, the danger of overhydrating that killed both soldiers and pack animals (Arr.6.25.6) would not have been a risk for the camel, but would have empowered it to endure longer stretches without water, as discussed above (pp.264-266).

And yet, there is no evidence that Alexander sought camels before departing for Gedrosia, which appears neglectful unless there were no accessible camels. Bosworth notes that "the preparations he made were as painstaking and meticulous as any recorded in the course of the expedition," 739 and the amount of time invested in turning Patala into a base for his fleet would certainly have allowed for the collection of necessary baggage animals. Further, Bosworth shows that for a somewhat smaller force, the Makran was not impossible to cross. He notes that in the early eighth century CE, the teenaged Umayyad conqueror Muhammad Ibn Qasim crossed the Gedrosian Desert with a more mobile and smaller force without much difficulty, but notably he brought along cavalry and camels, presumably to bear supplies. ${ }^{740}$ And yet Alexander set off camel-less from the land of the Oretae (Arr.6.22.1-3) and marched 60 days through the inhospitable Gedrosian Desert before reaching the more fertile satrapal capital of Gedrosia, Pura. On the way, he lost a

\footnotetext{
${ }^{739}$ Bosworth (1988), 139. Bosworth notes as well that the suffering during the march was enhanced by the ancient sources, which he adeptly reframes. Without undercutting the true horror of the march, he points to Alexander's timing the march with the rains, the presence of agricultural settlements in the region, and Arrian's selective use of Nearchus' narrative to flesh out the third and most grueling leg of the journey. See Bosworth (1996), 172-176.

${ }^{740}$ Bosworth (1988), 144.
} 
portion of his army to dehydration, starvation, and presumably heat exhaustion. The most detailed account of the devastating march is Arrian's, and he never indicates that camels were used, emphasizing only the destruction of the horses and mules that marched with the army. ${ }^{741}$ However, by the time supplies ran out, Alexander did ask for camels.

The tradition recorded by Diodorus, Plutarch, and Curtius is that as Alexander's army began to starve in the desert of Gedrosia, he sent messengers to the nearest satrapies, those of Parthia, Drangiana, and Areia, ordering them "to bring quickly to the

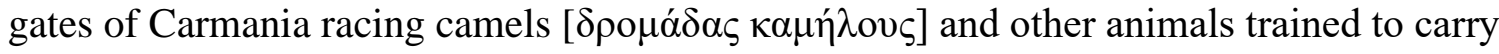
burdens, loading them with food and other necessities."742 According to these authors, the satraps did as they were commanded. ${ }^{743}$ As Badian has noted, it is not possible for the satraps of these regions to have sent aid in due time. Although Alexander's crossing of Gedrosia took 60 days (Arr.6.24.1), the sources do not indicate that he sent for assistance immediately, but rather in response to starvation. ${ }^{744}$ The distance would have made the task impossible. The nearest satrapy to which Alexander sent for assistance was Drangiana, whose capital, Phrada (Farah, Afghanistan) was over 500 miles from Carmania's edge (Karmen, Iran). Thus, Alexander might have requested assistance in this way, but that is not how it arrived. Arrian's account appears the most logical. He reports that the satraps Stasanor and Phrataphernes had sent supplies in advance, among them:

\footnotetext{
"an enormous number of pack animals and many camels; they had guessed, when they learned that he was marching to Gedrosia, that the army would suffer the fate that it had in fact suffered. These men and the camels and pack animals had arrived in the nick of
}

\footnotetext{
${ }^{741}$ Arr. 6.24.4-6, 6.25.1, 6.25.6, 6.26.5.

${ }^{742}$ Diod.17.105.7; Plut.Alex.63.3; Curt.9.10.17. Arrian does not note Alexander's request but alludes to it in the doubtful execution of Apollophanes (6.27.1), reported dead much earlier in combat with the Oreitai (Arr.Ind.23.5).

${ }^{743}$ Diod.17.105.8, Plut.Alex.63.3, Curt. 9.10.18).

744 Badian (1958), 147-150.
} 
time. Alexander distributed all the animals to the officers man by man, and proportionately to the squadrons, companies, and regiments." 745

While Plutarch's report of a $75 \%$ loss of men is highly suspect, ${ }^{746}$ Alexander's army must have withered in size and condition, a problem that could have been partially ameliorated with the aid of that desert ship, the dromedary. However, this animal's use had not been forgotten. Appearing here and there in the already scanty sources of Alexander's "successors," the camel remained a specialized transport unit under the rule of later Macedonian kings. Unfortunately it is not possible to trace their use in as much detail as we have within the context of Alexander's campaign. However, occasional glimpses give a sense of their continued importance, as summarized in appendix 2 , and there is no reason to assume that the generals who divided up and fought over Alexander's empire and the kings that succeeded them abruptly ceased to use pack camels.

\section{Conclusions to Chapters 5 \& 6}

In summation, we can conclude that while camels generally played an ancillary military role beyond the Arabian Peninsula, they qualified as valuable specialized troops in certain climactic and topographical conditions. From the time of the Assyrian to Macedonian rule in the East, camels appear in the sources as dependable members of the baggage train and occasionally as military mounts. The infrequency with which they are referenced compared to horses should not be a measure of their significance or contribution to ancient warfare. Many and varied ancient armies did not incorporate camels simply because they were all that was locally available, but employed them for

\footnotetext{
745 Arr.6.27.6.

746 Plut.Alex.66.4-5; see Bosworth (1988), 145.
} 
their unique capabilities. Among these, the most prominent are the camel's strong resistance to dehydration and unmatched economy of locomotion, which allows them to bear large burdens over great distances. The army of Alexander the Great made use of these skills from the Libyan Desert of Egypt to the wintry steppes of Sogdiana, loading camels with supplies and even riding them through inhospitable terrain that other baggage animals and mounts might not have survived. The status of camels as specialized troops is further reflected in the language ancient sources use to refer to them. While other baggage train animals are described as burden bearing or yoked more often than by their species, the camel is usually mentioned distinctly. The function of the camel is further elaborated, revealing that certain ones were used primarily as racing or messenger camels, while others were bred for bearing baggage and people.

We have also seen that camels' underrepresentation in scholarly literature is not a fair reflection of their contribution to ancient armies. Engels' rejection of the camel's superior ability to withstand climactic extremes relies largely on anecdotal evidence and does not take into account the desert-specific biological mechanisms that camels possess. Modern DNA sequencing and zoological observation has revealed that Old World camelids (the dromedary and Bactrian) developed traits that allowed for desert survival, and they did so at an accelerated (evolutionary) pace in order to survive. Gene evolution related to fat metabolism, vision, water reservation, and osmoregulation are some of the key features of camel development that make the animals so valuable to inhabitants of extreme climates. Such accelerated evolution "raises the possibility of camel-specific evolution to adapt to a desert environment," ${ }^{, 747}$ which ancient and modern armies did and

\footnotetext{
${ }^{747} \mathrm{Wu}$ et al. (2014), 7.
} 
do take advantage of.

After considering the logistical virtues of the dromedary and Bactrian within the context of their use by Alexander's troops, it is fair to categorize camels as a specialized unit, a camel corps on par with (although ultimately not as useful as) the elephant corps. Although most of Alexander's campaigning took place beyond the reach of the scalding khamsins and frosty deserts of the steppes, traveling even once through such a region required careful preparation and the adoption of non-traditional means of riding and carrying supplies, which the Macedonians ably managed. First using the camel for his famous journey to the Oracle of Siwah, an oasis amid the Libyan Desert, Alexander kept the camel throughout much of his Asiatic travel. He incorporated camels with the

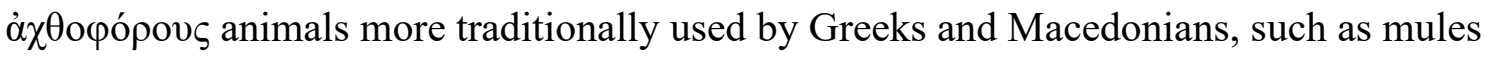
and horses, and used camels; superior strength and economy of motion to transport provisions through difficult climates and haul booty captured from conquered cities back to the occupied Persian capitals. Alexander also put camels to work as $\delta \rho 0 \mu \alpha ́ \delta \alpha \varsigma$, capable of sending messages rapidly through less than hospitable territory, and relied on similarly-trained and speedy animals to meet him at the borders of Carmania with muchneeded supplies. In this way, Alexander fits into a much larger pattern of conquering kings. Like Shalmaneser, Tiglath-Piliser III, Semiramis, and Cyrus before him, Alexander's adoption of a foreign means of military transport otherwise dominated by the Arabs, indicates his continuing policy of military improvement and the creation of specialized forces.

It is also important to remember that while animals are not always highly visible in the extant sources, they were visible to the campaigners, and they played key roles in 
ancient battles, when necessary supplies and men themselves required animal labor for transport, and horsepower was not always the most efficient. While I disagree with Engels' evaluation of camels, his work Alexander the Great and the Logistics of the Macedonian Army does highlight the ways in which questions of supply and travel influenced the Macedonian king's every move, and by extension, the work shows how crucial burden-bearing military animals were in antiquity, and how little attention they receive in scholarly literature. However, by highlighting the military utility of the both camel species' unique evolutionary adaptations, my arguments and conclusions above have rehabilitated the perhaps most neglected of the non-human participants in ancient Greco-Macedonian war. 
Part III: Dogs 


\section{Introduction}

For over a century, the domesticated dog has been a common, if underappreciated, feature of the modern military. From the scotch collies and "quick lunch" dogs of the Great War to bomb-sniffing dogs in Afghanistan, the canine's superior senses and social cognition have frequently been put to use by humans in a military context. Modern experimentation with dog training took off during the Franco-Prussian War and the Great War, during which Germans employed "Scotch collies" trained to sniff out the wounded and carry first aid or fortifying alcohol in packs with them. The Society of Red Cross Dogs served a similar purpose, founded in 1893. The "quick lunch dogs" that brought food and supplies to men in the trenches were trained in Paris to "crawl on their stomachs to escape flying bullets," and they were important ancillary players in the war effort. ${ }^{748}$ However, the incorporation of canines into military contexts is not a novelty, but in fact has a long pedigree worthy of examination.

The goal of this section is to do just that. I shall identify whether, and in what ways, dogs participated in a military context in ancient Greece. Because of the widespread but limited nature of the evidence, the scope of this section is considerably broader than its predecessors. Considering the Archaic through Hellenistic periods, with later documents when applicable, ${ }^{749}$ I use archaeological, epigraphic, and literary evidence to bring together a clearer picture of dogs' roles in ancient military. The nature of the evidence is such that it is unbalanced; for later periods, the literary evidence outweighs the archaeological, for earlier, the evidence is epigraphic and image-based.

\footnotetext{
748 See Philips (2018) and "Quick Lunch Dogs" (1918), 41.

${ }^{749}$ E.g. I use Arrian's Cynegeticus, as it is clearly in conversation with that of Xenophon's; Arrian writes that he will add what Xenophon left out, 1.1-4.
} 
Although ideally a relatively similar amount of all three media would be preferred, lacking a plethora of sources does not stymie the investigation. Indeed, moderate use of comparative and scientific sources can aid in providing a well-rounded answer.

Additionally, I will employ instead prominent evolutionary cognitive behavioral theories about the domesticated dog in order to show that canine behavior, from an evolutionary standpoint, did not vary considerably, if at all, over the past 2,700 years. This continuity permits comparisons between the modern and antique capabilities of military dogs. I wish to emphasize that this is not an attempt at cultural comparison, nor is it a comparison of cultural views on war, technology, or a dog's place in a military setting. Rather, my aim is to show that the domesticated dog had evolved to possess particular traits which made it better suited for working alongside humans than other domesticated animals. This potential for use in complex tasks, combined with an evident cultural appreciation for the dog in ancient Greece, helps bridge the chasm between whether dogs could be used for military purposes and how they were in fact used. As we shall see, canines were (and were recognized to be) biddable, intuitive, and capable of interpreting human social cues; physically they were resilient and capable of hard training through the hunt. By explaining the dog's capacity for military use, we will much more easily be able to connect references in ancient pottery, funeral stelae, and literature to actual military use of these animals.

In summary, the section will be organized thus. Chapter 7 will begin with a (A) brief survey of Canis familiaris and how it evolved from the now-distinct species Canis lupus. We will also outline the Greek scientific understanding of the dog as a distinct species, as well define Greek dog "breeds," such as they were, and establish a standard 
nomenclature for the duration of the chapter. Next, we will (B) outline the Greek social and cultural understanding of the dog, a complex and at times paradoxical set of beliefs that view dogs as fiercely loyal, protective, and noble, but also comedically gluttonous, shameless, and potentially dangerous. Understanding the Greek view of the domesticated dog will later aid us in determining its role in a military context.

In Chapter 8, we will consider (A) a brief survey of non-Greek military use of canines in antiquity, focusing primarily on early Near Eastern cultures which might have influenced Greek perception and use of the canine. Finally, we will (B) address the question of Greek use of military dogs, establishing how and whether dogs could plausibly be used in ancient Greek armies and then linking the knowledge of dogs' capabilities to the ways in which they actually participated. From this examination of the evidence, we shall see that canines often accompanied their masters on the march, participated in the defense of military camps as well as citadels, and occasionally performed ancillary work such as communication, tracking, or advertising the status of their master.

\section{A note on the use of HAS}

As I noted in the dissertation's introduction, the lack of HAS within the realm of ancient socio-military history is noticeable, and this is especially so in the case of the war dog, a figure that has been nearly invisible to scholars due to a paucity of literary evidence. This chapter will employ the tools and lenses of HAS more commonly than others not only because of the limitations of the literary evidence, but because of the evolutionary history shared by humans and dogs (see below p. 293f.). In 1941, Forster's brief but informative article listed literary accounts of war dogs and provided 
commentary, ${ }^{750}$ but by 1952 Cook's essay on war dogs attempted to reduce them to a figment of later Greeks' imaginations and to artistic motifs which "need have no particular meaning or relevance.",751

Although Calder has more recently pointed to pictorial evidence that suggests otherwise, the nature of her work limited her investigation. ${ }^{752}$ Similarly, Mayor offers a few sentences on the military dog's capacity as a guard in her broader essay on animals in warfare. ${ }^{753}$ Karunanithy published a study of dogs in the military that ranges from their use in ancient Egypt to the Seminole Wars of the 19th century. In this work he attempts to reproduce in sketches what the use of military dogs might have looked like for the ancient Magnesians and Epirotes, but a dearth of literary evidence limits detailed discussion. ${ }^{754}$ More recently, Rees published an article asserting that war dogs were not part of the Greek military, and even in their capacity as sentries they were "as useful as they were unreliable." ${ }^{, 755}$ Cook, Calder, and Rees are in this case using too narrow a scope to investigate the presence of dogs in the military realm of ancient Greece. The purpose of this chapter is to present a more thorough examination of military dogs in Greece and to consider relevant literary, epigraphic, and archaeological sources in order to form as complete a picture as possible of the dog's role.

As HAS expands, the roles animals (especially domesticated animals) played in making and impacting history are being considered in a new light—especially the canine. Pearson's excellent article on the agency of canines emphasizes that previously

\footnotetext{
${ }^{750}$ Forster (1941), 114-117.

${ }^{751}$ Cook (1950), 41.

752 Calder (2011), 71.

753 Mayor (2014), 282-293..

${ }^{754}$ Karunanithy (2008), 147-168.

${ }^{755}$ Rees (2013), VII.5.
} 
"academic historians have largely overlooked the presence of dogs in war or have argued that they constitute a form of technology." 756 Such reification of animals is easy in a society that buys, sells, owns, and infantilizes them, but this does not mean that humans do and did not recognize that their animals had the power of choice and, in some cases, distinct personalities and the capacity for rather human emotional attributes. Pearson notes that the "conflation of agency with human levels of intentionality and selfconsciousness provides a formidable obstacle for the integration of nonhumans into historical narratives in an active, history-shaping way."757 Agency, as Shaw has argued, exists along a continuum, including "intentional acts of a rational man" as well as "base actions, group actions, and less self-conscious actors, for instance a horse."758 Animal agency and human agency are not always expressed in the same way, but this does not negate the existence of the former. Accepting that dogs possess a degree of agency, by which they are able to influence and or effect change, is a precondition for bridging the gap between HAS and history.

As Pearson has noted, there are naturally differing degrees of intentionality between humans and animals, and a major reason for academic hesitation in ascribing agency to canines, among other animals, is doubt over their intentionality, which presupposes a degree of rationality and intent, rather than automatic or instinctive responses. Indeed, we have seen that ancient Greeks readily recognized the personality, individuality, and capacity for intentionality in their dogs. In the third century CE, Arrian notes personality differences in dogs explicitly: "for there are hounds that dislike each

\footnotetext{
${ }^{756}$ Pearson (2013), 129; cf. Shaw (2013), 8.

757 Ibid., 133.

${ }^{758}$ Shaw (2013b), 146.
} 
other and others that are not friendly, just like humans" (Cyn.12.4).

Plato makes canine judgment the guidelines by which guardians of the ideal state themselves should be judged, noting that there is no difference between a well-bred dog or a young man of elite status. While he has Socrates claim that the dog is a true philosopher only in a tongue-and-cheek sense, he does recognize the ways in which dogs fulfill the obligation of the citizen of being "amenable to their own people, but intractable against their enemies."759 Plato's Socrates ascribes this to the natural dispositions ( distinguish between friend and foreigner based on knowledge or familiarity with a person, not based on what they absorb through the five senses (Rep. 376B). While wrestling with whether land or sea animals possess greater intelligence, Plutarch relies on the dog as a key representative of land animals. He notes that "the dog's true capacity may be discerned from many other acts and reactions and the performance of duties, which are neither to be smelled out nor seen by the eye, but can be carried out or perceived only by the use of intelligence and reason." 760

As we shall see, dogs' ability to reason and make decisions is closely linked to social cognitive abilities which evolved in Canis familiaris alongside the evolution of human societies. I will employ aspects of HAS in order to address the titular questions of this chapter, relying on HAS' application as defined by Fogen and Thomas, who note that HAS is useful within the broader field of ancient history because it helps to determine the ways in which animals and humans were interconnected, often due to their occupation of the same "structures, 'networks' and communities, or at least...finding themselves

\footnotetext{
759 Plato Rep. 375C.

${ }^{760}$ Plut.Moralia 969C.
} 
together in a certain setting, context, or environment — wittingly or unwittingly."761 Both editors of Interactions Between Animals and Humans in Graeco-Roman Antiquity assert that the limited resources that accompany any study of antiquity do not entirely hamper their inquiry, as the ancients both wrote about and also depicted animals, and animals and humans together. ${ }^{762}$

${ }^{761}$ Fogen and Thomas (2017), 7.

${ }^{762}$ Ibid., 8. 


\section{Chapter 7: Domestication \& Perception of the Dog in Ancient Greece}

Because this chapter deals with the domesticated dog, an animal whose evolution coincided with human settlements, some discussion of this evolutionary process is warranted. As we shall see, the co-evolution of early human societies and the domesticated dog is what makes Canis familiaris so useful in combat. Further, it will be necessary to discuss the extent of the ancients' understanding of the dog's unique intellect and social cognition in order to make a case for its employment in war.

\section{Part A: Domestication \& Breed Theories in Antiquity and Modernity}

The evolution of canines hinged on their relationships with humans, thus it is unsurprising that many ancient peoples, especially the Greeks, were intimately familiar with dog behavior. The ubiquity of dogs in the ancient world as companion animals distinguished them to a degree from the "wild" and made them far less fascinating topics of biological discussion than more exotic animals. While Aristotle mentions dogs frequently, he does not devote lengthy discourses to them, but rather relies on them as a means of comparison for his readers, a familiar touchstone to illustrate the behaviors of a rather less well-known animal. For example, consider Aristotle's explanation of the protective purpose of body hair on quadrupeds. He discusses hair growth patterns broadly, noting that some animals "have thick hair all over the back part of their body (e.g. dogs), some of them have a mane (e.g. horses and such), others a flowing mane, like 
the male lion." ${ }^{, 763}$ Aristotle links physiological features of animals to behavioral traits and relies often on the dog as a means of proving his example. Animals with "projecting upper lip and jaws are quarrelsome; witness the dog," and "that have a sharp nose-tip are prone to anger; witness the dog." ${ }^{, 764}$ The dog was also used to illustrate positive physiological-behavioral correlations: "those who have a large head are sensitive; witness the dog.",765

The dog and horse especially serve as illustrative examples throughout his works, and other domesticated food sources make occasional appearances. In his Parts of Animals, Aristotle uses dogs and swine as a point of reference for mammary glands in animals with large litters (688B); dogs and swine are grouped with man among animals with long spleens (674A), and canines' and pigs' stomachs are used as archetypal descriptions of small and large guts, respectively (675A). This reveals intimate knowledge of canine intestines which correspond with occasional references to dog sacrifices in antiquity, ${ }^{766}$ however some references to dogs point to the close quarters in which dogs and humans lived. For example, in his discussion of animal intestines, Aristotle illustrates his point by reference to what must have been a common, if unpleasant, part of dog-ownership: "Thus, in some it [the large intestine] is wider near the stomach, and narrower towards the end (that is why dogs find difficulty in discharging their excrement); in the majority, however, it is narrower at the top, and wider at the end." 767

\footnotetext{
763 Aristotle, $P A, 658$ A.

764 Aristotle, Physiognomics $811 \mathrm{~A}$.

765 Ibid., 812A. "Sensitive" here indicates a degree of rationality.

766 See Day (1984), 21-32; Lonsdale (1979), 150-152. Plutarch (Mor.290B-C) notes that dogs were traditionally sacrificed to Hecate, to Ares in Sparta, and used for expiation rites in Boeotia.

${ }^{767}$ PA 675A-B
} 
The domestic dog was a common presence in the ancient Greek world, but what were its origins? At least as early as Xenophon, there was speculation about dogs' ancestors. In the Cynegeticus, Xenophon describes the two "types" of dog: the Castorian hound and the Alopecid (Vulpine) hound. The former references the type of "purebred" dog kept by the hero Castor, and the latter a crossbred between a dog and fox (3.1); Xenophon notes that by his day, "the nature of the parents has become fused" (ibid), with the majority of dogs possessing some form of defect, presumably due to their hybrid ancestors (3.2ff). Later Aristotle suggested hybridization not unlike the Alopecid canine that Xenophon references. He notes that hybridization is common among "dogs, foxes, wolves, and jackals" and illustrates his point with the Indian hound, which he claims is produced either from "the union of a dog with some wild doglike beast" (GA 746B) or from a dog and tiger whose progeny is bred down over three generations (HA 607A 4). In his Generation of Animals, Aristotle hits closer to the truth, recognizing that dogs can breed with certain members of the canid family, of which there are 38 members. Foxes, however, are not among the canids that can be crossbred with dogs. The strong resemblance between some breeds of domestic dog and certain wild canines like foxes, jackals, and dholes (Cuon alpinus, an east-Asian canid), made it difficult to determine whether the great variety of dog breeds originated from a single progenitor species or multiple different species of canid, a point which Darwin once noted may be permanently unsolvable. ${ }^{768}$

Up until very recently, Darwin was considered correct. However, a combination of DNA testing, morphological, paleontological, and behavioral studies of Canis

\footnotetext{
${ }^{768}$ Serpell 1995, 8; Brewer (2001), 5-20.
} 
familiaris revealed that the ancient Greeks' ideas about dogs' wild origins were correct, even if Xenophon's theory of a vulpine progenitor is not possible. ${ }^{769}$ We now know that Canis familiaris is the direct decedent of canis lupus, the wolf; more specifically, recent studies point to the grey wolf as the primary ancestor, of which there are currently several sub-species. ${ }^{770}$ The dog's resemblance to other canids stems from a common ancestor, potentially the Mesocyon or Tomarctus. ${ }^{771}$ The process of the domestication of Canis lupus occurred over a period of thousands of years, and paleontology offers us only a glimpse at the progression. As long ago as the Middle Pleistocene period, bones of Canis lupus have been found "in association" with the bones of early hominids. ${ }^{772}$ In France, China, and England such bone deposits range in age from 150,000 to 400,000 years ago, indicating that wolves and early humans cohabitated in some fashion for millennia. Fully evolved dog remains appear in the company of humans at least as early as 10,000 at the site of Ein Mallaha, Israel. There the body of a human was interred with a puppy approximately 12,000 years ago in the context of a small village of hunter-gatherers. ${ }^{773}$

If wolf bones in the company of humans date back as far as 150,000 years ago and clearly identifiable dogs appear at least 12,000 years ago, at what point did Canis lupus become Canis familiaris? The answer depends in large part on the way in which one identifies what constitutes a species. The categorization of species involves the

\footnotetext{
${ }^{769}$ Derr (2011), esp. 33-41, offers a tidy summary of recent biological, behavioral, and archaeological studies on the evolution of Canis familiaris from Canis lupus that is accessible for a non-specialist audience.

${ }^{770}$ Brewer et al. (2001), 5-20 provides a summary and evaluation of the three primary research methods zoologists used to arrive at this conclusion: comparison of morphology, observation of captive animals over generations, and behavioral assessments. See pp.21-27 for speculation on the manner in which canines were first domesticated. A more detailed zoological bibliography can be found in Serpell (1995), 8, 18-20.

${ }^{771}$ Brewer et al. (2001), 5-9.

${ }^{772}$ Clutton-Brock (1995), 8-20.

${ }^{773}$ Serpell (1995) 10-11; see 10ff. on the paleontological evidence for early domestication of the wolf.
} 
imposition of a specific structural definition atop a rather fluid reality; which traits count as determining factors of an animal's species? Brewer et al. deal with the issue well, ${ }^{774}$ noting that the family group Canidae is distinguished from bears, weasels, and raccoons, all of which share a common ancestor, the Miacid, by "good stereoscopic vision, a keen sense of smell, the ability to hear a wide range of frequencies, and long limbs and digitgrade feet that enable them to run fast and cover great distances. In addition, canids are highly intelligent social animals that take advantage of living in packs to rear their young and to hunt." 775 Whether the dog is a separate species from the wolf and coyote is somewhat contentious given their ability to interbreed, although they are generally considered distinct species.

The process of domestication itself is complex and quite unclear, traceable only by the paleontological record. Gradual changes to the wolf that accompanied its cohabitation with humans were not unlike natural evolution, but a social transformation was also at work. Serpell notes that the domesticated wolf became isolated from wild populations and forms a small "founder group, or deme"776 that evolved differently than its wild counterparts. Because the tame wolf would have eventually become enmeshed in human society, the specific traits selected for over millennia would be radically different from those which might help the wolf survive in the wild. Over time, Canis familiaris began to emerge, and the wolf was "no longer a wild carnivore but a part of human society with physical and behavioural characteristics adapted to its economic, aesthetic, or ritual functions."777 Genetic traits of heightened perception of one's surroundings,

\footnotetext{
${ }^{774}$ Brewer et al. (2001), 21-23.

${ }^{775}$ Ibid., 5-6.

${ }^{776}$ Serpell (1995), 15.

777 Ibid.
} 
linked closely with hormone levels, changed through generations of tamed wolves because characteristics such as "docility, lack of fear and tolerance of stress"778 were selected for by humans and better enabled tame wolves to survive in human society. Hare et al. rightly note that this transformation was not solely guided by artificial selection on the part of humans; wolves with traits that enabled them to understand human social cues more flexibly had a greater chance of flourishing in human environments, and both wolf and human took action for their own gain in cohabitating. ${ }^{779}$

Over time, genetic drift would have contributed to genetic variety among domesticated wolves-turned-dogs, creating a variety of characteristics. Serpell notes that there is no clear emergence of specific breeds until 3,000-4,000 years ago, but his citation of the "greyhound type" $" 780$ that appears on early Middle Eastern pottery hints at the true difficulty of identifying breeds in the ancient world. Recent studies of canines in antiquity have found it impossible to equate ancient breeds to modern ones, or indeed to identify the qualities of any specific ancient breeds at all. ${ }^{781}$ Ancient literary sources reference dozens of different breeds of dogs, although many breeds appear only in a single document. The most commonly-mentioned types of dog are the Carian, Cretan, Lacedaemonian/Laconian/Spartan, and Molossian. The Molossian is well-known in Athens from the fourth century funeral marker in the Cerameicus. The massive statue in [Image 7.1] belonged to the burial plot of the family of Lysimachides of Acharnae and was initially positioned as an acroterion of the peribolos, an impressive display.

\footnotetext{
778 Ibid.

${ }^{779}$ Hare et al. (2002), 1634-1636; Pearson (2013), 132.

${ }^{780}$ Serpell (1995), 16-18.

${ }^{781}$ For a discussion of dog breeds in antiquity, see: Hull (1964), 20-38; Merlen (1971), 28-34; Phillips and Willcock (1999), 12-18; Brewer et al. (2001), 25-27, 85-94, illustrative example of the saluki breed pp. $72-$ 73; Karunanithy (2008), 161-162.
} 
However, Molossians are infrequently portrayed in Athenian art, likely because their size made them more suitable for farm life. ${ }^{782}$ Phillips and Wilcock provide a useful visual that outlines the description of what constituted a breed standard according to ancient authors who wrote about canines specifically, among them: Xenophon, Arrian, Grattius, Oppian, Pollux, and Nemesianus. ${ }^{783}$

However, most of these descriptions are vague and do not permit us to link the passages to any contemporary images. For example, Arrian's description of the Celtic breed vertragus, unknown to the classical Greeks, emphasizes that its personality is high spirited and supercilious, its eyes bright, its body is long with a pointed muzzle, soft folded ears, a broad chest, hollow belly, firm legs, and its tail fine with a shaggy tip (Cyn.4-5). This does not vary significantly from images of the Molossian, and while the Celts certainly would have bred from different stock, distinguishing the two types, it is impossible for us to do so. While it can be assumed that a greyhound "type" existed based on the proliferation of such images in Archaic and Classical pottery, varying height and markings might indicate anything from different breeds to simply aesthetic variation. Similarly, whether Carian and Cretan hounds fit the greyhound mold or looked entirely different is unclear. Indeed, since breed names appear to be linked to the location from which the dogs were bred, rather than any specific set of characteristics, origin may have been of greater import to the Greeks. In sum, Merlen's 1971 summation of Xenophon's "good hound" remains true: "It must be admitted that, in the absence of any accompanying illustration, it is almost impossible to form any clear idea of the hound in

\footnotetext{
${ }^{782}$ My thanks to Ian Worthington for providing this photo and to Katia Margariti for the information about the peribolos from which the statue came.

${ }^{783}$ There is a convenient chart of such descriptions in Phillips and Willcock (1999), 17.
} 
question" 784

Before discussing the role dogs played in the ancient Greek military, it is necessary to make a general sketch of Greek perceptions of dogs to contextualize the animals' role in everyday life. Quite unlike the Egyptians, who had elevated the canine to holy status, ${ }^{785}$ and the Hebrews, who perceived of it as unclean, ${ }^{786}$ Greek attitudes toward dogs were two-fold and depended upon the nature and status of the animal. In antiquity as in modernity, the dog was considered something similar to "man's best friend" and highly valued for their loyalty and companionship.

\section{Part B Greek Perception of Dogs: Social and Cultural}

To the ancient Greeks, dogs were beloved pets and respected hunters, but they were also considered gluttonous and shameless by nature. Further, the unfamiliar dog was a potential enemy, appearing after battles alongside kites as gruesome undertakers. This duality of opinion co-existed easily then as it does today, and impacted the way the ancient Greeks referenced dogs in literature and used them in everyday life. ${ }^{787}$ Understanding Greek references to a dog, as to any cultural symbol, requires what Kitchell calls "cultural literacy."788 One must understand what is not written down to understand what is, and the same is true of images. Kitchell notes that "Greek authors had definite ideas as to the expected cultural literacy level of their audience and they wrote accordingly...classicists... like the ancient Greeks, possess in our cultural constructs the

\footnotetext{
${ }^{784}$ Merlen (1971),..

${ }^{785}$ Brewer et al. (2001), 28-47.

786 Ibid., pp. 49-70.

${ }^{787}$ Lewis and Llewellyn-Jones (2018), 180.

${ }^{788}$ Kenneth Kitchell (2017), 183-204.
} 
information that makes phrases like 'the far thunderer' or 'Tyrian purple'

understandable," and the same degree of cultural literacy may be extended to animals. ${ }^{789}$ Kitchell's example focuses on Euripides' Philoctetes, but we may draw a canine-focused example from Aeschylus.

The existence of the paradoxical Greek understanding of dogs as both virtuous and viceridden is clearly portrayed in Aeschylus' Agamemnon. Without the double understanding of dogs as both paragons of loyalty and also prone to shamelessness, Aeschylus' Clytemnestra's declaration would carry little weight:

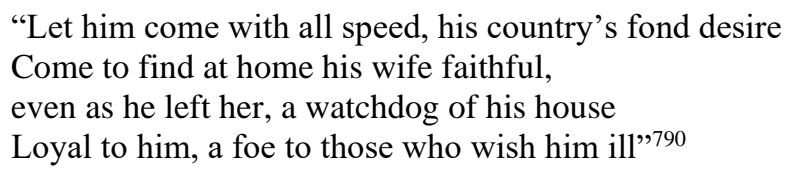

A certain degree of what Kitchell calls "animal literacy"791 is required for the passage to make sense. Clytemnestra invokes the dog as a known symbol of fidelity, but the

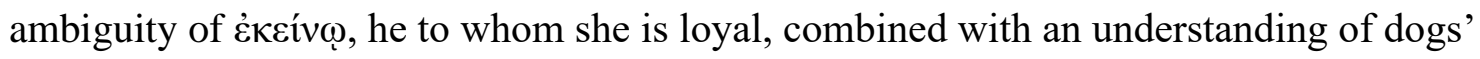
shamelessness, conveys her hidden meaning to the audience. ${ }^{792}$

\section{The Good Dog}

Perhaps the most praised of the dog's virtues is its loyalty to its human, best exemplified by the only dog to whom Homer gives a name. The 40 or so lines of the Odyssey describing Odysseus' final encounter with Argus (17.291-327) have poignant meaning

\footnotetext{
${ }^{789}$ Ibid., 185.

790 Aes.Ag.605-608; trans. H. Smythe, 1926.

791 Kitchell (2017), 186.

${ }^{792}$ Lilja (1976), 55-56 for varying interpretations and bibliography.
} 
and are reflective of a close bond between humans and their pet dogs, with which Homer expected an audience to empathize. After a 20-year absence, the king of Ithaca returns in disguise to reclaim his throne, appearing to all others a bedraggled beggar. It is significant that the only one to see past a disguise crafted by a goddess is Odysseus' aged hunting dog. While "steadfast" ( $\tau \alpha \lambda \alpha \sigma i ́ p \rho o v o \varsigma)$ is applied to Odysseus, it is epitomized in the scene by Argus, who "wagged his tail and dropped both ears" (17.302) in recognition, piteously crippled by old age and resting atop a pile of manure despite once having possessed marvelous speed and strength (17.315).

The similar conditions of Odysseus and Argus are deliberately employed by the poet, with Argus' suffering serving as an "anticipatory echo" of sorts suggestive of what Odysseus was to see upon entering his much neglected household. ${ }^{793}$ Indeed this realistic depiction of a dog (as opposed to the more fantastical) is the one in which an emotional connection between dog and man is expected to incite empathy. Seeing his dog in such a state, Odysseus cannot help but weep for him (17.304) and ask the swineherd Eumaeus about Argus' life. Here, Argus' loyalty stands out against the story of betrayal Eumaeus weaves, explaining that care for Argus (and by extension the rest of Odysseus' household) declined following the king's assumed death. The young men no longer took Argus out for exercise (17.294-295), and "heedless women give him no care” (17.319). Argus, "once he had seen Odysseus in the twentieth year" finally died (17.327), having fulfilled his duty to Odysseus' household.

\footnotetext{
${ }^{793}$ Beck (1991), 158. Beck asserts that this similarity between master and dog is not only intended, but part of a larger trope throughout the Odyssey, appearing in the cases of Alcinous' immortal hounds of metal, Circe's deceptive and ultimately deadly menagerie, the fierce guard dogs that almost attack Odysseus outside of the stables and whom he did not rear, and finally Argus. Within this construction of dogs foreshadowing the behavior or fate of their masters, Beck argues that readers (or listeners) were expected to accept as a truism that dogs and masters often behaved similarly, perhaps because their lives were more closely intertwined than humans and any other animal (158-167).
} 
Examples of canine fidelity are numerous, and this survey is far from exhaustive. We may consider the Homeric Hymn to Hermes in addition to the Odyssey, in which Apollo defends his sheepdog's capabilities when he finds his cattle have been stolen. Apollo touts his dogs' singlemindedness in their duty, which he notes is on par with

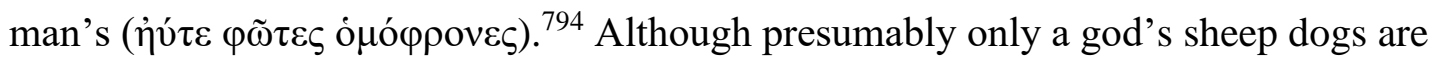

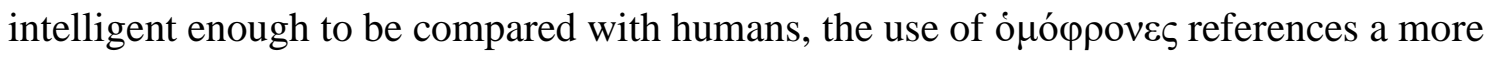
general understanding of how herding dogs think - they, like their wild ancestors, form a pack mentality to direct cattle and guard the animals on their master's behalf. ${ }^{795}$

Praise of loyal hounds is not confined to the world of poetry; accounts of canine fidelity emerge in later historical and philosophical works as well. Pliny notes that "of those animals which live alongside us, many are worthy of consideration, and the most faithful to mankind are the dog and the horse" (NH 8.142), a sentiment with which many Greek authors seem to agree. Plato sees the dog as one of the most intelligent and morally upright in the animal kingdom, using it as an example of the virtues which a human guardian of the state ought to exemplify. ${ }^{796} \mathrm{He}$ asserts that a dog is by nature gentle with those whom it knows but the contrary to strangers, an ideal protector and, in Plato's

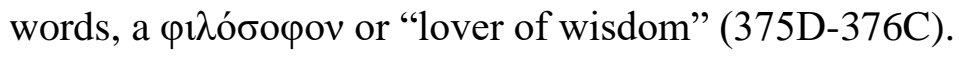

The dog's loyalty and capacity to learn are the basis of support for Plutarch's argument that land animals possess a higher intelligence than sea animals. The dog, he asserts, is manifestly capable of affection and dutiful service, neither of which things can be based on instinctual reactions to the senses, but must come from reason and

\footnotetext{
794 Homeric Hymn, Herm.195.

795 See Lilja (1976), 41-42.

${ }^{796}$ Rep. 375E- 376; Lonsdale (1979), 150.
} 


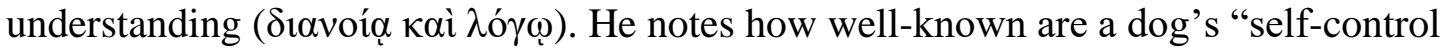
and obedience and sagacity on hunting parties to you who see and handle these matters every day" (Mor. 969C). Both Plutarch and Aelian provide numerous accounts of dogs that guard their masters' bodies after death or even follow their masters right onto the funeral pyre, such as the Hyrcanian hounds of Lysimachus did. ${ }^{797}$

While a degree of understanding between humans and dogs is to an extent possible, such accounts strain modern credulity. ${ }^{798}$ However, the significance of such stories is not their factual accuracy, but that they were considered likely by the author, his sources, and his readers or listeners. The stories reflect a Greek understanding of canine behavior and highlight the degree to which humans valued canine loyalty. The faithful hounds who guard their masters' corpses and even attempt to avenge them after death certainly have echoes of Argus' steadfastness in the face of Odysseus' widely-believed demise. It seems likely that a human understanding of canine loyalty has been a constant in dog-owning cultures since the domestication of the wild wolf; fidelity to members of a recognized social group is embedded in canine behavior. ${ }^{799}$ Archaeological sources indicate that to an extent this bond of trust and fidelity ran both ways, and many humans saw their dogs as more than utilitarian animals. Numerous grave stelae portray the dead

\footnotetext{
${ }^{797}$ Plut. Mor. 969E and Ael. DA 7.10 both tell the story of a Roman soldier (either Calvus or Galba) whose corpse was defended faithfully by his dog. Plut. Mor. 969 D-E also includes a story of a dog that effectively sought Pyrrhus' help in avenging his master's murder. Aelian claims that Darius III of Persia was in the end forsaken by all his friends except his dog, who remained at his side (DA 6.25). For stories of dogs leaping into coffins or funeral pyres see Ael.DA.7.40 and for Lysimachus' Hyrcanian hounds see Plut.Mor.970E; also found in Ael.DA 6.25.

${ }^{798}$ Osborne (2007), 61-97.

${ }^{799}$ See Bradshaw and Nott (1995), 115-130. Derr (2011), 87-108 theorizes that this similar social structure is what led Neanderthal hominins to interact with wolves in the first place, proposing that they coordinated hunting efforts due to overlaps in preferred prey.
} 
alongside their dogs, indicating the significance of that bond ${ }^{800}$ Dog burials in Greece, especially alongside humans, go back as far as the Bronze Age and continued through the Iron Age, an archaeological fact that lines up well with Homer's description of Patroclus' burial (Il.23.173-174). ${ }^{801}$ By the Classical Period, a number of epitaphs for or including dogs may be found in the Greek Anthology, although we must use caution in approaching them. ${ }^{802}$ Lilja's investigation of dogs in world cultures includes a discussion of Greek epitaphs. ${ }^{803}$ She cites two anonymous epitaphs for Tauron, the hunting dog who died from wounds sustained in a boar hunt and an epitaph for Lycus attributed to Simias of Rhodes. ${ }^{804}$ In a similar vein, a certain Addaeus wrote a poem of thanks to Artemis for preserving his dog Calathina in her labor (Greek Anth.9.303). A $4^{\text {th }}$ century canine burial lacking a funeral stele still carries a clear message that the dog was much loved by his owner. Interred in the Athenian agora, the dog was buried with a large beef bone alongside its head, tilted in the direction of its muzzle, ${ }^{805}$ perhaps a gift for the afterlife. In all of these cases, a bond between human and dog is clear.

Many pet dogs may also have been working dogs, but functional applications of pet ownership do not preclude affection. Indeed, Kitchell warns against viewing dog

\footnotetext{
${ }^{800}$ See e.g. Calder (2017), 81-82 and Calder (2011) figs. 202-203 on p. 187. While such images may be suggestive of wealth or status, Calder rightly notes that the dogs are not just "essential accessories of respectable leisure" $(2017,66)$ but companion animals. See further Zlotogorska (1997), in which over 300 grave stelae depicting dogs from Archaic Greece to Imperial Rome are catalogued.

${ }^{801}$ Day (1982), $22 \mathrm{ff}$.

${ }^{802}$ There is some uncertainty regarding the degree to which one could appear to 'mourn' for one's dog. Aelian attributes the Athenian Poliorchus' burial of his pets to ostentation, claiming that "he lived so luxuriously that he arranged public burial for his dogs and fighting cocks" (VH 8.4). Evidently this was a disputed practice, and Theophrastus pokes fun of the "man of petty ambition" who goes overboard in memorializing his pet: "when his Melitaean dog dies, he builds it a monument and inscribes on it a plaque: "Klados of Malta" (Char.21.9). While the construction of a monument, which most human burials did not receive, might qualify as ostentation, a moderate record of a dog's life does not appear to have been taboo. ${ }^{803}$ See especially Lilja (1976), 111-125.

${ }^{804}$ Lilja (1976) 113-114 citing Preisigke and Bilabel III:1 105 no.6754, Pollux Onomas.5.47.

${ }^{805}$ American School of Classical Studies at Athens (1973), Early Burials from the Agora Cemetaries, Princeton; Day (1984), 25.
} 
keeping in antiquity "through the lens of social Darwinism" 806 in which "primitive" societies like those Homer describes would have tolerated dogs for practical purposes, but only the more advanced Classical period polis was capable of keeping a pet dog for the sole purpose of companionship. Kitchell notes that this line of thinking grossly oversimplifies reality, and "human-animal relationships are rarely that simple, no matter the level of society in question." ${ }^{807}$ Certainly, pet-keeping was common in the ancient world, and it served multiple purposes, both practical and psychological. While some pets might have aided in human survival through guarding them, assisting in obtaining food, or keeping parasites and pests out of the house, others provided companionship, then as now. ${ }^{808}$ That companionship could extend to providing unseen health benefits. Calder rightly notes that there is no reason to suspect that the modern-day analysis that shows petting animals lowers blood pressure and stress cannot be applied in antiquity, as evolutionarily humans have not significantly changed..$^{809}$

If depictions on Attic pottery are any indication, pet dogs were ubiquitous in the ancient Greek world. ${ }^{810}$ They often appear indoors in Greek imagery, and with children, as in [Images 7.2-7.4]. Calder began her study on Greek attitudes toward animals with an investigation of shared living spaces, one of six key themes in the investigation of “intensive human-animal interaction." ${ }^{811}$ These circumstances presented an opportunity for humans and dogs to form a unique bond, distinct from other domesticated animals. In this chapter, I propose that this bond extended to travel beyond the household and

\footnotetext{
${ }^{806}$ Kitchell (2004), 179.

${ }^{807}$ Ibid.

${ }^{808}$ See Calder (2011), 79-97; Bodson, (2000), 27-41.

809 Ibid., 80.

${ }^{810}$ See Kitchell (2020), anticipated.

${ }^{811}$ Ibid., 3, 13-17.
} 
hunting route, up to and including a military march. There is no reason to assume that dogs were ill-suited for the trip (cf. Xen.Cyn.12.1), and, as we shall see, abundant reason for accepting that they may have accompanied their masters to war.

\section{The Bad Dog}

That dogs could personify both fidelity and shamelessness, nobility and gluttony, indicates that dogs were understood to have personalities and individual characteristics. They were neither mindlessly loyal nor slaves to impetus and instinct, but, like humans, they were capable of behaving in a multitude of ways and possessors of agency. While we have seen that the dog was a byword for loyalty in antiquity, capable of forming close bonds with humans, they also exhibited some of mankind's less admirable characteristics.

In Homer, the word "dog" is used as an insult or in the context of a threat as often as it appears in positive context within a simile. Noble and intelligent, dogs appear in the Iliad within the "nexus of 'dogs and men'... [who] compose a unified front against the wild beast." ${ }^{\prime 12}$ Both Trojans and Achaeans are likened to dogs in hunting scenes in a not unfavorable fashion. ${ }^{813}$ However, dogs were also considered to be shameless, greedy, and mischievous. For example, Achilles punctuates his furious reply to Agamemnon with adjectives in the vocative, calling him $\alpha \dot{v} \alpha 1 \delta \grave{\varepsilon} \varsigma(I l .1 .158)$ and a $\kappa v v \tilde{\omega} \pi \alpha(I l .1 .159)$, "dogface" because of his shameful greed. Variations on this including "dog-eyed," having the "front of a dog," and "dog fly" are used as an insult and battle taunt rather frequently among both men and gods. ${ }^{814}$ Helen insults herself as a dog because of the mischief that

\footnotetext{
812 Franco (2014), 19.

${ }^{813}$ Ibid., 19-20.

${ }^{814}$ E.g. I1.2.25, 9.373, 11.362, 21.394, 21.400, 22.345; Od.22.36.
} 
led her to be abhorred by all, ${ }^{815}$ and the violence associated with canines leads Teucer to characterize Hector as a mad dog whom he cannot slay in battle (Il.8.299). There is no difficulty in emphasizing the particularly negative characteristics of an animal for the sake of an insult. As Franco has noted, "in the absence of concrete proof, [that] the use of kyon as an insult must necessarily correspond to a general repugnance for the dog is untenable, and indeed contrary to the evidence of ancient sources." 816

Although the frequency with which Homer uses dog-words as an insult is not paralleled anywhere in Greek literature, the dichotomy between the valuable and virtuous dog and the gluttonous or opportunist persists. The Triptolemos Painter's early fifth century kylix portrays a series of images in which a human and dog communicate, vignettes which some scholars have categorized as stages of dog training. On side A we see a dog learning to "shake," but in the tondo, the dog appears to be attacking a young man and defecating at the same time, an unusual combination of bad behavior, as Pevnick notes, although dog defecation appears on several vessels, including a skyphos and an oddly graphic eye-cup, both likely with the goal of amusing the viewer. ${ }^{817}$

The view of dogs as gluttonous and prone to food-theft appears rather often in pottery, where dogs stand or sit near or beneath a table in a sympotic context, ${ }^{818}$ near a

${ }^{815}$ Il.6.344; see Graver (1995), 41-61.

816 Ibid., 8.

${ }^{817}$ Pevnick (2014), $156 \mathrm{ff}$.

${ }^{818}$ For example, an Athenian black-figure amphora c.550-500, housed in Hamburg, market, Galerie Neuendorf, Beazley Archive number 5723; an Athenian black-figure oinochoe, c.525-475, housed in Taranto, Museo Archeologico Nazionale: 143541, Beazley Archive number 23667; an Athenian blackfigure olpe c.550-500, housed in Rhodes, Archaeological Museum: 10480, Beazley Archive number 330149; an Athenian black-figure cup, c.550-500, housed in Munich, Antikensammlungen: 2082, Beazley Archive number 340229; and an Athenian black-figure amphora, c.525-475, housed in St. Petersburg, State Hermitage Museum: B1468, Beazley Archive number 9035073. 
butcher's table,${ }^{819}$ or being lured by humans holding out a leg of meat. They appear inexplicably drawn to grapes [Image 7.4], which are toxic to dogs, in several red figure pots of the late fifth and fourth centuries ${ }^{820}$ The gluttonous dog makes its appearance in comedy as well, indicating a light-hearted recognition of the food-oriented nature of many canines. Calder notes this characterization of dogs is especially common in Aristophanes, who describes even Cerberus as a kitchen thief. ${ }^{821}$

A more serious threat to humans than the food-thief dog was the pariah dog, the sub-set of semi-wild dogs that were reviled not for how much they ate, but for what. The term "pariah" dog comes from the Egyptologists' name for mongrels, any dog "whose genetic background was the product of indiscriminate breeding between any number of domestic and feral forms, ${ }^{, 822}$ although Brewer notes that technically any stray dog, regardless of breed, constitutes a pariah. Pariah dogs were and are still common in many parts of the Near East, North Africa, and Eastern and Southern Europe, and they scavenged for food in and around cities, often performing a necessary service through the consumption of decaying organic material. ${ }^{823}$ However, this behavior was also a source of great anxiety that clearly delineates the familiar, domesticated dog from the semi-feral pariah: domesticated dogs would guard their dead masters, as we have seen, but pariah dogs would consume the bodies of dead men.

\footnotetext{
${ }^{819}$ See the Athenian black-figure olpe, c.525-475, housed in Munich, Preyss, Beazley Archive number 10598.

${ }^{820}$ See for example the Athenian red-figure chous c.425-350, housed in Athens, National Museum: 12140, Beazley Archive number 14990; the Athenian red-figure chous c. 400-300, housed in St. Petersburg, State Hermitage Museum: 14851.1904, Beazley Archive number 16285; the Athenian red-figure choes c.425375, housed in Sydney, University, Nicholson Museum: 56, and 46.49, Beazley Archive number 1632616327.

${ }^{821}$ Ar.Knights 1030-34; see Calder (2011) 69-70.

822 Brewer et al. (2001), 39.

${ }^{823}$ Ibid., 87; Derr (2011), 62-63.
} 
The fear of becoming the food of dogs and kites is echoed frequently in Homer, whose warriors dread the improper disposal of their remains. Dogs that were abandoned or feral had to hunt and scavenge for food, and some of the most profitable locations in antiquity would have been urban centers and battlefields. Pariah dogs appear in the opening line of the Iliad; Homer invokes the Muses to sing of Achilles' wrath which "sent forth to Hades many valiant souls of heroes, and made them themselves spoil for dogs and every bird" (Il.1.3-4). Similar worries are issued in the form of threats and taunts throughout the poem, ${ }^{824}$ and tragedies set within the context of the Epic Cycle refer to dogs in the same fashion. ${ }^{825}$

While scavengers are "conjured up as a threat by Sophocles and Homer," they appear in the historical period as well and were "a real feature of the Greek landscape." 826 Thucydides remarks upon the behavior of scavenger dogs in 430 when plague decimated the Athenian population. Thucydides notes that the disease was so dissimilar from its predecessors that it "baffles description," and seems to have confused even scavenger animals, as dogs that usually consumed human refuse, including dead bodies, would not touch the plague-ridden ones.

Of all animals, Thucydides notes that the dogs are the best means of observing the symptoms of the plague because they shared the same living space with man, presumably in and around city dwellings (2.50).

Recently the very existence of pariah dogs in antiquity has come under fire. In her

\footnotetext{
${ }^{824}$ E.g. Il.2.391-393, 8.379, 11.815-818, 13.831-832, 17.557-559, 18.270-272 \&c

${ }^{825}$ E.g. Soph. AJ. 829-830 in which Ajax beseeches Zeus to send Teucer to his body so that he is not cast out by his enemies to be eaten by dogs; Soph.Antig. 697-698, where Antigone hears that Polyneices' body will be left out for the dogs; Eur.Her.556-570, where Heracles promises to slay and dishonor Lycus of Thebes by decapitating him and giving his body to the dogs to shred.

${ }^{826}$ Lonsdale (1979), 150; see also Merlen (1971), 27.
} 
discussion of the power of the canine metaphor and insult, Franco determines that the Homeric threat of throwing one's body to the dogs was without substance and merely rhetorical. While such a discussion may seem tangential to a chapter devoted to military dogs, it is in fact crucial to the understanding of the ancient Greek perception of dogs and the behavior of pariah dogs within a military space. The feral dogs that feast on the refuse of Troy's No Man's Land (some of whom might also belong to soldiers in the Achaean military camp) feature prominently in rhetoric Homeric threats. Franco explains that because dogs are an integrated part of the human community, potentially even a philos, ${ }^{827}$ their capacity for necrophagy was particularly appalling. However, she asserts that reference to this behavior was an unfounded and rhetorical sort of threat used by the warriors at Troy; she asserts further that there is no evidence for feral or semi-feral dogs that might have scavenged from the refuse of human cities or army camps. Those whom Thucydides mentions (as above, 2.50), she argues, are in fact domestic dogs, animals which might dig through the trash regularly but do not constitute a separate sub-set of canines. $^{828}$

Franco defends this argument by claiming that the twentieth century "Disneyfication" $" 829$ of dogs as a species has made modern writers and readers wary of discussing less appealing canine proclivities such as coprophagy and necrophagy. Thus, they created a fictitious class of "pariah" dog meant to keep the image of pet dogs appealing. However, here parts of Franco's argument are particularly difficult to untangle because of the contradiction within them. While she is at pains to explain that canines are

\footnotetext{
${ }^{827}$ Franco (2014), 53-58.

828 Ibid., 57.

${ }^{829}$ Ibid., 50.
} 
not only accustomed to, but actually prefer, human food, ${ }^{830}$ she also sees Thucydides' reference to corpse-eating dogs as a reference to domestic animals, which seems counterintuitive. While any dog in desperate straits would eat whatever meat was available, the distinction made between scavenger dogs and pet dogs is as relevant in antiquity as it is today. Finding it unpalatable at the very least, Greek dog owners would not have allowed their dogs to wander the city and eat what was sacrilegious to eat; indeed, dogs do not appear to have been fed a meat-centered diet at all. ${ }^{831}$ Dogs with no masters or dogs whose masters fought on the losing side of a battle, however, might find themselves with no other option, and no human to restrict their instinct. Whether the Homeric heroes are referencing pariah dogs or their own dogs is unclear (definitely not a case of cannibalism by proxy as per Franco), but proving that pariah dogs as a class did not exist seems an impossible task. ${ }^{832}$ We may lack an abundance of references to pariah dogs who forage, lacking master and pedigree, but Philipps rightly urges his readers not to "lose sight of the humble mongrel." 833 Indeed, it is this sort of stray dog to which Isocrates refers in To Demonicus, when he says that assisting bad men is akin to feeding

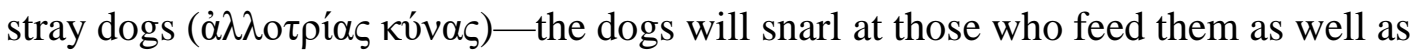
those who do not. (Demonic.1.29). These dogs that scavenged in and around cities constituted the majority of canines, and well-bred hunters, trackers, and lap-dogs were in

\footnotetext{
${ }^{830}$ Ibid., 25-27, Franco notes that dogs appear to have eaten processed grains and cooked meat scraps rather than raw meat.

${ }^{831}$ Indeed, pet dogs in the ancient world seem to have been fed grain-based diets. Columella recommends barley or wheat bread and boiled beans (7.12.7); Arrian speaks highly of wheat and barley (Cyn.8.2-3); Varro suggests bones and meat scraps are appropriate, but so is barley bread (2.9.8-10); Nemesianus and Grattius, worrying that canines might become accustomed to luxury, advises only milk and simple pap (Grattius Cyn.307-309; cf. Nemes.Cyn.152-154). See also Phillips in Brewer et al. (2001), 96-7.

${ }^{832}$ Archaeologists attempting to classify the status of dogs in the massive Ashkelon burial in Israel assume that the question facing them is whether the animals were pets or pariahs, as a number of Middle Eastern pariah types are known. See Wapnish and Hesse (1993), 55-80.

${ }^{833}$ Brewer et al. (2001), 87.
} 
the minority. Despite a plethora of humane societies, animal control facilities, and pounds in modernity, strays still roam the cities of South Eastern Europe, the Middle East, and North Africa. Philipps is right to note that "just as today... by far the most numerous dogs must have been humble pariahs." ${ }^{834}$

As we have seen, the Greeks differed from their Near Eastern counterparts ${ }^{835}$ in possessing a binary view of dogs: canines were noble, loyal, and capable of affection for human, or they were gluttonous, dangerous, and potentially worrisome. This division between a good dog and bad seems to correlate with the status of the dog as a companion animal (whether that be a hunting hound, herding dog, or lapdog) or pariah, although certainly pets are portrayed as being unduly food-oriented. A combination of literary, epigraphic, and archaeological evidence points to a culture which admired the canine and considered it a proper companion for humans of any age and capable of reciprocal affection and non-verbal communication. It is the unique position of dogs, who share the same living space and diet as humans, to be man's closest non-human companion.

In light of this, Franco makes the interesting argument that canines were informal members of men's circle of philoi. While dogs cannot reciprocate friendship in the same way as human philoi and were obviously not considered equals in status or political allies, there was still room for asymmetrical philia between them and their masters. Franco equates the philia between man and dog to that shared between father and child,

\footnotetext{
834 Ibid.

835 The general view of dogs as ritually unclean or morally contemptible in ancient Israel has been contested by Miller (2008), who argues that the pattern of understanding dogs in this light began with the work of D. W. Thomas in 1960. Instead, Miller asserts that the recorded use of dogs as herders (Job 30.1) and travel companions (Tob 6.2) suggests that they were more integrated into Eastern societies than we think. In fact, Miller's argument would make dogs of similar status in Israel as in Greece, permitting the existence of a positive and negative view of the animal. See esp. pp. 494-500.
} 
husband and wife, or master and slave, one of an inherently unequal nature in which one member of the relationship would show more devotion and loyalty than could or would be returned. ${ }^{836}$ While humans would provide food and shelter to their dogs, dogs were understood to be capable of providing more in turn, serving as loyal guards of the home and herd, companions in the hunt, and even risking or giving their own lives out of devotion to their masters. It is this sort of companionship or philia which must be kept in mind as we consider dogs' roles in the military realm. Indeed, it may have been the friendship between man and dog that brought the latter into the military sphere in the first place. Consider, as we conclude, Plutarch's account of Pericles' father, Xanthippus, during the Persian Wars.

During the Persian Invasion of 480, Athenian warriors parted with their families and set sail for Salamis, where they were to fight the enemy. Plutarch writes of the departure of Xanthippus, the father of Pericles, whose dog "could not endure to be abandoned by his master" (Plut.Themis.10) and so swam out alongside the trireme as far as the shores of Salamis, where it collapsed and died. Had Xanthippus left on a march to fight a pitched battle on land, his dog might have come along; but the battle was to be by sea, and his dog did what was customary-following Xanthippus until it was no longer possible. It is Xanthippus' dog to whom the Dog Mound on the island is attributed, supposedly the brave hound's tomb. ${ }^{837}$ While Xanthippus' dog is Plutarch's only specific anecdote, the biographer notes that the separation of families on this occasion brought "lamentations and tears," and the departure of their masters also pained tame animals,

\footnotetext{
${ }^{836}$ Franco (2014), 48-51.

${ }^{837}$ Plut.Themis.10; see also Plut. Marcus Cato 5.4 and Ael. DA 12.35, who mentions that Xanthippus had multiple dogs that swam after him.
} 
"which ran along with yearning cries of distress by the side of their masters as they embarked" (Themis.10). The parallel of human and animal anguish at the separation of Athens' strongest social unit, the oikos, suggests that domesticated animals that shared the same living spaces as humans also shared an attachment. Of particular interest is Xanthippus' dog, who, unlike other animals, did not stop at the docks, but leaped into the sea to follow his master, perhaps accustomed to accompanying him when he marched to war. While this anecdote in isolation cannot offer more than the suggestion of canines in the military sphere, we shall find in Chapter 8 that a combination of literary, epigraphic, and archaeological evidence can shed new light on the story of Xanthippus' wartime companion. 


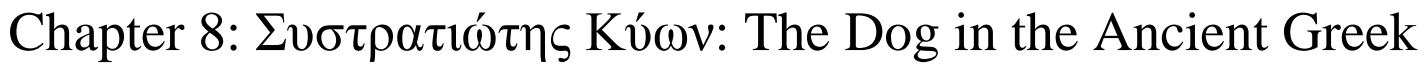 Military}

Now that we have considered the context of the domesticated dog's evolution as well as the culture of pet keeping and corresponding perceptions of canines in ancient Greece, we may address the dog's role in the military sphere in particular. Because this practice did not emerge in a vacuum, a survey of the use of war dogs by neighboring states is in order to provide additional points of comparison. Subsequently, we will investigate ancient literature and art for evidence of canines participation in war, considering as we progress the physiological and intellectual capacity of Canis familiaris to perform in a military setting.

\section{Part A. Dogs in the Military of Neighboring States: A Brief Survey}

The presence of dogs in the military sphere was not unique to Greece. In order to understand clearly how the Greeks incorporated canines into war, it is necessary to consider external influences and the context in which this custom grew up. While the Greek use of war dogs which I will propose context differed significantly from the way warriors in the Near East made use of the animals, stories recorded by Greek authors give scholars a sense of what tactics the ancient Greeks were aware of, whether they capitalized on them or not. The Greek adoption of Near Eastern artistic motifs in the Archaic or Geometric period transferred more than just painting styles. Indeed, R.M. Cook explains the Greek depictions of dogs in military sequences as a borrowing of an artistic trope from the East, rather than an actual practice (see below pp.352-354). What 
follows is not an exhaustive summary of ancient Near Eastern peoples' use of dogs in the military, but a sampling intended to show that the practice of bringing dogs to war was not a novelty of the Greeks, but in fact rather common.

At least as early as the Assyrians of the late seventh century, attack dogs were used in military settings. An Assyrian bas relief at Birs Nimrud shows a soldier wielding a shield and leaning toward a large mastiff as he enters battle, suggesting that the dog not only accompanied him on the march but actually participated directly in the fray. ${ }^{838}$ Similarly, Polyaenus tells us that Alyattes of Lydia reportedly used vicious hounds to drive the gargantuan Cimmerians of the steppes out of Anatolia in the sixth century. Polyaenus expresses no degree of disbelief when he reports this, remarking that the dogs were largely successful, either disabling or frightening off many of the warriors (Strat. 7.2.1). His report of Alyattes' subsequent seizure of the Ionian Colophonians' cavalry to bulk up his military forces is a curious sequitur considering that the Colophonians are reported as one of few peoples who regularly used attack dogs in the front lines. ${ }^{839}$ It is certainly possible that attack dogs were used in skirmishing the same way that police and military attack dogs are today. They could have been released as a vanguard before the onslaught of armed men, but this would be most effective against the poorly-armed.

Attack dogs employed by the king of the Garamantes, a North African people, helped bring their king back from exile, and Pliny reports that the those two hundred attacks dogs "did battle with those that offered resistance," $" 840$ although the nature of that conflict is unclear. He adds that in a similar fashion, the Magnesians and Hyrcanians

\footnotetext{
${ }^{838}$ Mayor (2014), 287.

${ }^{839}$ Polyaen. 7.2.2; Pliny $N H$ 8.40(61), 8.142.2-3.

${ }^{840}$ Pliny, NH 8.41; referenced in Mayor (2014), 287.
} 
along the Caspian Sea regularly employed dogs as front-line fighters organized into cohortes canum and trained to fight "fiercely in the front rank, never refusing battle, and...never requiring pay" (NH 8.41). Aelian repeats Pliny's account but adds that the Magnesians and Hyrcanians put spiked collars on their dogs, presumably both as a form of armor and means of inflicting greater injury. In Aelian's account of the Magnesian tradition, he implies that their enemies, in this case the Ephesians, also used attack dogs. ${ }^{841}$ These front-line fighters raise concerns for some scholars. Brewer et al. note with respect to the tradition of Colophon and Castabulum that "it is difficult to imagine that dogs, however large and fierce, would be effective attacking armed and armoured infantry." ${ }^{842}$ More recently Kitchell has characterized the use of front line attack dogs as possible, noting that Aelian's narrative regarding Colophon (Ael.VH 14.46) "is quite explicit" and that "it seems clear that the Hyrcanians and Magnesians took dogs into battle" 843 as well. Because there is no record of the technique used or casualty rates, very little can be gleaned from these references as historical incidents. At the most fundamental level, we may assume that, much like modern police dogs, ancient attack dogs could lunge at the exposed areas of a soldier's body, such as the thigh above the greave and below the shield. Attack dogs today are often trained to grab the arm of an enemy and a "lock and hold" position. This enables dogs to throw their weight into the bite, either pulling the man down, if they are large enough, or disabling his movements.

\footnotetext{
${ }^{841}$ DA 7.38, VH 14.46; cf. Strabo14.1.40, whom the Loeb editor Wilson believes refers to the same battle as discussed in $\mathrm{VH} 14.46$.

${ }^{842}$ Brewer et al. (2001), 94; It is worth noting that Aelian (DA 7.29) describes an unusually well-trained dog from the same Colophon in an anecdote illustrative of canine loyalty. He claims that a man from Colophon arrived at Teos and lost his money bag through the carelessness of his slave, but his dog, apparently well-trained, sat upon it and guarded it until his master located him and his money.

${ }^{843}$ Kenneth Kitchell (2014), 51.
} 
Such techniques are described in the Koehler method of attack dog training. ${ }^{844}$

Additionally, attack dogs could have been used effectively in the event of a rout, to pursue a disorganized enemy and keep up with cavalry. Dogs would also have an easier time fighting a soldier who lost footing, as is depicted graphically in the Great Altar of Pergamum, built under the aegis of Eumenes II in the second century [Image 8.1]. The East Frieze represents the Gigantomachy, and a large Molossian hound fighting alongside the goddess Artemis gnaws on the skull and face of a fallen giant that possesses the torso of a man and the nether regions of a serpent. In retribution, the giant gouges out the right eye of the dog with his right middle finger. To the left of this scene, Hecate appears in triple-form, wielding her torches and a broad shield against the giant Clytius, who has partially collapsed. One of Hecate's dogs, another massive Molossian, clamps his jaw tight about the giant's thigh and holds it in place with his foreleg, as dogs and wolves often do with their food. ${ }^{845}$ The relief is detailed enough to show the clenched upper muzzle of the dog complete with wrinkled skin and flared nostrils, as well as the deep gouges that his canines left in the flesh of Clytius' thigh. This degree of detail is highly suggestive - it could not have been solely imagination that led to the inclusion of dogs here. The animals' association with their respective deities is not traditionally tied to war, but to the hunt and guarding the crossroads. In combination with the literary accounts given above, these images suggest that in at least some cases, dogs must have fought in the front lines of battle.

Brewer et al.'s concern with the dogs' effectiveness against armored infantry is a

\footnotetext{
${ }^{844}$ See e.g. Koehler (1967), chapter 19. My thanks to Kenneth Kitchell for his advice on suggesting a modern parallel.

${ }^{845}$ See Schmidt (1965), pl. 15, p. 14, 30.
} 
fair one, but the extant accounts are brief and do not specify the armament of the enemy. Indeed, it is at least remotely possible that the Ionian Greeks used dogs not against fellow Greek phalanxes, but against invading and nomadic pillagers such as the Cimmerians, who had raided Ionia regularly before the time of Croesus, until Alyattes and his dogs fought them off (Hdt. 1.6). Against a traditional Greek phalanx a dog would have little chance, but against small bands of raiders they could have been quite effective, their participation in battle being only an extension of their recognized domestic role as guards.

The Persians made use of military dogs as well, although their role as front line fighters is unlikely and not directly illustrated as in the case of the Colophonians and Magnesians. The sole exception is the rather unusual (and likely fictitious) account of Cambyses' impious use of dog-soldiers. In his invasion of Egypt, Cambyses arrayed in his front lines any animals which the Egyptians considered sacred in order to prevent resistance (Polyaen.7.9; cf. Hdt.3.10-11). According to Polyaenus, this was how Cambyses successfully took Pelusium, but his alleged placement of dogs alongside cats, ibises, and sheep strains the imagination and seems more likely to be the author's creative way of emphasizing Cambyses' contempt for the Egyptian religion.

The more realistic presence of dogs in the military realm is revealed casually in several accounts of the Persian kings' armies. This is by far the most useful type of reference, in which an author notes the presence of a dog without fanfare, indicating that readers (or listeners) would not find its presence in a military setting very interesting. Forster highlights the role army camp dogs played in assisting Darius I in his escape from 
Scythia ${ }^{846}$ Routed, the Great King abandoned his camp to the Scythians, but in order to confuse the enemy, he left the dogs and donkeys behind, whose barking and braying made it seem from a distance as though the camp was still occupied. ${ }^{847}$ Although Herodotus only mentions the donkeys (4.129), Polyaenus (7.2.4) and Frontinus (1.5.25) specify that dogs were also used in this ploy. ${ }^{848}$ Because they and the donkeys were left behind, one must conclude that they had been brought to the military camp as well, not adopted from the region.

Another casual reference to dogs in the military realm which suggests their expected, albeit occasionally troublesome presence, occurs in Herodotus' account of Pharnuces' departure from Sardis in the early $5^{\text {th }}$ century. While the Persian army was assembling itself at Doriscus in Thrace in preparation of invasion (Hdt.7.59ff.), the hipparch Pharnuces, who had been left behind ill at Sardis, made his departure. As he was riding out, presumably with his attendants, a dog ran underneath his horse's legs, causing it to rear up and throw Pharnuces, who later died of his injuries (Hdt.7.88). The image of dogs running near horses in a military context is a familiar one in the ancient Near East, appearing on early Ionian art. ${ }^{849}$ While Cook sees this as merely an art motif with no basis in historical reality, Herodotus' mention of Pharnuces suggests otherwise.

Pharnuces was departing for war, and at least one dog was in attendance. While Cook is certainly right to allude to the dangers of dogs running too near to horses or chariots, ${ }^{850}$

\footnotetext{
${ }^{846}$ Forster (1941), 115.

${ }^{847}$ Forster (1941), 115; for other examples of animal noises contributing to military history see McCartney (1943), 222-226.

${ }^{848}$ Herodotus claims that the donkeys' main role was to scare the Scythian cavalry, rather than convince them that the camp was occupied. According to him, Scythian horses were afraid of donkeys and mules because those animals were not native to the region (4.129.2).

${ }^{849}$ Cook (1950), 39-40.

${ }^{850}$ Ibid., 39.
} 
the assumption that the two could not travel at close proximity is probably an exaggeration. In traditional fox hunts, dogs and horses often ran near one another, and the dogs knew enough to stay out from under the kick of the hooves. This coordination is depicted in the British impressionist Heywood Hardy's painting, "Full Cry," in [Image 8.2]. It is possible that dogs kept up with their masters horses quite often, even if the hound accompanying Pharnuces made a dangerous mistake.

It seems likely that dogs accompanied more than only the Persian hipparchs to Greece, as Herodotus reports that among Xerxes' massive host brought down into the Thermopylae valley were Indian hounds, a reference which stands out starkly against a

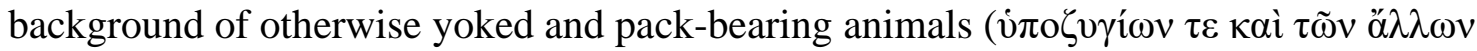

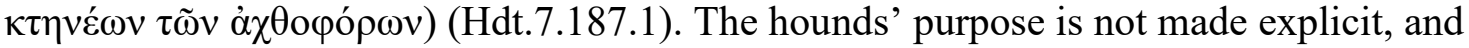
there is no record of their direct participation in the Battle of Thermopylae. Forster supposes that they were brought along "for military work as well as sport," ${ }^{851}$ although he does not specify what sort of military work. One might assume a combination of guarding the periphery of the camp and the pack animals, as Herodotus does note that the camels had a hard go of it in Thrace, succumbing to lion attacks (7.125). What Herodotus does make clear is the exceptional value of the Indian hounds, who are mentioned as a unit of wealth. While extolling the wealth of the Persian satrap of Babylon, he references not only a daily income of an artaba of silver, but the possession of 16,800 horses in addition to those kept for war, and so many Indian hounds that it took four Babylonian villages to feed them, which amounted to such a great cost that they were otherwise tax exempt (Hdt.1.192).

${ }^{851}$ Forster (1941), 115. 
Later authors characterize this breed of dog in terms of ferocity rather than expense, although the two are far from mutually exclusive. To the Greeks, the legendary Indian hound was so ferocious that it could only have been the offspring of a dog and a wild tiger. Aristotle describes the Indian hound, with which Alexander the Great would have become acquainted, as either a "dog-like beast" (GA 746a 34) or the thirdgeneration product of a female dog and male tiger, bred down presumably to make the animal biddable. ${ }^{852}$ The mythology that grew up around the Indian hound seems to have been catalyzed by Alexander's encounter with them since Herodotus adds nothing specific about their ferocity or use in battle. ${ }^{853}$ Strabo (15.1.31) and Aelian (DA 4.19) both assert that the Indian hound was mighty enough to take down lions, and both relate variations on a story of an Indian hound that endured the loss of a leg mid battle because it had been bred to be impervious to pain. ${ }^{854}$ Plutarch adds that the dogs were so fierce that they were indifferent to any opponent lesser than a lion, lying down and ignoring hinds, boars, and even wild bears, but responding aggressively only when challenged by lions (Mor.15.970).

The degree to which these Indian hounds were actually used in pitched battle hinges on a line of corrupted text in Plutarch's De Sollertia Animalium 15.970, and it seems unlikely. The current standard used in Loeb describes the Indian hound as $\tau$ òv

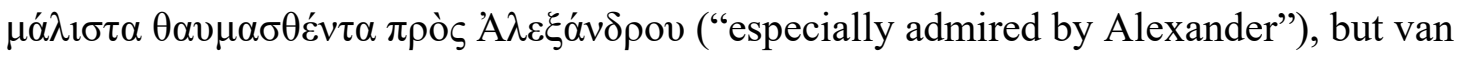

\footnotetext{
${ }^{852}$ E.g. Arist.HA 607 a4; Pliny NH 8.61; Ael.DA 8.1.

${ }^{853}$ Diod.17.92; Plut.De Sollertia Animalium 15.970.

${ }^{854}$ A duplicate of this story appears in Pliny $N H 8.61$ where the dog that is pitted against a host of wild animals and that fights and gets maimed by a lion is not the Indian hound, but a dog given to Alexander by the King of Albania, and so presumably a Molossian hound. It appears that Pliny confused the story of Alexander's Molossian with the legends of the Indian hounds, as he places Alexander's receipt of the gift from the Albanian king within India, an improbable event given the sheer distance the dog and herald would have traveled.
} 


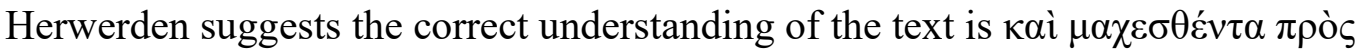
A $\lambda \varepsilon_{\varepsilon} \xi \alpha v \delta \rho o v$ ("[the sort of hound that] fought against Alexander"). While it is reasonable that these fearsome hounds might have served the Indians of the Punjab in battle or skirmishing, had they been used against Alexander certainly one of the extant Alexander histories would have mentioned it, especially Arrian's Indica, where the dogs are marveled at for their bravery, but not their battle prowess.

However, as we shall see, dogs' participation in the ancient military sphere was not limited to the front lines of battle. Their finely tuned sense of hearing and smell made them ideal auxiliaries in the military camp and amid a siege, and their unique coevolutionary bond to man made their presence on the march plausible as well. Now that we have considered the influences of neighboring states on Greek military practices, we may turn to the study of the Greek dogs of war.

\section{Part B: Dogs in the Military in Ancient Greece}

Thus far we have seen that canines in the service of ancient Near Eastern armies thought to have been both front-line fighters and strong presences in military camps. While several above accounts appear closer to fiction than fact, they represent a Greek understanding (at least as early as Herodotus) that canines had the potential to serve in a military capacity, even if the Greeks did not themselves have the famous tiger-bred Indian hounds. Admiration of brave, pain-resistant front-line warriors and fighters of lions falls into place nicely alongside Greek illustrations of their own dogs as fiercely loyal and discriminating, as we saw above in chapter 7. To this list we must add capable of intentionality and possessing agency, a fact which makes displays of loyalty so much 
more compelling.

Recently, Pearson has noted that the presence of dogs in the modern military has been analyzed and criticized as "project[ing] human qualities onto dogs." 855 To this charge, Pearson replies "There is more to such texts...the dogs were not purposeless objects that were simply manipulated by human intelligence. Instead, they were agents who were unwittingly drawn into the conflict, but whose abilities and characteristics allowed them to perform varied and skilled work in conjunction with human agents." $" 856$ Although Pearson has the modern implementation of military canines in mind, there is no reason that this statement could not be applied to antiquity. Indeed, Pearson rightly points out that the very domestication of the wolf and evolution of Canis familiaris was managed through the wolf-turned-dog's own agency. Both humans and the wolves that lived near humans "took action for their own short-term gain" $" 857$ through feeding and scavenging from human settlements. It is worthwhile to highlight the agency of military dogs in antiquity, a quality which made them excellent defenders of their masters and masters' territory, as we shall see.

As discussed above (pp.26), interest in HAS among ancient historians and classicists has escalated recently, and much has been written about domestic dogs, who are ubiquitous in the literary, epigraphic, and archaeological sources, appearing as pets, guards, companions, and especially hunting hounds. Fogen and Thomas rightly note that "There is hardly any area in the ancient world where animal and human lives are separated from each other," ${ }^{858}$ and this is especially true of dogs, who appear in the

\footnotetext{
${ }_{855}^{85}$ Pearson (2013), 133.

${ }^{856}$ Ibid.

${ }^{857}$ Ibid., 132.

${ }^{858}$ Fogen and Thomas (2017), 3.
} 
sources as the most common companion animal, likely due to their highly social natures and "capacity for a two-way partnership." 859

Calder's Cruelty and Sentimentality: Greek Attitudes to Animals 600-300 B.C. (2011) is a well-known recent work which employs HAS to analyze a combination of ancient literature and archaeology in the interest of uncovering what human perceptions of particular animals existed in antiquity. Calder focuses on six key themes in her study, noting in advance that the important context of religion and sacrifice is left out, meriting a book of its own. The themes she chooses to treat include: animals in human space, the roles of sheep and goats as sources of food, burden animals, animals that could endanger humans alongside those used to protect humans, and finally Greek views on animal knowledge and intentionality. ${ }^{860}$ Dogs play a prominent role in the work, characterized by Calder as food thieves within the context of human space, and capable of predatory aggression as well as protecting humans from the predatory aggression of wild animals. ${ }^{861}$ Adding to our consideration, her 2017 essay "Pet and Image in the Greek World," we see dogs portrayed as the most common companion animal while also serving as a means of "social integration and emotional security." ${ }^{862}$ However, Calder speaks only very briefly of the context of war, limiting the definition of military context to the act of engaging in pitched battle. Instead, she references Cook's argument that dogs never fought in pitched battles, and any imagery that implies as much uses the dog merely as a motif. ${ }^{863}$

\footnotetext{
${ }^{859}$ Calder (2017), 63-64.

${ }^{860}$ Calder (2011), 3.

861 Ibid., 69-71.

${ }^{862}$ Calder (2017), 64; see further pp.64-69.

${ }^{863}$ Ibid., 71, Cook (1950), 38-39. Also see below pp.352-354, cf. $366 f$.
} 
While Calder's work is one of the more recent studies employing HAS to analyze the role of dogs in the ancient Greek world, it does not stand alone. Dogs as hunters have been the focus of specialized studies going back to the ancient world itself with the Cynegetici of Xenophon and Arrian. In much modern scholarship, however, the military capabilities of canines are often relegated to a paragraph or even sentence, making the presence of dogs in ancient military settings appear rare or unlikely, which in fact it was not. Forster's 1941 article "Dogs in Ancient Warfare" sought to prove that dogs were indeed used in the ancient military; despite its limited length, the article provided a summary of literary citations that provide evidence of dogs serving in a military capacity in ancient Greece and Rome. Forster's goal was one of popular interest, "to collect, as far as possible, the passages dealing with the use of dogs in ancient warfare and make a comparison with modern practice," 864 and he sought to prove to an audience living through World War II that the military use of canines had a long pedigree.

In so doing, Forster brought to light otherwise overlooked evidence. Because his interest was primarily in revealing the quantity of literary references, Forster does not differentiate between the plausible and implausible uses of canines in warfare, documenting Cambyses' animal army during his invasion of Egypt as well as the more reasonable use of dog patrols by Spartan Agesipolis at the fourth century siege of Mantinea. ${ }^{865}$ Since Forster's work, very little has been done to assess, analyze, or define the Greeks' use of canines in a military context, and this is largely due to a lack of literary sources. Modern scholarship has often focused on the relationship between master and pet or huntsman and hunting hound, leaving the martial component of the

\footnotetext{
${ }^{864}$ Forster (1941), 114.

${ }^{865}$ Ibid., 115-116; Polyaen.Strat. 7.9, 2.25. See also below, p. 380.
} 
relationship aside. Existing discussions of dogs in an ancient military context are either brief, consisting of a few examples, or they assert the unlikelihood of canines having participated at all.

Of the latter sort is Cook, whose 1950 essay "Dogs in Battle" sharply criticized the contemporary scholarly acceptance of canines participating in battle, founding his argument on the alleged misinterpretation of Eastern Greek images which portray canines alongside chariots or single-rider horses, often running below alongside images of deer and hares, which Cook argues portray hunting scenes or simply nothing at all. ${ }^{866}$ Asserting that this motif was of Syrian origin and borrowed by Eastern Greeks during the Orientalizing Period of vase art, Cook argues that it cannot represent reality-especially not a Greek reality, but is only a borrowed decorative theme. Cook teases out the literary and representational evidence of dogs in war to deconstruct and cast doubt on each one, among them: Eastern Greek terracottas and reliefs, the Clazomenian Sarcophagi, Aelian's account of the Marathon dog (NA7.38), the significance of the Hippaemon stele, Pliny's account of the people of Castabulum using attack dogs in the front lines $(\mathrm{NH}$ 8.143), Polyaenus' account of Alyattes attack dogs (Strat.7.2.1), and Herodotus' account of the Perinthian-Paeonian conflict (Hdt. 5.1). Cook asserts that all literary references stem from the archaeological evidence and a misunderstanding on the part of many generations of Greeks of images of dogs running beside soldiers or chariots, which were merely motifs of eastern origin. ${ }^{867}$

While this argument has been generally accepted by scholars who mention dogs in the military, I find it problematic on three grounds. First, it assumes that generations of

\footnotetext{
${ }^{866}$ Cook (1950), 38-39.
}

867 Ibid., 39-40. 
later Greeks had access to Archaic monuments and had less ability than moderns, millennia removed, to interpret or "read" the images, with the result that they interpreted what was purely decorative as factual representation. Secondly, the argument that dogs did not serve in war is reductive, limiting military activities to the definition of charging into battle, which it is logical to assume dogs did not often do. Thirdly and most importantly is the wealth of archaeological evidence which has been unearthed and made more accessible since 1950, when Cook published his essay. Well over 100 vases portraying dogs in a military setting (few of them alongside hares and deer) strongly suggest, as we shall see, that it was not the Greeks who misinterpreted their forefathers' memorials and artwork, but modern historians.

A recent article by Rees outlines the majority of literary sources in which canines are mentioned in a military context and builds on Cook's argument by noting the sharp divergence in the nature of the sources that represent canines in war. ${ }^{868}$ Rees notes that early sources of information tend to be pottery, and literary sources occur later, with the earliest being Aeneas Tacticus in the mid-fourth century. Rees adds that "it is not until the Roman period that descriptions of dogs begin to match our expectations of wardogs, "869 which he illustrates through reference to Polyaenus' account of Alyattes' use of attack dogs in his battle with the Cimmerians (7.2.1). While Rees acknowledges that dogs did serve in a military context, patrolling and sending messages, he asserts that "these are not the actions of a war dog." 870

Once again, I argue that we must define our expectations of war-dogs clearly and

\footnotetext{
${ }^{868}$ Rees (2013).

${ }^{869}$ Ibid., 3.

${ }^{870}$ Ibid., 1.
} 
move past the assumption that a dog cannot qualify as a military animal unless it is charging into battle. The restrictive definition of militarily useful dogs as attack dogs is not a distinction made in the ancient sources, and it certainly is not a modern one. Indeed, guarding and patrolling citadels and military camps is an important part of Greek military training, most clearly highlighted in the practices of the fourth century ephebeia. One would not say that phulakes on patrol are not soldiers, simply because they are not actively battling an opponent. The same must be understood of canines: while front line fighters were certainly not common among the Greeks, dogs that played ancillary roles in a military context were.

Beyond the articles of Forster, Cook, and Rees, relatively little has been said of dogs in military settings. When canines in ancient Greek combat are mentioned by scholars, which is not frequent, a nod to Cook's argument generally suffices to cover the material. For example, Calder refers her readers to Cook's argument on dogs in warfare $;{ }^{871}$ Kitchell's Animals in the Ancient World from A to Z, an excellent research guide, is able to provide only a few scholarly references for dogs in a military setting, ${ }^{872}$ although Kitchell does suggest that Aelian's account of battlefield dogs are "quite explicit." ${ }^{\prime 873}$ Focused studies of dogs in the ancient world, or even in the ancient Greek world, generally limit or eschew discussion of dogs in a military context. Classical scholarship on the canine focuses on hunting, dogs' presence in poetry or fable, or they provide general overviews. ${ }^{874}$

Broader works on ancient Greek combat are similarly vague, rarely if at all

${ }^{871}$ Calder (2011), 71.

${ }^{872}$ Kitchell (2014), 47-53, esp. p.51.

873 Ibid., 51.

${ }^{874}$ E.g. Hull (1964), Lilja (1976), Leach (1961), Merlen (1971), Brewer et al. (2001). 
referencing the role of the canine, although this is understandable in light of the relatively brief ancient literary references. In the Cambridge History of Greek and Roman Warfare, dogs are referenced only once, through Agesipolis' use of sentry dogs to guard his military camp. ${ }^{875}$ More detail can be gleaned from HAS-focused works such as the Oxford Handbook of Animals in Classical Thought and Life, in which Mayor's essay "Animals in Warfare" contributes to the scholarly conversation about dogs by providing a selection of examples of military dogs used in the Mediterranean everywhere from North Africa to Corinth. Because of the essay's purpose within the broader work on animals in classical thought, Mayor is not able to devote a detailed discourse to canines. ${ }^{876}$ Works intending to explore the human perception of animals in antiquity or animal agency cannot devote time to a detailed excursus on one specific animal, but provide the platform for such a study. Lonsdale has shown that the ubiquity of dogs in the ancient world made them highly symbolically malleable, and they were considered helpful, hardworking, intelligent, and potentially magical. ${ }^{877}$ A more focused examination of select literary and archaeological sources, such as Sian Lewis’ and Lloyd Llewellyn-Jones’ Culture of Animals in Antiquity, lacks thorough analysis of dogs in the military realm because of the broad scope of the work as a whole.

So we see that despite the increase in HAS and the attention given to animals in the ancient world, few scholars have attempted to assemble an exhaustive list of references to military dogs. This is not the case in modern history, which has made the war dog a veritable hero and written the history of these veteran animals in abundance, ${ }^{878}$

\footnotetext{
${ }^{875}$ Krentz $(2007,166$.

876 Mayor (2014), 286-287.

${ }^{877}$ Lonsdale (1979), 149-152.

${ }^{878}$ See Gervase Phillips (2018), bibliography.
} 
as discussed in the opening of Part III. Phillips specifies that dog training for the military during WWI required a close relationship between man and dog, one which, excepting the warhorse, did not exist between soldiers and service animals. Phillips quotes the WWI British dog-trainer E.H. Richardson's advice: “complete confidence and affection must exist between dogs and keeper, and the man whose only idea of control is by coercion and fear is quite useless. ${ }^{879}$ Indeed, successful dog handlers in the First World War had to possess "a willingness to recognize the capacity of dogs to think and feel and even exhibit a degree of understanding of the tasks they were being asked to perform." $" 880$ This perspective implies a degree of intentionality on the canine's part ${ }^{881}$ and is reflected in the ancient training manuals for hunting as well.

In his Cynegeticus, Xenophon advises that "the hunter should call out as the chase begins: 'Tally ho! Well done, clever dogs!'” (Xen.Cyn.6.17, see also 6.19, 6.20). Arrian advises roughly the same: "it is good to cheer on the hound; for they are pleased when they recognize their master's voice, and they have a compensation for their efforts in knowing that he is watching them and seeing that they are working well" (Arr.Cyn. 17.1). The authors' assumption is clearly that the dogs are behaving as instructed not as automata or "machinery," but as beings with intentionality that decide to behave a certain way in order to obtain praise. Arrian notes that Well-bred dogs "like being praised, just like well-bred humans" (Cyn.18.1). Man's understanding of the capabilities of dogs has brought the species into closer regular contact with man than any other, and even companion or "pet" dogs establish some form of communicative relationship with their

\footnotetext{
${ }^{879}$ Phillips (2018), 80.

880 Ibid.

${ }^{881}$ Pearson (2013) and bibliography; see also on conceptualism and non-human animals: Crary (2012).
} 
masters. So long as the dogs were trained, they could be molded as needed, a truism that Plutarch attributes to Sparta's legendary founder Lycurgus, who uses the behaviors of well-trained and untrained puppies as an example of the two potential fates of men (Mor.3B).

In addition to HAS studies of pet and working animals, this chapter offers an opportunity for the investigation of canines participating in the military sphere of the ancient Greek world. In order to pursue this line of questioning, it is necessary first to redefine what constitutes a military context. Military context can be expanded beyond a pitched battle on a plain or a naval battle at sea to include activities such as: leaving home to go on the march, besieging a city, withstanding a siege, or establishing a night camp on campaign, and locations such as: citadels, city walls, and military camps. In interpretative sources like pottery, images of war implements and soldiers are indicative of context as well. By expanding the number of activities and locations considered military in context, we see a considerable increase in the presence of canines. They do not need to have stood in the front line of battle to have participated in a military event.

In order to survey and interpret the available data, it is necessary to follow three key steps. First, we must (1) separate the uncommon scenarios of war dogs fighting in the front lines from the more typical non-combative roles that the dogs played. Thereafter, it will be necessary to explain, if dogs did not participate in the front lines, what sorts of tasks were they capable of performing? An investigation (2a) of the specific traits and capabilities dogs possess is a necessary prerequisite to the examination of the tasks they actually performed in antiquity, and their (2b) biddability and training may be observed through tasks performed on the hunt. With this in mind, we will examine (3) Archaic and 
Classical Greek vase scenes and reevaluate the significance of the canine, which appears frequently in such images and strongly indicates canine accompaniment on the march. Thereafter it will be possible (4) to discuss the specific military duties dogs carried out.

\section{Front Line Fighters}

There are only a few records of dogs participating actively in human combat, but those that exist, when stitched together, do form a sort of pattern, and they are almost exclusive to Ionian states. Based on the extant records, it is plausible to suggest that in Archaic Greece, predating the widespread use of hoplite gear and advanced protective armor, attack dogs were used in the front lines. Even supposing that every extant record is accurate, this would still be a relatively rare phenomenon, but it is certainly worth consideration.

References to such war dogs in a Greek context are sparse, but they appear in Pliny, Aelian, and the epigraphic record. In his Natural History, Pliny records that the Ionian cities of Colophon and Castabulum had "troops of dogs for their wars; these fought fiercely in the front rank, never refusing battle" (Pliny, $\mathrm{NH}, 8.61$ ). He also somewhat drily notes that the war dogs were the most loyal supporters because they never required pay (ibid). Aelian reports on a similar event, noting that during a war with Ephesus, the Magnesians brought attack dogs to the front lines with them (VH 14.46). The conflict is unknown, but thought to have occurred in the seventh century. Strabo (14.1.40) references this Magnesian-Ephesian War in passing, noting that the Magnesians 
came out victors. While Kitchell does not cast either account into doubt, ${ }^{882}$ Cook writes that Aelian's record is based on his (mis)understanding of a roughly contemporary funerary stele for a cavalryman named Hippaemon and its accompanying epigram. ${ }^{883}$ The Hippaemon stele is lost, but some scholars suspect the Dorylaeum stele is a good sample image for how the Hippaemon stele would have looked. ${ }^{884}$ The Dorylaeum stele depicts a mounted horseman with a dog walking underneath (or beside) his horse, and an epigram concerning Magnesia which has been preserved in the Palatine Anthology reads:

“The man's name was Hippaemon, the horse's Podargos, the dog's Lethargos and the serving-man's Babes, a Thessalian, from Crete, of the Magnesian race, the son of Haemon. He perished fighting in the front ranks." 885

Taken as a genuine product of the Archaic period, the epigram indicates at the very least that soldiers brought their dogs to war with them, as well as their slaves. Cook himself does not contest the authenticity of the epigram, ${ }^{886}$ but he does not believe that Aelian's account explains the epigram, but rather "the epigram—or better the complete monument-explains Aelian." ${ }^{\prime 887}$ Cook asserts that the image of the dog near the horse is "a convention of East Greek art and need have no particular meaning of relevance." 888 While the particular significance of a particular animal's presence in art may be debatable, it is nearly impossible to prove that an image is entirely void of significance. He does not explain why the dog would be mentioned in the epigram, but asserts that contemporaries of the stele would not have understood it to mean that a dog participated in war, but "antiquarians of later times, when artistic conventions had changed, might

\footnotetext{
${ }^{882}$ Kitchell (2014), 51.

${ }^{883}$ Cook (1950), 41-42.

${ }^{884}$ Ibid., Greenhalgh (1974), 145.

${ }^{885}$ Greek Anth. 7 no. 304.

${ }^{886}$ Cook (1950), 40; see also Greenhalgh (1974), 145.

${ }^{887}$ Cook (1950), 42.

${ }^{888}$ Ibid., 41.
} 
easily have been misled." ${ }^{\prime 89}$ In that vein, Aelian was such a writer, misled by the combination of a funeral stele relief featuring a man, his horse, dog, and slave and an accompanying epigram naming a man, his horse, dog, and slave. Cook makes no attempt to explain why the dog would mentioned in the epigram if he was not near the place of battle.

Of further interest is the specificity of Aelian's account, quite different than Pliny's casual reference to the war dogs of Colophon and Castabulum. Aelian describes the means by which attack dogs were used in the front lines and even incorporates spearbearing slaves, one of whom is mentioned and named (Babes) in the Hippaemon epigram. ${ }^{890}$ Aelian notes:

\footnotetext{
"The Magnesians living by the Maeander were at war with Ephesus. Each of the cavalry took as his companion on campaign a hunting dog and a slave javelin-thrower. When battle was due to begin the dogs, which were fearsome, aggressive and ferocious to encounter, rushed forward and disturbed the enemy formation; the slaves jumped out in front of their masters and threw javelins. After the disorder already caused by the dogs the activity of the slaves also had its effect. Finally in their place the masters attacked." $" 891$
}

Nothing which Aelian describes is strikingly outlandish or difficult to imagine. While the participation of canines in battle against fellow Greeks after the adoption of the full panoply and standardization of the phalanx might be a bit far-fetched given the difficulty of attacking an armored man, it is plausible that dogs were used against less coordinated or well-armed forces. Indeed, Mayor links front line fighters described by Pliny ( $\mathrm{NH}$ 8.61) to the collared dogs in Assyrian bas-reliefs from the sixth century, suggesting that at least in Archaic armies the canines might have been useful. She notes that "large breeds can run twice as fast as humans and they can be trained to bite and hold down

\footnotetext{
889 Ibid.

${ }^{890}$ Greek Anth. 7 no.304.

${ }^{891}$ Ael. VH 14.46; Strabo 14.1 .40 alludes to what was likely the same military conflict.
} 
victims...for cultures that did not keep large domesticated canines, war dogs were intimidating, and the psychological deterrent was significant." ${ }^{\prime 892}$

The use of attack dogs is mentioned in Herodotus' account of the PerinthianPaeonian conflict as well. Before the Persian conquest of the late fifth century, Perinthus, a colony of Samos, went to war against the Paeonians, and they appear to have brought attack dogs with them. Herodotus claims that the two forces fought a three part duel, pitting man against man, horse against horse, and dog against dog (Hdt. 5.1.2). Cook attempts to reduce the significance of the conflict, saying "this sounds a curious match, but the dogs are engaged only in a dog fight. ${ }^{~} 893$ Following this logic, the horses were only engaged in a "horse-fight," which is clearly not the case. Herodotus' turn of phrase is meant to highlight the primary combatants of the war, the infantry, cavalry, and evidently the dogs. This is not evidence of the ubiquity of front line fighters, but might in fact represent the opposite, that the presence of canines on the field of battle is unusual enough to be worthy of record. Pollux's Onomasticon sheds further light on the passage because it mentions that Paeonian dogs were well-known fighters even the second century CE when Iulius Pollux's wrote (5.46-47), making it likely that Herodotus references the conflict, including the presence of canines, for that very reason.

Perhaps the best-known front-line fighter in antiquity was the Marathon dog who participated in the famous Athenian and Plataean victory over Darius I's army. He is mentioned by Aelian, who claims that an Athenian brought the dog along "as a fellow

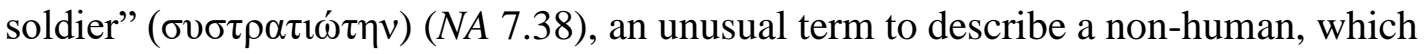
occurs nowhere else. The canine's participation as a front-line fighter is as conspicuous

\footnotetext{
${ }^{892}$ Mayor (2017), 286; the Assyrian bas-reliefs are also discussed in Brewer et al. (2001),

${ }^{893}$ Cook (1950), 42.
} 
as his recognition after death. Aelian notes that the Marathon dog "received the reward of the danger it had undergone in being seen among the companions of Cynegirus, Epizelus, and Callimachus" (NA 7.38) because the dog was painted into the Stoa Poicile portrait alongside these famous Marathonomachoi by the artist Micon or Polygnotus (ibid). Julius Pollux also records this note in his Onomasticon under the entry Micon, the likely artist of the painting, although he too notes that some attribute the art to Polygnotus. ${ }^{894}$ Because Aelian is the only source to mention the Marathon dog despite the number of times the Stoa Poicile's Marathon painting is referenced in ancient texts, ${ }^{895}$ a veil of doubt hangs over the entire event. Certainly, the presence of an Athenian dog in the front lines would have been out of place, hence Aelian's exaggerated characterization of the canine as a

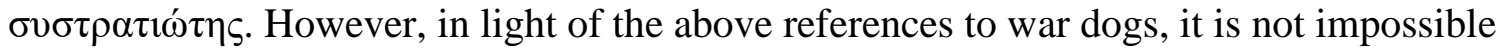
that one particularly stout fighter got involved. None the less, we must keep in mind Harrison's doubt that "Aelian may have had a good source for the presence of the dog in the painting, but he had never been in Athens himself." 896

\section{2a. The Capabilities of the Dog}

While dogs fighting in the front ranks among humans are infrequently referenced and would have proved especially difficult after the standardization of the phalanx and use of hoplite armor, Canis familiaris did not disappear entirely from military contexts. In fact, many of the military functions that dogs performed in antiquity are still functions

\footnotetext{
${ }^{894}$ Iulius Pollux entry Micon, 2.

${ }^{895}$ For an excellent survey of every reference to the Marathon painting in extant ancient literature, seeHarrison (1972).

${ }^{896}$ Harrison (1972), 376.
} 
carried out by dogs today. While my intention is not to interpret the ancient army's use of canines based solely on modern parallels, certain gaps in the records may be filled in by knowledge of what modern military dogs are capable of. Assuming similar cognitive abilities over a period of roughly 2,500 years does not require much defense, as the cognitive traits selected for in canines (non-aggression, biddability) in the pre-historic period during which they evolved from canis lupus and in the historical period have not significantly changed, even if certain aesthetic differences have since been manipulated by selective breeding. The domesticated dog's unique social cognition developed well before the historical period in question, but the process of refining and continuing to select for certain traits continued into the historical period. We see it in Arrian's Cynegeticus of the third century CE, who asserts that the best dogs are those who are naturally friendly to humans they know and aggressive toward those whom they do not (7.1-3).

Social cognition in dogs is, as we shall see, a significant component of their relationship to man. A distinctive difference between Canis familiaris and canis lupus is the former's uncanny ability to interpret human social cues, the product of thousands of years of selective evolution while living in the company of humans. The canine ability to understand human signals and respond well to training could just as easily have been manipulated by humans for military purposes 2,500 years ago as it is today. The physical capabilities of a dog, especially its speed, penchant for territorial aggression, and acute hearing and sense of smell made it a worthy companion of the ancient soldier. However, in a world where even a poor man could afford to keep a dog (Ael.NA.6.10), dogs were ubiquitous enough to be somewhat invisible in the literature. Unusual dogs, such as the 
front-line fighters mentioned above, merit a special place in the historical record, but much like other non-combatants in ancient military narratives (oxen, mules, slaves), most canines remained under the radar. Their presence is only mentioned casually or in reference to their specific function, and no thorough documentation of the number of dogs following an army appears to have been made. In depictions of humans and animals in martial contexts, however, dogs crop up much more frequently, indicating that they were part and parcel of a soldier's "kit" when he departed for war, an unremarkable addition to a coterie that might have also included a horse, slave, or attendant. As we shall see, dogs played ancillary but necessary roles as camp guards, messengers, and companions to soldiers, and the pictorial evidence suggests that they were more common than literary references might have one believe.

\section{a. Canine Social Cognition and Biddability}

Aelian remarks that "for a poor man it is enough to have a dog as a slave" because the dog is "capable of managing household affairs for those who have trained them" (NA 6.10). Although the thought of a dog taking on the duties illustrated in Xenophon's Oeconomicus is far-fetched, Aelian's attempt at emphasizing canine intelligence and obedience hits the mark. Plato's tongue-in-cheek praise of canine intellect as being on par with philosophy, as discussed above, was not entirely farcical either (e.g. above, p. 291, 303). The ancient Greeks clearly recognized the unusual ability dogs had to interpret human signals without extensive (or any) training, perhaps better than we recognize that ability today. Ancient peoples who employed working dogs would have been intensely aware of dogs' special social cognitive abilities, even if they did not conceptualize these skills in such a way. Today, at a time when dogs are infantilized and kept in large part for 
the purpose of companionship rather than the dual role of functional laborer and pet, the canine's evolutionarily specific adaptations are easily overlooked and so merit a brief reinvestigation.

In 2002, the collaboration of Harvard's Department of Anthropology, the MaxPlanck Institute for Evolutionary Anthropology, and Ipswich, Massachusetts's Wolf Hollow Wolf Sanctuary produced a significant study on the evolution of social cognition in canines. ${ }^{897}$ Hare et al.'s experiments showed that the canine ability to read and respond to human gestures and to communicate non-verbally with humans is an evolved trait that accompanied the domestication of the wolf tens of thousands of years ago. In the experiment, wolves reared by humans did not, either as puppies or mature adults, show any ability to read human communication signals, whereas dogs as young as only a few weeks were able to interpret and respond to gestures, glances, and body language. This strongly indicates that "during the process of domestication, dogs have been selected for a set of social-cognitive abilities that enable them to communicate with humans in unique ways." ${ }^{998}$ Even chimpanzees, animals capable of following human gestures and gazes toward a particular object, were unable to interpret the meaning.

Dogs were proven capable of noticing, following, and interpreting human signals such as: looking at, pointing at, tapping, or applying markers to, containers. Chimpanzees could only accomplish this after months of training during which they learned, but did not intuit, these human signals, much the way that human infants learn them. Wolves, despite passing many other memory tests, routinely failed to interpret human gestures. Hare et al. note that "these results provide the strongest support for the domestication

\footnotetext{
${ }^{897}$ Hare et al. (2002), 1634-1636.
}

${ }^{898}$ Ibid., 1634. 
hypothesis: that dogs' social-communicative skills with humans were acquired during the process of domestication" 899 based on human selection over time. They suggest that "it is likely that individual dogs that were able to use social cues to predict the behavior of humans more flexibly than could their last common wolf ancestor (which was only capable of using human social cues at low levels, like primates) were at a selective advantage. ${ }^{900}$ In addition to this, --- have shown that dogs do not follow the point gesture blindly, but consider it in addition to other contextual clues, including the human line of gaze and voice. ${ }^{901}$

More recently, Hare's reassessment of human cognition used dogs, among other animals, to prove that the theory of mind is not the distinguishing feature of the human behavioral phenotype. Close relatives of humans, such as chimpanzees, possess the ability to solve social problems by considering what their fellow chimpanzees as well as humans might be thinking, a trait which dogs also possess. While the canine ability to communicate non-verbally with humans may have emerged after only a few generations, as indicated in the Belyaev experiment with Siberian foxes, this ability was refined over time..$^{902}$

Further research on the ability of dogs to anticipate or speculate on human thoughts has proven that Canis familiaris has an exceptional intellect stemming from their evolution in close proximity to human societies. In 2009, coordination between Cambridge's Department of Animal Behavior and the Max Planck Institute for

\footnotetext{
${ }^{899}$ Ibid., 1636. Cf. Similar studies regarding dogs' ability to interpret pointing gestures, including Soproni et al. (2002) and Gácsi et al. (2009), who determined that neither age, nor sex, nor agility training elevated a dog's ability above its peers' in responding to the pointing gesture.

${ }^{900}$ Ibid.

${ }^{901}$ See Scheider et al. (2011).

${ }^{902}$ Hare (2007), 60-64.
} 
Evolutionary Anthropology led to the publication of a series of experiments that show that "even in the absence of overt behavioral cues [from humans], dogs are sensitive to others' visual access, even if that differs from their own. ${ }^{903}$ It is worth describing the experiment in brief in order to illustrate the tremendous capacity of the canine to cooperate effectively with humans by understanding and interpreting commands.

In Kaminski et al.'s experiment, ${ }^{904}$ an opaque and transparent barrier were placed in front of a dog with a toy placed behind each barrier, on the same side as the dog. Opposite the barriers, a human instructor sat down, able to view one toy through the barrier, but unable to view the toy behind the opaque barrier. The human commanded the dog to "bring it here" without gesturing or looking at either barrier, only the dog. Dogs routinely selected the toy behind the transparent barrier, showing sensitivity to the human's perspective and assuming the visible toy was the desired object. When the same study was repeated with the human turned away, looking at neither the dog nor the barriers, the dogs were inconsistent in the toy brought forward. While the exact mechanisms by which dogs reason are unclear, the experiment's results are generally that the dogs "showed behavioural strategies which are best explained with an existent sensitivity to the humans' visual access to the toys." ${ }^{" 905}$ This exemplifies an intellectual awareness and cooperation with humans that most animals lack.

The studies above clarify some of the evolutionary adaptations that make dogs the easiest of any domesticated animal to train. While this does not imply that every dog is of equal intelligence and capability, it does show that the interpretive ability of the species

\footnotetext{
903 Juliane Kaminski et al (2009), 979.

904 This experiment was repeated in a variety of ways with different breeds of dog and differing variables which I do not outline here. See especially Kaminski et al. (2009), 983-984, 990ff.

905 Kaminski et al. (2009), 989.
} 
overall is superior to even their nearest surviving relative within the canid family. While problems of common dog-training tasks such as house-breaking may come to mind as a particularly difficult exercise, the vast majority of dogs are able to learn this skill.

Comparatively, it would be exceptionally difficult to house train an ox, horse, or goat, not because these animals are unintelligent, but because of the less porous communicative barriers between them and humans.

Further evidence of the ease of training dogs to perform intricate tasks may be found in the United States' Military Working Dog Manual, which outlines the means by which canine handlers should train military dogs. None of the training exercises are especially complicated despite the exceedingly dangerous and complex tasks which the canine must perform. In section 7 of the manual, the method of training drug and explosives-detecting canines is covered in 15 pages, which includes the use of such dogs in any variety of locations, including aboard a ship, plane, vehicle, or in warehouses. ${ }^{906}$ Despite the span of over 2,400 years, this modern publication resembles Xenophon's and Arrian's own guides to dog training in many ways. Although sniffing out land mines and hunting hares are distinct tasks, the conditions in which they are performed are similar: potentially high stress situations, or circumstances in which environmental stress cannot be avoided.

\section{b. Specialized Canine Training}

Although Xenophon's and Arrian's guides to raising and training dogs focus on

906 United States Military Working Dog Training Handbook (1997), published by the U.S. Department of Defense, sections 7-1 -7-15. 
the hunt, they are useful to us here because they clearly illustrate that the Greeks could and did train their dogs to act in high-stress situations (such as a boar hunt ${ }^{907}$ ), to endure topographical and seasonal extremes, and to obey commands. All of these skills would have been necessary on the march and beneficial in a military camp, where dogs do appear in the ancient sources, as we shall see. Further, Xenophon routinely highlights the similarities between practicing the hunt and training for war throughout his Cynegeticus. Far from being a leisure pursuit practiced for its own sake, for Xenophon hunting was a practice by which young men "become well prepared for war and for other activities, as a result of which they will necessarily think, speak, and act well" (Xen.Cyn.1.18). This sentiment is echoed in Xenophon's Cyropaedeia, when he claims that the young Cyrus engaged in hunting often, viewing it as the best teacher for war (Cyr.8.1.34). Xenophon even goes so far as to say that the Achaean hero Menestheus was acknowledged superior in the administration of war, a rival (but not subordinate) only to Nestor, "from his attention to hunting matters" (Cyn.1.12).

While hunting is often considered the leisurely pursuit of the wealthy, those who could afford the well-bred hunting dogs, equipment, and spare time to engage in hunting, Xenophon asserts that the practice should not be viewed in such a light. His Cynegeticus is directed explicitly at all young men, not just aristocrats. If a man has enough money, "he should engage in hunting to the full extent of the benefit that he will get from it," and if he cannot afford it, "he should at least be enthusiastic about it, omitting nothing that his facilities allow" (Cyn.2.1). In order to present the practice as accessible for most if not all Greeks, Xenophon reminds his readers that "when one is hunting farmland, one must

\footnotetext{
${ }^{907}$ Xen.Cyn.10.21 notes that many hounds are killed in boar hunts, and even humans are in danger, circumstances which would have created a high stress scenario for dogs.
} 
keep off the seasonal produce and leave alone the springs and streams... and we should avoid setting the onlookers against the practice of hunting" (Cyn.5.34). For Xenophon, the skills learned on the hunt were applicable throughout life. They were especially important for the safekeeping of one's freedom, and the philoponia, self-control, valor, wisdom, glory, and piety learned through practicing the hunt all contributed to making Greece "invincible" (Cyn.1.7-17).

Part 12 of Xenophon's Cynegeticus lists out the explicitly martial benefits conferred upon practitioners of hunting: "enthusiasts for this sport will be benefitted in many ways...it promotes good physical health, improves sight and hearing, delays old age, and especially trains men for war. ${ }^{" 908}$ Hunting specifically prepares men for war by preparing them for the hardship of marching under arms on difficult roads or topography; Xenophon notes that hunters "will not become exhausted; for they will tolerate the hardship from having learnt to carry weapons for catching wild beasts" (12.2).

Additionally, hunters will be able to "sleep rough" and maintain a night guard. In battle hunters will "be able to act simultaneously to attack and to obey orders because this is how they themselves catch their quarry...if the enemy are routed, they will pursue their opponents in good order and with safety whatever the ground because of their previous practice" (ibid 12.3-4). All of these skills which men learn through hunting are also learned by their dogs. While dogs would have no need to pursue a routed enemy (12.4), their ability to keep up with a harsh march, manage difficult terrain, and act in good coordination with their human guides would have been crucial in a military setting. Indeed, the most crucial commands, to come or go, are basic requirements for any

${ }^{908}$ Xen.Cyn.12.1; Arrian's $3^{\text {rd }}$ century CE Cynegeticus does not dispute this (1.1). f 
hunting dog; Arrian explicitly notes that dogs should know to return to their masters even without being called, and this basic capability was simply expected of dogs:

\begin{abstract}
"What should happen is that a hound which has bounded off and is running around should return to the huntsman even if he does not call her himself, showing that she is capable of coming to heel if he now wishes; and if he does not want her back, she should bound off again, and then come back once more. They [dogs] show that they are properly trained when they come and lie down when called by the huntsman, not from fear, but from affection and respect for the one who feeds them..."909
\end{abstract}

It must be noted however that Xenophon nowhere explicitly states that while training for the hunt, men and their dogs will become better suited for combat, but this omission is not especially problematic. The purpose of the text is both instructive and persuasive; Xenophon intends to formulate a guidebook for hunters as well as to recharacterize hunting as more than a leisure sport for the wealthy. ${ }^{910}$ His call for more practitioners of the hunt $(2.11,5.34)$ must be based on the most practical benefits which the sport confers, namely military and life training for men $(1.18,12.1)$. That these benefits would be conferred on hunting dogs as well is implicit, but not especially significant for Xenophon, whose focus is on human hunters. Should a hunter and soldier choose to take a hunting dog with him on the march, the rigorous training Xenophon describes provides us with evidence that the dog would be well suited to this practice. Further, many of the techniques Xenophon advises to prepare a dog for the hunt, an event which requires self-control, concentration, and careful obedience, appear also in the U.S. Military Working Dog Handbook of 1997. Comparison of the two works reveals that the means of professional dog training have not much changed over the millennia and that

\footnotetext{
909 Arr.Cyn.7.5-6.

${ }^{910}$ Lewis and Llewellyn-Jones (2018), 192; for a general reference and introduction to the work, see Phillips and Willcock (1999).
} 
the skills canines are taught in the Cynegeticus are also useful in the military realm.

In his description of how to select superior hunting dogs, Xenophon goes into detail about canine misbehaviors that indicate either a bad dog or a bad trainer, which illustrate by default how a good dog behaves. Some of the expectations of a good hunting dog involve complex forms of human-canine communication. For example, Xenophon warns his readers against inferior trackers who, upon finding the scent of their quarry, either move their ears and keep their tail still or wag the tip of their tail but not move their ears (3.1-11). A good hunting dog is meant to communicate by standardized body language when it has found the trail, dropping its ears, wagging its tail, and keeping its nose on the scent (4.3). Further, a good hunting dog must know how to show the hunter exactly where the quarry is hiding without making noise to give away their position. Xenophon says that the dogs following the scent should "go all together along the line towards the form, quartering in circles" (4.3). Next, upon locating the hare's hiding place, the dogs must indicate where it is but refrain from attacking or eating it, yielding the kill to the human. To do this, Xenophon notes:

\footnotetext{
"they should show this clearly to the hunter by restless movements, giving further indication by their enthusiasm, their heads, their eyes, changes of posture, looking up in the air and into the undergrowth, repeatedly returning to the form of the hare, dashing forwards, backwards and sideways." 911
}

While a dog's ability to track and hunt prey is instinctual, refraining from attacking and consuming their quarry and communicating silently the exact location of this quarry by glances and body language is a skill set made even more complex by variation. While hunting a hare which hides itself in the brush, a dog should indicate its location in silence, but while hunting a boar holed up in its den, the dog should bark (Xen.Cyn.10.6). This

${ }^{911}$ Xen.Cyn.4.4; see also 6.16. 
same communicative skill set is taught to modern military dogs, who are instructed to indicate the location of an explosive device by pre-set form of communication: sitting on or in front of the location where the scent reaches its saturation point. ${ }^{912}$

Just like soldiers, dogs must learn to manage difficult terrain and harden their bodies to a hard march. Xenophon advises that a good hunting dog had a good physique, nose, and feet so that "they do not abandon the hunt when it is chokingly hot" $" 913$ or develop sores on their feet from running in mountainous territory. For this, dogs must be trained. Xenophon recommends taking hunting dogs out to different locations to prevent them from becoming too used to the same region or terrain (Cyn.6.4). Making the same recommendation, the Us Military Working Dog Handbook instructs handlers to vary the training area, time, and aids (false bombs) to avoid letting the dog become used to a pattern. ${ }^{914}$ Xenophon adds that even if there is not a hare to chase, dogs should be taken out to practice in the mountains so that they "develop good feet, and their bodies are improved by working in such places" (Cyn.4.9).

Xenophon also emphasizes the importance of dogs' abilities to respond to commands even in the heat of the chase. Obedience must override instinct and

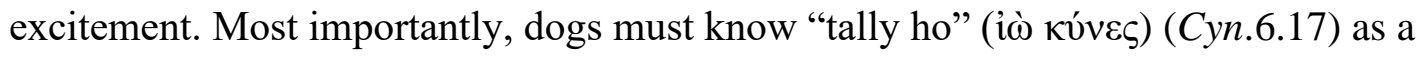

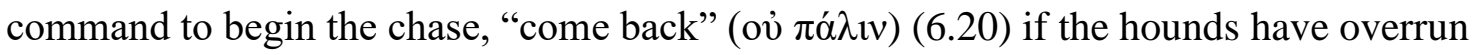
the line, and especially their own names (6.20), which Xenophon advises for this very reason should be short and have two syllables (7.5). The degree of verbal communication from the hunter is an important part of the chase not only because it provides instruction

\footnotetext{
912 U.S. Military Dog Training Handbook, 7-6.

${ }^{913}$ Xen.Cyn.4.6; however, when there is snow on the ground, Xenophon advises against taking dogs out on the hunt at all (8.2).

${ }^{914}$ U.S. Military Working Dog Handbook (1997), 7-2.
} 
to the dogs, but because it encourages them (6.25).

Although we have already shown that dogs did not regularly participate in the front lines of battle, it is worth noting that Xenophon's description of a boar hunt does show that dogs are capable of coordinating with humans who use military-grade spears when attacking large prey. Once a boar is caught in a net, the hounds are released to begin the attack at the same time as hunters bearing boar-spears and javelin-throwers approach to spear the animal. Some degree of coordination would have been necessary for the dogs to avoid leaping into the line of fire while at the same time avoid being gored by the boar's tusks (Cyn.10.8). The direct physical contact inevitable in a boar hunt, even with the use of nets, is what prompts Xenophon to recommended the use of a combination of some of the best trackers (10.4) and the most stalwart of hounds, the Indian, Cretan, Locrian, and Laconian (10.1).

Xenophon rounds out his work with a final defense of hunting as an "education in things that are real" (Cyn.12.7) which produce good soldiers, generals, and virtuous men. He asserts that his naysayers, who claim hunting only distracts men from their households, are wrong because unlike the venal pleasures, hunting assists in protecting the household (12.6-13). And on the other hand, those who "do not wish to improve themselves because of the labor involved...have the worst natures" (12.15). Xenophon's guidebook does present a rigorous training program for humans, but dogs are put through the same sort of training and presumably acquire a similar skill set, in addition to those that are natural to them. The dog was the training companion of the soldier who practiced hunting, and it is therefore unsurprising that dogs appear so frequently in departure-forwar scenes on Archaic and Early Classical vases. 


\section{The Dog in Military Scenes in Greek Pottery}

The military departure scene on Greek vases remained popular for several generations and has provided archaeologists and historians with a wealth of information about armor, weapons, and provisions. Equally important, these scenes provide key information about what the intended viewers and consumers of the images might have found attractive. Military departure scenes were more common in black figure than red figure art, during which mythological and indoors scenes grew in popularity, perhaps tied to new techniques which facilitated the incorporation of layered folds and jewelry in art. $^{915}$

However, in Archaic and early Classical vases, a variety of military scenes involving dogs were not uncommon. The presence of dogs in military scenes, especially departure scenes, has been noted by Calder, who uses a few images to illustrate the presence of the dog in everyday Greek life. She notes that the dogs may not be companions of the soldiers, but household members engaging in "abbreviated departure scenes." ${ }^{916}$ However, a more thorough investigation of Archaic and Classical Greek pottery reveals that dogs appear rather often in several different types of military scenes. Additionally, their presence in the departure scene occurs with significant degrees of variation, suggesting that this scene type was not strictly formulaic, but in fact had many variables that might have been manipulated by the artist or patron's life and preference. Initially, it is necessary to treat the issue of the dog's origin in ancient Greek

\footnotetext{
${ }^{915}$ In general, for the black-to-red figure art transition, see Boardman (1975), esp. pp. 212-234 for discussion of new scene types. See also Seifert (2014), 215-220.

${ }^{916}$ Calder (2011), 71.
} 
imagery. In 1950, R.M. Cook's essay on war dogs treated the famous Clazomenian sarcophagi, which originated in the eponymous Ionian polis in the late $6^{\text {th }}$ century. Excellent images of the sarcophagi in full color may be accessed through the British Museum's online collection. ${ }^{917}$ The edges of the sarcophagi are painted with black figure battle scenes featuring hoplites with spears and shields, well-decorated horses, and large canines. Cook asserts that the imagery is not meant to be a depiction of reality, but that the dog's presence is merely stylistic, a borrowed motif from the Syrians.

First, Cook notes that the dogs appear only where the cavalry appear and so "accommodate themselves to the horses, and if...the horses take no active part in the battle, the dogs take none either." ${ }^{\text {" } 18}$ Hence he concludes "the impression given by these jejune Clazomenian paintings is that the dog is an artistic appendage of the horse and has no necessary relevance to the main theme of the picture." ${ }^{\prime 919}$ Instead, it is a Greek borrowing of an earlier Syrian motif, examples of which Cook points to as an earlier stage of the image's development. Looking at East Greek terracottas that feature chariot racing and riders on horseback, he points out that dogs, hares, and deer are often seen running below the rider and horse, which, he notes, has no basis in reality. A dog running underneath the feet of a horse would be killed or severely injured, and even more so in the case of a chariot. Cook suspects that the Eastern Greeks adopted the combination from the Syrians, who used chariots for hunting and often depicted hunts from chariots,

\footnotetext{
${ }^{917}$ The Clazomenian Sarcophagi are housed in the British Museum and presently on display in section G13. It may be viewed electronically and searched by its museum (registration) number 1896,0615.1. The British Museum Curator's notes advise that researchers also reference the work of Murray, who was able to study the sarcophagi in significantly better condition before being damaged by German air raids in 1941. See: A. S. Murray, Terracotta Sarcophagi in the British Museum, 1-13, pls. 1-7.

${ }^{918}$ Cook (1950), 38-39.

${ }^{919}$ Ibid., 39.
} 
in which dogs were not symbolic images but realistic ones. ${ }^{920}$ The Greeks did not intend them to be realistic, according to Cook; Ionian Greek artists simply saw horses and dogs in Syrian artwork and copied them over, altering the scene from the hunt to battle in the case of Clazomenian sarcophagi because they were "sensitive to Attic taste.",921 The statement begs the question why burial containers for Ionians would need to meet with the approval of Attica. Further, what would make dogs in a clearly military setting, as opposed to the hunt, more "plausible" for the Attic Greeks if, as Cook re-asserts, they did not really use dogs in battle?

Cook's reduction of the image of the dog — but not any other figure in the painting - to "variations of a meaningless artistic convention" 922 seems unreasonable. One would have to assume that Greeks understood Syrian art to be literal, transformed it into a meaningless motif for their own use, but were sure to place the canine in a "plausible" scenario to placate any European Greeks who might view the image. It strains credulity, and the much more logical explanation seems to be that the dogs were featured in military scenes because dogs participated in military contexts. We may consider [Image 8.4] as an example, a fragment of a sarcophagus from Clazomenae that is presently housed in the British Museum. In this image, the war dog portrayed is not an afterthought or merely decorative addition to fill in empty space; the animal is carefully painted into the foreground of the image, giving it depth by placing the horses to the left of the dog in the background. The dog has been integrated into the image and performs an action within the same space as the armed warriors and horses.

\footnotetext{
920 Ibid., 38-40.

921 Ibid.

922 Ibid.
} 
Beneath the image in repetitious rows small outlines of lions appear, none of which are interacting or even proportional to the primary image. These may be fairly categorized as motifs, not unrelated to the image, but not interacting with it directly. It is safe to assume that lions were not used by Clazomenians on the field of battle, but their presence might be meant metaphorically to illustrate the courage and ferocity of the soldiers, a comparison made frequently by Homer. ${ }^{923}$ The dog, however, like the horse and soldiers, is integrated into the scene and at a glance very clearly part of the forward march. However, canines serving as front-line fighters were not typical in European Greece, and almost every literary reference to them comes from Ionia, as we have seen. Many Attic Greek vases reveal the other ways in which dogs participated in the military realm, and it is to those that we will now turn.

In order to collect a variety of ancient sources for dogs in the military realm, it is necessary to pay careful attention to the portrayal of the animals in pottery, where they appear much more commonly than in literature. Recently, Pevnick's inspection of a Triptolemos kylix led him to conclude that "although dogs appear with great frequency on painted pottery, they often escape mention, even in basic descriptions of vases; canine iconography still awaits a comprehensive study."924 This part of the chapter attempts to examine dogs exclusively in military scenes in order to evaluate their significance. Being unable to present an exhaustive survey of the military canine in any and all Greek pottery, I have used a relatively broad digitized archive to limit the search while providing sufficient information to create a case study.

\footnotetext{
${ }^{923}$ Cf. p.308 above, and occasions when Homer describes Hector as "rabid" to connote extreme displays of violence in battle: Il.9.304-306, 13.53; cf. 8.299 and Franco (2014), 31ff.

${ }^{924}$ Peynick (2014), 156.
} 
For this chapter I rely on the Beazley Archive, which has been digitized by the Classical Art Research Center (CARC) of Oxford. CARC's work facilitates the search of key motifs in ancient pottery, and I must note that I restricted myself to items which I could personally view; records without sketches or photos of the vessels were not included, as I could not verify their contents.

The location in which vessels were unearthed, as best can be traced, is not of as much concern as the point of origin. Many of the items that I catalogued (see Appendix 3) were of Attic origin but uncovered in southern Italy, and they do not differ significantly from their contemporaries uncovered in Attica or other parts of the Greek world. Obsorne presents a strong argument that "although the Etruscans were voracious consumers of Athenian pottery, their demand did not generally determine the iconography of the figure scenes" but in fact gave Etruscans a template for their own art. $^{925}$

An item by item investigation of

the archive's contents that featured \begin{tabular}{|l|l} 
Scene Type & Number of Vases
\end{tabular} \begin{tabular}{l|l} 
Departure Scene & 97
\end{tabular}

Static Military Scene $\quad 11$

canines in the same setting as Military March or Charge Scene 25

warriors turned up 156 vessels Dog on Shield 18 Varia 5

which date from c.600 to 450 and Total 156 include both black and red figure Chart 8.11 vessels. The vessel types tallied vary, but amphorae are the most predominant. Additionally, one finds krateres, cups, plates, lekythoi, hydriae, stamnoi, and one olpe. I have organized the images broadly by category into: (a) departure scenes, (b) static

925 Osborne (2001), 277. 
military scenes, possibly military camp scenes, and (c) military marches or charges (including battle). Dogs which appear only as shield emblems were charted separately and not used as evidence of canine participation in the military sphere. I place several scenes in a fourth category, "varia," as they represent a martial context distinct from the rest, as can be found in [Table 8.5] in Appendix 3. A summary of my findings appears in Chart 8.1 above, and a more detailed record may be found in [Table 8.1] of Appendix 3, with each vase listed by its catalogue number in CARC's Beazley Archive. Next, we shall analyze the contents of my findings.

\section{a. Departure Scenes}

Departure scenes became exceptionally popular in the fourth century are easily recognized by their nature, the most basic requirement of which is a clearly identifiable soldier and a non-combatant of some sort. Otherwise, the standards of the scene can shift considerably, including numerous or only two figures, figures of either sex, of varying ages, and a variety of different war-related accessories. ${ }^{926}$ One finds the soldier's "kit" depicted differently, presumably depending on the whims of the artist or the desire of the patron. The most basic elements are the spear and occasionally a sword (especially the machaera or kopis in Archaic vases), and armor included at least a helmet, curiass, and perhaps a hoplon or greaves as well. ${ }^{927}$ The number and type of warriors might differ, as might the presence of a horse, archer, the number or type of weapons, and the presence of

\footnotetext{
${ }^{926}$ Cf. Boardman (1975), 217-218, who notes that in the Archaic Period, red figure vase military scenes tended to be arming and departure scenes. By the classical Period, wife, mother, and father are the most commonly identifiable figures in addition to the warrior in departure scenes (Boardman 1989, 220).

${ }^{927}$ Cf. Boardman (1989), 220 and (1975), 217-218. Detailed depictions of armor in red figure vases are more common in the Archaic Period than the Classical, with the latter depicting more frequently only helmet, greaves, and possibly a corselet. The spear becomes commoner by the Classical Period than the cavalry sword (machaera).
} 
the heroicizing element, the war chariot. For our purposes, it is important to note that one of those varying aspects of the scene was the canine, who appears in no fewer than 111 departure scene vessels, and I suspect more.

Consider for example a late $6^{\text {th }} /$ early $5^{\text {th }}$ century black figure Attic olpe [Image 8.5], which portrays a fairly standard departure scene. Four unarmed men, two with staffs, flank a fully-armed hoplite in helmet, cuirass, and greaves who bears a pair of spears and his shield, held out his slightly extended left arm. This is a departure, the warrior leaving his community for war and being bid farewell by the elders who are unable to fight and the young man on the left without a beard, presumably too young. At the warrior's feet is a long-tailed dog, standing staunchly beside him in imitation of his pose, gaze aimed in the same direction as his master's. Anyone familiar with dogs would recognize that posture as one of dominance and perhaps preparedness. ${ }^{928}$

The casual observer might not have any difficulty interpreting the dog as the warrior's companion, one who consciously mimics his master's posture and stands in the same physical space, indicating that he belongs to the warrior, not the household. However, modern scholars have discarded the idea that dogs in departure scenes are doing anything more than saying goodbye, and this assumption is usually made on the basis of one or two images, rather than a careful consideration of a larger sample set. For example, Cook discredits the significance of a dog in a departure scene on one of the Clazomenian sarcogaphi, asserting that it is surely meant to belong to the household, not the warrior. ${ }^{929}$

Unfortunately, Cook was unable to survey more recent archaeological finds,

${ }^{928}$ Cf. Kitchell (2020), fig. 5.

${ }^{929}$ Cook (1950), 39 n.11. 
departure scenes in which the position of the dog is less ambivalent. Since then, Calder has noted that there is a difference between dogs who are "with" soldiers and those meant to stay at home, as they are differently depicted on vases. She draws on a black-figure neck amphora housed in Munich in which the dog's posture indicates its intentionalityit is going with the soldiers. Due to the broader nature of her work, she does not go into greater detail, referring the reader instead to Cook's argument regarding the presence of dogs in actual battle, which she also rejects as unlikely. ${ }^{930}$ Further, the difference recognized in the Munich vase is qualified as "a difficult point, for these could simply be abbreviated departure scenes.",931

Due to the sheer number of such scenes and the variable and customizable nature of the scenes' contents, I argue that if the dogs appear to be departing with the soldier, this is what the vase "reader" or viewer is intended to understand. Turning vase imagery into abstractions of reality presupposes that the artists and viewers are working with coded imagery, which would significantly narrow the pool of potential buyers and isolate those unable to "translate" the significance of images. Such a coding seems highly unlikely. Even in cases in which chariots are portrayed, instruments of war which were not used by Greeks in the Archaic and Classical periods, no Greek viewer would have had difficulty understanding that the chariot factors into the scene as an apparatus for battle, part of the soldier's "kit."

Even if Greek viewers did not use this equipment, they could recognize it as an appropriate image in a military departure scene. For canines, one must assume something similar. If canines were never taken to war, their appearance in departure scenes next to

\footnotetext{
${ }^{930}$ Calder (2011), 71, esp. fig. 184 p.186.
}

931 Ibid., 71. 
their masters, in static military scenes outside of the domestic sphere, and in military march scenes near horses or infantry would be out of place and confusing to the viewer of the vase.

\section{Type of Departure Scene}

Dog is "with" the warrior

Unclear whether dog is "with" the warrior

Dog is clearly not "with" the warrior

Total number of departure scene vases:
Number of

Corresponding Vases

72

18

7

97

Chart 8.2

In order to determine the role of canines in these images, I have divided the 97 departure scene vessels (excluding those in which the dog appears only a shield) which I surveyed into three sub-categories, shown in chart 8.2. Category (i) contains departure scenes in which the dog appears to be departing too and is categorized as "with" the warrior. Category (ii) contains images in which the dog's position is and body language is too ambivalent and, to avoid overstepping the bounds of interpretation, I do not count as "with" the warrior. Category (iii) contains images in which the dog is clearly staying home, indicated by its position far away from the soldier or by frightened body language. My investigation of CARC's digital archive yielded 97 departure scenes which featured dogs, and 72 of those featured dogs who were departing with the warrior, while 25 were either clearly not departing or too ambiguous to categorize. I determined the dog's position as "with" or not "with" the warrior based on two primary considerations: (1) the dog's position relative to the warrior and (2) the dog's body language. Regarding 
the first criterion, the spatial location of figures in painted pottery in relation to the leading or dominant figure (the warrior) has been successfully shown by Seifert to reflect their relationship to the dominant figure and their role in the scene in general. ${ }^{932}$ As a result, one may "read" the scene to mean a dog is departing if it stands close to the warrior, as in [Image 8.5], or if it appears to be leading the warrior away from the household. Additionally, the dog may be considered to be departing if it stands in front of a horse or chariot or appears to be leading the chariot. In at least a few cases, the dog makes actual eye contact with the war horses, as in [Image 8.6]. Contrarily, if the dog stands closer to the household or representations of the household like the wife, mother, or elderly father, it is more likely that the dog is remaining at home, as in [Image 8.7].

However, the dog's location alone is not enough to determine its intentionality. The dog's posture and body language must also be taken into account. In cases where the dog exhibits body language indicative of dominance, excitement, or aggression in conjunction with applicable spatial location, it may be understood to be departing. Dogs demonstrating postures indicative of anxiety, fright, or indifference, regardless of their spatial location in the image, are generally understood as not departing. While the "reading" of dog posture in ancient art may appear subjective at first blush, there is in fact a science to it. Kitchell's recent work on naturalistic canine representations takes body language into account and concludes that "if one spends time looking at the way dogs are depicted, it is clear that the artists were at pains to include natural, observed canine behaviors in their scenes...the same ones we can see today on a daily basis." 933 Kitchell provides numerous examples of dogs depicted in naturalistic poses, from

${ }^{932}$ Seifert (2014), 216.

${ }^{933}$ Kitchell (2020), 11. 
scratching their ears with their hind legs to sulking, head down, body hunched, while sitting outdoors while his master attends a music lesson. ${ }^{934}$ These postures would be familiar to anyone who has had extended contact with a dog, and they are easily recognizable because they are instinctive, not trained, behaviors. Kitchell has made an excellent case for the translation of canine posture in ancient images, offering a chart published by Dogs for Defense, a canine corps training unit based in St. Cloud, Minnesota. The "dog to English" translation chart offers a basic explanation for commonly-seen canine postures, with which most people would be familiar [Image 8.3]. While Kitchell acknowledges that not all ancient artists drew dogs with such care, ${ }^{935}$ the appearance of such a variety of realistic dog postures indicates that many artists were drawing from real life observation, meaning that the body language of the dog can inform us about its role in the scene.

Consider for example [Image 8.7], a painted hydria featuring a departure scene. In the scene, the dog is not only close to the mother/wife figure, but is in the "frightened" posture with its ears lowered and its tail tucked entirely between its legs. This dog is not departing for war, but staying home, and should thus be placed in category (iii). Some images are less clear cut. In [Image 8.8], a hydria painted with a departure scene, we see a fully-armed hoplite facing a Scythian archer who carries a hatchet and bow. Behind the hoplite is an elderly man with a cane, presumably the father figure. The large canine dominates the center of the image and lies beside the hoplite, facing the old man, paws stretched forward in a half-crouch. While the dog appears close to the dominant figure and even wears a collar, which is notable, its body language and gaze directed at the old

\footnotetext{
934 Ibid., 12, 18-19.

${ }^{935}$ Ibid., 11.
} 
man figure make it impossible to confirm that the dog is departing. Thus, it has been placed in category (ii).

Categories in which movement is involved are sometimes clearer-cut. For example, the lekythos in [Image 8.9] depicts on the body an arming scene. On the shoulder, it portrays the afterward: a warrior departing and walking away from a female figure toward another figure (presumably his squire) on horseback. A large dog follows behind the warrior and may be understood to be departing with him, as he is following closely behind the soldier en route to the squire.

As a final example, let us consider a black figure amphora in which the dog's intentionality is quite clear. In [Image 8.12], we see a departure scene in which a veiled woman with her feet facing left and in motion, reaches out to grip the arm of a hoplite in mid-turn. While she appears to be drawing him toward the left, his torso and head are twisted back to the right, where at his leg a dog stands in the "excited" pose, paw almost touching his calf. The dog and the hoplite are looking to the right, while the woman gazes at the hoplite and walks to the left. The partial twist of the hoplite's torso and the rearview of his helmet give this image the sense of movement, and the dog's role is key. It is clearly intent on departing with the warrior and appears to be playing a part in hurrying along the goodbye as well, eager to depart.

The complete list of departure scenes that I used may be found in [Table 8.1] in addition to those which have been the subject of discussion here. Further details on the categories of consideration and interpretation of body language may be found in the introduction to Appendix 3. However, because an argument of canine accompaniment to 
battle cannot be made with departure scenes alone, we must also look to the presence of canines in other military scenes.

\section{b. Static Military Scenes}

I have named the second broad category of vessels surveyed "static military scenes" and, more tentatively, military camp scenes. These are scenes which portray men dressed for war and usually also carrying implements of war without the domestic presence of women or old men who might indicate a departure scene. Of the survey images including warriors and dogs, 11 of them were static military scenes listed in [Table 8.2]. Like departure scenes, static military scenes have a number of variables, including the number and type of warriors, the posture of the warriors, and the presence of animals. For example, [Image 8.10] of a black Athenian neck amphora dated to c.525475 that features on side $a$ a departure scene, and on side $B$ a static military scene; the two appear to be interconnected, as the same man appears on both. On side $a$, a woman helps a warrior arm, holding his shield as he puts on his greave. To the right, an archer holds his quiver, and to the left, a second, fully-armed hoplite with a leg emblem on his shield looks politely away from the private indoors scene. On the amphora's side $b$ we see the second armed hoplite, distinguished by the leg on his shield, standing with two archers. Just behind the hoplite's leg is a large dog who stands with his tail held aloft and his ears back, head tilted up and looking at the archer in front of him. The stance is an aggressive one according to the DFDK9 chart in [Image 8.3], an appropriate attitude for a dog on the march. Because the amphora's $b$ side portrays a separate scene from the arming which occurred in the household, we know that this dog is active in a military context, as there is no indication of an indoor or public space setting. Aggressive 
behavior would have been valuable on the march, and the training a canine might receive as a guard dog could extend to the military camp, where it would be responsible for overseeing its master's belongings.

Another static military scene suggests slightly more movement in the facial expressions and postures of the figures. The red figure lekythos of [Image 8.11] depicts an armed hoplite in the center flanked by two foreign archers, who appear by their costume to be Scythian or Persian. Directly behind the hoplite and facing the archer to the right is a large black dog, whose body posture indicates excitement. He half-crouches, holding his tail aloft, and raises one paw. The lifting of a paw is not the result of training, but a natural canine response to excitement which humans have taken advantage of to teach pets to "shake hands." 936 Despite the small white line near the dog's mouth that looks like a cartoonish frown (and may in fact be a crack), the body posture indicates that the dog is being playful, not attacking. Indeed, there are numerous examples of Greek pots that depict dogs extending their paws to touch or "pet" a human. ${ }^{937}$ Here the excited body language of the canine is in sync with the relaxed pose of the hoplite and archers, especially the archer facing the dog, who appears to be extending a hand toward the animal.

Let us consider one more example of a static military scene. [Image 8.13] is a black figure amphora from the second half of the sixth century that depicts a fully armed

\footnotetext{
${ }^{936}$ Cf. Kitchell (2020), 16.

${ }^{937}$ For such images consider (1) the Athenian black figure amphora c.550-500, depicting the departure of Adrastus and archer, in which a dog stretches forth to place its paws on a seated elderly man. Housed in Florence, Museo Archaeologico Etrusco, 3822, Beazley Archive number 302083. (2) The Athenian black figure amphora, c.550-500, that depicts a dog pawing or petting a woman's skirt in a departure scene; the dog stands beside the warrior but its status is unclear. Housed in Cambridge, Fitzwilliam Museum, GR31: 1864, Beazley Archive number: 302288. (3) The Athenian black figure amphora c.550-500 in which a large Molossian-shaped dog stretches forth its paws toward the feet of a woman. Housed in Paris, Louvre F247, Beazley Archive Number: 302920.
} 
hoplite, his team of horses, and his dog. There is no context suggestive of a departure scene; the man, his four horses, and his dog stand alone in a clearly military scene. Less stiff than the lekythos discussed above, this amphora image is incredibly personalized and intimate. The warrior is petting one of his horses, hand resting atop its head and in its mane. The dog at the warrior's side is unusual in its coloring: white spots on its face, back, and front legs give it character, and the collar about its neck indicates that it is a valuable and well-trained dog, as collars were used for this purpose (Xen.Cyn.6.1). ${ }^{938}$ While the appearance of dogs does vary widely in military vase scenes, the use of two different paint colors to decorate the dog is uncommon and might suggest that the artist had a specific dog in mind, perhaps one of his own. Such variation is surely not indicative of a standardized scene in which the dog, unlike all other parts of the scene, is meant to be understood as purely symbolic.

\section{c. Military March Scenes or Charge Scenes}

The third category into which I have divided my sample set is one in which motion is indicated, either a military march or, in a few cases, the charge into battle. Of the 156 surveyed images depicting the dog and warrior motifs, 25 of them are military scenes with indication of movement such as a march or charge. Perhaps the best known is the black figure neck amphora cited by Calder [Image 8.14], which depicts a lively scene with warrior, horse, and dog. ${ }^{939} \mathrm{~A}$ warrior wearing greaves, cuirass, and crested helmet and gripping two spears is in the process of leaping up onto his horse's back, a sure indication that he is en route to battle, as one would not don a Corinthian helmet for a

\footnotetext{
938 Several dogs wearing collars appear alongside the warrior motif in pottery. A list of such images from my CARC survey may be found in [Table 8.6].

${ }^{939}$ See further Calder (2011), PL.9(A).
} 
departure ride given the limits it places on one's peripheral vision. In the foreground and beside the black horse a large white dog is leaping up, only its hind legs on the ground, a gesture of excitement for anyone who has ever owned a dog. In the location where names might have been inscribed for the horses, warrior, and dog, one finds only dots, which might suggest that this part could be filled in as desired or was simply meaningless and indicative of an illiterate audience.

In either case, the presence of name-dots above all three beings - not just the human - is strongly suggestive of their presence in the scene - they are not abstracted symbols. While there is no indication that the dog is meant to be understood as a participant in the upcoming battle, what matters is the dog's presence in a military setting. The dog has traveled toward the battlefield with his master and has accompanied him to war, even if the dog does not charge into battle.

In order to address Cook's argument fully and completely about the presence of dogs under running horses and chariots, let us re-assess the evidence. ${ }^{940}$ Of my sample selection, less than one third of the images feature dogs running underneath chariots or horses. Whether or not images of military charges conform to such a pattern is indicated in [Table 8.3], and even those which do depict the Syrian motif of a dog "under" (beside) a chariot horse contain some degree of variation. These images may indeed reflect the borrowing of a Syrian tradition by Attic artists. However, they may have been borrowed for a reason: the shared custom of bringing canines into combat, as Pharnuces did (see above pp.321-322). Furthermore, the depictions of dogs stretched out in a run beneath a chariot or horse are in the minority; in many martial images, the dog is incorporated more

\footnotetext{
${ }^{940}$ Cook (1950), 38-40.
} 
completely into the scene, as we have seen above. This is a strong indication of the depiction of a genuine Greek practice, even if a Syrian motif had been borrowed to depict it. Of my sample set, those which most clearly reflect the image Cook describes are two amphorae and one hydria from the earth sixth century to the earth fifth century: [Images

\subsection{5-8.18].}

In the amphorae depicted in [Image 8.15] and [Image 8.16], either side is similarly decorated with a depiction of a dog running beneath horses' hooves on one side, and a hare in its place on the opposite side. A red-figure hydria of a slightly later date appears in [Image 8.17], and an early black figure amphora in [Image 8.18] might represent the same general theme. This sort of imagery might be an easy way of indicating the speed of the horse or variations on a Syrian theme. However, it is worth noting that the variation within the images indicates more than slavish stenciling. [Images 8.15-8.16] portray a mounted hoplite riding his horse with a dog or hare below, but [Images 8.17-8.18] both show mythologized scenes with charioteers and warriors behaving differently; in the former vase, the warrior runs alongside the chariot, and in the latter, the warrior is riding beside the charioteer and leaning eagerly forward. There are noticeable differences applied to the dogs as well, with their tail positions and length as well as the depiction of scruffy fur at the neck varying by artist. Finally, it must be remembered that the position of the dogs "beneath" the horses could easily be a fault in an artist's understanding of perspective, rather than an intentional choice.

However, the application of such a specific theory does not fit the majority of military march and charge scenes. These involve dogs in a much clearer role, placing them not in the empty space beneath the horse, but rather in the march line, well 
integrated into the scene. Consider for example [Images 8.19-8.20], a pair of black figure lekythoi that are almost identical in design, both attributed to the Athena Painter Beazley. The duplication of such a similar image is indicative of its popularity, arguably because it portrayed a realistic event. The warrior on horseback wears a crested helmet and carries two spears, indicating that he is going to battle, not hunting. Alongside the horse's rear [Image 8.19] or front [Image 8.20] hooves trots a small dog, his forelegs stretched forward in a bounding motion, tail curled upward. The differences in the riders are small; the direction of their heads, the extent to which their left foot protrudes from the horse's flanks, and little more. These represent a significant departure from the stylized Syrian motif Cook discusses, and although two similar works by the same artist have survived, a significant variation in march scenes prove that the dogs were not mere decorative afterthoughts.

Within the category of military marches and charges, we may take for example [Image 8.21], a black figure Attic amphora from the second half of the sixth century. One side of the amphora depicts a static chariot from an awkward or perhaps humorous angle, showing the rear of all four horses. The head of the soldier and charioteer are visible up front, and a dog accompanies them not beneath the chariot, but in the space to the side, where the animal can be seen leaping up in excitement. The chariot is not yet in motion, so there is no need to indicate its speed.

Additionally, we can consider an amphora from c.525-475 which depicts a hoplite walking away from an easterner and his horses; the hoplite is following the lead of a pony-sized dog with a great bushy tail. ${ }^{941}$ In [Image 8.22], a fragmentary cup from the

${ }^{941}$ This black figure amphora is housed at Manchester, City Art Gallery \& Museum: 1885.21.AA.36. The Beazley Archive does not provide photos of either side of the amphora, and the dog is mostly cut off in the 
second half of the sixth century, a dog proudly marches in front of horses and soldiers. An oinochoe which portrays a military march or a scene in camp [Image 8.23] shows a large dog walking beside a warrior on horseback and approaching a Scythian archer whose back is turned. While the Scythian is looking away, the dog's face is placed firmly on the bag tied to the Scythian's belt, presumably his rations. Such a comedic touch rings true to life for anyone who has owned a dog and shows that its presence is anything but symbolic.

\section{d. Function from Form?}

While reading a dog's presence in a military context from a vase is manageable, interpreting the dog's significance or specific role within said context is much more difficult. Most of our analysis of function will rely on literary evidence, but a few specifics may be gleaned from Greek pottery. Because we have seen that dogs depart with warriors and exist apart from the domestic arena with armed men, we know that some canines make the campaign march with their masters. There is no reason to assume that this would be especially difficult; dogs which are trained to hunt in the mountains would not have any more difficulty marching along with their masters on campaign (Xen.Cyn.4.9).

Since dogs capable of keeping up on the march would be trained hunting dogs, it is safe to assume that they are generally capable of fending for themselves and not necessarily reliant on their master to provide food for them. After a battle, it is not implausible that canines from either side's camps might have foraged from the carnage of

image, except for his curly tail and the curator's notation that a dog is pictured there. For viewing reference, Beazley Number: 305971. 
the field. ${ }^{942}$ Certainly on longer campaigns hunting dogs would have been a desirable addition to the camp because of their ability to supplement the camp diet. Indeed, we know that Alexander the Great was given massive packs of Indian hunting dogs as a gift, animals which had a practical value while the massive Macedonian army was on the march. Diodorus records that Alexander received 150 such dogs from the Indian king Sopeithes, Indian hounds descended from tigers and impervious to pain. ${ }^{943}$

A less practical function that dogs on the march would have served is that of a status symbol. Like horses and fine armor or weapons, a well-to-do soldier might have brought a costly, well-bred, and well-trained hunting dog along with him. Naturally some dogs would have been kept as status symbols, especially if they were well-bred, welltrained, or expensive. The most (in)famous example of this is Alcibiades' extravagant purchase, which he admits was an attempt to distract the Athenian public:

\footnotetext{
"Possessing a dog of wonderful size and beauty, which had cost him seventy minas, he had its tail cut off, and a beautiful tail it was, too. His comrades chid him for this, and declared that everybody was furious about the dog and abusive of its owner. But Alcibiades burst out laughing and said: 'That's just what I want; I want Athens to talk about this, that it may say nothing worse about me.",944
}

While Alcibiades' mutilation of his dog is a gruesome example of wasteful extravagance, it also reveals how dogs served as status symbols. Xenophon explains this further when he indicates the cost in time and resources that goes into raising, training, breeding, and maintaining fine hunting dogs. He exhorts his readers to begin their education in hunting as youths, and he who has sufficient means should "spend as much as the benefit to himself is worth" (Cyn.2.1); those lacking in financial means should "at least supply

\footnotetext{
942 Cf. Franco (2014), 54-74, who ultimately concludes that the threat of dogs eating corpses is metaphorical rather than factual.

${ }_{943}$ Diod. 17.92, Strabo 15.1.31, Ael.NA 8.1; referenced also in Curt. 9.1.31.

944 Plut. Alc. 9.1
} 
enthusiasm" (ibid) for the sport.

The most costly aspect of hunting was undoubtedly the time spent training one's dogs, but the equipment was important too. Xenophon lists out that "accessories for the hounds are collars, leads and belts" (Cyn 6.1) and describes the preferable style of each, noting that the lead should never be part of the same fabric as the collar, as this would constitute a form of abuse. Leads and collars are both familiar to the modern reader, but Xenophon's inclusion of belts which "should have spikes sewn in to protect the breed

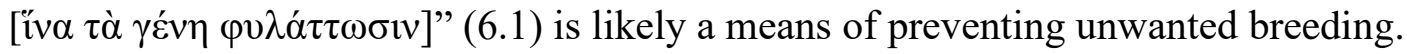

The close connection of collars and training for the hunt in Xenophon's Cynegeticus indicates that the collar served as, among other things, a status symbol, advertising that a particular dog was well-trained and an apt hunter. Certainly collars were not a requirement for a pet or working dog as they are today, and they do not appear consistently in pottery, as shown in [Table 8.6]. When collars do appear on dogs on pottery, the artist is making a conscious decision to communicate something. It is reasonable to assume that the presence of a collar is a good clue to the dog's value and thus the status it confers upon its master. Several such images exist, and the presence of a collar does not appear to be linked to the type or size of dog, although it is statistically more common on larger dogs.

For example, [Image 8.24], a black figure amphora from c.525-475 features a large dog with a prominent scruff stands beside a hoplite and has a collar painted about his neck. However, a collar is very cleanly etched onto the smaller, knee-high dog of [Image 8.25], a black figure Attic amphora featuring a departure scene. An amphora of the same period [Image 8.26] shows a massive and grizzled dog with a thick band about 
its neck as it walks beneath the feet of a horse, followed by a hoplite. As listed in chart 3, other such images suggest that the presence of collared dogs on the march was not unusual, although leashes do not appear on dogs in military scenes. This suggests that dogs on the march were well enough trained to obey vocal commands, as they would need to be if brought into camp.

One depiction of a leashed dog in a military departure scene might be the exception that proves the rule. In [Image 8.27], the dog is straining against the long leash and leaping up against a horse ridden by a warrior. The cavalryman is the only soldier in this departure scene, and a civilian holds the dog back with the chain, suggesting that the dog was meant to stay home and, judging by its tendency to excite the horse, perhaps not sufficiently trained to manage a campaign.

\section{The Function of the Military Dog in Ancient Greece: Literary Evidence}

As we have seen above, pictorial evidence as early as the Archaic Period is strongly suggestive of dogs accompanying their masters to war, especially if those dogs were well-bred, expensive, or specially trained, a detail occasionally denoted by the presence of a collar, which plays a key role in the training and working lives of hunting dogs. By expanding the definition of war dogs from front line fighters and considering the popularity of departure scenes featuring canines with their armed masters, we can better explain casual literary references to the presence of dogs in military settings.

As in so many cases, this study is limited by the quantity and nature of the literary sources. An ideally balanced investigation would include archaeological, epigraphic, and literary evidence from the Archaic through Roman periods, but this is not what is 
available. Instead, the sources that indicate the presence of canines in military contexts vary by nature across the centuries, but this does not make it impossible for us to reassemble fragmented clues and form a coherent picture of a broader military trend. Early literary sources, from Homer to Thucydides, generally lack the explicit reference to military canines and the manner in which they were used which one might desire. However, Archaic and early Classical vases do show the canine in these contexts, and explaining the presence of dogs in military departure scenes as well as scenes of battle and marching as purely symbolic is far more difficult than simply accepting the images as representations of reality. Additionally, the Archaic Period yields a few key pieces of epigraphic evidence indicating the importance of canines in the military by linking them through context to their soldier-master and his warhorse.

By the later Classical Period, the popularity of guidebooks like Aeneas Tacticus' Poliorcetica reveals more detailed explanations of the canine in the Greek military because the focus of guidebooks is narrow, the content specialized. One may be tempted to assume that the relative absence of dogs in Herodotus' and Thucydides' histories is indicative of a total absence of military canines in the historical periods each writer is concerned with. ${ }^{945}$ However, the existence of evidence for dogs in the military sphere before and after the era of Herodotus and Thucydides makes it difficult to believe that the practice of bringing canines to war vanished abruptly only to re-emerge later. Pottery featuring dogs in military scenes dwindles considerably by c.450 as red figure overtakes black, but so does the appearance of the most common military scene, the departure. ${ }^{946}$ The earliest literature referencing canines in a specifically military context is that of

\footnotetext{
${ }^{945}$ E.g. Cook (1950), Rees (2013).
}

${ }^{946}$ Seifert (2014), 215. 
Aeneas Tacticus in c. 350. It seems unreasonable that the custom of using dogs in the military would disappear for a century and then make an abrupt reappearance. What seems more likely is that the scanty nature of our sources makes it impossible to trace dogs' presence consistently or through the same media throughout Greece's history. Given the paucity of literary evidence, we must ask what, if anything, might account for the silence of fifth and early fourth century historians on dogs' presence in military contexts?

We might begin with the obvious - neither Herodotus nor Thucydides was writing an instructive manual, but rather an historical account. Neither man spends much time explaining how the Greeks make war; they simply expected that their audience would have this knowledge. Herodotus provides far more detail on how non-Greeks make war in his ethnographies, and Thucydides largely concerns himself with a combination of narrative and analysis of cause and effect. ${ }^{947} \mathrm{I}$ do not wish to suggest that these authors are neglecting a key part of a Greek army's defense, but rather that they leave the nuances unspoken due to the expected frame of reference their audience possessed about how a Greek army marched. As a result, occasional references to military details are not consistent, and the dearth of references to dogs is not evidence of their complete absence.

For the sake of illustration, we may consider the military use of slaves in ancient armies. Although it is generally accepted that slave attendants were employed as batmen or assistants, they are hardly referenced at all, their presence taken for granted. In her study of slaves' roles in the Athenian army, Sargent notes that it may be assumed that slaves were present in armies as attendants from "inadvertent remarks to be found not

\footnotetext{
${ }^{947}$ Wallace (1964), 251-261; on the complexity of Thucydides' methodology: Orwin (1989), 345-364.
} 
only in the strictly military writers, but in other Greek authors." 948 For example, Thucydides mentions the presence (and desertion) of attendant slaves during the Sicilian Expedition only by happenstance, in order to illustrate the troubles of Nicias' and Demosthenes' troops (Thuc.7.75.5). Thucydides' casual reference to slaves does not indicate that they were an unusual presence, but just the opposite. ${ }^{949}$ They are not mentioned consistently by Thucydides even in the case of the Sicilian Expedition. No slaves are mentioned among the troops departing for Sicily in 415 (Thuc.6.31), but the slaves' desertion of the Athenians during the campaign is highlighted because it impacts the narrative directly $(7.13,7.75)$.

Similarly, slaves are mentioned among the casualties of the Battle of Delium (Thuc. 4.101), but not among the forces sent out (4.93-94). More recently, Peter Hunt (1998) has argued that this conspicuous absence has ideological roots, reflective of the desire of free Greeks to avoid admitting any degree of debt to their slaves for many military victories. Whether the Greek historians held their silence about the role of slave attendants out of shame or merely disinterest, the general lack of references to slaves in ancient military histories is an excellent example of why omission does not equal absence.

Our sources for dogs in the Greek military are primarily fourth century and later, although many of these later accounts concern themselves with the Classical and Hellenistic periods. The earliest literary source to mention canines in explicitly military contexts is Aeneas Tacticus' Poliorcetica, a mid-fourth century military manual that provides guidelines for withstanding a siege, including fortifying the walls and gates,

\footnotetext{
${ }^{948}$ Sargent (1927a), 202.

${ }^{949}$ Sargent (1927b), 279.
} 
maintaining morale, repelling attacks and preventing treachery, maintaining a night guard, and managing sorties. Aeneas Tacticus provides the most detailed information on how to use dogs effectively in war, which is unsurprising given that the nature of his writing is a guidebook as opposed to a narrative history.

Narratives and anecdotes concerning Classical Greek history composed during the Roman period occasionally mention the role of the canine in an unspectacular fashion, suggesting that there was nothing particularly unusual about the dogs' presence in a military setting. While it is fair to bear in mind Rees' warning that a dearth of references to military dogs in Xenophon's time is more telling than anecdotes provided by later Greeks like Polyaenus, ${ }^{950}$ careful illumination and analysis of occasions on which military dogs are described in ancillary roles is an important part of our investigation.

The most obvious use for dogs in a military context is the use to which they were put in a domestic context as well: guards. Dogs appear in a domestic context as early as Homer, as we have seen (pp.301-302). Hesiod gives the impression that the "jagged toothed" guard dog behaves like a mercenary, who will refuse his duty if not fed and leave the house open to theft (Hes.WD, 604ff), but this seems an oversimplification of the complex human-dog relationship meant to emphasize the important role food plays in training and keeping a dog. More realistic limitations than a food strike are those of the guard dog in the domestic realm, a problem well illustrated by the fate of Alexander the tyrant of Pherae. Alexander kept a guard dog chained at the door of his bedroom, which Iulius Pollux notes could only be reached by ladder. ${ }^{951}$ Plutarch gives the lengthiest extant account, noting that the threat the dog presented was neutralized by a familiar face;

\footnotetext{
${ }^{950}$ Rees (2013), 5.

${ }^{951}$ Pollux, Onomasticon, entry Alexander of Pherae.
} 
Alexander's wife Thebe led the dog away, letting her three brothers into Alexander's bedroom so that they could kill him. ${ }^{952}$

In a military camp or besieged city, this canine behavior would prove less problematic. While dogs can be trained to bark only in certain conditions, their general tendency to sound the alert at the sight of unfamiliar faces in addition to their heightened senses makes them excellent guards (Plato, Rep. 376a). Additionally, dogs' capacity for facial recognition and finding their way home, so heavily praised by Pliny, was put to practical use by Epirotes and Thessalians according to Aeneas Tacticus. While discussing the many capabilities of the dog, Pliny says: "Dogs alone know their master...they alone recognize their own names, and the voice of a member of the household; they remember the way to places however distant, and no creature save man has a longer memory." ${ }^{953}$ In his much earlier work, Aeneas Tacticus indicates that these skills are especially useful for carrying messages:

Many in Epirus used to employ dogs in the following manner. After leading the dog away in leash they placed around his neck a strap, inside of which was sewed a letter. Then at night or during the daytime, they dispatched the dog to the person to whom he was sure to go, that is, to the one from whom he had been taken away. And this is also a Thessalian custom." 954

The implication is that one must steal the dog of the intended recipient of the message. In the context of a siege, the subject of the entire Poliorcetica, the besiegers would not have access to the interior of the city. Therefore, the passage must mean that those besieged should make a night sortie to snatch a dog from the military camp of the besiegers and trust it to bring the message back. Sadly Aeneas says nothing more of this custom or why

\footnotetext{
${ }^{952}$ Plut.Pel. 35; also found in Xen.Hel.6.4.36, Diod.16.14.1, which do not mention the dog.

${ }_{953}$ Pliny $N H$ 8.147/8.61.

${ }^{954}$ Aen.Polior.31.32.
} 
it appears to have died out by the time he writes. ${ }^{955}$

Dogs appear in the literary sources primarily as sentries, not messengers, and here they appear no earlier than the mid-fourth century, quite a while after military scenes become infrequent in pottery. However, this does not mean that they were not used in a military context during the interim. By the mid-fourth century, when Aeneas Tacticus wrote his Poliorcetica, the use of canines in military scenarios appears common. Aeneas Tacticus outlines the specific ways in which canines should be used in accordance with their unique abilities. He advises that:

\footnotetext{
"The best plan, however, on such nights is to have dogs tied outside the wall to keep watch. For they will detect at a greater distance the presence of a hostile spy, a deserter who is stealthily approaching the city, or one who is somewhere making his way out to desert; they will also by their barking rouse the sentinel if he happens to be asleep." 956
}

The dog does triple duty in this extension of its more commonly mentioned domestic role. The dog sounds the alert in at the approach of an enemy, prevents those inside from deserting and leaving, and keeps its human compatriots awake through the night. The round the clock watch which dogs kept was also potentially a hinderance to those wishing to leave the city and attempt a nighttime sally against the enemy encamped outside the walls. Aeneas Tacticus remarks that they should take all care to "suppress the howling of dogs and the crowing of cocks, making them mute for this occasion" (23.2), although his suggestion of cautery to make animals mute is baffling and would presumably have had the opposite effect.

Because the role sounds play in the successful sneak attack on an enemy camp or

\footnotetext{
${ }^{955}$ Karunanithy (2008), 164 re-imagines the early third century war between Pyrrhus of Epirus and Demetrius Poliorcetes had the practice of using canine messengers still been in effect.

956 Aen.Polior.22.14.
} 
wall is crucial, Aeneas Tacticus seems to have always in mind the presence of dogs and their sensitive hearing. Just as one should not startle them while exiting the city by night, those who wish to seize a city successfully must be careful not to call out to one another in the dark. He suggests instead that, should soldiers become separated by night, that they locate one another by whistling an agreed upon melody as the Thebans did when they retook the Cadmea from Sparta. In this too, men should exercise caution and "watch the dogs lest on account of the whistling there be some trouble from them" (24.18). On the other hand, at the times when one's city is being actively assaulted by siege engines, dogs within the walls should be tied up, "for when men are hurrying through the town, with noise of arms and confusion" dogs are likely to "make trouble" (28.2-3).

Aeneas Tacticus also advises that in circumstances in which treachery is feared, especially by the infiltration of spies, dogs can be used in an extension of their guarding duties as patrol animals. By walking dogs about the periphery of the walls, soldiers could rely on the animal's abilities to detect any approaches by night. Presumably Tacticus advises this because the dogs could follow the trail of one who has already entered the city, alerting the guards as to the location. That the Greeks regularly trained hunting dogs to track is well known, and adapting this ability for the purpose of a patrol is not overly difficult. The United States Army uses dogs in essentially the same way to locate underground explosives. ${ }^{957}$

Tacticus also cites the use of patrol dogs during the siege of Naxos, during which the garrison commander Nicocles closed off the ramps between the citadel and the parapets, suspecting an infiltration would occur from without. By stranding the sentries

${ }^{957}$ United States Military Working Dog Training Handbook (1997), section 7. 
on the walls, Nicocles also made it impossible for any invaders sneaking up the sides of the wall to enter further into the fortress. He kept a dog patrol on the ground outside the city to detect the scent of anyone who was or had been in the vicinity (22.19). Philip II of Macedon employed a similar tactic while making war in the Balkans. Polyaenus records that the king used bloodhounds to track his enemies, whose guerrilla tactics and tendency to hide in the thickets made them difficult to track by sight (Strat.4.2.16).

In a less tightly controlled setting, patrol dogs were used by Agesipolis in a similar fashion. During the 385 siege of Mantineia, patrol dogs were employed to prevent treachery. Polyaenus tells us that Sparta's allies were sympathetic to the besieged Mantineia and had begun sneaking supplies to the walled off city by sneaking out of camp at night. The Spartan king Agesipolis prevented this by allowing dogs to roam freely throughout the military camp, but putting them especially on the side of the camp that was closest to Mantineia, so that the allies' nighttime forays stopped, as they feared being discovered by the barking of dogs (Polyaen.2.25). Interestingly, Polyaenus offers no explanation as to where Agesipolis got the dogs, why dogs would be easily available in a military camp, or how Agesipolis was certain that once set free, they wouldn't simply leave the camp altogether. It is taken for granted that dogs are not an uncommon sight in military camps, and these were at least well enough trained that they were able to manage a patrol without being led or directed by humans. Indeed, free roaming dogs would have been more useful than leashed ones, as they could cover more territory in a less orderly (and thus anticipated) fashion.

Plutarch's Life of Aratus also refers to guard dogs serving as night watchmen, and the dogs prove significant players in the military action, even if they themselves were not 
fighting. A close analysis of the relevant pages will serve us in better understanding the role played by guard dogs in war, details which emerge in this account because of the role dogs played in nearly thwarting Aratus' endeavors. While laying out plans to seize a fortress close enough to use to launch raids and attacks against Antigonus Gonatas, Aratus received word that the Tower of Polygnotus in Sicyon had a worn down wall that ran level with the ground inside, ideal for scaling ladders (Plut.Arat.5.3-5). Plutarch tells us that Aratus' informant supply the warning that "it was hard to get to it undetected

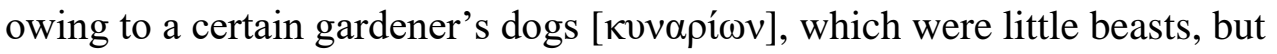
extraordinarily fierce and savage" (5.5). Whether Plutarch means to indicate by the diminutive that these were Melitaean dogs or not is unclear, but their presence as guards actively shaped the response of Aratus' men during the attack. Firstly, Plutarch outlines Aratus' detailed plans for the siege: the specialized construction of appropriately sized scaling ladders that could also be taken apart for easy storage, arming his men and house slaves, hiring mercenaries, and sending four light-armed men ahead to take care of the dogs first. Caphisias and four companions were selected to approach the tower in advance and tell the gardener that they were travelers in order to gain access to his house. Thereafter they were to shut him and his dogs up in it to make their night attack in silence (6.1-3).

This was not, however, what happened. When Aratus approached, Caphisias informed him and his men that he had trapped the gardener in his home but failed to trap the dogs, who had bounded off and escaped. While small dogs obviously did not present a military threat on their own, the threat they served as guards was significant enough to demoralize Aratus' men. Plutarch notes that “most of his men were disheartened at this 
and urged Aratus to retire; but he tried to encourage them, promising to lead them back if the dogs should prove too troublesome for them" (7.3). This is a considerable amount of concern over dogs which Plutarch notes were small in size and kept by a gardener rather than posted on the walls, and it reveals the significant role that canines did play in ancillary military matters. Although they were not trained attack dogs, as guards, they posed a significant enough threat to give Aratus' men second thoughts about sneaking into the tower by night.

We are given more nuance as the attack actually begins. The smaller dogs of the gardener, although not described as sentries, served as a first alert system for the citadel. Aratus' men are able to get from the garden to the wall despite the barking of the dogs because they time their attack at the changing of the guard, which is announced by the clanging of the bell, which could easily have explained the dogs' barking to sentries on duty (7.5). Aratus and his men lean their ladders against the wall and crouch low on them, beneath the parapet, and temporarily escape notice by the larger guard dogs stationed on the walls. Plutarch finds this odd and suggests that perhaps the dog nearest them was particularly sluggish or overtired that day (8.1).

However, because the presence of the invaders had kept the small dogs in the vicinity of the ladders, their yipping attracted the attention of the large guard dog on the wall, whom Plutarch says began to bark at them so that "the whole place resounded with barking" (8.2).

Interestingly, Plutarch characterizes this guard dog as $\theta \eta \rho \alpha \tau \iota \kappa$ s, a hunter, and notes that its barking prompted a sentry to ask of the huntsman, the dog's handler ( $\tau$ o v

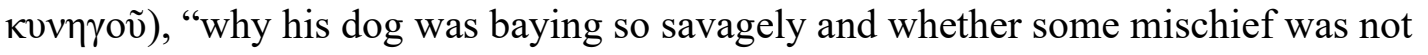


afoot" (8.2). Although Xenophon makes no mention of well-trained hunting dogs being used as guards, this must have been a practice by the third century. Much later, Oppian's $2^{\text {nd }}$ century C.E. Cynegeticus declares "array then for the hunt such breeds of warlike dogs" (1.425-426), suggestive of the potential of dogs to cross easily between the contexts of hunting and war, which are closely linked even in Xenophon's Cynegeticus. Indeed among the suggested two-syllable names for dogs in Xenophon's work are the parts of weapons which, unlike the throwing spear, were employed exclusively in military contexts: $\pi$ ó $\rho \pi \alpha \xi$ (shield handle), $\sigma \tau \dot{\rho} \rho \alpha \xi$ (spike on butt-end of a spear shaft), $\xi 1 \varphi \tilde{\omega} v$ ("of the swords") (Xen.Cyn.7.5).

Certainly the ability of dogs to indicate the location of prey $(4.4,6.16)$ could be put to use in the military context of a night watch. Plutarch emphasizes next that the huntsman was in league with Aratus and announced that his dog had been startled by the bell and was responding only to that, protecting Aratus and his men from discovery. This also explains how Aratus and forty men were able to scale the walls and sneak into the citadel without further upsetting the hunting dog. Evidently the dogs made quite an impression on Aratus, who would later on seize and guard the Acrocorinth with "four hundred men-at-arms, and fifty dogs with as many keepers”(Plut.Arat.24.1).

\section{Conclusions to Chapters $7 \& 8$}

Now we have seen that the epigraphic, archaeological, and literary evidence, in isolation, does not allow for the formation of a clear idea of the canine's role or presence in the ancient Greek military realm. However, by drawing together three genres of 
evidence not previously considered jointly, we gain a much broader perspective. Archeological and epigraphic evidence from the sixth through the early fifth centuries combined with literary evidenced composed in reference to the second half of the fourth century through the third reveals the Greek use of dogs in a military context. Compiling the evidence allows us to see a broad trend across four centuries, but the nature of that evidence does not allow us to bridge the gap between c.475-350, where one would perhaps expect at least a passing reference to dogs in military context. As Owen Rees has noted, it is suspicious that Hellenistic and Roman writers make note of canines used in Classical Greece's military where our contemporary authors do not. It strikes one as odd that the Marathon Dog should be mentioned only by Aelian and not by Herodotus, who gives us the principle historical account of that battle, nor by Pausanias, who describes the Marathonomachoi painting in the Stoa Poicile and makes no mention of a dog. It is quite possible that dogs, like slaves, are infrequently if ever referred to in literary accounts of a military campaign, especially because dogs were not primarily combatants. The assumption that bringing one's dog along on campaign was the prerogative of owners and breeders and merited no mention might also explain the relative absence of a canine presence in the works of Herodotus, Thucydides, and Xenophon. Dogs might be portrayed in vase art the way all the accoutrements of battle were, but they were so customary that there was no real need for an historian to explain them to his audience. Another possibility is a change in custom over centuries. The presence of dogs in a military context during the Archaic and early Classical periods might be reflective of the high social status of the hoplite and cavalryman, both of whom are portrayed bringing large dogs along with them in black- and red-figure pottery. 
The relative disappearance of dogs from the historical record by the time of Herodotus, Thucydides, and Xenophon might reflect a shift in custom, but more likely, it reflects a shift in taste. Later red-figure vases tended to feature domestic and mythical scenes, preferring them over traditional military scenes. The absence of combat canines in the literary evidence might, however, signal a genuine waning in the tradition of bringing dogs along. The reappearance of dogs in later literary sources in military camps and citadels suggests that, if the trend did decline between roughly 475-350, it reappeared as the art of siege craft became more standardized, giving the canine a very specific military role. Aeneas Tacticus' Poliorcetica outlines the part dogs were meant to play, and first century BCE and CE authors like Polyaenus and Plutarch, who report on the presence of dogs in military camps and citadels, might be more interested in discussing these details than their predecessors were, given the more visible role canines played in combat in their own eras.

The dearth of literary evidence in a period which is otherwise comparatively well documented makes anything more than supposition impossible, but this does not render the entire question moot. Indeed, if historical investigations were limited to the time periods for which one has abundant evidence, there would be very little writing about antiquity at all. The purpose of this chapter was not to provide an all-encompassing description of military dogs in ancient Greece, but rather to illuminate the many and varied ways in which canines did participate in a military context and unite a variety of sources with the goal of gaining as complete a picture of the past as possible. This was managed by several different approaches.

At first, we analyzed the Greek cultural understanding of the dog at large, the 
results of which shined a light on the unique position of canines in the ancient Greek world. A clear bifurcation of perception between the beloved loyal pet and potentially threatening unfamiliar dog reveals that the Greeks had a more complex understanding of the domesticated dog than they did of most other animals. Indeed, the close quarters in which dogs and humans ate, slept, and lived indicates a cross-species friendship on par with the modern phrase "man's best friend."

Certainly the dog's virtues of loyalty and intelligence are often praised by the Greeks. This acceptance of canine intellect made dogs ideal partners in the hunt, herding, protecting the home, companionship, and war as well. The ancient Greeks' appreciation of canine intellect is not a cultural construct, but an evolutionary reality. By investigating the evolution of social cognition in canines, we have provided a scientific basis for understanding the employment of dogs in such varied tasks. Hopefully we have thus assuaged the fear that dogs were "as useful as they were unreliable" 958 by revealing how, when trained, canines can be at least as reliable as humans in even high-stress situations.

Finally, by expanding the definition of "war dogs" from simply "attack dogs," we significantly broadened our scope of inquest. The use of archaeological record beyond the Clazomenian Sarcophagi gave us greater insight into the sort of images produced and consumed by everyday Greeks, images which we may reasonably interpret as objectively understandable rather than coded with hidden meaning. These images lend strength to the scarcity of contemporary references to dogs in military contexts, allowing us to read between the cultural lines and visualize armies and military camps more completely,

${ }^{958}$ Rees (2013), 5. 
bringing into the picture players that appear only infrequently in the literature. 


\section{Part IV: Horses}




\section{Introduction}

As stated in the introduction of this dissertation, my research focus consists of three in-depth case studies of under-studied or mis-represented war animals in the ancient Greek world. However, scholars have been inquiring about everything from the origin point of the warhorse (whether a chariot puller or battle mount) to the fully developed cavalry tactics of the late Classical Period. As a result, the warhorse has been investigated more than any other military animal in antiquity and does not require a complete study here. It is instructive to consider investigations of ancient cavalry here as a model and goal of where the studies of other military animals need to go. This final chapter balances out the above case studies by surveying cavalry in antiquity; in addition, it puts the examination of elephants, camels, canines, and other military animals into a more appropriate context.

When one thinks of animals participating in warfare in antiquity, inevitably the warhorse springs to mind. This is unsurprising - the sword and sandal films of the twentieth and twenty-first century have contributed to crafting a particular image of the animal that emphasizes the strength, ferocity, and grandiosity of the ancient warhorse. For example, one finds exciting cavalry charges in Scott's Gladiator, HBO's Rome, and Stone's Alexander. Although these films overemphasize the shock value of the horse, they cater to the popularity of the image of the warhorse, just as the ancients themselves did. The horse is the was the first and most often-depicted animal in Greek pottery. ${ }^{959}$ In Geometric pottery it was often shown in association with the archaizing war chariot. The stick-figure-esque design was reproduced in the plastic arts for the purpose of votive

${ }^{959}$ Kitchell (2020). 
offerings, as we see in the votive bronze statues from $8^{\text {th }}$ century Olympia photographed in Llewellyn-Jones and Lewis' excellent sourcebook on animals in antiquity. As Llewellyn-Jones and Lewis note, the horse was "the dedicatory animal par excellence" because of the status it conferred on its owner, implying that (s)he possessed considerable wealth, land, and leisure time. ${ }^{960}$ While the horse in [Image 9.1] appears highly stylized and far from lifelike, it is easily recognizable. The horse was a familiar animal to the Greeks, appearing frequently in art and literature, and quite often in the context of war.

The sources for horses are more abundant than for other military animals. However, the majority of literary evidence regarding the organization, funding, and use of ancient cavalry comes largely from the Classical Period. We are indebted to Xenophon for much of what is known about ancient horse keeping, training, and cavalry in the ancient world. As an experienced cavalryman himself, Xenophon produced a "how-to" manual for the aspiring cavalry commander, his Hipparchicus, as well as a more general guide to horse-rearing, Peri Hippikes. In addition to his detailed historical narratives, Anabasis and Hellenica, which often pay special attention to cavalry engagements, Xenophon is the most comprehensive source on ancient cavalry. As Spence has noted, Xenophon's guide books oscillate between providing information about how ancient Greeks did manage horses and how he believed they ought to do so, making it difficult to determine when is recommending a change or simply articulating common practice. Spence recommends (and follows through with) comparison of Xenophon's records with contemporary vase paintings to confirm details in question. ${ }^{961}$ Of the other literary evidence, Spence notes that it "consists primarily of separate references in a variety of

\footnotetext{
${ }^{960}$ Llewellyn-Jones and Lewis (2018), 135-6.

961 Spence (1993), xxi-xxxiv summarizes the extant evidence nicely.
} 
works of different genres, ${ }^{, 962}$ and the archaeological evidence spans everything from funeral stelae to sympotic vessels. Thorough studies of cavalry from a military (Greenhalgh, Worley, Gaebel), social (Spence), and political (Bugh) perspective have already combed through the evidence, and broader studies of equids as working and companion animals in antiquity may also be found (Clutton-Brock, Griffith).

A suitable introduction to ancient Greek warhorses should begin with consideration of the best-known examples. Some of the most famous Greek warhorses were Xanthus and Balius, or "Golden" and "Dappled," the immortal Greek-speaking horses of Achilles who prophesy his death in Troy (Il.16.148-150; 19.400-419). Less well known despite Homer's efforts is Pedasus, the mortal warhorse with whom Achilles sacked Eetion, whom Homer calls equal to his immortal compatriots (Il.16.152-4). Perhaps even more famous is Bucephalas, the Thessalian horse tamed and ridden into battle by Alexander the Great. ${ }^{963}$ Upon Bucephalas ' death, Alexander gave him a grander funeral than most humans received and subsequently named a city for him: Bucephalia. ${ }^{964}$ We may tentatively add to the list Podargus, the horse of Hippaemon discussed in chapter 4 (pp.335-336), whose death in battle is implied in the Magnesian's brief epigram.

But behind the few famous examples are tens of thousands of unnamed horses whose function in battle have been the focus of scholarly debate for over a century. As

\footnotetext{
962 Ibid., xxv.

${ }^{963}$ The fullest anecdote appears in Plut. Alex 6; cf. 32.7, 44.2-3, 61; Diod. 17.76.5-8; Curt. 6.5.17-21; Arr. 5.14.4, 5.19.4-6.

${ }^{964}$ Arr. 5.19.4, 5.29.5. Alexander was imitated but never quite matched by several Roman emperors, whose favorite horses received tombs, but not cities. This is as much a reminder of social status as a testament to affection, although the latter should not be excluded. Augustus dedicated a tomb to his favorite horse (Pliny $\mathrm{NH}$ 8.155); the emperor Lucius Verus built a tomb for his preferred racehorse (SHA Verus 6.3-4), and the Hellenophile emperor Hadrian commemorated his horse Borysthenes on his own tomb. See Llewelyn-Jones and Lewis (2018), 140-141.
} 
we shall see, horses pulled chariots in a variety of contexts during the Late Bronze Age, appearing at Mycenae and on Minoan Crete both in graves and art, often associated with the chariot. Exactly when "proper" cavalry emerged south of Thessaly is unclear, although depictions of mounted warriors appear in the early Archaic Period. Whether they served as true cavalry, fighting from horseback, or simply used the horse as a means of transport on the battlefield, is debated. There is abundant evidence of horses being used as a firing platform for archers and lightly-armed javelin men, but whether knights actively fought with spears and swords from horseback in the Archaic Period, using shock tactics, is unclear. There is, however, general agreement of true cavalry's existence by the opening of the Peloponnesian War (431-404). From there, broadly speaking, most scholars concur that the Greeks began to experiment with cavalry tactics, expanding the warhorse's repertoire from mopping up operations to shock tactics. The functional utility of the horse in this manner is still somewhat debated, as we shall see. By the time of Philip II and Alexander the Great, cavalry reached the "pinnacle" 965 of its development in the ancient Greek world, transformed from an auxiliary force to the primary punching arm of the Macedonian army. The careful coordination of infantry and cavalry (and eventually, elephants too) culminated in what Wrightson has called the "perfection of combined arms" $" 966$ a defining characteristic of the armies of Alexander and the Diadochs. In chapters 9 and 10, I will illustrate how the chariot-pulling horses of the Bronze Age transformed to the sophisticated cavalry of Philip and Alexander's day, and discuss the tactical value of the animals. Just as in Parts I-III, chapter 9 will (A) provide a general description of the (1) origin of domesticated horses, (2) horse breeds in antiquity, and (3)

\footnotetext{
965 Hyland (2013b), 513.

966 Wrightson (2015), 59.
} 
Greek knowledge of the horse; (B) discuss the evolution of ancient Greek cavalry from the (1) Late Bronze Age and Dark Ages through (2) the Archaic Period. Although the Classical Period onwards yields more specific information and imagery, the early period of cavalry development should not be neglected by default.

In chapter 10, I will (A) discuss the use of Greek cavalry in its more evolved form in (1) the Classical Period, (2) consider the changes it underwent following the reforms of Philip and Alexander, and finally consider its use through (3) the Hellenistic Period. Thereafter (B) I will engage in a thematic discussion of cavalry tactics within the context of the Classical through Hellenistic Period will be considered. Because the majority of information on Greek tactics pertains to the Classical Period and a distinct shift is visible by the reign of Philip II, Macedonian cavalry tactics will be discussed in part II. 


\section{Chapter 9: The Early Warhorse}

\section{Part A: The Origin of Domesticated Horses}

Before we consider how horses were used in combat, it is necessary to understand their origins as domesticated animals. The earliest domestication of the horse and donkey occurred c. 4,000, well after the domestication of food animals like ovines, bovines, and pigs, which occurred c. 7,000 ${ }^{967}$ Clutton-Brock and Donaghy both provide a survey of early humans' first uses of wild horses, which goes back at least as far as the most recent ice age, c. 10,000, at which time wild horses provided meat and pelts for Western Europeans. ${ }^{968}$ While one might have served as a semi-domesticated pet, much as initially camp-following wolves may have been tame, this was not same as the domesticated horse or Equus caballus. The first archaeological remains indicating a domesticated horse date to c. 4,000 and are found at the Neolithic site of Dereivka, north of the Black Sea in the modern Ukraine. This is in keeping with the quasi-mythological tradition of the Greeks, who saw the Scythians as a race of horse-masters. Bones of 52 horses were dug up from Dereivka, and at one level, a horse was found buried beside two canines. ${ }^{969}$ It is this site that led Sidnell to conclude that horse domestication has its origins in the Eurasian steppes, although they were likely used to pull vehicles rather than for riding. ${ }^{970}$

\footnotetext{
967 Donaghy (2014), 16.

968 Clutton-Brock (1992), 53-5; Donaghy (2014), 11-17.

${ }^{969}$ Clutton-Brock (1992), 53-55. Cf. Donaghy (2014), 16-17, who presents the conflicting arguments of Levine and Bokonyi, who disagree over the domesticated status of the horse bones. The horse bones of the Botai people, who occupied the steppes of Kazakhstan c. 3,500-3,000, are similarly difficult to interpret. However, archaeological research indicates horses were not killed there, but kept, as high phosphate levels in deeper strata of the soil alongside post-holes are indicative of manure and suggestive of a stable yard. 970 Sidnell (2006), 3-5.
} 
However, Clutton-Brock initially suggested differently. Although she notes that biologists were wary of concluding that horses were initially kept for riding, given their ability to provide meat, milk, and draught animal services, Dereivka offered something new. The horse skulls that were unearthed that showed unusual wear on their premolars, where a bridle and bit would have done damage. Additionally, antler tines unearthed near the horses are assumed to have been pieces of the bridle that survived. ${ }^{971}$ However, subsequent carbon-dating proved that the graves dated at the earliest to the eighth century, making them no longer significant evidence for the early development of horse riding. Although he disagrees with the criteria used to determine bit-use by the Dereivka horses, Donaghy does not find it implausible that horse riding has an early history, as the practice of herding horses for any extended period of time would require riders, too. Nonetheless, capturing or keeping horses for meat would not. ${ }^{972}$ It seems most likely that the domestication and riding of horses occurred not in a single location, but sporadically and spontaneously in several places as (probably deadly) attempts to mount and break draught horses were made. ${ }^{973}$ Because a variety of evidence regarding varying sizes of horses exists, whether they constituted wild or domesticated versions of the animal is still debated.

The earliest known horses in Greece date only to c. 2,000, although in Western Anatolia and the Troad, zoological remains date back to 3,000. Piggott points to several Middle to Late Helladic horse burial sites across Greece, including Lerna, Nichoria,

\footnotetext{
${ }^{971}$ Clutton-Brock (1992), $54 \mathrm{f}$. along with fig. 4.4 of the antler tine bridle pieces.

972 Donaghy (2014), 18-25 provides a good summary of the historiography of the question of horse riding on the pre-historic steppes.

973 On the domestication of equids as draught animals see Clutton-Brock (1992), 67-79.
} 
Marathon, Data, Dendra, and Paros. ${ }^{974}$ Horse-raising, which the Greeks knew as hippotropheia (also the name of the associated Athenian liturgy), was endemic to Thrace, Macedonia, and Thessaly, but more difficult and costly in southern Greece where access to open plains was rarer. As a result, horse breeders tended to hail from northern regions; indeed the most famous horse of all, Alexander the Great's Bucephalas, was a Thessalian horse, marked out, according to Pliny ( $N H$ 8.64) by the brand of an ox to indicate his origin. ${ }^{975}$

\section{Horse Breeds}

In general, we are limited with regard to what can be known about ancient Greek horse breeds. As in the case of dogs, the ancient Greeks named horse breeds by the region from which they hailed, hence we know of Arcadian, Messenian, and Boeotian horses, all of which Donaghy has grouped under the general umbrella of "Greek horses." His work offers detailed assessment of grazing grounds and regional reputation for horse-raising, and the identification of specific breeds need not concern us here. ${ }^{976}$ The variety of "breeds" available to northern peoples like the Thessalians and Macedonians, would have been greater due to their proximity to horse-rearing peoples like the Thracians,

Paeonians, and Scythians, as well as their history of Persian occupation. Breeding was certainly complicated by interactions with other horse-raising peoples, and the Greeks would have had occasion to intermingle their stock with Thracian, Scythian, and certainly Persian breeds. By the Classical Period Hyland notes that the famous Thessalian mounts were begotten by Thracian horses, who in turn shared genetic material with Scythian and

\footnotetext{
974 Piggott (1992), 59-60.

${ }^{975}$ Cf. Donaghy (2014), 104-6.

976 Donaghy (2014), 72-115.
} 
hardy Cimmerian mounts. After Plataea, the Greeks had access to Persian horses as war booty, whom they likely bred with their own. Evidently the Thracians were also eager to diversify their breeding program, as Herodotus points out $(1.131 .2 ; 7.40 .4)$ that they made off with Xerxes' eight pure white horses, Nisaian in breed. ${ }^{977}$

Hyland notes that by the Classical Period at least 57 horse brands were known, by which buyers determined breed. Kroll offers considerably more detail on brand types. ${ }^{978}$ No direct correlation between ancient and modern breeds exists among horses; as with dogs, what constituted a breed changed quickly over time through human intervention and natural selection, making the assessment of ancient art a vain search for specificity. A glance at literary and epigraphic sources indicates that the same coloring and patterns available today existed in antiquity, too. Homer describes horses in various shades of brown, white, and dappled patterns. The Athenian cavalry archive, a series of over 600 lead tablets dating from the mid $-4^{\text {th }}$ to the mid- $3^{\text {rd }}$ centuries, provides a list of horses insured by the Athenian state. This list includes the color, brand, and value of the animal. The numerous tablets found in Athens (both the agora and cerameicus tablets) contain just about every horse coloring or color combination, including red-brown

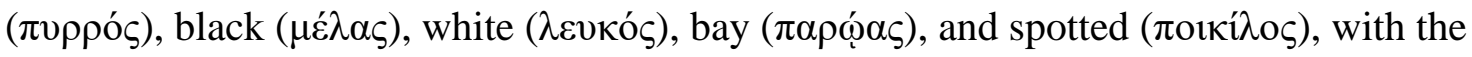

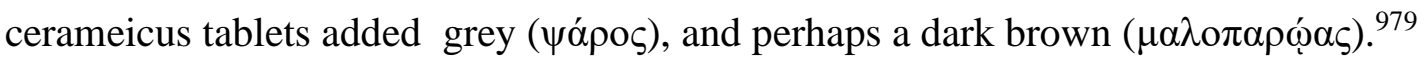
References to brands (and thus "breeds," after a fashion) appears in the cavalry lists as well, indicative not of the owner, but of the breeder. ${ }^{980}$

\footnotetext{
${ }^{977}$ Hyland (2013a), 492-5; Donaghy (2014), 100-115; On the famous Nisaian horses, see the bibliography provided in the commentary of Llewellyn-Jones and Lewis (2018), 134-5 and a depiction of the Nisaian horse on the Apadana relief of Persepolis' east staircase. See further on the breed: Donaghy (2014), 186190.

${ }^{978}$ Hyland (2013a), 493; Kroll (1977), 83-140.

979 Kroll (1977), 86.

${ }^{980}$ Gaebel (2002), 19-20.
} 
Greek horse height is another controversial topic. General knowledge holds that Greek horses were small compared to eastern breeds, and especially compared to modern horses. To a degree this is true, as the modern Clydesdale stands a staggering 16-18 hands high. However, other modern competitive horses, like the Arabian, fall close to the ancient Greek horse at 14.1-15.1 hh according to the United States Equestrian Federation (AR104 Breed Standards). Neolithic European horses such as those in Dereivka burial in Ukraine measured between 12-14 hh, with the Dereivka horse at 14.1hh. Sidnell equates this breed with modern New Forest, Fell, and Icelandic riding horses. ${ }^{981}$ Hyland reports on horse graves which show Greek breeds at 14.3 and $15 \mathrm{hh}$, and an Achaemenid Persian mount at $16 \mathrm{hh}$. Thus, eastern mounts may have been taller, but not by much. ${ }^{982}$ Although pottery cannot be used as a metronomically accurate bellwether of height ratios, a black figure Athenian krater from the late Archaic period may give us a general idea of how the average man measured up to a horse [Image 9.2].

Some historians have asserted that horses were bred for height or width based on their intended use, with leggy horses having been bred in antiquity for display and chariot pulling, while stouter, shorter animals were kept for combat. ${ }^{983}$ In general, the same variation of heights seen in modernity can be traced to Neolithic times, with the exception of large draft horses. As Gaebel notes, a height of even 12.5 hands is sufficient for cavalry maneuvers - indeed the Mongols that mastered the open steppes rode ponies

\footnotetext{
981 Sidnell (2006), 2.

982 Hyland (2013a), 494-5; cf. Donaghy (2014), 180-3 notes for example that the horses reared in grain-rich Bactria and Sogdiana would not have differed much in height from the horses used by the Greeks and Macedonians, estimating about $14 \mathrm{hh}$, , but in quality their diets may have made them superior cavalry mounts. The one exception in height may have been the Nisaian horse, whose healthy size Donaghy attributes to "Medic clover," or alfalfa, which has a far higher protein content than any other form of horse fodder (184-90).

983 Gaebel (2002), 22 and bibliography. On horse-drawn chariots in Greece see Piggott (1992), 58-63, CLutton-Brock (1992), 112-113; on horse racing, a good introduction is Bell and Willekes (2014).
} 
of approximately this height. Greek horses at 14-15 hh. could and did serve in combat. Furthermore, the average human height was less in antiquity than today as well, making the human-horse height ratio roughly equivalent to today's. ${ }^{984}$

\section{Horse Biology \& Greek Knowledge of the Horse}

The biology of the Greek warhorse is not largely different from its modern descendant. The wild ancestor of the domesticated horse becomes scarce in the archaeological record around c. 7,000, ${ }^{985}$ and the animals used by the ancient Greeks were the familiar, domesticated Equi Caballi. The Greeks make no mention of the wild horse other than the hippagros, whose identity historians have guessed at but not resolved. The description of a tusked, maned, and cloven-hoofed animal from Ethiopia might be a gnu, roan antelope, or Cape eland, but it was certainly not a wild horse. ${ }^{986}$ Aristotle wrote extensively of the horse's biology and psychology, and Xenophon's Hipparchicus and Peri Hippikes contain helpful details regarding horse-rearing, feeding, and management in general. ${ }^{987}$ For our purposes here, a horse's age and working lifespan are significant, as they determine its military function. Bugh has compared the age requirements and lifespan of the U.S. Cavalry with the writings of Xenophon and Aristotle and found that they are quite similar. Both estimate an average horse's lifespan at 20 years, with a working lifespan of 10-15, given a starting point of sexual maturity. ${ }^{988}$ Both Aristotle (HA 5796b4-8) and the pre-WWII U.S. Army agree that maturity is

\footnotetext{
${ }^{984}$ Gaebel (2002), 20-22; Hyland (2003a), 494-5.

985 Clutton-Brock (1992), 54.

${ }^{986}$ Kitchell (2014), 86-7; Opp. Cyn. 3.251-261.

987 See Kitchell (2014), 90 for bibliography on Aristotle's writings.

988 Bugh (1988), 69.
} 
reached at the age of five for mares and six for stallions, as this is when they lose their milk teeth. Xenophon suggests that training, especially for the military, may begin when a horse is younger ( $P H$ 1.2-2.5, 3.2, 9.1), but offers his reader a word of caution about buying a horse that has already reached maturity:

"First, then, he [the buyer] must not fail to ascertain the age. A horse that has shed all his milk teeth does not afford much ground for pleasing expectations, and is not so easily got rid of." 989

\section{Part B- The Evolution of Greek Cavalry: From Chariots to Horseback}

There are numerous works that seek to trace the emergence of Greek cavalry, but a detailed dissection of each argument is not appropriate here. Some of the largest and most influential studies of Greek cavalry are those of Greenhalgh (1978), Bugh (1988), Spence (1993), Worley (1994), and Gaebel (2002), whose bibliographies may be mined for additional resources. Because this section of the chapter is not an historiographical essay, it will illustrate the evolution of cavalry in broad brushstrokes and provide references to more detailed and particular arguments when necessary. Generally speaking, the evolution of Greek cavalry must be studied through Athens, as good evidence is lacking for the other Greek poleis, and even Athens' pre-Classical cavalry is something of a mystery. The five above authors generally agree that by 477 the Athenians had what we would recognize as a cavalry, or a unit of mounted warriors who fight from horseback and coordinate their efforts. How that military unit came to be is hotly contended.

989 Xen. PH 3.1. 


\section{Warhorses in the Late Bronze Age (1400-1100) and Dark Ages (1100-800)}

Before cavalry, horses were used like other beasts of burden to draw sledges, wagons, and eventually chariots in the Indus Valley, Middle East, and Neolithic Europe. ${ }^{990}$ Considered "prestige vehicles" by the first half of the third millennium, their exact appearance is known from life, as some were entombed with their royal owners. ${ }^{991} \mathrm{~A}$ four-wheeled chariot appears on the "Standard of Ur," but Clutton-Brock argues that such a vehicle is unlikely to have been used for anything but ceremonial purposes, as swift or sharp turns for a vehicle without swiveling axles would cause it to turn over. This explains why the two-wheeled chariot "became the normal means of transport in peace and war."992 The two-wheeled chariot appears more commonly in Egyptian and Assyrian art, including the depiction of Tutankhamun's chariot, which dates to the $14^{\text {th }}$ century, as well as that of Assyrian king Ashurbanipal in the $7^{\text {th }}$ century. Interestingly, in both depictions the height of the horse is emphasized through extra décor on the animals' heads. Tutankhamun's horses wear Vegas-style ostrich feather headgear, and Ashurbanipal's horses are decorated with spiraling horns and long pom-poms. ${ }^{993}$ If any of this finery appeared in battle, its effect would be similar to the horsehair crests worn by hoplites - it makes the enemy appear taller, grander, and generally more intimidating, although such adornment would ultimately hamper functionality.

In the Greek world, the first warhorses were chariot horses, used as vehicles of transportation on the battlefield, just as they appear throughout the Iliad. ${ }^{994}$ Depictions of

\footnotetext{
${ }^{990}$ Piggott (1992) provides a detailed inspection of the evolution of animal-powered vehicles from sledges to oxcarts in the Middle East and Europe, pp. 13-36.

991 Piggott (1992), 37-38; cf. 42-45 on the technology of chariots.

992 Clutton-Brock (1992), 69; cf. 72-73 on the two-wheeled chariot from beginnings of the sixteenth century onward.

993 Clutton-Brock (1992), figs. 6.1 and 6.2; on equid domestication in Egypt and Assyria see pp. 80-95.

${ }^{994}$ In general on Mycenaean and Greek chariots see Piggott (1992), 58-63; Gaebel (2002), 32-43.
} 
chariots appear as early as the $17^{\text {th }}$ century in Mycenaean shaft graves, although whether any of them depict a battle is unclear. Piggott points to a chariot-riding swordsman on a stone stele, and another grave held a signet ring that depicted a hunting archer on a chariot. Seals, pots, and frescoes also depict chariot-riders, but Piggott emphasizes that none show anything that could qualify as battlefield images. Further, the Mycenaean depictions do not artistically resemble those of the Near East, but take on "distinctive local forms," 995 which suggests the Mycenaean Greeks developed and used chariots on their own and did not blindly copy an artistic motif from the East. The majority of Mycenaean horse and chariot images depict rituals, racing, hunting, and transport perhaps to battle but not through the thick of the fighting. Although Piggott is reluctant to describe the chariot stele in terms of a battle scene, the rider in the chariot is in the process of drawing his sword, leaning forward in the vehicle which suggests rapid movement. ${ }^{996}$ In general, the presence of a horse or horse-drawn vehicle bespoke wealth and status, and the animals were worthy motifs of funerary art. In some cases the horses themselves were interred with their masters, as at Lerna, Arnos (Marathon), and Arkhanes on Crete, which may be suggestive of some overlap between status emblem and companion animal. ${ }^{997}$

Because the war chariot is a key part of epic story-telling, the "sina qua non of the Homeric nobleman," 998 one naturally looks to its historical uses in the Mycenaean period. Unfortunately, little is known about how they were used; the literary evidence comes from the Iliad and must be considered cautiously. Unlike their eastern counterparts,

\footnotetext{
995 Piggott (1992), 60.

996 Ibid., Plate 5.

${ }^{997}$ Cf. Kitchell (2014), 89-90.

998 Greenhalgh (1978), 7.
} 
Homer's Achaeans appear to have had almost no knowledge of massed chariotry, but rather used the vehicles like taxis, darting across the battlefield to dismount and fight where they would. The use of such vehicles by the Egyptians, Hittites, and Mycenaeans in the Bronze Age required coordinated massed attacks in order to overwhelm the enemy, not merely transport the warrior. ${ }^{999}$

However, archaeological evidence of large storehouses of chariots and chariot parts on Knossos suggests a tradition of massed chariot attacks and provides firmer evidence than the depictions of chariots in Mycenaean shaft graves. The Linear B tablets of Knossos reveal that at least 1,000 pairs of wheels were in storage and over 340 chariot carts, an impressive collection. At Pylos, at least 200 are reported. ${ }^{1000}$ Such high numbers indicate that chariots played a key role in battles and must have been used together. Greenhalgh further suggests that this Mycenaean practice is carried over into the Iliad in a handful of scenes, relics from the days of true chariot fighting. For example, Nestor rallies his men at Troy to unite their chariots in a coordinated attack. ${ }^{1001}$ He also encourages his men to fight from the chariot, rather than dismounting first, and claims that this is the way men sacked cities in the past. ${ }^{1002}$ Such a comment is suggestive of an historical transition from chariots as transport vehicles towards chariots as fighting platforms, a step in the direction of true cavalry.

Worley has since argued that Greenhalgh's assertions are too conservative, and the Late Bronze Age constituted a period of military experimentation around the

\footnotetext{
${ }^{999}$ Ibid, 7-11.

1000 Greenhalgh (1978), 19-39; Rawlings (2007), 21-23.

1001 Il.4.293-309; unfortunately Homer does not specify that there were 200.

1002 Il. 4.303-308; Greenhalgh (1978), 7; he also points to Il. 11.289, 15.352-354 as examples of coordinated chariot movements, although not a massed attack; see in general pp.7-18.
} 
Mediterranean in which the use of the horse as a fighting platform began, a transition Greenhalgh does not see until the late Archaic Period at the earliest. ${ }^{1003}$ Worley's interpretation of the Knossos arms issue list, in combination with Late Bronze Age pottery, departs sharply from Greenhalgh. ${ }^{1004}$ Worley asserts that armored, if not armed, riders already existed simultaneously with the chariot and only continued to develop from there. Images of riders with armor and weaponry appeared in Mycenae by c. 1300, and they carry short spears, swords, and knives as well. There is some precedent for a transition from using chariot taxis to using the chariot and even the horse itself as a fighting platform in Egypt, where a depiction of a riding warrior appears in the late $15^{\text {th }}$ century tomb of Sen Mut. Additionally, the victory monument from the early $13^{\text {th }}$ century battle at Kadesh depicts mounted archers or at least scouts. ${ }^{1005}$ Gaebel's more conservative approach to limited Bronze Age evidence anchors the birth of cavalry in ninth century Assyria based on the depiction of horsemen on monuments, and he distinguishes these horsemen from scouts or mounted infantry. ${ }^{1006}$ Since then, Donaghy has generally concurred with his timeline based on the findings of Hyland (2003, 90), who concludes that true cavalry emerged in Assyria in the early $9^{\text {th }}$ century under the reign of Tukulti Ninurta II (890-884), likely as a result of his campaigns in mountainous Armenia, where chariots would have been useless. Hyland speculates that the Urartean people may have developed this habit first. ${ }^{1007}$ By the $8^{\text {th }}$ century, the victory statues of Tiglath-Pileser III make Assyrian adoption of cavalry clear, as they depict armed riders in

\footnotetext{
1003 Worley (1994), 169 sees this period beginning c. 1400.

1004 Ibid., 9 f.

1005 On Sen Mut see Worley (1994), 11 and Gaebel (2002), 44; on Kadesh see Worley (1994), 12.

1006 Gaebel (2002), 44-51; cf. Worley (1994), 32-35 on Assyrian cavalry. Both scholars agree that overlap existed between the use of the chariot and the emergence of cavalry, without the latter needing to replace the former, a process which Gaebel (2002), 48 argues is not visible until the seventh century.

${ }^{1007}$ Donaghy (2014), 56-58; Hyland (2003), 90.
} 
commemoration of the king's wars against the Arabs. By the the $7^{\text {th }}$ century, the relief of King Ashurbanipal depicts cavalrymen carrying spears as well as mounted archers in battle against Arabian (camel) cavalry. Despite the fact that Assyrian art does not depict any clear evidence of coordination of horsemen, Gaebel recognizes them as cavalry. This is due in large part to the presence of mounted archers, who could not fight with much success as individuals. Their effectiveness lay in concentrated firepower. ${ }^{1008}$

With the collapse of the Mycenaean society at the end of the Bronze Age, the complex palace system of Greece disintegrated along with all evidence of chariot use. Thereafter, chariots would appear in life among the Greeks only in sporting and ceremonial events. In literature and art, however, the war chariot lived on. Greenhalgh has suggested that Dark Age bards brought the horse and chariot together as a deliberately archaizing interpretation of contemporary warfare, aware of the chariotry of the Mycenaeans only in the vaguest sense and ascribing to the chariot much of the role of the contemporary war horse, which was namely a vehicle of transportation to and on the battlefield. ${ }^{1009}$ Much of what the chariot appeared to do in Homeric literature, especially as regards its close association with kings and princes in the Iliad, reflected what the warhorse did in Dark Age and early Archaic warfare.

Greenhalgh points out that the long tradition of past dominance of the military sphere by the hippotrophic economic elite is noted in Aristotle, and concludes that the tradition of utilizing the horse-and-chariot combination in epic poetry to archaize a depiction of Geometric/Archaic warfare carried over into the medium of pottery as

\footnotetext{
${ }^{1008}$ Gaebel (2002), 47-49.

${ }^{1009}$ Greenhalgh (1978), 40-41; cf. Rawlings (2007), 27-28.
} 
well. ${ }^{1010}$ While numerous Late Geometric pots depict soldiers fighting after dismounting from their chariots, there is no historical evidence of the war chariot's use in Greece after the collapse of the Mycenaean palace system (except in Cyprus). Those chariots which are depicted on vases, Greenhalgh argues, are "heroic property."1011 Their forms are inspired by contemporary racing (not war) chariots, and in vase paintings they behave exactly as in the Iliad, used as transport devices in almost every instance.

\section{Warhorses in the Archaic Period (c. 800-479)}

It is the Archaic Period which is the most contentious among scholars of Greek cavalry due to the varying interpretations of Archaic pottery. Depictions of armored men on horseback with a variety of weapons, stances, and accompanying figures, have yielded a wide range of explanations. Those of Helbig and Greenhalgh held sway for the greater part of the $20^{\text {th }}$ century and were only rebutted in the last thirty or so years. As suggested in his analysis of the Dark Age, Greenhalgh follows Helbig's argument that Archaic depictions of armored men on horseback show only mounted hoplites, not true cavalry. Such fighters would use their horse to get to and from the battlefield and move about it, but they did all their fighting as hoplites. Neither he nor Helbig (1902) nor Larsen (1967) see the Athenian hippeis as a proper cavalry force, merely an economic class which could

afford to use horse transport in a military setting. ${ }^{1012}$ Because of the long shadow cast by this interpretation, it is worth summarizing.

Helbig's and Greenhalgh's evidence for this is primarily pictorial and problematically interpretive. Until end of $7^{\text {th }}$ century, Greenhalgh contends that there no

${ }^{1010}$ Greenhalgh (1978), 42; Arist. Ath.Pol. 1297b.16-19, 1289b.33.

1011 Ibid., 63.

1012 See Worley (1994), 21-23 for a critique of previous views. 
convincing evidence of cavalry in Corinthian pottery, but there is some evidence of mounted infantry, a carry-over of the heroic tradition in which horses serve the function chariots once had. Using a series of different vases and etchings as evidence, Greenhalgh argues that even the more convincing depictions of men fighting from horseback really represent hoplites moving hither and thither on the field, not true cavalry. He contends that there is only one preserved portrayal of an armed man fighting from horseback in this period, a Corinthian soldier on an aryballos [Image 9.3]. Other images he asserts depict men either standing near their horses or in the process of dismounting before fighting. In Sparta, an ivory fibula [Image 9.4] depicts an armored man on horseback, whom Greenhalgh interprets likewise as mounted infantry. In Athens, the case is much the same, with limited depictions of armed men on horseback. ${ }^{1013}$ It is not until the $6^{\text {th }}$ century that proper cavalry are depicted in black figure pottery in Athens, with armed men fighting from horseback without the hoplon, which Greenhalgh uses as a the signifier of an infantry soldier. He notes "by themselves the Attic Late Geometric horsemen with their various items of arms and armour indicated both a knowledge of riding and a military use for the mounted horse in the later eighth century, but little more," and "battles continue to be fought exclusively on foot."1014

Transforming Helbig's original interpretation, Greenhalgh sees "true" cavalry appear in Greece by the $6^{\text {th }}$ century, although he argues that their emergence occurred alongside the continued tradition of mounted hoplites, both of which are depicted in Attic pottery, with the latter being in the majority. Because military scenes in Corinthian

\footnotetext{
1013 Greenhalgh (1978), 84-90.

${ }^{1014}$ Ibid., 88-89; although less pottery and carvings are available from the regions of Euboea, the Greeks in the East, and Sparta, Greenhalgh maintains his overarching argument and provides an assessment of each region and plates of relevant archaeological finds (90-95.)
} 
pottery fell out of favor by the second half of the $6^{\text {th }}$ century, conclusions are restricted to the first half of the $6^{\text {th }}$ century. ${ }^{1015}$ Greenhalgh does point to an early $6^{\text {th }}$ century Corinthian cup [Image 9.5] which he argues supports the predominance of mounted infantrymen rather than cavalry. The cup depicts a battle between infantry in which squires and their masters' horses are portrayed as well, although clearly off to the side and "behind" the phalanx. Greenhalgh interprets this to mean the horses were held back for their masters until victory for one side or the other was clear, at which point the victorious horse-owners would mount and pursue their enemies. Those fortunate enough to possess horses on the losing side would use them to manage their escape.

Unfortunately for the hoplite on one cup, his squire appears to have fled in advance of him, leaving him to pursue his horse and flee the enemy on foot. ${ }^{1016}$

Attic pottery of the $6^{\text {th }}$ century yields evidence of both mounted infantry and proper cavalry. ${ }^{1017}$ By the second half of the $6^{\text {th }}$ century, Greenhalgh notes that "unmistakable representations of cavalry steadily increase throughout the rest of the century, and in particular the representations of cavalry in battle."1018 These consist of both armored knights without a shield and unarmored knights. Occasionally a cavalryman might possess a pelta, but not a hoplon. In the Greek East, Greenhalgh is less certain, claiming a dearth of evidence for true cavalry. Additionally, he suggests that the Dorylaeum stele [Image 9.6], which has been paired with the Hippaemon epigram (PA 7.304), might depict a mounted hoplite, rather than a true knight. ${ }^{1019}$

\footnotetext{
1015 Ibid., 96.

1016 Ibid., fig 50, p. 96; note also the presence of a fleeing dog alongside the men. Cf. fig. 51 and pp. 96-97.

1017 Ibid., extensive discussion pp. 111-136.

1018 Ibid., 118.

${ }^{1019}$ Ibid., 143-145; cf. Schede (1928), 2-3 and Pl. 2.
} 
This view has since been questioned or critiqued by scholars who view Helbig's initial interpretations as problematic or who voice concern that a contemporary obsession with hoplite warfare has blinded readers to the role and significance of ancient cavalry. In his 1988 study of Athenian cavalry, Bugh claims that there is no conclusive evidence of hippeis as anything more than a Solonian economic category before the middle of the $5^{\text {th }}$ century. He does, however, admit that he finds the existence of Archaic Greek cavalry credible, although the evidence will always be debated because the great majority is pictorial and differentiating between a mounted infantryman and a true hippeus is problematic. $^{1020}$

Spence (1993) addressed the issue in passing, as the primary focus of his work was a thorough study of the functions of the Athenian cavalry. His work has served to boost the significance of the Greek warhorse despite the veil of the "hoplite ethos," and he implies that both Helbig and Greenhalgh have attempted to explain away depictions of true Athenian cavalry that fail to fit their paradigms. ${ }^{1021}$ Spence sees Helbig's argument against the existence of true Athenian cavalry until 477 as erroneous, but believes it is a credible date for the Athenian reforms that created a larger cavalry corps of 300 hippeis, based on a series of stylistic arguments. ${ }^{1022}$ Ultimately concluding that the evidence is somewhat ambiguous, Spence maintains that Archaic Athens had $a$ cavalry from the period of Solon's reforms, when Pollux's Onomasticon claims that each Athenian naucrary (of which there were 48) was required to produce two horsemen as well as ships and crews, from which their administrative name comes. These naucraries were replaced

\footnotetext{
${ }^{1020}$ Bugh (1988), 3-4.

1021 Spence (1993), 10-13.

1022 Ibid., 13-15, cf. Helbig (1902), 229-236.
} 
by demes during the Cleisthenic reforms of 508, permitting us to date their existence to the Archaic Period and, at the latest, the sixth century. ${ }^{1023}$ Bugh, however, hesitates to place such weight on Pollux's account. ${ }^{1024}$

Spence also considers a fifth century inscription for evidence of a transition period between the 96-man Athenian cavalry of the Archaic Period and the 1,000-man cavalry of the Peloponnesian War (431-404). An inscription from c.450 (IG I² 400) refers to three hipparchoi serving simultaneously and provides a terminus ante quem for the reforms which re-arranged how and how many cavalrymen were required to serve the state. The reference to three hipparchoi indicates a corps of 300 men. ${ }^{1025}$ Spence allows that the small naucraric cavalry of 96 men may have been disbanded during the Cleisthenic reforms of 508, which explains in part their absence at Plataea, but he finds it more plausible that the naucraric contribution to navy and cavalry was maintained until Themistocles' reforms in $483 .^{1026}$

Cavalry was limited in much of the Greek world due to the nature of the terrain and the cost of horses, and initially horses were the purview of the aristocracy. However, by the period of oligarchic and democratic transition, the infantryman is generally touted by historians as more tactically significant and more commonly found. However, Worley (1994) has revived the reputation of the ancient Greek cavalry by showing that it did play a significant supporting role in battle. Worley notes that "the modern preoccupation with the hoplite has led to a disregard for or misunderstanding of the roles played by other

\footnotetext{
1023 Pollux 8.108; Arist. Ath.Pol. 21.5, cf. Bugh 4-6.

${ }^{1024}$ Cf. Bugh (1988), 4-6. Exactly how and whether the tradition of demanding hippeis from bureaucratic subdivisions occurred is unclear.

1025 Spence (1993), 14-15.

${ }^{1026}$ Spence (1993), 11-13, contra Ath.Pol. 21.5; cf. Hignett (1958), 21-22, 69-70.
} 
types of soldiers....Greek cavalry has been especially subject to this neglect." ${ }^{1027}$ He cites the assumptions of other scholars like Calkwell and Pritchett that cavalry was underdeveloped until Philip II's day, and thus generally ignored by scholars

In answer to that, Worley asserts that cavalry was well developed by the Archaic Period and in active use, even playing a significant role in the eighth century combat. ${ }^{1028}$ Indeed, he sees the hippeis as "preeminent on the battlefield" 1029 in the Archaic Period and defies Bugh's opening statement that there is no conclusive evidence of hippeis as anything more than a Solonian economic category before the middle of the fifth century. ${ }^{1030}$ Worley uses literary accounts and contemporary inscriptions to argue that cavalry participated in the First Messenian War (740-720) ${ }^{1031}$ and the Lelantine War (late $700 \mathrm{~s})^{1032}$, playing a regular and significant role in Archaic warfare. His argument generally supports Aristotle's assertion that the Archaic hippeis of Athens held political and social sway because of their contributions to war. The Lelantine War between Eretria and Chalcis on Euboea must have involved cavalry, as a contemporary pillar inscription, dedicated to Artemis Amarynthia, indicates that Eretrian army had 600 cavalry, and certainly the Thessalians did. ${ }^{1033}$ Worley even suggests that the pre-arranged weapons code that forbade the use of projectile weapons (Strabo 10.1.10) was engineered by the Eretrians and Chalcidians to protect their horses. ${ }^{1034}$ In Sparta's case, the shift toward a

\footnotetext{
1027 Worley (1994), 1.

${ }^{1028}$ Ibid., 3, cf. 21-58.

1029 Ibid., 170.

1030 Bugh (1988), 3.

1031 Worley (1994), 23-26; Paus. 4.7.3 ff. On the problematic nature of Pausanias as a source, see Worley's p. $182-3$ n.5.

1032 Worley (1994), 26-32, Arist. AthPol 1286b.33ff. confirms both poleis on Euboaea raised horses; on the pillar to Artemis Amarynthia p. 27.

${ }^{1033}$ Plut.Mor. 760e-f + Worley (1994), 185 n.33.

1034 Worley (1994), 27.
} 
hoplite-dominant army occurred sometime before the Second Messenian War, Worley theorizes, based on Tyrtaeus' poetry (and the conspicuous absence of horsemen) and the egalitarian nature of the Lycurgan reforms. ${ }^{1035}$

The difference in Greenhalgh's and Worley's arguments seems to rest in the definition of what constitutes cavalry more than in the available evidence. Worley takes into consideration not only warriors who were trained to fight only as mounted soldiers, but dragoons as well, who could fight on foot or on horseback. ${ }^{1036}$ By expanding the definition of cavalry to include any group of men who used horses in battle and were equipped to fight mounted (but not required to), he is better able to address some of the exceptions to Greenhalgh's pottery argument mentioned by Spence. ${ }^{1037}$ While evidence from $8^{\text {th }}$ century battles is persuasive, Worley's assertion that Archaic cavalry engaged in shock tactics seems to extrapolate beyond what the evidence allows, although CluttonBrock has indicated the possibility of this as well. ${ }^{1038}$ Too little detail survives to know this with any certainty, and furthermore the fact that cavalry shock tactics did not become truly effective on the battlefield until the fourth century Theban ascendency suggests that the practice had not been evolving steadily from the late eighth century.

In his 2002 study of Greek cavalry, Gaebel asserts that Worley's theory of Archaic cavalry shock tactics is "unproved and unlikely." 1039 In a partial revival of Greenhalgh's theory, Gaebel views Archaic depictions of armored horsemen as "mounted

\footnotetext{
1035 Ibid., 26f.

1036 Ibid., 4-5.

1037 Spence (1993), 10 n. 46.

1038 The vase Clutton-Brock (1992), 107-109 fig. 8.4 references does depict mounted warriors attacking hoplites, but it does not depict an attack of a phalanx. The hoplites are scattered and depicted as individuals, suggesting that the cavalry was brought in to conduct mopping up operations or exploit a gap in the line, rather than catalyzing the initial charge. The difficulty of proving something as specific as the use of shock tactics so early without literary evidence has not been resolved.

${ }^{1039}$ Gaebel (2002), 278, cf. Worley (1994), 58
} 
hoplites," not cavalry but concedes that Archaic pottery from Corinth and Athens does depict the gradual shift from mounted hoplites to true cavalry. ${ }^{1040}$ Nonetheless, in his view cavalry played no real or significant role in warfare from 650-430 and were absent from the field because they could not defeat hoplites or contribute to hoplite battles' agonal aspects. ${ }^{1041}$ Certainly, they do not appear in significant numbers during the Persian Wars, but the location and terrain of the land battles could explain why.

Gaebel dismisses cavalry as superfluous among the hoplite-minded Greeks south of Thessaly, claiming that before the fifth century they never sought to expand their tactical repertoire because they were satisfied with agonal hoplite battles. ${ }^{1042} \mathrm{He}$ views Greek cavalry as a slowly-evolving arm of the ancient army from the middle $5^{\text {th }}$ century forward, with the hippotrophic peoples of Macedonia and Thrace having an advantage. These peoples developed cavalry more extensively, Gaebel argues, because they were constantly interacting with non-Greek enemies, which required them to develop new forms of asymmetrical combat on a routine basis. The southern Greeks, fighting only other hoplite-organized southern Greeks, sought no more than the continuation of phalanx fighting This view seems reductionist and adheres too strongly to the hoplitecentric view that sidelines all other forms of fighting. Van Wees has since shown that this is untrue, and that a variety of non-hoplite forms of combat existed in the Archaic Period as well, although he sees cavalry as particularly undesirable because of the use of longrange weaponry and the connotation of cowardice. ${ }^{1043}$ However, Gaebel believes that it

\footnotetext{
1040 Gaebel (2002), 58-59.

1041 Ibid., 84-85.

1042 Gaebel (2002), 278-280; the theory of the Greek preference for agonal hoplite battles derives from Hanson's prolific corpus, consider Hanson (1989), (1993), and (2013).

1043 Van Wees (2004a), 65-68..
} 
was not until the southern Greeks came into contact with their "horsey" neighbors to the North and the Persian army during Xerxes' invasions that they gave cavalry serious consideration, a point with which Willekes has agreed in her more recent study of the evolution of cavalry. ${ }^{1044}$

${ }^{1044}$ Willekes (2015), 48. Willekes notes that after the Persian Wars, "the Greeks began to realize that an army deficient in cavalry could be a liability , particularly when Greek infantry where faced with Persian cavalry." 


\section{Chapter 10: Evolved Cavalry in The Classical \& Hellenistic Ages}

\section{Introduction}

Scholars are in agreement that readily identifiable cavalry units appear by the early Classical Period in several poleis, and cavalry usage generally improved overtime through use of integrative tactics, although never quite reaching in Greece the level of professionalism that cavalrymen of Macedonia possessed under Philip and Alexander (see below section A.2). As Rawlings rightly notes, cavalry participation in Classical battles is often marginalized by scholars, but was certainly a factor, both in pitched battles and skirmishes or campaigns. ${ }^{1045}$ As early as the opening of the Peloponnesian War, cavalry served "[as] the first and principal line of defense against invasions or incursions; to gain victory by surprise; to prevent the envelopment of a phalanx; and to defeat a withdrawing foe." 1046 While arguably always playing second fiddle to the hoplite, there was nevertheless an ancient understanding of "the general usefulness of cavalry, and, especially, the threat that it could pose to a hoplite army when it was well handled" and the "sometimes decisive" assistance offered by cavalry forces to a hoplite phalanx. ${ }^{1047}$ While Philip II would integrate infantry and cavalry in a dynamically transformative way, generations of generals paved the way for him.

\footnotetext{
1045 Rawlings (2007), 70.

1046 Worley (1994), 3. For a detailed discussion of cavalry participation in the Peloponnesian War, see Bugh 79-119; Gaebel 90-109.

1047 Gaebel (2002), 63.
} 


\section{A. The Classical Period (479-360)}

For our purposes, the investigation of the Classical Period will stop with Philip's rise to power in Macedonia in order to highlight the impact of his reforms and the way that his son utilized them. Prior to a discussion of Macedonia, our study will focus on different horse-rearing parts of Greece.

\section{a. Boeotia}

Although hippotrophic peoples like the Thessalians and Macedonians had a long history of cavalry, it appears to have taken stronger root in certain southern Greek poleis than in others. As we have discussed above, Archaic Athens likely had $a$ cavalry, but the degree to which it was used is unclear. Boeotian cavalry certainly existed in the Archaic Period, as it appears at Plataea fighting alongside Mardonius' men (e.g. Hdt. 9.31) and even engages in a fairly effective screening tactic to guard the routed Persians (Hdt. 9.6869). The cavalry must therefore have been established prior in order to fight in a functional way. However, by the later fifth century, both Boeotia and Athens invested heavily in cavalry, augmenting their forces by integrating recruitment lines and regulations into the pre-existing bureaucracy in order that either state could call upon 1,100 and c. 1,000 citizen horsemen, respectively. ${ }^{1048}$

Boeotia in general was horse-pasturing land, and as Spence points out, the citizens of its largest city had been called "horse-racing Cadmeians" since Homer (Il. 4.391). By 447 however, the political and bureaucratic unity of Boeotian poleis under the hegemony of Thebes pooled the regional resources well, resulting in an army that Diodorus called "inferior to none of the Greek nations in the number of its men and in military valour"

1048 On Boeotian cavalryman see Spence (1993), 19-22; Worley (1994), 60-64 
(Diod. 15.26.1). The Boeotian League, divided into 11 districts, required 1,000 hoplites and 100 cavalry from each, but as Worley notes, instances of raising significantly larger numbers in emergencies exist. In 396, the Boeotian League raised a force of 2,000 cavalry to defend against an Athenian invasion of Thebes. ${ }^{1049}$ This was possible because of careful federal-district coordination. The Boeotian horse fell under the purview of a federal hipparchus, who was selected and overseen by the Boeotarchs. It was to this federal hipparchus that the eleven district-level hipparchoi reported, each of whom was elected by district-level councils. Sub-divisions of command continued at district level, where forces of 100 horsemen were sub-divided into iliae of 50, each of which was overseen by an ilarchus. A nuanced hierarchy of command facilitated both organization and training, making it possible for squadrons to operate uniformly on the field. Worley reconstructs their standard formation, suggesting a width of ten men and a depth of five, but with the flexibility to form a narrow file in the case of a targeted attack. ${ }^{1050}$ Although the Boeotian cavalry's combat record is "mixed," 1051 its reputation in the late fifth century was not. As the strategos Hippocrates addresses his Athenian troops before the Battle of Delium in 424, he reminds them what is at stake: "if we conquer, the Peloponnesians will never invade your country without the Boeotian horse, and in one battle you will win Boeotia and in a manner free Attica" (Thuc. 4.95.2). This is a fine way of side-stepping what a threat the Boeotian horse presently was to the Athenians, and

\footnotetext{
1049 Diod. 15.26.4, cf. Worley (1994), 61.

1050 see Worley (1994), 60-4 and bibliography for information on Boeotian districting and cavalry. Cf. Spence (1993), 19-22 on Boeotian cavalry.

1051 Spence (1993), 22.
} 
indeed it was Boeotian cavalry that cost them the battle by surprising the infantry from behind. ${ }^{1052}$

\section{b. Athens}

Near the same time as Boeotia, Athens enhanced its cavalry from 300 to 1,000, all of whom would have been recruited from Athens' upper class youth. This drastic shift in state requirements is often pinpointed to the years immediately following the Battle of Tanagra during the First Peloponnesian War (460-445). Gaebel and Bugh argue that the defection of Thessalian cavalry ${ }^{1053}$ to the Spartan side so crippled the Athenians that it convinced the people of the necessity of a larger cavalry force. ${ }^{1054}$

By the end of the Archaic Period, both states certainly began to pour money and energy into enhancing their cavalry, indicative of its significance on the battlefield. The former provided state-assisted maintenance of war horses as well as insurance, and the latter recruited cavalry from throughout the region while forming the Boeotian Confederacy (Worley 3). It is at this time that Spence $(1993,9)$ estimates Athens expanded its cavalry from 300 to 1,000 , demanding 100 hippeis from every phyle. ${ }^{1055}$

Before the Peloponnesian War, Athenian forces were augmented to 1,000 citizens

\footnotetext{
1052 Thuc. 4.96.5-6, and on Delium see Gaebel (2002), 97-100.

1053 Thuc. 1.107.7-1.108.1; Diod. 11.80, cf. Gaebel (2002), 87.

${ }^{1054}$ Gaebel (2002), 87-88; Bugh (1988) 52; cf. Worley (1994), 68-9, who finds this plausible but does not believe this is the creation point of Athenian cavalry. Spence (1993), 12-13 finds c.477 a plausible startdate for the creation of the Athenian cavalry of 300, although he emphasizes that some sort of cavalry must pre-date the Persian Wars. Contrarily, Gaebel (2002), 87points to the fact that the Athenians used Thessalian cavalry at Tanagra and that a few years later, when a Thessalian prince named Orestes sought Athenian aid in attacking Pharsalus, the Athenians were once again thwarted due to lack of cavalry (Thuc. 1.111.1; Diod. 11.83.34), cf. Bugh (1988), 58. However, Gaebel's dismissal of Pausanias' description of a stele depicting Athenian horsemen at Tanagra is too quick. Acknowledging that "there is a possibility that some Athenian horsemen were present at this battle" but concluding that the Athenians still "did not have a cavalry force as such" (87) based on their loan of hoplites to Orestes seems strained. I find Worley's assessment of a modest cavalry force more persuasive.

${ }^{1055}$ Spence (1993), 9; see Worley (1994), 69f.. on new organizational methods of Athenian cavalry.
} 
and 200 hippotoxotai (likely Scythians) ${ }^{1056}$ but Worley proposes a step in between that would have lessened the financial strain on citizens and demand only 60 from each phyle. About a decade before the outbreak of the Peloponnesian War, the demand was increased from 60 per phyle to 100, likely facilitated by Athens' imperial wealth, as horse ownership was state subsidized (see below). Like the Boeotians, each Athenian cavalry phyle was sub-divided into two iliae of 50 men each. An elected phylarch commanded the cavalry of his phyle, and two hipparchoi oversaw the total cavalry force, each managing five phylai or 500 men. ${ }^{1057}$ Because Athens was far from being "horse country," the cavalry's ranks were filled with the economic elite. Xenophon advises that it was the place of a young man of means to serve, and he alludes vaguely to a legal process by which a reluctant individual could be compelled to do so, if his wealth permitted:

"As for the men, you must obviously raise them as required by the law, from among those who are most highly qualified by wealth and bodily vigour, either by obtaining an order of the court or by the use of persuasion. The cases that should be brought before the court, I think, are those of men who otherwise might be suspected of having bribed you not to apply for a judgment. For the smaller men will at once have a ground for escaping, unless you first compel the most highly qualified to serve." 1058 (Xen. Hipparch. 1.9-10).

The assumption that the elite might try to bribe their way out of service indicates the | extreme financial risk involved. Horses were expensive to keep and maintain, and certainly expensive to lose in war. The cavalry insurance provided by the state is not dated before the fourth century, ${ }^{1059}$ and undoubtedly eligible citizens were anxious about a risk that amounted to a minor liturgy.

\footnotetext{
1056 Worley (1994), 196 n. 64.

1057 Worley (1994), 70-71; Arist. Ath.Pol. 49.2, 61.4f; Xen. Hell. 2.4.31, Hipparch. 1.8, 2.2, 8.17; Spence 917.

1058 Xen. Hipparch. 1.9-10.

${ }^{1059}$ Kroll (1977), 99. See p. 97f.
} 
However, there were some financial bolsters offered by the state, alongside a general commendation of the glory of cavalry service, to entice eligible knights. State subsidies to hippeis cost Athens 40 talents per annum, ${ }^{1060}$ a testament to Athenian valuation of cavalry's role and the state's wealth during its period of empire. Athens offered its cavalry the katastasis, an advance from the state which loaned prospective cavalrymen up to 1,200 drachmae to purchase a warhorse, with the understanding that the sum should be repaid upon the soldier's retirement. At most, this would be 10-15 years, at which point the horse would be past service. ${ }^{1061}$ Bugh rightly notes that this is an extraordinary sum and could have covered the cost of a well-bred race horse; most loans must have been in a lower range. ${ }^{1062}$ State insurance on horses that were injured or died in battle, recorded in an annual timesis, is recorded only during the Hellenistic Period. ${ }^{1063}$ The sitos provided state-financed funding at the sum of 4 obols per day for horse feed in order to ensure the proper upkeep of the animal. ${ }^{1064}$ This was especially important if the animal had been purchased through the katastasis, as a horse which was not properly cared for and trained was subject to immediate repossession by the state, and the animals were inspected at regular dokimasiai. ${ }^{1065}$ Spence and Worley both doubt whether the four obol sum was likely to have covered the full cost of feeding a horse, but the offer would have at the very least significantly defrayed costs of care. ${ }^{1066}$

\footnotetext{
${ }^{1060}$ Xen. Hipparch. 1.19; Worley (1994), 71 finds this sum reasonable and even suggests that it covers only the cost of the sitos, as the katastasis would be paid back in full.

${ }^{1061}$ Bugh (1988), 69-70; Worley (1994), 70-71.

${ }_{1062}$ Bugh (1988), 58. On the cost of a warhorse see also Spence (1993), 183-4, Appendix 4.

${ }^{1063}$ Cf. Bugh (1988), 57; Kroll (1977),97-100.

${ }^{1064}$ Bugh (1988), 53 f.; Worley (1994), 71-72; Ath.Pol. 49.1-2 on the details of the loan process.

${ }^{1065}$ Bugh (1988), 58f.

1066 Worley (1994), 71; Spence (1993), 183-4 suggests that a horse would have eaten more than the 4 obol per day sitos provided, and fluctuating grain prices based on Athenian control of maritime trade would have made it impossible for a horse to live entirely on state-subsidized grain.
} 


\section{c. Sparta and Others}

Similar state programs are not recorded for other cavalry-owning poleis, and in fact very little information exists about the cavalries of other Greek states south of Thessaly. Argos' Homeric epithet, "horse-grazing" (Il. 2.287, 15.30) would not have been applicable in the Classical Period. Spence suspects that the Argives may have lacked cavalry entirely until the fourth century (e.g. Thuc. 5.59.3), although a cavalry force appears by c. 370 in battle with the Phliasians, which the Argives lose. ${ }^{1067}$ Similarly, Corinth, Phleious, Elis, and Achaia likely did not possess strong cavalries until the fourth century, and little record exists (Spence 4-9 for summary). Locris and Phocis were both early producers of cavalry as they had horsemen during the time of the Persian Wars, although they were compelled to medize. Both continue to appear in the sources down through the late Classical Period, when they are mentioned at Gaugamela with Alexander's cavalry. ${ }^{1068}$ Spence provides a good overview of the Thessalian, Macedonian, and Chalcidician tradition of horse raising and cavalry. ${ }^{1069}$

Conspicuously absent was Greece's most militaristic state. In fact the Lacedaemonians resisted the creation of a cavalry unit, and it was not until they were beset by Athenian raids during the Peloponnesian War that the Spartans developed one c.424 (Thuc.4.55.2), with 400 hippeis. Prior to this, their familiarity with horses was limited to competitive equitation and chariot racing, ${ }^{1070}$ and Spartan cavalry played a modest and not particularly memorable role during the Peloponnesian War. During the Spartan king Agesilaus' invasion of Anatolia in the early fourth century, he was obliged

\footnotetext{
1067 Xen. Hell. 7.2.4; in general Spence (1993), 4-5.

1068 Diod. 17.57.3-4; Curt. 4.13.29 records the Locrians; cf. Spence (1993), 17-19.

1069 Spence (1993), 23-30; cf. Sidnell (2006), 75-126 on Macedonians.

${ }^{1070}$ See Spence (1993), 2-4 and bibliography on Spartan horsemanship.
} 
by constant attacks by Tissaphernes to re-develop a stronger cavalry. Cavalry is only mentioned infrequently in the sources, but Worley imagines that Xenophon played a large role in helping organize it. ${ }^{1071}$ For a time, Agesilaus had some success with coordinated attacks between infantry and cavalry, as at the 395 Battle of Sardis, where peltasts supported the light Greek cavalry in the initial charge, followed by a vigorous hoplite march. ${ }^{1072}$

Nevertheless, Spartan cavalry played a very limited role in the Corinthian War (395-386) despite Agesilaus' recent innovations (Xen. Hell. 3.4.16; Ages.1.25). The cavalry came in handy to protect the Spartans as they returned to Europe and marched south, warding off Thessalian raids. However, at the fighting near Lechaeum (390), the Spartan cavalry proved too "timid" to help the Spartans, and the cavalry screen meant to protect the hoplites failed to advance farther than the infantry and was therefore unable to ward off Iphicrates' peltasts. ${ }^{1073}$ This problem appeared again during the period of the Theban ascendency, when the Theban general Epaminondas' well-trained cavalry crashed into the Spartan horse and forced them back into their own hoplite ranks. ${ }^{1074}$ Xenophon attributes the Spartans' poor cavalry skills to their lack of training - a surprising criticism to level at the most famous infantry in Greece. While the Thebans had been fighting a war against the Orchomenians, the Spartan cavalry was out of practice, and furthermore, most Spartan cavalrymen did not regularly bond or practice fighting while mounted.

"For the richest men kept the horses, and it was only when the ban was called out that the appointed trooper presented himself; then he would get his horse and such arms as were

1071 Worley (1994), 138.

1072 Xen. Hell. 3.4.24; with Worley (1994), 140-141 and Gaebel (2002), 118-119.

1073 Xen. Hell. 4.5.6; Spence (1993), 145f.

1074 Xen. Hell. 6.4.10-15; Diod. 15.51-56; Plut. Pel. 20-23; Gaebel (2002), 129-132; Worley (1994), 142-5. 
given him, and take the field on the moment's notice. As for the men, on the other hand, it was those who were least strong of body and least ambitious who were mounted on the horses." 1075

The flaws in this system are obvious. Disregarding the lack of physical strength attributed to knights, a lack of practice is sufficient to explain the Spartan failure to produce a quality cavalry in the fourth century. Fierce dedication to infantry fighting as major Greek powers developed and expanded their cavalry left the Spartans improperly protected on the field. Xenophon exhorts his readers to train thoroughly with their horse, noting that it is not numbers, but expertise, of cavalry that wins a battle. In a (predictably misogynistic) equation, he notes:

"For both horses and men that are carelessly trained in this respect will naturally be like women struggling with men. On the contrary, those that are taught and accustomed to jump ditches, leap walls, spring up banks, leap down from heights without a spill, and gallop down steep places, will be as superior to the men and horses that lack this training as birds to beasts." 1076

Indeed in Athens a warhorse was expected to pass regular examination not only for its health, but its behavior and drill form, subject to a wheel-shaped brand should it not pass muster. ${ }^{1077}$

\section{Transformation of Cavalry under Philip II, Alexander the Great (360-323)}

It is surprising that despite the considerable number of studies on ancient cavalry, relatively little space has been devoted to the study of it in the Hellenistic Period. Gaebel (2002 has since filled the gap with a narrative military history with a focus on cavalry that includes the Diadochs and even Hannibal. More recently, Wrightson $(2015,2019)$

\footnotetext{
1075 Xen. Hell. 6.4.11.

${ }^{1076}$ Xen. Hipparch. 8.2-3, cf. 1.25

1077 Arist. Ath Pol 49.1; cf. Bugh 59.
} 
has made the Hellenistic Period the focus of his military study of combined arms theory, which necessarily includes cavalry. Focused studies of Philip II, Alexander, and his more successful generals and Successors, have further highlighted the preeminent role of cavalry in Greco-Macedonian combat of the late Classical and Hellenistic Periods. The trend toward increasing cavalry presence and participation in battle after the Peloponnesian War was a gradual one that involved many generations of generals drawing on the successes and failures of their predecessors. ${ }^{1078}$ One of the most dynamic innovators was the Argead king Philip II of Macedon, whose military reforms allowed him to secure and then expand Macedonian borders as well as prepare for the Asian campaign carried out by his son, whose brilliant military career owed much to his father's legacy.

Under Philip II's regency and reign, the Macedonian military was streamlined and professionalized through re-organization of both infantry and cavalry around a strong central power. This organizational focus helped mend age-old dynastic disputes between Upper and Lower Macedonia and incorporate both regions' strong cavalry traditions into the growing Argead military. By unifying the region and eventually becoming tagus of Thessaly, ${ }^{1079}$ Philip increased the size of the Macedonian cavalry from a mere 600 in 358 (Diod. 16.4.3) to 3,000 by $352(16.35 .4-5),{ }^{1080}$ and these were not all nobles. Because of the high risk of cavalry service, commensurate rewards were offered, including promotion. Philip's cavalry may have consisted of noblemen whose rank and leisure time for training made them ideal candidates, but non-nobles had the option of promotion as

\footnotetext{
${ }^{1078}$ Cf. Gaebel (2002), 131; I would not go so far as to discredit the genius of Epaminondas as Gaebel and Hanson do. 1079 See Spence (1993), 22-25 and Donaghy (2014), 100-106 on horses in Thessaly

${ }^{1080}$ See further Worthington (2008), 26.
} 
high as the Companion Cavalry, who rode into battle alongside the king on the right wing. Such elevation in rank was dependent on talent and conspicuous acts of bravery. The possibility of promotion kept troops fighting fit and in frequently competition with one another, as men of such rank were not only paid more, but often received special incentives like land grants, a policy which Alexander continued. ${ }^{1081}$

Horses had long been of symbolic significance to the Macedonian monarchy, but under Philip they became the punching arm of the battle line. In a reversal of Greek norms, Philip swapped the infantry for the cavalry as the primary attack arm of the army. Recognizing the significance of horsepower against bellicose horse-rearing neighbors like the Thracians and Paeonians. ${ }^{1082}$ and the comparatively horse-poor southern Greeks, Philip trained his cavalry not only in missile-warfare, but in hand-to-hand combat, a feature of cavalry combat that would characterize his son's eastern campaigns as well. Philip's cavalry was divided into ilae based on the region they hailed from in order to encourage cooperation and easy communication, and doubtless also to preserve unique regional skill-sets to form specialist mounted troops. ${ }^{1083}$ Borrowing the wedge formation from his neighbors to the north, Thrace and Scythia, Philip altered the Greek norm of using the phalanx square (or rhomboid, in the case of the Thessalians) as a battlefield formation. ${ }^{1084}$ The Scythian wedge, which looks from a bird's eye view like a lambda, used its tapered point to penetrate the enemy lines more easily, which would in turn be broken up to create openings for the horses to charge through and their riders, through

\footnotetext{
1081 Worthington (2008), 30, see also: Plut.Alex.15.4.6. In general on PII's military reforms see Worthington (2008), 29-30; Gabriel (2010), 72-81; Worthington (2014), 32-41.

1082 The Paeonians were used to support the prodromoi, indicating that they were skilled riders. See Worthington (2008), 30 and Gaebel (2002), 172-173.

1083 Worthington (2008), 29-30; Gabriel (2010), 73.

1084 Worley (1994), 157, cf. 31-32; Philip may have adopted it after his Scythian campaign cf. Worthington (2088), 138-40.
} 
hand-to-hand combat, to hack their way through phalanxes.

This approach sounds more implausible than it is. The first few notches cut into a phalanx's front lines would have been managed by the prodromoi, or light armed cavalry who make the initial attack and attempt to create small gaps in the front line. The rest Gabriel puts neatly: "a typical phalanx was eight men, or about twenty-four feet, deep. An average horse is between nine and ten feet long. A horse has to advance only about twice its length before it has reached the back of the phalanx. Given that the animal weighed about 1000 pounds, even the slightest momentum is sufficient to carry it into the depth of the phalanx." ${ }^{1085}$ Naturally once one hoplite was killed, the horse would already have an opening into the front rank - there was little the hoplites nearby could do, given the necessity of holding their spears in unison. Twisting about to fight with a sword against the intrusion would further weaken the line that was still being held intact. ${ }^{1086}$ Once hoplites began to flee, the battle was over, and Macedonian cavalry could pursue. Unfortunately, much of Gabriel's conclusion has been drawn from Alexander's tactics, given the general lack of tactical detail for Philip's battles with the Greeks. ${ }^{1087}$ Worthington notes that we know almost nothing about PII's Thracian campaigns in 342, although he reconstructs Philip's likely route and forces with reliance on the orators, showing that he brought cavalry against the hippotrophic Thracians. ${ }^{1088}$ Against Onomarchus at Crocus Field, Philip's victory is attributed specifically to his cavalry by Diodorus (16.35.5) although how this was managed is not known. Gaebel's use of

\footnotetext{
1085 Gabriel (2010), 78.

${ }^{1086}$ Cf. Gabriel (2010), 79-82.

${ }^{1087}$ Cf. Gaebel (2002), 146-58, esp. 154: Chaeronea is “anything but clear" 154; p. 151-152 at Crocus Field, it is clear that the cavalry played a starring role, although the specifics are lost. Gaebel's close study of cavalry (where it can be 'seen' in the sources) under Philip shows that it played a frequently significant role, both with Greeks and non-Greeks

1088 Worthington (2008), 122-124; Dem. 9.49.
} 
Maurice's Strategicon permits a convincing reconstruction of Philip's 339 campaign against the Scythians. By using his cavalry to fight at close quarters, he would deprive the Scythians of their preferred long-range weapons while managing to match their speed and agility. ${ }^{1089}$ Philip himself certainly led the cavalry in his campaign against the Triballi in the summer of 339, as he received a crippling leg wound and had his horse cut out from under him by near-fatal friendly fire. ${ }^{1090}$ In any case, the reputation of Philip's cavalry spread throughout Greece. Gabriel points out how it is echoed in the lost play of Mnesimachus, Philip, in which the Macedonian king's cavalryman boasts that he and his fellows make a meal of swords, torches, and broken arrowheads, sleeping at night on a shield in lieu of a pillow. ${ }^{1091}$

Gaebel rightly notes that one should not assume that the cavalry served the Macedonians as some sort of "magical tool with which to pry apart the ranks of the phalanx." Rather, "the Macedonian victories of the period resulted as much from hard fighting as from superior generalship." "1092 And, some have asserted, from superior horses. Following Cawkwell, Gabriel has argued that Macedonian horses were superior to those in Greece, largely because of interbreeding with the Persian Nisaean horse. ${ }^{1093}$ However, his assumption that Macedonians "unlike the Greeks, took great care to see to their [horses'] health and training"1094 based on Xenophon's admonitions and instructions about how to care for a horse (Hipparch. 1.4-8) seems unfair. Horses were especially valuable and costly in the horse-poor parts of southern Greece, and there is no good

\footnotetext{
${ }^{1089}$ Gaebel 153-4; cf. Maruice Strat.11.2.21, 29, 52, 67 on Scythian fighting techniques.

1090 SWorthington (2008), 101.

${ }^{1091}$ Gaebel (2002), 82.

1092 Gaebel (2002), 152.

1093 Gabriel (2010), 73-75; cf.Donaghy (2014), 184-190.

1094 Gabriel (2010), 74.
} 
reason to assume that those who could afford them neglected their health or feeding.

The Macedonians did however have access to horse breeds from Thessaly, Persia, Paeonia, Thrace, and even Scythia, allowing for more selective breeding. During the period of the Persian occupation of Thrace (late $6^{\text {th }}$-early $5^{\text {th }}$ centuries) and subsequent Persian occupation of Macedonia during the Persian Wars, Macedonians would have had access to Persian bloodlines (especially the coveted Nisaean, Hdt. 7.40), and it is shortly thereafter that the caduceus brand appears on Macedonian horses, which Donaghy and Kroll have suggested is indicative of a coveted regional thoroughbred. ${ }^{1095}$ Philip went to great lengths to make further improvements of his horse stock, as Justin reports that he imported 20,000 mares from Scythia for breeding (Just. 9.2.16). While the number is untenably high and probably an exaggeration, it is at the very least a reflection of Philip's measures to strengthen the Macedonian cavalry. ${ }^{1096}$

While Macedonia may have produced coveted breeds, there was no "Macedonian horse" to compare to a "Greek horse." Macedonia's strength lay in sharing its borders and equine bloodlines with so many other horse-rearing peoples. It is important to note that Alexander's favorite and most famous mount was not a Persian breed, but Thessalian, branded with the "ox-head" mark famous across Greece. Following a recent discovery and genetic analysis of a horse burial in Sidnos, whose "somatometrics indicate a phenotype of the native Thessalian horse breed to which Bucephalas belonged,"1097 we can guess that Macedonian horses were not much, if any, taller than Greek ones. The Sidnos mare measured just shy of 14 hands at the withers, perhaps suggestive of

\footnotetext{
1095 Donaghy (2014), 111; Kroll (1977), 88.

1096 See Donaghy (2014), 111-112 on Macedonian cavalry, and in general Sidnell (2006), 75-126.

1097 Antikas (2008), 35 in Donaghy (2014), 112.
} 
Bucephalas ' own height. While some American ranchers consider this animal a "pony," it was a stout vehicle and weapon on the ancient battlefield. With the help of Bucephalas and tens of thousands like him, the Macedonian invasion of Asia under Alexander defeated the famed Persian cavalry.

Although more detailed information about Macedonian cavalry arms, armor, and tactics comes from the campaigns of Alexander, most if not all details must have applied to the cavalry under Philip as well, as Alexander brought his father's veteran cavalry with him to Asia within two years of the late king's death. He began his campaign with 5,000 horsemen, of which 1,800 were Macedonian (Arr.1.11.3; Diod. 17.17.3-5) and pushed the cavalry arm to the limits of its potential”"1098 through the use of shock tactics and combined arms. In three of four of Alexander's major pitched battles, cavalry was used to penetrate the enemy line (the exception being Hydaspes, where Alexander rightly used his infantry in this regard for fear of scattering his cavalry before the elephants). Cavalry was no longer secondary in significance to the infantry, but worked alongside foot soldiers in coordinated effort to break the enemy line.

The flexibility and speed for which Alexander's cavalry was known was due in large part to their weaponry. Unlike his Persian opponents, Alexander's most effective cavalry did not use long-range weapons, but fought hand to hand with thrusting spears. ${ }^{1099}$ Alexander's cavalrymen (and likely also Philip's) were lightly armed with a cuirass, helmet, and no shield. A horseman carried a xuston or doru, words used interchangeably by the sources to describe a spear short enough to be wielded with one

\footnotetext{
1098 Gaebel (2002), 160.

1099 This is not to suggest that light cavalry and javelin men were not employed by Alexander, but rather that when the decisive blow was dealt, it came from a cavalry scrum. Cf. Gaebel (2002), who points to the role of cavalry and the thrusting spear at Granicus in Curt. 4.16.23.
} 
hand (unlike the sarissa) and typically used by cavalry as a thrusting weapon. Because it was counterbalanced by a metal butt with a shorter point, the ideal grip would fall about 2/3 of the way down the shaft. ${ }^{100}$ Gaebel estimates the length at 7-10 feet long, which would enable a man to hold and balance it, unlike the 16-18 foot sarissa, which required a two-handed grip. ${ }^{1101}$ There has been some debate regarding the ability of a horseman to carry a sarissa into battle, as certain light-armed cavalry in Alexander's army, the prodromoi, are referred to as the sarissophoroi occasionally. ${ }^{1102}$ In 1977, Markle advanced the theory that these horsemen carried actual sarissae, which in addition to being impossibly difficult on horseback would be relatively useless in the close push of combat.

Since then, Gaebel has argued that this is extremely unlikely due to the impracticable weight and length of the sarissa. Had light cavalry been so armed, the sarissa would have been reduced to a one-time use. Once it was thrust forward into the enemy, it would need to be dropped in favor of the sword, which Markle believed was plausible. However, Gaebel raises the additional point that the use of the sarissa from horseback would have required an absolutely straightforward charge, as any turning with such a long weapon would put nearby riders at risk and the knight himself could fall off. Because Markle's primary evidence rests in length ratios of the sarissae as they appear in the Alexander mosaic and Alexander sarcophagus, and Greek artists are not known for their dedication to realistic mathematical proportions, Gaebel finds cause to dismiss the

\footnotetext{
1100 Gabriel (2010), 75.

${ }^{1101}$ Gaebel (2002), 161-4 and n.11-13; he distinguishes between the xuston and doru (lances) and the shorter javelin meant for use as a projectile weapon, denoted by akon and palta. As per Gaebel's examples: xuston in Arr. 1.16.1; Diod. 17.20.3; doru in Arr. 1.15.2, 6; Plut.Alex. 16.4. On xuston length, cf. Gabriel (2010), 75, who offers 8-10 feet, similar to Gaebel.

1102 Gaebel (2002), 160-164.
} 
claim. ${ }^{1103}$ Since then, biographers of the sarissa's inventor, Worthington ${ }^{1104}$ and Gabriel $^{1105}$ have concurred with Gaebel, finding it improbable that the sarissophoroi are named literally. Worthington suggests that the 'sarissae' under discussion are merely long spears, and Gabriel adds that sarissa may simply have been a common Macedonian term for spear. Since the sources rotate words for spear but single the sarissa out, it seems to me that Worthington's interpretation is more likely. A longer than usual cavalry spear might merit the term sarissa because, like the infantry sarissa, it is longer than that which is typically used by knights. It cannot possibly be the same weapon wielded by the infantry.

The knights' spears could be aimed over the horse's head, resting between the ears, so as to thrust up toward the throat and face of the enemy cavalryman, as Xenophon suggests (Hipparch. 3.3). Arrian describes what such shock tactics look like in his account of Granicus:

"Riding far ahead of the line and leading on a body of horse, formed in a wedge shape, [Alexander] charges forth in advance of his men, thrusts his lance [doru] into Mithridates' face and hurls him to the ground." 1106

Arrian's account reveals the degree of training a rider would need to function effectively. Thrusting a spear through the enemy with the added velocity of a horse's movement requires good timing, but twisting the spear to the side from horseback (and sans stirrups or saddle) hard enough to dislodge the rider required excellent balance and considerable lower body strength. Because the male center of gravity is in the shoulders, not the hips,

\footnotetext{
${ }^{1103}$ see Gaebel (2002), 168-72 for full discussion and n. 36 for bibliography; see also Markle 1977, 1978, 1982

${ }^{1104}$ Worthington (2008), 29.

${ }^{1105}$ Gabriel (2010), 75.

${ }^{1106}$ Arr. 1.15.7.
} 
cavalrymen would likely have spent as much time training to stay on the horse as to aim a weapon. Additionally, as knights did not carry multiple spears as javelin men did, the weapon would have to be retrieved from horseback as well, dislodged from the dead, and re-used. Curtius offers an instructive example of the repeated use of the weapon from horseback when he describes Alexander and his Companion Cavalry fighting a Persian squadron after Gaugamela:

"For when the leader of the horsemen rushed upon him...the king [Alexander] ran him through with his spear [hasta]; and when he fell from his horse, Alexander killed the next man and then several others with the same weapon."1107

However, in a cavalry scrum, or a cavalry attack on infantry, the spear was not always an effective weapon. Cavalrymen carried a short sword or long dagger as well (kopis or machaera) that measured at most 25 inches. Such a weapon could be drawn in the event that the spear shaft snapped (e.g. Arr.1.15.6) or the press of battle became too close to wield a longer weapon. ${ }^{1108}$ This would have been quite common, since most of Alexander's cavalry fought at close range more often than from afar. ${ }^{1109}$ Perhaps the most famous example of a cavalry sword in action is Granicus, when Cleitus the Black used a kopis to shear off the arm of a Persian noble, saving Alexander's life. which explains why Cleitus the Black used a sword, not a spear, to rescue Alexander at Granicus. Arrian says: "Spithridates had already raised his scimitar to cut down Alexander, but Cleitus son of Dropides, smartly slipping in, drove at Spithridates' shoulder and shore it off scimitar and all." 1110

\footnotetext{
${ }^{1107}$ Curt. 4.16.23.

${ }^{1108}$ Gaebel (2002), 161-164.

${ }^{1109}$ E.g. At Granicus in 334, cf. Arr. 1.15.4; Plut. Alex. 16.4.

${ }^{1110}$ Arr. 1.15.8; cf. Diod. 17.20.6; Curt. 8.1.20 says Cleitus slew Rhosaces, whom Arrian claims Alexander slew first, before Spithridates attempted to avenge the death.
} 
While trained fighters did most of the damage, horses participated in the scrum of battle as well. Gaebel suggests that cavalrymen encouraged their horses to engage in shoulder barging, or slamming into another horse's shoulder and side in an attempt to establish dominance, something that horses do naturally in the wild. In Arrian's account of the Battle of Granicus, Gaebel sees a reference to this behavior. Arrian (1.15.2) claims

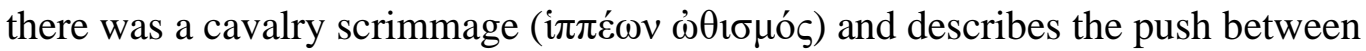
Macedonians and Persians on the banks of the river as Alexander's cavalry attempted to ride up: "It was a cavalry struggle, though on infantry lines, horse pressed against horse, man against man, wrestling one with another." ${ }^{1111}$ While Granicus presents an unusual case because of the positioning of Persian cavalry on the edge of the riverbank, ${ }^{1112}$ the close range of cavalry fighting is clear from the weapon choice, and it is plausible that the equine proclivity for shoulder barging was exploited successfully by cavalry.

Like his father, Alexander was particularly fond of the hammer and anvil approach, which employed both cavalry and infantry in key roles. Initially, the prodromoi would charge before the bulk of the cavalry, serving to absorb the first round of enemy blows and harass enemy lines, stalling the Persian advance and shifting the impetus to the Macedonians. Subsequently, the Companion Cavalry (the "hammer") charged forward, usually from the right wing, to sweep the enemy line and disrupt its good order through the use of shock tactics. In so doing, the cavalry forced enemy troops toward the Macedonian phalanxes in the center and left (the "anvil"). Under Alexander, the cavalry charge became the "decisive element in battle...as part of the coordinated infantry-

\footnotetext{
1111 Arr. 1.15.4; Gaebel (2002), 167.

${ }^{1112}$ An excellent treatment of the numerous problems surrounding the ancient accounts of the Battle of Granicus may be found in Hammond (1980).
} 
cavalry attack." 1113

While the infantry had to withstand the onslaught of the enemy's charge, the cavalry was obligated to cut through the enemy line quickly and efficiently at a critical point, ${ }^{1114}$ and in Alexander's case, his men were typically faced with non-hoplite formations. Gaebel argues that Alexander gave his cavalry such a crucial role because of the composition of the Persian army "with their numerous fine missile-hurling cavalry, poorly supported by weak infantry."1115 Had he been combating Greek armies, whose strength lay in their infantry, Macedonian cavalry may have played a less prominent role. Against the Persians, cavalry was routinely used to penetrate and disrupt the line.

The hammer and anvil approach is a classic example of combined arms, a term with a modern ring but ancient roots. Philip and Alexander's use of combined arms has been noted by in some fashion by most scholars, ${ }^{116}$ but it has most recently been the subject of a focused study by Wrightson. Wrightson defines the goal of combined arms practice as "to enable a coordination of action in a battle that brings each unit into offensive or defensive action to mutually support the rest of the army."1117 Before the "perfection" of combined arms under the Diadochs, Philip experimented successfully by coordinating cavalry and infantry attacks. Wrightson cites Philip's battle at Heraclea Lyncestis in 358 as an example of the Macedonian general and king's brilliant use of combined arms. ${ }^{1118}$ Pitted against the Illyrian king Bardylis, Philip coordinated the

\footnotetext{
1113 Worley (1994), 171.

1114 See Gaebel (2002), 190-194 on the details of the Macedonian charge. Questions of whether cavalry can break an infantry line are addressed in Worley (1994), 162-3; Konijnendijk (2018), 115.

1115 Gaebel (2002), 190.

1116 e.g. Worley (1994), 145, who sees the origin with fourth century Thebes but acknowledges the finalized form occurred under Philip and Alexander's reigns; cf. Gaebel $(2002<0,162 \mathrm{f}$ who notes similar tactics. 1117 Wrightson (2015), 60.

${ }^{1118}$ Diod. 16.4-8; Front. Strat. 2.3.2, Wrightson (2015), 60-61; Worthington (2008), 33-35; Hammond (1994), 25-27
} 
attacks of cavalry and infantry to overwhelm the hardy Illyrian warriors. As Diodorus describes it, Philip's cavalry swept past the Illyrian front and attacked them on the flanks while Philip himself led the infantry in a frontal clash, pinning them in place. Because the Illyrians appeared to fight in some ways like the Greeks, ${ }^{1119}$ the battle was not a swift victory. However, by pressing the front of the Illyrian ranks with infantry and using cavalry to cut through their sides and eventually sweep about to the rear, Philip forced the Illyrians to flight, at which time his cavalry was used to cut down the majority of that battle's casualties, which Diodorus records at over 7,000 men (16.4.7).

Alexander used a similar approach in his campaign against the Triballi in 335 (Arr. 1.2.57), an example which Willekes gives to illustrate the impact of coordinated fighting. Her explanation is worth quoting in full:

\begin{abstract}
"Alexander's line effectively functioned like a giant bullwhip. The Greek cavalry on the left side held the defenses, moving forward to take up a pursuit only at the end of the battle. The sarissa-phalanx in the center held their ground and slowly moved forward to push through any gaps in the enemy line. The key attach came from the right, where the Macedonian cavalry surged forward to engage the horsemen, supported by the hypaspists who moved amongst the horses pulling down enemy cavalrymen." 1120
\end{abstract}

The key, she notes, to Alexander's success was never giving his enemy opportunity to pause, regroup, or catch their breath. Alexander had to time the advance of the infantry and cavalry so that the Macedonian knights caught their counterparts, cut them down, and worked to pierce the line. Macedonian infantry held it and poured through gaps created by the aggressive cavalry, who did more than fire at the enemy from a distance.

However, this sort of coordinated effort did not emerge from a vacuum. As Wrightson and Hunt have recognized, Philip and Alexander's techniques represented the

\footnotetext{
${ }^{1119}$ Diod. 16.4.6 specifies that they formed themselves into a square, which is suggestive of the hoplite hollow square formation.

${ }^{1120}$ Willekes (2015), 49
} 
"culmination of classical trends" 1121 and the most effective use of combined forces by Greek armies. It stands to reason that such advances would occur under the auspices of a king who demanded a professional, thoroughly-trained army and hailed from a hippotrophic land like Macedonia. ${ }^{1122}$

\section{The Hellenistic Period (322-31)}

Because Philip and Alexander set the stage for cavalry use by the Diadochs and through the Hellenistic Age, their combined arms practices persisted, but cavalry no longer played the starring role. Naturally, the introduction of elephants into ancient combat in the period of the Diadochs complicated things. Cavalry had to be trained to tolerate elephants and plan accordingly in pitched battle, as has been discussed in chapters one and two. Additionally, Philip and Alexander's tactical innovations had less impact during the period of the Diadoch Wars (323-281) because the combatants were not fighting the same type of enemy - they were fighting equally well-trained and battlehardened veterans of Alexander's wars. It is thus unsurprising that many of the early battles of the Hellenistic Period were determined by treachery and error rather than strategic superiority. ${ }^{1123}$ The replication of Alexander's unusual genius was unlikely, and the Diadochs were not often contending with the horse-rich and infantry-poor armies of the East.

Certain Seleucid rulers were able to imitate some of Alexander's tactical successes in their campaigns to the East; Gaebel points to Antiochus III, whose sobriquet

\footnotetext{
${ }^{1121}$ Hunt (2007), 145 in Wrightson (2015), 60.

1122 E.g. Gabriel (2010), 72-73; Wrightson (2015), 60-61.

1123 Gaebel (2002), 290.
} 
"Megas" invites comparison. His successes against western infantry were more limited, suggesting that the policy of strategic flexibility promoted by Xenophon (Hipparch 9.1-2) and used by Philip and Alexander had somehow fallen by the wayside. Gaebel calls Antiochus III a cavalry general with an army based around the Macedonian phalanx, an unfortunate combination that led to severe losses at Raphia and Magnesia. Similarly, he blames Philip IV's loss at Cynoscephalae on the failure of the Macedonian generals to guard the flanks efficiently with cavalry. ${ }^{1124}$

The only cavalry-centric account of Hellenistic combat of which I am aware is Gaebel's, who devotes a chapter to the period after the Diadoch Wars to examine declining use and effectiveness of Macedonian cavalry. Gaebel rightly points out the jarring incongruity of the ancient sources and twentieth-century scholars as regards cavalry deployment after Alexander. While numerous scholars have maintained that the Macedonian horse played a prominent role in combat, the ancient sources tend to favor dominance of the infantry. With the exception of certain eastward-roving Seleucid kings, the generals of the Hellenistic era were fighting armies trained in the Greco-Macedonian mode of fighting, and they approached familiar enemies with a view toward military symmetry. As a result, cavalry once again played a role subordinate to infantry. ${ }^{1125}$

\section{B. Tack \&Tactics}

\section{Horse Tack}

1124 Gaebel (2002), 292-293.

1125 Ibid., 199-262. 
In the ancient world, horse tack was limited and crude, as the treed saddle did not appear until the Roman Period, and the stirrup not until the early Middle Ages. Early uses of horses as draft animals often attached them to carts or chariots with yokes about the shoulders or chest. A diagram of different yoke types has been sketched out by CluttonBroch. ${ }^{1126}$ Horses were controlled by reins attached to a nose band or bridle, and an early depiction of a horse bridle appears on the fragmentary lid of an Athenian pot from the mid- $7^{\text {th }}$ century in [Image 10.1]. and horseshoes had not yet been invented. Because of the relatively dry climate of the Mediterranean and Middle East, where horses were domesticated, horseshoes would have been unnecessary, as the keratin-based hoof wears evenly and does not crack. However, any podiatric ailment was crippling; Xenophon opens his work on the art of horsemanship with a warning to the prospective horse-buyer to inspect the feet first and look for a high hoof, in which the frog is elevated from the ground. He recommends rapping on the hoof and listening for a hollow sound, which would indicate unhealthy wear. In such cases, purchase should be avoided, as any other good points the horse possesses will be worthless if his feet are injured (PH 1.2-3; cf. 4.3). In wetter climates, hoof-health would have been more commonly problematic, and it appears to have been the soggy English terrain that prompted the creation of the first horseshoe, the hipposandal, in the first four centuries CE. ${ }^{1127}$

The stirrup was not an invention of antiquity, and its absence is testament to the high skill of ancient riders. The famous "Parthian shot," which should probably be called the "Assyrian shot," was mastered as early as the $7^{\text {th }}$ century. Assyrian cavalrymen were able to send their horses charging in retreat while at the same time twisting about to fire

\footnotetext{
1126 Clutton-Brock (1992), 71-72.

${ }^{1127}$ Clutton-Brock (1992), 73 with fig. 5.10; cf. Gaebel (2002), 28.
} 
arrows at the enemy in the rear. Riders could control their horses with bridle and bit, but otherwise had to rely on powerful leg muscles and excellent balance, and presumably familiarity and communication with their mount. ${ }^{1128}$ The first use of stirrups is usually attributed to Ango-Saxons, ${ }^{1129}$ but in fact the innovation belonged to China. Fourth century CE graves have yielded the earliest-known stirrups, and a Hungarian tomb dating to the seventh century contained stirrups of Chinese design, suggestive of export. Additionally, a predecessor to the stirrup, likely used as a mounting aid, appeared in ancient India and Scythia, indicating that numerous cultures were experimenting with means of facilitating horse riding. ${ }^{1130}$

Until Roman times, ancient riders went without a saddle; they relied instead on a rough cloth to provide friction and padding, as needed, although bareback was also considered acceptable (Xen. $P H$ 7.5). Slightly more elaborate seating equipment was found in the Pazyryk horse grave, including stiff saddle pads, multiple layers of cushioning, and a wood spacer. ${ }^{1131}$ By the Roman Imperial Period, a horned treed saddle and girth assisted in keeping a rider mounted, but earlier customs were not abandoned. The saddle is the center of considerable debate over the Greek and Macedonian use of shock tactics, which some scholars contend would have been impossible due to the instability of their seat on the horse. Lacking a diveted saddle or stirrups for security, it was generally assumed that a rider would fly off the rump of his horse upon impact. However, as we have discussed above, shock tactics did not involve slamming into a wall

\footnotetext{
${ }^{1128}$ Clutton-Brock (1992), 73-75 shows how 20 ${ }^{\text {th }}$ century rider and archer J. Spruytte imitated the Parthian shot without stirrups or saddle, proving that a trained rider could manage it. See also fig. 5.11 and 5.12 for Etruscan bronze of a Parthian mounted archer.

${ }^{1129}$ Cf. White (1962), who argues that the Anglo-Saxons invented it but only the Franks understood the stirrup's utility in shock tactics.

${ }^{1130}$ Clutton-Brock (1992), 76.

${ }^{1131}$ Hyland (2013a), 507-509.
} 
of shields or spears at full force, and there is no reason to assume that a cavalryman could not wield a weapon while using his horse to push into the front ranks of a phalanx. Indeed Spence has protested that this assumption is inaccurate as well as illogical, noting that if charging the enemy and wielding a weapon from horseback were as risky as all this, cavalry use would have deteriorated over time, not increased. The cost of maintaining and training a warhorse was simply too high to merit such a risk. ${ }^{1132}$ In fact, the Greeks found ways around such problems. For example, Xenophon advises riding horseback not as though one is sitting in a chair, but as though one is standing with legs splayed. The upper part of the leg should rest tightly against the horses' sides, while the lower leg should be allowed to dangle without tension. In this way, striking a barrier while running at a good clip would make the rider less vulnerable to broken bones. ${ }^{1133}$

Mounting without stirrups and a saddle was a difficult task. While one might argue that ancient Greek horses were a few hands shorter than some of their modern decedents, it would still not be possible to swing a leg over their back without assistance (and it must be remembered that the average Greek man was much shorter, too). Instead, Xenophon advises holding the horse's reins with the left hand and gripping the mane near the ears with the right to hoist oneself astride. Additionally, a soldier might use his spear for leverage and lift himself up that way. It was important not to rest the knee on the horse's back, but to get it entirely over for a clean seat (PH 7.1-3). While Xenophon's initial example advises mounting from the horse's left side, a military tradition resulting from the fact that cavalrymen carry their swords on their left hip, he also advises

\footnotetext{
1132 See Spence (1993), 43-49 on problems of instability.

1133 Xen. PH 7.5-7; Spence (1993), 46-9 and plates 7, 8, and 13 for illustrations of the chair seat versus the straight leg seat.
} 
practicing mounting from the right, so in case a man should find himself unmounted in battle he could leap on from either side as quickly as needed (PH 7.4). |

The use of snaffles and curbs to control a horse are well documented thanks to grave findings. Hyland discusses their use and notes that even the gentler ancient varieties would appear cruel by modern standards. ${ }^{1134}$ Among the Greeks, snaffles were more common, and a variety of bit types existed. A snaffle consisted of a nose band and bit, attached to the reins that control the horse as the rider pulls. Bit types varied, including straight bars and bars with hinges in the center. Others may have had blunt protrusions on them as well, but all snaffles permit the horse to open its mouth. Contrarily, the curb and psalion did not. The curb did not come into being until the Roman period, and it utilized more severe and painful force than a snaffle. Distinguished by use of leverage, the curb applied force to the cheek pieces and jaw of a horse when the reins were tugged, and in some cases the cheek pieces of Roman curbs were lined with studs on the interior. Hyland describes the function of a Roman bit when joined to a metal curb based on the example uncovered in Roman-occupied Thrace. It:

\footnotetext{
"has everything possible jammed onto it: a very high port, crush bar, internal accretions, and, what most lack, a true curb chain so designed that it could not lie flat and so had multiple pressure points. When the rein is activated the port hits the palate, the upper branch rotates pressuring the poll via the headstall, and the crush bar hits the delicate bones above the chin groove where the curb chain bites." 1135
}

This runs directly against Xenophon's advice. While he does not object to a sharp bit for training purposes, he advises that the goal is to compel the horse to obey with the gentler bit option (PH 10.6). Xenophon writes:

The mouth must neither be pulled so hard that he holds his nose in the air, nor so gently that he takes no notice. As soon as he raises his neck when you pull, give him the bit at once. Invariably,

\footnotetext{
${ }^{1134}$ Hyland (2013a), 505-506 with illustration fig. 23.3.

${ }^{1135}$ Hyland (2013a), 505 with fig. 23.3, depicted on left side; cf. Gaebel (2002), 25-28.
} 
in fact, as we cannot too often repeat, you must humour you horse whenever he responds to your wishes. And when you notice that high carriage of his neck and lightness of hand give him pleasure, you should not deal hardly with him as though you were forcing him to work, but coax him as when you want to stop; for thus he will break into a fast pace with most confidence. ${ }^{1136}$

The ancient warhorse wore more than tack into battle-occasionally it was armored, although how often is unclear. Xenophon suggests full coverage, which could not have been financially feasible for every horse-owner. Armor plating for the head, chest, and thighs was advisable, and especially for the vulnerable belly, which Xenophon says could be managed through longer saddle covers with thick quilting. ${ }^{1137}$ Softer leather muzzles existed for the transport of the horse, and Hyland suspects that they may have been used for battle as well. Xenophon instructs his readers to put a muzzle ( $\kappa \mu$ ó $\varsigma$ ) on any horse that is led about without a bridle, "for the muzzle prevents him from biting without hampering his breathing; and moreover, when it is put on, it goes far towards preventing any propensity to mischief." ${ }^{1138}$ Hyland suggests that in battle this may also have prevented horses from spreading panic through nervous whinnies, discouraging mass

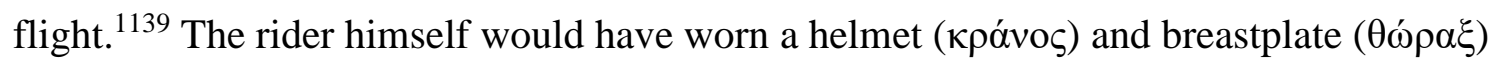
at the very least, although it is possible he carried a pelta as well. Xenophon suggests a full panoply for protection and lists of a series of costly purchases, including: a neck covering made separate from the breastplate to fit the throat, essentially an ancient gorget (PH 12.2), a finger-to-shoulder gauntlet (called simply a $\chi \varepsilon i ́ \rho)$ for the left arm (12.5), flaps $(\pi \tau \dot{\varepsilon} \rho v \gamma \varepsilon \varsigma)$ to cover the midsection where the breastplate ends (12.4), and a calf-skin guard for the underside of the right arm, to protect it when it is raised with the spear

\footnotetext{
1136 Xen. $P H$ 10.12-13.

1137 Xen. PH 12.8-9; Gaebel (2002), 28-29; Hyland (2013a), 509-510.

1138 Xen. $P H$ 5.3.

${ }^{1139}$ Hyland (2013a), 507.
} 
(12.7). The appearance of fully armored horse units, or cataphractarii, occurred under Hadrian in the second century CE, and the armor consisted of a chamfron and side plates. Hyland notes that the "oven men" or clibanarii were both fully armored as well, clothed in either leather or scaled armor. ${ }^{1140}$

\section{Tactics}

Because a discussion combined arms practices and Philip and Alexander's unique approaches to warfare appears above (p.423f.), primarily Greek, Classical Period tactics will be discussed here. South of Thessaly, cavalry became increasingly visible in the sources by the turn of the fourth century. A lack of horses made Xenophon's “Ten Thousand" vulnerable to sporadic Persian attacks in Anatolia, prompting Xenophon to create one from pack animals and skilled Rhodian slingers. ${ }^{1141}$ Spartan cavalry stumbled through the Corinthian war, fending off marauding Thessalian horsemen (Xen. Hell. 4.3.3-5) but failing to use its horses effectively against Iphicrates' peltasts, against whom heavily-armored hoplites were useless. ${ }^{1142}$ During the period of Theban ascendency, Boeotian cavalry played a starring role in the Theban victories at Leuctra and Mantineia, and the wisdom of Pelopidas and Epaminondas was undoubtedly passed down to the royal Argead hostage in Thebes, the future king Philip II. ${ }^{1143}$

There is no need to re-hash the role of cavalry in the numerous skirmishes and pitched battles of the above campaigns, but a word should be offered about cavalry

\footnotetext{
1140 Despite Xenophon's suggestions, the Greeks did not typically put armor on their horse, and certainly not as much as the cataphractarii and clibinarii. Armored horses are described by Heliodorus Aeth. 9.15 and, as they appeared among Persian troops, in Amm. Marc. 24.6, 25.1. Cf. Hyland (2013a), 509-510.

${ }^{1141}$ Gaebel (2002), 110-115; Xen. Anab. 3.3.16f.

1142 Gaebel (2002), 119-123.

${ }^{1143}$ Gaebel (2002), 129-140.
} 
tactics, especially given the oft-presented image of Greek combat as a hoplite affair. In his 2018 cultural study of Greek tactics, Konijnendijk discredits the long-held notion that the Greeks saw cavalry as ineffective in battle. The most commonly-cited explanation for this is Xenophon's speech to his men at Cunaxa (Anab. 3.2.10-32), who were anxious at the approach of the Persian horse. Xenophon reassured them that:

\begin{abstract}
"If anyone of you is despondent because we are without horsemen while the enemy have plenty at hand, let him reflect that your ten thousand horsemen are nothing more than ten thousand men; for nobody ever lost his life in battle from the bite or kick of a horse, but it is the men who do whatever is done in battles. Moreover, we are on a far surer foundation than your horsemen: they are hanging on their horses' backs, afraid not only of us, but also of falling off; while we, standing upon the ground, shall strike with far greater force if anyone comes upon us and shall be far more likely to hit whomsoever we aim at." 1144
\end{abstract}

Taken out of context, the passage appears to support the idea that cavalry is ineffective against hoplite forces because of a lack of thrusting power from a mounted warrior.

Worley and Konijnendijk have both pointed out that Xenophon would have known about the effectiveness of a well-trained cavalry against unsupported infantry, and in this case he is at pains to exhort his men to bravery. Later in the same campaign Xenophon recognized that his band of mercenaries would never survive without slingers and cavalry to assist in guarding their flanks as they marched. ${ }^{1145}$ In fact, horsemen could "make heavy infantry dance to their tune" 1146 if deployed correctly. At times infantry have taken great pains to avoid contact with cavalry, retreating to terrain that horses cannot manage. Konijnendijk points to the Battle of Lamia in 322, when the Macedonian forces withdrew from the plains to the rocky high grounds in fear of the Thessalian cavalry. ${ }^{1147}$ He notes that the presence of cavalry "shaped Greek warfare at both the strategic and the tactical

\footnotetext{
${ }^{1144}$ Xen. Anab. 3.2.18-19.

1145 Anab. 3.3.16; Konijnendijk (2018), 102; Worley (1994), 124-5.

1146 Konijnendijk (2018), 102.

${ }^{1147}$ Diod. 18.15.4, Konijnendijk (2018), 102-3.
} 
level,"1148 as the speed of the cavalry could turn any marching formation into an easy target and permit a small number of mounted men to contain or control a large body of foot soldiers. In evidence, he cites the defeat of the Argive rearguard by Phleiasian horsemen in 369 (Xen. Hell.7.2.4) and how a mere 50 Syracusan cavalrymen compelled the Boeotian army to advance or fall back on a whim by using javelins and cavalry speed (Xen. Hell. 7.1.21).

In fact there is a great deal that cavalry could do to disrupt or disarm infantry. While the image of mounted soldiers charging down the enemy at breakneck speed are a product of Hollywood, cavalry was used to break up hoplite formations in antiquity. Willekes notes that cavalry charges could not have occurred at all out springs because of the lack of seat security. ${ }^{1149}$ Without stirrups and a steady saddle, a rider would have no leverage to thrust a weapon out, and he certainly could not drive his horse blindly into a wall of spears. ${ }^{1150}$ To be effective, cavalry and infantry had to work together, advancing in an orderly (and moderately paced) fashion to make the most of their assault. Willekes points to Arrian's description of Alexander's cavalry charge at Issus as evidence (Arr. 2.10.3), in which he began at a marching pace in order to avoid disrupting the good order of the phalanx and causing one wing to advance too quickly. Upon reaching the enemy infantry, a cavalryman would have to cut through the ranks to fight, projecting force with his horse but not crashing into the frontlines at a full gallop. ${ }^{151}$

Cavalry's origins in the Archaic Period as half vehicle, half firing platform, still influenced hippeis' functionality in later years. Initially, horsemen advanced before the

\footnotetext{
1148 Konijnendijk (2018), 103.

1149 Willekes (2015), 50-51.

${ }^{1150}$ Cf. Spence (1993), 103-104.

1151 Willekes (2015), 50-51.
} 
hoplite phalanx and may have engaged the enemy by riding close and flinging javelins against them before riding off. Naturally the best attacks were on the flanks and rear of a hoplite phalanx, or exploiting any gaps created by ill-timed advances. ${ }^{1152}$ By the Classical Period this basic function had evolved to include a degree of coordination with infantry, and cavalry was viewed as a fully functional and necessary arm of the military. Iphicrates, famous for employing light-armed skirmishers in battle, once claimed that he did not view himself as a hippeus, archer, hoplite, or peltast, but as one capable of commanding all of those. ${ }^{1153}$ And certainly all of those elements were required in order to support the hoplites, who were the most vulnerable warriors on the field due to limited mobility and maneuverability. The shadow of the monolithic hoplite ethos so dominates scholarship that the ability of light-armed and mounted warriors to do damage to the phalanx is often ignored. As Konijnendijk points out, "we have little reason to assume that hoplites naturally ruled supreme in the sort of pitched battles in open ground that scholars tend to regard as the true form of Greek warfare." ${ }^{\prime 154}$ He points to battles like Spartolos (Thuc. 2.79.3-6) and Lechaion (Hell. 4.5.11-18) where light-armed warriors were successful in breaking up a hoplite phalanx despite level ground, and adds that cavalry had the same potential and could manage this with fewer numbers.

Cavalry faces the obvious limitations of terrain, training, and the physical strength of the animal. Pre-selecting an ideal battle site was key to effective cavalry use. A hippeus might be forced to abandon his horse if the terrain becomes impracticable; Xenophon recalled abandoning his own horse in Anatolia when the ground became too

1152 Worley (1994), 36-58.

${ }^{1153}$ Plut.Mor. 187b; cf. Konijnendijk (2018), 104

${ }^{1154}$ Ibid., 105. 
rugged (Anab. 3.4.49). It is for good reason then that he warns hipparchoi to use only the strongest men and horses if he anticipates the need for strategic retreat, as these animals, being well trained, would successfully escape the enemy. Otherwise "the men on the slowest mounts are bound to be taken prisoners; others to be thrown through lack of horsemanship; and others to be cut off owing to inequalities in the ground" (Hipparch.

\subsection{3; cf. 5.1).}

The physical limits of the warhorse could make or break an opening charge, making the regular dokimasiai in Athens a necessity. It is reasonable to assume that some equivalent of an annual horse dokimasia occurred in other Greek poleis as well, in order to ensure that warhorses would perform well. A soldier would become familiar with his horse throughout a period of training and should theoretically know how much the animal can handle. Xenophon advises that every hippeus have a good sense of an average horse's timing, so as to know how long it would take an enemy rider to cut down a man running on foot, and how much of a head start a slow horse needs to escape a fast one (Hipparch 5.1). He even suggests that the state double its current endurance requirements for the animal "so that any horse unable to keep up will be rejected" (Hipparch. 1.13). His point was not to abuse the animal, but undoubtedly to preserve its and its rider's lives. Spence points to the disastrous Cilician campaign of Demetrius Poliorcetes as a warning: he exhausted his horses through overwork and lost most of his cavalry on a forced march from his headquarters in Coele Syria to Malus, Cilicia. ${ }^{1155}$

The general contexts in which cavalry was used are well outlined and described in Spence's study, which he restricts to c. 450-300. A good military narrative of Hellenistic

${ }^{1155}$ Diod. 19.80.2, cf. Spence (1993), 39. 
cavalry, although without a separate study of Hellenistic tactics, may be found in Gaebel. ${ }^{156}$ As should be expected, most of the functions performed by Classical Greek cavalry were also carried out throughout the Hellenistic Period, at which time combined arms tactics became more common. However, before the Greeks achieved the "perfection of combined arms," ${ }^{1157}$ cavalry played effective supporting roles alongside infantry and even engaged in independent maneuvers.

\section{a. Supportive Role of Cavalry}

At the most basic level, horsemen were useful as protectors of infantry before, during, and after a battle. Hippeis guarded men on the march (see below) and sometimes served like a smoke-screen in front of infantry on the battlefield, making it impossible for the enemy to guess at a general's deployment strategy. However, cavalry was most regularly deployed on the wings in order to guard the exposed flanks of a phalanx. While the right flank is generally described as particularly vulnerable because men carried their shield on their left arm, a hoplite phalanx was really only equipped to defend itself from the front. ${ }^{1158}$ Lack of such protection when the enemy possessed cavalry could be devastating, as was the case for the Athenians in Syracuse at the 414 Battle of Epipolae (Thuc.7.61-4). As soon as the Spartan general Gylippus sent his cavalry to assault the Athenian left flank, "the cavalry attacked and routed the left wing of the Athenians, which was opposed to them; and the rest of the Athenian army was in consequence defeated by the Syracusans and driven headlong within their lines" (Thuc. 7.6.3).

However, Spence rightly stresses the difference between statistically common

\footnotetext{
1156 Gaebel (2002), 199-262.

1157 Wrightson (2015), 1598.

1158 Spence (1993), 151-153, cf. Thuc. 5.71.1.
} 
deployment patterns and necessary innovation. Ancient generals often adjusted their deployment based on considerations of terrain and enemy expectations and did not adhere blindly to conventional military wisdom. In cases where natural barriers like streams, gorges, and foothills already protected the flanks, cavalry could be placed before or behind the infantry, as was the case at Leuctra, where the Thebans paced their cavalry in the center, in advance of their infantry. For the Thebans this worked quite well, as their expertly-trained horsemen were able to thrust the Spartan horse back into the ranks of their hoplites. However, this formation could also be necessary based on topographical barriers blocking the wings. ${ }^{1159}$ On other occasions, generals have placed cavalry in front of infantry in an attempt to eliminate the enemy's numerically inferior cavalry, denuding the wings of his army and making the infantry vulnerable. Spence points to Pelopidas' use of this technique at Cynoscephalae in 364. ${ }^{1160}$

The cavalry charge is a particularly tendentious topic, but it formed a key part of a general's strategy. Because some scholars question the possibility of using shock tactics before the stirrup at all (above, p.439-440), Alexander's repeated success with his Companion Cavalry appears difficult to explain. Spence does so concisely: noting that the "popular concept of cavalry as a shock arm seems to have developed in the postclassical period from an erroneous perception of cavalry... as an irresistible force which charged across the battlefield and smashed into the enemy lines using its momentum and mass to ride down the helpless and hapless infantry,"1161 which is of

\footnotetext{
1159 The ancient sources for Leuctra are conflicting and confusing, cf. Xen. Hell. 6.4.9-15; Diod. 15.55-56; Plut. Pelop. 23; Paus. 9.13.3-12; Gaebel (2002), 129-132. Konijnendijk (2018), 24-37 offers a historiographical summary and thoughtful analysis of the problematic nature of the battlefield accounts. ${ }^{1160}$ Spence (1993), 153-154, Plut. Pelop. 32.2.

1161 Spence (1993), 104-105.
} 
course a gross exaggeration. Instead, the charge slowed before impact, as neither horse nor man would ride blindly into a wall of spears, and horses moved into the melee. Rather, the "shock" effect is psychological, not physical. ${ }^{1162}$ The imposing presence of an army of mounted soldiers charging against an infantry could force the line into retreat, to break off in places, or back up at an uneven rate, affording the horsemen small openings in which to use their spears. If the infantry line did not break, cavalrymen were obliged to begin hacking their way through by hand, creating openings by fighting with the front line soldiers, a tactic that was best managed with the wedge formation under Philip and Alexander. ${ }^{1163}$

If both armies possessed cavalry, horsemen would be pitted against fellow horsemen on the field. It was necessary to eliminate the most mobile threat, and cavalry only functioned well against infantry if they had total control of the field. Konijnendijk points to Epaminondas' forethought at Second Mantineia (362); the Theban general saw the Spartans forming their cavalry six deep in phalanx-like formation and ordered his own to form a significantly deeper column. Epaminondas reasoned that "when he cut through the enemy's cavalry, he would have defeated the entire opposing army; for it is very hard to find men who will stand firm when they see any of their own side in flight." ${ }^{1164}$ In order to ensure success, he placed light-armed infantrymen amid his cavalry, men called hamippoi who were meant to run alongside the horse and fight amid cavalry.

\footnotetext{
1162 Cf. Keegan (1977), 95-7, 154-60 as per Spence (1993), 105f.

1163 Spence (1993), 107-110; Spence (109 n. 259) also suggests that generals used the wedge formation for cavalry was used south of Scythia before Philip, including Epaminondas at Mantineia, based on Xen. Hell. 7.5.24.

${ }^{1164}$ Konijnendijk (2018), 111 citing Xen. Hell . 7.5.24; cf. Gaebel (2002), 139-140; Worley (1994), 146152.
} 
Second Mantineia serves as the sole extant account of how hamippoi operated in battle, and there is still some uncertainty regarding how often they were employed at all (Xen.Hell. 7.5.23-4; Diod. 15.85.4-5). Described as light-armed infantrymen who ran alongside the horsemen, perhaps by gripping at their manes, ${ }^{1165}$ this "nasty secret weapon"1166 of the cavalry supposedly worked to deplete the enemy cavalry by giving their own side another angle of attack. This appears a profoundly risky position for a light-armed runner, who would be subject to sword blows from overhead and horse hooves from below. Perhaps this is why hamippoi are so infrequently mentioned. Prior to Second Mantineia, they are described by Gelon of Syracuse in a list of forces that he promises to send to aid the Greeks against the impending Persian threat. ${ }^{1167}$ They are mentioned again at First Mantineia (418) at 500 in number amid the Boeotian cavalry (Thuc. 5.57.2). Konijnendijk has argued that Xenophon's insistence on their significance paired with infrequent reference is an indication that they were not a widespread military practice. ${ }^{1168}$ It is not until the late fourth century that it is certain the Athenian cavalry possessed hamippoi, ${ }^{1169}$ and in the Classical Period only the Boeotians are recorded using them. However, Worley suggests that they were a Boeotian innovation meant to work inside a loosely packed cavalry formation, and they were not unique to the Greeks. Caesar describes the Germans' use of a similar tactic in Gaul (B.Gall 1.48) as well as at Pharsalus amid his mercenary specialist forces (B. Civil.3.84). ${ }^{1170}$ Certainly it would take

\footnotetext{
1165 cf. Spence (1993), plate 10, a photo of a 4th century grave relief that depicts a psilos running alongside a hippeus and gripping the horse's tail, which Spence suggests is a hamippos.

1166 Konijnendijk (2018), 111.

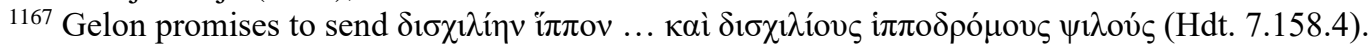

${ }^{1168}$ Konijnendijk (2018), 111; Xen. Hipparch. 5.13, 8.18-19, 9.7. Cf. Spence (1993), 54-55.

1169 Arist.Ath.Pol 49.1 cf. Spence (1993), 54-55.

1170 Worley (1994), 62-3; cf. Gaebel (2002), 139, who only references them at Second Mantineia and says little else.
} 
a hippotrophic people to establish this sort of tactic, as the hamippoi would need practice running in formation and dodging the enemy's swings and his horse's hooves. Unfortunately no record of this special force's success exists beyond the overall victory at Second Mantineia.

Another option for defeating enemy cavalry involved coordinating multiple units of the army in a cascading charge, one of the earliest examples of combined forces. In such an assault, the cavalry would lead the attack, followed closely by lighter armed foot soldiers and then the slower hoplites, with each successive "wave" of forces adding shock value to the battle. However, only the first few waves would be deeply involved in the battle. ${ }^{1171}$ Konijnendijk has collected a list of all recorded Greek battles in which the cascading charge is referenced, and the majority of them initiate with cavalry. The earliest example involving cavalry occurred along the Tigris, when Xenophon's men successfully used this assault method against the Persians in the order of cavalry, peltasts, hoplites. ${ }^{1172}$ By the middle fourth century, it appears more widespread, and Aeneas Tacticus recommends using it defensively in the same order employed by Xenophon: first the cavalry should cut off any means of retreat, light infantry should engage directly, and heavy infantry should be in pursuit immediately thereafter (16.7).

Once a battle had ended, cavalry played a crucial role in either securing a victory or salvaging a defeat. In the case of victory, it was the hippeis that did the most effective and long-lasting damage to the enemy forces by pursuing the fleeing infantry and cutting them down in the field. These, Konijnendijk notes, are the "real killers"1173 of the field.

\footnotetext{
${ }^{1171}$ Konijnendijk (2018), 111.

1172 Xen. Anab. 3.4.2-4; cf. Konijnendijk (2018), 111-112 and table 2.

1173 Konijnendijk (2018), 200.
} 
Because of a horse's comparative speed and endurance, a small number of riders could decimate a large retreating force of infantry and auxiliary troops. While the hoplites do the work of breaking the enemy phalanx by exploiting gaps created by cavalry shock tactics or light-armed missile-launchers, cavalry works to denude the flanks of support and attack hoplites where they were vulnerable, forcing a retreat. ${ }^{1174}$ Because obliterating the enemy's army was the goal of any battle — not merely winning control of the fieldcavalry was crucial in following up an immediate battlefield victory. It allowed the victors "to wipe out an enemy army rather than just breaking its will to fight," and once one army had decisively won, "pitched battle turned into the gleeful and systematic destruction of the enemy's ability to carry on the war." 1175 Consider for example the Battle of Delium (424), after which the entire Athenian army fled in some disorder. Thucydides notes that they were cut down "in particular by the cavalry," composed of Boeotian and Locrian horse, and the late hour and sunset were all that saved the routed Athenians from complete annihilation (Thuc. 4.96.7-8). The Thessalian forces of Alexander of Pherae were less fortunate. Following the death of Pelopidas in battle, his own allied Thessalian cavalry darted too late to his aid, but "charging up, routed the entire phalanx of the enemy, and, following on a great distance in pursuit, filled the country with their dead bodies, slaying more than three thousand of them."1176

However, cavalry also played a defensive post-battle role by screening either strategic retreat or flight. The Battle of Anapus River (415/4) in Syracuse is an excellent example of both post-battle functions of the cavalry and how problematic the Athenian

\footnotetext{
1174 Spence (1993), 151-157.

1175 Konijnendijk (2018), 195; seealso 188-205; Spence (1993), 157-62.

1176 Plut.Pelop.32.7; cf. Konijnendijk (2018), 200-202.
} 
lack of horsemen was throughout the Sicilian campaigns (415-413). Near Anapus River in Syracuse, the Athenians squared off against Syracuse and its cavalry, 1,200 strong (Thuc. 6.67.2). Before the battle, Nicias warned his men that they had no choice but to defeat the enemy, because if they were routed, escape was impossible: "we must conquer or hardly get away, as we shall have their horse upon us in great numbers" (Thuc.6.68.3). Fortunately for the Athenians, the interruption of a strong thunderstorm served as sufficient distraction to thrust back the Syracusan forces. A total rout however, was impossible because of the Syracusan horse. The Athenians were "held in check by the numerous and undefeated Syracusan horse, who attacked and drove back any of their heavy infantry whom they saw pursuing in advance of the rest."1177 Thus cavalry played a defensive role in the most crucial moment of conflict for both the victor and the vanquished and offered vital assistance to the infantry body that has so often been singled out for focus in studies of ancient combat.

\section{b. Independent Roles of Cavalry}

Cavalry played important defensive roles while operating independently as well. Because of their speed and capability of firing projectile weapons like javelins, hippeis could harass and slow down a phalanx without needing to penetrate or destroy it (Spence 126-33 on mobile defense). The best example of this is the role of Athenian cavalry throughout the Archidamian War (431-421). Pursuant to Pericles' plan to make Athens an island, drawing the people within the city walls to avoid pitched infantry battle against Spartan hoplites, cavalry was used to defend the farmland that lay outside the city (Thuc.

\footnotetext{
1177 Thuc. 6.70.3; cf. Spence (1993), 161-2,; Plut.Nic.16.4-5, who acknowledges a lack of cavalry as a
} weakness in the Athenian army and shows how it limited Nicias' victory 
2.22.2). A cavalry of $1,000^{1178}$ could not have been ubiquitous throughout Attica, but it was enough to prevent widescale destruction of cropland despite being outnumbered by the Spartan army. ${ }^{1179}$ The Athenians may have been more successful had Sparta not been aided by their Boeotian, Locrian, and Phocian allied cavalry, but any interference with the laborious task of destroying crops in Attica could have been effective. ${ }^{1180}$ Well after Pericles' death, mobile defense operations continued during the Deceleian War as well, when Athenian cavalry was sent out almost daily to prevent incursions from Spartanoccupied Deceleia (Thuc. 7.27.5).

In the pre-modern world, reconnaissance missions were primarily performed by cavalry, due to the necessity of stealth and speed. According to Xenophon, it was important for cavalry to move independently in order to scope out territory in advance of the rest of the army in order to locate the enemy and observe any changes in terrain or natural barriers that the army would soon be facing. ${ }^{1181}$ There is some suggestion in the Hipparchichus that reconnaissance of this nature was not a generally recognized facet of war, as Xenophon recommends it in the strongest terms "so that whole companies may not go astray" (Hipparch.4.4). Indeed, Spence laments a lack of historical examples before Alexander's Asian campaigns, but it seems reasonable to assume that armies often relied on local guides rather than marching blindly through unfamiliar territory (Spence 134).

Reconnaissance missions that pertained to the security of an army on the march

1178 Thuc. 2.13.8 includes the hippotoxotai, making a total of 1,200.

${ }^{1179}$ E.g. Thuc. 3.1.2; cf. Gaebel (2002), 92-95 on the Periclean policy of using a mobile cavalry defense.

${ }^{1180}$ Hanson (1983) and Spence (1993), 127-128 have both noted the difficulties of laying waste to farmland in Greece.

${ }^{1181}$ Spence (1993), 133-5; cf. Xen. Hipparch. 4.4-4.6 
are more commonly recorded. Cavalry was used to scout ahead and screen infantry when it was most vulnerable — on the move and out of battle formation. Despite Xenophon's recommendation to march in battle formation, topography would not always permit this (Hipparch 4.3). Indeed, Xenophon recognized the need for cavalry on his march through Anatolia when his infantry was routinely and effectively assaulted by light-armed and mounted Persian warriors (Anab. 3.3.16-20). While guarding the sides and rear of men in marching file, hippeis primarily worked at keeping any enemies armed with projectile weapons just out of firing range. ${ }^{1182}$

Cavalry may also have done well operating alone when raiding, where their speed and agility would allow them 'to penetrate and damage the enemy's territory with relative impunity." 1183 Because the Athenian cavalry was so successful defending farmland against Spartan incursions, it stands to reason that a more successful wartime raid could be managed with cavalry rather than infantry. Under Pericles' leadership early in the war, the Athenian army invaded the Megarid, raiding so successfully that they continued to do this annually, sometimes relying solely on cavalry (Thuc. 2.31.1-3). Indeed, the Athenians engaged in cavalry raids against Megara until 424 and the capture of the port city Nisaea (Thuc. 4.69.4). Xenophon advocates in particular for cavalry raids on armies, rather than cities, noting that the larger an army, the more apt it is to blunder, either by thinning out as men go their separate ways to forage, or by falling behind the rest of the army. In these cases, a small unit of horsemen would be enough to do considerable damage if they strike quickly and without warning. ${ }^{1184}$

\footnotetext{
1182 See Spence (1993), 141-151 on the role of cavalry in supporting roles and reconnaissance missions. 1183 Spence (1993), 135.

${ }^{1184}$ E.g. Xen. Hipparch. 7.8-10; cf. Spence (1993), 135-136.
} 
Spence asserts that ancient cavalry may have played a modest role in internal security, but the lack of a police force in Greek poleis, in addition to the general lack of space for cavalry operations within city walls, makes examples few and far between. The most notable is the use of cavalry by the Thirty. During the Oligarchic Coup of 404, cavalry was used to evacuate Eleusis and imprison its occupants, who were later executed by the hipparchus Lysimachus (Hell 2.4.36). Unsurprisingly the prestige of the hippeis in Athens plummeted for a generation after this debacle. ${ }^{1185}$ Generally speaking, horsemen operated well on the offensive or defensive, but required flat, open spaces in order to support infantry, ward off flank attacks, screen a strategic retreat, or pursue a post-battle rout.

\section{Conclusions to Chapters $9 \& 10$}

The above survey represents only a small slice of the considerable library of scholarship on the ancient Greek warhorse. The ways in which it functioned tactically are only a single part of the overall picture. The social role of the warhorse, which conferred the status of hippotrophos or hippeus on its master, also at times carried with it implications of political allegiances and elitism. Spence has convincingly shown that the use of cavalry by the Thirty to commit mass killings branded the cavalry as brutal, oligarchic, and dangerous to the democratic state. ${ }^{1186}$ The value of the horse market in the ancient world offers a viable lens through which to understand the political and

\footnotetext{
${ }^{1185}$ Xen. Hell. 2.4.8; Spence (1993), 136-7. On shifting Athenian attitudes toward the hippeis in this period see especially pp. 216-224.

${ }^{1186}$ E.g. Spence (1993), 164-230.
} 
economic maneuverings around the lush Krisaian Plain (Howe, 2003). The appropriation of the cavalry by the Athenian state led to a complex enmeshment of private ownership and state subsidies, as investigated by Bugh (1988) and Kroll (1977).

While sources on ancient cavalry are comparatively more abundant than other military animals, that should not stop scholars from using the copious studies of the ancient warhorse as a model to guide the close study of other military animals. Through the lens of human animal studies, the contexts of interaction between animals and humans in the ancient military sphere remain to be discovered and articulated. The degree of scholarly dedication to the study of the warhorse is not only reflective of the nature of the sources, but also of an early modern military tradition that privileges the visibility of the horses in the military sphere over numerous other animals. Only recently has that begun to change. The Hyde Park Animals in War Memorial discussed in the introduction pays due, if belated, honors to the numerous non-human combatants of Britain's many wars. The field of ancient human animal studies needs to follow this lead. The study of military animals offers more than objective details regarding tactical evolution and logistics - it illustrates the many and varied experiences of combatants, human and not, offering for analysis a considerably richer military landscape. Most of the ancient past will remain permanently blurred or entirely invisible to students of history. Therefore, we cannot afford to ignore or discard any approach to history that might afford us glimpses of the ways in which animals informed and influenced the combat experience of a martial society. 


\section{Summing Up: Final Conclusions}

In a special series of History \& Theory, entitled "Does History Need Animals?", environmental historian Brett Walker remarks that the question itself is indicative of a deep-seated problem within a number of academic fields. He asserts that "our reluctance to join the rest of the animal kingdom on its terms, on more natural terms, exposes a lingering devotion to human 'exceptionalism,' one that is inherent in the humanities and social sciences." 1187 The surge in popularity of social history in the post-war period made it academically acceptable, desirable, and necessary to go beyond the study of the politically powerful to consider persons of all social types, especially those who have been oppressed. This shift from the study of the political and economic elite to "history's sufferers" ${ }^{\prime 188}$ recognized new and subtle forms of agency that were no less potent while challenging traditional and engrained views of historical agency.

This expansion in scope largely halted, however, with the human animal. Considerations of environment and the numerous non-human beings that effected change in the past were limited to their direct interactions with man. This hampers the study of the past by applying conceptual blinders to the reader, who sees and understands only the role of the human. We read of cavalry, but much less of horses. Walker claims that "[animals] permeate our history and we theirs; tug at the threads and our stories, woven as they are into the same tightly knit tapestry, will not disentwine." 1189 Even though the

\footnotetext{
1187 Walker (2013), 45.

1188 Shaw (2013a), 4.

1189 Walker (2013), 49.
} 
barriers are numerous and the sources limited in perspective, cobbling together an image of the past must include human as well as non-human actors.

One of those barriers in particular is the issue of historical agency. If animals lacked it, could they in any meaningful way effect change or affect past events? If one defines agency narrowly and along a human bias, the answer would be no. Many animals display no evidence of the ability to reason, and none display at the level of the homo sapiens. But using the sole Aristotelian criterion for differentiating man from beastlogos - to likewise determine whether past actors possessed agency is self-defeating. Although much of my research above discusses the way humans used or employed animals, it should be abundantly clear that this is not the same as equating animals with tools. Indeed, we have seen that elephant agency often proved the undoing of well laid plans by the Diadochs. The unique bond between man and dog made collaboration possible within the high-stress circumstances of the hunt and of war. More importantly, all of the above studies emphasize human reliance on animal participants in the military sphere, making them critical features of the martial landscape.

Shaw defines the agent or historical actor in the most basic sense as "someone without whom things, especially a particular doing, might have been significantly different," 1190 and concludes that the contributions of animals, especially to war (his focus of study), means that agency must exist along a continuum. He rightly stresses that rational agency is not the sole or key facet of historical agency, but equates it to one spine on a "starfish" of agency. ${ }^{1191}$ After all, when animals act, they do so with a purpose, even if it might not correspond cleanly with human purpose within the context of the

\footnotetext{
1190 Shaw (2013b), 148.

${ }^{1191}$ Ibid., 151.
} 
moment. ${ }^{1192}$ Shaw's overall argument for "unities," or the creation of a combined agent consisting of human and animal, leads him to conclude that ultimately animal agency always involves humans. I suspect that this is too narrow a definition, but as his study derives from the focus on animals engaged in human warfare, it is contextually appropriate.

Because my dissertation is similarly focused, the question of intentionality and rationality is less significant. I have sought to consider, in the most basic sense, the impact that understudied animals have had on the phenomenon of human warfare in the ancient past. In the above ten chapters, I have discussed the roles of war elephants, camels, canines, and horses, the four animals which Shaw claims are the most prominent co-species to humans within the framework of war. ${ }^{1193}$ I have drawn the general conclusion that their participation significantly affected, for better or worse, the outcome of human wars; specific conclusions have varied by category. We have seen that the use of war elephants, in the Indian tradition, was fundamentally irreconcilable with Greek phalanx warfare. A combination of physiological and behavioral qualities of the elephants themselves, in addition to the Macedonian practice of relying on the projection of force through cavalry strikes and the distancing element of the sarissa, made elephants a greater wartime burden than benefit. Only in unique cases and against unfamiliar foes were elephants especially useful in battle, and the psychological impact of their deployment was not guaranteed.

However, the Indian tradition of close affiliation between king and elephant was

\footnotetext{
${ }^{1192}$ Cf. Ibid., 156f.

${ }^{1193}$ Shaw (2013b), 149. Sciatur that I discovered this article during the final edit of my dissertation, and its contents assisted in fleshing out my concluding statements. The reference to commonplace battlefield agents was a happy coincidence.
} 
adopted by Greeks with far greater success. The animals served as a talisman in battle, both a reminder of Diadoch generals' success in the formerly mythic world of India and also a promise of martial strength and stability, a persuasive device used to (make the Diadochs appear worthy kings). The association of Alexander with the elephant was used by the first generation of Hellenistic generals-turned-kings to establish their legitimacy. Depictions on coinage and at least a few statues are strongly suggestive of the close entanglement of elephant, Alexander, and Diadoch imagery. Public displays in the empires of the Seleucids and Ptolemies routinely featured elephants. Parades advertising foreign and exotic tribute, martial strength, and, under Philadelphus, the legacy of Alexander and Ptolemy Soter, used the elephant as one of several potent symbols. But such displays were not, as we have seen, limited to the domestic sphere - the deployment of elephants in the many wars between the Ptolemies and Seleucids became routine, expected. An elephant corps, whether of Indian or African animals, was an ante necessary to meet. Against foreign invaders like Rome, or natives, like the people of Judea, the mighty display of the Seleucid elephant was a threat and reminder of the crushing power of the dynasty's military arm. Even as enemies found ways to cope with elephant warfare, Hellenistic kings continued to deploy them.

We have also investigated the less menacing but equally intrepid camel, of both the Arabian and Bactrian variety. While these animals are often sidelined in studies of ancient Greek warfare, the above investigation has given good reason to reverse that pattern. While only the Arabs ever created a successful and permanent camel corps (with due honors to Cyrus' “impromptu” brigade), Alexander's army readily incorporated both dromedaries and Bactrian camels into their military menagerie in the interest of 
efficiency and skill diversification. Both Philip and Alexander are well known for their integration of a wide range of specialist troops on the field, operating under the modern theory of combined arms. The highly mobile archer Agrianians, Indian mahouts, and skilled siege engineers represent only the human fraction of the Macedonian army's specialized forces. I have argued above that camels merit inclusion in this category as well, even if the Macedonians never conceived of them with this specific terminology. Their abilities to weather some of the most extreme ecosystems on the planet made them an important addition to the army. Despite Engels' dismissive attitude toward dromedaries and general neglect of the Bactrian, a survey of modern zoological studies has proven that the camel's sturdy response to extreme temperatures, aridity, and water or food shortages made them literal life savers on several occasions for Macedonian troops and, en route to Siwah, for Alexander himself. In addition to their doughty resilience, camels served in a less dramatic (but no less significant) capacity as pack animals and messengers, crossing desert regions that would take a relay team of horses considerably longer. While reference to the camel is often lost in the ancient Alexander narratives, which at times leave out key logistical details and the roles of beasts of burden, the above research has shown that they merit greater consideration, and a study of their own.

A study of the dog in ancient combat is long overdue, with Forster's 1941 article the most recent to give due credit to the ancient Greek military canine. Above, I have made a start to such study in my dissertation, where I argued that by expanding our consideration of a military dog from an attack dog that stands at the front lines to a dog that assists in military endeavors (much like the service canine of present day), we will find that the dog is quite visible to us in the military arena of Ancient Greece. Archaic 
and Classical depictions of canines in military settings proves that they were present within the sphere of war, if not on the front lines of battle. Far from slavishly copied decorative patterns or meaningless afterthoughts, canines depicted in military scenes on Attic pottery reflect an aspect of ancient life that the artist took for granted and modern viewers overlook. Dogs are portrayed on vases in a great variety of shapes, sizes, and postures, most of which accurately reflect actual canine body language. By using a survey of the Beazley Archive to sift through and categorize numerous vases, I have shown that canines are integrated carefully into departure scenes, military marches, and even depictions of charges. An investigation of later Classical and Hellenistic discussions of Ionian traditions of battlefield dogs and the use of canines in auxiliary military activities drives home the point. Dogs were unquestionably participants in warfare.

The most visible non-human participant in ancient battle was, of course, the horse. My survey of the warhorse above outlined the numerous and varied functions of ancient cavalry, highlighting the flexibility and versatility of the horse. Its evolution from a chariot-puller to a mount for an armored cavalryman, and the debates surrounding this transformation, are evidence of an early human recognition of the horse's value in combat. It was through the perfection of Shaw' horse-human "unity" that many scholars argue Philip and Alexander revolutionized ancient combat. As a result, a study of the two halves of that "unity", soldier and horse, rather than simply "cavalry," would be worthwhile. In the future, I should like to expand this research to include the intersectionality of the horse as a war mount and companion animal, drawing comparisons with the dog. Chapters 9 and 10 do not offer this, but are intended to serve as a point of comparison for the prior three studies, representative of the extent to which 
the warhorse has been investigated as well as the distance that considerations of other military animals need to go.

Although a study of animals within the field of history will always be hindered by the problematic nature of the human-centered source, it is imperative to forge ahead through the venues the evidence permits. The modern estrangement from the natural world through urbanization and technological innovation does not represent the ancient experience, and by excluding or failing to consider the roles of animals we limit ourselves to vignettes of the past. Considering non-human actors brings us closer to a panorama. So, it is necessary and best to flesh out as much of the ancient landscape and experience as possible, and this inevitably draws us to the study of animals. Shaw answers History \& Theory's question neatly:

\footnotetext{
"We have usually made 'our' history not by ourselves alone, but with our intimate allies, our assemblages, with interagency, and among unities, that is, with uncanny animals, the historical animals, whose presence historians should find and write into their accounts. To understand the history people have made really does require animals." 1194
}

${ }^{1194}$ Shaw (2013a), 11. 


\section{Appendix 1: Images}

NB: As noted in the introduction to the dissertation, photos will not be included in the published version of the dissertation due to copyright. While the members of the Dissertation Committee have access to them for purposes of evaluation, below I will cite the bibliographic information associated with each image so that the reader may locate it.

\section{Image 1.1}

Elephas maximus maximus

Photo of Indian elephant family in the

Kaziranga National Park of Assam, India

Source: World Wildlife Fund

\section{Image 1.2}

Elephas Africana Africana (African bush elephant)

African bull elephants at watering hole in Zimbabwe

Source: World Wildlife Fund, photographer Herve Morand

\section{Image 1.3}

Elephas Africana cyclotis (African forest elephant)

Photo of African forest elephant in Gabon.

Source: World Wildlife Fund, photographer Herve Morand

\section{Image 1.4}

Alexander's "Porus medallion," one example. Obv. Macedonian

cavalryman charging elephant. Rev. Alexander (?) holding the thunderbolt.

Source: Stewart (1993), fig 69

\section{Image 1.5}

Other variations of the "Porus medallions." Left is similar to Image 1.4; right shows $o b v$. Indian archer with longbow, rev. Indian elephant.

\section{Images 1.6-1.8}

Image 1.6- Silver tetradrachm of Seleucus I, Susa mint, c. 298-280. Obv. Profile of Zeus; rev. Athena in elephant-drawn chariot.

Image 1.6- Gold stater of Ptolemy I, Cyrene mint, c. 304-298. Obv. Profile of Ptolemy. Rev. Alexander with thunderbolt in a chariot drawn by elephants.

Image 1.7- Silver tetradrachm of Antiochus III, Nisibis mint, c. 204-200. Obv. Profile of Antiochus with diadem. Rev. Indian elephant.

Source for all: Morkholm (1991), figs. 135, 122, 357.

\section{Image 3.1}

(Left)- Alexander's Zeus-Heracles tetradrachm, re-minted by Ptolemy I. Minted at Alexandria. Obv. Heracles in the Nemean lion scalp. Rev. Zeus seated on throne holding eagle.

(Right)- Ptolemy I's Alexander-Athena tetradrachm, date debated. Minted at Alexandria. Obv. Profile of Alexander in elephant-skin cap; rev. Athena Promachos and Ptolemaic eagle.

Source: Morkholm (1991), figs. 91-92. 


\section{Image 4.1}

Pair of Bronze statuettes depicting Arsinoe II (left) and Ptolemy II Philadelphus (right). Ptolemy wears the elephant-skin cap and carries the studded club of Heracles.

Source: Kyrieleis (1975), plate 9, fig. 1.

\section{Image 4.2}

Bronze statuette of cavalryman with elephant-skin cap and chlamys. Possibly Alexander.

Source: Kyrieleis (1975), plate 10 fig. 1

\section{Image 5.1}

Bactrian camels on the Mongolian steppe.

Photo credit: World Wildlife Fund

\section{Image 5.2}

Bactrian camel in winter.

Photo in Great Gobi Strictly Protected Area,

Park A, Mongolia.

Photo credit: Edge of Existence Programme of the Zoological Society of London

\section{Image 5.3}

Bactrian camel and calf shedding

Photo in Great Gobi Strictly

Protected Area, Park A, Mongolia

Photo credit: Edge of Existence (Zoological Society of London)

\section{Image 5.4}

Dromedary riders of the FFCBD (fédération Française des chameaux de Bactriane et des dromadaires).

Photo Credit: FFCBD

\section{Image 5.5}

Dromedary imported to Australian Outback

Photo Credit: Emma Marris, Oct. 2017, writer for National Geographic.

\section{Image 5.6}

A herder and his dromedaries at the Pushkar Camel Fair in Rajasthan, India.

Photo Credit: Annapurna Mellor, 2018

\section{Image 5.7}

Attic black figure skyphos depicting two youths and a Bactrian camel

Munich, Antikensammlungen: 2008

Beazley Archive \#310291

c. $575-525$

\section{Image 5.8}

Attic red figure pelike depicting a rider on a Bactrian camel with oddly dromedary-like features. Wurzburg, Universitat, Martin von Wagner Mus.: H4803

Beazley Archive \# 216607

c. $450-400$ 


\section{Image 6.1}

Map of Alexander's journey to Siwah

Out of Romm (2012), 100.

\section{Image $7.1 \rightarrow$ (right)}

Molossian hound marble sculpture from Kerameikos

Photo credit: Ian Worthington

Kerameikos Archaeological Museum

P670

\section{Image 7.2}

Athenian red-figure chous fragment depicts baby crawling to small dog. Munich, Arndt

Beazley Archive Number 4198

c. $450-400 \mathrm{BCE}$

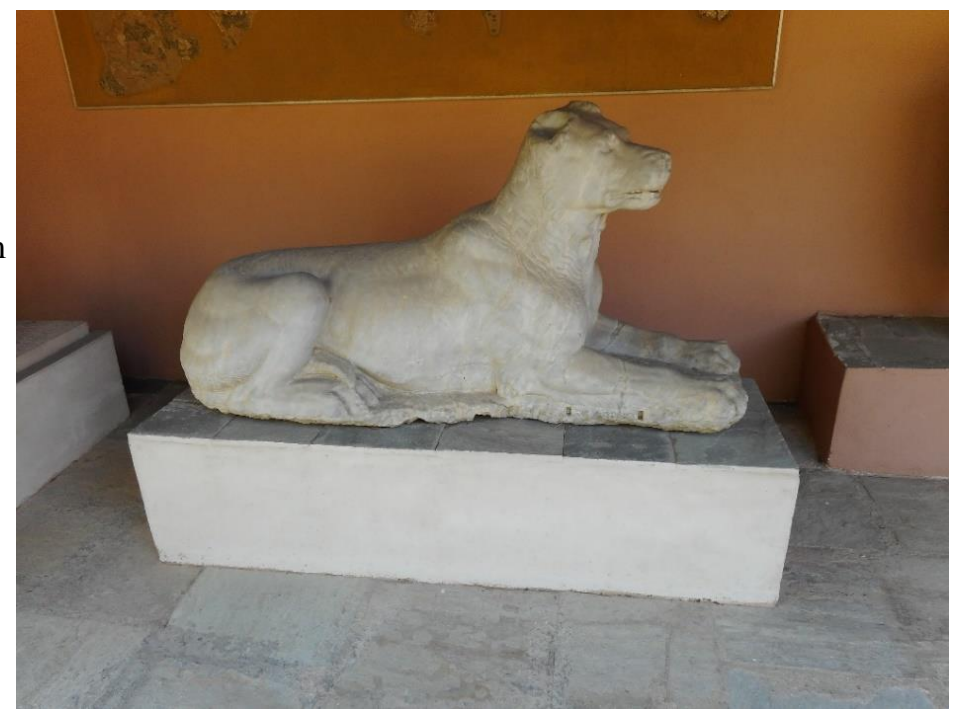

\section{Image 7.3}

Athenian red figure chous depicts toddler playing with small dog

Brussels, van Branteghem

Beazley Archive Number 4199

C. $450-400$

\section{Image 7.4}

Athenian red-figure chous depicts mother holding child up to grapes while dog begs.

Erlangen, Friedrich-Alexander-Universitat: I321

Beazley Archive Number: 10227

c. $450-40 \mathrm{BCE}$

\section{Image 8.1}

East Frieze of the Altar of Zeus at Pergamum

Depicts the Gigantomachy and shows here Hecate and her torch (left) and Artemis (right) with a large Molossian hound attacking the head of a giant.

See Schmidt (1965), fig 15 and Bruns (1965), figs 18-19.

\section{Image 8.2}

"Full Cry" fox hunt impressionist portrait

By Heywood Hardy

\section{Image 8.3}

"Translation" guide to common canine postures and body language Source: DFDK9.com, Dogs for Defense

Found in: Kitchell (2020), fig. 5 p. 11.

\section{Image 8.4}

Claozmenian Sarcophagus fragment of warriors marching and dog.

British Museum

Museum Number: 1886,0326.1

c. $525-515 \mathrm{BCE}$ 


\section{Image 8.5}

Attic black figure olpe depicts departure of warrior with dog.

Rome, Musei Capitolini

Beazley Archive Number: 351432

c. $525-475$

\section{Image 8.6}

Attic black figure amphora depicts departure of chariot warrior with dog.

Antikensammlungen (Munich)

Beazley Archive number: 301840

c. $550-500$

\section{Image 8.7}

Attic red figure hydria depicts departure of warrior and frightened dog.

Benaki Museum, Athens

Beazley Archive number: 9029956

c. $475-425$

\section{Image 8.8}

Attic black figure hydria depicts departure of warrior and dog lying down.

London, British Museum, number 1843.1103.88

Beazley Archive Number: 200166

c. $550-500$

\section{Image 8.9}

Attic black figure lekythos depicts departure of warrior and dog (on shoulder).

Athens, National Museum

Beazley Archive number: 301145

c. $575-525$

\section{Image 8.10}

Attic black figure hydria depicts soldier flanked by archers and dog, static military scene.

Glasgow, Sir William Burrell Collection 19.59

Beazley Archive Number: 9464

c. $525-475$

\section{Image 8.11}

Athenian red figure lekythos depicts warrior and a dog pawing a foreign archer.

St. Petersburg, St. Hermitage Museum: 671

Beazley Archive Number: 203132

c. $500-450$

\section{Image 8.12}

Attic black figure hydria depicts woman gripping warrior's arm as he turns to face dog; dog looking away. New York, Metropolitan Museum: 41.162.234

Beazley Archive Number: 305535

c.550-500 BCE 


\section{Image 8.13}

Athenian black figure amphora depicts departure of warrior; warrior pets horse beside dog.

Northampton, Castle Ashby

Beazley Archive Number: 303388

C. $550-500$

\section{Image 8.14}

Athenian black figure amphora depicts warrior mounting horse in armor; dog leaps in foreground.

Oxford, Ashmolean Museum, 1884.710

Beazley Archive Number: 361410

c. $525-475$

\section{Image 8.15}

Athenian black figure amphora depicts mounted warrior and dog running alongside.

Berlin, Schloss Charlottenburg, 4823

Beazley Archive Number: 300757

c. $575-525$

\section{I mage 8.16}

Athenian black figure amphora depicts mounted warrior and dog running alongside.

Tubingen, Eberhard-Karls-Univ., Arch. Inst.: S101298

Beazley Number: 300758

c. $575-525$

\section{Image 8.17}

Athenian black figure hydria depicts warrior and dog running alongside chariot.

Nimes, Musee Archaeologique, D863.1.8

Beazley Archive Number: 351210

c. $525-475$

\section{Fig. 8.18}

Athenian black figure amphora depicts warrior and charioteer in chariot, dog running alongside.

Berlin, Antikensammlung: F1716

Beazley Archive Number: 310322

c. $575-525$

\section{Image 8.19}

Athenian black figure lekythos, white ground depicts departure of mounted warrior, dog walks alongside.

Beazley Archive number: 351621

Basel, market, Munzen und Medaillen A.G.

c. $525-475$

\section{Image 8.20}

Athenian black figure lekythos, white ground depicts departure of mounted warrior, dog walks alongside. Neuchatel, Seyrig

Beazley Archive Number: 351622

c. $525-475$ 


\section{Image 8.21}

Athenian black figure amphora depicts departure of warrior in chariot, dog leaps alongside.

London, British Museum, 1843.11-3.14

Beazley Archive Number: 302121

c. $550-500$

\section{Image 8.22}

Athenian black figure cup depicts march of Amazons, horse, and dog walks alongside.

Orvieto, Museo Civico, Coll. Faina: 2599

Beazley Archive Number: 9654

c. $550-500$

\section{Image 8.23}

Athenian black figure oinochoe depicts march of mounted warrior, archer, and dog, who sniffs archer's belt pack.

Laon, Musee Archeologique Municipal: 37.972A

Beazley Archive Number: 306812

c. $525-475$

\section{Image 8.24}

Athenian black figure amphora

Glasgow, Sir William Burrell Collection: 19.59

Beazley Archive Number 9464

c. $525-475$

\section{Image 8.25}

Athenian black figure amphora

Rome, Candelori Collection

Beazley Archive Number: 1480

c. $550-500$

\section{Image 8.26}

Athenian black figure amphora depicts mounted page, warriors, archer, and large dog by horse.

Geneva, Musee d'Art et d'Histoire: 14989.1937

Beazley Archive Number: 5695

c.550-500

\section{Image 8.27}

Athenian black figure amphora depicts warrior mounting horse alongside naked youths; dog on leash leaps. St. Petersburg, State Hermitage Museum: 161

Beazley Archive Number: 310442

c 575-525

\section{Image 9.1}

Bronze votive statuette of mare and foal

Found at Olympia

New York Metropolitan Museum of Art 1999.526

Image from Llewellyn-Jones and Lewis (2018), 135.

c. late $8^{\text {th }}$ century 


\section{Image 9.2}

Black Figure Attic krater depicts warrior, attendants, and horse in departure scene

Tampa Museum of Art 1981.005

Beazley Archive \#4367

c. $575-457$

\section{Image 9.3}

Corinthian aryballos depicts mounted warrior, which Greenhalgh interprets as a rare mounted hoplite in battle.

Photo in Greenhalgh (1978), 87 fig. 48

Photo credits: Perachora vol. 2 no. 1590, pl. 61.

c. $7^{\text {th }}$ century

\section{Image 9.4}

Ivory fibula plaque depicts an armored warrior with hoplon and spear riding a horse with a bridle and reins. Greenhalgh interprets as mounted hoplite.

Photo in Greenhalgh (1978), fig. 49 p. 95.

Photo credits not listed.

c. late $7^{\text {th }}$ century

\section{Image 9.5}

Corinthian cup depicts hoplites in battle with riders behind them, which Greenhalgh interprets as mounted squires holding the hoplites' horses for them.

Photo in Greenhalgh (1978), fig. 50 p. 97

Brussels, Musées Royaux d'Arte et d'Histoire

c. $6^{\text {th }}$ century

\section{Image 9.6}

Dorylaeum Stele

Archaic funeral stele depicting horseman, squire, and front foreleg of dog on left edge.

From Schede (1928), pl. 2.

\section{Image 10.1}

Athenian black figure Lid fragment depicting horse's nose and bridle

Athens, Agora Museum P25268

Beazley Archive number: 31231

c. $650-600$ 


\section{Appendix 2: A Note on the Camel Use of the Diadochs}

Of all the Successor dynasties, the Ptolemies would have had the easiest access to dromedaries due to their close proximity to the Nabateans, who appear to have constituted the primary camel dealers for Alexander's successors. However, there was no restriction of trade. It was from Arabs that Antigonus Monophthalmus acquired his pack camels for his attempted invasion of Egypt. ${ }^{1195}$ His was to be a two-pronged invasion; Antigonus marched from Antongeia through Coele Syria with his troops, and his son Demetrius followed with the armada along the coast until they met at Gaza. Eager to attack before Ptolemy could prepare a defense, Antigonus left from Gaza with a reported 130,000 medimnoi of grain and animal fodder, all packed on camelback. (Diod. 20.7374). This is an impossible number. If calculated in terms of wheat grain, it would have required over 23,000 camels to transport. There is not however any reason that we should disbelieve Antigonus' employment of camels. He planned his march through the notoriously dangerous Barathra region, in which the sure-footed camel would have been an asset. The so-called "Pits" were famous for quicksand and hidden lakes, which destroyed part of the army of Artaxerxes. ${ }^{1196}$ Although ultimately thwarted by Ptolemy's quick garrisoning of landing points, Antigonus' troops made the trek through the wastelands and, in retreat, quickly back again (Diod.20.76.4-6).

${ }^{1195}$ Worthington (2016), 165-166; Champion (2014), 124-129.

${ }^{1196}$ In order of reference: Diod.20.73.3; Diod.1.30, Diod.16.46.4-5. 
Ptolemy II Philadelphus, the son and heir of Alexander's general, was reportedly the first to cut a road, by means of an army, for the camel-led transport of goods to the Red Sea and Coptus. He installed overnight watering stations in underground cisterns to facilitate trade travel (Strabo 17.1.45), continuing his father's policy. ${ }^{1197}$ Philadelphus' roads must have still been in use by Strabo's time in the first century BCE/CE, indicating a mercantile economy at least partially powered by camelwork. As we have already seen (p.234), Demetrius' foray into the Nabatean Arabs' territory resulted in unsuccessful conquest but the capture of some 700 camels, a worthy prize (Plut.Demetr. 7.7).

By the reign of Antiochus III, camels appear in the front lines of battle. The formation of the Seleucid line at the Battle of Magnesia reveals the breadth of Antiochus' empire and the great variety of specialized troops within it. Among the elephant corps, Phrygian peltasts and Dahae archers were Arabs who rode on swift dromedaries, armed with bow and arrow and, for close combat, long thin knives (App.Syr.6.32). This is the first reference to a plausible bladed weapon wielded from camel back, and it is unfortunate that Appian provides no further details. Unfortunately for Antiochus, the Arabian camel corps does not appear to have inspired the same fear in the enemy cavalry that Cyrus' did. In fact, Antiochus' close imitation of ancient Persian tactics may have cost him the battle. The horses drawing his scythed chariots were thrown into disorder by the Romans, resulting in the veering of these vehicles too close to the camel corps, which broke apart (App.Syr. 6.33-34), although as we have seen (pp.161-166), it was ultimately the elephants that cost the Macedonians the battle.

${ }^{1197}$ Worthington (2016), 194-196. 


\section{Appendix 3: Summary of Beazley Archive Dog and Warrior Scenes}

What follow below are a series of charts containing my findings from the survey of the CARC's Beazley Archive of pottery. I have provided a general guide to the subcategories of identification that I used to sort and analyze the images. Sub-categories which are used in the analysis of every scene type are described only under heading $\mathbf{I}$. While I acknowledge that "reading" ancient art is ultimately subjective, I proceed on the assumption that a reasonable individual (ancient or modern) could view the image and understand what was happening. In the interest of full transparency, I have provided the organizational components below as well as a means of accessing the images in question. Due to space constrains however, I was not able to include my detailed notes on all 156 pots.

NB: While the majority are not, some of the vessels depicting military scenes are mythical in nature, and these have been included too. The departure/return scenes featuring Ajax bearing Achilles' body often contain a dog, and they have been counted as well.

\section{Departure Scenes (Table 8.1)}

Vase Number- This refers to the Beazley Archive catalogue number so that readers may locate and view all vases with ease.

Dog near warrior? - The spatial location of the dog is crucial in determining whether it is understood to be departing with the warrior or remaining at home, although this factor alone is inconclusive. Descriptions in this category include "yes," "no," as well as more specific notations as to where the dog is located. The use of "equidistant" means the dog is standing between a representative of the household (e.g. old man or woman figure) and 
the warrior. Often the dog is shown farther from the household leading the chariot horses away

Dog posture- Based on the DFDK9 and Kitchell's (2020) analysis, which shows dogs were often portrayed with situation-appropriate body language. Because fragmented images often fail to show the whole of the dog, its posture is determined as best is possible. In cases where the forelegs and head of the dog are visible but the tail is lost, for example, one may be unable to determine whether the dog is simply alert, or also dominant. Generally the key words affiliated with the DFDK9 chart are used, although in some cases other descriptors are added, e.g. "running," "sniffing," or "attentive" based on a clearly visible action the dog is performing.

Age: The age of the vessel is estimated to a fifty year period. I rely on the dating of these pots by the archaeologists of the Beazley Archive.

Shape: The type of vessel on which the image was found. "Fr." Indicates a pot fragment.

Fabric: The fabric is abbreviated; $\mathrm{ABF}$ is "Athenian black figure" technique, and ARF is "Athenian red figure" technique.

Provenance: If known, the provenance is listed.

Dog Type: Rather than try to describe the dog in the image by naming the ancient breed (which is usually impossible), I describe the animal's width and height. The dog may be lean or stout, and may be short, of medium height, tall, or, in a few cases, lion-sized. Naturally the difference between a dog of medium and tall height is somewhat subjective, and the reader is welcome to investigate each cited image for her- or himself.

Dog "with" the warrior? The final category contains a "yes," "no," or "unclear" label based on my reading of the pot and considerations of the dog's location relative to the warrior and overall body

\section{Static Military Scenes (Table 8.2)}

This chart contains many of the same categories as the Departure Scenes chart. An addition to the category is the question Mythic?, as a few scenes depict mythological military scenes.

\section{Military March or Charge Scenes (Table 8.3)}

This chart contains several distinct categories.

Scene Type: Because the category indicates a martial scene in which movement or rapid movement is indicated, the nature of the scene is labeled here. This category may include 
labels like "charge," "march," "escape" (e.g. Aeneas' escape from Troy), and the popular ambush of Troilus by Achilles scene, abbreviated "ambush of Tr."

Cook's Pattern?: This category considers whether the image of a charge mirrors the Syrian pattern Cook (1950) describes, which consists of a hound running beneath or alongside a horse or chariot.

\section{Dogs on Shields (Table 8.4)}

This chart contains one new category

Warrior type: Although the dog serves only as a decoration on a shield, the warrior type is noted. In almost all cases, the warrior appears to be a hoplite, and in one case, he is an archer. Other labels include "mythical," when the warrior is part of a mythological scene, or "Achilles," who merits his own category.

Dog type: While this category is unchanged from those above in terms of descriptive terminology, it is limited. Because the dog appears on a shield and not next to live individuals, its height is especially difficult to identify.

\section{Varia Scenes with Dogs (Table 8.5)}

This category includes scenes which feature motifs of armed warriors and dogs, but which are not immediately or easily classifiable as military, although they are often related.

Scene type: Vases have been placed in this category because the scene depicted is not easily identifiable, so what appears in this column is often the interpretation of the archaeologists of the Beazley Archive. Category types include "extispicy," possible departure scene, and particular mythological scenes that occur within a military context.

Dog "with" warrior?: Because these scenes are more difficult to parse, I have added this category as with Table 8.1 in order to determine whether dogs appear to be participating in the same activity as the warrior. This varies by scene type. 
Table 8.1 Departure Scenes Featuring Dog and Warrior Motifs

\begin{tabular}{|c|c|c|c|c|c|c|c|c|}
\hline $\begin{array}{l}\text { Vase } \\
\text { Number }\end{array}$ & Dog near warrior? & Dog posture & Age & Shape & Fabric & $\begin{array}{l}\text { Provena } \\
\text { nce }\end{array}$ & Dog Type & $\begin{array}{l}\text { Dog "with" } \\
\text { warrior? }\end{array}$ \\
\hline 169 & yes & alert & $575-525$ & cup & $\mathrm{ABF}$ & Etruria & $\begin{array}{l}\text { lean, middle } \\
\text { height }\end{array}$ & yes \\
\hline 1017 & yes & neutral & $550-500$ & amphora & $\mathrm{ABF}$ & Etruria & $\begin{array}{l}\text { lean, short } \\
\text { height }\end{array}$ & yes \\
\hline 1474 & yes & anxious/neutral & $550-500$ & amphora & $\mathrm{ABF}$ & $\mathrm{n} / \mathrm{a}$ & $\begin{array}{l}\text { stout, large } \\
\text { height }\end{array}$ & yes \\
\hline 1480 & yes & dominant & $550-500$ & amphora & $\mathrm{ABF}$ & Etruria & $\begin{array}{l}\text { lean, short } \\
\text { height }\end{array}$ & yes \\
\hline 2186 & no & running & $550-500$ & plate & $\mathrm{ABF}$ & $\mathrm{n} / \mathrm{a}$ & $\begin{array}{l}\text { lean, short } \\
\text { height }\end{array}$ & no \\
\hline 3891 & directly behind & dominant & $550-500$ & amphora & $\mathrm{ABF}$ & $\mathrm{n} / \mathrm{a}$ & $\begin{array}{l}\text { lean, middle } \\
\text { height }\end{array}$ & unclear \\
\hline 5445 & no & neutral & $550-500$ & amphora & $\mathrm{ABF}$ & $\mathrm{n} / \mathrm{a}$ & $\begin{array}{l}\text { lean, short } \\
\text { height }\end{array}$ & unclear \\
\hline 5728 & yes & begging & $550-500$ & amphora & $\mathrm{ABF}$ & Etruria & $\begin{array}{l}\text { lean, middle } \\
\text { height }\end{array}$ & yes \\
\hline 6805 & no, leading horses & alert & $550-500$ & krater & $\mathrm{ABF}$ & $\mathrm{n} / \mathrm{a}$ & $\begin{array}{l}\text { stout, large } \\
\text { height }\end{array}$ & yes \\
\hline 7418 & Near archer & dominant & $550-500$ & amphora & $\mathrm{ABF}$ & Etruria & $\begin{array}{l}\text { stout, large } \\
\text { height }\end{array}$ & yes \\
\hline 8240 & no, leading horses & neutral & $475-425$ & krater & ARF & $\mathrm{n} / \mathrm{a}$ & $\begin{array}{l}\text { lean, large } \\
\text { height }\end{array}$ & yes \\
\hline 8266 & yes & neutral & $550-500$ & plate & $\mathrm{ABF}$ & Eleusis & $\begin{array}{l}\text { lean, middle } \\
\text { height }\end{array}$ & yes \\
\hline
\end{tabular}




\begin{tabular}{|c|c|c|c|c|c|c|c|c|}
\hline 10711 & no, leading horses & alert & $575-525$ & amphora & $\mathrm{ABF}$ & Etruria & $\begin{array}{l}\text { stout, large } \\
\text { height }\end{array}$ & yes \\
\hline 10722 & yes & dominant & $550-500$ & amphora & $\mathrm{ABF}$ & $\mathrm{n} / \mathrm{a}$ & $\begin{array}{l}\text { lean, short } \\
\text { height }\end{array}$ & yes \\
\hline 10846 & near chariot & dominant & $550-500$ & amphora & $\mathrm{ABF}$ & $\mathrm{n} / \mathrm{a}$ & $\begin{array}{l}\text { stout, large } \\
\text { height }\end{array}$ & yes \\
\hline 11957 & yes & $\mathrm{n} / \mathrm{a}$ & $550-500$ & amphora & $\mathrm{ABF}$ & Etruria & $\begin{array}{l}\text { stout, } \\
\text { middle } \\
\text { height }\end{array}$ & unclear \\
\hline 13161 & yes & $\begin{array}{l}\text { neutral/chewin } \\
\mathrm{g}\end{array}$ & $525-475$ & amphora & $\mathrm{ABF}$ & Bologna & $\begin{array}{l}\text { stout, } \\
\text { middle } \\
\text { height }\end{array}$ & yes \\
\hline 14223 & yes & alert & $550-500$ & amphora & $\mathrm{ABF}$ & $\begin{array}{l}\text { Gela, } \\
\text { Sicily }\end{array}$ & $\begin{array}{l}\text { stout, } \\
\text { middle } \\
\text { height }\end{array}$ & yes \\
\hline 14728 & yes & $\begin{array}{l}\text { neutral/attentiv } \\
\mathrm{e}\end{array}$ & $525-475$ & amphora & $\mathrm{ABF}$ & $\mathrm{n} / \mathrm{a}$ & $\begin{array}{l}\text { stout, } \\
\text { middle } \\
\text { height }\end{array}$ & yes \\
\hline 14893 & yes & neutral & $550-500$ & amphora & $\mathrm{ABF}$ & $\mathrm{n} / \mathrm{a}$ & $\begin{array}{l}\text { stout, } \\
\text { middle } \\
\text { height }\end{array}$ & unclear \\
\hline 15752 & yes & alert & $525-475$ & amphora & $\mathrm{ABF}$ & $\mathrm{n} / \mathrm{a}$ & $\begin{array}{l}\text { stout, large } \\
\text { height }\end{array}$ & yes \\
\hline 17746 & yes & alert/neutral & $550-500$ & amphora & $\mathrm{ABF}$ & $\mathrm{n} / \mathrm{a}$ & $\begin{array}{l}\text { lean, middle } \\
\text { height }\end{array}$ & yes \\
\hline 19166 & yes & alert & $550-500$ & amphora & $\mathrm{ABF}$ & $\mathrm{n} / \mathrm{a}$ & $\begin{array}{l}\text { stout, } \\
\text { middle } \\
\text { height }\end{array}$ & yes \\
\hline 22999 & yes & alert/attentive & $550-500$ & amphora & $\mathrm{ABF}$ & $\mathrm{n} / \mathrm{a}$ & $\begin{array}{l}\text { lean, middle } \\
\text { height }\end{array}$ & yes \\
\hline
\end{tabular}




\begin{tabular}{|c|c|c|c|c|c|c|c|c|}
\hline 23064 & yes & Excited & $550-500$ & amphora & $\mathrm{ABF}$ & $\mathrm{n} / \mathrm{a}$ & $\begin{array}{l}\text { lean, short } \\
\text { height }\end{array}$ & yes \\
\hline 23083 & yes & anxious & $550-500$ & amphora & $\mathrm{ABF}$ & $\mathrm{n} / \mathrm{a}$ & $\begin{array}{l}\text { stout, } \\
\text { middle } \\
\text { height }\end{array}$ & unclear \\
\hline 24035 & yes & $\begin{array}{l}\text { neutral/attentiv } \\
\mathrm{e}\end{array}$ & $550-500$ & amphora & $\mathrm{ABF}$ & $\mathrm{n} / \mathrm{a}$ & $\begin{array}{l}\text { stout, large } \\
\text { height }\end{array}$ & yes \\
\hline 24124 & equidistant & excited & $550-500$ & amphora & $\mathrm{ABF}$ & $\mathrm{n} / \mathrm{a}$ & $\begin{array}{l}\text { lean, short } \\
\text { height }\end{array}$ & unclear \\
\hline 25697 & no, leading horses & neutral & $525-475$ & krater & $\mathrm{ABF}$ & $\mathrm{n} / \mathrm{a}$ & $\begin{array}{l}\text { stout, large } \\
\text { height }\end{array}$ & yes \\
\hline 26140 & $\begin{array}{l}\text { no, sniffing } \\
\text { horses }\end{array}$ & $\begin{array}{l}\text { neutral, } \\
\text { sniffing }\end{array}$ & $550-500$ & amphora & $\mathrm{ABF}$ & $\mathrm{n} / \mathrm{a}$ & $\begin{array}{l}\text { lean, middle } \\
\text { height }\end{array}$ & unclear \\
\hline 32003 & yes & neutral & $575-525$ & cup & $\mathrm{ABF}$ & $\mathrm{n} / \mathrm{a}$ & $\begin{array}{l}\text { lean, short } \\
\text { height }\end{array}$ & yes \\
\hline 45349 & yes & neutral & $525-475$ & amphora & $\mathrm{ABF}$ & $\mathrm{n} / \mathrm{a}$ & $\begin{array}{l}\text { lean, shorth } \\
\text { eight }\end{array}$ & yes \\
\hline 200166 & yes & lying down & $550-500$ & amphora & $\mathrm{ARF}$ & Etruria & $\begin{array}{l}\text { stout, large } \\
\text { height }\end{array}$ & no \\
\hline 200175 & yes & frightened & $525-475$ & amphora & $\mathrm{ARF}$ & Etruria & $\begin{array}{l}\text { lean, short } \\
\text { height }\end{array}$ & unclear \\
\hline 200184 & yes & excited & $525-475$ & hydria & ARF & Locri & $\begin{array}{l}\text { lean, short } \\
\text { height }\end{array}$ & yes \\
\hline 201654 & equidistant & curious/neutral & $525-475$ & amphora & $\mathrm{ARF}$ & Etruria & $\begin{array}{l}\text { lean, large } \\
\text { height }\end{array}$ & unclear \\
\hline 201657 & yes & neutral/sniffing & $525-475$ & amphora & $\mathrm{ARF}$ & Etruria & $\begin{array}{l}\text { stout, large } \\
\text { height }\end{array}$ & yes \\
\hline 202074 & yes & $\begin{array}{l}\text { aggressive/teet } \\
\mathrm{h}\end{array}$ & $525-475$ & amphora & $\mathrm{ABF}$ & Etruria & $\begin{array}{l}\text { stout, lion } \\
\text { sized! }\end{array}$ & yes \\
\hline
\end{tabular}




\begin{tabular}{|c|c|c|c|c|c|c|c|c|}
\hline 202097 & yes & neutral & $525-475$ & amphora & ARF & $\mathrm{n} / \mathrm{a}$ & $\begin{array}{l}\text { stout, large } \\
\text { height }\end{array}$ & yes \\
\hline 202133 & equidistant & neutral/alert & $500-450$ & amphora & ARF & $\begin{array}{l}\text { Basilcat } \\
\text { a }\end{array}$ & $\begin{array}{l}\text { lean, short } \\
\text { height }\end{array}$ & unclear \\
\hline 202458 & yes & alert & $500-450$ & stamnos & ARF & Nola & $\begin{array}{l}\text { stout, large } \\
\text { height }\end{array}$ & yes \\
\hline 206596 & beside archer & alert/staring & $500-450$ & amphora & ARF & Etruria & $\begin{array}{l}\text { lean, middle } \\
\text { height }\end{array}$ & yes \\
\hline 213886 & yes & alert & $475-425$ & stamnos & ARF & Etruria & $\begin{array}{l}\text { lean, middle } \\
\text { height }\end{array}$ & yes \\
\hline 301051 & no & alert & $575-525$ & amphora & $\mathrm{ABF}$ & Etruria & $\begin{array}{l}\text { lean, short } \\
\text { height }\end{array}$ & no \\
\hline 301145 & following away & $\begin{array}{l}\text { neutral/walkin } \\
\mathrm{g}\end{array}$ & $575-525$ & lekythos & $\mathrm{ABF}$ & $\mathrm{n} / \mathrm{a}$ & $\begin{array}{l}\text { stout, } \\
\text { middle } \\
\text { height }\end{array}$ & yes \\
\hline 301359 & yes & alert & $550-500$ & amphora & $\mathrm{ABF}$ & $\mathrm{n} / \mathrm{a}$ & $\begin{array}{l}\text { lean, short } \\
\text { height }\end{array}$ & yes \\
\hline 301473 & yes & alert & $550-500$ & amphora & $\mathrm{ABF}$ & Etruria & $\begin{array}{l}\text { lean, short } \\
\text { height }\end{array}$ & yes \\
\hline 301573 & equidistant & $\begin{array}{l}\text { neutral, } \\
\text { sniffing }\end{array}$ & $550-500$ & amphora & $\mathrm{ABF}$ & Etruria & $\begin{array}{l}\text { stout, } \\
\text { middle } \\
\text { height }\end{array}$ & unclear \\
\hline 301756 & yes & neutral & $550-500$ & amphora & $\mathrm{ABF}$ & Etruria & $\begin{array}{l}\text { stout, large } \\
\text { height }\end{array}$ & yes \\
\hline 301840 & no, leading horses & dominant & $550-500$ & amphora & $\mathrm{ABF}$ & Sicily & $\begin{array}{l}\text { lean, middle } \\
\text { height }\end{array}$ & yes \\
\hline 301894 & yes & $\begin{array}{l}\text { neutral } \\
\text { (Aggressive?) }\end{array}$ & $550-500$ & amphora & $\mathrm{ABF}$ & $\mathrm{n} / \mathrm{a}$ & $\begin{array}{l}\text { stout, large } \\
\text { height }\end{array}$ & yes \\
\hline
\end{tabular}




\begin{tabular}{|c|c|c|c|c|c|c|c|c|}
\hline 302051 & no, leading horses & neutral & $550-500$ & hydria & $\mathrm{ABF}$ & Etruria & $\begin{array}{l}\text { stout, } \\
\text { middle } \\
\text { height }\end{array}$ & yes \\
\hline 302062 & no & $\begin{array}{l}\text { excited, paw } \\
\text { raised }\end{array}$ & $550-500$ & $\begin{array}{l}\text { hydra } \\
\text { (frag) }\end{array}$ & $\mathrm{ABF}$ & $\mathrm{n} / \mathrm{a}$ & $\begin{array}{l}\text { lean, middle } \\
\text { height }\end{array}$ & unclear \\
\hline 302083 & on old man's lap & frightened & $550-500$ & amphora & $\mathrm{ABF}$ & $\mathrm{n} / \mathrm{a}$ & $\begin{array}{l}\text { lean, middle } \\
\text { height }\end{array}$ & no \\
\hline 302130 & yes & neutral & $550-500$ & amphora & $\mathrm{ABF}$ & Sabina & $\begin{array}{l}\text { stout, large } \\
\text { height }\end{array}$ & yes \\
\hline 302133 & yes + archer & $\begin{array}{l}\text { neutral/domina } \\
\text { nt }\end{array}$ & $550-500$ & amphora & $\mathrm{ABF}$ & $\mathrm{n} / \mathrm{a}$ & $\begin{array}{l}\text { stout, large } \\
\text { height }\end{array}$ & yes \\
\hline 302156 & yes + archer & $\begin{array}{l}\text { neutral/domina } \\
\text { nt }\end{array}$ & $550-500$ & amphora & $\mathrm{ABF}$ & Etruria & $\begin{array}{l}\text { stout, } \\
\text { middle } \\
\text { height }\end{array}$ & yes \\
\hline 302182 & equidistant & neutral & $550-500$ & amphora & $\mathrm{ABF}$ & $\mathrm{n} / \mathrm{a}$ & $\begin{array}{l}\text { stout, lion } \\
\text { sized! }\end{array}$ & unclear \\
\hline 302288 & yes & excited & $550-500$ & amphora & $\mathrm{ABF}$ & Etruria & $\begin{array}{l}\text { stout, } \\
\text { middle } \\
\text { height }\end{array}$ & unclear \\
\hline 302396 & yes & neutral/curious & $550-500$ & amphora & $\mathrm{ABF}$ & Etruria & $\begin{array}{l}\text { lean, middle } \\
\text { height }\end{array}$ & yes \\
\hline 302920 & yes & dominant & $550-500$ & amphora & $\mathrm{ABF}$ & $\mathrm{n} / \mathrm{a}$ & $\begin{array}{l}\text { stout, large } \\
\text { height }\end{array}$ & yes \\
\hline 303058 & yes & $\begin{array}{l}\text { dominant/steali } \\
\text { ng }\end{array}$ & $500-450$ & amphora & $\mathrm{ABF}$ & $\mathrm{n} / \mathrm{a}$ & $\begin{array}{l}\text { stout, large } \\
\text { height }\end{array}$ & yes \\
\hline 303408 & on old man's lap & frightened & $550-500$ & amphora & $\mathrm{ABF}$ & $\mathrm{n} / \mathrm{a}$ & $\begin{array}{l}\text { stout, large } \\
\text { height }\end{array}$ & unclear \\
\hline 303435 & yes & neutral & $550-500$ & amphora & $\mathrm{ABF}$ & $\mathrm{n} / \mathrm{a}$ & $\begin{array}{l}\text { stout, } \\
\text { middle } \\
\text { height }\end{array}$ & yes \\
\hline
\end{tabular}




\begin{tabular}{|c|c|c|c|c|c|c|c|c|}
\hline 305505 & yes, in front & $\begin{array}{l}\text { playful/deferen } \\
\text { tial }\end{array}$ & $525-475$ & lekythos & $\mathrm{ABF}$ & $\mathrm{n} / \mathrm{a}$ & $\begin{array}{l}\text { lean, short } \\
\text { height }\end{array}$ & yes \\
\hline 305535 & yes, behind & excited & $550-500$ & amphora & $\mathrm{ABF}$ & $\mathrm{n} / \mathrm{a}$ & $\begin{array}{l}\text { lean, short } \\
\text { height }\end{array}$ & yes \\
\hline 310431 & yes & $\begin{array}{l}\text { neutral/domina } \\
\text { nt }\end{array}$ & $575-525$ & amphora & $\mathrm{ABF}$ & Etruria & $\begin{array}{l}\text { stout, large } \\
\text { height }\end{array}$ & yes \\
\hline 310450 & no & neutral & $575-525$ & amphora & $\mathrm{ABF}$ & $\mathrm{n} / \mathrm{a}$ & $\begin{array}{l}\text { lean, middle } \\
\text { height }\end{array}$ & unclear \\
\hline 310457 & yes & $\begin{array}{l}\text { neutral/domina } \\
\text { nt }\end{array}$ & $575-525$ & $\begin{array}{l}\text { oinocho } \\
\text { e }\end{array}$ & $\mathrm{ABF}$ & $\mathrm{n} / \mathrm{a}$ & $\begin{array}{l}\text { lean, middle } \\
\text { height }\end{array}$ & yes \\
\hline 320124 & yes & neutral & $550-500$ & amphora & $\mathrm{ABF}$ & $\mathrm{n} / \mathrm{a}$ & $\begin{array}{l}\text { stout, } \\
\text { middle } \\
\text { height }\end{array}$ & yes \\
\hline 320186 & no, by old man & alert/attentive & $550-500$ & amphora & $\mathrm{ABF}$ & $\mathrm{n} / \mathrm{a}$ & $\begin{array}{l}\text { stout, } \\
\text { middle } \\
\text { height }\end{array}$ & no \\
\hline 320202 & yes & alert/attentive & $550-500$ & amphora & $\mathrm{ABF}$ & $\mathrm{n} / \mathrm{a}$ & $\begin{array}{l}\text { lean, middle } \\
\text { height }\end{array}$ & yes \\
\hline 320225 & no, leading horses & neutral & $550-500$ & hydria & $\mathrm{ABF}$ & Etruria & $\begin{array}{l}\text { lean, middle } \\
\text { height }\end{array}$ & yes \\
\hline 320256 & yes & dominant & $550-500$ & amphora & $\mathrm{ABF}$ & $\mathrm{n} / \mathrm{a}$ & $\begin{array}{l}\text { stout, } \\
\text { middle } \\
\text { height }\end{array}$ & yes \\
\hline 320285 & yes & $\begin{array}{l}\text { neutral/domina } \\
\text { nt }\end{array}$ & $550-500$ & amphora & $\mathrm{ABF}$ & Etruria & $\begin{array}{l}\text { stout, } \\
\text { middle } \\
\text { height }\end{array}$ & yes \\
\hline 320286 & yes & $\begin{array}{l}\text { dominant/neutr } \\
\text { al }\end{array}$ & $550-500$ & amphora & $\mathrm{ABF}$ & $\mathrm{n} / \mathrm{a}$ & $\begin{array}{l}\text { stout, } \\
\text { middle } \\
\text { height }\end{array}$ & yes \\
\hline
\end{tabular}




\begin{tabular}{|c|c|c|c|c|c|c|c|c|}
\hline 320287 & yes & $\begin{array}{l}\text { neutral/attentiv } \\
\mathrm{e}\end{array}$ & $550-500$ & amphora & $\mathrm{ABF}$ & Bologna & $\begin{array}{l}\text { stout, large } \\
\text { height }\end{array}$ & yes \\
\hline 320318 & yes & neutral & $550-500$ & amphora & $\mathrm{ABF}$ & Etruria & $\begin{array}{l}\text { lean, middle } \\
\text { height }\end{array}$ & yes \\
\hline 320390 & yes & neutral/alert & $550-500$ & amphora & $\mathrm{ABF}$ & Etruria & $\begin{array}{l}\text { lean, short } \\
\text { height }\end{array}$ & yes \\
\hline 320397 & yes & neutral/alert & $550-500$ & amphora & $\mathrm{ABF}$ & Orvieto & $\begin{array}{l}\text { lean, short } \\
\text { height }\end{array}$ & yes \\
\hline 330050 & yes & neutral & $550-500$ & $\begin{array}{l}\text { oinocho } \\
\mathrm{e}\end{array}$ & $\mathrm{ABF}$ & $\mathrm{n} / \mathrm{a}$ & $\begin{array}{l}\text { lean, short } \\
\text { height }\end{array}$ & yes \\
\hline 340498 & yes & alert/attentive & $550-500$ & amphora & $\mathrm{ABF}$ & $\mathrm{n} / \mathrm{a}$ & $\begin{array}{l}\text { lean, short } \\
\text { height }\end{array}$ & yes \\
\hline 351432 & equidistant & alert/dominant & $525-475$ & olpe & $\mathrm{ABF}$ & $\mathrm{n} / \mathrm{a}$ & $\begin{array}{l}\text { lean, short } \\
\text { height }\end{array}$ & yes \\
\hline 1012942 & no, leading horses & neutral? & $525-475$ & lekythos & $\mathrm{ABF}$ & $\mathrm{n} / \mathrm{a}$ & $\begin{array}{l}\text { lean, middle } \\
\text { height }\end{array}$ & yes \\
\hline 9029281 & no, beside woman & unclear & $550-500$ & krater & $\mathrm{ABF}$ & $\mathrm{n} / \mathrm{a}$ & $\begin{array}{l}\text { lean, short } \\
\text { height }\end{array}$ & no \\
\hline 9029843 & yes & $\begin{array}{l}\text { neutral/walkin } \\
\mathrm{g}\end{array}$ & $575-525$ & hydria & $\mathrm{ABF}$ & Etruria & $\begin{array}{l}\text { lean, short } \\
\text { height }\end{array}$ & yes \\
\hline 9029956 & no & frightened & $475-425$ & hydria & $\mathrm{ARF}$ & $\mathrm{n} / \mathrm{a}$ & $\begin{array}{l}\text { lean, short } \\
\text { height }\end{array}$ & no \\
\hline 9030364 & $\begin{array}{l}\text { near, beside } \\
\text { horses }\end{array}$ & neutral? & $550-500$ & amphora & $\mathrm{ABF}$ & $\mathrm{n} / \mathrm{a}$ & $\begin{array}{l}\text { lean, middle } \\
\text { height }\end{array}$ & yes \\
\hline 9031201 & in front of horse & seated & $550-500$ & $\begin{array}{l}\text { amphora } \\
\text { (fr) }\end{array}$ & $\mathrm{ABF}$ & $\mathrm{n} / \mathrm{a}$ & $\begin{array}{l}\text { lean, middle } \\
\text { height }\end{array}$ & unclear \\
\hline 9031264 & yes & alert/dominant & $550-500$ & amphora & $\mathrm{ABF}$ & $\mathrm{n} / \mathrm{a}$ & $\begin{array}{l}\text { lean, middle } \\
\text { height }\end{array}$ & yes \\
\hline 9032300 & yes & neutral/sniffing & $550-500$ & amphora & $\mathrm{ABF}$ & $\mathrm{n} / \mathrm{a}$ & $\begin{array}{l}\text { stout, large } \\
\text { height }\end{array}$ & yes \\
\hline
\end{tabular}




\begin{tabular}{|l|l|l|l|l|l|l|l|l|}
\hline $\begin{array}{l}\text { side a of } \\
310430\end{array}$ & yes & neutral/curious & $575-525$ & amphora & ABF & Orvieto & $\begin{array}{l}\text { lean, short } \\
\text { height }\end{array}$ & yes \\
\hline $\begin{array}{l}\text { side a of } \\
301535\end{array}$ & yes & alert/dominant & $550-500$ & amphora & ABF & n/a & $\begin{array}{l}\text { stout, large } \\
\text { height }\end{array}$ & yes \\
\hline $\begin{array}{l}\text { side a of } \\
13856\end{array}$ & facing, near youth & dominant & $550-500$ & amphora & ABF & Paestum & $\begin{array}{l}\text { lean, short } \\
\text { height }\end{array}$ & unclear \\
\hline $\begin{array}{l}\text { side b of } \\
301535\end{array}$ & yes & alert/dominant & ibid & ibid & ibid & ibid & $\begin{array}{l}\text { stout, } \\
\text { middle } \\
\text { height }\end{array}$ & yes \\
\hline $\begin{array}{l}\text { side b of } \\
310430\end{array}$ & yes & neutral & ibid & ibid & ibid & ibid & $\begin{array}{l}\text { lean, short } \\
\text { height }\end{array}$ & yes \\
\hline $\begin{array}{l}\text { side b of } \\
13856\end{array}$ & no, leading horses & aggressive & ibid & ibid & ibid & ibid & $\begin{array}{l}\text { lean, short } \\
\text { height }\end{array}$ & yes \\
\hline
\end{tabular}


Table 8.2 Static Military Scenes Featuring Dog and Warrior Motif

\begin{tabular}{|c|c|c|c|c|c|c|c|c|}
\hline $\begin{array}{c}\text { Vase } \\
\text { Number }\end{array}$ & Dog posture & $\begin{array}{l}\text { Dog near } \\
\text { warrior? }\end{array}$ & Age & Shape & Fabric & Provenance & Dog Type & Mythic? \\
\hline 9464 & neutral & yes & $\begin{array}{l}525- \\
475\end{array}$ & amphora & $\mathrm{ABF}$ & $\mathrm{n} / \mathrm{a}$ & stout, large height & no \\
\hline 10723 & aggressive & yes & $\begin{array}{c}550- \\
500\end{array}$ & amphora & $\mathrm{ABF}$ & Etruria & stout, large height & no \\
\hline 11589 & neutral & yes & $\begin{array}{c}525- \\
475\end{array}$ & krater & $\mathrm{ABF}$ & Paestum & $\begin{array}{c}\text { stout, middle } \\
\text { height }\end{array}$ & no \\
\hline 203132 & excited & $\begin{array}{l}\text { yes, and near } \\
\text { archer }\end{array}$ & $\begin{array}{c}500- \\
450\end{array}$ & lekythos & ARF & $\mathrm{n} / \mathrm{a}$ & $\begin{array}{l}\text { stout, middle } \\
\text { height }\end{array}$ & no \\
\hline 203952 & sniffing & near archer & $\begin{array}{l}500- \\
450\end{array}$ & $\begin{array}{l}\text { cup } \\
\text { frags }\end{array}$ & ARF & Eleusis & $\begin{array}{l}\text { stout, middle } \\
\text { height }\end{array}$ & no? \\
\hline 301458 & neutral & yes, two & $\begin{array}{c}550- \\
500\end{array}$ & amphora & $\mathrm{ABF}$ & $\mathrm{n} / \mathrm{a}$ & stout, short height & no \\
\hline 302202 & neutral/dominant & yes, and archers & $\begin{array}{c}550- \\
500\end{array}$ & amphora & $\mathrm{ABF}$ & Etruria & stout, large height & no \\
\hline 302792 & excited & faces & $\begin{array}{c}550- \\
500\end{array}$ & amphora & $\mathrm{ABF}$ & $\mathrm{n} / \mathrm{a}$ & lean, short height & no \\
\hline 303388 & neutral & yes & $\begin{array}{c}550- \\
500\end{array}$ & amphora & $\mathrm{ABF}$ & Nola & $\begin{array}{l}\text { stout, middle } \\
\text { height }\end{array}$ & no \\
\hline 351103 & alert/curious & no, leading horses & $\begin{array}{c}525- \\
475 \\
\end{array}$ & krater & $\mathrm{ABF}$ & $\mathrm{n} / \mathrm{a}$ & $\begin{array}{c}\text { lean, middle } \\
\text { height }\end{array}$ & no \\
\hline 203103 & recumbent (2) & yes & $\begin{array}{c}500- \\
450\end{array}$ & lekythos & $\mathrm{ARF}$ & $\mathrm{n} / \mathrm{a}$ & $\begin{array}{l}\text { lean, unclear } \\
\text { height }\end{array}$ & yes \\
\hline
\end{tabular}


Table 8.3 Military March or Charge Scenes Featuring Dog and Warrior Motif

\begin{tabular}{|c|c|c|c|c|c|c|c|c|c|}
\hline Vase Number & Scene Type & Dog posture & Age & Shape & $\begin{array}{c}\text { Fabri } \\
\mathrm{c}\end{array}$ & $\begin{array}{c}\text { Provenan } \\
\text { ce }\end{array}$ & Dog Type & $\begin{array}{l}\text { Mythi } \\
\text { c? }\end{array}$ & $\begin{array}{l}\text { Cook's } \\
\text { pattern? }\end{array}$ \\
\hline 2715 & march & $\begin{array}{c}\text { dominant/frockin } \\
\mathrm{g}\end{array}$ & $\begin{array}{c}500- \\
450 \\
\end{array}$ & lekythos & $\mathrm{ABF}$ & $\mathrm{n} / \mathrm{a}$ & $\begin{array}{c}\text { lean, short } \\
\text { height }\end{array}$ & no & no \\
\hline 3367 & escape & neutral & $\begin{array}{c}550- \\
500\end{array}$ & amphora & $\mathrm{ABF}$ & $\mathrm{n} / \mathrm{a}$ & $\begin{array}{l}\text { lean, middle } \\
\text { height }\end{array}$ & yes & $\mathrm{n} / \mathrm{a}$ \\
\hline 3440 & $\begin{array}{l}\text { ambush of } \\
\text { Tr. }\end{array}$ & running & $\begin{array}{c}524- \\
475 \\
\end{array}$ & lekythos & $\mathrm{ARF}$ & $\mathrm{m} / \mathrm{a}$ & $\begin{array}{c}\text { lean, short } \\
\text { height }\end{array}$ & yes & yes \\
\hline 5695 & march & neutral/sniffing & $\begin{array}{c}550- \\
500\end{array}$ & amphora & $\mathrm{ABF}$ & $\mathrm{n} / \mathrm{a}$ & stout, tall height & no & no \\
\hline 7324 & pre-charge & dominant & $\begin{array}{c}550- \\
500\end{array}$ & hydria & $\mathrm{ABF}$ & $\mathrm{n} / \mathrm{a}$ & $\begin{array}{l}\text { lean, middle } \\
\text { height }\end{array}$ & no & no \\
\hline 8654 & march & neutral & $\begin{array}{c}550- \\
500\end{array}$ & cup & $\mathrm{ABF}$ & Orvieto & $\begin{array}{l}\text { lean, middle } \\
\text { height }\end{array}$ & no(?) & no \\
\hline 13250 & charge & dominant & $\begin{array}{c}550- \\
500\end{array}$ & cup & $\mathrm{ABF}$ & Etruria & $\begin{array}{c}\text { lean, short } \\
\text { height }\end{array}$ & no & yes \\
\hline 200550 & charge & excited/leaping & $\begin{array}{c}525- \\
475 \\
\end{array}$ & cup & $\mathrm{ARF}$ & Etruria & $\begin{array}{c}\text { lean, middle } \\
\text { height }\end{array}$ & yes & no \\
\hline 300757 & charge & running & $\begin{array}{l}575- \\
525\end{array}$ & amphora & $\mathrm{ABF}$ & Attica & $\begin{array}{c}\text { lean, middle } \\
\text { height }\end{array}$ & no & yes \\
\hline 300758 & charge & running & $\begin{array}{l}575- \\
525\end{array}$ & amphora & $\mathrm{ABF}$ & $\mathrm{n} / \mathrm{a}$ & $\begin{array}{c}\text { lean, middle } \\
\text { height }\end{array}$ & no & yes \\
\hline 302062 & $\begin{array}{c}\text { march/char } \\
\text { ge }\end{array}$ & $\begin{array}{l}\text { dominant, } \\
\text { sniffing (2) }\end{array}$ & $\begin{array}{c}550- \\
500 \\
\end{array}$ & $\begin{array}{l}\text { hydria } \\
\text { (frag) }\end{array}$ & $\mathrm{ABF}$ & $\mathrm{n} / \mathrm{a}$ & stout, tall height & no & no \\
\hline 302063 & march & $\begin{array}{l}\text { dominant, } \\
\text { sniffing (3) }\end{array}$ & $\begin{array}{c}550- \\
500\end{array}$ & hydra & $\mathrm{ABF}$ & Etruria & $\begin{array}{l}\text { lean, middle } \\
\text { height }\end{array}$ & no & no \\
\hline
\end{tabular}




\begin{tabular}{|c|c|c|c|c|c|c|c|c|c|}
\hline 302121 & march & excited/leaping & $\begin{array}{c}550- \\
500 \\
\end{array}$ & amphora & $\mathrm{ABF}$ & Etruria & $\begin{array}{c}\text { lean, middle } \\
\text { height }\end{array}$ & no & no \\
\hline 305971 & march & neutral/dominant & $\begin{array}{l}525- \\
475\end{array}$ & amphora & $\mathrm{ABF}$ & $\mathrm{n} / \mathrm{a}$ & lean, lion sized! & no & no \\
\hline 306812 & march & neurtal/stealing & $\begin{array}{l}525- \\
475\end{array}$ & oinochoe & $\mathrm{ABF}$ & $\mathrm{n} / \mathrm{a}$ & $\begin{array}{c}\text { lean, short } \\
\text { height }\end{array}$ & no & no \\
\hline 310322 & $\begin{array}{l}\text { chariot } \\
\text { charge }\end{array}$ & running & $\begin{array}{l}575- \\
525\end{array}$ & amphora & $\mathrm{ABF}$ & Orvieto & $\begin{array}{c}\text { lean, middle } \\
\text { height }\end{array}$ & no & yes \\
\hline 310353 & $\begin{array}{c}\text { ambush of } \\
\text { Tr. }\end{array}$ & alert/dominant & $\begin{array}{c}575- \\
525\end{array}$ & amphora & $\mathrm{ABF}$ & $\mathrm{n} / \mathrm{a}$ & $\begin{array}{c}\text { lean, short } \\
\text { height }\end{array}$ & yes & no \\
\hline 351199 & $\begin{array}{c}\text { ambush of } \\
\text { Tr. }\end{array}$ & alert & $\begin{array}{c}525- \\
475\end{array}$ & hydria & $\mathrm{ABF}$ & $\mathrm{n} / \mathrm{a}$ & $\begin{array}{c}\text { lean, large } \\
\text { height }\end{array}$ & yes & no \\
\hline 351210 & charge & running & $\begin{array}{c}525- \\
475\end{array}$ & hydria & $\mathrm{ABF}$ & $\mathrm{n} / \mathrm{a}$ & $\begin{array}{l}\text { stout, middle } \\
\text { height }\end{array}$ & no & yes \\
\hline 351621 & march & playful/running & $\begin{array}{c}525- \\
475\end{array}$ & lekythos & $\mathrm{ABF}$ & $\mathrm{n} / \mathrm{a}$ & $\begin{array}{c}\text { lean, short } \\
\text { height }\end{array}$ & no & yes \\
\hline 351622 & march & playful/running & $\begin{array}{c}525- \\
475\end{array}$ & lekythos & $\mathrm{ABF}$ & $\mathrm{n} / \mathrm{a}$ & $\begin{array}{c}\text { lean, short } \\
\text { height }\end{array}$ & no & yes \\
\hline 361410 & charge? & excited/leaping & $\begin{array}{l}525- \\
475\end{array}$ & amphora & $\mathrm{ABF}$ & $\mathrm{n} / \mathrm{a}$ & $\begin{array}{l}\text { lean, middle } \\
\text { height }\end{array}$ & no & yes \\
\hline $\begin{array}{c}\text { side } b \text { of } \\
301780\end{array}$ & march & $\begin{array}{c}\text { excited/sniffing } \\
\text { (2) }\end{array}$ & $\begin{array}{c}550- \\
500\end{array}$ & amphora & $\mathrm{ABF}$ & Etruria & $\begin{array}{c}\text { lean, middle } \\
\text { height }\end{array}$ & yes & no \\
\hline $\begin{array}{c}\text { side a of } \\
301780\end{array}$ & sack of city & excited & ibid & ibid & ibid & ibid & $\begin{array}{c}\text { lean, middle } \\
\text { height }\end{array}$ & yes & $\mathrm{n} / \mathrm{a}$ \\
\hline 310170 & $\begin{array}{c}\text { ambush of } \\
\text { Tr. }\end{array}$ & running & $\begin{array}{l}575- \\
252\end{array}$ & hydria & $\mathrm{ABF}$ & Etruria & $\begin{array}{l}\text { lean, middle } \\
\text { height }\end{array}$ & yes & no \\
\hline
\end{tabular}


Table 8.4 Scenes in which Dogs appear on Shields

\begin{tabular}{|c|c|c|c|c|c|c|c|c|}
\hline $\begin{array}{c}\text { Vase } \\
\text { Number }\end{array}$ & Age & Shape & Fabric & Provenance & Dog posture & Dog Type & $\begin{array}{c}\text { Warrior } \\
\text { type }\end{array}$ & Mythic? \\
\hline 13855 & $525-475$ & cup & $\mathrm{ABF}$ & Etruria & seated, alert & lean, curly tail & hoplite & no \\
\hline 200360 & $525-475$ & cup & ARF & $\mathrm{n} / \mathrm{a}$ & Neutral/sniffing & short, long & hoplite & no \\
\hline 200731 & $525-475$ & cup & ARF & $\mathrm{n} / \mathrm{a}$ & playful & lean, medium height & hoplite & no \\
\hline 201042 & $525-475$ & cup & ARF & $\mathrm{n} / \mathrm{a}$ & Neutral & lean, medium height & hoplite & no \\
\hline 201440 & $525-475$ & cup & ARF & Etruria & dominant & lean, medium height & hoplite & no \\
\hline 202366 & $500-450$ & krater & ARF & Falerii & alert & lean, medium height & hoplite & no \\
\hline 203671 & $525-475$ & cup & ARF & $\mathrm{n} / \mathrm{a}$ & excited & lean, short height & archer & no \\
\hline 203841 & $500-450$ & cup & ARF & Etruria & neutral & spitz & hoplite & no \\
\hline 203902 & $500-450$ & cup & ARF & $\mathrm{n} / \mathrm{a}$ & neutral & lean, medium height & Achilles & yes \\
\hline 204502 & $500-450$ & cup & ARF & Orvieto & neutral & spitz & hoplite & no \\
\hline 204538 & $500-450$ & cup & ARF & Etruria & neutral & lean, medium height & mythical & yes \\
\hline 214641 & $475-425$ & amphora & ARF & $\mathrm{n} / \mathrm{a}$ & neutral & lean, medium height & hoplite & no \\
\hline 301894 & $550-500$ & amphora & $\mathrm{ABF}$ & $\mathrm{n} / \mathrm{a}$ & neutral & lean, medium height & hoplite & no \\
\hline 310396 & $575-525$ & amphora & $\mathrm{ABF}$ & $\mathrm{n} / \mathrm{a}$ & neutral/frightened & lean, unclear height & mythical & yes \\
\hline 320056 & $550-500$ & amphora & $\mathrm{ABF}$ & $\mathrm{n} / \mathrm{a}$ & sitting & lean, medium height? & mythical & yes \\
\hline 320107 & $550-500$ & amphora & $\mathrm{ABF}$ & Etruria & neutral & lean, medium height & hoplite & no \\
\hline 340572 & $550-500$ & amphora & $\mathrm{ABF}$ & $\mathrm{n} / \mathrm{a}$ & crouching & $\begin{array}{l}\text { stout, medium } \\
\text { height? }\end{array}$ & hoplite & no \\
\hline 9026847 & $525-475$ & amphora & $\mathrm{ABF}$ & Etruria & standing & lean, unclear & hoplite & no \\
\hline
\end{tabular}


Table 8.5 of Varia Scenes Featuring the Dog and Warrior Motif

\begin{tabular}{|l|l|l|l|l|l|l|l|l|l|}
\hline $\begin{array}{l}\text { Vase } \\
\text { Number }\end{array}$ & $\begin{array}{l}\text { Scene } \\
\text { Type }\end{array}$ & $\begin{array}{l}\text { Dog near } \\
\text { warrior? }\end{array}$ & $\begin{array}{l}\text { Dog body } \\
\text { posture }\end{array}$ & Age & Shape & $\begin{array}{l}\text { Fabr } \\
\text { ic }\end{array}$ & $\begin{array}{l}\text { Provena } \\
\text { nce }\end{array}$ & Dog type & $\begin{array}{l}\text { Dog "with" } \\
\text { warrior? }\end{array}$ \\
\hline 5727 & extispicy & yes & dominant & $\begin{array}{l}550- \\
500\end{array}$ & $\begin{array}{l}\text { ampho } \\
\text { ra }\end{array}$ & ABF & n/a & $\begin{array}{l}\text { n/a, middle } \\
\text { height }\end{array}$ & yes \\
\hline 301490 & departure? & $\begin{array}{l}\text { no, under } \\
\text { horse }\end{array}$ & playful & $\begin{array}{l}550- \\
500\end{array}$ & $\begin{array}{l}\text { ampho } \\
\text { ra }\end{array}$ & ABF & n/a & $\begin{array}{l}\text { lean, middle } \\
\text { height }\end{array}$ & unclear \\
\hline 302036 & $\begin{array}{l}\text { supplicati } \\
\text { on? }\end{array}$ & $\begin{array}{l}\text { no, under } \\
\text { horse }\end{array}$ & neutral & $\begin{array}{l}550- \\
\text { hydria }\end{array}$ & ABF & n/a & $\begin{array}{l}\text { stout, middle } \\
\text { height }\end{array}$ & yes \\
\hline 310442 & military & $\begin{array}{l}\text { on leash of } \\
\text { youth }\end{array}$ & $\begin{array}{l}\text { leaping/excite } \\
\text { d }\end{array}$ & $\begin{array}{l}575- \\
525\end{array}$ & $\begin{array}{l}\text { ampho } \\
\text { ra }\end{array}$ & ABF & Etruria & $\begin{array}{l}\text { lean, middle } \\
\text { height }\end{array}$ & unclear \\
\hline 320425 & $\begin{array}{l}\text { rec. of } \\
\text { Helen }\end{array}$ & $\begin{array}{l}\text { yes, by } \\
\text { Menelaus }\end{array}$ & alert & $\begin{array}{l}550- \\
500\end{array}$ & $\begin{array}{l}\text { ampho } \\
\text { ra }\end{array}$ & ABF & n/a & $\begin{array}{l}\text { lean, short } \\
\text { height }\end{array}$ & unclear \\
\hline
\end{tabular}


Table 8.6 Pots Featuring the Dog and Warrior Motif in which Dogs wear Collars

\begin{tabular}{|l|l|l|}
$\begin{array}{l}\text { Beazley Archive } \\
\text { Number }\end{array}$ & Scene Type & $\begin{array}{l}\text { If departure scene, is } \\
\text { dog "with" soldier? }\end{array}$ \\
\hline $\begin{array}{c}\text { 7418 departure } \\
\text { 10711 departure }\end{array}$ & yes \\
\hline 13161 departure & yes \\
\hline 14893 departure & unclear \\
\hline 23083 departure & unclear \\
\hline 200175 departure & unclear \\
\hline 201654 departure & unclear \\
\hline 206596 departure & yes \\
\hline 301359 departure & yes \\
\hline 301840 departure & yes \\
\hline 310431 departure & yes \\
\hline 303388static military & n/a \\
\hline 351103 static military & n/a \\
\hline 3367 escape (milt.) & n/a \\
\hline
\end{tabular}




\section{Bibliography}

Adcock, F.E. 1957. The Greek and Macedonian Art of War. University of California Press. Berkeley and Los Angeles.

Anson, Edward 2015. Eumenes of Cardia: A Greek Among Macedonians. Brill.

Arnold-Biucchi, Carmen 2006. Alexander's Coins \& Alexander's Image. Harvard University Art Museums.

Arnon, I. 1992. Agriculture in Dry Lands: Principles and Practice. In series of Developments in Agriculture and Managed-Forest Ecology. Vol 26. New York: Elsevier.

Badian, Ernst 1958. “The Eunuch Bagoas.” CQ 8:3-4, pp. 144-157.

Bakhsh, Abdulsalam, Wael M. El-Deeb, Awatif A. Al-Judaibi 2012. "Camel Urine and Milk in the Arab Heritage (Folk Medicine) A Review. In Knoll and Burger (eds.) (2012). Camels in Asia and North Africa: Interdisciplinary Perspectives on their Past and Present Significance. OAW. Pp. 187-192.

Bar-Kochva 1973. "On the Sources and Chronology of Antiochus I's Battle against the Galatians.” PCPS vol. 199, pp. 1-8.

Beck, William 1991. "Dogs, Dwellings, and Masters: Ensemble and Symbol in the Odyssey.” Hermes 119:2, pp. 158-167.

Bell, Sinclair and Carolyn Willekes (2014). "Horse Racing and Chariot Racing." In Campbell (ed.) The Oxford Handbook of Animals in Classical Thought and Life. OUP pp. 478-90.

Bernand, André 1972. Le Paneion d'El-Kanaïs: les inscriptions grecques. Brill.

Bevan, Edward Robert 1985. The House of Seleucus vol. I. New Edition, Ares Publishers.

Bieber, Margarete 1963. Alexander the Great in Greek and Roman Art. Argonaut.

Bigwood, J.M. 1993. "Aristotle and the Elephant Again." The American Journal of Philology. Vol. 114 No. 4, pp. 537-555.

Bilde, Per, Troels Engberg-Pedersen, Lise Hannestad, and Jan Zahle (eds) 1996. Aspects of Hellenistic Kingship. Series Studies in Hellenistic Civilization vol. VII. Aarhaus University Press. 
Boardman, John 1989. Athenian Red Figure Vases: The Classical Period. Thames \& Hudson.

and Marie-Louise Vollenweider 1978. Catalogue of the Engraved Gems and Finger Rings [Ashmolean Museum, Oxford] Vol I: Greek and Etruscan. Oxford: Clarendon Press.

1975. Athenian Red Figure Vases: The Archaic Period, a handbook. Thames and Hudson

Bodson, Liliane 2000. "Motivations for Pet-Keeping in Ancient Greece and Rome: A Preliminary Survey.” In Podberscek et al. (2000), pp. 27-41.

Bosworth, A.B. 2007. "Rider in the Chariot: Ptolemy, Alexander and the Elephants." In K. Sheedy (ed.) 2007. Alexander and the Hellenistic Kingdoms, The Westmoreland Collection. Pp. 17-22.

2002. The Legacy of Alexander: Politics, Warfare and Propaganda under the Successors. OUP.

1992. Alexander and the East: The Tragedy of Triumph. Oxford: Clarendon Press.

1988a. Conquest and Empire: The Reign of Alexander the Great. CUP. 1988b. From Arrian to Alexander: Studies in Historical Interpretation. OUP. 1980-1995. Commentary on Arrian's History of Alexander. Vols. I-II. Clarendon Press. Oxford.

Bradshaw, John and Helen M.R. Nott 1995. "Social and Communication Behaviour of Companion Dogs" In J. Serpell (ed.) 1995. The Domestic Dog: Its Evolution, Behaviour and Interactions with People. CUP. Pp. 115-130.

Brewer, Douglas, Terence Clark, and Adrian Phillips 2001. Dogs in Antiquity: Anubis to Cerberus, The Origins of the Domestic Dog. Aris \& Phillips.

Bright, David and Barbara Bowen 1983. "Emblems, Elephants, and Alexander.” Studies in Philology vol. 80, no. 1, pp. 14-24.

Brown, Blanche 1995. Royal Portraits in Sculpture and Coins: Pyrrhus and the Successors of Alexander the Great. Peter Lang Publishing.

Brown, Edwin 1982. “The Lycidas of Theocritus' Idyll 7.” In Harvard Studies in Classical Philology vol. 85. HUP. Pp. 59-100. 
Bugh, Glen 1988. The Horsemen of Athens. Princeton Legacy Library.

Burke, T. J. 1975. "Probable Tetanus in Asian Elephants." Journal of Zoo and Wildlife Medicine (previously Journal of Zoo Animal Medicine). Vol. 6, pp. 22-24.

Burstein, Stanley M 1996. "Ivory and Ptolemaic Exploration of the Red Sea. The Missing Factor.” Topoi 6:2 pp. 799-807

Calder, Louise 2011. Cruelty and Sentimentality: Greek Attitudes to Animals 600-300 B.C. Oxford: Archaeopress.

Campbell, Gordon (ed.) 2014. Oxford Handbook of Animals in Classical Thought and Life. OUP and Lawrence Tritle 2013. The Oxford Handbook of Warfare in the Classical World. OUP. (trans.).1989. Agatharcides of Cnidus: On the Erythraean Sea. The Hakluyt Society. Cambridge.

Casson, Lionel 1993. "Ptolemy II and the Hunting of African Elephants." Transactions of the American Philological Association 123, pp. 247-260.

Chakravarti, P.C. 1941. The Art of War in Ancient India. Bulletin No. XXI. University of Dacca.

Champion, Jeff. 2014. Antigonus the One-Eyed: Greatest of the Successors. Pen \& Sword Military. Barnsley. 2009. Pyrrhus of Epirus. Pen \& Sword Military.

Charles, Michael 2008. "African Forest Elephants and Turrets in the Ancient World." Phoenix 62 no. 4, pp. 338-362.

2007. "Elephants at Raphia: Reinterpreting Polybius 5.84-5." $C Q$ vol. 57 no. 1, pp. 306-311.

Chaudhary, Zafar Iqbal. "Reproduction in the Dromedary Camel." In T. Gahlot (ed) (2000). Selected Topics on Camelids. Bikaner: The Camelid Publishers. Pp. 466498.

Clutton-Brock, Juliet 1995. "Origins of the Dog: Domestication and Early History." In J. Serpell (ed.) 1995. The Domestic Dog: Its Evolution, Behaviour and Interactions with People. CUP. Pp. 8-20. 
1992. Horse Power: A History of the Horse and the Donkey in Human Societies. HUP.

Cohen, Getzel 2019. The Hellenistic Settlements in the East from Armenia and Mesopotamia to Bactria and India. University of California Press.

Collins, Nina 1997. "The Various Fathers of Ptolemy I.” Mnemosyne vol. 50 fasc. 4, pp. 436-476.

Cook, R.M. 1950. “Dogs in Battle.” Festschrift Andreas Rumpf. Krefeld.

Coşkun, Altay 2012. "Deconstructing a Myth of Seleucid History: The So-Called 'Elephant Victory' Revisited. Phoenix. Vol. 66 no. 1, pp. 57-73.

Crary, Alice 2012. “Dogs and Concepts.” Philosophy 87:340, pp.215-237.

Curtis, John and Ann Searight. 2003. "The Gold Plaques of the Oxus Treasure: Manufacture, Decoration, and Meaning." In Culture through Objects: Ancient Near Eastern Studies in Honour of P.R.S. Moorey. Oxford: Griffith Institute, pp. 219-247

Dahlborn, Kristina 2000. "Physiological Explanations to Why the Camel Can Survive and Produce under Desert Conditions." In T. Gahlot (ed) (2000). Selected Topics on Camelids. Bikaner: The Camelid Publishers. Pp. 466-49818-34.

Day, Leslie Preston 1984. "Dog Burials in the Ancient Greek World." American Journal of Archaeology 88:1, pp. 21-32

Derr, Mark 2011. How the Dog Became the Dog: From Wolves to Our Best Friends. Overlook: Duckworth.

Devine, A.M. 1985a. "Diodorus' Account of the Battle of Paraitacene (317 BC)." AncW 12 pp. $75-86$. . 1985b. "Diodorus' Account of the Battle of Gabene." AncW 12 pp.87-96.

Donaghy, Thomas 2014. Horse Breeds and Breeding in the Greco-Persian World: 1st and 2nd Millennium BC. Cambridge Scholars Publishing.

Dostal, Walter 2012. "Riding Camels in Arabia: Outline of a Revised Cultural History." In Knoll and Burger (eds.) 2012. Camels in Asia and North Africa: Interdisciplinary Perspectives on their Past and Present Significance. OAW. Pp. 123-130.

Downey, Glanville 1959. "Libanius' Oration in Praise of Antioch (Oration XI)." Proceedings of the American Philosophical Society vol. 103, no. 5, pp. 652-686. 
Edgar, C.C. 1906. “Two Bronze Portraits from Egypt.” JHS 26 pp. 281-282.

Engels, David 2017. Benefactors, Kings, Rulers. Studies on the Seleukid Empire Between East and West. Peeters.

Engels, Donald 1978. Alexander the Great and the Logistics of the Macedonian Army. University of California Press.

Epplett, C. 2007. "War Elephants in the Hellenistic World." In Heckel et al. (2007), 209-232.

Errington, Robert M. 1990. A History of Macedonia. University of California Press.

Erskine, Andrew (ed) 2003. A Companion to the Hellenistic World. Blackwell. 2002. "Life After Death: Alexandria and the Body of Alexander." $G \& R$ vol. 49 no. 9 , pp. 163-179.

Fischer-Bovet, Christelle. 2014. Army and Society in Ptolemaic Egypt. Cambridge University Press. Cambridge and New York.

Fleischer, Robert .1996. "Hellenistic Royal Iconography on Coins." Aspects of Hellenistic Kingship. Edited by Per Bilde, Troels Engberg-Pedersen, Lisa Hannestad, and Jan Zahle. Aarhus University Press. Pp.28-40

Fogen, Thorsten and Edmund Thomas (eds.) 2017. Interactions between Animals and Humans in Graeco Roman Antiquity. De Gruyter

Fogen, Thorsten 2007. "Pliny the Elder's Animals: Some Remarks on the Narrative Structure of Nat. Hist. 8-11.” Hermes vol. 135. No. 2. Pp. 185-198.

Forster, E.S. 1941. "Dogs in Ancient Warfare." G\&R 10 no. 3, pp. 114-117.

Fox, Lane 1996. "Text and Image: Alexander the Great, Coins, and Elephants." Bulletin of the Institute of Classical Studies. Vol. 41, pp. 87-108.

Franco, Christiana 2014. Shameless: The Canine and the Feminine in Ancient Greece. University of California Press.

Fuller, J.F.C. 1958. The Generalship of Alexander the Great. Eyre \& Spottiswoode. London.

1945. Armament and History. Charles Scribner's Sons. New York.

Gabriel, Richard 2010. Philip II of Macedonia: Greater than Alexander. Potomac Books. 
Gácsi, Márta, Edina Kara, Bea Belényi, József Topál, and Ádám Miklósi 2009. "The Effect of Development and Individual Differences in Pointing Comprehension of Dogs.” Animal Cognition vol. 12, pp. 471-479.

Gaebel, Robert 2002. Cavalry Operations in the Ancient Greek World. University of Oklahoma Press.

Gahlot and B.P. Chadha. "Training and Sport of the Dromedary Camel." In T. Gahlot (ed) (2000). Selected Topics on Camelids. Bikaner: The Camelid Publishers. Pp. 577-591.

Ganguli, Kisari Mohan (trans.) 1883-1896. Mahabharata. Public Domain.

Gauthier-Pilters, Hilde and Anne Innis Dagg 1981. The Camel: Its Evolution, Ecology, Behavior, and Relationship to Man. University of Chicago Press.

Gera, Dov and Wayne Horowitz 1997. "Antiochus IV in Life and Death: Evidence from the Babylonian Astronomical Diaries." Journal of the American Oriental Society vol. 117 no. 2 pp. $240-252$.

Gethin, Rupert 1998. The Foundations of Buddhism. Opus.

Gilibert, Alessandra 2011. Syro-Hittite Monumental Art and the Archaeology of Performance: The Stone Reliefs at Carchemish and Zincirli in the Earlier First Millennium BCE. Berlin: Walter de Gruyter.

Glover, R.F. 1944. “The Elephant in Ancient War.” CJ 39 no. 5, pp. 257-169. 1948. "The Tactical Handling of the Elephant." $G \& R 17$ no. 49, pp. 1-11. 1950. "Some Curiosities of Ancient Warfare.” G\&R 19 no. 55, pp. 1-9.

Grainger, John 1990. Seleucus Nicator: Constructing a Hellenistic Kingdom. Routledge. 2010. The Syrian Wars. Brill.

Graver, Margaret 1995. “Dog-Helen and Homeric Insult.” Classical Antiquity 14 no.1, pp. 41-61.

Green, Peter 1990. From Alexander to Actium: The Historical Evolution of the Hellenistic Age. University of California Press.

Greenhalgh, P.A.L. 1974. Early Greek Warfare: Horsemen and Chariots in the Homeric and Archaic Ages. CUP. 
Grenot, Claude J 1974. "Physical and Vegetational Aspects of the Sahara Desert." In G.W. Brown (ed.) (1974) Desert Biology: Special Topics on the Physical and Biological Aspects of Arid Regions. Academic Press. Pp. 103-157.

Griffith, Mark 2006. "Horsepower and Donkeywork: Equids and the Ancient Greek Imagination.” Classical Philology 101:3, pp. 185-246.

Gruen, Eric 2018. “The Coronation of the Diadochi.” Karanos 1, pp. 109-119.

1996. "Hellenistic Kingship: Puzzles, Problems and Possibilities." Aspects of Hellenistic Kingship. Edited by Per Bilde, Troels Engberg-Pedersen, Lise Hannestad, and Jan Zahle. Aarhus University Press. P.p. 116-125.

Irfan and Vivekanand Jha 2004. Mauryan India: A People's History of India. Tulika.

Hadley, R. A. 1974. "Royal Propaganda of Seleucus I and Lysimachus.” JHS. 94. Pp, 5065.

Hamilton, J.R. 1969. Plutarch: Alexander (Commentary). OUP.

Hammond, N.G.L. 1980. “The Battle of the Granicus River.” JHS 100 pp. 73-88. 1983. "Army Transport in the Fifth and Fourth Centuries." GRBS 24 pp.27-31.

Hanson, Victor Davis 1994. The Western Way of War: Infantry Battle in Classical Greece. University of California Press. 1983. Warfare and Agriculture in Classical Greece. University of California Press.

Hare, Brian 2007. "From Nonhuman to Human Mind: What Changed and Why?" Current Directions in Psychological Science 16 no. 2 pp. 60-64. , Michelle Brown, Christina Williamson, and Michael Tomasello 2002. "The Domestication of Social Cognition in Dogs." Science 298 No. 5598, pp. 16341636.

Harrison, Evelyn 1972. "The South Frieze of the Nike Temple and the Marathon Painting in the Painted Stoa." American Journal of Archaeology 76 no.4, pp. 353-378.

Heckel, Waldemar 2012. The Conquests of Alexander the Great. CUP. , Lawrence Tritle, and Pat Wheatley 2007. Alexander's Empire: Formulation to Decay. Regina Books.

Helbig, Wolfgang 1902. Les hippeis athéniens. Imprimerie nationale, Athens. 
Holt, Frank 2003. Alexander the Great and the Mystery of the Elephant Medallions.

University of California Press.

1988. Alexander the Great and Bactria. Brill.

Houghton, A. and C. Lorber 2002. Seleucid Coins: A Comprehensive Catalogue. Part I: Seleucus I through Antiochus III. Lancaster.

Howe, Tim 2003. "Pastoralism, the Delphic Amphiktyony, and the First Sacred War: The Creation of Apollo's Sacred Pastures." Zeitschrift für Alte Geschichte Bd. 52 H. 2, pp. 129-146.

Hubbell, Harry 1935. "Ptolemy’s Zoo.” $C Q$ vol. 31 no. 2. Pp. 68-76.

Hull, Denison 1964. Hounds and Hunting in Ancient Greece. University of Chicago Press.

Hunt, Peter 2007. “Military Forces.” In In P. Sabin, H. van Wees, M. Whitby (eds.) 2007. The Cambridge History of Greek and Roman Warfare Volume I. CUP. Pp. 108146.

1998. Slaves, Warfare, and Ideology in the Greek Historians. CUP.

Hyland, Ann 2013. "War and the Horse, Part I: Breeding and Keeping a Warhorse." In Campbell and Tritle (eds.). The Oxford Handbook of Warfare in the Classical World. OUP. Pp. 493-511.

2013. "Part II: The Development and Training of Cavalry in Greece and Rome." In Campbell and Tritle (eds.). The Oxford Handbook of Warfare in the Classical World. OUP. Pp.. 512-526.

2003. The Horse in the Ancient Greek World. Surrey.

Jenkins, G. K. 1990. Ancient Greek Coins. Second Edition. Seaby.

Jensen, Lloyd 1963. "Royal Purple of Tyre." Journal of Near Eastern Studies Vol. 22 No. 2, pp. 104-118.

Kaminski, Juliane, Juliane Brauer, Josep Call, Michael Tomasello 2009. "Domestic dogs are sensitive to a human's perspective." Behaviour 146 no.7, pp. 979-998.

Karunanithy, David 2008. Dogs of War: Canine Use in Warfare from Ancient Egypt to the 19th Century Seminole Wars. Yarak,

Kistler, John 2006. War Elephants. Praeger. 
Kitchell, Kenneth 2020 (anticipated). "Seeing the Dog: Naturalistic Canine

Representations from Greek Art." Arts 9 no. 1. From Animals in Ancient Material Cultures vol 1.

2017. “'Animal Literacy' and the Greeks: Philoctetes the Hedgehog and Dolon the Weasel" in Fogen and Thomas (2017), pp.183-204.

2014. Animals in the Ancient World from A to Z. Routledge.

2004. "Man's Best Friend? The Changing Role of the Dog in Greek Society," PECUS. Man and animal in antiquity. Proceedings of the conference at the Swedish Institute in Rome, September 9-12, 2002, pp. 177-182.

Koehler, William 1967. The Koehler Method of Guard Dog Training. Howell Book House.

Kohler-Rollefson, Ilse. "The Camel and Human Society." In T. Gahlot (ed) (2000). Selected Topics on Camelids. Bikaner: The Camelid Publishers. Pp. 1-14.

Konijnendijk, Roel 2018. Classical Greek Tactics. Brill.

Kosmin, Paul 2014. The Land of the Elephant Kings: Space, Territory, and Ideology in the Seleucid Empire. HUP.

2013. “Apologetic Ethnography: Megasthenes' Indica and the Seleucid Elephant." In Ancient Ethnography, edited by Eran Almagor and Joseph Skinner. Bloomsbury. Pp. 97-116.

Krentz, Peter 2007. "War [Archaic and Classical Greece].” In P. Sabin, H. van Wees, M. Whitby (eds.) 2007. The Cambridge History of Greek and Roman Warfare Volume I. CUP. Pp. 147-185.

Kritt, B. 1997. The Early Seleucid Mint of Susa. Lancaster.

Kroll, John 1977. “An Archive of the Athenian Cavalry.” Hesperia 46, pp. 83-140.

Kyrieleis, Helmut. Bildnesse der Ptolemaer. Deutsches Archaeologisches Institut. Mann Verlag.

Lane Fox, R. 1996. "Text and Image: Alexander the Great, Coins and Elephants." Bulletin of the Institute of Classical Studies vol. 41, pp. 87-108.

Laws, R.M., I.S.C. Parker, and R.C.B. Johnstone 1975. Elephants and their Habitats: In North Bunyoro, Uganda. Clarendon Press. 
Lewis, Sian and Lloyd Llewellyn-Jones (eds) 2018. A Culture of Animals in Antiquity: A Sourcebook with Commentaries. Routledge

Lilja, Saara 1976. Dogs in Ancient Greek Poetry. Helsinki, Societas Scientiarum Fennica.

Lloyd, Alan 1982. "Nationalist Propaganda in Ptolemaic Egypt," Historia: Zeitschrift für Alte Geschichte. Bd. 31, H. 1, pp. 33-55.

Lonsdale, Steven 1979. "Attitudes Towards Animals in Ancient Greece” $G \& R$ 26:2, pp. 146-159.

Lorber, Catherine 2005. "A Revised Chronology for the Coinage of Ptolemy I." The Numismatic Chronicle. Vol 165 pp. 45-64.

2012. "An Egyptian Interpretation of Alexander's Elephant Headdress." American Journal of Numismatics vol. 24, pp. 21-31.

Luckenbill, Daniel David (trans) 1926. Ancient Records of Assyria and Babylonia Vol I. University of Chicago Press.

Mairs, Rachel 2010. "Egyptian 'Inscriptions' and Greek 'Graffiti' at El Kanais (Egyptian Eastern Desert)." In J. Baird and C. Taylor 2010. Ancient Graffiti in Context. Routledge. Pp. 153-164.

Manley, Deborah and Sahar Abdel-Hakim (eds) 2006. Traveling through Sinai: From the Fourth to the Twenty-First Century. American University in Cairo Press.

Markle, M.M. 1978. "Use of the Sarissa by Philip and Alexander of Macedon, American Journal of Archaeology 82, pp. 486-497.

1982. "Macedonian Arms and Tactics Under Alexander the Great." In B. BarrSharrar and E. Borza 1982. Macedonia and Greece in Late Classical and Early Hellenistic Times. National Gallery of Art. Pp. 87-111.

Mayor, Adrienne 2014. “Animals in Warfare.” In Campbell (2014), 282-293. . 2003. Greek Fire, Poison Arrows, and Scorpion Bombs: Biological and Chemical Warfare in the Ancient World. The Overlook Press. Woodstock and New York.

McCartney, Eugene 1943. "On Keeping Animals Silent in Peace and War.” CJ 38 no.4 pp. 222-226.

1934. "The Couch as a Unit of Measurement." CPh 29, pp.30-5. 
Meeus, Alexander 2013. "What We do not Know about the Age of the Diadochi: The Methodological Consequences of the Gaps in the Evidence." In V. Troncodo and E. Anson (eds.) 2013. After Alexander: The Time of the Diadochi (323-281 BC). Oxbow Press. Pp. 84-98.

Merlen, R.H.A. 1971. De Canibus: Dogs and Hounds in Antiquity. J.A. Allen \& Co.

Miller, Geoffrey 2008. "Attitudes toward Dogs in Ancient Israel: A Reassessment." Journal for the Study of the Old Testament vol. 32.4, pp. 487-500.

Morkholm, O. 1991. Early Hellenistic Coinage, from the Accession of Alexander to the Peace of Apameia (336-188 BC). CUP.

Mueller, Katja 2006. Settlements of the Ptolemies: City Foundations and New Settlement in the Hellenistic World. Peeters.

Mullin, Molly 1999. "Mirrors and Windows: Sociocultural Studies of Human-Animal Relationships." Annual Review of Anthropology 28, pp. 201-224.

Newell, Edward T. 1941. The Coinage of the Western Seleucid Mints from Seleucus I to Antiochus III. Numismatic Studies no. 4. New York: American Numismatic Society.

1938. The Coinage of the Eastern Seleucid Mints, from Seleucus I to Antiochus III. Numismatic Studies no. 1. New York: American Numismatic Society.

Nousek, Debra 2008. "Turning Points in Roman History: The Case of Caesar's Elephant Denarius." Phoenix vol. 62 no. 3 pp. 290-307.

Nowak, Ronald M. 1999. Walker's Mammals of the World Vol II, Sixth Edition. John Hopkins University Press.

Ogden, Daniel 2013. "The Alexandrian Foundation Myth: Alexander, Ptolemy, the Agathoi Daimones, and the Argolaioi. In V. Troncoso and E. Anson (eds.) 2013. After Alexander: The Time of the Diadochi (323-281 BC). Oxbow. Pp. 241-253.

Ogden, David (ed.) 2002. The Hellenistic World: New Perspectives. The Classical Press of Wales \& Duckworth.

Oliver, G. J. 2007. War, Food, and Politics in Early Hellenistic Athens. OUP.

Orwin, Clifford 1989. "Thucydides' Contests: Thucydidean Methodology in Context." The Review of Politics 51:3, pp. 345-364. 
Osborne, Catherine 2007. Dumb Beasts and Dead Philosophers: Humanity and the Humane in Ancient Philosophy and Literature. OUP.

Osborne, Robin 2001. "Why did Athenian pots appeal to the Etruscans?" World Archaeology 33:3, pp. 277-295.

Pangiotis, P., Iossif and Cathrine Lorber (2010). "The Elephantarches Bronze of Seleucos I Nikator.” Syria T 87. Pp. 147-164.

Pant, G. N. 1997. Horse \& Elephant Armour. Agam Kala Prakshan Delhi.

Payne, Katharine, William Langbauer, Elizabeth Thomas 1986. "Infrasonic Calls of the Asian Elephant (Elephas Maximas).” Behavioral Ecology and Sociobiology 18 no. 4, pp. 297-301.

Pearson, Chris 2013. "Dogs, History, and Agency.” History and Theory 52 no. 4, pp. 128-145.

Peters, John and Hermann Thiersch 1905. Painted Tombs in the Necropolis of Marissa. The Committee of the Palestine Exploration Fund, London.

Pevnick, Seth 2014. "Good Dog, Bad Dog: A Cup by the Triptolemos Painter and Aspects of Canine Behavior on Athenian Vases.” In J. Oakley (ed.) 2014. Athenian Potters and Painters vol. III. Oxbow. Chapter 16.

Phillips, A.A. and M.M. Willcock 1999. Xenophon and Arrian: On Hunting, edited with an Introduction, Translation, and Commentary. Aris \& Phillips.

Philips, Gervase 2018. “Technology, 'Machine Age' Warfare, and the Military Use of Dogs, 1880-1918.” Journal of Military History 82 no. 1, pp. 67-94.

Piggott, Stuart 1992. Wagon, Chariot and Carriage: Symbol and Status in the History of Transport. Thames and Hudson.

Podberscek, Anthony, Elizabeth Paul, James Serpell (eds) 2000. Companion Animals \& Us: Exploring the Relationships Between People \& Pets. CUP

Potts, D.T. 2004. "Camel Hybridization and the Role of Camelus bactrianus in the Ancient Near East." Journal of the Economic and Social History of the Orient. 47:2, pp.143-165.

Préaux, Claire 1939. L'économie royale des Lagides. Arno. 
Price, M. J. 1982. "The 'Porus' Coinage of Alexander the Great: A Symbol of Concord and Community." In S. Scheers (ed.) 1982. Studia Paulo Naster Oblata vol. I, Orientalia Louvaniensia 12. Leuven. Pp. 75-88.

Pryce, F. N. 1935. “A Portrait of Alexander the Great.” The British Museum Quarterly 9:4 pp. 134-135.

“Quick Lunch Dogs” 1918. (No author named) Scientific American 118 no. 21, p. 41.

Rabb, Theodore 2011. The Artist and the Warrior: Military History through the Eyes of the Masters. YUP.

Rawlings, Louis 2007. The Ancient Greeks at War. Manchester University Press.

Rees, Owen 2013. "Let Slip the Dogs of War.” Ancient Warfare Magazine VIII.5.

Ren, Lei, Charlotte Miller, Richard Lair, John Hutchinson 2010. "Integration of Biomechanical Compliance, Leverage, and Power in Elephant Limbs." Proceedings of the National Academy of Sciences of the United States of America. Vol. 107 no. 15, pp. 7078-7082.

Rice, E.E. 1983. The Grand Procession of Ptolemy Philadelphus. OUP.

Richter, Gisela 1984. The Portraits of the Greeks. Cornell University Press.

Roisman, J. 2012. Alexander's Veterans the Early Wars of the Successors. University of Texas Press.

Rolfe, John C. 1936. “On Ammianus Marcellinus, xxiii 3.9.” The American Journal of Philology 57:2 pp.137-139.

Romm, James (ed) 2005. The Landmark Arrian. New York: Anchor Books. 1989. "Aristotle's Elephant and the Myth of Alexander's Scientific Patronage." The American Journal of Philology. Vol. 110 no. 4, pp. 566-575.

Rop, Jeffery 2013. "Reconsidering the Origin of the Scythed Chariot." Historia: Zeitschrift für Alte Geschichte Bd. 62, H. 2 pp. 167-181.

Roth, Jonathan. "War.” In P. Sabin, H. van Wees, M. Whitby (eds.) 2007. The Cambridge History of Greek and Roman Warfare Volume I. CUP. Pp. 368-398.

Rose, Reuben J 2000. "Physiology of Exercise in the Racing Camel (Camelus dromedarius)." In T. Gahlot (ed) (2000). Selected Topics on Camelids. Bikaner: The Camelid Publishers. Pp. 35-50. 
Saber, Ashraf Sobhy 2000. "Statics and Dynamics of the Locomotor System of the Dromedary Camel." In In T. Gahlot (ed) (2000). Selected Topics on Camelids. Bikaner: The Camelid Publishers. Pp. 89-113.

Sabin, Philip 2007. "Land Battles." In P. Sabin, H. van Wees, M. Whitby (eds) 2007. The Cambridge History of Greek and Roman Warfare Volume I. CUP. Pp.399-433.

Sachs, A.J. and H. Hunger 1988-2002. Astronomogical Diaries and Related texts from Babylonia. 3 Vols. Vienna.

Sargent, Rachel 1927a. "The Use of Slaves by the Athenians in Warfare: In Warfare by Land.” Classical Philology 22 no.2, pp. 201-212. 1927b. "The Use of Slaves by the Athenians in Warfare: In Warfare by Sea." Classical Philology 22 no. 3 pp. 264-279.

Schede, Martin 1928. MEISTERWERKE DER TÜRKISCHEN MUSEEN ZU KONSTANTINOPEL: Band I. Griechische und römische Skulpturen des Antikenmuseums. Berlin and Leipzig: Walter de Gruyter and Co.

Scheider, Linda, Susanne Grassmann, Juliane Kaminski, and Michael Tomasello 2011. PLoS-One vol 6, e21676.

Schmidt, Evamaria 1965. The Great Altar of Pergamon. Peter Owen.

Schwartz, H.J. and M. Dioli (eds) (1992) The One-Humped Camel (Camelus dromedarius) A Pictorial Guide to Diseases, Health Care, and Management. Weikersheim: Verlag Josef Margraf.

Scullard, H.H. 1974. The Elephant in the Greek and Roman World. Thames and Hudson. Cambridge.

Seifert, Martina 2014. "Oikos and Hetairoi: Black-Figure Departure Scenes Reconsidered." In J. Oakley (ed.) 2014. Athenian Potters and Painters vol. III. Oxbow. Pp. 215-220.

Sekunda, Nick 2007. “Land Forces.” In P. Sabin, H. van Wees, M. Whitby (eds.) 2007. The Cambridge History of Greek and Roman Warfare Volume I. CUP. Pp. 325356.

1998. Seleucid and Ptolemaic Reformed Armies 168-145 BC. Vol I: The Seleucid Army under Antiochus IV Epiphanes. Montvert. 1984. The Army of Alexander the Great. Osprey. Long Acre. 
Serpell, James (ed.) 1995. The Domestic Dog: Its Evolution, Behaviour and Interactions with People. CUP.

Shamasastry, R. 1915. Kautilya's Arthashastra. Chaukhamba.

Sharma, Urmila, and S. K. Sharma (1996). Indian Political Thought. New Delhi: Atlantic Publishers.

Sharples, Ian 1994. "Curtius' Treatment of Arrhidaeus.” Mediterranean Archaeology vol. 7, pp. 53-60.

Shauenburger, Konrad 1955-56. "Die Cameliden im Altertum.” Bonner Jahrbucher 155-156, pp. 59-94.

1962. "Neue Antike Cameliden.” Bonner Jahrbucher 162, pp. 98-106.

Shaw, David Gary 2013a. "A Way with Animals." History and Theory (Theme Issue 52: Does History Need Animals?) Pp. 1-12.

2013b. "The Torturer's Horse: Agency and Animals in History." History and Theory (Theme Issue 52: Does History Need Animals?) Pp. 146-167.

Sheedy, Kenneth (ed.) 2007. Alexander and the Hellenistic Kingdoms, The Westmoreland Collection.

Sherwin-White, Susan and Amélie Kuhrt. From Samarkhand to Sardis: A New Approach to the Seleucid Empire. University of California Press.

Sidnell, Philip 2006. Warhorse: Cavalry in Ancient Warfare. Hambledon Continuum.

Singh, Sarva Daman 1965. Ancient Indian Warfare with Special Reference to the Vedic Period. Leiden: Brill.

Smith, R.R.R. 1986. "Three Hellenistic Rulers at the Getty." The J Paul Getty Museum Journal 14 pp. 59-78

Smith, Sir William (ed) 1875. A Dictionary of Greek and Roman Antiquities. London: John Murray.

Snyder, Lynn and Elizabeth Moore (eds.) 2002. Dogs and People in Social, Working, Economic or Symbolic Interaction, from the Proceedings of the 9th Conference of the International Council of Archaeozoology. Oxbow.

Soproni, K, A. Miklósi, J. Topál, V. Csányi 2002. “Docs' (Canis familiaris) Responsiveness to Human Pointing Gestures." Journal of Comparative Psychology vol. 116 no. 1, pp. 27-34. 
Spawforth, A. 2007. "The Court of Alexander the Great between Europe and Asia." In A. Spawforth (ed.) 2007. The Court and Court Society in Ancient Monarchies. CUP. Pp. 82-120.

Spence, I.G. 1993. The Cavalry of Classical Greece. Clarendon.

Spinage, Clive 1994. Elephants. T \& A.D. Poyser.

Stanwick, Paul 2002. Portraits of the Ptolemies. University of Texas Press.

Stewart, Andrew 1993. Faces of Power: Alexander's Image and Hellenistic Politics. University of California Press.

Stoneman, Richard. 2008. Alexander the Great: A Life in Legend. Yale University Press. New Haven.

Sukumar, Raman 2003. The Living Elephants: Evolutionary Ecology, Behavior and Conservation. OUP. 1994. Elephant Days \& Nights: Ten Years with the Indian Elephant. OUP. 1992. The Asian Elephant: Ecology and Management. CUP.

Tabbaa, Darem 2012. "The Economic Significance and Traditional Management of Dromedaries in Syria." In Knoll and Burger (eds.) (2012). Camels in Asia and North Africa: Interdisciplinary Perspectives on their Past and Present Significance. OAW. Pp. 163-168.

Tadmor, Hayim (ed) 1994. The Inscriptions of Tiglath-Pileser III, King of Assyria. Critical Edition with Introductions, Translations, and Commentary. Israel Academy of Sciences and Humanities.

Tarn, W.W. 1940. “Two Notes on Seleucid History 1. Seleucus' 500 Elephants 2. Tarmita." JHS vol. 60 pp. 84-94.

Thompson, Dorothy 2018. "Ptolemy I In Egypt: Continuity and Change." In Ptolemy I and the Transformation of Egypt, 404-282 BCE. Edited by Mckechnie and Cromwell. Brill. Pp. 6-26.

Trinks, Alexandra, Pamela Burger, Norbert Benecke, Joachim Burger 2012. "Ancient DNA Reveals Domestication Process: The Case of the Two-Humped Camel." In Knoll and Burger (eds.) (2012). Camels in Asia and North Africa: Interdisciplinary Perspectives on their Past and Present Significance. OAW. Pp 79-86. 
Troncoso, Victor Alonso 2013. "The Diadochi and the Zoology of Kingship: The Elephants." In V. Troncoso and E. Anson (eds.) 2013. After Alexander: The Time of the Diadochi. Oxbow Press. Pp. 254-70.

United States Military Working Dog Training Handbook 1997 edition. Published by the U.S. Department of Defense

Van Wees, Hans 2004a. Greek Warfare: Myths and Realities. Bristol Classical Press. 2004b. "Germs of Truth: Reviewed Work: Greek Fire, Poison Arrows and Scorpion Bombs: Biological and Chemical Warfare in the Ancient World by Adrienne Mayor." American Scientist 92 no. 3 pp. 280-281.

Varisco, Daniel Martin 2012. "What Camels Eat: A Study in Arabic Ethnobotony.” In Knoll and Burger (eds.) (2012). Camels in Asia and North Africa: Interdisciplinary Perspectives on their Past and Present Significance. OAW. Pp. 151-162.

Walker, Brett 2013. "Animals and the Intimacy of History." History and Theory (Theme Issue 52: Does History Need Animals? Pp. 45-67.

Wallace, W.P. 1964. “Thucydides.” Phoenix 18:4, pp. 251-261

Walter, H. and E. Stadelmann. (1974) "A New Approach to the Water Relations of Desert Plants.” In G.W. Brown (ed) Desert Biology: Special Topics on the Physical and Biological Aspects of Arid Regions Vol. II. New York: Academic Press. Pp. 214-302.

Wapnish, Paula and Brian Hesse 1993. "Pampered Pooches or Plain Pariahs? The Ashkelon Dog Burials.” The Biblical Archaeologist 56 no. 2, pp. 55-80.

Waterfield, Robin. 2011. Dividing the Spoils: The War for Alexander the Great's Empire. Oxford University Press. Oxford and New York.

Wheatley, Pat 2009. "The Diadochoi, or Successors to Alexander." Alexander the Great: A New History. Edited by Waldemar Heckel and Lawrence Tritle. Malden. Pp. 53-68.

Wheeler, Everett 2007. "Land Battles.” In Sabin et al. (2007), 186-222.

White, J. R. 1962. Medieval Technology and Social Change. OUP.

Wiedner, Ellen 2015. "Chapter 53: Proboscidea.” In. M. Fowler and R. Miller (eds.) 2015. Fowler's Zoo and Wild Animal Medicine Vol. 8. Elsevier. Pp. 517-532.

Wilcken, Ulrich 1967. Alexander the Great. New York: Norton. 
Willekes, Carolyn 2015. "Equine Aspects of Alexander the Great's Macedonian Cavalry.” In T. Howe, E. Garvin, and G. Wrightson (eds.) 2015. Greece, Macedon and Persia: Studies in Social, Political and Military History in Honour of Waldemar Heckel. Oxbow. Pp. 47-58.

Woodfin, Edward C. 2012. Camp and Combat on the Sinai and Palestinian Front: The Experience of the British Empire Soldier, 1916-18. Palgrave Macmillan.

Worley, Leslie 1994. Hippeis: The Cavalry of Ancient Greece. Westview Press.

Worthington, Ian 2016. Ptolemy I: King and Pharaoh of Egypt. OUP.

2014. By the Spear: Philip II, Alexander the Great, and the Rise and Fall of the Macedonian Empire. Oxford University Press. Oxford and New York. 2008. Philip II of Macedonia. YUP.

Wrightson, Graham 2015. "Macedonian Armies, Elephants, and the Perfection of Combined Arms." In T. Howe, E. Garvin, and G. Wrightson (eds.) 2015. Greece, Macedonia, and Persia: Studies in Social, Political, and Military History in Honor of Waldemar Heckel. Oxbow Books. Pp. 59-68.

Wu, Huiguang, Xuanmin Guang, Mohamed AL-Fageeh, Junwei Cae, Shengkai Pan, Huanmin Zhou, and Junyi Wang 2014. "Camelid Genomes Reveal Evolution and Adaptation to Desert Environments." Nature Communications 5:5188 pp.1-38.

Yagil, Reuven 2000. "Ecophysiology of the Desert Camel.” In T. Gahlot (ed) (2000). Selected Topics on Camelids. Bikaner: The Camelid Publishers. Pp. 51-60.

Younan, Mario and David M. Mwangi 2012. "The Informal Camel Milk Marketing Sector in Kenya and Somalia." In Knoll and Burger (eds.) (2012). Camels in Asia and North Africa: Interdisciplinary Perspectives on their Past and Present Significance. OAW. Pp. 207-218.

Yousef, M.K., M.E.D. Webster, and O.M. Yousef 1989. "Energy Costs of Walking in Camels, Camelus dromedarius. Physiological Zoology 62:5, pp. 1,080-1,088.

Zahran, M.A. and A.J. Willis 1992. The Vegetation of Egypt. London: Chapman \& Hall. Zervos, O. H. 1967. “The Early Tetradrachms of Ptolemy I.” ANS Museum Notes 13, p. $1-16$.

Zhao, X 2000. "Reproduction in the Bactrian Camel.” In T. Gahlot (ed) (2000). Selected Topics on Camelids. Bikaner: The Camelid Publishers. Pp. 499-538.

Zlotogorska, M. 1997. Darstellungen von Hunden auf Griechischen Grabreliefs von der Archaik bis in die Romische Kaiserzeit, Hamburg. 


\section{VITA}

Jenna Rice was born in Evansville, Indiana in 1989, where she lived until 2012. She developed an early interest in animal biology and Greek mythology in grade school, and by high school became fascinated by ancient cultures, at which point she decided to pursue a graduate degree in Greek history. Jenna attended the University of Evansville from 2008-2012 and earned a BA with a history major and minors in Spanish and French. Her MA and $\mathrm{PhD}$ were completed at the University of Missouri through the History Department between 2012-2020, where Curators' Professor Ian Worthington was her faculty advisor and dissertation director. During this time, Jenna's interest shifted from Greek religion and literature to Greek socio-military history, which influenced later studies. Her master's thesis investigated the use of and changes in violence during the Indian campaign of Alexander the Great (327-325) and resulted in a publication in Arctos in 2019. Jenna was fortunate enough to have the opportunity to research and write a dissertation that combined her early love of zoology and Greek culture with her more recent interest in the ancient military sphere. 